\title{
Mijnbouw en arbeidsmarkt in Nederlands-Limburg: Herkomst, werving, mobiliteit en binding van mijnwerkers tussen 1900 en 1965
}

Citation for published version (APA):

Langeweg, S. (2011). Mijnbouw en arbeidsmarkt in Nederlands-Limburg: Herkomst, werving, mobiliteit en binding van mijnwerkers tussen 1900 en 1965. [Doctoral Thesis, Maastricht University]. Uitgeverij Verloren. https://doi.org/10.26481/dis.20111215sl

Document status and date:

Published: 01/01/2011

DOI:

10.26481/dis.20111215sl

Document Version:

Publisher's PDF, also known as Version of record

Please check the document version of this publication:

- A submitted manuscript is the version of the article upon submission and before peer-review. There can be important differences between the submitted version and the official published version of record.

People interested in the research are advised to contact the author for the final version of the publication, or visit the DOI to the publisher's website.

- The final author version and the galley proof are versions of the publication after peer review.

- The final published version features the final layout of the paper including the volume, issue and page numbers.

Link to publication

\footnotetext{
General rights rights.

- You may freely distribute the URL identifying the publication in the public portal. please follow below link for the End User Agreement:

www.umlib.nl/taverne-license

Take down policy

If you believe that this document breaches copyright please contact us at:

repository@maastrichtuniversity.nl

providing details and we will investigate your claim.
}

Copyright and moral rights for the publications made accessible in the public portal are retained by the authors and/or other copyright owners and it is a condition of accessing publications that users recognise and abide by the legal requirements associated with these

- Users may download and print one copy of any publication from the public portal for the purpose of private study or research.

- You may not further distribute the material or use it for any profit-making activity or commercial gain

If the publication is distributed under the terms of Article $25 \mathrm{fa}$ of the Dutch Copyright Act, indicated by the "Taverne" license above, 
Mijnbouw en arbeidsmarkt in Nederlands-Limburg 
Maaslandse Monografieën, 75

\author{
Onder redactie van \\ Prof. Dr. P.J.A. Nissen (voorzitter) \\ Dr. W.J.M.J. Rutten (redactiesecretaris) \\ Prof. Dr. E. Aerts \\ Prof. Dr. R. Aerts \\ Prof. Dr. A.M.J.A. Berkvens \\ Mevr. Dr. J.C. Dekker \\ Dr. M. van der Eycken \\ Dr. J.J. de Jong \\ Dr. R. Nouwen \\ Raad van Advies \\ Drs. Th.J.F.M. Bovens (Maastricht) \\ H. Reijnders (Hasselt) \\ Prof. Dr. C. Bruneel (Louvain-la-Neuve) \\ Prof. Dr. A. Heinen (Aken) \\ Prof. Dr. P.M.M. Klep (Nijmegen) \\ Prof. Dr. A. Labrie (Maastricht) \\ Prof. Dr. J.M.W.G. Lucassen (Amsterdam) \\ Prof. Dr. J.C.G.M. Jansen (Maastricht) \\ Prof. Dr. H. Soly (Brussel) \\ Prof. Dr. R. van Uytven (Antwerpen)
}

De in deze serie verschenen delen staan vermeld op pag. 358-359

Stichting Maaslandse Monografieën

De Stichting Maaslandse Monografieën werd in 1964 in het leven geroepen door het Sociaal Historisch Centrum voor Limburg en Limburgs Geschied- en Oudheidkundig

Genootschap en staat onder bestuur van:

Drs. F.L.J.F. Jadoul (voorzitter)

Mevr. Mr. C. de Koster (secretaris)

Drs. H.J.L.M. Boersma MBA (penningmeester)

Mevr. Drs. B.J.F.M. Berden-Van Lier

Prof. Dr. P.M.J.E. Tummers 


\title{
Mijnbouw en arbeidsmarkt in Nederlands-Limburg
}

\section{Herkomst, werving, mobiliteit en binding van mijnwerkers tussen 1900 en 1965}

\author{
door
}

SERGE LANGEWEG

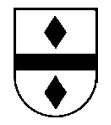

Hilversum

Verloren 
Dit onderzoek kwam tot stand met steun van de Nederlandse Organisatie voor Wetenschappelijk Onderzoek en het Discovery Center Continium Kerkrade.

Op het omslag: Houwers van de Domaniale Mijn. De mijnwerker links draagt een zogenaamd Arsch-leder (zitvlakbeschermer). Omstreeks I950.

Bron: Fotocollectie Continium Kerkrade, F353.

ISBN 978-90-8704-254-7

Tevens verschenen als proefschrift aan de Universiteit Maastricht.

(C) 20II Serge Langeweg \& Uitgeverij Verloren, Torenlaan 25, I2II JA Hilversum

Typografie Rombus, Hilversum

Omslagontwerp Het Lab, Arnhem

Druk Wilco, Amersfoort

Bindwerk Van Waarden, Zaandam

No part of this book may be reproduced in any form without written permission from the author and publisher. 


\section{Inhoud}

Woord vooraf

I Arbeidsmarktonderzoek en Nederlandse steenkolenmijnbouw I5

De arbeidsmarkt voor mijnwerkers $\quad$ I5

$\begin{array}{ll}\text { Theoretisch kader } & \text { I7 }\end{array}$

Mijnbouw in de historiografie

Opzet en indeling $\quad$ 2I

Bronnen en methodologie $\quad 23$

2 Steenkolenmijnbouw in Nederland $\quad 27$

$\begin{array}{ll}\text { Oude en nieuwe steenkolenvelden } & 27\end{array}$

Van concessie tot onderneming: de particuliere mijnen $\quad 29$

De Oranje-Nassau Mijnen $\quad 29$

De mijn Willem-Sophia 3 I

Laura \& Vereeniging $\quad 32$

De Domaniale Mijnmaatschappij $\quad 35$

$\begin{array}{ll}\text { De mijn Neuprick } & 36\end{array}$

Een nieuwe Nederlandse mijnbouwpolitiek: Staatsmijnen $\quad 37$

Productie, markt en arbeidsplaatsen $\quad 4 \mathrm{I}$

$\begin{array}{ll}\text { Besluit } & 49\end{array}$

3 Demografische en ruimtelijke aspecten van de arbeidsmarkt voor mijnwerkers 50

De demografische ontwikkeling 52

Bevolkingsgroei $\quad 52$

Beroepsbevolking en economische structuur $\quad 58$

De regionale spreiding van de arbeidsmarkt voor mijnwerkers $\quad 59$

$\begin{array}{ll}\text { Mijnbouw, werkgelegenheid en woningbouw } & 60\end{array}$

$\begin{array}{ll}\text { Pendel naar de mijn } & 63\end{array}$

Herkomst en richting van de pendelstromen $\quad 68$

$\begin{array}{ll}\text { Besluit } & 73\end{array}$

4 Mijnwerkers uit Nederland $\quad 75$

Limburgers en andere Nederlanders in de mijn $\quad 76$

$\begin{array}{ll}\text { De opbouw van een mijnwerkersbestand, I900-I930 } & 79\end{array}$

$\begin{array}{ll}\text { Personeelsvoorziening op een rurale arbeidsmarkt } & 79\end{array}$ 
Herkomst $\quad 84$

Nederlanders uit Duitse mijnen $\quad 86$

$\begin{array}{ll}\text { Selectie } & 95\end{array}$

Een eerste poging tot selectie: Staatsmijnen $\quad 96$

Selectie door de katholieke geestelijkheid: de Arbeidsbeurs voor de Limburgsche 98

Mijnstreek

$\begin{array}{ll}\text { I930: een tussenbalans } & \text { I02 }\end{array}$

$\begin{array}{lr}\text { Crisis en oorlog, I93I-I944 } & \text { IO2 }\end{array}$

$\begin{array}{ll}\text { Werving en selectie in de jaren dertig } & \text { I02 }\end{array}$

$\begin{array}{ll}\text { Bezetting } & \text { I08 }\end{array}$

Wederopbouw, I945-1965 II3

Rekruteringsmoeilijkheden $\quad$ II3

Werving en selectie $\quad$ II5

$\begin{array}{lll}\text { Besluit } & \text { I2I }\end{array}$

5 Buitenlandse arbeiders in de Nederlandse steenkolenmijnen $\quad$ I23

$\begin{array}{ll}\text { Buitenlanders in de mijn } & \text { I25 }\end{array}$

$\begin{array}{ll}\text { De periode van opbouw, I900-I930 } & \text { I27 }\end{array}$

$\begin{array}{ll}\text { De jaren vóór de Eerste Wereldoorlog } & \text { I27 }\end{array}$

Belgische vluchtelingen en geïnterneerden $\quad$ I3 I

Duitse en Belgische grensarbeiders $\quad$ I35

Naar georganiseerde werving: de jaren twintig $\quad$ I39

$\begin{array}{ll}\text { Crisis en oorlog, I93I-I944 } & \text { I49 }\end{array}$

$\begin{array}{ll}\text { Ontslaggolven } & \text { I49 }\end{array}$

Bezetting $\quad$ I55

$\begin{array}{ll}\text { Wederopbouw, I945-I965 } & \text { I59 }\end{array}$

$\begin{array}{ll}\text { Rekruteringsgolven van buitenlandse arbeidskrachten } & \text { I59 }\end{array}$

$\begin{array}{ll}\text { Poolse ex-militairen en displaced persons } & \text { I77 }\end{array}$

$\begin{array}{ll}\text { Regulering } & \text { I83 }\end{array}$

Gastarbeiders $\quad$ I86

Italianen, 1948-1951 $\quad 186$

Oostenrijkers en Italianen, 1955-1957 $\quad 187$

Italianen, Spanjaarden, Joegoslaven en Marokkanen, 1961-1965 I9I

Besluit $\quad$ I99

6 Binding aan de mijn $\quad 202$

Het verloop $\quad 205$

De periode van opbouw, I900-I930 2II

Wandervögel 2 2II

$\begin{array}{ll}\text { De Eerste Wereldoorlog } & 2 \mathrm{I} 3\end{array}$

$\begin{array}{ll}\text { De jaren twintig: naar meer stabiliteit } & \text { 2I4 }\end{array}$

$\begin{array}{ll}\text { De Contact-Commissie voor het Mijnbedrijfen de cao } & 215\end{array}$

$\begin{array}{ll}\text { Het Algemeen Mijnwerkersfonds van de Steenkolenmijnen in Limburg } & 217\end{array}$

$\begin{array}{ll}\text { De Geneeskundige Dienst der Nederlandse Steenkolenmijnen } & \text { 2I8 }\end{array}$ 
Sociale voorzieningen op bedrijfsniveau

Steun aan katholieke initiatieven

Crisis en oorlog, I93I-I944

Ontslagbeleid, personeelsvoorziening en binding aan het bedrijf 223

Bezetting en nasleep

Wederopbouw, I945-I965

Binding, conjunctuur en arbeidsmarkt

Lonen en arbeidsverloop

Grensarbeid

Herkomst en binding

Een mijnwerkerstraditie

Binding door de OVS

Besluit

7 Samenvatting en conclusies

De arbeidsmarkt voor mijnwerkers in Limburg

De arbeidsvoorziening: problemen en mogelijkheden $\quad 257$

Een dubbele arbeidsmarkt $\quad 259$

Binding versus autonomie $\quad 26 \mathrm{I}$

$\begin{array}{ll}\text { De regionalisering van de mijnarbeidsmarkt } & 264\end{array}$

Bijlagen $\quad 266$

I De personeelsbezetting bij de Nederlandse mijnbedrijven, I895-I972 266

2 De nettoproductie van steenkolen bij de particuliere mijnen, I895-I973 270

3 De nettoproductie van steenkolen bij Staatsmijnen, I906-I973 276

4 De steenkolenbalans van Nederland, I895-I970

5 De West-Europese steenkolenmijnbouw: productie en personeel, I900-I965 284

6 Economisch-geografische gebieden in Limburg $\quad 286$

7 Verantwoording van het kaartmateriaal (metadata) $\quad 287$

7a Kaartenreeks 'Aandeel mijnarbeiders in de mannelijke beroepsbevolking, $\quad 290$ I909, I930, I947 en I960'

7b Kaartenreeks 'Gemeentelijk aandeel mijnarbeiders in het totaal van de provincie, I909, I930, I947 en I960'

7c Het aandeel van mijnwerkers in de mannelijke beroepsbevolking. Locatie- $\quad 298$ quotiënten Limburgse gemeenten, I909, I930, I947 en I960

8 Steekproef uit de kaartadministratie van het Algemeen Mijnwerkersfonds 30I

9 Nationaliteitsbewijzen 303

Io De geboorteplaats in de mijnstreek van nieuwe AMF-leden 304

II Onderzoek naar de mijnwormziekte $\quad 305$

I2 De herkomst van nieuwe ondergronders in de Nederlandse steenkolen- 306 mijnen, I905-I925

I3 De herkomst van nieuwe ondergronders bij Staatsmijnen en de particuliere mijnen, I905, I9I3-I925 
I4 Het aandeel per provincie in de totale Nederlandse bevolking en het aandeel per provincie in de inschrijvingen van nieuwe AMF-leden

I5 Buitenlandse nationaliteiten in de Nederlandse steenkolenmijnen (totale arbeidersbestand), 1905-1973

I6 Buitenlandse nationaliteiten in het arbeidersbestand ondergronds van de Nederlandse steenkolenmijnen, I9I3-I973

I7 Buitenlandse nationaliteiten in het arbeidersbestand bovengronds van de Nederlandse steenkolenmijnen, I9I3-I973

I8 Het overlevingspercentage van intreders in het Algemeen Mijnwerkersfonds, 324 I9I9-I96o

I9 Het verloop van het ledental van de pensioenkas van het Algemeen Mijnwerkersfonds, I920-1960

20 Het verloop van de OVS-ers bij de gezamenlijke Nederlandse steenkolenmijnen, I945-1965

\section{Geraadpleegde bronnen}

Archieven en documentatie

Gepubliceerde bronnen en literatuur

\section{Summary}

\section{Grafieken}

2.I De netto-steenkolenproductie in Nederland, I895-I974 (in tonnen x I.000)

2.2 Ondergrondse, bovengrondse en totale arbeidersbezetting bij de Nederlandse steenkolenmijnen, I895-I974 (per 3i december)

2.3 Nettoprestatie per ondergrondse dienst totaal en nettoprestatie per ondergrondse dienst in de afbouw, gezamenlijke mijnen, 1895-1972 (in tonnen)

3.I De bevolkingsgroei in de provincie Limburg, de oostelijke en de westelijke mijnstreek, I899-I97I (indexcijfers, I889=I00)

3.2 Geboorte- en migratiesaldo provincie Limburg, I88I-I975 (in promille, vijfjaarlijkse totalen)

3.3 Geboorte- en migratiesaldo oostelijke mijnstreek, I88I-I975 (in promille, vijfjaarlijkse totalen)

3.4 Geboorte- en migratiesaldo westelijke mijnstreek, I88I-I975 (in promille, vijfjaarlijkse totalen)

4.I Het aantal en percentage Nederlanders in het arbeidersbestand van de Nederlandse steenkolenmijnen, I905-1965 (per 3i december)

4.2 De bevolking en de aanvragen van nationaliteitsbewijzen in de oostelijke mijnstreek 80 als percentage van het Limburgse totaal, I875-I9I4

4.3 Nederlandse mijnwerkers in het Ruhrgebied, I893, I902-I9I4

4.4 Het aantal nieuwe aanmeldingen voor werk ondergronds bij de Nederlandse steenkolenmijnen, afkomstig uit een Duitse mijn, en het aantal Duitsers in dienst bij de Nederlandse steenkolenmijnen op 3I december, I905-I9I8 
4.5 Het aandeel Nederlandse arbeiders bij Staatsmijnen en de particuliere mijnen, 1905-1938 77

4.6 Het percentage Limburgers in de Nederlandse steenkolenmijnen, I9I9-I935

5.I Het aantal en percentage buitenlanders in het arbeidersbestand van de Nederlandse I25 steenkolenmijnen, 1905 - 1965

5.2 Het jaarlijkse groeipercentage van de ondergrondse bezetting in de Nederlandse I26 steenkolenmijnen: Nederlanders en buitenlanders, I906-I965 (I906-ıgig totale bezetting)

5.3 Ervaren ondergronders, afkomstig van Nederlandse en buitenlandse mijnen, I905-1925 I28

5.4 Arbeiders zonder eerdere mijnbouwervaring, afkomstig uit Nederland en het buiten- I28 land, 1905-1925

5.5 Herkomst ervaren buitenlandse ondergronders, 1905-1925 I29

5.6 De verdeling van buitenlandse nationaliteiten in de Nederlandse steenkolenmijnen, I30 I905-1913 (ondergronds en bovengronds)

5.7 De verdeling van buitenlandse nationaliteiten in de Nederlandse steenkolenmijnen, I32 I9I4-I9I8 (ondergronds en bovengronds)

5.8 Aangeworven Belgische geïnterneerden voor ondergrondse arbeid in de Nederlandse I34 steenkolenmijnen, I916-ı198

5.9 De verdeling van buitenlandse nationaliteiten in de Nederlandse steenkolenmijnen, $\quad$ I36 I9I9-I930 (ondergronds en bovengronds)

5.IO Het aantal grensarbeiders, woonachtig in Duitsland en België, ondergronds en boven- $\quad \mathrm{I}_{3} 8$ gronds in de Nederlandse steenkolenmijnen, I920-I940

5.II Het aantal naturalisaties tot Nederlander van mijnwerkers in Limburg, I906-I933 I42

5.I2 De verdeling van buitenlandse nationaliteiten in de Nederlandse steenkolenmijnen, I54 I93I-I939 (ondergronds en bovengronds)

5.13 De verdeling van buitenlandse nationaliteiten in de Nederlandse steenkolenmijnen, I56 1940-1944 (ondergronds en bovengronds)

5.I4 De verdeling van buitenlandse nationaliteiten in de Nederlandse steenkolenmijnen, I60 1945-1965 (ondergronds en bovengronds)

5.15 Indienstgenomen ondergrondse mijnwerkers naar herkomst, 1960-1964 192

6.I De redenen van uittreding uit het Algemeen Mijnwerkersfonds, 1920-1960 204 (als percentage van het totale aantal uittreders)

6.2 Jaarlijks vertrokken arbeiders, absoluut en als percentage van de gemiddelde arbeiders- 206 bezetting bij de gezamenlijke Nederlandse steenkolenmijnen, I9II-I965

6.3 Het overlevingspercentage van de arbeidskrachten in de Nederlandse steenkolen- 207 mijnen r9r9-1960

6.4 Het overlevingspercentage van de intreders in het AMF, I919-1930 208

6.5 Het overlevingspercentage van de intreders in het AMF, I93I-I944 209

6.6 Het overlevingspercentage van de intreders in het AMF, 1945-1955 209

6.7 Her arbeidersverloop bij Staatsmijnen en de particuliere mijnen, I9II-I938 2I3 (jaarlijks vertrek als percentage van de gemiddelde arbeidersbezetting)

6.8 Het totaal aantal mutaties van arbeidskrachten tussen Nederlandse mijnzetels, $\quad$ 2I4 I907-I925 (als percentage van de jaarlijkse arbeidersbezetting op 3I december)

6.9 De aanmeldingen en plaatsingen in het mijnbedrijf van OVS-ers, I945-I965 248

\section{Tabellen}

2.I Concessieaanvragen voor de ontginning van steenkool in Nederland, I839-1899 28

2.2 Tekorten aan mijnwerkers bij de gezamenlijke Nederlandse steenkolenmijnen, I95I-I965 
2.3 Het aandeel van verschillende energiebronnen in het energieverbruik in de EGKS, $\quad 48$ 1950-1965 (in procenten)

3.I De beroepsbevolking in de mijnbouwsector naar geslacht, I889-1971 (percentages)

3.2 De potentiële beroepsbevolking ( $\mathrm{I}_{5}-64$ jaar) in relatie tot de totale bevolking in de provincie Limburg, de oostelijke en de westelijke mijnstreek, I909-I96o (totaal, mannen en vrouwen; in indexcijfers, $1909=100$ )

3.3 Vervangingsindex mannelijke beroepsbevolking provincie Limburg, oostelijke en westelijke mijnstreek, I909-I96o (uitstroom op korte termijn op de arbeidsmarkt (6o-64-jarigen) gedeeld door de instroom op korte termijn (Io-I4-jarigen))

3.4 De beroepsdeelneming in Limburg, de oostelijke en westelijke mijnstreek, 1909-1960 (totaal, mannen en vrouwen, als percentage van de leeftijdsgroep 15-64 jaar)

3.5 De verdeling van de beroepsbevolking (mannen en vrouwen) naar economische sectoren in Limburg en Nederland, I889-1960 (in procenten)

3.6 Het aandeel van de sector steenkolenmijnbouw in de Limburgse mannelijke beroeps- $\quad 58$ bevolking, I889-1960

3.7 De mannelijke beroepsbevolking in de steenkolenmijnbouw, I909-I960 (absoluut en in percentage van de totale mannelijke beroepsbevolking)

3.8 De woongemeenten in Limburg van de mannelijke mijnwerkers, I909-I960 verdeeld naar mijnzetelgemeenten en overige Limburgse gemeenten. Absoluut en percentages

3.9 Middelen van vervoer, gebruikt door forenzen naar de mijnzetelgemeenten, I947 en 1960

3.10 Afgelegde afstanden door forenzen naar de mijnzetelgemeenten, I947 en I960

3.II Woonplaats van de mannelijke mijnwerkers in Limburg, verdeeld naar economischgeografisch gebied, I909-I960 (exclusief de zeven mijnzetelgemeenten in gebied 6)

3.I2 Het achterland van de Limburgse mijnzetelgemeenten

4.I De geboorteplaats van nieuwe AMF-leden, I900-1965 78

4.2 Huwelijkssluitingen, waarbij de bruidegom mijnwerker was $8 \mathrm{I}$

4.3 Het verloop onder Nederlandse mijnwerkers in de Rijnprovincie en in Westfalen, $\quad 89$ I907-I9I4

4.4 Het aandeel mijnwerkers in de aanvragen van nationaliteitsbewijzen, I875-1914 90 (in percentages van het totaal aantal aanvragen)

4.5 De opgegeven bestemming van mijnwerkers uit de provincie Limburg en uit de oostelijke mijnstreek, die een nationaliteitsbewijs aanvroegen, I875-I9I4 (in procenten)

4.6 Het aantal inschrijvingen van houwers en leerhouwers bij de Arbeidsbeurs voor de Limburgsche Mijnstreek in Heerlen, I9I2-I9I6

4.7 Het verloop van ondergrondse arbeiders tussen de Staatsmijnen en de particuliere mijnen, I905, I913-1925

4.8 Het aantal door de steenkolenmijnen aangenomen mijnwerkers en het aantal plaatsingen van mijnwerkers via de (districts-)arbeidsbeurzen van Heerlen en Sittard, I9I3-I930

4.9 Het aantal werkvrije dagen in de Nederlandse steenkolenmijnbouw, I93I-I936

4.Io Het aantal in dienst genomen mijnwerkers naar nationaliteit bij de gezamenlijke Nederlandse steenkolenmijnen, I93I-I939

4.II De gemiddelde leeftijd van intreders bij het AMF, I92I-I965 Io6

4.12 Het aantal en percentage plaatsingen in België en Duitsland via de districtsarbeidsbeurs Sittard, I936-1939

4.13 Het verzuim in het ondergrondse bedrijf van de Nederlandse steenkolenmijnen, II2 1938-1947 (in promille van het aantal mogelijke diensten) 
4.I4 Ondergronds tewerkgestelde politieke delinquenten bij de Nederlandse steenkolenmijnen, 1945-1957

5.I Buitenlandse ondergronders in de Nederlandse steenkolenmijnen, I930 en I938 I53

5.2 Het percentage Nederlanders en buitenlanders, werkzaam ondergronds, I950, I957 I59 en 1965

5.3 Indienstgetreden en vertrokken Italiaanse en Oostenrijkse arbeiders bij de Nederlandse I9I steenkolenmijnen, I957-1959

6.I Vertrek uit de mijnbouwsector: gemiddeld per jaar, I9I9-I955 (in percentage van aantal 208 intreders per cohort)

6.2 De carrière op I augustus IgIg van de intreders in het AMF 2I2

6.3 Nationaliteit van de ontslagen arbeiders bij Staatsmijnen en de Oranje-Nassau Mijnen, 224 I932-I935

6.4 De duur van het dienstverband en het moment van indiensttreding van in de periode 226 I-I-I93I tot en met 3I-I2-I935 ontslagen mijnwerkers

6.5 Percentage ongehuwden in de totale arbeidersbezetting bij de Nederlandse steenkolen- 227 mijnen, 1920-1965

6.6 Categorie 30-plussers als percentage van de totale ondergrondse arbeidersbezetting bij 227 de Nederlandse steenkolenmijnen, I919-1964

6.7 Het jaarlijkse vertrekpercentage bij de leesjongensopleiding van Staatsmijnen (als 228 percentage van het totaal aantal in opleiding in het betreffende jaar) en bij de AMF-leden, I929-I944

6.8 Het overlevingspercentage na 5 jaar bij ex-leesjongens en AMF-leden, I929-I944 229

6.9 Het rendement van bij de Staatsmijnzetels Wilhelmina en Hendrik indienstgetreden 229 ondergronders zonder interne vooropleiding ('volwassenen') en ex-leesjongens en ex-OVS-ers, I929-1961

6.1o Verloop en geschooldheid in de gezamenlijke Nederlandse steenkolenmijnen, I957 23I

6.II Indexcijfers van gemiddeld verdiende brutolonen van volwassen mannelijke arbeiders 233 in de nijverheid en van het ondergrondse mijnpersoneel, I95I-I954

6.12 Gemiddeld verdiend weekloon van mannelijke arbeiders in guldens, I95I-1954 233

6.I3 De pendelbeweging tussen Limburg, België en West-Duitsland in de mijnbouwsector, 239 ig6o-1965

6.I4 Verloop naar herkomst bij de Oranje-Nassau Mijnen, I952-I955 240

6.15 De geboortestreek van nieuwe mijnwerkers, jonger dan I8 jaar, in het AMF, 1945-1965 247

6.I6 Vertrek op eigen verzoek van OVS-ers, I95I-1965 249

6.17 Het personeelsverloop in de Nederlandse steenkolenmijnen en enige andere sectoren, $\quad 254$ 1957-I964 (in percentages van de gemiddelde personeelsbezetting in het betreffende jaar)

8.I Globale chronologische verdeling registratienummers A-kaarten AMF

Verklaring der tekens in tabellen en bijlagen

$\cdot=$ de gegevens ontbreken

$-=$ nul

$\mathrm{o}(\mathrm{o}, \mathrm{o})=$ het getal is minder dan de helft van de gekozen eenheid

niets (blank) = een cijfer kan op logische gronden niet voorkomen 


\section{Woord vooraf}

Dit proefschrift had niet tot stand kunnen komen zonder de steun, stimulans en betrokkenheid van velen. Allereerst dank ik mijn promotor Ad Knotter en copromotor Willibrord Rutten. Zij lieten mij binnen het thema van het onderzoek de ruimte eigen keuzes te maken en droegen er door hun constructieve kritiek aan bij, dat mijn inzichten in de problematiek van mijnbouw en arbeidsmarkt werden aangescherpt. Een bron van inspiratie was ook mijn collega-promovendus en kompel in de mijnbouwhistorie Leen Roels. Ik denk met plezier terug aan onze vele gesprekken, die gelukkig niet alleen over mijnwerkers gingen, maar even zo vaak over eten, drinken en muziek. Dat we nu opnieuw collega's zijn, bij het Continium in Kerkrade, doet me veel genoegen.

Promoveren naast een volledige baan is een probleem op zich. Mijn werkgever, in de persoon van directeur Hans Gubbels, ben ik er zeer erkentelijk voor dat hij op coulante wijze instemde met mijn verzoek om buitengewoon verlof, net in een tijd dat Industrion een metamorfose onderging tot Discovery Center Continium. Mijn Kerkraadse collega's dank ik voor hun begrip dat ik er vaak niet was en werk soms noodgedwongen wat langer bleef liggen dan de bedoeling was.

Het verlof gaf mij de mogelijkheid tijdelijk bij de Universiteit Maastricht in dienst te treden, waar ik, dankzij financiële steun van de Nederlandse Organisatie voor Wetenschappelijk Onderzoek, aan deze studie kon werken. Mijn werkplek kreeg ik bij het Sociaal Historisch Centrum voor Limburg (SHCL), waar ik me vanaf de eerste dag volledig opgenomen wist in een hecht team.

Voor mijnbouwhistorisch onderzoek zijn de collecties van het SHCL en het Regionaal Historisch Centrum Limburg (RHCL) een ware Fundgrube. De medewerkers van beide instellingen ben ik dankbaar voor hun assistentie bij het opsporen, opvragen en bewerken van de soms zeer omvangrijke reeksen van bronnen. Een speciaal woord van dank wil ik richten aan Erwin Steegen, die bereid was zijn deskundigheid op het gebied van het Geografisch Informatiesysteem (GIS) in te zetten bij het vervaardigen van het kaartmateriaal voor dit boek. Mijn dank gaat verder uit naar Annemie de Bruin, Carin de Bruin ( $\downarrow)$, Thei Dibbets, Roos Dullens ( $\downarrow$ ) en Corrie van Lith die als enthousiaste vrijwilligers vele duizenden cijfermatige en andere gegevens invoerden in databases. Helaas moet aan twee van hen dit een postuum dankwoord zijn.

De directie van het AZL in Heerlen dank ik voor de toestemming die ik kreeg om een steekproef te trekken uit de kaartadministratie van het Algemeen Mijnwerkersfonds die er wordt bewaard. Bij de praktische uitvoering van de steekproef ten kantore van het AZL waren Jan Meijers en zijn medewerkers van de afdeling Mijnpensioenen zeer behulpzaam. De 
resultaten van de steekproef vormen een van de fundamenten van deze studie.

Voorts een woord van dank aan mijn collega's in Maastricht en Kerkrade die betrokken waren bij het drukklaar maken van het manuscript voor de uitgever. Ella Muyres-Schilder en Willibrord Rutten van het SHCL namen de tekst kritisch door, hielden de tijdsplanning in de gaten en zorgden voor de communicatie met de uitgever. Paul Arnold (SHCL) en Mijke Harst-Van den Berg (Continium) droegen zorg voor het scannen en digitaal fotograferen van het beeldmateriaal voor dit boek.

Last but not least ben ik het bestuur van de Stichting Maaslandse Monografieën erkentelijk voor de bereidwilligheid deze studie in de gelijknamige reeks op te nemen.

Maastricht, juli 20II 


\section{Hoofdstuk I \\ Arbeidsmarktonderzoek en Nederlandse steenkolenmijnbouw}

\section{DE ARBEIDSMARKT VOOR MIJNWERKERS}

Met de opening van de Oranje-Nassau Mijn in Heerlen in I899 ging de Nederlandse mijnbouw een nieuwe periode in. Vergeleken met de traditionele mijnbouw die van oudsher in Kerkrade was geconcentreerd, werd de steenkolenwinning in de twintigste eeuw gekenmerkt door grootschaligheid. De nieuwe mijnen verschenen in een betrekkelijk klein gebied in het zuiden van de provincie Limburg. De mijnstreek strekte zich uit van de Duitse grens bij Kerkrade in het oosten tot aan de Maas ter hoogte van Geleen in het westen. Aan de Duitse kant van de grens ging het Nederlandse mijngebied over in het kolenbekken rond de stad Aken. Daar was de steenkolenmijnbouw, die er, net als in Kerkrade, terugging tot de Middeleeuwen, in de loop van de negentiende eeuw geëxpandeerd. ${ }^{\mathrm{I}}$ Ten westen van de Maas sloot het Kempische kolenbekken aan op de Nederlandse mijnstreek. De exploitatie van de kolenlagen in de Kempen ging in het begin van de twintigste eeuw van start. ${ }^{2}$

De ontwikkeling van de mijnbouwsector betekende een grondige transformatie van de regio, waar de economie en de arbeidsmarkt traditioneel in hoofdzaak waren gebaseerd op landbouw en kleinschalige plattelandsnijverheid. Met de komst van de mijn veranderde de structuur van de regionale arbeidsmarkt. Kwalitatief, doordat nieuwe beroepsdeelmarkten ontstonden, gerelateerd aan de mijnbouwsector. ${ }^{3}$ Ook in kwantitatieve zin deed de mijnbouw een zwaar beroep op de regionale arbeidsmarkt. De vraag naar mijnwerkers was enorm. Op deze plaats kan als illustrering worden volstaan met de vaststelling dat in 1958 de Nederlandse mijnbouwsector werk bood aan ruim 60.000 mensen, terwijl dat aantal zes decennia eerder nauwelijks 500 bedroeg. ${ }^{4}$

De transformatie was een ruimtelijk langzaam opschuivend proces. Naarmate de mijnbouw in de loop van de twintigste eeuw vanuit Kerkrade in noordwestelijke richting uitbreidde, werden steeds nieuwe gebieden opgenomen in de arbeidsmarkt voor mijnwerkers. Dit proces werd gestimuleerd door de uitbreiding van de verkeersinfrastructuur en de vervoersmogelijkheden. Omstreeks I960 was vrijwel de hele provincie Limburg in het bereik van de arbeidsmarkt van de mijnbedrijven gekomen, al nam in het algemeen het rela-

\footnotetext{
I Friedrich Schunder, Geschichte des Aachener Steinkohlenbergbaus (Essen I968).

2 Luc Minten e.a., Een eeuw steenkool in Limburg (Tielt 1992); Tine De Rijck en Griet van Meulder, De ereburgers. Een sociale geschiedenis van de Limburgse mijnwerkers (Berchem 2000).

3 In de theorievorming over arbeidsmarkten wordt er algemeen van uitgegaan dat 'de arbeidsmarkt' feitelijk een conglomeraat is van allerlei deelmarkten of segmenten. Een van de lijnen waarlangs een indeling van deelmarkten kan worden gemaakt is die van beroepsspecifieke kwalificaties. Zie onder meer: H.G. Hamaker, Arbeidsmarkt en personeelvoorziening (Alphen aan den Rijn/Brussel I978 ${ }^{2}$ ) 66-67; C. de Galan en A.J.M. van Miltenburg, Economie van de arbeid (Alphen aan den Rijn I991 $^{3}$ ) 53; Jacques van Hoof, De arbeidsmarkt als arena. Arbeidsmarktproblemen in sociologisch perspectief (Amsterdam 1987) 46-49.

4 Sociaal Historisch Centrum voor Limburg (verder SHCL), Archief Gezamenlijke Steenkolenmijnen in Limburg (verder GSL), Statistiek.
} 
tieve belang van mijnarbeid op plaatselijk niveau af naarmate de geografische afstand tot de mijnbedrijven toenam. Bovendien bevond zich onder de mijnwerkers in Limburg een in de loop van de tijd in omvang fluctuerend contingent arbeidsmigranten uit Nederland-buitenLimburg en uit het buitenland. ${ }^{5}$

De opbouw, uitbouw en consolidatie van de arbeidsmarkt voor mijnwerkers in de periode I900-1965 is het centrale thema van dit boek. Uitgangspunt van de analyse is het ondernemersbeleid. Door welke overwegingen lieten de mijndirecties zich leiden in hun personeelsbeleid ten aanzien van werving, selectie en binding aan het bedrijf en welke gevolgen had dit beleid voor de samenstelling van de mijnwerkerspopulatie op korte en langere termijn? De keuze voor het ondernemersbeleid als startpunt is gemotiveerd door de vooronderstelling dat de vormgeving van de mijnarbeidsmarkt sterk werd bepaald door het beleid van de ondernemers. De vestigingsplaats van steenkolenmijnen is primair afhankelijk van geologische factoren. Het is dus geen vanzelfsprekendheid dat er voldoende geschikte arbeidskrachten in de eigen omgeving aanwezig zijn en dat betekent dat mijnondernemers een actief arbeidsmarktbeleid moesten voeren. ${ }^{6}$ Daarnaast is deze keuze ook pragmatisch bepaald door de beschikbaarheid van bronnenmateriaal. Het ondernemersbeleid ten aanzien van arbeidsmarktfacetten als werving, selectie en binding van arbeidskrachten aan het bedrijf is nu eenmaal beter (in bedrijfsarchieven en rapporten) gedocumenteerd dan het arbeidsmarktgedrag van de actoren aan de aanbodzijde. Deze keuze betekent overigens geenszins dat het arbeidsmarktgedrag van de mijnwerkers niet aan bod komt. Omdat ondernemers voor een deel reageerden of anticipeerden op het (verwachte) arbeidsmarktgedrag van (potentiële) arbeidskrachten, zijn uit ondernemersbeleid ook indirect antwoorden te distilleren op de vraag waarom en wanneer mensen bereid waren te kiezen voor het beroep van mijnwerker in de Nederlandse steenkolenwinning.

Het samengaan van beide partijen op de arbeidsmarkt voor mijnwerkers werd sterk beïnvloed door de aard van met name het werk ondergronds. 'It is invariably said by miners that pitwork can never be other than an unpleasant, dirty, dangerous and difficult job', constateerden auteurs die een mijnbouwgemeenschap in het Engelse graafschap West-Yorkshire onderzochten. ${ }^{7}$ Overal in Europese mijnbouwgebieden hadden mijndirecties moeite om geschikte arbeiders te vinden voor het zware werk ondergronds. ${ }^{8}$ Velen zochten pas hun toevlucht tot een baan in de steenkolenwinning als alternatieven om aan de kost te komen waren uitgeput. En als die alternatieven er bij een omslag van de conjunctuur weer kwamen, merkten de mijnbedrijven dat onmiddellijk aan de vrijwillige ontslagname. Dit gegeven impliceerde dat de mijndirecties zich in een moeilijke concurrentiepositie bevonden ten opzichte van andere beroepsdeelmarkten en in hun personeelsbeleid veel aandacht moesten

5 Ook op geografisch gebied kan een onderscheid tussen arbeidsdeelmarkten worden gemaakt. Onderscheiden kunnen worden de lokale, gewestelijke, nationale en internationale arbeidsdeelmarkten. Hamaker, Arbeidsmarkt, 69-7I.

6 Dick Geary, 'Rapport Session Protest, organization, and industrial relations in mining in the rgth and 2oth centuries', in: Klaus Tenfelde (ed.), Towards a social history of mining in the $19^{\text {th }}$ and $20^{\text {th }}$ centuries / Sozialgeschichte des Bergbaus im 19. und 20. Jahrhundert. Papers presented to the International History Congress Bochum, Federal Republic of Germany, September $3^{\text {td }}-7^{\text {th }}, 1989$ / Beiträge des Internationalen Kongresses zur Bergbaugschichte Bochum, Bundesrepublik Deutschland, 3.-7. September 1989 (München 1992) 559-564.

7 Norman Dennis, Fernando Henriques and Clifford Slaughter, Coal is our life: an analysis of a Yorkshire mining community (Londen I974) 38 .

8 Ad Knotter, 'Inleiding: Arbeidsmigranten en grensarbeiders. Vergelijkende perspectieven op de mijnarbeidsmarkten in het Belgisch-Duits-Nederlandse grensgebied in de twintigste eeuw', Tijdschrift voor sociale en economische geschiedenis (verder TSEG) V nummer 3 (2008) 2-29, aldaar 2-4. 
besteden aan het propageren van het werk in de mijn. Bovendien hadden de Nederlandse mijnen door hun geografische ligging tussen verschillende buitenlandse kolenbekkens ook te maken met de concurrerende deelmarkt voor mijnarbeid in aangrenzende regio's.

\section{THEORETISCH KADER}

In haar opzet sluit deze studie aan bij het sociologisch arbeidsmarktonderzoek. In de sociologie wordt arbeid niet in de eerste plaats gezien als alle menselijke activiteiten welke productie ten doel hebben, maar vooral als vorm van gedrag. ${ }^{9}$ Daarbij gaat de aandacht voornamelijk uit naar de gedragingen van vragers en aanbieders op de werkgelegenheidsmarkt. Daarmee vond de arbeidssociologie aansluiting bij ontwikkelingen in de institutionele economische arbeidsmarkttheorie, waarin de arbeidsmarkt wordt onderscheiden in een loonen een werkgelegenheidsmarkt. ${ }^{\text {10 }}$

De aandacht van klassieke en neo-klassieke economen was primair gericht op de processen van prijs- of loonvorming op de arbeidsmarkt. Die processen weken volgens hen op de arbeidsmarkt niet principieel af van andere economische markten. De prijsvorming op de arbeidsmarkt zou op dezelfde wijze als goederenprijzen tot stand komen in het vrije samenspel van vraag en aanbod. Het loonpeil zorgde er als een wetmatigheid steeds voor dat tussen de gevraagde en aangeboden hoeveelheden arbeid een evenwichtssituatie ontstond. Bij stijgend loonpeil steeg het aanbod van arbeid en daalde de vraag. Bij een dalend loonpeil was het precies andersom. De consequentie was dat bij elk loonpeil iedereen die voor die beloning wilde werken, ook een baan zou vinden. De leer impliceerde dat loonvorming en arbeidsallocatie altijd onlosmakelijk met elkaar verbonden zijn in een model van volledige mededinging. Dat model veronderstelde homogeniteit, volledige concurrentie, individuele participatie en autonome marktposities van arbeid. ${ }^{\text {II }}$

Deze (neo-)klassieke economische visie kreeg sedert de jaren twintig en dertig van de twintigste eeuw steeds meer kritiek, naarmate de economische werkelijkheid aantoonde, dat het abstracte arbeidsmarktmodel niet klopte. ${ }^{\mathrm{I} 2}$ Vooral op macro-niveau vervulde het loon zijn evenwicht brengende functie slechts in beperkte mate. De arbeidsmarkt bleek een onvolkomen markt. Institutionalistische economen vroegen aandacht voor institutionele en machtfactoren, normen en gewoonten die hun invloed op de arbeidsmarkt deden gelden. Ze betoogden dat, in tegenstelling tot veel andere markten, op de arbeidsmarkt de ontmoeting van vraag en aanbod (de ruil) en de loonvorming (prijsvorming) twee duidelijk te onderscheiden en veelal ook gescheiden processen zijn. ${ }^{13}$ Enerzijds bestaat de allo-

9 Hamaker, Arbeidsmarkt, 56.

Io Ibidem, 56. Zie ook: J.A.A. van Doorn, Arbeidsmarkt en arbeidsbestel. Brugpijlers tussen sociologie en economie. Rede uitgesproken bij de aanvaarding van het ambt van gewoon hoogleraar in de sociologie van de Nederlandsche Economische Hoogeschool te Rotterdam op 26 januari 1961 (Assen I96I) 4-6.

II Hamaker, Arbeidsmarkt, 54. Zie ook: Toni Pierenkemper, 'Historische Arbeitsmarktforschung, Vorüberlegungen zu einem Forschungsprogramm', in: Toni Pierenkemper/Richard Tilly, Historische Arbeitsmarktforschung: Entstehung, Entwicklung und Probleme der Vermarktung von Arbeitskraft (Göttingen I982) 9-36.

12 Van Doorn, Arbeidsmarkt, 4-6.

I3 In hedendaagse arbeidseconomische handboeken wordt algemeen onderschreven dat het bij een arbeidsmarkt gaat om een imperfect market. Zie onder meer Derek Bosworth, Peter Dawkins and Thorsten Stromback, The economics of the labour market (Harlow I996); Joyce P. Jacobson and Gilbert L. Skillman, Labor markets and employment relationships. A comprehensive approach (Malden/Oxford/ 
catie- of werkgelegenheidsmarkt, waar de verdeling van de aangeboden arbeidsprestaties over de vragers naar arbeid wordt geregeld, en anderzijds de loonmarkt, waar de prijzen voor de arbeidsprestatie worden vastgesteld..$^{14}$ Ook werd erop gewezen dat op de arbeidsmarkt niet het totale aanbod met elkaar in concurrentie treedt, maar dat die markt een niethomogeen, gesegmenteerd karakter heeft. Feitelijk bestaat 'de arbeidsmarkt' niet, maar is er sprake van een conglomeraat van deelmarkten, waartussen de uitwisseling beperkt is. Die deelmarkten of segmenten worden gevormd door non-competing groups, groepen die elkaar op de arbeidsmarkt nauwelijks concurrentie aandoen. ${ }^{55} \mathrm{Bij}$ de verklaring en de analyse van de arbeidsmarkt werd een belangrijke plaats ingeruimd voor sociale, culturele en emotionele variabelen, die het arbeidsmarktgedrag van vragers en aanbieders mede bepalen. ${ }^{16}$

Deze benadering werd door sociologen overgenomen. In het sociologisch arbeidsmarktonderzoek wordt gezocht naar de voorwaarden en vormen van arbeidsmarktgedrag. Een belangrijk concept in deze benadering is het begrip strategie, dat in de jaren 1970 werd ontwikkeld als reactie tegen structuralistische theorievorming. ${ }^{17}$ Deze laatste legde te veel de nadruk op de structurele bepaaldheid van maatschappelijke ontwikkelingen en de ondergeschiktheid van het individuele handelen daaraan. Het begrip strategie nuanceerde deze opvatting door de focus te richten op de mogelijkheden van individuen en groepen om invloed uit te oefenen op historische processen. Er is sprake van strategieën wanneer historische actoren bewust en doelgericht proberen de werkelijkheid naar hun hand te zetten. De strategische keuzemogelijkheden van de actoren zijn echter niet onbeperkt. Ook de aanhangers van het strategieconcept onderkennen dat economische, maatschappelijke en ideologische factoren grenzen stellen aan de handelingsvrijheid van groepen en individuen.

Voor arbeidsmarktstudies betekent deze benadering dat 'de arbeidsmarkt' niet op de eerste plaats wordt bestudeerd op basis van een abstract economisch model van vraag, aanbod en prijsvorming, maar als een sociale arena, waarin individuele en/of collectieve actoren hun eigen doelstellingen proberen te verwezenlijken door strategieën die gericht zijn op beïnvloeding van elkaars gedrag. ${ }^{18}$ De strategieën van vragers en aanbieders resulteren in sociale processen als transformatie, mobiliteit, mobilisering (rekrutering), segmentering en regulering. ${ }^{19}$

Doordat het arbeidsmarktgedrag van vragers en aanbieders wordt bepaald door een veelheid van factoren van economische, sociale, demografische, geografische, juridische en

Carlton 2004); Pietro Garibaldi, Personnel economics in imperfect labour markets (Oxford 2006); Tito Boeri and Jan van Ours, The economics of imperfect labor markets (Princeton and Oxford 2008).

14 Hamaker, Arbeidsmarkt, 56-57.

15 De Galan en Van Miltenburg, Economie van de arbeid, 53, 157.

16 Robert M. Solow, The labor market as a social institution (Cambridge Ma 1990) 4-20. Volgens Solow wijkt de werking van de arbeidsmarkt af van die van andere markten, doordat bij arbeidsmarktpartijen common sense een rol speelt. Dat 'gezonde verstand' zorgt ervoor dat de harde economische marktwerking wordt afgezwakt door overwegingen van billijkheid, rechtvaardigheid en sociale status.

17 Michiel Baud en Theo Engelen, 'Nawoord: arbeid, inkomen en gezinsstrategie', in: Michiel Baud en Theo Engelen, Samen wonen, samen werken? Vijfessays over de geschiedenis van arbeid en gezin (Hilversum 1994) I49-I58.

I8 Van Hoof, Arbeidsmarkt, I77-I8I.

19 Leo Noordegraaf, 'Arbeid en arbeidsmarkt; Recent onderzoek in historiografisch perspectief', Tijdschrift voor Sociale Geschiedenis (verder TuSG) XIII (november 1987) 357-372, aldaar 359-368. Voor een praktische toepassing van het strategieconcept in historische arbeidsmarktstudies: Bart Pluymers, De Limburgse mijnwerkers (1917-1939); Ontstaan en consolidatie van de arbeidsmarkt voor mijnarbeid (Limburgs Universitair Centrum, Diepenbeek 1996). Een verkorte versie van het rapport verscheen als artikel: Mieke Van Haegendoren/Bart Pluymers, 'Belgisch-Limburgse mijnwerkers in de jaren twintig; Willige slachtoffers van het kapitaal of een blauwe-maandag compagnie?’ TvSG XXIV (I998) 3I-55. 
In de lampisterie van de Julia. Voorman Martin Hanssen geeft een petlamp met accu en een benzinelamp aan houwer Aloys Hendriks. 1951. Bron: Fotocollectie Continium Kerkrade, F2701.

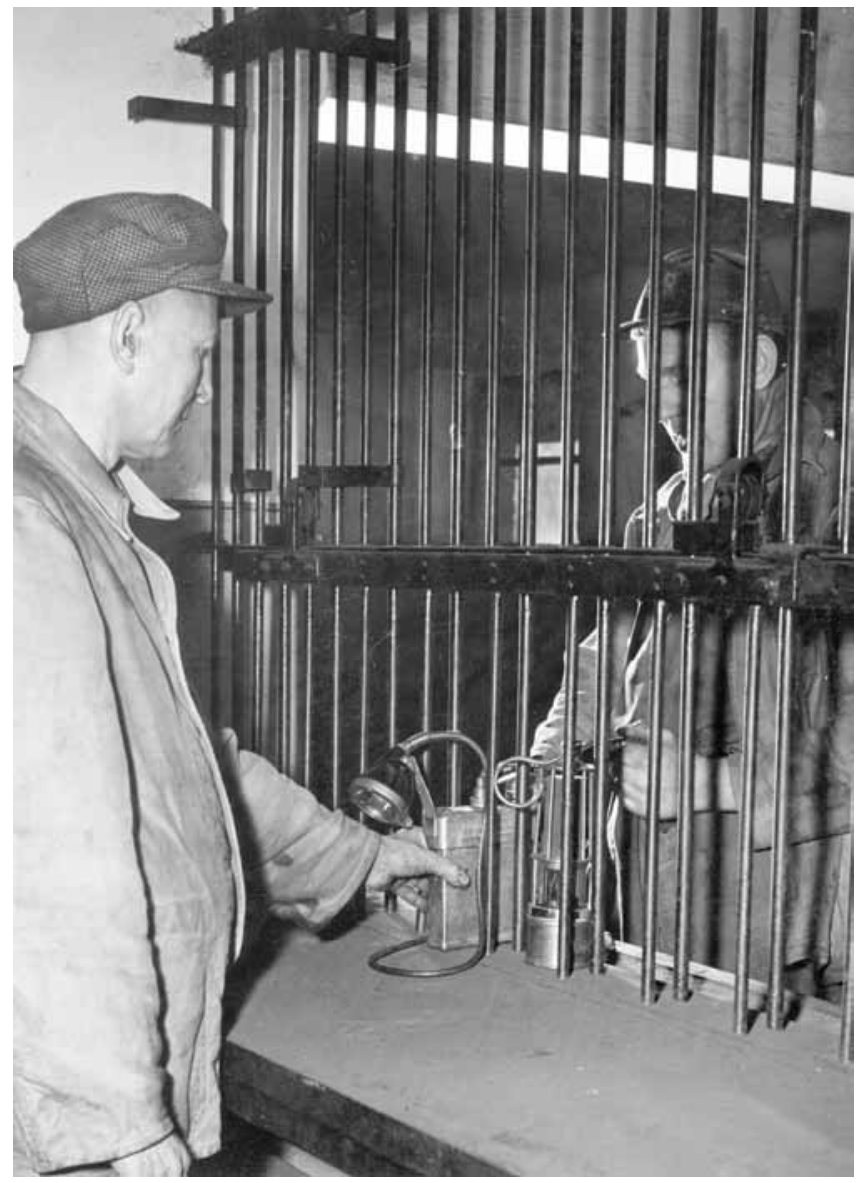

culturele aard, is de bestudering van het functioneren van de arbeidsmarkt interessant als ingang tot integraal interdisciplinair onderzoek. Integraal dient hier te worden opgevat in de betekenis van 'in onderlinge samenhang'. ${ }^{20}$

\section{MIJNBOUW IN DE HISTORIOGRAFIE}

Over de geschiedenis van de steenkolenmijnbouw bestaat internationaal een bibliotheek aan studies. Hieronder worden slechts enkele grote lijnen geschetst met de nadruk op de mijnbouw in Nederland.

De focus in internationale studies over mijnbouwgeschiedenis is traditioneel gericht op de arbeidsverhoudingen. Het onderzoek richtte zich aanvankelijk op de organisaties van mijnwerkers en hun werkgevers, alsmede op de ideologieën achter deze organisaties. De 
laatste kwart eeuw werden in deze onderzoekstraditie nieuwe gezichtspunten geïntroduceerd op basis van theorieën over gender, etniciteit en processen van klassenvorming. ${ }^{21}$ Bovendien werd steeds vaker de regio als niveau van onderzoek gehanteerd. Een regionale benadering bood de mogelijkheid meer in detail op het thema van onderzoek in te gaan en dat maakte de vergelijking met andere regio's mogelijk. Het was vooral Klaus Tenfelde die de regionale aanpak voor de bestudering van de sociale verhoudingen in mijnbouwregio's bepleitte en met succes vorm gaf. ${ }^{22}$

In Nederland was het thema van de arbeidsverhoudingen in de steenkolenmijnbouw tot omstreeks 1970 ingebed in een katholieke sociologische traditie. ${ }^{23}$ Het onderzoek, met Remigius Dieteren als voornaamste exponent, kenmerkte zich in het algemeen door een sterk moralistische benadering. Zo legde Dieteren in zijn proefschrift over de migratie in de mijnstreek een verband tussen migratie en criminaliteit. ${ }^{24}$

In de loop van de jaren zestig sloeg de sociale geschiedenis van de Limburgse mijnstreek een andere richting in. Meer en meer werd het katholieke perspectief verlaten. Dat gold bijvoorbeeld voor de thema's van sociale verandering, mobiliteit, migratie en integratie. Brassé en Van Schelven kwamen in I980 met een rapport, waarin de assimilatie van enkele groepen buitenlandse migranten in de mijnstreek werd behandeld. ${ }^{25}$ Aan migratie en de rol van migranten in het Limburgse mijnbedrijf en de Limburgse samenleving werd daarna enige tijd weinig aandacht meer besteed, totdat het thema omstreeks I99o opnieuw op de agenda van onderzoekers kwam. Dat leidde onder meer tot een aantal studies over mijnwerkers van Poolse, Sloveense en Marokkaanse afkomst. ${ }^{26}$

Het duidelijkst kwam het veranderde perspectief tot uiting in het proefschrift van Loek Kreukels. ${ }^{27}$ Kreukels analyseerde in zijn boek de arbeidsverhoudingen in de Nederlandse mijnbouw tussen I900 en I940 aan de hand van het kernbegrip sociale controle, ontleend aan de marxistische traditie. In zijn analyse behandelde Kreukels en passant ook een aantal aspecten van de arbeidsmarkt, zoals de loonontwikkeling en het personeelsbeleid van de mijnondernemingen. Deze aspecten kregen ook de aandacht in detailstudies. ${ }^{28}$

2I Voor een overzicht zie: Stefan Berger, Andy Croll and Norman La Porte (ed.), Towards a comparative history of coalfield societies (Aldershot/Burlington 2005) I-II.

22 Tenfelde, Towards a social history of mining; Gerald D. Feldman and Klaus Tenfelde (ed.), Workers, owners and politics in coal mining. An international comparison of industrial relations (New York/Oxford/Munich I990).

23 Voor een overzicht van de Limburgse mijnbouw in de historiografie: B.P.A. Gales en E.J.G. van Royen, 'De fabrikanten van de geschiedenis: sociaal-economische geschiedschrijving en Limburg', Publications de la Société Historique et Archéologique dans le Limbourg CXXV (I989) I26-184, aldaar I50-162.

24 Remigius Dieteren, De migratie in de Mijnstreek 1900-1935. Een sociaal-historische studie (Maastricht 1959).

25 Paul Brassé en Willem van Schelven, Assimilatie van vooroorlogse immigranten. Drie generaties Polen, Slovenen en Italianen in Heerlen ('s-Gravenhage I980).

26 A.P. Versteegh, De onvermijdelijke afkomst? De opname van Polen in het Duits, Belgisch en Nederlands mijnbedrijf in de periode 1920-1930 (Hilversum 1994); Stephan Wojtkowiak, Je moet weten hoe haas hupt. Herinneringen aan een microkosmos in Limburg (Schinveld 2000); Frans Wojciechowski, Voor brood en urijheid. Honderd jaar Polen in Zuid-Limburg 1900-2000 (Heerlen 2000); idem, 'Het Poolse huis in Brunssum 1937-2002. 65 Jaar brandpunt van Pools verenigingsleven in Zuid-Limburg', Brunssumse Geschiedenissen (Brunssum 2002) 9-52; idem, 'Zij kwamen van ver Towarzystwo Sw. Wojciecha w Heerlen I910-20ro. De geschiedenis van de oudste Poolse vereniging in Nederland', themanummer Het Land van Herle (Heerlen 20Io); Milena Mulders, Met de buik het brood achterna. Mijn Sloveense geschiedenis (Amsterdam 2009); Tanja Cranssen, 'Marokkaanse mijnwerkers in Limburg, I963-1975', Studies over de sociaal-economische geschiedenis van Limburg (verder SSEGL) XLVIII (2003) I2I-I48.

27 L.H.M. Kreukels, Mijnarbeid: volgzaamheid en strijdbaarheid. Geschiedenis van de arbeidsverhoudingen in de Nederlandse steenkolenmijnen (Assen/Maastricht 1986).

28 Ik noem hier slechts: G.C.M. Vromen, 'Personeelsbeleid bij de Nederlandse mijnen tijdens de jaren dertig', SSEGL XXXII (I987) 27-79; J.M.G. Pieters, Lonen en bedrijfsresultaten bij de Nederlandse steenkolenmijnondernemingen in de Gemeenschappelijke Steenkolenmarkt van de EGKS (Rotterdam I98I); E.J.G. van Royen, 'Beheersaspecten in het huisvestingsbeleid van mijnondernemingen en roomskatho- 
Economische en technische aspecten stonden lange tijd minder in de belangstelling van onderzoekers en auteurs. Raedts behandelde in zijn degelijke handboek over de geschiedenis van de Limburgse steenkolenmijnbouw ook economische aspecten. ${ }^{29}$ De economische motieven achter de sluiting van de Nederlandse mijnen namen een belangrijke plaats in in de omvangrijke studie van Messing..$^{\circ}$ Peet en Rutten publiceerden een uitgebreide geschiedenis van de Oranje-Nassau Mijnen vanuit bedrijfseconomisch perspectief. ${ }^{3 \mathrm{I}}$

Op het gebied van de techniekgeschiedenis van de steenkolenmijnbouw dient vooral te worden gewezen op het werk van Ben Gales. Gales richtte zich voornamelijk op de achttiende- en negentiende-eeuwse mijnbouw, onder andere in zijn proefschrift, ${ }^{32}$ maar van zijn hand verschenen ook studies over de ontwikkeling van de techniek in de steenkolenwinning in de twintigste eeuw. 33

Arbeidsmarktaspecten ontbreken in dergelijke studies allerminst. Een integrale interdisciplinaire benadering van deze aspecten, in combinatie met een langetermijnanalyse, kwam ik echter niet tegen. Door deze aanpak van de historische bestudering van de mijnarbeidsmarkt onderscheidt dit proefschrift zich van eerder onderzoek.

\section{OPZET EN INDELING}

Deze studie makt deel uit van een breder onderzoeksproject, dat een langetermijnanalyse behelst van de arbeidsmarkt voor mijnwerkers in de vier voormalige mijnbouwbekkens van de huidige Euregio Maas-Rijn in vergelijkend perspectief. ${ }^{34}$ Met dit comparatieve uitgangspunt wordt aangesloten bij een van de hierboven beschreven tendensen in de internationale bestudering van de geschiedenis van mijnbouwdistricten.

Een eerste proeve van de comparatieve en grensoverschrijdende studie naar de vier mijnbouwgebieden verscheen in 2008 als themanummer in het Tijdschrift voor Sociale en Economische Geschiedenis. ${ }^{35}$ In een zestal artikelen werden verschillen en overeenkomsten bij de inzet van arbeidsmigranten en grensarbeiders in de voormalige mijnbouwgebieden belicht. Daarnaast verscheen elders een artikel waarin de aanwezigheid van buitenlandse mijnwerkers in de Nederlandse en Luikse steenkolenwinning werd vergeleken. ${ }^{36}$

lieken in Zuid-Limburg, I900-1940', in: P.M.M. Klep e.a. (ed.), Wonen in het verleden $17^{e}-20^{\ell}$ eeuw. Economie, politiek, volkshuisvesting, cultuur en bibliografie (Amsterdam I987) 8I-94.

29 C.E.P.M. Raedts, De opkomst, de ontwikkeling en de neergang van de steenkolenmijnbouw in Limburg (Assen I974).

30 F.A.M. Messing, Geschiedenis van de mijnsluiting in Limburg. Noodzaak en lotgevallen van een regionale herstructurering 1955-1975 (Leiden I988).

3I Jan Peet en Willibrord Rutten, Oranje-Nassau Mijnen. Een pionier in de Nederlandse steenkolenmijnbouw 1893-1974 (Zwolle 2009).

32 B.P.A. Gales, Ondergronds bovengronds. Techniek en markt van de Limburgse steenkolenmijnbouw gedurende de achttiende en negentiende eeuw (Capelle a/d Ijssel 2002). Het boek verscheen ook als handelseditie onder de titel Delven en slepen. Steenkolenmijnbouw in Limburg: techniek, winning en markt gedurende de achttiende en negentiende eeuw (Hilversum 2004).

33 B.P.A. Gales, 'Himmel, Hergot, Sakermint! Kool in de roetsj! Het begin van wetenschappelijk bedrijfsbeheer in de Limburgse mijnbouw in de jaren twintig' Jaarboek voor de Geschiedenis van Bedriif en Techniek (verder JbGBT) X (I993) I6I-215; idem, 'Houwen en stof bijten? Maakbaarheid in een mijnstreek', SSEGL XLV (2000) 27-64; idem (ed.), 'Delfstoffen', Techniek in Nederland in de twintigste eeuw Deel II (2000) I7-III.

34 In dit project participeren de Vrije Universiteit Brussel, de RWTH Aachen en Maastricht University. De andere dissertatieprojecten worden uitgevoerd door Leen Roels (Luikse mijnbouwbekken, MU), Kristin Klank (Akense mijnbouwgebied, RWTH) en Bart Delbroek (Belgische Kempen, VUB).

35 Ad Knotter (ed.), Themanummer 'Arbeidsmigranten en grensarbeiders', TSEG V nummer 3 (2008).

36 Serge Langeweg en Leen Roels, 'Buitenlandse arbeiders in de steenkolenmijnen van Luik en Nederlands-Limburg: een vergelijking', SSEGL LIII (2008) 89-II5. Een licht gewijzigde versie verscheen later: Serge Langeweg/Leen Roels/Ad Knotter, 'Regional 
Hoewel dit boek in eerste instantie geen systematische vergelijkende aanpak ambieert, zal voor een beter begrip van het onderwerp - de arbeidsmarkt voor mijnwerkers in Nederlands-Limburg - geregeld en waar mogelijk ook over de grens worden gekeken.

De studie beslaat de periode I900-I965. Als startpunt is gekozen voor I9oo, omdat de mijnbouw in Limburg op dat moment snel begon te expanderen. Hoewel de geschiedenis van de Limburgse steenkolenwinning werd afgesloten met de sluiting van de laatste mijn in december 1974, werd het jaar 1965 als eindpunt voor het onderzoek gemarkeerd. Op I7 december ${ }_{1965}$ kondigde minister van Economische Zaken J.M. den Uyl de sluiting van de Limburgse mijnen aan. Van een normaal functionerende arbeidsmarkt voor mijnwerkers was daarna geen sprake meer. De jaren tot 1974 stonden in het teken van een gefaseerde beeindiging van de steenkolenwinning. Voor de aanbodzijde van de arbeidsmarkt verdween daarmee elk toekomstperspectief voor een carrière in het mijnbedrijf. Voor het personeelsbeleid van de mijnen betekende de onontkoombare sluiting dat de aandacht niet primair meer was gericht op rekrutering, maar op afvloeiing, herplaatsing en omscholing. ${ }^{37}$

Het inhoudelijke gedeelte van deze studie is onderverdeeld in vijf hoofdstukken. In hoofdstuk 2 zal bij wijze van introductie op het onderwerp kort de economische ontwikkeling van opkomst, bloei en achteruitgang van de Nederlandse mijnbouw in de twintigste eeuw worden geschetst in termen van werkgelegenheid, markt en productie.

In hoofdstuk 3 verlegt zich de focus naar de aanbodzijde van de arbeidsmarkt. De demografische ontwikkeling komt hierin ter sprake. Duidelijk zal worden dat de groei van de beroepsbevolking gunstig was voor de mijnbedrijven. Tengevolge van een relatief hoog geboortesaldo en tijdelijke periodes met een hoog migratiesaldo vertoonde de Limburgse mijnstreek een bevolkingspiramide met een brede basis. Daarnaast komen in dit hoofdstuk enkele ruimtelijke aspecten van de arbeidsmarkt aan de orde. Door de expansie van de mijnbouw, het huisvestingsbeleid van de mijnondernemingen en de toenemende vervoersmogelijkheden breidde de arbeidsmarkt voor mijnwerkers zich in de loop van de twintigste eeuw als een olievlek uit over vrijwel de hele provincie.

Het centrale thema van hoofdstuk 4 is de rekruteringsstrategie van de mijnondernemingen op de regionale en nationale arbeidsmarkt. Betoogd wordt dat de mijndirecties zich lieten leiden door een beleid dat een duidelijke preferentievolgorde liet zien van lokale, regionale, provinciale, nationale en internationale arbeidskrachten. Doel van dit beleid van rekrutering van in de streek gewortelde arbeidskrachten was de vorming van een vaste en stabiele kern van mijnwerkers. Dit was echter een moeilijk proces, dat pas tijdens de crisis van de jaren 1930 met succes kon worden doorgevoerd.

Hoofdstuk 5 gaat over de voor de mijnondernemingen in principe minst preferente groep: buitenlandse arbeidskrachten. De rekrutering van mijnwerkers uit het buitenland was tot halverwege de jaren 1920 ingegeven door het gebrek aan ervaren mijnwerkers op de meer preferente arbeidsmarkten. Ervaren buitenlanders hielden de productie op peil en leidden in de pijler hun Nederlandse collega's op tot volleerde mijnwerkers. De werving van ongeschoolde buitenlandse arbeidskrachten na omstreeks I925 had vooral tot doel kwantitatieve tekorten op te vullen. Zij werden de voornaamste slachtoffers van de ontslaggol-

labour markets and international migration in twentieth-century Europe: the cases of coal mining in Liège (B) and Limburg (NL) compared', Mitteilungsblatt des Instituts für soziale Bewegungen. Forschungen und Forschungsberichte 40 (2008) IOI-I20.

37 Het proces van sluiting en herstructurering is uitgebreid beschreven in: Messing, Geschiedenis van de mijnsluiting. 
ven in de jaren dertig. Deze groep vormde een secundair segment op de arbeidsmarkt voor mijnwerkers. Datzelfde kan in het algemeen worden gezegd van de gastarbeiders die in de jaren na de Tweede Wereldoorlog vooral in mediterrane landen werden geworven.

In hoofdstuk 6 wordt onderzocht op welke wijze de mijndirecties de eenmaal geworven arbeidskrachten aan het bedrijf bonden. Het succes van deze bindingsstrategieën wordt afgemeten aan het personeelsverloop. Anderzijds wordt het verloop ook gebruikt als indicatie voor autonomiestrategieën van de mijnwerkers. De vraag wordt beantwoord in hoeverre de mijnwerkers de mogelijkheid hadden zich aan het beleid van de mijnen te onttrekken.

Een samenvatting met algemene conclusies besluit dit boek.

\section{BRONNEN EN METHODOLOGIE}

De kern van dit onderzoek is een langetermijnanalyse van aspecten van de Limburgse arbeidsmarkt voor mijnwerkers. De basis wordt gevormd door reeksen van geaggregeerd cijfermateriaal. De cijfers werden verzameld uit verschillende gepubliceerde bronnen en uit archieven, die zijn ondergebracht in de collecties van het Historisch Centrum Limburg in Maastricht. ${ }^{3}$ De belangrijkste gepubliceerde bron wordt gevormd door de jaarverslagen van de Ingenieur der Mijnen. Deze hoogste ambtenaar van het Staatstoezicht op de Mijnen, die later de rang van Hoofdingenieur en nog weer later die van Inspecteur-Generaal kreeg, publiceerde jaarlijks een lijvig rapport, waarin hij vele aspecten van het mijnbedrijf behandelde, gelardeerd met rijk cijfermateriaal, soms zelfs in retrospectieve reeksen. ${ }^{39}$ De jaarverslagen van Staatstoezicht dekken de hele onderzochte periode.

Een tweede gepubliceerde bron die van belang was bij het verzamelen van cijfermateriaal is de jaarlijkse verslaglegging door het Algemeen Mijnwerkersfonds van de Steenkolenmijnen in Limburg (AMF). In zijn jaarverslagen vermeldde dit in I9I9 opgerichte pensioenfonds veel cijfermatige gegevens over de ingeschreven mijnwerkers. Aangezien deelname aan het AMF verplicht was, geven de AMF-gegevens waardevolle informatie over de samenstelling van de mijnwerkerspopulatie op het gebied van bijvoorbeeld leeftijd en burgerlijke staat. De jaarverslagen van het AMF bestrijken de jaren vanaf igig; vanaf ig6r werden ze echter veel beknopter, wat ten koste ging van het opgenomen cijfermateriaal.

Een laatste Fundgrube voor gepubliceerd geaggregeerd cijfermateriaal wordt gevormd door de tabellen en grafieken die de Mijnindustrieraad vanaf I949 jaarlijks publiceerde. ${ }^{40}$

In de categorie archieven moet vooral worden gewezen op de kwantitatieve overzichten die de afdeling Statistiek van de Gezamenlijke Steenkolenmijnen in Limburg (GSL) samenstelde. ${ }^{4 \mathrm{I}}$ Op het gebied van bijvoorbeeld omvang en samenstelling van het personeel, pro-

\footnotetext{
${ }^{8}$ In het Historisch Centrum Limburg (HCL) werken het Regionaal Historisch Centrum Limburg (RHCL) en het Sociaal Historisch Centrum voor Limburg (SHCL) nauw samen. Op termijn wordt een fusie tussen beide instellingen beoogd.

39 Staatstoezicht op de Mijnen is een overheidsdienst, door het Franse bestuur in I8ro opgericht. De dienst is belast met het toezicht op de naleving van wettelijke bepalingen die van toepassing zijn bij het opsporen, winnen, opslaan en transporteren van delfstoffen. www.sodm.nl/organisatie. Zie ook: Van 1810 Administration des Mines tot 1960 Staatstoezicht op de Mijnen (Bijlage bij het Verslag van de Inspecteur-generaal der Mijnen over het jaar 1959).

40 De Mijnindustrieraad (MIR), een overlegorgaan van werkgevers en werknemers, werd in 1945 opgericht als publiekrechtelijke bedrijfsorganisatie in de Nederlandse steenkolenmijnindustrie. Zie bijvoorbeeld: Math. Akkermans, De publiekrechtelijke bedriifsorganisatie in de Nederlandse steenkolenmijnindustrie (doctoraalscriptie Universiteit van Amsterdam 1986).

4I De Vereniging Gezamenlijke Steenkolenmijnen in Limburg (GSL) was een belangenvereniging van werkgevers in het mijnbe-
} 
ductie, afzet, arbeidsproductiviteit, lonen en opleidingen geeft de statistiek waardevolle informatie, die in sommige gevallen doorlopende reeksen vanaf $\mathrm{Igoo}$ bevat. Ook wordt soms een uitsplitsing gemaakt op bedrijfsniveau.

Uit het bovenstaande overzicht, dat nog kan worden aangevuld met kwantitatieve gegevens uit rapporten, verslagen, interne onderzoeksnotities op bedrijfsniveau en secundaire literatuur, blijkt dat er geen gebrek is aan cijfermatig materiaal over de mijnwerkerspopulatie. Toch dienen er enkele kanttekeningen bij de beschikbare cijferreeksen te worden gemaakt. Die kanttekeningen kunnen worden gegroepeerd aan de hand van twee vragen: wie werden geteld en wanneer werd er geteld?

De mijnen maakten om te beginnen een onderscheid tussen de formele en de effectieve personeelsbezetting. De formele bezetting bestond uit de medewerkers die een 'officieel' dienstverband bij het mijnbedrijf hadden. Van die formele bezetting was in de praktijk niet iedereen beschikbaar. Militaire dienst (voor bovengronders), opleiding, buitengewoon verlof zonder behoud van loon en langdurige arbeidsongeschiktheid waren er verantwoordelijk voor dat niet iedereen die op de loonlijst stond ook effectief in het mijnbedrijf aan de slag was. Met andere woorden: de formele sterkte was altijd hoger dan de effectieve. De beschikbare cijfers geven dit verschil niet altijd aan. ${ }^{42}$

Een ander onderscheid was dat tussen medewerkers in eigen dienst en ingehuurd personeel, bijvoorbeeld via onderaannemers. Deze laatste categorie was gedurende de hele onderzoeksperiode bij de mijnbedrijven aanwezig, al was hun aandeel in de totale personeelsbezetting marginaal. In 1956 bedroeg het aandeel nauwelijks I procent. ${ }^{43}$ Ook dit onderscheid klinkt niet altijd in de gepubliceerde cijfers door.

Belangrijker voor de beoordeling van de cijfers is de hiërarchische onderverdeling die de mijnbedrijven hanteerden. De personeelsbezetting was hiërarchisch opgebouwd. Er bestond een rangensysteem van functies. Een belangrijke cesuur, zowel ondergronds als bovengronds, lag bij de functie van 'opzichter': met het bereiken van deze rang verliet de functionaris de rijen van de arbeiders en trad hij toe tot de beambten. Naarmate het bovengrondse bedrijf groeide, en zeker de chemische tak van Staatsmijnen met relatief meer geschoolde functies, nam het percentage beambten in het personeelsbestand toe. Ook de voortschrijdende mechanisatie en rationalisatie in het onder- en bovengrondse mijnbedrijf sedert de jaren twintig leidden tot een groter aantal werkzaamheden op beambtenniveau. ${ }^{44}$ Het aandeel van de beambtengroep bedroeg medio jaren zestig ongeveer 15 procent van het totale personeelsbestand bij de mijnen. ${ }^{45}$ Van dat beambtencorps waren eind 1959 bijna 2.000 functionarissen ( 26 procent) ondergronds aangesteld..$^{46}$ Dat kwam neer op gemiddeld één beambte per vijftien à zestien ondergrondse arbeiders. Bovengronds was op dat moment I 8 procent van het personeel beambte. Helaas is van de beambtengroep op geaggregeerd niveau niet veel meer dan de getalsterkte overgeleverd. Bronnen die van jaar tot

drijf. Een voorloper werd al in I904 opgericht. De GSL bleef tot het einde van de steenkolenmijnbouw in Limburg functioneren. Zie: Paul Arnold, Jac. van den Boogard en Willibrord Rutten, Historisch vademecum Limburg 1900-2000 (Maastricht 1999) 8.

42 Messing, Geschiedenis van de mijnsluiting, bijlage VI.I, 558-566.

43 Zie hoofdstuk 4.

44 Verslag van de gezamenlijke steenkolenmijnen in Limburg aan de Mijnindustrieraad betreffende de economische gang van zaken in het jaar $1960,2 \mathrm{I}$.

45 Idem [1954-I970].

46 Idem 1961, 22. 
jaar inzicht geven in de samenstelling van het beambtencorps en zijn arbeidsmarktgedrag zijn niet voorhanden. De cijferreeksen in de hierboven beschreven bronnen betreffen voornamelijk de arbeidersbezetting. Daarom behandelt deze studie hoofdzakelijk de 'arbeiders' in de mijnbedrijven. De groep beambten zal slechts incidenteel voor het voetlicht worden gebracht.

Binnen de arbeidersbezetting bestond een functionele indeling. Het aantal functies in een mijnbedrijf was groot en zeer divers. ${ }^{47}$ Er waren direct bij de steenkolenwinning betrokken ondergrondse mijnbouwkundige functies als houwer en stutter, naast meer technische als bankwerker of elektricien en ondersteunende als seingever of locomotiefmachinist. Bovengronds waren er arbeiders in de briket- en cokesfabrieken, in de kolenwasserijen, in reparatie- en metaalverwerkingswerkplaatsen en in de transportsector, naast laboranten in de chemische tak van Staatsmijnen, medisch personeel in de verbandkamers, portiers en magazijnmedewerkers, en administratieve krachten. ${ }^{48}$ Naarmate de mijnen mechaniseerden en rationaliseerden, kwamen er functies bij, terwijl andere van inhoud veranderden of zelfs verdwenen. De geaggregeerde cijferreeksen over een periode van ruim zes decennia laten niet toe op het niveau van functies te differentiëren. Dat heeft voor deze studie tot consequentie dat op geaggregeerd niveau het begrip 'mijnwerker' noodgedwongen zeer ruim gedefinieerd moest worden als 'arbeider in dienst van een steenkolenmijnonderneming'. Soms is het mogelijk te verfijnen tot het niveau van de ondergronders, waar de arbeidsmarktfricties steeds het grootst waren. In de kwalitatieve analyse zal echter waar mogelijk nog verder worden gedifferentieerd naar functies.

Ten slotte dient te worden gewezen op het tijdstip van telling. Het algemene onderscheid dat hier gemaakt kan worden is dat tussen de gemiddelde personeelsbezetting gedurende een jaar en de momentopname op 3I december van elk jaar. In de opgaven van de mijnbedrijven wordt in de meeste gevallen gewerkt met de personeelsbezetting op 3 I december. Tenzij anders vermeld, wordt in dit onderzoek hetzelfde telmoment aangehouden. Deze telmethode heeft als nadeel dat het personeelsverloop dat binnen een jaar plaatsvond buiten beschouwing blijft. Door daarnaast gebruik te maken van in- en uittredegegevens van het AMF kon dit bezwaar worden ondervangen.

De cijfermatige gegevens van de mijnondernemingen werden aangevuld met twee steekproeven, die vertrekken vanuit de aanbodzijde van de arbeidsmarkt. De eerste is een steekproef uit de Limburgse aanvragen voor nationaliteitsbewijzen. ${ }^{49}$ Vóór de Eerste Wereldoorlog waren dat verplichte documenten voor Nederlanders die zich op de Duitse arbeidsmarkt wilden aanbieden. Analyse van deze gegevens maakt duidelijk in hoeverre Limburgse arbeidskrachten werkgelegenheid in het nabije Duitsland prefereerden boven werk in de Limburgse mijnen en geeft daarmee een indruk van het arbeidsmarktgedrag van Limburgers in de opbouwfase van de Nederlandse mijnbouw.

Aspecten van arbeidsmarktgedrag van mijnwerkers in Limburg worden ook inzichtelijk gemaakt door middel van een steekproef uit de inschrijvingen in het AMF. ${ }^{\circ}$ De steekproef

47 Een helder overzicht van de diversiteit van aan de mijnbouw gerelateerde functies geeft de lijst die door het AZL in Heerlen wordt gehanteerd bij de uitvoering van de pensioenregeling van het Algemeen Mijnwerkersfonds en het Beambtenfonds: de lijst maakt onderscheid tussen 499 ondergrondse en 85 o bovengrondse functies.

48 Messing, Geschiedenis van de mijnsluiting, bijlage VI.2, 567 .

49 Deze steekproef wordt verder besproken in bijlage 9.

50 Voor een nadere uitleg over deze steekproef zij verwezen naar bijlage 8. 
maakt het mogelijk de carrière binnen de mijnbouwsector van individuele mijnwerkers te volgen. De gegevens uit de steekproef worden vooral gebruikt om de binding aan de mijnbedrijven in kaart te brengen. Daarbij kan worden gedifferentieerd naar periode van intrede en naar herkomst van de betrokkene.

$\mathrm{Al}$ het cijfermateriaal werd geanalyseerd met behulp van de omvangrijke secundaire literatuur over de regionale sociale en economische ontwikkeling, in het bijzonder die van de mijnindustrie. Onontbeerlijk was ook het rijke kwalitatieve bronnenmateriaal in de archieven van de afzonderlijke mijnondernemingen, de GSL en de Nederlandse Katholieke Mijnwerkersbond. Dit materiaal maakt het mogelijk de arbeidsmarktstrategieën van de actoren en de motieven daarachter in kaart te brengen. 


\section{Hoofdstuk 2 \\ Steenkolenmijnbouw in Nederland}

Tussen I899 en I928 werden in Limburg elf nieuwe steenkolenmijnen geopend, terwijl de oude Domaniale Mijn in Kerkrade sterk uitbreidde. De twaalf mijnzetels werden geëxploiteerd door vier particuliere ondernemingen en één staatsbedrijf. Al die mijnzetels waren nog in productie toen in december 1965 de minister van Economische Zaken J.M. den Uyl de gefaseerde beëindiging van de mijnbouwactiviteiten in Limburg aankondigde. In die periode van zes decennia transformeerde de steenkolenmijnbouw in Limburg van een marginale activiteit tot een economische monocultuur.

In dit hoofdstuk wordt bij wijze van inleiding de ontwikkeling van de mijnbouwsector kort besproken in termen van productie en werkgelegenheid. Het doel is de context te schetsen, waarin de vraagzijde van de arbeidsmarkt voor mijnwerkers functioneerde.

\section{OUDE EN NIEUWE STEENKOLENVELDEN}

Steenkolenmijnbouw in Nederland was omstreeks I850 niet meer dan een randverschijnsel. Alleen in Kerkrade, pal op de grens met Pruisen, werd steenkolen gewonnen. De mijnbouwactiviteiten in deze grensstreek, doorsneden door het riviertje de Worm, waren echter veel ouder. Sedert de dertiende eeuw, maar wellicht zelfs eerder, werden in de streek tussen Kerkrade en Aken steenkolenlagen, die hier zeer dicht aan de oppervlakte kwamen, ontgonnen. ${ }^{\mathrm{I}}$ Het Wormbekken is hiermee een van de oudste mijnbouwgebieden van Europa.

In het midden van de negentiende eeuw kende Kerkrade twee steenkolenmijnen. De Domaniale Mijn was in de Franse tijd ontstaan uit de mijnen die de abdij Kloosterrade (Rolduc) sedert 1742 exploiteerde. ${ }^{2}$ In 1845 was de mijn door de toenmalige eigenaar, de Staat der Nederlanden, verpacht aan de Aken-Maastrichtse-Spoorwegmaatschappij (AMSM). Voor negentiende-eeuwse begrippen was de Domaniale een grote mijn. ${ }^{3}$

De tweede mijn was de Neuprick. Ook deze kleinere mijn had haar wortels in het Ancien Régime. In de Franse tijd was de onderneming voortgekomen uit een ouder mijnbedrijf, de Prickkoul, waarschijnlijk daterend uit de zeventiende eeuw.4 De Neuprick was sinds

I Raedts, Opkomst, 4-6.

2 Joep Offermans, De abdij Kloosterrade - Rolduc (1104-1830) (Rotterdam 2003) 390.

3 B.P.A. Gales, 'Mijnbouw', Geschiedenis van de techniek in Nederland in de negentiende eeuw. De wording van een moderne samenleving IV (Zutphen 1993) I3-35.

4 Loek Kreukels, Kolen en kompels. De geschiedenis van de Nederlandse mijnwerkers (Amsterdam/Brussel I986) 20. 
I849 in handen van een Duitse mijnbouwmaatschappij: de Pannesheider Bergwerksverein. ${ }^{5}$

$\mathrm{Al}$ in de achttiende eeuw bestond het vermoeden dat het steenkolenterrein van het Wormbekken zich in noordwestelijke richting uitstrekte tot ver in de ondergrond van de latere provincie Limburg. ${ }^{6}$ Toch duurde het tot het midden van de negentiende eeuw voordat de belangstelling voor eventueel winbare steenkolenvoorraden toenam. De interesse werd na I850 overal groot door de opkomende industrie met zijn stoommachines en de uitbreiding van het spoorwegnet, vooral in nabije Duitse industriecentra als het Ruhrgebied. In de jaren 1850 waagden pioniers zich ook aan boorcampagnes in Zuid-Limburg. Het achttiende-eeuwse vermoeden werd op meerdere plaatsen bevestigd: inderdaad kwamen winbare steenkolenlagen in de Limburgse ondergrond voor.

In Nederland was omstreeks I850 nog steeds de mijnwetgeving van kracht die in I8Io, in de Franse tijd, was uitgevaardigd. Wat betreft de exploitatie van steenkool ging de wet uit van het concessiestelsel. Dit hield in dat exploitatie van nauwkeurig omschreven steenkoolvelden alleen was toegestaan na concessieverlening door de overheid. ${ }^{7}$

TABEL 2.I CONCESSIEAANVRAGEN VOOR DE ONTGINNING VAN STEENKOOL IN NEDERLAND, I839-I899

\begin{tabular}{|c|c|}
\hline jaren & aantal aanvragen \\
\hline I839-49 & Io \\
\hline I850-59 & I8 \\
\hline I860-69 & 2 \\
\hline I870-79 & $3 \mathrm{I}$ \\
\hline I880-89 & - \\
\hline I890-99 & 40 \\
\hline totaal & IOI \\
\hline
\end{tabular}

Bron: Rapport van de Staatscommissie, ingesteld bij Koninklijk Besluit van 26 november 1946, no 1 ('s-Gravenhage I948) 40.

Als uitvloeisel van de exploratieactiviteiten na I850 werden tot 1880 ruim vijftig concessieaanvragen bij de overheid ingediend (tabel 2.I). Het merendeel daarvan werd afgewezen, omdat de aanvragers de aanwezigheid van voldoende ontginbare kolenlagen niet konden aantonen. Met de exploitatie van de wel verleende concessies, dertien in totaal, wilde het niet vlotten. De concessionarissen zelf werden daarvoor primair verantwoordelijk gehouden. Het merendeel van hen, buitenlandse ondernemers met name, zou helemaal niet van plan zijn zelf met de aanleg van een mijn te beginnen. Artikel 7 van de mijnwet van I8ro bepaalde dat concessiebezitters niet verplicht waren tot ontginning over te gaan. Dit bood de mogelijkheid om concessies te verwerven als speculatieobject, dat men hoopte in de toekomst te kunnen verhandelen. Om deze praktijken tegen te gaan, nam de overheid na

5 Schunder, Geschichte des Aachener Steinkohlenbergbaus, I4I-I43. De Pannesheider Bergwerksverein ging in I858 op in een groter geheel: de Vereinigungsgesellschaft für Steinkohlenbergbau im Wurmrevier, die op dat moment alle mijnbedrijven in het Duitse deel van het Wormgebied in handen had.

6 Gales, 'Mijnbouw', 15.

7 In de Franse tijd moesten gegadigden de aanvraag indienen bij de Prefect van het betrokken departement; in de tijd daarna bij Gedeputeerde Staten van de provincie. 
I873 in de concessie-aktes op dat er een waarborgsom van 30 à 35.000 gulden door de aanvrager moest worden gestort. De concessionaris zou dit bedrag voor 80 procent terug ontvangen naarmate de ontginningswerken vorderden. Onbedoeld was de overheid er door deze maatregel echter debet aan, dat de ontwikkeling van de mijnbouw werd vertraagd. ${ }^{8}$ De aanleg van een mijn was een onderneming met risico's. Het aanboren van steenkool was geen garantie voor een succesvolle ontginning en zeker niet in Limburg. Het dekterrein was sterk waterhoudend en dat maakte schachtaanleg tot een lastige opgave. De enkele onderneming die het in de jaren I86o had gewaagd schachten af te diepen, kreeg al snel te kampen met zulke grote technische en daardoor ook financiële problemen, dat de pogingen moesten worden gestaakt. Kandidaat-exploitanten bedachten zich wel tweemaal voordat ze in die gegeven omstandigheden investeerden in een waarborgsom. Die aarzeling werd verder bevorderd door het ontbreken van een goed spoorwegnet in Limburg, een voorwaarde voor een rendabele mijnbouwonderneming. Toen zich in het decennium I880-189o ook nog een diepe kolencrisis in West-Europa voordeed, was het met nieuwe mijnbouwactiviteiten in Limburg voorlopig gedaan. In het decennium I880-1889 werd geen enkele nieuwe concessie voor de ontginning van steenkolen aangevraagd, zo blijkt uit tabel 2.I.

Uiteindelijk werd door slechts drie van de dertien concessie-aanvragers de waarborgsom betaald. De overige concessionarissen kregen herhaaldelijk uitstel, maar in I89o en I89I werden hun concessies bij Koninklijk Besluit vervallen verklaard. ${ }^{9}$

\section{VAN CONCESSIE TOT ONDERNEMING: DE PARTICULIERE MIJNEN}

\section{De Oranje-Nassau Mijnen ${ }^{\text {Io }}$}

Bij Koninklijk Besluit van 2 mei 1893 werd aan de twee jaar eerder opgerichte NV Maatschappij tot Exploitatie van Limburgsche Steenkolenmijnen de concessie 'Oranje Nassau' verleend. ${ }^{\text {II }}$ De concessie bestond uit een verzameling vervallen kleinere concessies, aangevuld met enkele nieuwe velden en was 3.379 ha groot, een voor die tijd ongekend groot complex van mijnvelden. ${ }^{12}$ De concessieverlening was in Limburg de belangrijkste uiting van een hernieuwde belangstelling voor de steenkoolvoorraden na de omslag van de economische conjunctuur in het begin van de jaren 1890 . Drijvende krachten achter de nieuwe onderneming waren de Nederlandse spoorwegbouwer Henri Sarolea en de Duitse mijnbouwexperts Friedrich en Carl Honigmann.

Sarolea (1844-1900) was op dat moment als directeur van de Nederlandsche Zuider Spoorwegmaatschappij betrokken bij de aanleg van een spoorwegverbinding Sittard-Heerlen-Herzogenrath. Deze verbinding, die in 1896 werd geopend, zou van grote betekenis

8 Kreukels, Mijnarbeid, 20.

9 Raedts, Opkomst, II5-II6.

Io Zie vooral: Peet en Rutten, Oranje-Nassau Mijnen.

II C.E.P.M. Raedts, 'Van een moeilijk begin naar volle ontplooiing', Oranje-Nassau Post Sluitingsnummer Mijnzetel Oranje-Nassau I en centrale bovengondse bedrijuen van de Oranje-Nassaumijnen (1974) 7-I8, aldaar II.

12 Peet en Rutten, Oranje-Nassau Mijnen, 32. 
worden bij de ontsluiting van de steenkolenlagen en de uitbouw van de mijnindustrie in het gebied rond Heerlen. ${ }^{13}$

Ondertussen was op I oktober 1893 aan de spoorweg-in-aanleg nabij het geprojecteerde station in Heerlen begonnen met het afdiepen van de schachten die het Oranje Nassauveld zouden gaan ontsluiten. Hierbij maakte men gebruik van de expertise van de mijnbouwdeskundige Friedrich Honigmann (I84I-I9I3). De familie Honigmann kende een traditie van het bedrijven van mijnbouw als ontwikkelingsprojecten. Ze legden mijnen aan, verkochten ze en ondernamen een nieuw project. Friedrich was de technisch expert van de familie. Hij ontwikkelde een eigen methode van schachtafdieping, waarvoor hij in 1894 patent ontving. De 'Honigmann-methode' was met name geschikt voor de aanleg van schachten in waterhoudend terrein. In Heerlen was sprake van 95 tot 97 meter dikke drijfzandlagen, waarin de schachten moesten worden aangelegd. Hoe lastig de schachtafdieping desondanks was, blijkt wel uit de tijd die men voor de werkzaamheden nodig had. Pas in I899, zes jaar na het begin van de aanleg, kon de eerste Oranje-Nassaumijn beginnen met produceren.

Het grote concessiegebied van de mijnonderneming gaf in de eerste decennia van de twintigste eeuw aanleiding tot de opening van nog drie mijnzetels. De in I894 aangekochte concessie 'Carl' was de basis voor een tweede zetel van de Oranje-Nassau Mijnen. Met de aanleg van de ON II in de gemeente Schaesberg werd in 1898 begonnen. Hoewel reeds in 1904 en 1905 uit de voorbereidende ondergrondse werken steenkolen werden gedolven, kwam de ON II pas in 1906 in geregelde productie. Het grote belang van een goede transportweg bleek hier eens te meer, aangezien gewacht moest worden op het gereedkomen van een spooraansluiting die de nieuwe mijnzetel verbond met de spoorlijn Sittard-Herzogenrath..$^{14}$

In juni 1908 nam de Franse commanditaire vennootschap Les Petits-Fils de François de Wendel \& Cie de Oranje-Nassau Mijnen over. De familie De Wendel had grote belangen in de staalindustrie in Lotharingen, dat sedert 1870 in Duitse handen was. De bevoorrading van de cokesfabrieken van De Wendel in Lotharingen met eigen steenkool schijnt de belangrijkste reden voor de overname te zijn geweest. De Wendel wilde zich onafhankelijk maken van de cokeskolen die tegen hoge prijzen via het Rheinisch-Westfalisches Kohlensyndikat in Essen moesten worden betrokken. De firma De Wendel had op dat moment per jaar ongeveer één miljoen ton cokes nodig voor haar hoogovens in Hayange en Joeuf. Daarvan werd 40 procent geleverd door de eigen mijnen in Hamm (Westfalen) en Crespin-Nord. ${ }^{15}$ De verwachting was dat het Oranje-Nassauveld daaraan een productie van vier- à vijfhonderdduizend ton per jaar kon toevoegen. Daartoe moest het noordelijke gedeelte van de Oranje-Nassauconcessie door een derde mijnzetel worden ontsloten. Hier verwachtte men een voorraad vetkool aan te treffen, groot genoeg om cokesfabrieken te bouwen. Nadat in het noorden van het concessiegebied nabij Heerlerheide proefboringen waren verricht, werd daar in 1912 begonnen met de aanleg van de schachten van de mijnzetel ON III. De luchtschacht van deze mijn op de Heksenberg in Heerlen, waarvan de bouw in I9I3 begon, werd later uitgebouwd tot een vierde mijnzetel: de ON IV. De ON III kwam in I917, de ON IV in 1928 in regelmatige ontginning.

13 Raedts, Opkomst, I23-I26.

I4 [W.A.J.M] Van Waterschoot van der Gracht, 'De Limburgsche steenkolenmijnindustrie gedurende de laatste 40 jaar', Veertig jaren spoor en mijnen in Zuid-Limburg, 1896-1936 (Heerlen 1936) 76-88, aldaar 79.

15 Oranje-Nassau Groep; jubileumuitgave 1893-1993 (Amsterdam z.j.) II. 
De verwachtingen over de cokeskolenvoorraad van de Oranje-Nassau Mijnen kwamen niet uit. De mijnzetels leverden voornamelijk magere kolen voor huisbrand in plaats van vetkolen, die voor de cokesfabricage nodig waren. Tot de bouw van een Oranje-Nassau cokesfabriek in de Limburgse mijnstreek kwam het niet. Al met al bleken de Oranje-Nassau Mijnen weinig te passen in de industriële bedrijvigheid van het huis De Wendel. Hoewel in het Interbellum sprake is geweest van verkoop van de Oranje-Nassau Mijnen, bleven de mijnzetels tot het laatst toe in handen van het De Wendel-concern. ${ }^{16}$

De Oranje-Nassau Mijnen waren het grootste particuliere mijnbedrijf in Nederland. De topproductie werd behaald in 1937 , toen de vier ontginningszetels samen 2,93 miljoen ton kolen naar boven haalden. Van die vier zetels leverde ON III sedert I923 het grootste aandeel in de productie. In 1958 hadden de Oranje-Nassau Mijnen de grootste personeelsbezetting in hun bestaan met 9.750 arbeiders en beambten. Het mijnbedrijf produceerde vooral huisbrandkolen, hoewel de concessievelden van de ON III en ON IV ook meer gasrijke kolen bevatten.

In I97I beëindigde de ON II als eerste van het concern de productie. Bij de ON III en ON IV, die in 1967 waren geïntegreerd, kwam de laatste steenkool in 1973 naar boven. Eind december 1974 sloot ook de ON I.

\section{De mijn Willem-Sophia}

In 1856 werd de Bergwerkvereeniging voor Nederland opgericht. De maatschappij, waarin de Duitse invloed sterk was, stelde zich ten doel de ondergrond in Limburg te exploreren op de aanwezigheid van ontginbare steenkoollagen. Vooral in het oostelijk gedeelte van ZuidLimburg leverden boringen gunstige resultaten op. Voor de Bergwerkvereeniging was dat aanleiding twee concessies aan te vragen, die door de regering werden verleend onder de namen 'Willem' (I860) en 'Sophia' (I86I). De concessies waren respectievelijk 458 ha en 649 ha groot. ${ }^{17} \mathrm{Op}$ I2 juli I 862 begon het uitdiepen van een ontginningsschacht in het gehucht Ham (gemeente Kerkrade). Het waterhoudende dekterrein bleek enorme problemen mee te brengen. Weliswaar bereikte men in 1878 eindelijk op $5 \mathrm{I}$ meter diepte het carboon, maar ook toen was de watertoevloed te groot om de operatie tot een succes te kunnen maken. De mislukking betekende het einde van de Bergwerkvereeniging, die in I88I failliet werd verklaard.

De conclusie lag voor de hand dat het met de beschikbare techniek kennelijk niet mogelijk was de velden Willem en Sophia vanuit een schacht bij Ham te ontginnen. Vandaar dat een nieuw initiatief om de steenkolenlagen in deze concessies te ontginnen, begon met verkenningsboringen op andere plaatsen. Toen deze behoorlijke resultaten opleverden, kwam een nieuwe maatschappij tot stand: de SociétéAnonyme des charbonnages Néerlandais Willem et Sophia. Deze groep, bestaande uit Franstalige Belgische mijnondernemers uit le Centre, nam in 1898 de failliete boedel over. In I899 begon de onderneming met de aanleg van twee schachten bij Spekholzerheide (Kerkrade). De werkzaamheden werden uitgevoerd volgens een nieuw ontwikkeld procedé: de bevriesmethode. ${ }^{18} \mathrm{Bij}$ deze methode van schachtaanleg bevroor men

I6 Raedts, 'Van een moeilijk begin', I8.

17 Rapport van de Commissie voor de Mijnen, ingesteld bij Koninklijk Besluit van 17 April 189g, no 50 (z.p. Igoo) I4.

18 Raedts, Opkomst, Io6-iı3. 
de drijfzandlagen, waar doorheen de schacht moest worden afgediept. Op die manier kregen die lagen voldoende stevigheid, zodat instortingen tijdens de aanleg werden voorkomen.

In 1902 kwam de mijn Willem-Sophia in geregelde productie. Het was gemeten naar productie en personeelsbezetting het kleinste mijnbedrijf van Nederland, met slechts één ontginningszetel. In 1937 bereikte de mijn haar grootste jaarproductie met 503.000 ton. Het topjaar wat betreft de personeelsbezetting was I959, toen de Willem-Sophia 2.007 arbeiders en beambten in dienst had. De Willem-Sophia produceerde huisbrandkolen. De mijn sloot in $1970 .{ }^{19}$

\section{Laura \& Vereeniging}

Nadat proefboringen hadden aangetoond dat ontginbare steenkoollagen in de ondergrond aanwezig waren, verleende de overheid bij Koninklijk Besluit van 9 september 1876 op verzoek van de molenaar A.H. Wackers uit Herzogenrath en diens zwager G.A. Schümmer uit Kohlscheid concessie voor het veld 'Laura' met een oppervlakte van 457 ha. Een andere concessie, in het noorden aansluitend bij het Lauraveld, werd bij Koninklijk Besluit van I8 februari 1877 toegewezen aan de Vereinigungsgesellschaft für Steinkohlenbergbau im Wurmrevier. Deze concessie, met de naam 'Vereeniging', was 454 ha groot. ${ }^{20}$ Toen Wackers en Schümmer in 1887 niet in staat bleken de in de concessie-akte vereiste waarborgsom te voldoen, nam de Vereinigungsgesellschaft, samen met de Eschweiler Bergwerksverein (EBV) de concessie Laura over. Door deze samenvoeging van beide concessies ontstond een aaneengesloten mijnveld van ruim goo ha.

Op 26 juni 1899 werd in Brussel de Société des Charbonnages Réunis Laura et Vereeniging S.A. opgericht. De initiatiefnemer was de zakenman Albert Thijs (I849-I9I5) die fortuin had gemaakt in Congo. De kort tevoren door Thijs opgerichte Banque d'Outremer was de voornaamste aandeelhouder. ${ }^{21}$ Andere deelnemers waren de Amsterdamse Bank en het bankiershuis Oppenheim uit Keulen. De Vereinigungsgesellschaft en de EBV brachten de concessies Laura en Vereeniging in. ${ }^{22}$ De vennootschap was statutair gevestigd in Brussel met een administratieve en productiezetel in Eygelshoven onder de naam 'Maatschappij tot exploitatie der Steenkolenmijnen Laura \& Vereeniging'. ${ }^{23}$

In 1900 werd begonnen met het afdiepen van de schachten van de mijn Laura in Eygelshoven volgens de bevriesmethode. De aanleg werd ernstig bemoeilijkt door grote wateroverlast en vele andere tegenslagen. Pas in 1907 was er sprake van een geregelde productie in de mijn Laura. De mijn was sinds I9or aangesloten op de spoorlijn Sittard-Herzogenrath. ${ }^{24}$

I9 In 1952 was de beschikbare kolenvoorraad van de mijn uitgebreid door de verwerving van de concessie Melanie van de Eschweiler Bergwerksverein (EBV), die de meeste mijnzetels in het Duitse mijnbouwbekken rond Aken exploiteerde, Steenkool (1952) 84-85.

20 G. Brouns, Uit de geschiedenis van Laura \& Vereniging (Eygelshoven I975) I-5.

2I In 1928 zou de Banque d'Outremer fuseren met de Société Générale de Belgique, die voortaan de grootste aandeelhouder van Laura \& Vereeniging was.

22 De Vereinigungsgesellschaft en de EBV fuseerden in I907, waarmee een van de grootste mijnbouwbedrijven in Duitsland ontstond.

23 Paul Arnold, 'Laura en Julia. Een kleine geschiedenis van de Naamloze Vennootschap Laura \& Vereeniging', SSEGL L (2005)

I39-I72, aldaar I42.

24 Brouns, Geschiedenis, $18-27$. 


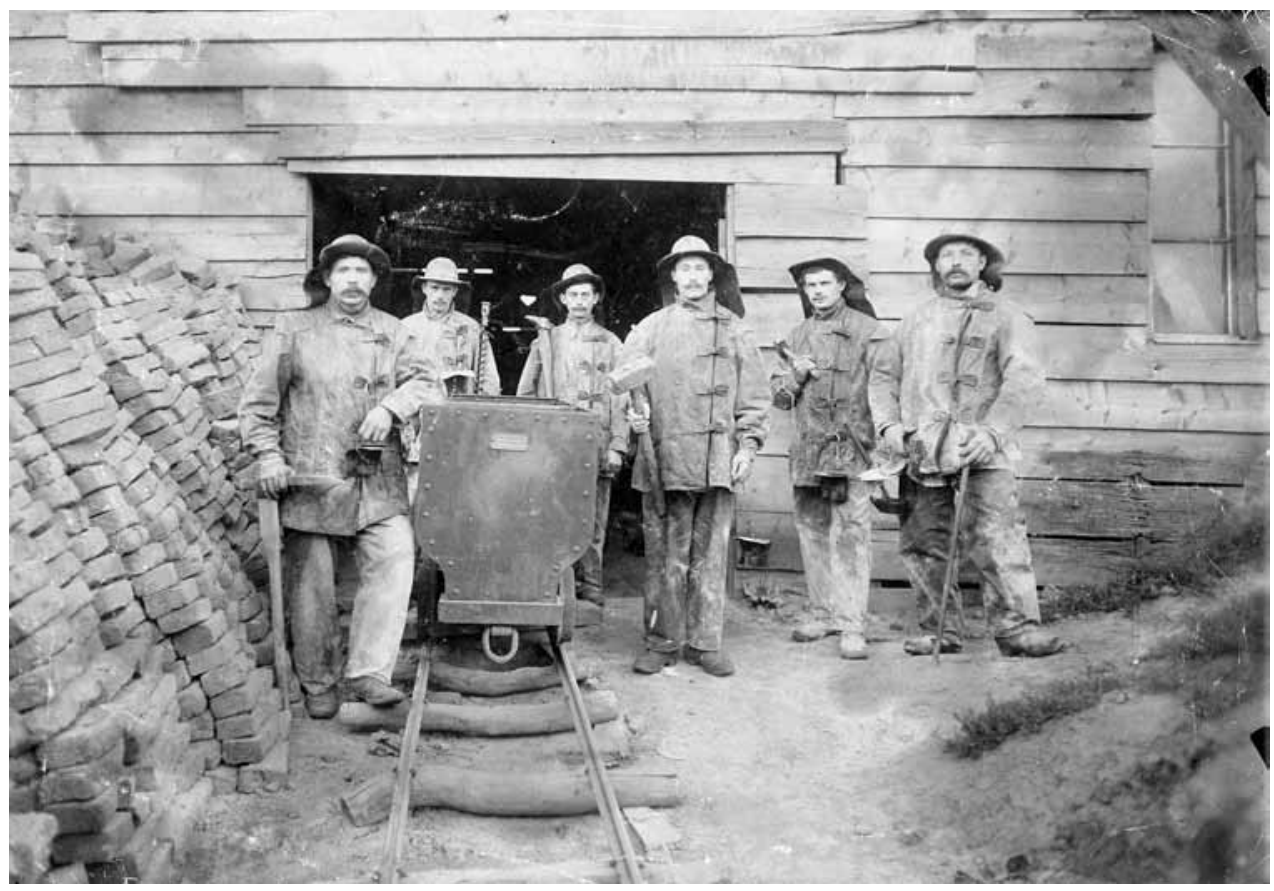

Schachtwerkers bij het afdiepen van schacht I van de Laura. 1901. Bron: Fotocollectie Continium Kerkrade, F2840.

De velden 'Laura' en 'Vereeniging' werden doorsneden door de sterk waterhoudende Feldbiss-storing. Deze geologische breuk had ertoe geleid dat de kolenlagen in de concessie Vereeniging ongeveer tweehonderd meter dieper lagen dan die in het Lauraveld. Doorbreking van de Feldbiss-storing en ontginning van de daarachter gelegen lagen vanuit de schachten van de Laura achtte men onmogelijk. ${ }^{25}$ Bovendien was geconstateerd dat een deel van de kolenvoorraad achter de breuk een hoger gehalte aan gas bevatte. Het bovengrondse bedrijf van de Laura, dat gasarme huisbrandkolen verwerkte, was niet ingericht voor andere steenkoolsoorten. ${ }^{26} \mathrm{Al}$ die complicaties makten de bouw van een tweede, zelfstandige mijnzetel onontkoombaar. Om die economisch rendabel te doen zijn, was echter uitbreiding van het concessieveld noodzakelijk. Die uitbreiding vond men in het aangrenzende veld 'Eendracht' dat sedert I9II in bezit was van Staatsmijnen. Na lange onderhandelingen stemden de overheid en het Staatsmijnbedrijf in met de verkoop van een deel (299 ha) van 'Eendracht' aan Laura \& Vereeniging. ${ }^{27}$ In I92I werd in het oosten van de gemeente Eygelshoven begonnen met de aanleg van de schachten voor de nieuwe mijnzetel: de Julia. De Julia kwam in 1928 in regelmatige productie. Bij de aanleg was de Julia een van de modernste mijnen van Europa. De Julia produceerde naast huisbrand ook kolen met een hoger gasge-

25 Door nieuwe technieken en het onttrekken van grote hoeveelheden water aan de Feldbiss als gevolg van de mijnbouw, lukte het in resp. 1942, 1959 en 1968 de mijnen Laura en Julia ondergronds met elkaar te verbinden.

26 Arnold, 'Laura en Julia', I46-I47.

27 De concessie Eendracht lag ten oosten van de concessie Vereeniging, en strekte zich uit tot aan de grens met Duitsland. Door de samenvoeging was de oppervlakte van het veld Vereeniging uitgebreid tot $702 \mathrm{ha}$. In de jaren 1950 werd het concessiegebied van Laura \& Vereeniging opnieuw vergroot door de verwerving van het Duitse veld 'Vorwärts-Erweiterung' (264 ha) van de EBV. 


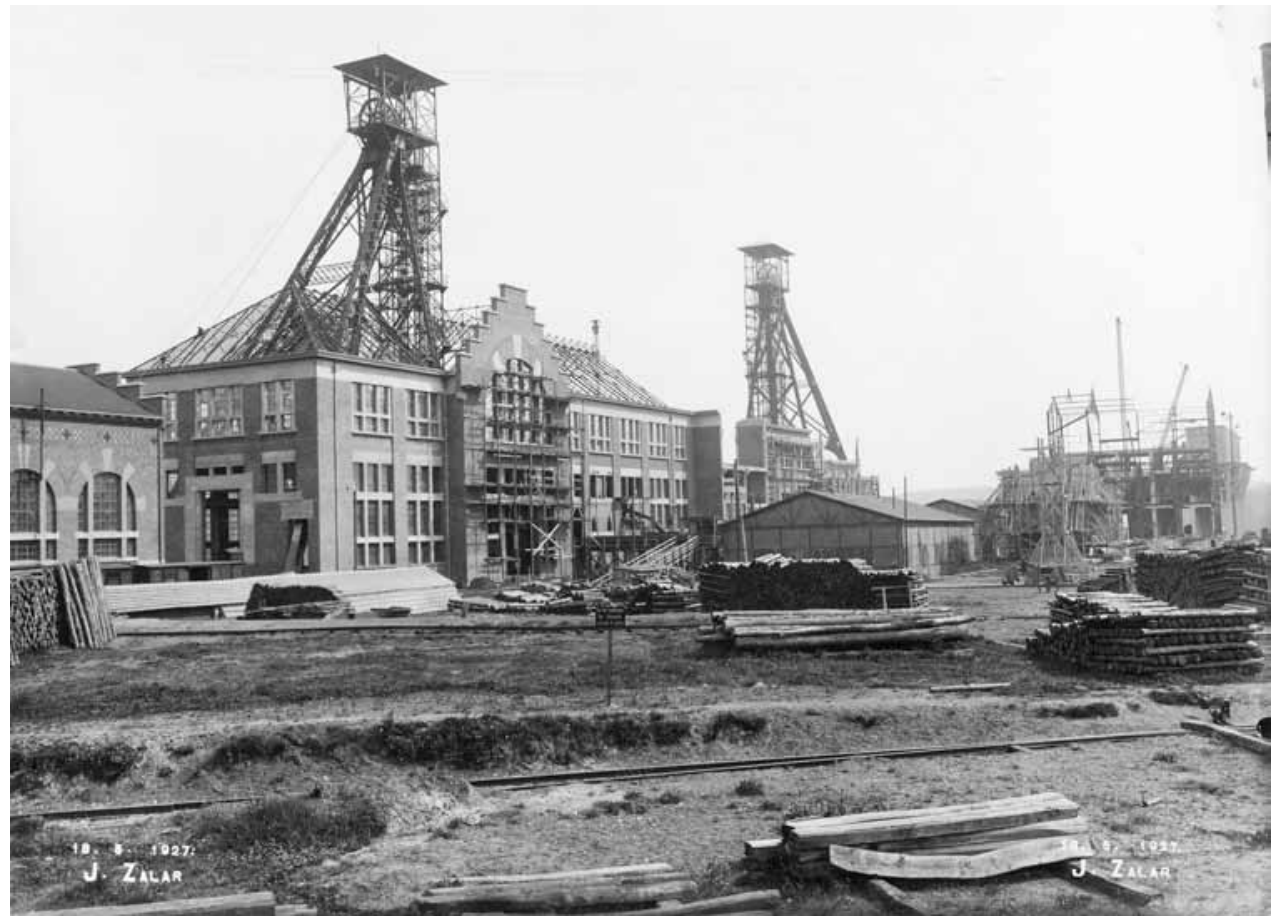

Het schachtgebouw, de wasserij en zeverij van de Julia in aanbouw. 1927. Bron: Fotocollectie Continium Kerkrade, F2639.

halte. Met name in het veld Eendracht kwamen kolenlagen voor met een gasgehalte van Io tot 13 procent. In het noordoosten van deze concessie vond men zelfs lagen met een gasgehalte van 20 tot 25 procent, dus geschikt voor cokes. ${ }^{28}$ Een eigen cokesfabriek bezat Laura \& Vereeniging echter niet.

Aan het eind van 1967 tekende zich de naderende sluiting van de Laura af. Na een geleidelijke concentratie van bovengrondse werkplaatsen, magazijnen en diverse diensten op de Julia, werd het ondergrondse personeel in zijn geheel naar de Julia overgeplaatst. De werkpunten in het Lauraveld waren vanuit de Julia bereikbaar via een verbindingssteengang op de 365-verdieping. De in de Laura gedolven kolen werden aanvankelijk wel nog via de schachten van deze mijnzetel naar boven gebracht; verdere verwerking vond echter plaats op de Julia. In I 970 werd de mijn Laura gesloten. ${ }^{29}$ Op 20 december 1974 kwamen de laatste Julia-kolen naar boven.

Laura \& Vereeniging had haar grootste productie in 1937 met I, 55 miljoen ton. Tot vlak na de Tweede Wereldoorlog ontliep het productiepeil van beide mijnzetels elkaar niet veel, maar vanaf 1947 nam de Julia steeds het grootste deel van de totale productie voor haar rekening. De top in de personeelsbezetting bereikte Laura \& Vereeniging in 1958 , toen 5.298 arbeiders en beambten in dienst waren. 


\section{De Domaniale Mijnmaatschappij}

Zoals hierboven vermeld, verpachtte de Staat der Nederlanden in I845 de Domaniale mijn aan de Aken-Maastrichtse-Spoorwegmaatschappij (AMSM). ${ }^{\circ}$ De pachtovereenkomst, met een duur van 99 jaar, was een compensatie voor het grote risico dat met de aanleg van de spoorweg was verbonden..$^{3 \mathrm{r}}$ De mijn zou het welslagen van het project moeten garanderen. Andersom kon de Domaniale van de spoorweg profiteren: verwacht werd dat het transport van de steenkool per spoor uitbreiding van de markt zou betekenen. ${ }^{32}$ Van deze verwachtingen kwam echter in de negentiende eeuw niet veel terecht: de spoorwegmaatschappij leidde een kwijnend bestaan, dat slechts door de opbrengsten van de mijn kon worden gerekt. De uitbreiding van de markt voor de antraciet van de Domaniale door aansluiting op het spoor, viel eveneens tegen. ${ }^{33}$ Toch zou de oude Domaniale zich in de twintigste eeuw ontwikkelen tot een moderne mijn. Vooral na I897 gingen de ontwikkelingen snel.

De jaren I897 en I898 markeerden de omslag bij de AMSM van voornamelijk spoorwegactiviteiten naar in hoofdzaak mijnexploitatie. In I897 nam de Belgische Staat alle op haar grondgebied geëxploiteerde spoorlijnen over. Ook het Belgische tracé van de lijn AkenMaastricht-Hasselt werd gekocht. Een jaar later verwierf de Königliche Eisenbahn Direktion Köln het Duitse deel. Het op Nederlands grondgebied gelegen gedeelte van de spoorlijn kwam in handen van de Nederlandse Staat. De verbinding, die in de overeenkomst van I845 was gelegd tussen de mijnontginning en de spoorwegexploitatie, kwam door deze transactie te vervallen. De Nederlandse regering ging bij Koninklijk Besluit van 24 augustus I9oo akkoord met een statutenwijziging, waarin was vastgelegd dat de activiteiten van de AkenMaastrichtse Spoorwegmaatschappij zich zouden beperken tot het beheer en genot van de aan het Koninkrijk der Nederlanden toebehorende steenkolen aan de Worm. Het concessiegebied van de mijn had een oppervlakte van 690 ha, waarvan 173 ha onder Duits grondgebied lag. Het grootste gedeelte van het aandelenpakket bleef in Duitse handen, totdat in I9I9 de Rotterdammer Willem van der Vorm (I873-I957) erin slaagde het te verwerven voor de Scheepvaart- en Steenkolenmaatschappij, die als belangrijkste importeur van Engelse kolen een voorname rol speelde op de Nederlandse steenkolenmarkt. Het in Nederlandse handen overgaan van het aandelenpakket had tot gevolg dat in I925 de naam Aken-Maastrichtse Spoorwegmaatschappij werd gewijzigd in Domaniale Mijn Maatschappij NV. ${ }^{34}$ De duur van het pachtcontract met de Nederlandse Staat werd verlengd tot 3I december I952. $\mathrm{Na}$ die datum werd overeengekomen dat de overeenkomst zou gelden voor onbepaalde tijd tot wederopzegging door een van beide partijen. Voor deze constructie was gekozen, omdat onzekerheid bestond over de kolenvoorraad van de mijn. Wanneer de onderneming kon aantonen dat verdere exploitatie van de kolenlagen niet langer economisch verantwoord was, had zij het recht de overeenkomst met de Staat te ontbinden. Van deze clausule werd gebruik gemaakt in de jaren zestig, toen duidelijk was dat de steenkolenmijnen op afzien-

\footnotetext{
30 Voor een beschrijving van de totstandkoming van deze maatschappij: A.H. Jenniskens, Het spoor. Honderdvijftig jaar spoorweggeschiedenis Maastricht (Maastricht I985) 9-16.

3I De spoorweg van Aken naar Maastricht werd in 1853 geopend; de verlenging ervan naar Hasselt in I 856 . Pas in $187 \mathrm{I}$ kwam de zijtak van het hoofdspoor naar de Domaniale Mijn gereed.

32 Gales, Delven en slepen, 255-26r.

33 Ibidem, 272-282.

34 Raedts, Opkomst, I66-I67.
} 
bare tijd zouden verdwijnen. In I966 zegde de Domaniale Mijn Maatschappij het pachtcontract op. De Nederlandse Staat nam de aandelen van de maatschappij over en kon vervolgens zelf bepalen in welk tempo de sluiting van de mijn kon plaatsvinden. Het beheer van de Domaniale kwam tijdelijk in handen van Staatsmijnen. Eind augustus I969 werd de laatste steenkool uit de Domaniale naar boven gebracht. 35

De Domaniale Mijnmaatschappij was na de Willem-Sophia de kleinste kolenmijn van Nederland. De mijn had één ontginningszetel, die in 1933 een topproductie van iets meer dan een miljoen ton behaalde. Het maximale aantal arbeiders en beambten bereikte de Domaniale al in 1923 , met een personeelsbezetting van 3.538 personen. De Domaniale was een huisbrandmijn.

\section{De mijn Neuprick}

De kapitaalkrachtige Pannesheider Bergwerksverein die de mijn Neuprick in I849 verwierf, was in staat de verouderde installaties te vernieuwen. Bovendien realiseerde de maatschappij een ondergrondse verbinding tussen de Neuprick en de mijn Neu-Voccart, die vlak over de grens in Pruisen was gelegen. ${ }^{36}$ Die verbinding was essentieel voor zowel de ventilatie in de Neuprick, die slechts over één schacht beschikte, als voor het afvoer van water via de NeuVoccart naar de Worm. ${ }^{37}$ De Neuprick was vanaf die tijd vrijwel voortdurend in productie. ${ }^{38}$ De jaarlijkse productie nam in de tweede helft van de negentiende eeuw fors toe. In 1852 werd slechts I.089 ton steenkool naar boven gehaald. Een halve eeuw later was de jaarlijkse steenkolenproductie gestegen tot ruim 60.000 ton. ${ }^{39}$ Daarmee was de Neuprick overigens een van de kleinere mijnen in het Wormgebied. De afzet was vooral op Duitsland gericht. De mijn had een smalspoorverbinding met paardentractie met het Duitse spoorwegnet bij Kohlscheid. In I902 werd deze verbinding vervangen door de aanleg van een zijlijn naar de tramlijn Aken-Herzogenrath.

In 1898 , toen men in de Neuprick kolen beneden het 210-meter niveau begon te ontginnen, kreeg men ernstige moeilijkheden met de afvoer van het mijnwater. De verbinding met de Neu-Voccart voor de waterafvoer bevond zich op de diepte van 2Io meter. Het water beneden dat niveau moest worden opgepompt. Dat ging goed tot in I904. Toen vond een grote waterdoorbraak plaats, waardoor de 270-meter verdieping onder water kwam te staan. De aanschaf van nieuwe machines om het water de baas te worden, bleek te kostbaar en op I augustus 1904 werd de productie in de mijn Neuprick gestaakt. Op het moment van sluiten werkten er ongeveer I6o mensen, die allen nieuw emplooi vonden bij mijnbedrijven in de omgeving. De concessie Neuprick-Bleijerheide kwam in I907 in handen van de Eschweiler Bergwerksverein. Deze maatschappij hield de concessie jarenlang in reserve, maar besloot in I96I het veld te verkopen aan de Domaniale Mijnmaatschappij.40

35 Ibidem, 209-2I0.

36 'Dat was de Neuprick', Steenkool (1949) 154-156.

37 Raedts, Opkomst, I04-Io6.

38 Met uitzondering van de jaren I86I-I867, waarschijnlijk ten gevolge van ondergrondse onderhoudswerkzaamheden. Van Waterschoot van der Gracht, 'Limburgsche steenkolenmijnindustrie', 78.

39 Ibidem, 78.

40 Verslag van de Inspecteur-Generaal der Mijnen over het jaar 1961, I4. 


\section{EEN NIEUWE NEDERLANDSE MIJNBOUWPOLITIEK: STAATSMIJNEN}

Economische en sociale overwegingen lagen ten grondslag aan het besluit van de Nederlandse overheid zich rechtstreeks met de exploitatie van de Limburgse steenkolenvoorraden te gaan bezighouden..$^{4}$ Aan het eind van de negentiende eeuw was het duidelijk geworden dat met de toenemende industrialisatie de exploitatie van steenkool van grote betekenis was voor de welvaart van het land. Het bestaande concessiestelsel leek echter de voorspoedige ontwikkeling van een eigen Nederlandse steenkolenwinning in de weg te staan. In de praktijk hadden de concessionarissen nauwelijks gebruik gemaakt van de gelegenheid om het ontginningswerk aan te pakken. Bovendien waren veel van de uitgegeven concessies in handen van buitenlandse ondernemers. De vrees was dat buitenlandse belangen in de Limburgse steenkool de overhand zouden krijgen. Niet alleen zou dat ongunstig voor Nederland kunnen uitwerken in geval van kolenschaarste, het zou bovendien opdrijving van de kolenprijzen in de hand werken. In feite was dat trouwens al het geval, omdat de bepaling van de kolenprijs op de Nederlandse markt in handen was van het Rheinisch-Wetsfälisches Kohlen Syndikat en de door dit syndicaat beheerste Steenkolen-Handelsvereeniging. Volgens een door de verantwoordelijke minister van Waterstaat, Handel en Nijverheid Cornelis Lely in I899 ingestelde 'Commissie voor de Mijnen' zou een krachtig Staatsmijnbedrijf, als grote speler op de wereldmarkt, dergelijke ongewenste ontwikkelingen kunnen tegengaan. ${ }^{42}$

Naast deze economische overwegingen was er ook een sociaal argument voor staatsexploitatie. In het verlengde van de Ueberfremdung door buitenlands kapitaal vreesde men de aantrekkingskracht die de mijnstreek zou hebben op buitenlandse arbeiders. Sociale ontwrichting van de Limburgse samenleving door massale immigratie werd als schrikbeeld gezien. Wanneer de staat de verdere steenkolenexploitatie in handen had, zou men het tempo van ontginning en daarmee de benodigde arbeidskrachten kunnen reguleren. Men achtte het van essentieel belang voor de sociale ontwikkeling van de mijnstreek dat de uitbreiding van de mijnbouw gelijke tred zou houden met de aanwezige voorzieningen als huisvesting en onderwijs. Door een geleidelijke ontwikkeling van de mijnbouw zou ook rekening worden gehouden met de beschikbare arbeidskrachten in eigen streek, waardoor de werkgelegenheid ten goede zou komen aan de Limburgse bevolking. Deze kwestie komt in een volgend hoofdstuk nog uitgebreid ter sprake.

Een op basis van deze argumenten door Lely ingediende wet waarin alle op dat moment bekende, maar nog niet in concessie uitgegeven kolenvelden werden gereserveerd voor ontginning door de staat, stond op 24 juni rgor in het Staatsblad. ${ }^{43}$

Op I mei 1902 ging de dienst der Staatsmijnen in Limburg officieel van start. De dienst begon onmiddellijk met een nadere verkenning van de voor staatsexploitatie aangewezen terreinen. Bij Koninklijk Besluit van 8 januari 1903 werd vastgesteld dat de eerste staatsmijnzetel zou worden aangelegd op het terrein dat in artikel 2 sub B van de wet van 24 juni Igor stond omschreven. Kort daarna begon men met de aanleg op een perceel in Terwinse-

4I Een overzicht van de achtergronden van het besluit tot staatsexploitatie van de Limburgse steenkolenlagen en een samenvatting van de literatuur over dat onderwerp in: Serge Langeweg, 'Begin en einde van beleid: de staatsmijnen in Limburg', Openbaar Bestuur. Tijdschrift voor beleid, organisatie \& politiek nummer ro (2004) II-I4.

42 Rapport Commissie voor de Mijnen.

43 'Wet betreffende exploitatie van Staatswege van steenkolenmijnen in Limburg', Staatsblad van het Koninkrijk der Nederlanden nummer I70 (IgOI). 


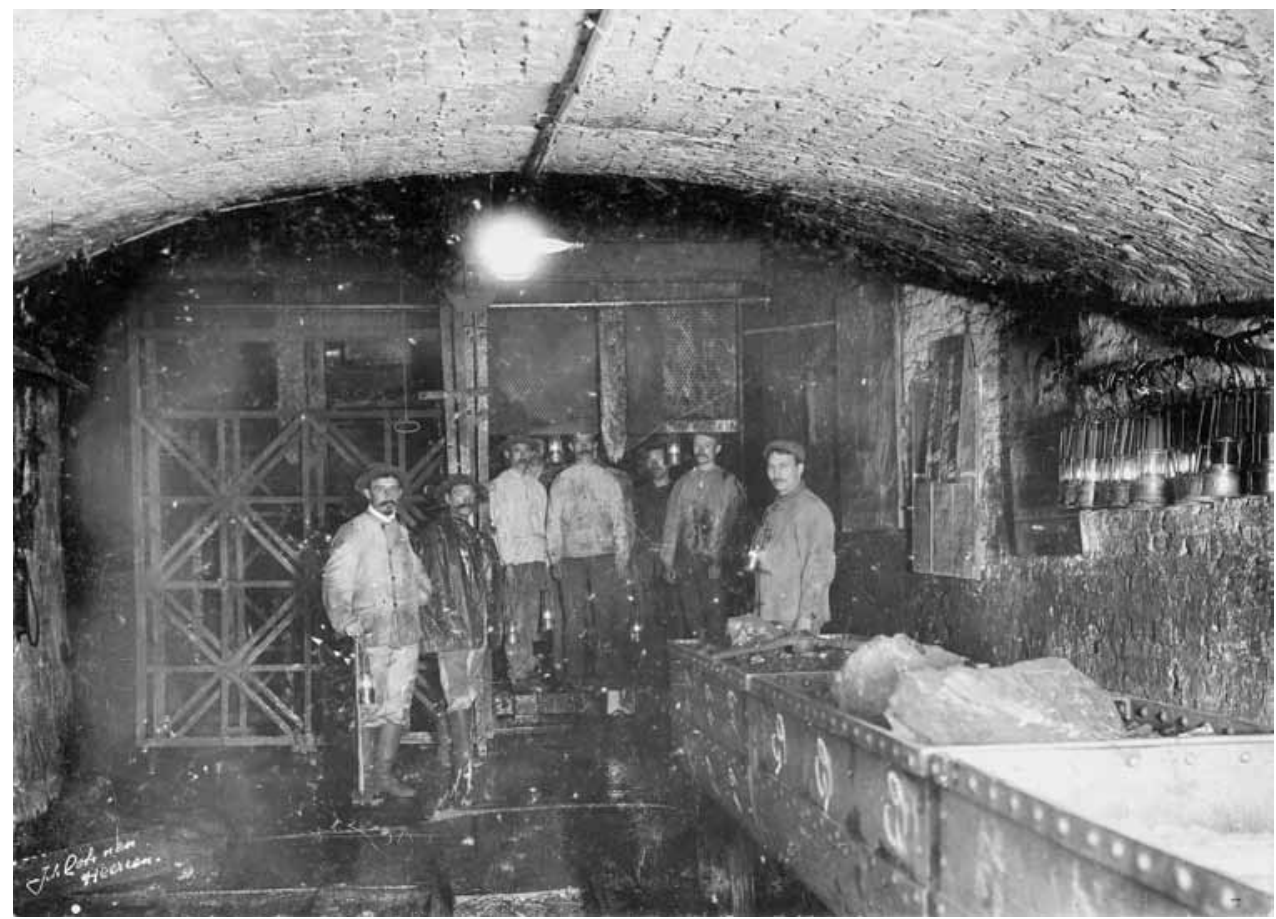

De laadplaats in Staatsmijn Wilhelmina. 1909. Bron: Fotocollectie Continium Kerkrade, F5678.

len. Deze mijnzetel, die aanvankelijk als Staatsmijn B - naar het betreffende wetsartikel werd aangeduid, kreeg later de naam Staatsmijn Wilhelmina. ${ }^{44}$ De bouw van de schachten en de overige bedrijfsinstallaties duurde ruim drie jaar. In I9o6 werd de eerste steenkool gedolven en op I januari I9o9 werd de mijn officieel in gebruik genomen. Drie staatsmijnzetels kwamen daarna nog in exploitatie: de Emma in Hoensbroek-Treebeek (1913), de Hendrik in Brunssum-Rumpen (I917) en de Maurits in Geleen-Lutterade (I925).

Met de successievelijke opening van de staatsmijnzetels breidde het Limburgse steenkolenbekken zich in noordwestelijke richting uit. In de streek tussen Kerkrade en Geleen werden naar het westen toe de steenkolenlagen steeds dieper en de steenkolen steeds gasrijker. ${ }^{45}$ Steenkolen kunnen worden geclassificeerd naar het percentage vluchtige stoffen dat er in aanwezig is. In oplopend gasgehalte zijn dat antraciet en magere kolen, ess- (halfvet) en rookzwakke kolen (3/4-vetkool) en vetkool. Antraciet en magere kolen zijn gasarm en in het bijzonder geschikt voor huisbrand. Ess- en rookzwakke kolen bevatten een hoger percentage gas. Deze variëteiten zijn veel minder bruikbaar voor huishoudelijke toepassing, maar meer voor de industrie en elektrische centrales. Vetkolen zijn zeer gasrijk en voor huisbrand ongeschikt. Bij verhitting vergruizen deze kolen tot brokjes en klitten aaneen tot sintels. Vetkolen zijn echter van grote betekenis voor de fabricage van cokes, een harde en nagenoeg 


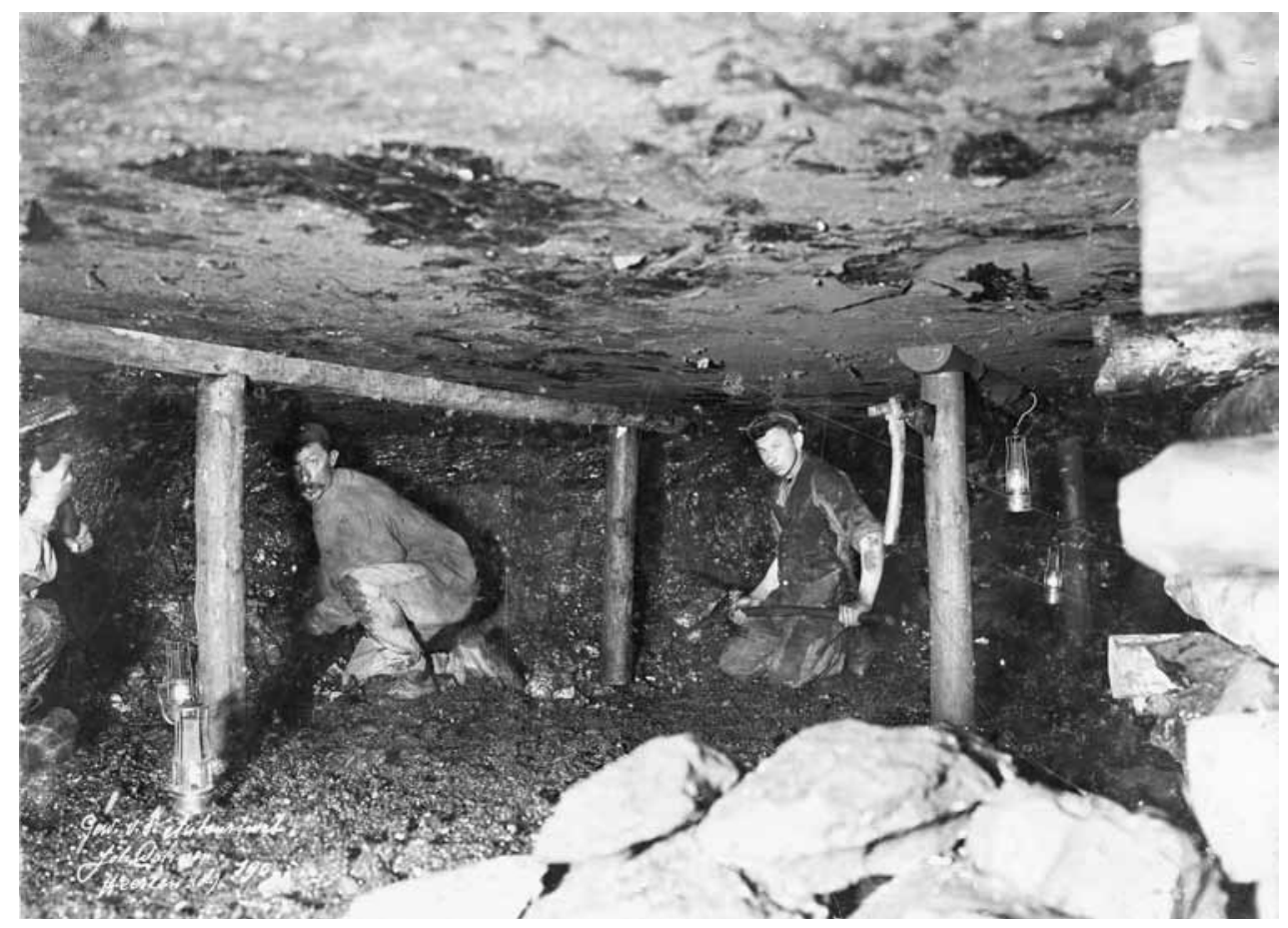

Houwers in een pijler in Staatsmijn Wilhelmina. 1909. Bron: Fotocollectie Continium Kerkrade, F5680.

rookvrije brandstof met een laag gehalte aan de bestanddelen zwavel en fosfor. Verder zijn vetkolen geschikt als brandstof in de industrie en voor schepen en stoomlocomotieven. ${ }^{46}$

Door deze geologische omstandigheden produceerde de oostelijk gelegen Staatsmijn Wilhelmina voornamelijk antraciet, terwijl in de drie andere staatsmijnzetels in de eerste plaats vetkolen werden gedolven. De winning van vetkolen resulteerde in de bouw van cokesfabrieken door het Staatsmijnbedrijf bij de Emma in Treebeek (I9I9) ${ }^{47}$ en de Maurits in Geleen (r929).

Bij de bereiding van cokes komen grote hoeveelheden gas vrij. Staatsmijnen realiseerde daarvoor van begin af aan verscheidene aanwendingsmogelijkheden. Het gas werd gebruikt als energiebron in de eigen bedrijven en verkocht aan derden voor huishoudelijk en industrieel gebruik. Van groot belang werd de toepassing van gas als grondstof voor de bereiding van stikstofmeststoffen en andere chemische producten. De chemische tak van Staatsmijnen ging in I930 van start met de opening van het Stikstofbindingsbedrijf (SBB) in Geleen. Vooral na de Tweede Wereldoorlog kenden de chemische activiteiten van Staatsmijnen een snelle ontwikkeling. Naarmate de steenkolenwinning in de jaren zestig minder rendabel werd, transformeerde Staatsmijnen (later onder de naam DSM) in een chemische multinational. ${ }^{48}$

46 Messing, Geschiedenis van de mijnsluiting, 55-56.

47 Cokesfabriek Emma werd in 1954 geheel vernieuwd en in Beek gevestigd.

48 Messing, Geschiedenis van de mijnsluiting, 55-57. Zie voor de ontwikkeling van de chemische tak van het bedrijf ook: Ernst Hom- 


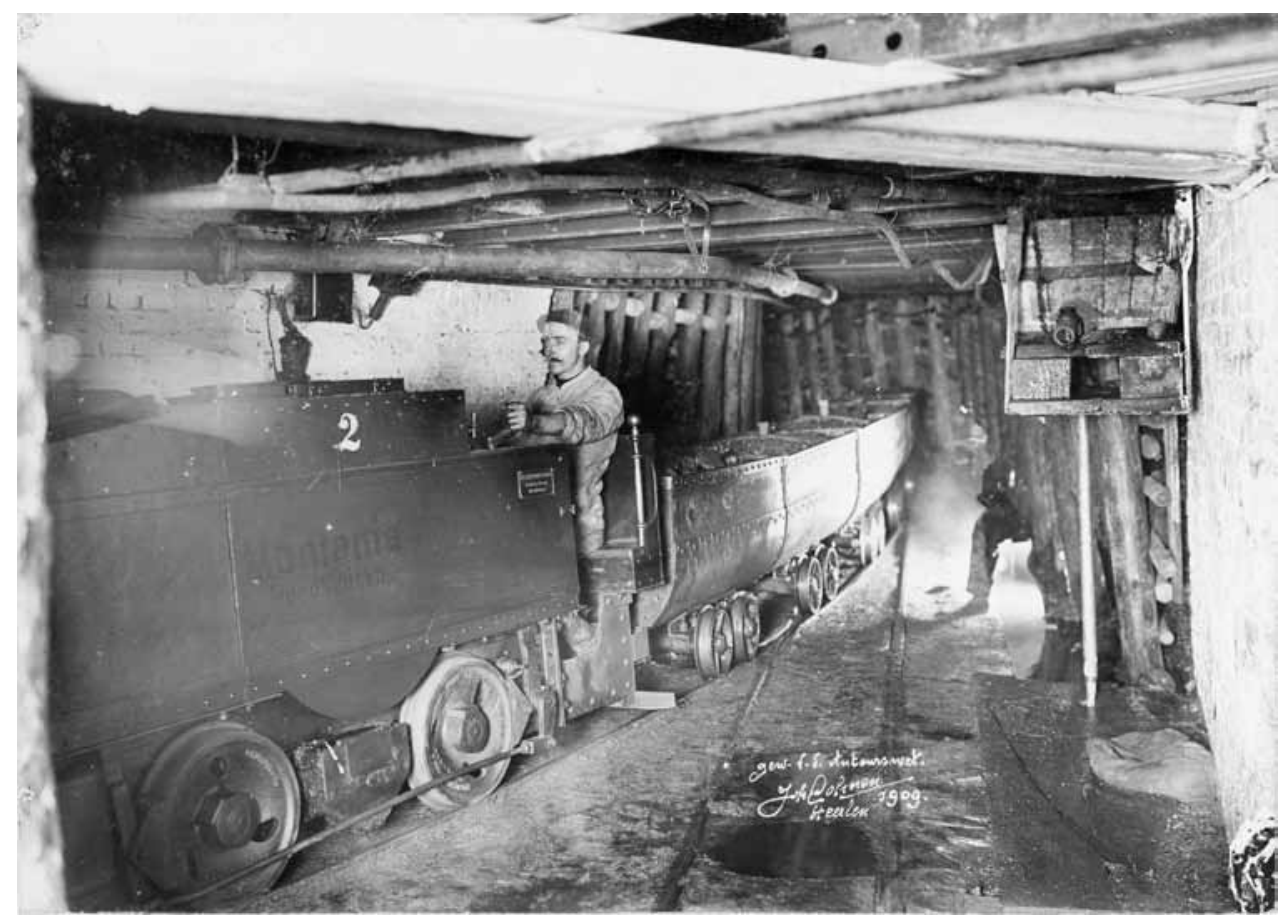

Ondergronds kolentransport in Staatsmijn Wilhelmina. 1909. Bron: Fotocollectie Continium Kerkrade, F5681.

Het beëindigen van de steenkolenmijnbouw door Staatsmijnen kreeg in nauwelijks tien jaar tijd zijn beslag. In I962 besloot het bedrijf de verdere aanleg van de nieuwe mijnzetel Beatrix, die in 1952 was begonnen, stop te zetten. Een jaar later integreerden de bovengrondse bedrijven van de Emma en de Hendrik. In I966 integreerden ook de ondergrondse bedrijven van beide mijnzetels, wat feitelijk neerkwam op de sluiting van de Hendrik. ${ }^{49}$ Staatsmijn Maurits en de bijbehorende cokesfabriek sloten in 1967 , cokesfabriek Emma in I968 en Staatsmijn Wilhelmina in I969. Het definitieve einde van de steenkolensector van Staatsmijnen kwam in 1973 met de sluiting van de Emma/Hendrik.

Van I924 tot I 967 was het Staatsmijnbedrijf verantwoordelijk voor meer dan de helft van de Nederlandse steenkoolproductie. Het topjaar was 1937 met een productie van 8,4 miljoen ton (zie grafiek 2.I). Het grootste aandeel in de productie leverde sinds I929 de Maurits. De maximale personeelsbezetting in zijn geschiedenis bereikte het Staatsmijnbedrijf in 1958 met 42.213 arbeiders en beambten.

burg, Groeien door kunstmest. DSM Agro 1929-2004 (Hilversum 2004); Arjan van Rooij, Building plants: markets for technology and internal capabilities in DSM's fertiliser business, 1925 -1970 (Amsterdam 2004).

49 Messing, Geschiedenis van de mijnsluiting, I88-200. 


\section{PRODUCTIE, MARKT EN ARBEIDSPLAATSEN}

De opening van elf nieuwe mijnzetels tussen I899 en I928 had een enorme toename van zowel de Nederlandse kolenproductie als het aantal arbeidsplaatsen in de mijnbedrijven tot gevolg. In I898 bedroeg de jaarproductie van de twee mijnen die op dat moment in geregelde productie waren 150.000 ton. Dat was niet meer dan 3 procent van het nationale kolenverbruik (bijlage 4). Nederland was vrijwel volledig afhankelijk van de import van buitenlandse kolen uit Duitsland, Engeland en België..$^{\circ}$ Drie decennia later was de Nederlandse kolenproductie vertachtigvoudigd. Het aantal arbeidsplaatsen was in die periode met de factor 63 toegenomen van nauwelijks zeshonderd tot bijna 38.000 (grafiek 2.2)..$^{\text {I }}$

In I930, aan de vooravond van de economische depressie, produceerden de mijnen in Limburg ruim twaalf miljoen ton. Het aanbod was gediversifieerd: naast huisbrandkolen waren steenkolen met een hoger gasgehalte, geschikt voor industrieel gebruik en voor de fabricage van cokes beschikbaar gekomen. Fijnkool werd in eigen fabrieken samengeperst tot briketten voor huishoudelijk en industrieel gebruik. De productie van de Nederlandse mijnen was inmiddels goed voor 94 procent van het binnenlandse verbruik..$^{2}$

Tot de Eerste Wereldoorlog hadden de Nederlandse mijnen grote moeite een plaats voor hun product op de binnenlandse markt te veroveren. De kolenmarkt werd gedomineerd door het in 1893 opgerichte Rheinisch-Westfälisches Kohlensyndikat (RWKS), een samenwerkingsverband van de mijnen in het Ruhrgebied. De Nederlandse vertegenwoordiger van het RWKS was de Steenkolen-Handelsvereeniging (SHV). Door de kartelvorming en de gunstige vrachtprijzen via de Rijn was de prijs van de Duitse kolen op de Nederlandse markt lager dan de steenkolen uit de Limburgse mijnen, die niet over een gezamenlijk verkoopapparaat beschikten en werden geconfronteerd met hoge transportkosten. Hoewel de Limburgse mijnen er tussen I9Io en I9I4 in slaagden hun afzet op de Nederlandse markt wat te verhogen, moesten ze hun productie toch voor het grootste deel in het buitenland afzetten. In I9I3 ging 64 procent van de verkochte Nederlandse kolen naar het buitenland. ${ }^{53}$

Het uitbreken van de Eerste Wereldoorlog leidde tot een volledige wijziging van de situatie op de afzetmarkten voor steenkolen. Door de oorlogssituatie daalde de invoer van steenkolen dramatisch. In I9I8 bedroeg de import in Nederland nog slechts I, 2 miljoen ton, 9 procent van de hoeveelheid van I9I3. De Nederlandse mijnen voerden de productie op van I,9 miljoen ton in I9I3 tot bijna 3,5 miljoen ton in I9I8, onder meer door in die jaren drie nieuwe mijnzetels in geregelde productie te brengen. De gezamenlijke kolenproductie van de mijnen in Limburg dekte aan het eind van de oorlog 72 procent van het binnenlandse verbruik. De totale hoeveelheid beschikbare kolen voor de Nederlandse markt halveerde echter tijdens de jaren I9I4-I9I8, zoals uit de steenkolenbalans blijkt (bijlage 4). Het kolentekort gaf de regering aanleiding over te gaan tot een algehele distributie en prijszetting van steenkool in Nederland. ${ }^{54}$ Toen bleek dat het in april I9I5 opgerichte Kolenbureau niet geheel voldeed, stelde de regering in januari igı 6 in plaats daarvan de Rijkskolendistributie

50 Kreukels, Mijnarbeid, 45 .

$5 \mathbf{I}$ Het aantal arbeidsplaatsen in I 898 is inclusief degenen die betrokken waren bij de aanleg van de ON-I.

52 Desondanks bleef import belangrijk, omdat de samenstelling van de Nederlandse steenkolen naar soorten en afmetingen een

uitgebreide soortenruil met buitenlandse kolen noodzakelijk maakte. Rapport Staatscommissie 1946, 72.

53 Kreukels, Mijnarbeid, 45-50.

54 Raedts, Opkomst, I55. 


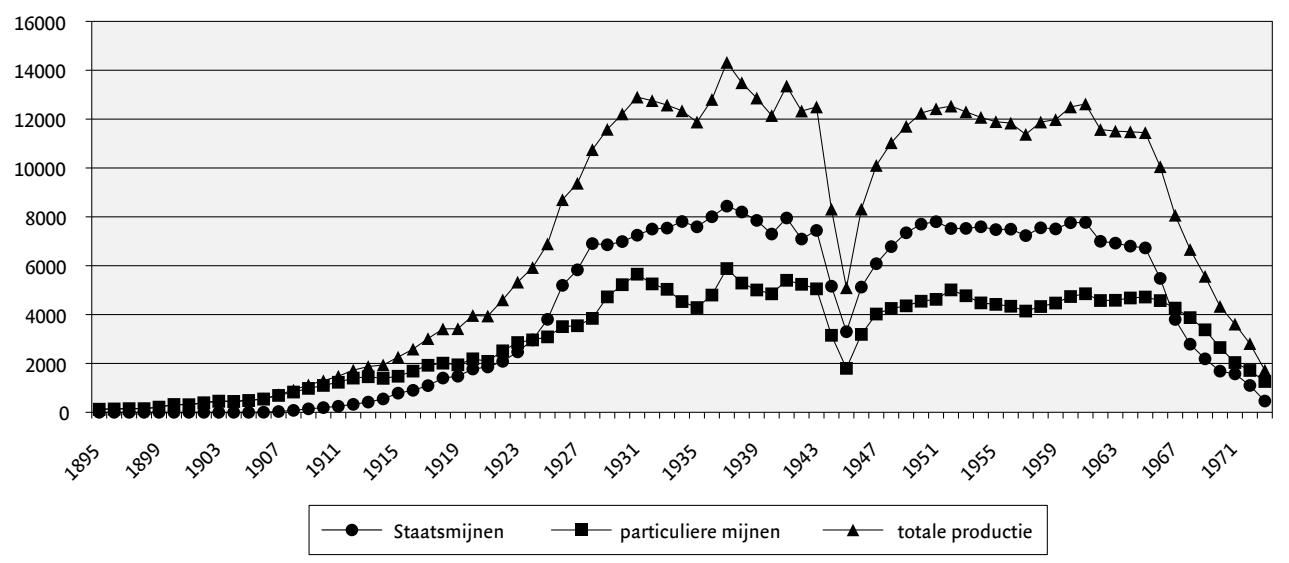

Bron: SHCL, Archief GSL, Statistiek I-A.

(RKD) in. De RKD verdeelde alle ter beschikking gekomen kolen en stelde ook de prijzen hiervan vast. Ondanks deze prijsregulering waren de jaren van de kolendistributie, die pas op I januari I92I werd afgeschaft, gouden tijden voor de mijnen. De jaarlijkse winstcijfers waren hoog, vooral bij de particuliere mijnen. ${ }^{55}$ Vooral het besluit van de RKD om met ingang van I juni I920 alle loonsverhogingen en andere kostprijsverhogingen als gevolg van verbeteringen in de arbeidsvoorwaarden aan de mijnen te vergoeden, was voor de mijnen bijzonder aantrekkelijk.

De kolenschaarste in Europa duurde in I9I9 en I920 voort. De export van Amerikaanse kolen liep sterk terug ten gevolge van een groot aantal mijnwerkersstakingen, de Franse productiecapaciteit was afgenomen door de ernstige schade die de mijnen van de departementen Nord en Pas-de-Calais tijdens de oorlog hadden opgelopen, in Groot-Brittannië waren uitvoerbeperkende maatregelen van kracht en Duitsland had een deel van de mijnindustrie moeten afstaan aan Polen en Frankrijk. Door de schaarste stegen de kolenprijzen naar recordhoogten, hetgeen uitbreiding van de productiecapaciteit in de hand werkte. ${ }^{56}$ In het begin van i92I sloeg de economische conjunctuur om. De vraag naar kolen nam af. Die ontwikkeling werd veroorzaakt door een opmerkelijke vertraging van het totale energiegebruik die vanaf 1920 duidelijk werd. Bovendien ondervonden kolen in toenemende mate concurrentie van aardolieproducten. Het aandeel van kolen in het wereldenergieverbruik daalde van 93 procent in I9I3 naar 77 procent in I929. ${ }^{57}$ Deze ontwikkelingen aan de vraagzijde van de markt leidden tot overcapaciteit bij de steenkolenmijnen en tot daling van de prijzen. Het antwoord van de Nederlandse mijnen op de toenemende internationale concurrentie op de kolenmarkten was uitbreiding van de productiecapaciteit, zoals uit grafiek 2.I duidelijk blijkt. Drie nieuwe mijnzetels kwamen in productie, waaronder de zeer groot opgezette Staatsmijn Maurits. Ook werd de arbeidsproductiviteit verhoogd door het bedrijf

55 Kreukels, Mijnarbeid, 59-66.

56 Ibidem, 276.

57 Ibidem, 274. 
te rationaliseren en te mechaniseren. Het scientific management deed zijn intreden in de $\mathrm{Ne}$ derlandse mijnen. ${ }^{8}$ Met deze maatregelen slaagden de mijnbedrijven erin de vaste lasten per ton te verlagen. De resultaten baarden overal opzien. De Nederlandse mijnen groeiden in de jaren twintig uit tot de grootste en modernste van Europa. Het aantal arbeidsplaatsen nam tot en met I93 I vrijwel voortdurend toe. Grafiek 2.3 laat zien dat de arbeidsproductiviteit vanaf het begin van de jaren I920 tot 1936 vrijwel onafgebroken een stijgende lijn vertoonde. In dat anderhalve decennium verdrievoudigde de gemiddelde productie per ondergronder van 870 tot 2.670 kilo per dienst. In West-Europees perspectief bleef de omvang van de Nederlandse kolenproductie en de werkgelegenheid in de mijnen echter gering. Nederland was en bleef een kleine speler op de internationale steenkolenmarkt (bijlage 5).

Na I93 I kwam een eind aan de voortdurende productiestijging van de Nederlandse mijnen. Met uitzondering van de exceptionele jaren onmiddellijk na de bevrijding (I944-I945) schommelde de jaarlijkse productie tot het begin van de sluitingsoperatie in I966 voortaan rond de twaalf miljoen ton. Nieuwe mijnzetels kwamen er in die periode niet bij. Wel investeerden de mijnbedrijven geregeld in schachtinstallaties en de aanleg van ondergrondse werken, waarmee nieuwe kolenlagen konden worden ontsloten. Het aantal bezette arbeidsplaatsen daalde slechts tijdens de jaren van de economische crisis (I932-I935) en in de jaren I944-I945. In I958 telden de gezamenlijke Limburgse mijnen met ruim 56.000 arbeiders de grootste personeelsbezetting in hun geschiedenis.

De eerste hapering in de productiestijging van de gezamenlijke Limburgse mijnen werd merkbaar in 1932. Door de moeilijkheden bij de export en de binnenlandse afzet ten gevolge van de mondiale economische crisis nam de productie bij vooral de particuliere mijnen tot 1935 af. De productie van Staatsmijnen had minder last van de economische teruggang. Door het meer gevarieerde kolenassortiment kon het staatsbedrijf zich richten op de productie van vetkool voor de fabricage van cokes, waarvoor de markt gunstiger was dan voor de antraciet van de particuliere mijnen. Bovendien was Staatsmijnen, dankzij de inmiddels opgebouwde chemische tak van het bedrijf, minder afhankelijk van de afzet van steenkool dan de andere Nederlandse mijnen. Het bedrijfsbeleid van Staatsmijnen was er in de crisisjaren op gericht de productie op te voeren om op die manier de kosten per eenheid product te doen dalen. ${ }^{59}$ Dat Staatsmijnen minder getroffen werd door de economische teruggang bleek ook uit de ontwikkeling van de werkgelegenheid in de eerste helft van de jaren I930. Aan het eind van 1935 , toen het dieptepunt van de crisis was bereikt, was de personele bezetting ten opzichte van het topjaar I93 I weliswaar met II,5 procent afgenomen, maar dat percentage stak toch gunstig af bij de achteruitgang van de werkgelegenheid bij de particuliere mijnen, die over dezelfde periode 39 procent bedroeg.

Pas in 1936 en 1937 trok de economische conjunctuur aan; de productie steeg en bereikte in 1937 zelfs de hoogste jaarproductie die de gezamenlijke Nederlandse mijnen ooit behaalden: 14,3 miljoen ton. Ook de werkgelegenheid trok weer aan, een proces dat na het uitbreken van de Tweede Wereldoorlog aanvankelijk gewoon doorging. Voor veel Nederlandse arbeiders waren de mijnen een toevluchtsoord, omdat men als mijnwerker was vrijgesteld

58 Gales, 'Himmel', I6I-2I5.

59 G.C.M. Vromen, De Limburgse mijnen en hun mijnwerkers 1900-1939. De opbouw van een stabiel arbeidersbestand (doctoraalscriptie, Leiden 1986) 29. 
GRAFIEK 2.2 ONDERGRONDSE, BOVENGRONDSE EN TOTALE ARBEIDERSBEZETTING BIJ DE NEDERLAN DSE STEEN KOLENMIJNEN, I895-I974 (PER 3I DECEMBER)

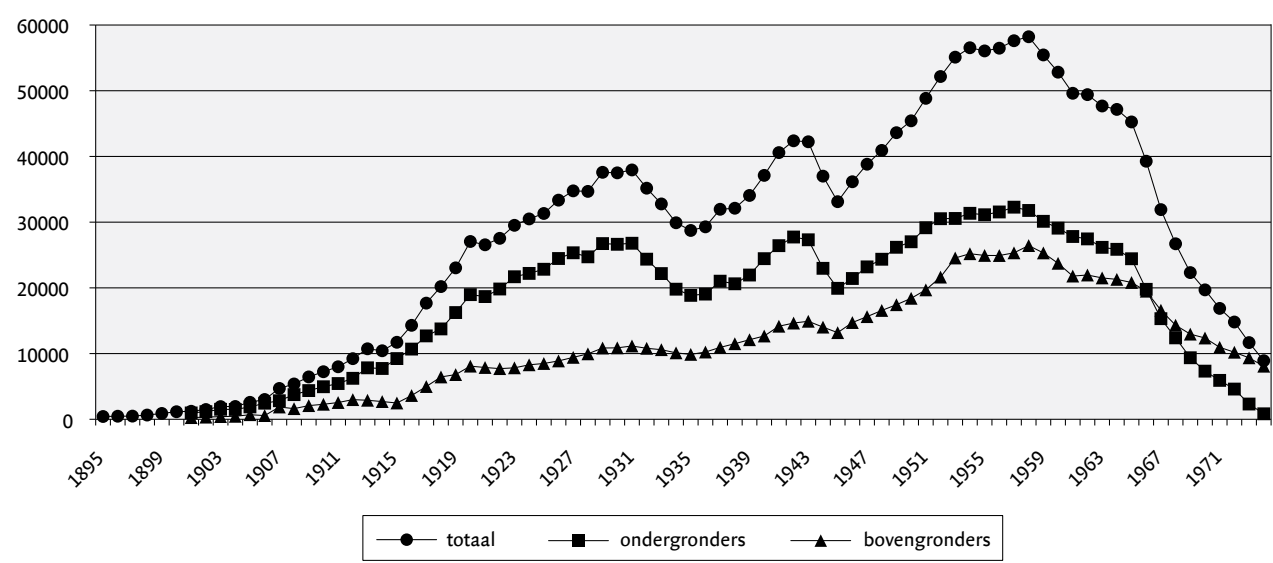

Bron: (Jaar)verslagen (Hoofd-)Ingenieur / Inspecteur-Generaal der Mijnen; SHCL, ArchiefGSL, Statistiek VIII-I/2 en VIII-9-Io.

GRAFiEK 2.3 NetTopRESTATIE PER ONDERGRONDSE DiENST TOTAAL EN NETTOPRESTATIE PER ONDERGRONDSE DIENST IN DE AFBOUW, GEZAMENLIJKE MIJNEN, I895-I972 (IN TONNEN)

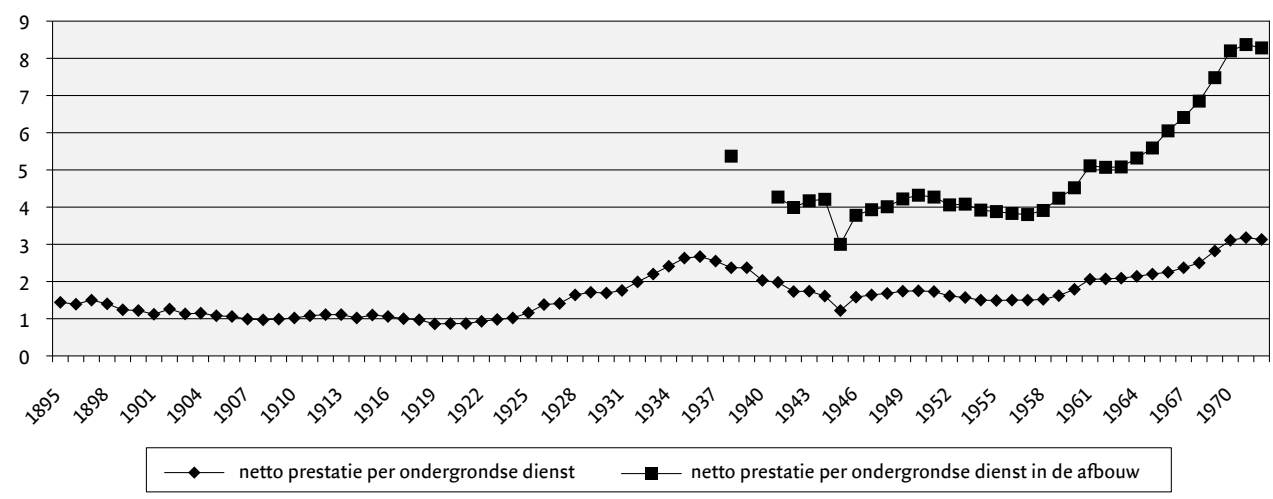

Bron: 1895 t/m 1935: Van Waterschoot van der Gracht, 'De Limburgsche steenkolenmijnindustrie', 84. I936 t/m 1972: SHCL, ArchiefGSL, Statistiek V-I en V-5.

van verplichte arbeid in Duitsland.$^{60}$ Dat het bij deze mijnwerkers-tegen-wil-en-dank in veel gevallen om onervaren arbeiders ging, blijkt onder meer uit de scherpe daling van de arbeidsproductiviteit in de jaren van de bezetting. Eind I 943 was de productie per man en per ondergrondse dienst met 27 procent afgenomen ten opzichte van I939. Desondanks bleef de kolenproductie tot eind 1943 onder Duitse druk vrij stabiel. ${ }^{6 r}$

6o Serge Langeweg, Van Adreskantoor tot Arbeidsvoorziening. Arbeidsbemiddeling en arbeidsmarkt in Zuid-Limburg, 1904-1994 (Leeuwarden/Mechelen I994) 76-78.

6r Frank van Buren, 'Kolenwinning onder Duitse druk: productie- en arbeidsverhoudingen in de Limburgse mijnen tijdens de bezetting I940-I944', SSEGL XLIX (2004) I35-I64. 
Onmiddellijk na de bevrijding in september 1944 bleek de toestand bij de Nederlandse mijnen deplorabel. Door oorlogsschade aan installaties, moeilijkheden met de materiaalvoorziening voor het werk ondergronds, problemen met de voedselvoorziening voor de mijnwerkers, zuiveringen in de mijnbedrijven gecombineerd met sociale onrust en vrijwillig vertrek op grote schaal van personeel uit de mijnen, daalde de productie in 1944-I945 tot het niveau van 1923 en bereikte de arbeidsproductiviteit de laagste waarde sinds $1925 .{ }^{62}$ Een spoedig herstel van de productie en de productiviteit was dringend gewenst. De mijnen werden gezien als de motor van de Nederlandse wederopbouw en het verbruik van energie nam na I945 spectaculair toe. ${ }^{63}$ Voor de mijnen betekende dat een gunstige kolenmarkt die tot 1958 aanhield. Het probleem was echter dat de productie en productiviteit niet gelijk opgingen met de stijgende vraag. De toenemende discrepantie blijkt duidelijk uit de Nederlandse steenkolenbalans (bijlage 4). Terwijl sedert het eind van de jaren twintig in minstens 90 procent van de Nederlandse steenkolenbehoefte door de Limburgse mijnen kon worden voorzien, nam dat percentage in de loop van de jaren vijftig af tot 65 procent in 1957 . De Nederlandse regering zag die ontwikkeling met zorg aan en ondernam pogingen om de nationale steenkolenbasis te verstevigen. Dit resulteerde onder meer in de aanleg van de vijfde staatsmijnzetel, de Beatrix, waarmee in 1952 werd begonnen. Ook werd gesproken over de ontsluiting van de mijnvelden in de Peel. ${ }^{64}$

Dat de productie zich na een snelle stijging uit het diepe dal van onmiddellijk na de bevrijding sedert het begin van de jaren vijftig stabiliseerde op een jaarlijks niveau van omstreeks twaalf miljoen ton ligt niet aan een vermindering van afzetmogelijkheden. De oorzaken waren veeleer dat de grenzen van de productiemogelijkheden waren bereikt. De productie van steenkool is weinig flexibel. Toename van productie is pas mogelijk nadat nieuwe kolenlagen zijn ontsloten. Dat vereist omvangrijke, tijdrovende en kostbare technische werken in het ondergrondse bedrijf. De Limburgse mijnen investeerden in de jaren vijftig volop in het ontsluiten van nieuwe kolenlagen. Dit ging gepaard met een mechanisatiegolf. De mechanisatie werd echter ernstig bemoeilijkt door de specifieke geologische omstandigheden in de Limburgse mijnen, zoals slechte dak- en vloerverhoudingen, onregelmatige of gestoorde steenkoollagen. Die problemen werden groter naarmate de mijnen in de jaren vijftig dieper werden. ${ }^{65}$ De gebergtedruk en de temperatuur namen toe en de nettoproductie in verhouding tot de brutoproductie nam af. ${ }^{66}$ Bovendien werden de mijnen in de naoorlogse periode geconfronteerd met een erfenis uit het verleden. Tot I937 waren in versneld tempo de lagen met het hoogste rendement afgebouwd. Alleen bij afbouw van dikke lagen woog de kostprijs van de kolen op tegen de lage verkoopprijs in de crisisjaren. ${ }^{67}$ Deze zogenaamde roofbouw had als consequentie dat er een aanslag werd gepleegd op de levensduur van de mijn. Voor een goede bedrijfsvoering moesten zowel gunstige als ongunstige lagen tegelijkertijd worden ontgonnen, om niet op den duur voor het probleem te komen dat er alleen nog maar dunne onrendabele lagen zouden zijn. Toen de mijnen na

\footnotetext{
62 Raedts, Opkomst, I76-I8I; Wim van der Linden, 'De naoorlogse zuiveringen in het mijnbedrijf als reactie op sociale en religieuze tegenstellingen', SSEGL XLIX (2004) I9I-213.

63 Messing, Geschiedenis van de mijnsluiting, I3.

64 Gales, 'Houwen en stof bijten', 50.

65 Rob Wolf, Mijnbouw, techniek en onderwijs (doctoraalscriptie Sociale en Ekonomische Geschiedenis, Nijmegen I978) II 28.

66 Messing, Geschiedenis van de mijnsluiting, 62-64.

67 A. Grond, 'Over kolenvoorraad, gemiddelde laagdikte en nog wat', Steenkool (1946) 152-153.
} 
de oorlog weer overgingen tot een gelijkmatige ontginning van de kolenlagen had dat zijn weerslag op zowel de productie als de productiviteit. Ook het feit dat de afstand die de mijnwerkers van de schacht naar het steeds diepere kolenfront moesten afleggen steeds groter werd, had negatieve gevolgen voor de arbeidsproductiviteit. In 1950 becijferde de Inspecteur-Generaal der Mijnen dat voor alle mijnen gezamenlijk een achteruitgang van slechts één minuut in de nuttige (productieve) werktijd een productievermindering van ongeveer vijftig ton netto kolen betekende. ${ }^{68}$

De voortdurende ontsluiting van nieuwe kolenlagen had een grote vraag naar personeel tot gevolg. Ondanks de toenemende mechanisering was de steenkolenmijnbouw ook in de naoorlogse periode een arbeidsintensieve sector. Bovendien leidde mechanisering tot een nieuwe vraag naar specifieke functies. Zo bleek er bijvoorbeeld in 1952 een tekort te zijn aan ondergrondse metaalarbeiders. ${ }^{69}$ De snel toenemende vraag naar mijnwerkers in de jaren vijftig blijkt duidelijk uit de ontwikkeling van de personeelsbezetting bij de mijnen (grafiek 2.2). Al in 1947 werd het peil van onmiddellijk vóór de economische crisis van de jaren dertig bereikt. In het volgende decennium nam de bezetting verder toe met gemiddeld I.6oo personen per jaar. Daarbij valt op dat de grootste toename plaatsvond tot en met 1954 (gemiddeld 2.I0o mijnwerkers per jaar). In de periode 1955 tot 1958 was de gemiddelde jaarlijkse toename veel minder. Gemiddeld nam de personeelsbezetting in die jaren met slechts I46 personen toe. De grafiek geeft echter momentopnames van telkens de laatste dag van het jaar en verhult daarmee fundamentele problemen in de personeelsvoorziening van de mijnen.

Dat het in de grafiek steeds om bezette arbeidsplaatsen gaat en niet om de vraag naar arbeid blijkt uit voortdurende berichten over tekorten aan mijnwerkers. Van jaar tot jaar maakte het Districtsbureau voor de Arbeidsvoorziening melding van een grote vraag naar arbeidskrachten voor de mijnindustrie. Ondanks intensieve wervingsacties, in nauwe samenwerking tussen de mijnbedrijven en de arbeidsbureaus, lukte het niet de personeelsbezetting op het gewenste peil te brengen. Pas in 1958 was er sprake van een situatie van voldoende aanbod op de regionale arbeidsmarkt en werden er geen tekorten meer gemeld. $7^{\circ}$

Uit tabel 2.2 blijkt dat de tekorten tot en met 1957 aanzienlijk waren. In de eerste helft van de jaren vijftig beliep het tekort 3 à 4 procent van de personeelsbezetting op 3 I december, in de jaren 1955 tot en met 1957 ging het zelfs om 6 à 7 procent. In combinatie met de hierboven geconstateerde stagnerende ontwikkeling in de personeelsbezetting in precies dezelfde jaren, mag worden verondersteld dat de arbeidsmarkt voor mijnwerkers goeddeels was afgeroomd. Die veronderstelling wordt verder gestaafd door het feit dat de gezamenlijke Nederlandse mijnen in 1955 overgingen tot de systematische werving van mijnwerkers in het buitenland..$^{7}$

Het gevolg van het achterblijven van de gewenste eigen steenkolenproductie was dat Nederland in toenemende mate kolen uit het buitenland moest betrekken. Invoer uit andere EGKS-landen kon weinig soelaas bieden, want het tekort aan energie deed zich in de hele

68 Verslag van de Inspecteur-Generaal der Mijnen over het jaar 1950, ro.

69 Arbeidsmarktbeschrijuing van de Provincie Limburg 1952, 48.

70 Idem 1958, 26.

7I Serge Langeweg, 'Bekende buren en verre vreemden. Buitenlandse arbeiders in de Nederlandse steenkolenmijnen, I900I974', TSEG V nummer 3 (2008). Zie voor dit thema verder hoofdstuk 5. 
TABEL 2.2 TEKORTEN AAN MIJNWERKERS BIJ DE GEZAMENLIJKE NEDERLANDSE STEENKOLENMIJNEN, I95I-I965

\begin{tabular}{|c|c|c|c|}
\hline jaar & ondergronders & bovengronders & totaal \\
\hline I95I & I.805 & 338 & 2.143 \\
\hline I952 & I.490 & $\cdot$ & $\cdot$ \\
\hline I953 & I. 425 & • & • \\
\hline I954 & I. 500 & 500 & 2.000 \\
\hline I955 & 2.000 & $2.200^{\star}$ & 4.200 \\
\hline 1956 & • & - & 3.900 \\
\hline I957 & $\cdot$ & $\cdot$ & 3.500 \\
\hline I958 & - & - & - \\
\hline I959 & - & - & - \\
\hline I96o & - & - & - \\
\hline I96I & 450 & I. $150^{\star \star}$ & I.6oo \\
\hline 1962 & - & • & $\mathrm{I} .200$ \\
\hline I963 & - & - & 1.000 \\
\hline I964 & - & • & I.000 \\
\hline I965 & • & • & 750 \\
\hline
\end{tabular}

Bron: Arbeidsmarktbeschrijuing van de Provincie Limburg [195I-1965].

$\star \quad$ Hieronder begrepen I.20o leerlingen voor de Ondergrondse Vakscholen.

$\star \star$ Hieronder begrepen 850 leerlingen voor de Ondergrondse Vakscholen.

Europese gemeenschap gelden. Nog in 1957 constateerde de Inspecteur-Generaal der Mijnen dat de kolenproductie in de landen van de EGKS achterbleef bij de gehele industriële productie met als gevolg een structureel gebrek aan energie. De invoer uit derde landen, met name uit de Verenigde Staten, steeg dat jaar tot 44 miljoen ton. De kolenimporteurs sloten langjarige contracten af om voor geruime tijd gedekt te zijn..$^{22}$

Het tekort aan steenkool zorgde anderzijds voor een snel voortgaande penetratie van aardolie op de energiemarkt (tabel 2.3). De voordelen van aardolie ten opzichte van steenkool bleken legio: de exploitatiekosten waren laag, het aanbod was overvloedig, de transportkosten laag en de industriële toepasbaarheid uitstekend. ${ }^{73}$

Het toegenomen gebruik van olie, de import van goedkope steenkool uit de Verenigde Staten, de conjuncturele teruggang in 1958 en een paar zachte winters veroorzaakten in I958 een kolencrisis: de verkopersmarkt van kolen sloeg om in een kopersmarkt. ${ }^{74}$ Vooral de markt voor industrie- en cokeskolen raakte verzadigd. Voor de Nederlandse mijnen vielen de directe gevolgen van de kolencrisis, die tot ig6o zou aanhouden, op zich mee. De steenkolen- en cokesbalans van Staatsmijnen, producent van voornamelijk industrie- en cokeskolen, vertoonde geen schokkend beeld. Ook de particuliere mijnen, die vooral huis-

72 Raedts, Opkomst, $201-202$.

73 Messing, Geschiedenis van de mijnsluiting, I3.

74 Ibidem, I22-I26. 
TABEL 2.3 HET AAN DEEL VAN VERSCHILLEN DE ENERGIEBRONNEN IN HET ENERGIEVERBRUIK IN DE EGKS, I950-I965 (IN PROCENTEN)

\begin{tabular}{|l|r|r|r|r|}
\hline & $\mathbf{1 9 5 0}$ & $\mathbf{1 9 5 5}$ & $\mathbf{1 9 6 0}$ & $\mathbf{1 9 6 5}$ \\
\hline Steenkool & 70 & 65 & 52 & 36 \\
\hline Bruinkool & 8 & 8 & 7 & 5 \\
\hline Aardolie & I2 & I8 & 30 & 49 \\
\hline Aardgas & 0 & I & 3 & 4 \\
\hline Primaire elektriciteit & I0 & 8 & 8 & 6 \\
\hline Totaal & 100 & 100 & 100 & 100 \\
\hline
\end{tabular}

Bron: Messing, Geschiedenis van de mijnsluiting, I5.

brand produceerden, kwamen de kolencrisis zonder veel problemen door. De mijnen gingen over tot een personeelsstop en de tijdelijke contracten van de kort tevoren aangeworven buitenlandse arbeiders werden niet verlengd. ${ }^{75}$ Desondanks waren de jaren van de kolencrisis (I958-I960) voor de toekomst van de Nederlandse mijnbouw van cruciale betekenis. Vooral betekenden ze een psychologische breuk. ${ }^{76}$ Structurele verschuivingen op de energiemarkt kwamen duidelijk aan het licht. De daling in de afzet van steenkool en cokes en het toenemende belang van andere energiebronnen riep met name bij Staatsmijnen de vraag op naar de toekomstige rentabiliteit van steenkolenmijnen en cokesfabrieken. Voor alle Nederlandse mijnen gold dat het concurrentievermogen ten opzichte van andere steenkolenbekkens in de Gemeenschap verminderde, omdat in het buitenland de mijnbouwsectoren meestal gesubsidieerd werden door de nationale overheden. ${ }^{77}$

De bedenkingen over de toekomst van de Nederlandse mijnbouw werden vergroot door aanhoudende personele problemen. Na I958 daalde de bezetting van de gezamenlijke mijnen voortdurend. Voor een deel hield dat verband met een nieuwe mechanisatiegolf, die eind jaren vijftig in gang was gezet en tot doel had de arbeidsproductiviteit te verhogen..$^{7}$ Dat de uittocht groter was dan de mijnen wensten, blijkt echter uit de tekorten die sedert I96I weer jaarlijks werden gemeld (tabel 2.2). Nadat de kolencrisis duidelijk had gemaakt dat de rol van steenkolen op de energiemarkt tanende was, was het vertrouwen van veel Limburgers in de toekomst van de werkgelegenheid afgenomen. Vooral jonge mijnwerkers zeiden het zware werk ondergronds vaarwel en maakten van de ruime werkgelegenheid in andere sectoren gebruik om hun beroepscarrière elders voort te zetten.

Doordat vooral jonge mijnwerkers vertrokken, werden de mijnen geconfronteerd met een vergrijzing van de personeelsbezetting. ${ }^{79}$ In het verlengde daarvan lag een toenemend aantal pensioneringen. Dat was het gevolg van het feit dat bij de opkomst van de mijnen, dertig à veertig jaar eerder, vooral jonge mannen waren aangetrokken, die vanaf de tweede

75 Langeweg, 'Bekende buren', 74.

76 Gales, 'Houwen en stof bijten', $5 \mathrm{I}$.

77 Messing, Geschiedenis van de mijnsluiting, ing.

78 B.P.A. Gales, J.P. Smits en R. Bisscheroux, 'Steenkolen', Techniek in Nederland in de twintigste eeuw. II: Delfstoffen, Energie, Chemie (Zutphen 2000) 45-65, aldaar 6o.

79 Arbeidsmarktbeschrijuing van de Provincie Limburg $1965,23$. 
helft van de jaren vijftig de pensioengerechtigde leeftijd van 55 of 60 jaar bereikten. ${ }^{80}$ De problemen met de personeelsvoorziening werden zó groot, dat het natuurlijk verloop niet kon worden aangevuld. Sedert 1962 kon de kolenproductie niet op peil worden gehouden. Om de personeelstekorten op te vangen, besloten de mijnen in 196r opnieuw buitenlandse arbeidskrachten aan te werven, een politiek die ze tot de aankondiging van de mijnsluitingen eind 1965 volhielden. Met de aankondiging van die mijnsluitingen hield een normaal functioneren van de arbeidsmarkt voor mijnwerkers in feite op te bestaan.

\section{BESLUIT}

In de geschiedenis van de Limburgse steenkolenwinning in de periode I900-1965 zijn grofweg drie periodes te onderscheiden. De eerste begon omstreeks I9oo toen buiten het oude kerngebied Kerkrade de mijnbouw snel tot ontwikkeling kwam. Tot 1928 kwamen er naast de oude Domaniale Mijn nog vier mijnbouwondernemingen tot stand, die samen elf ontginningszetels exploiteerden. Hieronder nam Staatsmijnen, met vier ontginningszetels, al in de jaren twintig qua productie en personeelsbezetting een overheersende positie in.

Een tweede episode begon met de mondiale economische depressie van de jaren dertig, die de Limburgse mijnen in I93 I bereikte. De economische malaise was minder aan de productie en productiviteit af te lezen dan aan de personeelsbezetting. De werkgelegenheid in de Limburgse mijnbouwsector daalde in de eerste helft van de jaren dertig aanzienlijk. Pas na de Tweede Wereldoorlog konden de Limburgse mijnen zich verder ontplooien en begon een derde tijdvak. Tijdens de jaren van wederopbouw was de vraag naar steenkool groot. Tot de kolencrisis van 1958 maakten de mijnen een gouden tijd door. Staatsmijnen werkte aan de aanleg van een vijfde ontginningszetel en er werd voor de toekomst al gesproken over nog meer nieuwe mijnen in de Peel. Moeilijkheden bij het aanbod van arbeidskrachten speelden de mijnen echter parten.

De kolencrisis van 1958 en de penetratie van aardolie en aardgas op de energiemarkt maakten duidelijk dat het Limburgse steenkolentijdperk zijn langste tijd had gehad. Die ongunstige vooruitzichten maakten de arbeidsmarkt voor mijnwerkers nog moeilijker dan in de jaren vijftig. In december 1965 besloot het kabinet Cals dat de Limburgse steenkolenexploitatie geen toekomst meer had en kondigde minister Den Uyl de geleidelijke sluiting van de mijnen aan. 


\section{Demografische en ruimtelijke aspecten van de arbeidsmarkt voor mijnwerkers}

In hoofdstuk 2 werd de kwantitatieve ontwikkeling nagegaan van de vraag naar mijnwerkers, in het licht van de economische evolutie van de mijnbouwsector in Nederlands-Limburg. Dit hoofdstuk belicht kwantitatieve aspecten van het arbeidsaanbod. Allereerst wordt aandacht besteed aan de demografische ontwikkeling. Wil er op de arbeidsmarkt op lange termijn een balans bestaan tussen vraag en aanbod, dan dient de groei van de (beroeps)bevolking gelijke tred te houden met de vraag naar arbeiders. Die demografische groei wordt in dit hoofdstuk geanalyseerd. Zoals in de demografie gebruikelijk, wordt in de totale bevolkingsgroei onderscheid gemaakt tussen natuurlijke groei en groei door migratie.

De werkgelegenheid in de mijnbouw had verschuivingen in de verdeling van de beroepsbevolking over economische sectoren ten gevolg. Vooral gold dat voor de mannelijke beroepsbevolking. Zoals uit tabel 3.I blijkt, was mijnarbeid vooral een mannenaangelegenheid, al maakten in de loop van de eeuw ook vrouwen hun opwachting in de mijnbedrijven. Zij vonden vrijwel uitsluitend emplooi in administratieve en verzorgende functies.

TABEL 3.I DE BEROEPSBEVOLKING IN DE MIJNBOUWSECTOR NAAR GESLACHT, I889-I97I (PERCENTAGES)

\begin{tabular}{|c|c|c|}
\hline & mannen & vrouwen \\
\hline I889 & I00,0 & 0,0 \\
\hline I909 & I00,0 & 0,0 \\
\hline I930 & 99,8 & 0,2 \\
\hline I947 & $99, \mathrm{I}$ & 0,9 \\
\hline I960 & 98,6 & $\mathrm{I}, 4$ \\
\hline I97I & 96,2 & 3,8 \\
\hline
\end{tabular}

Bron: CBS, Volks- en beroepstellingen, I889-I97I.

Ook in ruimtelijke zin had de uitbreiding van de mijnbouwsector consequenties voor de arbeidsmarkt. Omdat de plaatselijke arbeidsmarkt in onvoldoende mate kon voldoen aan de vraag vanuit de mijnbedrijven, moest arbeid van elders worden aangetrokken. Door de nog zeer gebrekkige infrastructuur in de eerste decennia van de twintigste eeuw was pendel tussen de wervingsgebieden en de mijn nauwelijks mogelijk. Verhuizen was meestal de enige optie. Door woningbouw creëerden de mijnen en sociale woningbouwverenigingen arbeiderswijken in de onmiddellijke nabijheid van de mijnbedrijven. Mijnwerkers afkomstig uit alle windstreken woonden er naastelkaar. Wervings-en woongebied waren dus niet identiek. 


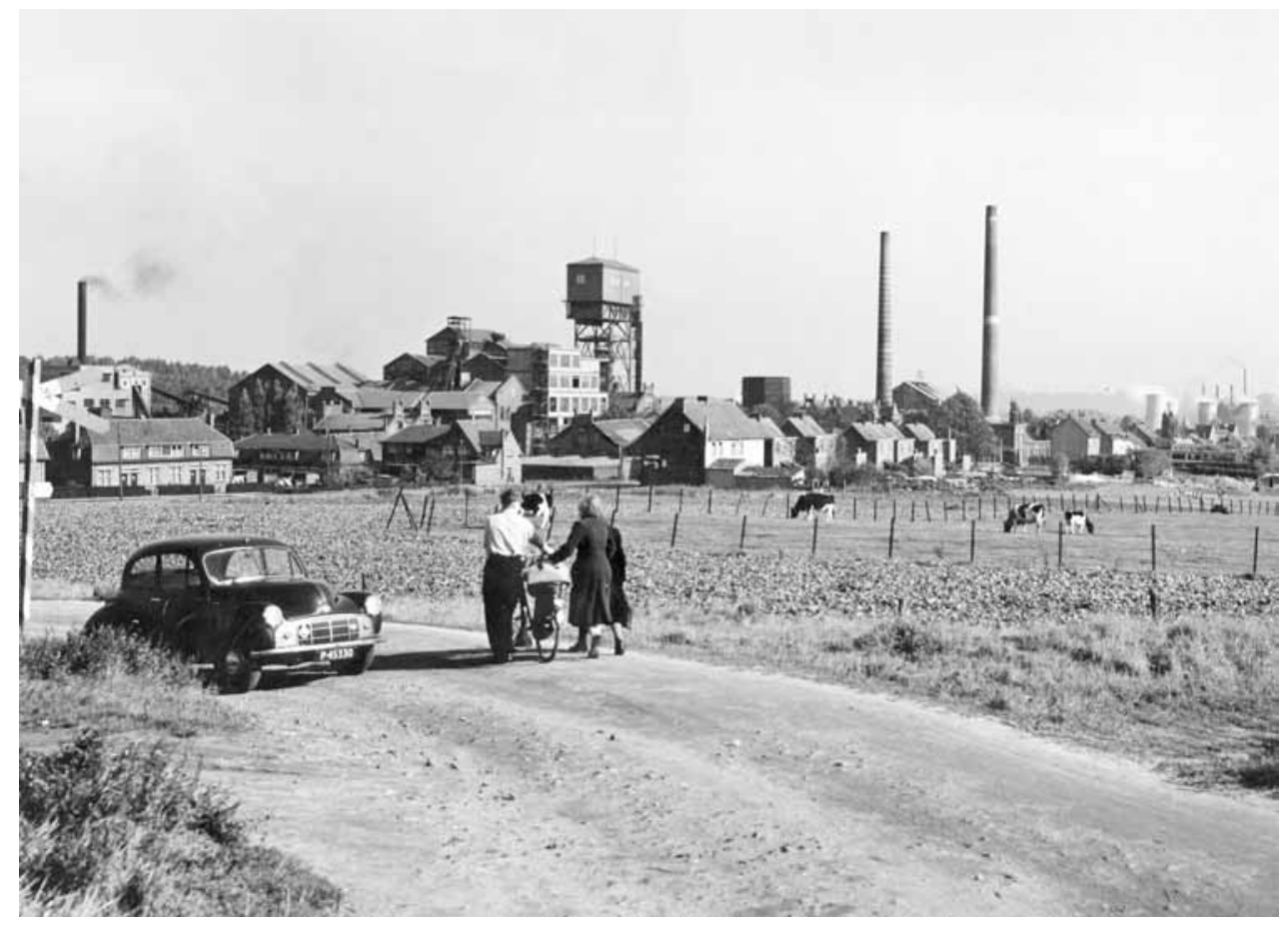

De Laura en de Julia (rechts) in Eygelshoven. 1952. Bron: Fotocollectie Continium Kerkrade, F2497.

Naarmate de verkeersinfrastructuur en de vervoersmogelijkheden werden uitgebreid door de aanleg van spoor- en tramlijnen, de komst van de autobus en - vooral na de Tweede Wereldoorlog - de toename van eigen gemotoriseerd vervoer, werden de pendelmogelijkheden groter. Het woongebied van de mijnwerkers breidde zich in de loop van de tijd als een olievlek uit over grote delen van de provincie en zelfs over de Duitse en Belgische grensstreek. Wervings- en woongebieden konden meer en meer gaan samenvallen, al bleef ook in de jaren vijftig en zestig rekrutering in verderweg gelegen gebieden noodzakelijk. Het Staatsmijnbedrijf hanteerde in die tijd een vrij formele cesuur tussen wervings- en woongebied in de vorm van de zogenaamde dertien-urengrens. Geen mijnwerkers werden aangenomen wanneer en zolang zij zo ver van de mijnzetels woonden dat de werktijd met de reisduur samen meer dan dertien uur bedroeg. ${ }^{\mathrm{I}}$ De bedrijfsleiding van de Oranje-Nassau Mijnen legde die grens op twaalf uur. ${ }^{2}$

In dit hoofdstuk wordt nagegaan hoe dit proces van toenemende ruimtelijke spreiding van de woonplaatsen van mijnwerkers verliep in het kielzog van de uitbreiding van de mijnindustrie.

I H.C.W. Roemen e.a., Verkenning omtrent het huidige en toekomstige personeelsuraagstuk van de mijnbouw in Nederlands Limburg (Luxemburg I957) I5.

2 P.J.M. Reumkens, Een onderzoek naar het verloop van mijnwerkers werkzaam bij de Oranje-Nassau Mijnen (z.p. I958) 67. 


\section{DE DEMOGRAFISCHE ONTWIKKELING}

De demografische ontwikkeling van de provincie Limburg en haar samenstellende delen is al vaker onderwerp van onderzoek geweest. ${ }^{3}$ Hier kan worden volstaan met een korte samenvatting onder verwijzing naar de desbetreffende literatuur. Doel is de demografische context te schetsen waarin de arbeidsmarkt voor mijnwerkers zich in de loop van de twintigste eeuw ontwikkelde. Daarom is in onderstaande grafieken als niveau van analyse gekozen voor de beide mijnstreken in Limburg, zoals gedefinieerd in de demografische opgaven van de provincie Limburg. ${ }^{4}$ Cijfers voor de totale provincie Limburg gelden steeds als referentiekader.

\section{Bevolkingsgroei}

Tussen de momenten van de volkstelling van 1889 en die van I97I groeide de bevolking

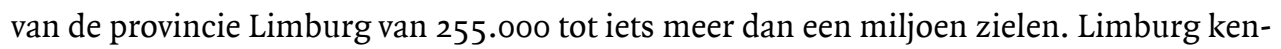
de daarmee een snellere groei dan het nationaal gemiddelde. ${ }^{5}$ Die verviervoudiging van de Limburgse bevolking was niet gelijkmatig over de provincie verdeeld. Uit grafiek 3.I

Grafiek 3.I De beVolkingsgroei in De provincie Limburg, DE OOSTELIJKe EN DE WESTELIJKE MIJNSTREEK, I889-I97I (IN DEXCIJFERS, I889=IOo)

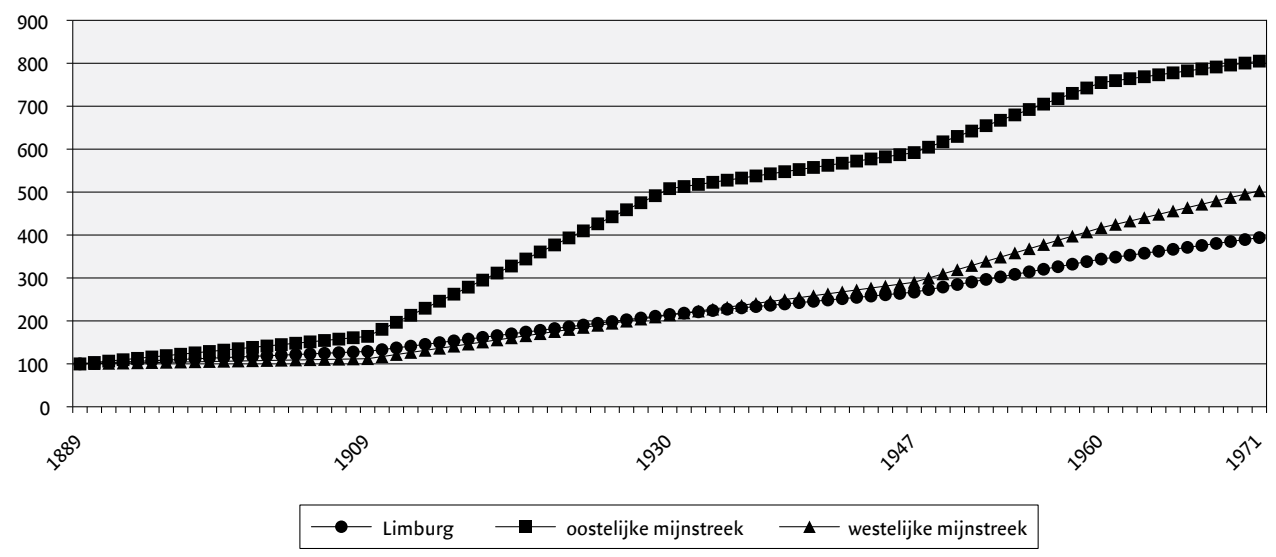

Bron: Eigen berekening op basis van CBS Volkstellingen, I889-I97I.

3 Zie bijvoorbeeld de publicaties van J. Wachelder, die omstreeks Ig6o verschenen in het Jaarboek van het Sociaal Historisch Centrum voor Limburg / Studies over de sociaal-economische geschiedenis van Limburg, respectievelijk over bevolkingsgroei (I955), geboorteoverschot (1956), migratie (1957), algemene historisch-demografische ontwikkeling (1960), geboorteniveau (1962) en gezinsgrootte (I964); Th.L.M. Engelen, Fertiliteit, arbeid, mentaliteit: de uruchtbaarheidsdaling in Nederlands-Limburg, 1850-1960 (Assen/Maastricht 1987); M.P.G. Panhuysen, 'Vruchtbaarheid en mijnarbeid. Een gezinsreconstructie te Heerlen I87I-I9I6', SSEGL XXXVII (I992) 7II27; J.C.G.M. Jansen en W.J.M.J. Rutten, Geschiedenis van de landbouw in Limburg in de twintigste eeuw (Leeuwarden/Mechelen I992), met name hoofdstuk II (bevolkingsontwikkeling en beroepsstructuur).

4 Zie bijlage 6. SHCL, Doc 7: Demografische gegevens van de provincie Limburg.

5 Jansen en Rutten, Geschiedenis van de landbouw, 78. Zie ook: E.W. Hofstee, Korte demografische geschiedenis van Nederland van 1800 tot heden (Haarlem I98I) tabel 2, I24-I25. 
GrafieK 3.2 Geboorte- EN Migratiesaldo provincie Limburg, i88i-I975 (IN PROMILLE, VIJFJAARLIJKSE TOTALEN)

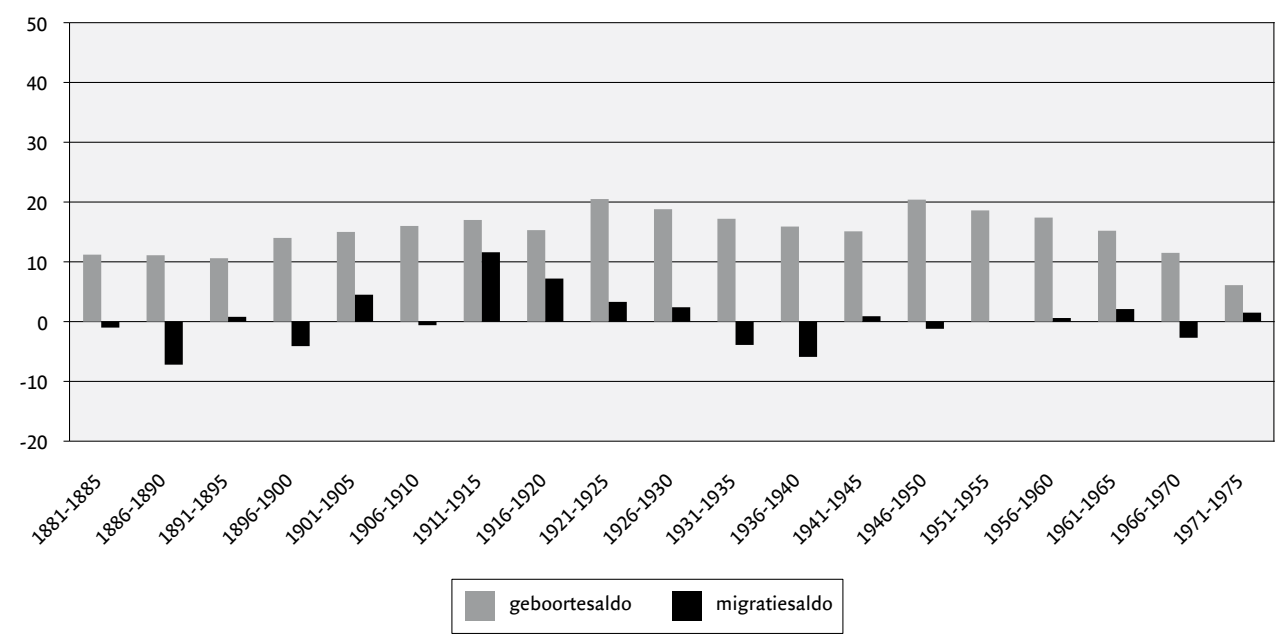

Bron: SHCL, Doc 7: Demografische gegevens van de provincie Limburg.

GrafieK 3.3 Geboorte- EN Migratiesaldo oostelijke mijnstreek, I88I-I975 (IN PROMILLE, VIJFJAARLIJKSE TOTALEN)

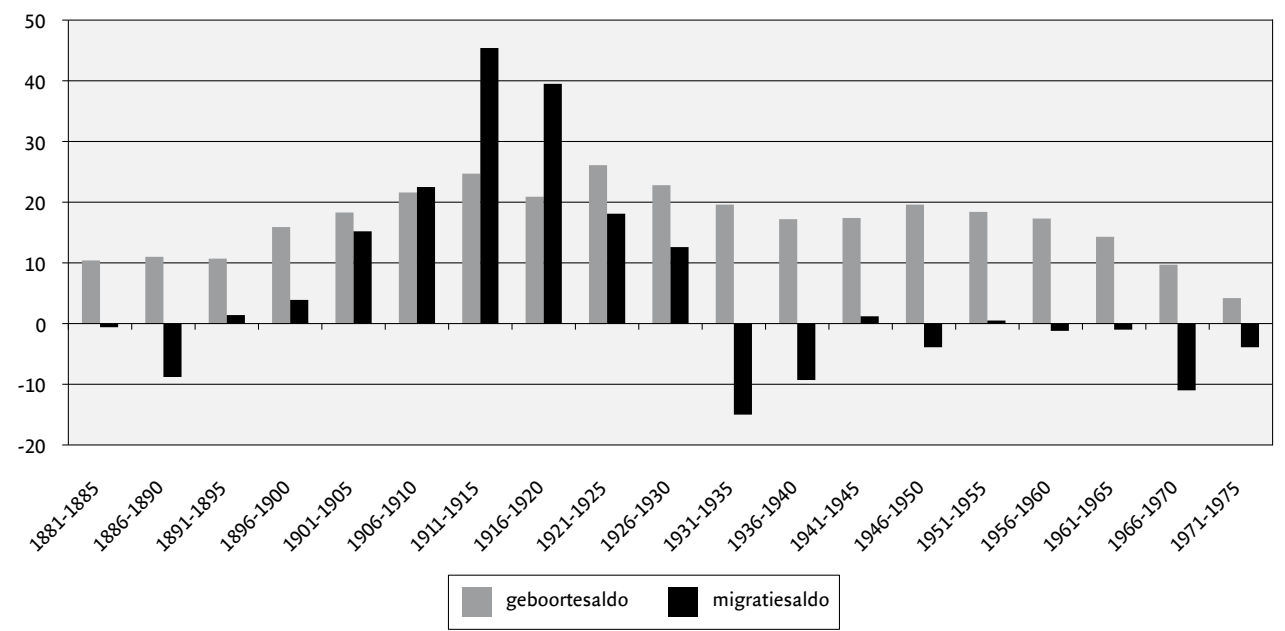

Bron: SHCL, Doc 7: Demografische gegevens van de provincie Limburg.

blijkt de relatief grote aanwas van beide mijnstreken ten opzichte van de provincie als geheel. Ook de verschillen tussen beide mijnstreken vallen in het oog. De oostelijke mijnstreek rond Heerlen en Kerkrade kende vooral tussen I909 en I930 een groeispurt. Het bevolkingsaantal verdriedubbelde in die periode. Tot I96o vlakte de groei vervolgens af, al steeg de bevolking nog steeds sneller dan in de provincie Limburg als geheel. Pas in de jaren zestig werd de groei van de bevolking in de oostelijke mijnstreek trager dan in de hele provincie. 
Grafiek 3.4 Geboorte- EN Migratiesaldo WestelijKe MiJNSTREeK, I88I-I975 (IN PROMILLE, VIJFJAARLIJKSE TOTALEN)

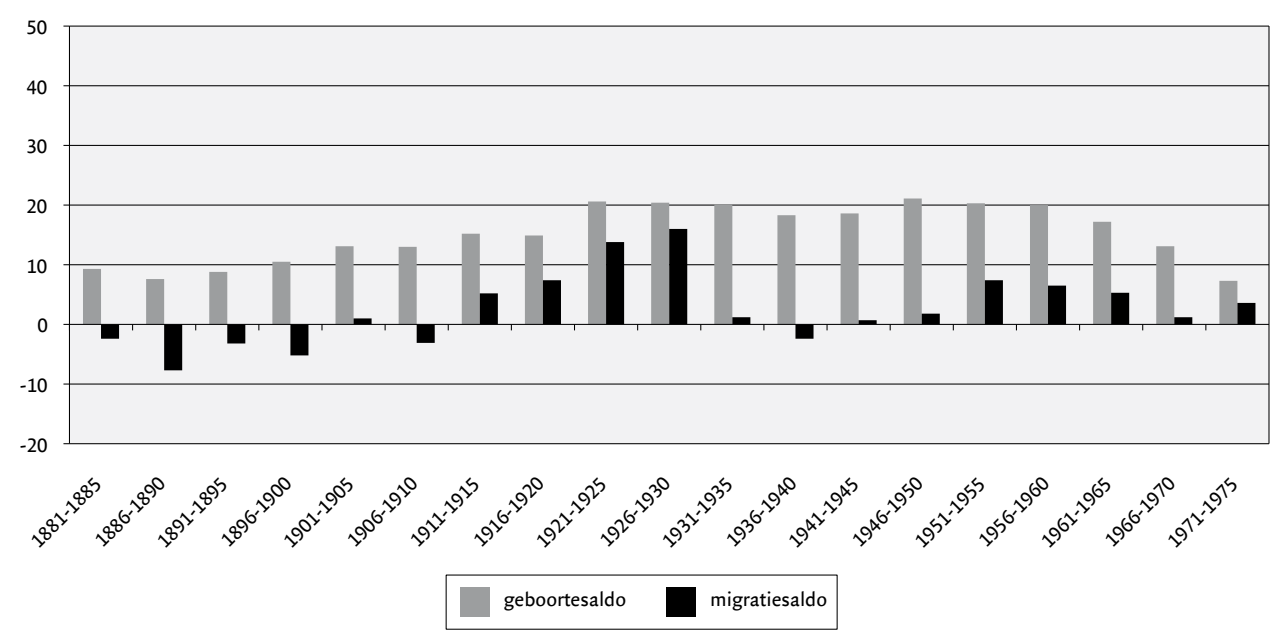

Bron: SHCL, Doc 7: Demografische gegevens van de provincie Limburg.

De bevolkingstoename in de westelijke mijnstreek rond Geleen vertoonde een meer geleidelijke ontwikkeling. Tot 1930 volgde deze regio de trend van de provincie als geheel. Daarna deed zich een versnelling voor: tot I947 licht, maar in de periode tot aan de volkstelling van I97I werd het verschil met de totale provinciale bevolkingsgroei groter.

De totale bevolkingsgroei wordt bepaald door twee componenten: het geboortesaldo of de natuurlijke groei (het verschil tussen het geboorte- en sterftecijfer), en het migratiesaldo (het verschil tussen vestiging en vertrek). In de grafieken $3.2 \mathrm{t} / \mathrm{m} 3.4$ zijn die samenstellende componenten in vijfjaarlijkse totalen in beeld gebracht voor de provincie Limburg en beide mijngebieden.

Bij de beoordeling van bovenstaande grafieken dient een onderscheid te worden gemaakt tussen de effecten op lange en op korte termijn. Wanneer we de lange periode i896I965 bekijken, dan blijkt dat de bevolkingsgroei van de provincie Limburg voor 95 procent werd veroorzaakt door natuurlijke groei en voor slechts 5 procent door migratie. Bovendien waren beide mijnstreken verantwoordelijk voor de opname van die migranten. In de oostelijke mijnstreek kwam de groei van de bevolking voor 82,5 procent op conto van natuurlijke groei, terwijl het aandeel van het migratieoverschot 17,5 procent bedroeg. Voor de westelijke mijnstreek waren die cijfers respectievelijk 80,5 en I9,5 procent.

De verklaring voor de hoge geboortesaldo's lag vooral bij de ontwikkeling van de vruchtbaarheid, het product van fertiliteit en nuptualiteit. ${ }^{6}$ Mede ten gevolge van de invloed van de katholieke leer over gezinsvorming en geboortebeperking, waren tot in de jaren vijftig

6 Jansen en Rutten, Geschiedenis van de landbouw, 94-97. Overigens daalden ook de sterftecijfers. In de periode I89I-I895 kwam het Limburgse sterftecijfer (20,8 promille) op een hoger niveau dan het landelijk gemiddelde ( 19,7 promille). Daarna zette een daling in, zowel provinciaal als landelijk. In Limburg bleef het niveau echter nog vier decennia op een relatief hoog niveau liggen. Pas in de vijfjaarlijkse periode I93I-I935 was het Limburgse cijfer met 8,9 promille op hetzelfde peil als het Nederlandse gemiddelde gekomen. Hofstee, Korte demografische geschiedenis, tabel I, I22-123. 
van de twintigste eeuw nergens in Nederland de huwelijken zo vruchtbaar als in Limburg (en Noord-Brabant). Pas na i96o daalde de huwelijksvruchtbaarheid in Limburg door deconfessionalisering, het gebruik van anticonceptiemiddelen en de acceptatie van vrijere denkbeelden over huwelijksleven en seksualiteit. Die daling was sterker dan waar ook in Nederland. In I970 was Limburg van het ene uiterste in het andere gekomen en kende de provincie de laagste huwelijksvruchtbaarheid van het land. ${ }^{7}$

Ook veranderingen in het huwelijkspatroon na circa I9oo waren verantwoordelijk voor de snelle toename van de vruchtbaarheid in Limburg. Meer mensen traden in het huwelijk. En wie trouwde, deed dat in het algemeen op jongere leeftijd. In Limburg ging dat proces sneller dan elders in Nederland. Terwijl zowel het aantal ongehuwden als de gemiddelde huwelijksleeftijd aan het eind van de negentiende eeuw in Limburg hoger lag dan het Nederlandse gemiddelde, had de provincie omstreeks 1930 aansluiting gevonden bij de rest van het land. ${ }^{8}$

Een bijkomend effect van de hoge vruchtbaarheid was dat de Limburgse bevolking erg jong was. Bij de volkstelling van I930 was 45 procent van de Limburgers jonger dan twintig jaar, bij de tellingen van 1947 en I96o was dat telkens 42,4 procent. In Nederland bedroegen die percentages respectievelijk 4I, 37,7 en 38,5. Gevolg was dat Limburg ervan verzekerd was dat steeds grote aantallen jonge mensen in de vruchtbare leeftijdsgroepen terecht kwamen. Het effect daarvan op de bevolkingsgroei was, dat Limburg tot het begin van de jaren zestig zeer hoge geboortecijfers hield. ${ }^{9}$

Hoewel op de lange termijn dus het geboortesaldo in hoge mate verantwoordelijk was voor de bevolkingsgroei, kon op kortere termijn en per regio verschillend het beeld echter compleet anders zijn. ${ }^{\text {Io }}$ De invloed van het migratieoverschot op de groei van de bevolking was soms spectaculair. In de oostelijke mijnstreek was in de jaren I906-I920 de aanwas ten gevolge van het migratieoverschot groter dan de natuurlijke groei. Vooral tussen I9II en I920 was de invloed van migratie enorm. Ruim 65 procent van de bevolkingsgroei kwam voor rekening van het migratieoverschot. Na 1920 vlakte het belang van de migratie iets af, maar desondanks werd ook in de jaren twintig 35 à 40 procent van de bevolkingsgroei veroorzaakt door migratoire aanwas. De bevolkingsgroei kwam tussen I896 en I930 voor meer dan de helft (50,6 procent) op rekening van een migratieoverschot. Die winst verdween in de periode I93 I tot 1965 weer voor een belangrijk deel. De oostelijke mijnstreek noteerde in die periode een totaal vertrekoverschot van 25.715 personen. Desondanks groeide de bevolking in dezelfde jaren dankzij grote geboorteoverschotten met ruim roo.00o zielen.

De ontwikkeling in de westelijke mijnstreek was minder spectaculair. Bovendien werd de invloed van migratie op de bevolkingsgroei een decennium later merkbaar dan in de streek rond Heerlen en Kerkrade. Dat kan worden verklaard door de uitbouw van Staatsmijn Maurits met nevenbedrijven bij Geleen vanaf I9I5. Vanaf de periode I9II-I9I5 steeg de invloed van het migratieoverschot op de bevolkingsgroei voortdurend om in de jaren 1926-1930 uit te komen op bijna 44 procent van de bevolkingsgroei. Over de langere periode I896-I930 was het aandeel van migranten in de bevolkingsgroei 28,8 procent. De crisis van de jaren

7 Hofstee, Korte demografische geschiedenis, tabel 6, I32.

8 Ibidem tabel 4, I28-130.

9 Jansen en Rutten, Geschiedenis van de landbouw, 97.

Io Wim Derks, 'De arbeidsmarkt in Limburg 1960-2005: is de sluiting van de mijnen verwerkt?', SSEGL L (2005) I73-196, aldaar 
TABEL 3.2 De POTENTIËLE BEROEPSBEVOLKING (I5-64 JAAR) IN RELATIE TOT DE TOTALE BEVOLKING IN DE PROVINCIE LIMBURG, DE OOSTELIJKE EN WESTELIJKE MIJNSTREEK, I9O9-I960 (TOTAAL, MANNEN EN VROUWEN; IN INDEXCIJFERS, I9O9=IOO)

\begin{tabular}{|l|c|c|c|c|c|c|}
\hline \multirow{2}{*}{} & \multicolumn{5}{|c|}{ provincie Limburg } \\
\cline { 2 - 7 } & \multicolumn{3}{|c|}{ totale bevolking } & \multicolumn{2}{c|}{ potentiële beroepsbevolking } \\
& totaal & mannen & vrouwen & totaal & mannen & vrouwen \\
\hline I909 & I00 & I00 & I00 & 100 & I00 & I00 \\
\hline I930 & I66 & I68 & I65 & I72 & I73 & I7I \\
\hline I947 & 206 & 206 & 207 & 225 & 222 & 227 \\
\hline I960 & 265 & 264 & 267 & 274 & 269 & 279 \\
\hline
\end{tabular}

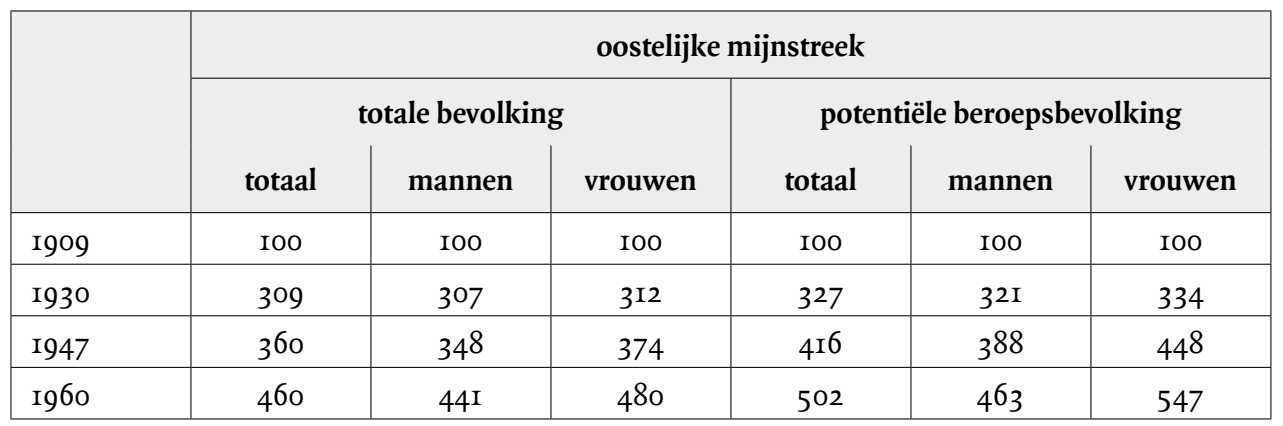

\begin{tabular}{|l|c|c|c|c|c|c|}
\hline \multirow{2}{*}{} & \multicolumn{5}{|c|}{ westelijke mijnstreek } \\
\cline { 2 - 7 } & \multicolumn{3}{|c|}{ totale bevolking } & \multicolumn{2}{c|}{ potentiële beroepsbevolking } \\
& totaal & mannen & vrouwen & totaal & mannen & vrouwen \\
\hline I909 & I00 & I00 & I00 & I00 & I00 & I00 \\
\hline I930 & I82 & I82 & I8I & I83 & I85 & I8I \\
\hline I947 & 246 & 243 & 249 & 262 & 256 & 270 \\
\hline I960 & $35 \mathrm{I}$ & 343 & 360 & $36 \mathrm{I}$ & 346 & 376 \\
\hline
\end{tabular}

Bron: Eigen berekening op basis van CBS Volkstellingen, I9o9-ı96o.

dertig betekende ook voor de westelijke mijnstreek een cesuur. Het relatieve belang van migratie voor de bevolkingsgroei nam ook in deze regio na 1930 af. Maar de omslag was geleidelijker. Terwijl in de oostelijke mijnstreek tussen 1930 en 1965 slechts een enkele vijfjaarlijkse periode een gering migratieoverschot vertoonde en de hele periode een vertrekoverschot liet zien, bleef het migratiesaldo in de westelijke mijnstreek over de hele periode tussen I93I en I 965 positief. Hoewel het aandeel van het vestigingsoverschot in de bevolkingsgroei niet meer de waarden van vóór I930 haalde, kan niettemin in het tijdvak 193II965 I5,4 procent van de bevolkingstoename worden toegeschreven aan migratoire groei. 
De groei van de totale bevolking betekende een toename van de potentiële beroepsbevolking, gedefinieerd als het aantal mannen en vrouwen in de leeftijdscategorie i5 tot en met 64 jaar. De verjonging van de bevolking die hierboven werd geconstateerd, had zelfs tot gevolg dat de categorie 15 - tot en met 64 -jarigen sneller steeg dan de totale bevolking. Dat gold voor de beide mijnstreken, maar ook voor de provincie Limburg als geheel (tabel 3.2).

De structureel hoge geboortesaldo's hadden tot gevolg dat gedurende de hele periode een natuurlijke aanvulling van de potentiële beroepsbevolking plaatsvond. Voortdurend stonden per uittreder op de arbeidsmarkt in theorie drie à vier jongeren klaar om de opengevallen plaats in te nemen (tabel 3.3).

TABEL $3 \cdot 3$ VERVANGINGSINDEX MANNELIJKE BEROEPSBEVOLKING PROVINCIE LIMBURG, OOSTELIJKE EN WESTELIJKE MIJNSTREEK, I9O9-I960 (UITSTROOM OP KORTE TERMIJN OP DE ARBEIDSMARKT (60-64-JARIGEN) GEDEELD DOOR DE INSTROOM OP KORTE TERMIJN (IO-I4-JARIGEN))

\begin{tabular}{|l|c|c|c|}
\hline & Limburg & oostelijke mijnstreek & westelijke mijnstreek \\
\hline I909 & 4,2 & 4,5 & 3,2 \\
\hline I930 & 3,5 & 5,9 & $4, \mathrm{I}$ \\
\hline I947 & 3,0 & $3, \mathrm{I}$ & 3,6 \\
\hline I953 & 3,2 & $3, \mathrm{I}$ & 3,8 \\
\hline I960 & 3,5 & $3, \mathrm{I}$ & 3,9 \\
\hline
\end{tabular}

Bron: Eigen berekening op basis van: SHCL, Doc 7: Demografische gegevens van de provincie Limburg.

In de praktijk neemt niet de hele potentiële beroepsbevolking deel aan het arbeidsproces. Daarom moet ook worden gekeken naar de beroepsdeelneming of participatiegraad: degenen die daadwerkelijk op de arbeidsmarkt actief (willen) zijn als percentage van de bevolking in de leeftijdsgroep I5-64 jaar (tabel 3.4). ${ }^{\text {II }}$

TABEl 3.4 De BeroepsDeELNEMING IN Limburg, De OOSTELIJKe EN WESTELIJKE MIJNSTREEK, I909-I960 (TOTAAL, MANNEN EN VROUWEN, ALS PERCENTAGE VAN DE LEEFTIJDSGROEP I5-64 JAAR)

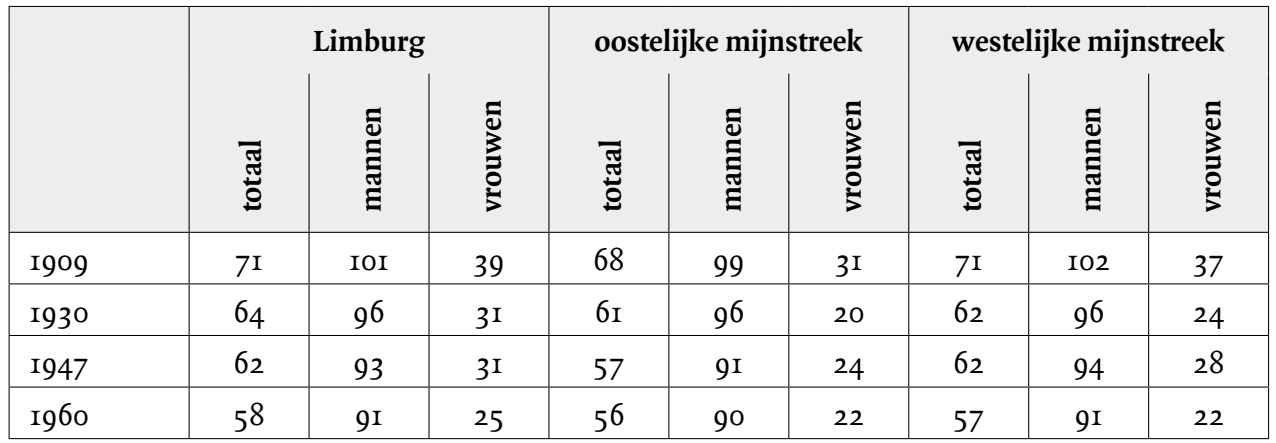

Bron: Eigen berekening op basis van CBS Volkstellingen, I909-1960.

II De Galan en Van Miltenburg, Economie van de arbeid, 30-3I. 
In de oostelijke mijnstreek was de beroepsdeelneming relatief laag. Zeker is hier de invloed van de mijnbouw als dominerende werkgelegenheid debet aan. Mijnarbeid was zwaar werk met relatief veel kans op vroegtijdige invaliditeit. Ook de lagere pensioenleeftijd van mijnwerkers op 55- of 6o-jarige leeftijd speelde een rol. In de westelijke mijnstreek blijkt de beroepsdeelneming eveneens iets lager dan het Limburgse gemiddelde, maar was er wel hoger dan in de oostelijke mijnstreek: een aanwijzing dat de arbeidsmarkt er minder eenzijdig op mijnbouw was gericht. In beide mijnstreken was de participatie van vrouwen laag: mijnbouw was een mannenwereld (zie ook tabel 3.I) en kennelijk was er weinig alternatieve werkgelegenheid voor vrouwen.

\section{Beroepsbevolking en economische structuur}

In de loop van de twintigste eeuw veranderde de economische structuur en de aard van de werkgelegenheid in Limburg fundamenteel. De dominerende positie van de landbouw nam vooral na Igog snel af, al had Limburg pas bij de volkstelling van I 960 minder beroepsbeoe-

TABEL 3.5 DE VERDELING VAN DE BEROEPSBEVOLKING (MANNEN EN VROUWEN) NAAR ECONOMISCHE SECTOREN IN LIMBURG EN NEDERLAND I889-I960 (IN PROCENTEN)

\begin{tabular}{|l|c|c|c|c|c|c|}
\hline & \multicolumn{2}{|c|}{ landbouw } & \multicolumn{2}{c|}{ nijverheid } & \multicolumn{2}{c|}{ diensten (handel en verkeer) } \\
& Limburg & Nederland & Limburg & Nederland & Limburg & Nederland \\
\hline I889 & 47 & 33 & 28 & 3 I & 25 & 36 \\
\hline I909 & 4 I & 28 & 35 & 34 & 24 & 38 \\
\hline I930 & 25 & 2I & 46 & 38 & 29 & 4 I \\
\hline I947 & 2I & 20 & 45 & 37 & 34 & 43 \\
\hline I960 & 9 & II & 54 & 42 & 37 & 47 \\
\hline
\end{tabular}

Bron: Jansen en Rutten, Geschiedenis van de landbouw, ro8.

TABEL 3.6 HET AAN DEEL VAN DE SECTOR STEEN KOLEN MIJNBOUW IN DE MANNELIJKE LIMBURGSE BEROEPSBEVOLKING, I889-I960

\begin{tabular}{|l|c|c|c|}
\hline & beroepsbevolking & steenkolenmijnbouw & percentage \\
\hline $\mathrm{I} 889$ & 65.666 & $\mathrm{I} . \mathrm{I} 62$ & $\mathrm{I}, 8$ \\
\hline $\mathrm{I} 899$ & 85.074 & 2.096 & 2,5 \\
\hline $\mathrm{I} 909$ & 98.334 & 6.704 & 6,8 \\
\hline $\mathrm{I} 930$ & $\mathrm{I} 62.522$ & 37.034 & 22,8 \\
\hline $\mathrm{I} 947$ & 202.069 & 39.965 & $\mathrm{I} 9,8$ \\
\hline $\mathrm{I} 960$ & 240.003 & $52.2 \mathrm{I} 7$ & $2 \mathrm{I}, 8$ \\
\hline
\end{tabular}

Bron: CBS, Volks- en beroepstellingen, I889-196o. 
fenaren in de landbouwsector dan het rijksgemiddelde. De neergang van de werkgelegenheid in de landbouw werd voor een deel gecompenseerd door het toenemende belang van de dienstensector, al bleef die zwak ontwikkeld. Vooral de nijverheid won in de loop van de twintigste eeuw aan belang.

In die ontwikkeling was de rol van de steenkolenmijnbouw als verschaffer van werkgelegenheid groot. Het belang van de bedrijfsgroep steenkolenmijnbouw voor de economische structuur en arbeidsmarkt in de provincie Limburg blijkt uit tabel 3.6.

Binnen de provincie waren er echter grote verschillen. Een nadere analyse van de reikwijdte van de arbeidsmarkt voor mijnwerkers op gemeentelijk en regionaal niveau kan dat duidelijk maken.

\section{DE REGIONALE SPREIDING VAN DE ARBEIDSMARKT VOOR MIJNWERKERS}

Uitgangspunt van de analyse in deze en volgende paragrafen zijn aan de CBS-beroepstellingen van I909, I930, I947 en I960 ontleende gegevens omtrent het aandeel van mijnwerkers in de beroepsbevolking op gemeentelijk niveau. In de CBS-cijfers zijn inbegrepen de pendelaars die vanuit Limburg in een Duitse of Belgische mijn werkten. Zeker vanuit het zuiden van de provincie waren de mijnen rond Aken, in de Kempen en bij Luik in principe goed bereikbaar voor Limburgse grensarbeiders. Het waren op het totaal aan mijnwerkers echter geen grote aantallen en ze veroorzaken geen ruis in het kaartbeeld.

In de bijlagen $7 \mathrm{~A}$ en $7 \mathrm{~B}$ zijn twee reeksen van kaarten opgenomen. De kaarten benaderen de ruimtelijke spreiding van de Limburgse arbeidsmarkt voor mijnwerkers op twee verschillende manieren. De eerste reeks (A) focust op het gemeentelijk niveau en laat het plaatselijke belang zien van de werkgelegenheid in de mijnbouw voor de mannelijke beroepsbevolking. De B-reeks gaat uit van het totale aantal mijnwerkers en verdeelt dat over de verschillende woongemeenten. Op die manier kunnen concentraties van mijnwerkers in beeld worden gebracht.

In beide reeksen zijn twee patronen te herkennen. Het eerste is dat gedurende de hele periode I909-1960 de kern van de mijnwerkers woonde in een gemeente waar een mijn was gevestigd, of in een naburige plaats. In 1909 betrof dit 92 procent van de mijnwerkers; in 1960 bedroeg het nog 78 procent. In de betreffende gemeenten, die de kern van de mijnstreek vormden, was de mannelijke beroepsbevolking in hoge mate afhankelijk van de werkgelegenheid bij de mijnbedrijven. In extreme gevallen, zoals Brunssum in 1930, was meer dan 70 procent van de mannelijke beroepsbevolking in dienst van de mijn.

Het tweede patroon is dat de arbeidsmarkt zich, in het kielzog van het ontstaan van nieuwe mijnen, als een olievlek uitbreidde over de rest van de provincie. Terwijl de mijnwerkers in 1909 in 44 van de 123 Limburgse gemeenten ( 36 procent) woonden, waren er in 1960 nog slechts drie Limburgse gemeenten zonder mijnwerkers: de drie meest noordelijk gelegen gemeenten Mook en Middelaar, Gennep en Ottersum. In het begin van de jaren Ig6o was de gemeente Deurne in het Noord-Brabantse deel van de Peel het verste punt waar mijnwerkers van de Limburgse mijnen woonden. ${ }^{\mathrm{I}}$ 
Beide patronen zijn terug te vinden in de zogenaamde locatiequotiënten, die de mate van over- of ondervertegenwoordiging van mijnwerkers in de plaatselijke beroepsbevolking ten opzichte van een referentiegebied (de provincie Limburg) uitdrukken (bijlage $7 \mathrm{C}$ ). De gemeenten met een mijnzetel binnen de grenzen laten doorgaans de hoogste waarden zien. In de loop van de eeuw namen de waarden in de mijnstreekgemeenten echter af. Bedroeg in I909 het hoogste locatiequotiënt nog 8,76 (Kerkrade), in I96o bereikte geen enkele gemeente een waarde hoger dan 3,04 (Eygelshoven), een bewijs dat de mijnwerkerspopulatie zich meer over de provincie had verspreid.

De verklaring voor beide patronen dient te worden gezocht in de ontwikkeling van de woningbouw aan de ene, en de toenemende mobiliteit aan de andere kant.

\section{Mijnbouw, werkgelegenheid en woningbouw}

Toen in I928 de laatste mijnen in productie kwamen, was de mijnbouw allang geen vrijwel exclusief Kerkraads fenomeen meer. Sinds het begin van de eeuw was de mijnbouw in noordwestelijke richting opgeschoven. Behalve in Kerkrade waren er nu ook mijnen in de gemeenten Heerlen, Eygelshoven, Schaesberg, Brunssum, Hoensbroek en Geleen.

$\mathrm{Al}$ in het begin van de eeuw leidde de groei van de werkgelegenheid in de nieuwe mijnen tot woningnood. Door het ontbreken van goede verkeersverbindingen en vervoersmogelijkheden waren de mijnen vanuit veel plaatsen in Limburg slecht bereikbaar. ${ }^{13}$ Mijnwerkers waren daardoor welhaast verplicht in de onmiddellijke nabijheid van de mijn te gaan wonen. Voor de mijnondernemingen was woningbouw daarom van groot belang. Goede huisvestingsmogelijkheden waren een onmisbaar lokmiddel bij het rekruteren van nieuwe mijnwerkers en hielpen bij het vasthouden van eenmaal geworven arbeiders. ${ }^{\mathrm{I}}$ Behalve de mijnondernemingen zelf maakte de katholieke sociale beweging, onder leiding van de aalmoezenier van sociale werken dr H.A. Poels, werk van woningbouw. In IgII richtte Poels 'Ons Limburg' op, een koepelorganisatie van plaatselijke woningbouwverenigingen. ${ }^{15}$

In nauwe samenwerking slaagden beide bouwheren, mijnondernemingen en 'Ons Limburg', er tot I930 in om bijna I5.000 woningen in de mijnstreek af te leveren voor arbeiders en beambten. ${ }^{16}$ De geograaf Overhage onderscheidde een aantal factoren dat bepalend was voor de locatie van de nieuwe huisvesting, vaak in de vorm van woninggroepen of kolonies. ${ }^{17}$ De grondprijs speelde een voorname rol, evenals de gesteldheid van het terrein. Waar mogelijk hield men rekening met de overheersende windrichting, zodat de bewoners van de nieuwbouw zo min mogelijk last van rook, roet en stof van het mijnterrein zouden ondervinden. Maar de belangrijkste factor was de nabijheid van de mijn. Waar een mijnzetel ontstond, ontstond ook woningbouw. Van het hierboven genoemde aantal van $\mathbf{1 5}$.000 woningen werden er bijna II.000 gebouwd in de zeven mijnzetelge-

13 Staatscommissie over de Werkloosheid. Deel IX Eindverslag ('s-Gravenhage 19I4) 544.

14 Van Royen, 'Beheersaspecten', 85-86.

15 Remigius Dieteren, Veertig jaar arbeiderswoningen in Limburg: "Ons Limburg”, 1911-1951 (Heerlen I95I).

I6 Antoine Dohmen, Mijnkolonies in Zuid-Limburg. Stedebouw met een missie (scriptie Technische Universiteit, Eindhoven I995) 52.

17 Paul Overhage, Heerlen. Der städtische Mittelpunt des südlimburgischen Bergbaugebietes. Landschafts-, Wirtschafts-, Bevölkerungs- und Siedlungsbild (Hamburg 1939) I60-I6I. 


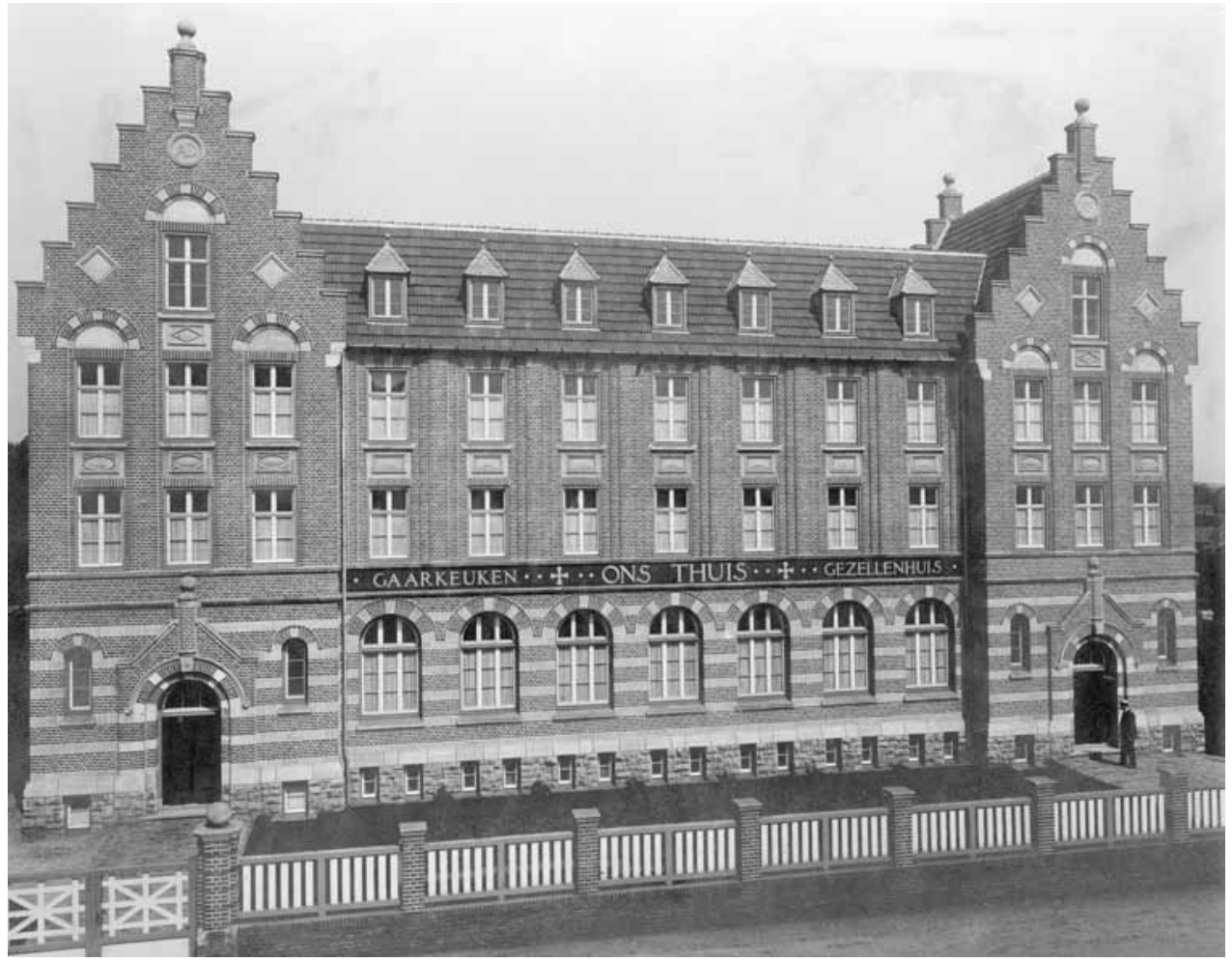

Het gezellenhuis aan de Laurastraat in Eygelshoven. Omstreeks 1920. Bron: Fotocollectie Continium Kerkrade, F4805.

meenten, met Heerlen als koploper ${ }^{18}$ Omdat de bouw van nieuwe woonwijken eerst en vooral de mijnen volgde, schoof de woningbouw in noordwestelijke richting op. De eerste woninggroepen kwamen al in 1905 tot stand in Heerlen en Schaesberg, vanaf I9Io werd ook gebouwd in Eygelshoven, Brunssum en Hoensbroek, na I920 was het de beurt aan Geleen. ${ }^{19}$

Een nieuwe bouwgolf vond na de Tweede Wereldoorlog plaats. Door de snelle bevolkingsgroei werd het woningvraagstuk opnieuw het sociale probleem bij uitstek. ${ }^{20}$ Een tekort aan woningen stond de werving van mijnwerkers in de weg. ${ }^{21}$ 'Ons Limburg' bouwde tussen 1945 en 1964 ruim 30.000 nieuwe woningen, waarvan 5.000 in opdracht van 'Thuis Best', een stichting die huurwoningen voor personeelsleden van de mijnondernemingen exploiteerde. Ook de mijnen zelf gingen zich weer met huisvesting bezighouden: voor ongehuwden werden gezellenhuizen ingericht, nieuwe eengezinswoningen in de huursec-

I8 Met de term mijnzetelgemeenten is hier bedoeld de zeven gemeenten met minstens één mijnzetel binnen de grenzen: Kerkrade, Heerlen, Schaesberg, Eygelshoven, Hoensbroek, Brunssum en Geleen. Zie ook: Th.J.M. Gijsen, 'Enige aspecten van de gevolgen van de ontwikkeling van de Mijnindustrie voor de Mijnstreekgemeenten', in: M. Kemp (ed.), Mijn en spoor in goud (Maastricht I952) I4I-I49.

19 Overhage, Heerlen, tabel 40 , I6o.

20 Bouwen in Limburg. Woningbouw door de Vereniging Ons Limburg sinds haar oprichting (Heerlen z.j.) 9.

2I Roemen e.a., Verkenning, 30. Zie ook hierna hoofdstuk 4. 
tor kwamen tot stand en het eigen-huizenbezit van de mijnwerkers werd gestimuleerd. De nieuwe woningen kwamen hoofdzakelijk in de oostelijke en westelijke mijnstreek. Soms werden bestaande kolonies zoals Treebeek (tussen Hoensbroek en Brunssum), de Hopel (Eygelshoven) en Lotbroek (Hoensbroek) uitgebreid. ${ }^{22}$

De concentratie van de mijnwerkersbevolking in de buurt van de mijnzetels leidde ertoe dat de werkgelegenheid in de betreffende gemeenten tot aan de sluitingsoperatie vanaf de jaren zestig werd gedomineerd door de mijnbouw. Al bij de beroepstelling van Igog was in de gemeenten Kerkrade en Schaesberg meer dan de helft van de mannelijke beroepsbevolking mijnwerker, zoals blijkt uit kaart A-ıgog. In Eygelshoven en Heerlen was ongeveer 40 procent van de werkzame mannen actief in de mijnbouw. In Hoensbroek was al ruim een kwart van de mannelijke beroepsbevolking in dienst van de mijn. Sinds I 908 was daar op de gemeentegrens met Heerlen Staatsmijn Emma in aanleg. Op 3 I december I9o9 had het bedrijf I 84 mijnwerkers op de loonlijst staan. ${ }^{23}$ Wellicht dat onder hen ook al arbeiders vertegenwoordigd waren uit het vrij dichtbij gelegen Geleen. Hoewel die gemeente in I909 nog geen mijn binnen de grenzen had, was toch al ruim I3 procent van de mannelijke beroepsbevolking in de mijnbouw actief. Geleen had een station aan de spoorlijn van Sittard naar Heerlen en dus was de mijnstreek goed bereikbaar. In Brunssum, waar Staatsmijn Hendrik pas in IgII in aanleg kwam, was in Igog de mijnarbeid als bron van werkgelegenheid daarentegen nog van weinig betekenis.

Toen op 3 I december 1930 opnieuw een beroepstelling werd gehouden, was de invloed van de mijnbouw op de werkgelegenheid voor mannen enorm toegenomen. Bijna een kwart van de Limburgse werkzame mannen vond emplooi in een van de mijnen. In de eigenlijke mijnzetelgemeenten was de betekenis van het werk in de kolenwinning van nog veel groter belang (kaart A-I930). De woningbouw, die vooral in deze gemeenten was gerealiseerd, had er voor gezorgd dat in zes van de zeven gemeenten meer dan de helft van de mannen mijnwerker was. Voor het eerst nam de oude mijnstad Kerkrade niet meer de koppositie in. In absolute aantallen had Heerlen inmiddels de meeste mijnwerkers binnen de grenzen. Het aandeel van de mijnbouw in de werkgelegenheid was er echter lager dan in de andere mijnzetelgemeenten van de oostelijke mijnstreek. In een middelgrote stad als Heerlen, die een centrumfunctie voor de oostelijke mijnstreek uitoefende, was het arbeidsaanbod minder eenzijdig op mijnbouw gericht, ${ }^{24}$ al was het aandeel van 5 I procent mijnwerkers in de mannelijke beroepsbevolking niettemin fors. Maar het stak toch schril af tegen de situatie in de arbeidersgemeenten Brunssum, Schaesberg en Eygelshoven, waar het aandeel van de mijnbouw in de totale werkgelegenheid voor mannen rond de 70 procent lag.

Hoewel het plaatselijke belang van de werkgelegenheid in de mijnen na I930 zeer groot bleef, waren de percentages mijnwerkers in de beroepsbevolking bij de tellingen van 1947 en I960 wat lager. Dat wijst er op dat er meer alternatieven beschikbaar kwamen. Wellicht heeft dat ook te maken met de toenemende mobiliteit in de periode na de Tweede Wereldoorlog, die het makkelijker maakte een baan buiten de mijnbouwsector te aanvaarden. ${ }^{25}$

22 Loek Kreukels, 'De mijnkolonie', Weet je nog koempel? De mijnen in Limburg (Zwolle 2004) 297-320, aldaar 315-317.

23 Jaarverslag van het bedrijf der Staatsmijnen over het jaar 1909, 7.

24 Overhage, Heerlen, I22, I33-134.

25 Over het algemeen was de Limburgse arbeidsmarkt in de jaren vijftig zeer krap. Roemen e.a., Verkenning, 64-74. 
TABEL 3.7 DE MANNELIJKE BEROEPSBEVOLKING IN DE STEEN KOLENMIJNBOUW, I909-I960 (ABSOLUUT EN IN PERCENTAGE VAN DE TOTALE MAN NELIJKE BEROEPSBEVOLKING)

\begin{tabular}{|c|c|c|c|c|c|c|c|c|}
\hline & \multicolumn{2}{|c|}{1909} & \multicolumn{2}{|c|}{1930} & \multicolumn{2}{|c|}{ I947 } & \multicolumn{2}{|c|}{ 1960 } \\
\hline & aantal & $\%$ & aantal & $\%$ & aantal & $\%$ & aantal & $\%$ \\
\hline Kerkrade & 2.679 & 59,7 & 6.983 & 63,2 & 6.214 & $5 \mathrm{I}, 3$ & 7.696 & 56,9 \\
\hline Heerlen & I. 348 & 39,2 & 7.433 & $5^{\mathrm{I}, \mathrm{O}}$ & 6.825 & 40,4 & 8.857 & 45,2 \\
\hline $\begin{array}{l}\text { Hoens- } \\
\text { broek }\end{array}$ & I37 & 27,0 & 2.654 & 63,2 & 2.335 & 47,7 & 3.465 & 54,2 \\
\hline $\begin{array}{l}\text { Bruns- } \\
\text { sum }\end{array}$ & 33 & 7,3 & 3.317 & 72,3 & 3.455 & 60,1 & 4.138 & $6 \mathrm{I}, 3$ \\
\hline $\begin{array}{l}\text { Schaes- } \\
\text { berg }\end{array}$ & 404 & 53,0 & I. 703 & 67,3 & I. 474 & 57,2 & 2.393 & 61,2 \\
\hline $\begin{array}{l}\text { Eygels- } \\
\text { hoven }\end{array}$ & 165 & $44, \mathrm{I}$ & I.027 & 67,9 & 837 & 58,3 & I.I 52 & 66,2 \\
\hline Geleen & 107 & 13,6 & I.66o & 44,0 & 2.072 & 37,3 & 2.683 & 31,0 \\
\hline Limburg & 6.704 & 6,8 & 37.034 & 22,8 & 39.965 & I9,8 & 52.217 & $2 \mathrm{I}, 8$ \\
\hline
\end{tabular}

Bron: CBS, Volks- en beroepstellingen, I909-196o.

De toenemende mobiliteit leidde er toe dat er steeds meer mijnwerkers niet in de onmiddellijke nabijheid van de mijn woonden, maar besloten om vanuit een andere woongemeente te pendelen. Ook het beleid van de mijnondernemingen speelde daarop in door voor hun werknemers een uitgebreid net van busdiensten op te zetten. Daaraan lagen twee overwegingen ten grondslag: het inzicht dat de groei van de woningvoorraad in de onmiddellijke omgeving van de mijnbedrijven geen gelijke tred kon houden met de uitbreiding van de personeelsbezetting en de overtuiging dat het voor het welzijn van de mijnwerker beter was als hij in zijn vertrouwde omgeving kon blijven wonen. Daar had hij familie en vrienden en vaak een woning met een stukje grond om te tuinieren. ${ }^{26}$ Wat voor de mijnwerker goed was, was immers ook goed voor de mijn: men hoopte er het grote personeelsverloop mee te beperken.

\section{Pendel naar de mijn}

De invloed van de werkgelegenheid in de expanderende mijnbouw was niet beperkt tot de gemeenten waar de mijnbedrijven gevestigd waren. Uit tabel 3.8 en de kaartenreeks in bijlage $7 \mathrm{~B}$ blijkt dat in de loop van de periode I909-1960 een steeds groter percentage van de mijnwerkers in de Limburgse mijnen een woonplaats had buiten de zeven eigenlijke mijnzetelgemeenten. Vooral na de Tweede Wereldoorlog was de toename van het aantal mijn- 
werkers, woonachtig in niet-mijnzetelgemeenten, opmerkelijk (tabel 3.8). Het gevolg was dat de pendelstroom naar de mijnzetelgemeenten in omvang toenam.

TABEL 3.8 DE WOONGEMEENTEN IN LIMBURG VAN DE MANNELIJKE MIJNWERKERS, I909-I960, VERDEELD NAAR MIJNZETELGEMEENTEN EN OVERIGE LIMBURgSE GEMEENTEN. ABSOLUUt EN PERCENTAgES

\begin{tabular}{|l|c|c|c|c|c|c|c|c|}
\hline & \multicolumn{2}{|c|}{ I909 } & \multicolumn{2}{c|}{ I930 } & \multicolumn{2}{c|}{ I947 } & \multicolumn{2}{c|}{ 1960 } \\
& aantal & $\%$ & aantal & $\%$ & aantal & $\%$ & aantal & $\%$ \\
\hline $\begin{array}{l}\text { mijnzetel- } \\
\text { gemeenten }\end{array}$ & 4.873 & 72,7 & 24.777 & $67, \mathrm{I}$ & $23.2 \mathrm{I2}$ & $58, \mathrm{I}$ & 30.384 & $57, \mathrm{I}$ \\
\hline $\begin{array}{l}\text { overige } \\
\text { Limburgse } \\
\text { gemeenten }\end{array}$ & $\mathrm{I} .83 \mathrm{I}$ & 27,3 & $\mathrm{I} 2.257$ & 32,9 & $\mathrm{I} 6.753$ & $4 \mathrm{I}, 9$ & 21.833 & 42,9 \\
\hline totaal & 6.704 & 100,0 & 37.034 & 100,0 & 39.965 & 100,0 & 52.217 & 100,0 \\
\hline
\end{tabular}

Bron: Eigen berekening op basis van CBS, Volks- en beroepstellingen, I909-196o.

Vervoersmogelijkheden en uitbreiding van de verkeersinfrastructuur, met toenemende mobiliteit als gevolg, speelden in dit proces een voorname rol. Voor de Eerste Wereldoorlog waren de vervoersmogelijkheden in de mijnstreek en omgeving schaars. De spoorlijn Sittard-Heerlen-Herzogenrath (I896) doorsneed het mijndistrict, maar de meeste dorpen en mijnzetels waren ver van de stations gelegen. Alleen de Oranje-Nassau I lag in de directe omgeving van een station (Heerlen). Eigen vervoer was eerder uitzondering dan regel. De fiets kwam pas na I9ı langzamerhand binnen financieel bereik van arbeiders. ${ }^{27}$ Deze situatie was een ernstige belemmering voor de personeelsvoorziening van de mijnen. 'Waar de Limburgse mijnen met veel gebrek aan werkkrachten te kampen hebben en vestiging van vele vreemde werklieden niet is in het belang van gezonde arbeiderstoestanden, kan op de wenschelijkheid van nieuwe spoor- en tramverbindingen in dit opzicht nauwelijks genoeg worden gewezen', merkte de Hoofdingenieur der Mijnen in I907 op. ${ }^{28}$ Deze klacht van de hoogste ambtenaar van het Staatstoezicht op de Mijnen zou tot in de Eerste Wereldoorlog regelmatig terugkeren. Mijnwerkers moesten vaak uren reizen om van hun woonplaats de mijn te bereiken. Zo waren mijnwerkers uit Maastricht verplicht via Sittard naar Heerlen te sporen, een tijdrovende en omslachtige reis. Wie naar Kerkrade wilde, moest uitstappen bij station Rolduc, waarna een voettocht van een klein uur wachtte naar de Domaniale Mijn. ${ }^{29}$ Een andere mogelijkheid was de trein naar Simpelveld (aan de spoorlijn Maastricht-Aken) te nemen en van daar te voet naar de mijn te gaan, een tocht van eveneens vele kilometers. Bovendien hield de dienstregeling van het spoor geen enkele rekening met de wisseling van diensten op de mijnen. Wachttijden waren lang en als de mijnwerkers uit de nachtdienst kwamen, was er soms helemaal geen trein. De vervoersmogelijkheden per trein naar de

27 A.A. Albert de la Bruhèze en F.C.A. Veraart, Fietsverkeer in praktijk en beleid in de twintigste eeuw. Overeenkomsten en verschillen in fietsgebruik in Amsterdam, Eindhoven, Zuidoost-Limburg, Antwerpen, Manchester, Kopenhagen, Hannover en Basel (Den Haag 1999) 43-44.

28 Jaarverslag van den Hoofd-Ingenieur der Mijnen over 1907, 2.

29 Johan Blok, Cor Campagne en Sjef Janssen, Trams in Midden- en Zuid-Limburg 1888-1950 (Heerlen I998) I5. 


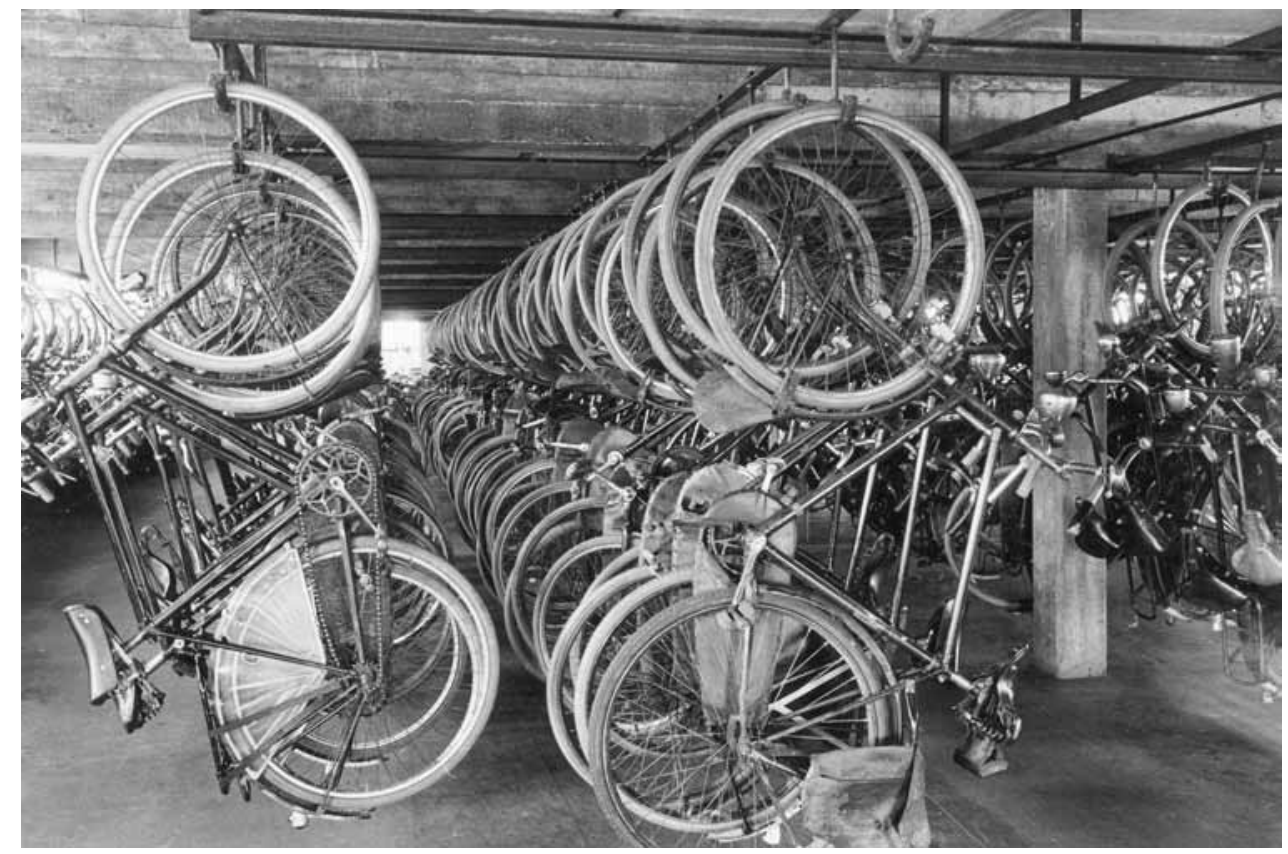

Na de Tweede Wereldoorlog nam het vervoer per fiets naar de mijn verder toe. Bij de Laura werd in 1957 een nieuwe rijwielstalling gebouwd. 1957. Bron: Fotocollectie Continium Kerkrade, F2856.

mijnen werden echter verbeterd door de aanleg van de lijn van Heerlen naar Schin op Geul met directe aansluiting naar Maastricht in I9I4 en door de bouw van de mijnspoorwegen Heerlen-Schaesberg-Staatsmijn Wilhelmina en Nuth-Staatsmijn Hendrik, die door Staatsmijnen ook werden opengesteld voor personenvervoer. ${ }^{30}$ De spoorlijn Simpelveld-Kerkrade Centrum-Schaesberg kwam in I934 gereed, maar werd pas na de Tweede Wereldoorlog ook bereden door personentreinen. ${ }^{3 \mathrm{I}}$

$\mathrm{Al}$ omstreeks I9oo werd de oplossing van het vervoersprobleem gezien in de aanleg van een net van tramwegen. Lang bleef het echter bij plannen. Pas in I9I8 werd door Staatsmijnen een stoomtramverbinding Heerlen-Hoensbroek-Staatsmijn Emma aangelegd. De lijn, met halteplaatsen aan de Oranje-Nassaumijnen I en III en Staatsmijn Emma, was een groot succes, maar was alleen niet voldoende om de grote achterstand op het gebied van het openbaar vervoer in Limburg weg te nemen. ${ }^{32}$ Aandacht vanuit Den Haag ontstond pas toen in de Eerste Wereldoorlog het belang van de Limburgse kolenvoorraad voor de nationale economie duidelijk werd. Op ro oktober I9I8 stelde de minister van Waterstaat een commissie in die tot taak kreeg te onderzoeken welke tramwegen in het belang van een doelmatige ontwikkeling van de mijnexploitatie in Zuid-Limburg moesten worden aangelegd.

30 J.M.A.G. Gillissen, De invloed van de Staatsmijnen in Limburg op de ontwikkeling van het locale personenvervoer en op de woningbouw in de mijnstreek tot negentien honderd en veertig (kandidaatsscriptie, z.p. z.j.) I7-Ig.

3I A.H.M. Kistermann, 'Het Miljoenenlijntje', Historische en Heemkundige Studies in en rond het Geuldal. Jaarboek 1994 (Valkenburg aan de Geul r994) r80-I97.

32 W.J.M. Leideritz, Trams en tramlijnen. De stoomtram van Noord-Brabant en Limburg (Rotterdam I972) 83-85. 
TABEL 3.9 MIDDELEN VAN VERVOER, GEBRUIKT DOOR FORENZEN NAAR DE MIJNZETELGEMEENTEN, I947 EN I96O

\begin{tabular}{|c|c|c|c|c|c|c|c|c|}
\hline & \multicolumn{2}{|c|}{ Brunssum } & \multicolumn{2}{|c|}{ Eygelshoven } & \multicolumn{2}{|c|}{ Geleen } & \multicolumn{2}{|c|}{ Heerlen } \\
\hline & 1947 & 1960 & 1947 & 1960 & 1947 & г96o & 1947 & г960 \\
\hline & $\%$ & $\%$ & $\%$ & $\%$ & $\%$ & $\%$ & $\%$ & $\%$ \\
\hline te voet & 6,3 & $\mathrm{I}, 2$ & $\mathrm{I} 8,2$ & 3,8 & 0,7 & $\mathrm{O}, \mathrm{I}$ & $\mathrm{I} 7,8$ & 7,2 \\
\hline per fiets & 53,7 & 45,9 & $7 \mathrm{I}, 6$ & 57,8 & $5 \mathrm{I}, 7$ & 38,8 & $42, \mathrm{I}$ & 30,4 \\
\hline gemotoriseerd & 40,0 & 52,9 & I0,2 & 38,4 & 47,6 & $6 \mathrm{I}, \mathrm{I}$ & $40, \mathrm{I}$ & 62,4 \\
\hline $\mathrm{N}$ & 2.247 & 3.126 & $2.94 \mathrm{I}$ & 4.229 & $9 \cdot 301$ & I2.905 & 9.705 & $\mathrm{I} 8.24 \mathrm{I}$ \\
\hline
\end{tabular}

\begin{tabular}{|l|c|c|c|c|c|c|}
\hline \multirow{2}{*}{} & \multicolumn{2}{|c|}{ Hoensbroek } & \multicolumn{2}{c|}{ Kerkrade } & \multicolumn{2}{c|}{ Schaesberg } \\
& I947 & I960 & I947 & I960 & I947 & I960 \\
\cline { 2 - 7 } & $\%$ & $\%$ & $\%$ & $\%$ & $\%$ & $\%$ \\
\hline te voet & 4,7 & $\mathrm{I}, 6$ & 3,6 & $\mathrm{I}, 6$ & 27,0 & $\mathrm{I} 2,4$ \\
\hline per fiets & 40,2 & 44,8 & 49,7 & 26,3 & 47,5 & 44,6 \\
\hline gemotoriseerd & $55, \mathrm{I}$ & 53,6 & 46,7 & $72, \mathrm{I}$ & 25,5 & 42,9 \\
\hline $\mathrm{N}$ & $\mathrm{I} .237$ & I.4I5 & I.I90 & 2.I2I & $3.94 \mathrm{I}$ & 5.313 \\
\hline
\end{tabular}

Bron: Eigen berekening in procenten op basis van absolute aantallen in de CBS Volkstellingen, I947 en I96o.

De minister noemde in zijn rede bij de installatie van de Commissie de oplossing van het vraagstuk van tramaanleg in de Limburgse mijnstreek urgent. ${ }^{33}$ Vooral zou de aanleg van 'doeltreffende verbindingen van de verschillende mijnen met de bestaande en in opkomst zijnde bevolkingscentra' een zegen zijn voor de mijnwerkers, vooral ook omdat de dienstregeling van de aan te leggen tramlijnen zich zou richten op de mijnwerkersdiensten. ${ }^{34} \mathrm{Het}$ voorbereidende werk van de Commissie resulteerde in de oprichting op I5 februari I92I van de Limburgsche Tramweg Maatschappij (LTM), die een net van tramlijnen in Zuid-Limburg ging aanleggen en exploiteren. Hoewel slechts een klein deel van de geprojecteerde lijnen werd gerealiseerd, betekende de aanleg van tramlijnen een flinke verbetering van het personenvervoer. ${ }^{35}$

Toch waren vooral de stoomtramlijnen geen lang leven beschoren. De exploitatie was kostbaar en in de jaren twintig gingen ze hevige concurrentie ondervinden van autobusdiensten met directe verbindingen en daardoor kortere reistijden. De eerste initiatieven voor busdiensten kwamen van mijnwerkers, die ze voor eigen rekening en risico gingen

33 De Commissie stond onder voorzitterschap van het Tweedekamerlid ir. M.C.E. Bongaerts.

34 Verslag van de Commissie, inzake den aanleg en de exploitatie van tramwegen, in verband met de ontwikkeling van de mijnexploitatie in ZuidLimburg (Heerlen z.j.) 2, Io.

35 Aangelegd en in exploitatie genomen werden de stoomtramlijnen Maastricht-Gulpen-Vaals, met aftakking naar Wijlre en Roermond-Roosteren-Grevenbicht-Sittard, en de elektrische tramlijnen Sittard-Heerlen, Hoensbroek-Brunssum, Heerlen-Kerkrade en Valkenhuizen-De Locht. 
TABEL 3.IO AFGELEGDE AFSTANDEN DOOR FORENZEN NAAR DE MIJNZETELGEMEENTEN, I947 EN I960

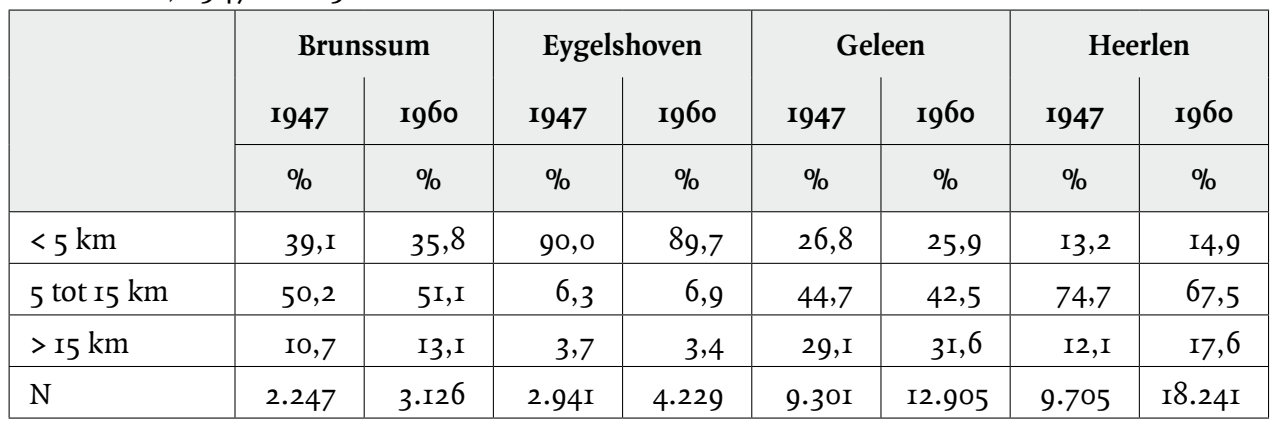

\begin{tabular}{|c|c|c|c|c|c|c|}
\hline & \multicolumn{2}{|c|}{ Hoensbroek } & \multicolumn{2}{|c|}{ Kerkrade } & \multicolumn{2}{|c|}{ Schaesberg } \\
\hline & I947 & 1960 & 1947 & 1960 & I947 & 1960 \\
\hline & $\%$ & $\%$ & $\%$ & $\%$ & $\%$ & $\%$ \\
\hline$<5 \mathrm{~km}$ & $44, \mathrm{I}$ & 32,9 & $7, \mathrm{I}$ & $\mathrm{I} 2,7$ & $36, \mathrm{I}$ & 33,2 \\
\hline 5 tot $15 \mathrm{~km}$ & 42,9 & $56, \mathrm{I}$ & 73,6 & 70,8 & $5 \mathrm{I}, 6$ & 52,8 \\
\hline$>\mathrm{I} 5 \mathrm{~km}$ & 13,0 & II, 0 & 19,2 & 16,5 & $\mathrm{I} 2,3$ & $\mathrm{I} 4, \mathrm{O}$ \\
\hline $\mathrm{N}$ & I. 237 & $\mathrm{I} .4 \mathrm{I} 5$ & I.I9o & $2.12 \mathrm{I}$ & $3.94 \mathrm{I}$ & 5.313 \\
\hline
\end{tabular}

Bron: Eigen berekening op basis van CBS Volkstellingen, I947 en I96o.

exploiteren. ${ }^{36}$ In I924 en 1925 alleen al werden in Zuid-Limburg ongeveer 38 autobuslijnen geopend. ${ }^{37}$ Ook de LTM ging autobusdiensten exploiteren. De mijnen sloten contracten af met verschillende autobusondernemingen om mijnwerkers van en naar de mijn te vervoeren. Uit verkeerswaarnemingen door de provincie Limburg bleek dat het vervoer per autobus tussen 1929 en 1938 met bijna 50 procent was gestegen. ${ }^{3}$ Slechts het geëlektrificeerde tramwegennet in de mijnstreek hield, dankzij het massale mijnwerkersvervoer, de concurrentie met de autobus nog vol tot het begin van de jaren vijftig.

De opmars van het gemotoriseerd vervoer zette zich na de Tweede Wereldoorlog in versneld tempo door (tabel 3.9). Die stijging is toe te schrijven aan de verdere uitbreiding van het net van openbaar vervoer en aan het door de mijnen georganiseerde bedrijfsvervoer. ${ }^{39}$ In 1950 werden dagelijks 8.800 mijnwerkers per bus vervoerd, hetgeen meer dan een verdubbeling was ten opzichte van tien jaar eerder. ${ }^{4} \mathrm{Maar}$ ook het toegenomen bezit van eigen gemotoriseerd vervoer, in de vorm van bromfiets, motor, scooter en auto, speelde in de naoorlogse jaren een belangrijke rol. Vooral het gebruik van de bromfiets groeide in de jaren vijftig spectaculair. Telde Nederland in 195050.000 bromfietsen, tien jaar later waren het er

36 Blok e.a., Trams, I5.

37 Gillissen, Invloed, 34.

38 P.H.M. Charpentier, De verkeersontwikkeling op de wegen in Zuid-Limburg in de periode 1927-1941 en het beleid, dat nodig was bij de aanpak van het wegenverkeersuraagstuk (doctoraalscriptie KU, Nijmegen I989) 62.

39 Wereld van groei, 157.

40 Blok e.a., Trams, i6. 
al meer dan een miljoen! ${ }^{41}$ De mijnen zagen zich daardoor genoodzaakt ruime bromfietsstallingen te bouwen.

De beschikbaarheid van gemotoriseerd vervoer, in welke vorm dan ook, leidde ertoe dat de afstand die de pendelaars naar de Limburgse mijnbouwgemeenten aflegden in het algemeen toenam. Desondanks gold voor de naoorlogse periode nog steeds dat een ruime meerderheid van de forenzen op een afstand van minder dan vijftien kilometer van het werk woonde (tabel 3.ro).

Er bestonden echter opvallende verschillen tussen de gemeenten. Zo blijkt dat de pendelaars naar Eygelshoven over het algemeen de kortste afstand aflegden. Ruim 96 procent van de forenzen woonde op minder dan 15 kilometer van het werk. Aan de andere kant van het spectrum bedroeg het percentage korte- en middellangeafstandsforenzen (tot vijftien kilometer) in Geleen ongeveer 70 procent. Op basis van een onderzoek naar de woonplaatsen van de arbeiders van de vier Staatsmijnzetels constateerde Overhage dat er een verband bestond tussen de grootte van de mijn en de woonplaats van de mijnwerkers. Hoe groter de mijn - en Staatsmijn Maurits in Geleen was de grootste mijn van Limburg - hoe kleiner het percentage arbeiders dat in de onmiddellijke omgeving woonde. Overhage veronderstelde dat de reden hiervoor was dat de woongelegenheid bij de grotere mijnzetels niet voldoende was om het grote aantal arbeiders te huisvesten. ${ }^{42}$

\section{Herkomst en richting van de pendelstromen}

Om een meer gedetailleerd beeld te krijgen waar de pendelaars naar de mijnen vandaan kwamen, is de provincie ingedeeld in acht economisch-geografische gebieden. ${ }^{43}$ Voor elk van deze gebieden en voor een viertal jaren waarin een volks- en beroepstelling werd gehouden, is het aantal mijnwerkers berekend dat in deze gebieden woonde, alsmede het aandeel van elk van de gebieden in het totale aantal mijnwerkers. In de mijnstreek werden de zeven mijnzetelgemeenten uit tabel 3.8 buiten beschouwing gelaten. Tabel 3.II geeft het resultaat van deze berekeningen.

Het is duidelijk dat de kern van de mijnwerkers in de mijnstreek woonde, zelfs wanneer de zeven eigenlijke mijnzetelgemeenten buiten beschouwing worden gelaten. Dat gold voor de gehele onderzochte periode. Wanneer binnen de mijnstreek nog een onderverdeling gemaakt wordt in enerzijds de westelijke mijnstreek rond Geleen en anderzijds de oostelijke mijnstreek met Heerlen en Kerkrade als centrale plaatsen, blijkt dat het laatste gebied steeds het leeuwendeel uitmaakte. Dat is goed verklaarbaar uit het feit dat elf van de twaalf mijnen in dit gebied gelegen waren. Opvallend is echter dat het aandeel van de mijnstreek in de loop van de tijd verminderde. Van bijna 90 procent in Igog daalde het voortdurend tot ruim 67 procent in I96o. Hierboven (tabel 3.8) bleek reeds, dat ook de mijnwerkerspopulatie in de eigenlijke mijnzetelgemeenten relatief afnam. Een steeds groter contingent van de mijnwerkers pendelde in de loop van de twintigste eeuw dus naar het werk vanuit een regio buiten de eigenlijke mijnstreek. Dat proces is zichtbaar op de kaarten in de bijlagen $7 \mathrm{~A}$ en $7 \mathrm{~B}$. Tot 1947 kwam het grootste deel van de pendelaars uit overig Zuid-Limburg (Maastricht en het heuvelland). Het rurale heuvelland dat zich langs de zuidgrens van de provincie uitstrekt

\footnotetext{
4I J.W. Drukker, De elektronische steentijd. Vijftig jaar techniek en samenleving (Den Haag 1996) I8-20.

42 Overhage, Heerlen, II8.

43 Zie bijlage 6 .
} 
TABEL 3.II WOON PLAATS VAN DE MANNELIJKE MIJNWERKERS IN LIMBURG, VERDEELD NAAR ECONOMISCH-GEOGRAFISCH GEBIED, I9O9-I960 (EXCLUSIEF DE ZEVEN MIJNZETELGEMEENTEN IN GEBIED 6)

\begin{tabular}{|c|c|c|c|c|c|c|c|c|}
\hline \multirow{2}{*}{$\begin{array}{l}\text { economisch- } \\
\text { geografisch } \\
\text { gebied }\end{array}$} & \multicolumn{2}{|c|}{1909} & \multicolumn{2}{|c|}{1930} & \multicolumn{2}{|c|}{ I947 } & \multicolumn{2}{|c|}{1960} \\
\hline & $\mathbf{N}$ & $\%$ & $\mathbf{N}$ & $\%$ & $\mathbf{N}$ & $\%$ & $\mathrm{~N}$ & $\%$ \\
\hline $\begin{array}{l}\text { I Mook - Arcen } \\
\text { en Velden }\end{array}$ & - & - & - & - & I2 & 0,0 & IO & 0,0 \\
\hline $\begin{array}{l}2 \text { Venray - } \\
\text { Grubbenvorst }\end{array}$ & 8 & 0,4 & 3 & 0,0 & $3 \mathrm{I}$ & 0,2 & 102 & 0,5 \\
\hline $\begin{array}{l}3 \text { Maasbree - } \\
\text { Weert-Thorn }\end{array}$ & - & - & 49 & 0,4 & 326 & 0,2 & I.IOI & 5,0 \\
\hline 4 Venlo-Beesel & - & - & 7 & 0,0 & 50 & 0,3 & 232 & $\mathrm{I}, \mathrm{I}$ \\
\hline $\begin{array}{l}5 \text { Swalmen - } \\
\text { Roermond - Echt }\end{array}$ & - & - & 793 & 6,5 & I. 526 & $9, \mathrm{I}$ & $2.27 \mathrm{I}$ & IO, 4 \\
\hline $\begin{array}{l}6 \text { Sittard - Kerk- } \\
\text { rade (mijnstreek) }\end{array}$ & I. 599 & 87,3 & 8.989 & 73,4 & II. 689 & 69,7 & I4.690 & 67,3 \\
\hline $\begin{array}{l}7 \text { Maastricht en } \\
\text { omstreken }\end{array}$ & 45 & 2,5 & 982 & 8,0 & I. $3 \mathrm{II}$ & 7,8 & I. 394 & 6,4 \\
\hline 8 het heuvelland & I79 & 9,8 & I.434 & $\mathrm{II}, 7$ & I. 8 o 8 & Io,9 & 2.033 & 9,3 \\
\hline totaal & 1.831 & 100,0 & 12.257 & 100,0 & I6.753 & 100,0 & 21.833 & 100,0 \\
\hline
\end{tabular}

Bron: Eigen berekening op basis van CBS, Volks- en beroepstellingen, r9o9-ı 960.

van Eijsden in het westen tot Vaals in het oosten scoorde steeds hoger dan de agglomeratie Maastricht. In I96o bleek de arbeidsmarkt te zijn opgeschoven in noordelijke richting. Mijnwerkers woonachtig in Noord- en Midden-Limburg (het gebied ten noorden van Susteren) hadden de pendelaars vanuit het zuiden van de provincie getalsmatig ingehaald. ${ }^{44}$ Vooral de streek tussen Swalmen en Echt leverde in toenemende mate pendelaars voor de mijnen.

Uit tabel 3.II en de kaartenreeksen blijkt echter alleen waar de pendel naar 'de mijnen' vandaan kwam en hoe zich het fenomeen in de loop van de tijd kwantitatief ontwikkelde. Dat beeld kan nader worden gespecificeerd op gemeenteniveau. Op die manier kan worden onderzocht of de onderscheiden gemeenten met een mijnbouwbedrijf binnen de grenzen beschikten over een eigen specifiek achterland waar hun mijnwerkers woonden. Voor de periode vóór de Tweede Wereldoorlog zijn de bronnen waarmee deze vraag zou kunnen worden beantwoord, schaars. Uit incidentele gegevens blijkt echter dat de Kerkraadse mijnen Domaniale en Willem-Sophia van begin af aan voor een belangrijk deel hebben kunnen putten uit het in de onmiddellijke omgeving aanwezige arbeiderspotentieel, dat van oudsher bekend was met mijnarbeid. ${ }^{45}$ De mijnen Laura en Julia in Eygelshoven daarentegen waren veel

44 Het aantal pendelaars vanuit de gebieden $\mathrm{I} t / \mathrm{m} 5$ bedroeg in $\mathrm{I} 960 \mathrm{3} .7 \mathrm{I} 6$ (7,I procent van het totaal). In de Zuid-Limburgse gebieden 7 en 8 woonden op dat moment 3.427 mijnwerkers (6,6 procent).

45 Achim Korres, 'Historische interacties in de Euregio Maas-Rijn: migratiestromen in een grensgebied', SSEGL XLVI (2002) 7-26, aldaar 23 . 
meer aangewezen op arbeiders die buiten het dorp woonden. Tussen I909 en I935 woonde slechts tussen de I5 en 20 procent van de mijnwerkers in Eygelshoven zelf. ${ }^{46}$ De noordwestelijk gelegen Staatsmijn Maurits had veel mijnwerkers in dienst die in Midden-Limburg bleven wonen. De mijn zette al in de jaren twintig pendelbussen in om de arbeiders op te halen en na de dienst weer naar huis te brengen. In I939 reden drie maal per dag 27 autobussen tussen de Maurits en eindstations in zeventien verschillende Limburgse gemeenten. ${ }^{47} \mathrm{De}$ bussen reden tot Thorn, Roermond en Posterholt in het midden van de provincie. Het toegenomen belang van de Midden-Limburgse gemeenten blijkt ook uit de kaartenreeksen.

Voor de periode na de Tweede Wereldoorlog zijn meer kwantitatieve gegevens beschikbaar. In de gepubliceerde volkstellingen van I947 en I96o zijn uitgebreide overzichten opgenomen van het aantal werkforenzen met hun herkomst, bestemming en de sector waarin ze werkzaam waren. Hierin zijn echter niet de mijnwerkers als beroepsgroep uitgesplitst. Wel worden onderscheiden de mannen werkzaam in de nijverheid, exclusief de bouw. Deze categorie lijkt geschikt om te dienen als indicator voor de herkomst en omvang van de groep pendelende mijnwerkers naar de zeven mijnzetelgemeenten, waar, zoals we in tabel $3.7 \mathrm{za}-$ gen, het belang van mijnarbeid in de werkgelegenheid immers zeer groot was.

Zoals tabel 3.Ir laat zien, was het pendelverkeer vanuit de economisch-geografische gebieden in Noord-Limburg (de gebieden I, 2 en 4) naar de mijnzetelgemeenten ook in de naoorlogse periode met 0,5 à I procent van het totaal van marginale betekenis. Vanuit de streek Weert-Maasbree-Thorn (gebied 3) leverden vooral de gemeente Thorn, en in mindere mate Wessem forenzen. De bestemming was in 1947 uitsluitend Geleen. In I96o blijkt er echter ook een pendelstroom naar het verderweg gelegen Heerlen te zijn ontstaan, vooral uit Helden. Forenzenverkeer naar de overige mijnbouwgemeenten in de oostelijke mijnstreek vanuit dit gebied was er vrijwel niet.

Het economisch-geografisch gebied rond Roermond (gebied 5) was van groter belang. Elke gemeente leverde forenzen voor minstens één van de zeven mijnzetelgemeenten. Zowel in 1947 als in I96o woonden de meeste pendelaars in Echt, de meest zuidelijk gelegen gemeente in dit gebied. De forenzen uit dit gebied hadden in meer dan 80 procent van de gevallen als bestemming Geleen, de meest nabij gelegen mijnzetelgemeente. De afstand varieerde van 18 kilometer vanuit Echt tot 36 kilometer vanuit Swalmen. Brunssum en Hoensbroek liggen, gerekend vanuit de meeste gemeenten in het gebied rond Roermond, niet veel verder, maar deze mijnzetelgemeenten hadden weinig aantrekkingskracht op pendelaars uit dit gebied. Dat gold in nog veel sterkere mate voor Schaesberg, Eygelshoven en Kerkrade, die echter op een aanmerkelijk grotere afstand ( 30 tot 49 kilometer) van dit herkomstgebied gelegen zijn. Alleen Heerlen met zijn goede verkeersverbindingen trok meer dan enkele tientallen forenzen uit het betreffende gebied, vooral uit Echt. Zij reisden elke dag 30 kilometer.

Ook het forenzenverkeer uit Maastricht en omgeving (gebied 7) was vooral gericht op Geleen. 70 à 80 procent van de pendelaars had Geleen als bestemming. Al voor de Tweede Wereldoorlog reden drie keer per dag zeven bedrijfsbussen van de Maurits naar het zuiden van de provincie, waar ze mijnwerkers ophaalden in Maastricht, Meerssen en Bunde..$^{8}$ Geleen was voor alle gemeenten in dit gebied het meest nabij van alle mijnzetelgemeenten

46 Brouns, Geschiedenis, 52.

47 Overhage, Heerlen, 95.

48 Ibidem, 95. 


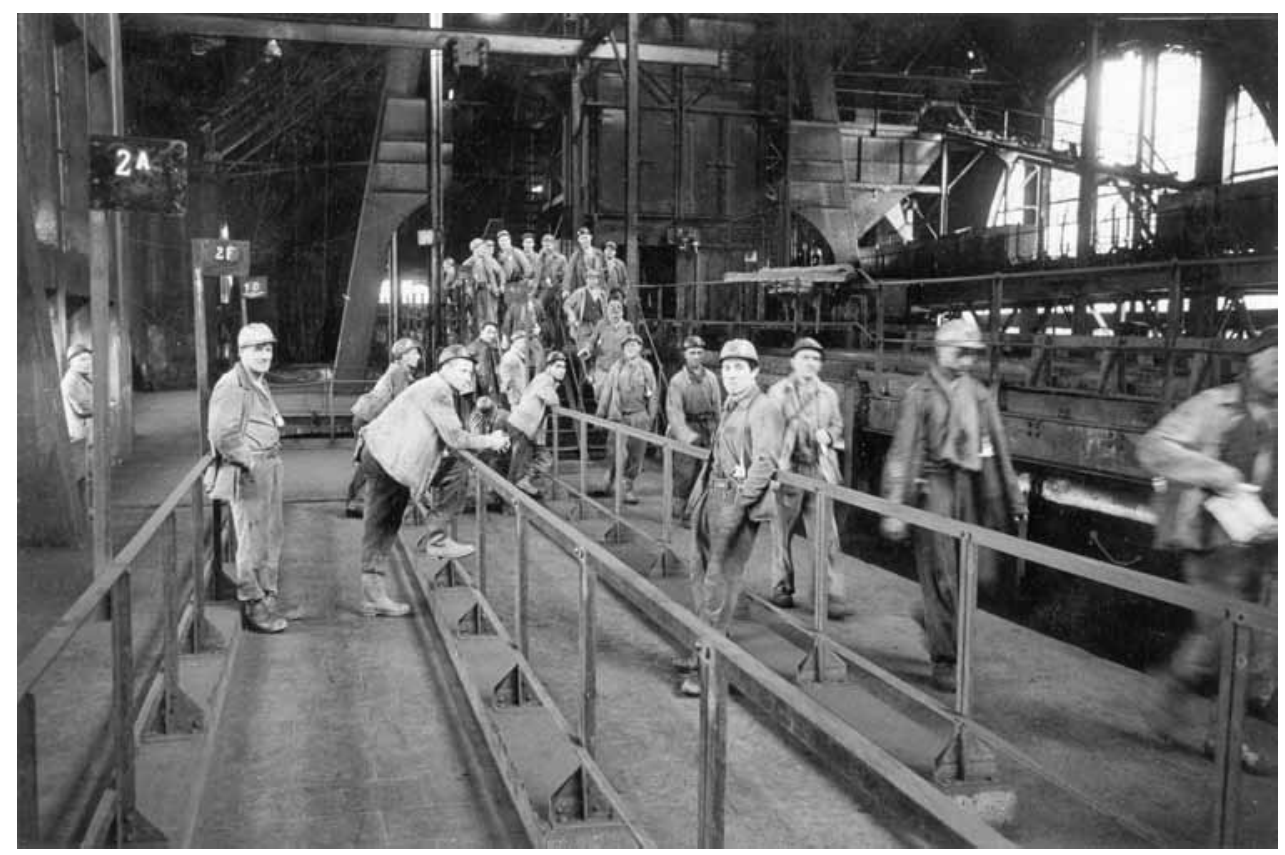

Mijnwerkers aan het begin van de dienst op de losvloer van de Julia. 1957. Bron: Fotocollectie Continium Kerkrade, F2556.

(I3 tot 2I kilometer). In de oostelijke mijnstreek scoorde de stad Heerlen met afstand het hoogst bij de pendelaars vanuit dit gebied. Het aantal forenzen naar de overige mijnzetelgemeenten bedroeg niet meer dan enkele tientallen.

Het heuvelland (gebied 8) vormde overduidelijk onderdeel van het achterland van de oostelijke mijnstreek. Slechts 3 à 4 procent pendelde naar Geleen. Bedrijfsbussen van de Maurits reden tot Vaals. ${ }^{49}$ Het is opvallend dat slechts een beperkt aantal gemeenten in dit gebied de forenzen voor de oostelijke mijnstreek leverde. Daarbij lijken afstand en bereikbaarheid weer een rol te spelen bij de bestemming. Vanuit de oostelijk gelegen gemeenten Wittem, Wijlre en Vaals pendelden honderden mannen naar voornamelijk Kerkrade en Schaesberg, mijnzetelgemeenten die op een afstand van ongeveer ${ }_{5} 5$ kilometer van de woonplaats liggen. Staatsmijn Wilhelmina liet autobussen rijden naar Mechelen, Wittem en Vaals. ${ }^{50}$ Valkenburg leverde vooral forenzen aan het nabije en makkelijk per spoor bereikbare Heerlen. Brunssum, Hoensbroek en Eygelshoven waren de minst populaire mijnzetelgemeenten voor de pendelaars uit het heuvelland. Dit waren de gemeenten met de grootste reisafstanden. Pendel naar de mijnstreek was onbeduidend vanuit Bemelen, Noorbeek, Mheer, Cadier en Keer, Gronsveld, Sint Geertruid, Slenaken, Eijsden en Margraten. Deze plattelandsgemeenten liggen over het algemeen verder verwijderd van de mijnzetelgemeenten; in veel gevallen bedraagt de afstand zelfs meer dan twintig kilometer. Behalve Eijsden hadden de 
TABEL 3.I2 Het ACHTERLAN D VAN DE LimbuRgSE MiJNZETELGEMEENTEN

\begin{tabular}{|c|c|c|c|c|c|}
\hline \multicolumn{2}{|c|}{ Brunssum } & \multicolumn{2}{|c|}{ Eygelshoven } & \multicolumn{2}{|c|}{ Geleen } \\
\hline $1925-1946$ & 1947-196o & $1925-1946$ & 1947-1960 & $1925-1946$ & I947-196o \\
\hline Schinveld & Schinveld & Ubach o/W & Ubach o/W & Sittard & Sittard \\
\hline Heerlen & Heerlen & $\begin{array}{l}\text { Nieuwen- } \\
\text { hagen }\end{array}$ & $\begin{array}{l}\text { Nieuwen- } \\
\text { hagen }\end{array}$ & Stein & Stein \\
\hline & Sittard & Kerkrade & Kerkrade & Beek & Echt \\
\hline & & & & & Beek \\
\hline
\end{tabular}

\begin{tabular}{|c|c|c|c|c|c|}
\hline \multicolumn{2}{|c|}{ Heerlen } & \multicolumn{2}{|c|}{ Hoensbroek } & \multicolumn{2}{|c|}{ Kerkrade } \\
\hline $1925-1946$ & 1947-196o & $1925-1946$ & 1947-1960 & $1925-1946$ & 1947-196o \\
\hline Hoensbroek & Hoensbroek & Brunssum & Brunssum & Simpelveld & Simpelveld \\
\hline Voerendaal & Voerendaal & Heerlen & Heerlen & Bocholtz & Bocholtz \\
\hline & Brunssum & Nuth & Nuth & Wittem & Heerlen \\
\hline & & & Sittard & & \\
\hline
\end{tabular}

\begin{tabular}{|l|l|}
\hline \multicolumn{2}{|c|}{ Schaesberg } \\
1925-1946 & \multicolumn{1}{|c|}{ 1947-1960 } \\
\hline Bocholtz & Kerkrade \\
\hline Heerlen & Heerlen \\
\hline & $\begin{array}{l}\text { Nieuwen- } \\
\text { hagen }\end{array}$ \\
\hline & \\
\hline
\end{tabular}

Bron: AMF, steekproef uit lidmaatschapskaarten, I925-I946; CBS, Volkstellingen, I947-1960.

gemeenten geen spoorwegverbinding, en de bussen van Staatsmijnen deden dit deel van het heuvelland niet aan. Fietsen was een weinig aantrekkelijke optie vanwege het geaccidenteerde terrein. Aan te nemen is ook dat de bewoners van de meer westelijk gelegen dorpen in het heuvelland zich voor industriële werkgelegenheid richtten op Maastricht.

De gemeenten in de westelijke mijnstreek waren voornamelijk gericht op Geleen: ruim 80 procent van de forenzen vond daar werk. Het grootste contingent kwam uit Sittard, de grootste gemeente in het gebied. Ook Stein, Beek, Elsloo en Urmond, maximaal zeven kilometer van Geleen verwijderd, leverden honderden forenzen. Pendelverkeer vanuit de westelijke naar de oostelijke mijnstreek was er uit Sittard, dat voornamelijk aan Heerlen en Brunssum leverde. Ook vanuit Schinnen, de meest oostelijk gelegen gemeente in de westelijke mijnstreek, reisden pendelaars naar Heerlen en Brunssum. De pendel vanuit de westelijke mijnstreek naar de mijnen van Kerkrade, Schaesberg en Eygelshoven was te verwaarlozen. De afstand was te groot en de vervoersmogelijkheden ontoereikend. 
Omgekeerd was het forenzenverkeer van de oostelijke mijnstreek naar Geleen eveneens klein. Binnen de oostelijke mijnstreek was een patroon te herkennen van mijnzetelgemeenten met een specifiek achterland vanwaar pendelaars naar de mijn reisden. De gemeenten Bingelrade, Jabeek, Merkelbeek en Schinveld vormden onmiskenbaar het achterland van het naburige Brunssum. Ook trok Brunssum veel pendelaars uit Heerlen en Hoensbroek. Daarentegen was vanuit Wijnandsrade, Eygelshoven, Klimmen, Bocholtz, Voerendaal en Kerkrade het forenzenverkeer naar Brunssum minimaal.

Net als voor de Tweede Wereldoorlog werd het achterland van de mijnzetelgemeente Eygelshoven vooral gevormd door Kerkrade, Ubach over Worms en Nieuwenhagen. Bovendien waren de mijnen Laura en Julia in Eygelshoven gericht op het Duitse grensgebied dat als het ware het natuurlijke achterland van deze mijnen vormde. ${ }^{5 \mathrm{I}}$ De arbeidsvoorziening vanuit Limburg werd er bemoeilijkt door de afgelegen locatie van beide mijnzetels. Wie van het noorden of westen kwam, moest eerst verschillende andere mijnbedrijven passeren, alvorens de Laura en de Julia te bereiken. Heerlen trok pendelaars uit alle gemeenten van de oostelijke mijnstreek, maar vooral uit Hoensbroek en Brunssum. Het achterland van Hoensbroek werd voornamelijk gevormd door Heerlen en Brunssum. Kerkrade trok, behalve forenzen uit Heerlen, vooral pendelaars uit de nabij gelegen dorpen Bocholtz en Simpelveld. Uit diezelfde gemeenten pendelden dagelijks ook arbeiders naar Schaesberg, slechts enkele kilometers verder dan Kerkrade. Schaesberg was echter vooral afhankelijk van pendelaars uit Heerlen, Kerkrade en, in mindere mate, Nieuwenhagen.

Vatten we een en ander samen in een tabel (tabel 3.12), dan blijkt er een patroon te bestaan, dat in de loop van de tijd nauwelijks aan verandering onderhevig was. Afstand lijkt daarbij de belangrijkste rol te spelen.

\section{BESLUIT}

In de periode I889-I97 I kende de provincie Limburg een snelle demografische groei. In die jaren verviervoudigde de bevolking. Die bevolkingsgroei werd voor 95 procent veroorzaakt door natuurlijke groei. Dit algemene beeld vertoonde echter op kortere termijn en regionaal soms grote afwijkingen. Zo kwam in de streek rond Heerlen en Kerkrade (de oostelijke mijnstreek) tussen I900 en I930 ten gevolge van de grote aantrekkingskracht van de werkgelegenheid in de expanderende mijnbouw, meer dan de helft van de bevolkingsgroei op het conto van het migratieoverschot. In de westelijke mijnstreek, waar in I9I5 werd begonnen met de aanleg van de grote Staatsmijn Maurits, was de invloed van migratie op de groei van de bevolking vooral in de jaren twintig groot.

Vanaf I930 werd een belangrijk deel van de migratoire groei van de voorafgaande decennia teniet gedaan door vertrekoverschotten. Vooral in de oostelijke mijnstreek was dat het geval.

De groei van de totale bevolking betekende ook een toename van de beroepsbevolking. Het blijvend hoge geboortesaldo zorgde voor een voortdurende natuurlijke aanvulling van de beroepsbevolking. De categorie I5 $_{5}$ tot en met 64 -jarigen steeg sneller dan de totale be- 
volking. Dat gold niet alleen voor de beide mijnstreken, maar ook voor de provincie Limburg als geheel.

In de eerste drie decennia van de twintigste eeuw gingen elf nieuwe steenkolenmijnen van start in de streek tussen Kerkrade en Geleen. De tienduizenden mijnwerkers die de arbeidsintensieve bedrijven nodig hadden, konden niet uitsluitend in de regio worden gerekruteerd. Migratie en pendel naar de mijnstreek waren noodzakelijk. Twee problemen dienden zich daarbij aan: een tekort aan woningen in de nabijheid van de mijnbedrijven en ontoereikende vervoersmogelijkheden. Huisvesting voor de nieuwkomers in de mijnstreek werd gerealiseerd door de mijnen zelf en door woningbouwverenigingen, die meestal opereerden onder de koepel van 'Ons Limburg'. De woningen werden over het algemeen onder de rook van de mijnbedrijven gebouwd. De mijnwerkersbevolking concentreerde zich daardoor in de gemeenten met de mijnbedrijven binnen de grenzen en de naburige plaatsen. Een belangrijke oorzaak hiervan was dat het openbaar vervoer zich aanvankelijk nauwelijks uitbreidde. Pas na I920 kwam er een fijnmaziger net door de aanleg van tramlijnen en de komst van de autobus. Het eigen gemotoriseerde vervoer van de mijnwerkers in de vorm van bromfiets, scooter en auto nam na I950 fors toe.

Dankzij de toename van de vervoersmogelijkheden werd pendel voor meer mijnwerkers een optie. De woonplaatsen van de mijnwerkers werden daardoor meer verspreid over de provincie. In 1960 waren er alleen nog in het uiterste noorden gemeenten waar geen mijnwerkers woonden. Doordat de woningbouw vóór omstreeks I 930 hoofdzakelijk had plaatsgevonden in de eigenlijke mijnzetelgemeenten, bleef de kern van de mijnwerkersbevolking toch in de mijnstreek geconcentreerd. De pendelstroom naar de westelijke mijnstreek was voor een belangrijk deel afkomstig uit Midden-Limburg en Maastricht. Het uiterste zuiden van de provincie leverde vooral forenzen aan de mijnen rond Heerlen en Kerkrade. 


\section{Hoofdstuk 4 \\ Mijnwerkers uit Nederland}

De mijnen verschenen in een ruraal gebied zonder industriële tradities van betekenis. Behalve voor de naar schatting I.500 ervaren mijnwerkers uit het grensgebied tussen Kerkrade en Schinveld, die omstreeks I 900 in de twee mijnen bij Kerkrade werkten of dagelijks naar een van de steenkolenmijnen vlak over de grens in de streek rond Aken pendelden, was de mijnarbeid diep onder de grond voor de Zuid-Limburgse beroepsbevolking een onbekend en onbemind metier. ${ }^{1}$ De mijnondernemingen hadden daarom problemen met de personeelsvoorziening op de regionale arbeidsmarkt en zagen zich gedwongen ook een beroep te doen op arbeidsmigranten van buiten Limburg. Uit alle Nederlandse provincies kwamen jonge mannen naar 'het donkere zuiden' om hun geluk in de mijnen te beproeven. Daarnaast wisten ook veel buitenlanders de weg naar de Nederlandse steenkolenindustrie te vinden of werden ze door de mijndirecties actief geworven. In dit hoofdstuk staat de groep mijnwerkers uit Nederland centraal. De rol van buitenlandse mijnwerkers is onderwerp van hoofdstuk 5 .

De mijndirecties en de Nederlandse overheid hadden een voorkeur voor Nederlandse mijnwerkers. Er bestond geen enkel verschil van mening over het beginsel dat bij de werving van personeel de voorrang moest worden gegeven aan autochtone arbeiders. ${ }^{2}$ Dit principe gold ook voor de particuliere mijnen, die toch buitenlandse eigenaren hadden. Men ging uit van een soort hiërarchie van preferente groepen. De Hoofdingenieur der Mijnen, de hoogste ambtenaar van Staatstoezicht op de Mijnen, vermeldde die al in Igog in zijn jaarverslag. ${ }^{3}$ Bovenaan de preferentielijst van de Hoofdingenieur stonden arbeiders uit de mijnstreek. Zich realiserend dat deze regionale arbeidsmarkt niet volledig aan de vraag naar mijnwerkers zou kunnen voldoen, somde hij vier andere rekruteringsbronnen op. Het meest verwachtte hij van arbeiders uit de Zuid-Limburgse dorpen gelegen buiten de onmiddellijke omgeving van de mijnbedrijven. Zijn volgende voorkeur ging uit naar Nederlanders afkomstig van buiten Zuid-Limburg. Wanneer die ervaring hadden opgedaan in een Belgische of Duitse mijn waren ze extra welkom, al gaf de Hoofdingenieur toe dat de kans klein was dat Nederlanders hun baan in een buitenlandse mijn zouden willen opgeven om in Limburg mijnwerker te worden. Hun in het buitenland opgebouwde rechten in ziekenen pensioenfondsen zouden ze daarmee immers prijsgeven. Helemaal onderaan de lijst van preferente groepen stonden buitenlandse mijnwerkers.

Een dergelijke hiërarchie van preferente groepen bleef bestaan tot aan de sluiting van de mijnen vanaf 1966 . In een verordening van de Mijnindustrieraad uit 1963 werden de voor-

\footnotetext{
I Serge Langeweg, 'Trekarbeiders en pendelaars. Grensarbeid in oostelijk Zuid-Limburg, I875-I9I4', Zestig jaar vorsen in de geschiedenis: Jubileumboek Het Land van Herle 1945-2005 (Heerlen 2006) 295-308.

2 Kreukels, Mijnarbeid, 82-83.

3 Jaarverslag van den Hoofd-Ingenieur der Mijnen over 1909, I-4.
} 
keuren in het rekruteringsbeleid nog eens uit de doeken gedaan: 'Bij de werving van personeel worden terzake van de streek van herkomst de volgende prioriteiten in acht genomen:

I Personeel afkomstig uit eigen streek; onder eigen streek wordt verstaan: de mijnstreek met de aangrenzende gebieden vanwaar personeel [...] redelijkerwijze dagelijks van huis naar het werk heen en weer kan worden vervoerd.

2 Personeel afkomstig uit Nederland buiten eigen streek

3 Personeel afkomstig uit andere EEG-landen

4 Personeel afkomstig uit andere landen dan EEG-landen'. ${ }^{4}$

In het jargon van de jaren zestig lijkt het een echo van de opvatting van Staatstoezicht van een halve eeuw eerder. Nog steeds werd een duidelijke voorkeur uitgesproken voor arbeiders uit eigen streek of uit de rest van Nederland. Arbeiders uit het buitenland kwamen pas in aanmerking wanneer de meer preferente groepen op de arbeidsmarkt in onvoldoende mate aan de vraag naar mijnwerkers konden voldoen.

Wat kwam er in de loop van de ruim zes decennia die dit onderzoek beslaat, van die preferentievolgorde van de mijnondernemingen terecht? Slaagden de mijnen erin voldoende mijnwerkers op de regionale en nationale arbeidsmarkt te rekruteren en waar kwamen die mijnwerkers dan vandaan?

Als criterium voor herkomst is gekozen voor de geboorteplaats. Uiteraard is dat niet noodzakelijkerwijze de laatste verblijfplaats, voordat iemand besloot naar de Limburgse mijnen te komen. Tussen de geboorte en het moment dat men mijnwerker kon of wilde worden, kon een heel migratietraject zijn afgelegd. Binnen het kader van dit onderzoek was een representatief levenslooponderzoek naar de geografische herkomst van de mijnwerkerspopulatie niet praktisch uitvoerbaar. De geboorteplaats van de groep 'Nederlanders' werd provinciaal onderverdeeld. Voor de provincie Limburg werd een verdere verfijning aangebracht door ook de groep mijnwerkers die in de eigenlijke mijnstreek werd geboren in de beschouwingen te betrekken.

\section{LIMBURGERS EN ANDERE NEDERLANDERS IN DE MIJN}

Het aantal Nederlanders dat bij de Limburgse mijnondernemingen werkte, nam in de loop van de twintigste eeuw fors toe. Bij de aankondiging van de mijnsluitingen in december I965 bedroeg hun aantal bijna het twintigvoudige van zestig jaar eerder. De werkgelegenheid in de mijnen was in dezelfde periode echter ook sterk gestegen. Het aantal Nederlanders alleen zegt dan ook niet veel over de mate waarin zij aan de vraag naar mijnwerkers op de arbeidsmarkt konden voldoen. Het aandeel van de Nederlanders in het totale personeelsbestand van de Limburgse mijnen is een betere indicator voor de stand van de nationale arbeidsmarkt voor mijnwerkers. Uit grafiek 4.I blijkt dat in de Limburgse mijnen Nederlandse mijnwerkers steeds het merendeel van de arbeidersbezetting hebben gevormd. Nadere beschouwing van de grafiek laat in de loop van de tijd een ontwikkeling zien, die aanleiding geeft tot het onderscheiden van een drietal subperioden. Het tijdvak van opbouw van de Limburgse mijnindustrie (Igoo tot I930) laat in het algemeen een dalende tendens

'Verordening betreffende de werving en tewerkstelling van mijnpersoneel', Verordeningenblad Bedrijfsorganisatie 10/1963. 

STAN D VAN DE NEDERLANDSE STEEN KOLENMIJNEN, I905-I965 (PER 3I DECEMBER)

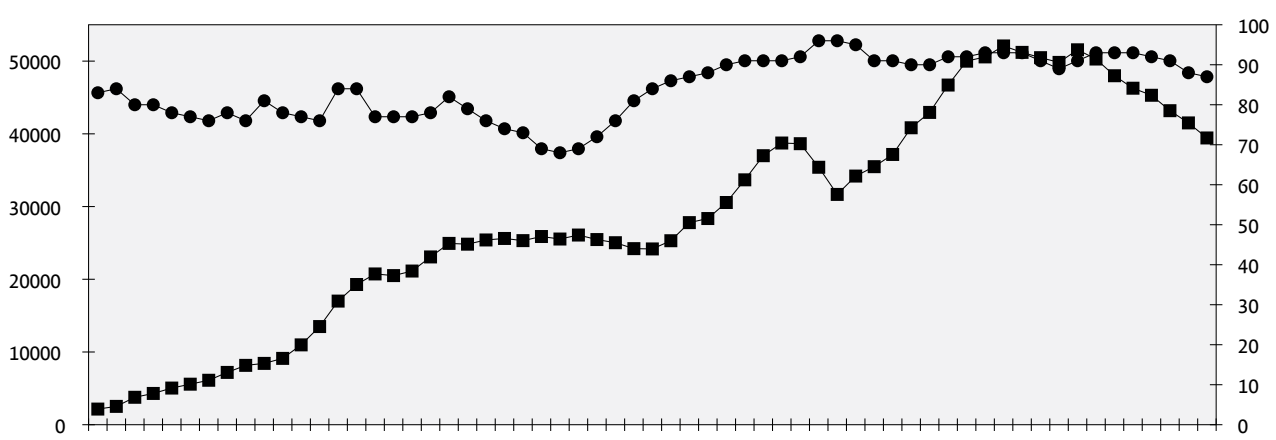

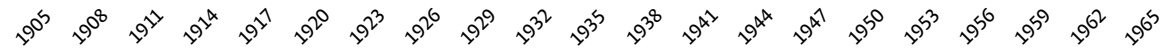

$\because$ aantal $\longrightarrow$ percentage

Bron: (Jaar)verslagen (Hoofd-)Ingenieur / Inspecteur-Generaal der Mijnen, I905-I965.

zien in het aandeel Nederlanders. Na I93I, toen de mondiale economische depressie ook in de Nederlandse mijnen toesloeg, is een toename van het percentage Nederlanders onder de mijnwerkers zichtbaar. Tot aan de bevrijding van de Duitse bezetting in 1944-I945 bleef het aandeel van de Nederlanders stijgen tot uiteindelijk 96 procent, het hoogste percentage in de geschiedenis van de Limburgse mijnbouw in de twintigste eeuw. In de periode van wederopbouw (I945-I965) stabiliseerde het aandeel Nederlandse mijnwerkers op een niveau dat rond de go procent lag, al was er in het midden van de jaren vijftig en na ig6o een lichte daling waar te nemen. Ten tijde van de aankondiging van de mijnsluitingen bedroeg het aandeel Nederlanders niettemin nog steeds 87 procent.

Gepubliceerde overzichten van de provinciale herkomst van de groep Nederlanders voor de hele periode ontbreken. Slechts in de jaren I9I9-I938 wordt in de jaarverslagen van het Algemeen Mijnwerkersfonds (AMF) een uitsplitsing gemaakt naar provincie van geboorte. Steeds is dit een momentopname op de laatste dag van het jaar. Om toch een indruk te krijgen van de ontwikkeling naar herkomst binnen Nederland, wordt gebruik gemaakt van een aselecte steekproef uit nieuwe inschrijvingen bij het AMF. ${ }^{5}$ De verkregen gegevens zijn geen momentopname, maar geven een meer dynamisch beeld van indiensttreding en ontslag. Tussen circa I900 en 1965 was gemiddeld genomen iets meer dan de helft van de in dienst genomen mijnwerkers Limburger van geboorte. Van de Nederlanders was 74 procent Limburger. Buiten Limburg leverden Noord-Brabant en Gelderland doorgaans de meeste mijnwerkers, maar vergeleken met Limburg was het aandeel in de totale personeelsvoorziening marginaal. Voor de overige provincies geldt dat in nog sterkere mate. Zowel het hoge percentage Nederlanders als het aandeel van de Limburgers in deze groep lijken aanwijzingen dat het preferentiebeleid van de mijnondernemingen inzake de werving en selectie van personeel succes heeft gehad. 
Dat het geen vanzelfsprekendheid was dat mijnbedrijven in ruime mate een beroep konden doen op de regionale en nationale arbeidsmarkt kan worden geilllustreerd met het voorbeeld van het naburige mijnbouwdistrict rond de Belgische stad Luik. ${ }^{6}$ Vooral na de Tweede Wereldoorlog droogde daar het regionale en nationale arbeidsaanbod van mijnwerkers op, en moesten de mijnondernemingen in steeds grotere mate een beroep doen op buitenlandse arbeiders. Vanaf I95I had meer dan de helft van de mijnwerkers in Luik een niet-Belgische nationaliteit. Twintig jaar later was het aandeel van buitenlandse arbeiders in de Luikse mijnen opgelopen tot meer dan 70 procent. In die jaren waren er mijnen in Luik, waar ondergronds geen enkele Belg meer werkte. ${ }^{7}$

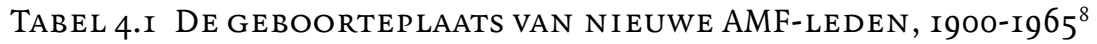

\begin{tabular}{|c|c|c|c|c|c|c|c|c|c|c|}
\hline & 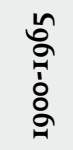 & $\%$ & 咅 & $\%$ & 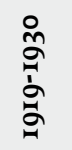 & $\%$ & 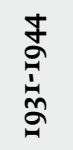 & $\%$ & 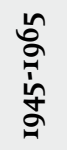 & $\%$ \\
\hline Groningen & IO & 0,6 & 2 & 0,5 & I & 0,2 & I & 0,2 & 6 & $\mathrm{I}, 3$ \\
\hline Friesland & 24 & $\mathrm{I}, 4$ & II & 3,0 & 7 & $\mathrm{I}, 6$ & - & - & 6 & $\mathrm{I}, 3$ \\
\hline Drenthe & 29 & $\mathrm{I}, 7$ & 9 & 2,4 & II & 2,6 & 5 & $\mathrm{I}, 2$ & 4 & 0,9 \\
\hline Overijssel & 24 & $\mathrm{I}, 4$ & 9 & 2,4 & 6 & $\mathrm{I}, 4$ & 5 & $\mathrm{I}, 2$ & 4 & 0,9 \\
\hline Gelderland & 47 & 2,8 & I9 & 5,2 & 15 & 3,5 & 2 & 0,5 & II & 2,3 \\
\hline Utrecht & IO & 0,6 & 3 & 0,8 & 2 & 0,5 & 2 & 0,5 & 3 & 0,6 \\
\hline Noord-Holland & 33 & 2,0 & 8 & 2,2 & 6 & $\mathrm{I}, 4$ & 6 & $\mathrm{I}, 5$ & I3 & 2,8 \\
\hline Zuid-Holland & 37 & 2,2 & 6 & $\mathrm{I}, 6$ & 5 & $\mathrm{I}, 2$ & 9 & 2,2 & I7 & 3,6 \\
\hline Zeeland & 4 & 0,2 & 3 & o,8 & - & - & - & - & I & 0,2 \\
\hline Noord-Brabant & 82 & 4,9 & 17 & 4,6 & I8 & 4,2 & 23 & 5,7 & 24 & $5, \mathrm{I}$ \\
\hline Limburg & 854 & $5 \mathrm{I}, 2$ & $2 \mathrm{II}$ & 57,3 & IO4 & 24,2 & 312 & 77,4 & 227 & 48,4 \\
\hline Nederland & I.I54 & $69, \mathrm{I}$ & 298 & $8 \mathrm{I}, 0$ & $\mathrm{I} 75$ & 40,8 & 365 & 90,6 & 316 & 67,4 \\
\hline buitenland & 515 & 30,9 & 70 & 19,0 & 254 & 59,2 & 38 & 9,4 & 153 & 32,6 \\
\hline totaal & I.669 & 100,0 & 368 & 100,0 & 429 & 100,0 & 403 & 100,0 & 469 & 100,0 \\
\hline $\begin{array}{l}\text { Limburg in \% } \\
\text { Nederland }\end{array}$ & & 74,0 & & 70,8 & & 59,4 & & 85,5 & & $7 \mathrm{I}, 8$ \\
\hline
\end{tabular}

Bron: Eigen berekening op basis van steekproef AMF-leden. Zie bijlage 8 voor een bespreking van de steekproef.

6 Langeweg en Roels, 'Buitenlandse arbeiders'. Specifiek over de Luikse situatie: Leen Roels, 'Buitenlandse arbeiders in de Luikse steenkolenmijnen, I900-I974', TSEG V nummer 3 (2008) I04-I25.

7 Roels, 'Buitenlandse arbeiders', I22.

8 In de tabel is de fase van opbouw gesplitst in twee kolommen: vóór I-8-19I9 en I9I9-I930. Dat heeft een bronnentechnische reden. Op I-8-igrg kwam het AMF tot stand. Van alle mijnwerkers die als lid werden ingeschreven, werd op dat moment een kaart aangemaakt, waarop hun carrière als mijnwerker tot dan toe werd opgetekend. Dit gedeelte van de steekproef is dus een momentopname van de mijnwerkers die per I-8-IgIg nog in dienst waren. Het verloop vóór die datum blijft dus volledig buiten beschouwing. Dit kan het beeld vertekenen. Vanaf I-8-IgIg betreft de steekproef echter alle ingeschreven nieuwe mijnwerkers, die hun carrière begonnen. 
Het succes van de Nederlandse mijnen op de regionale en nationale arbeidsmarkt blijkt nog duidelijker wanneer de perioden van opbouw, crisis en oorlog en wederopbouw afzonderlijk worden genomen en vervolgens met elkaar vergeleken (tabel 4.I).

In de periode van opbouw (I9I9-I930) was nog geen kwart van de nieuwe mijnwerkers Limburger. Het aandeel van de Limburgers in de groep Nederlandse mijnwerkers bedroeg bijna 6o procent. Van hen kwam 58 procent uit de mijnstreek (bijlage ro).

Tijdens de jaren van crisis en oorlog veranderde het beeld echter volkomen. Van alle mijnwerkers die in die periode in dienst kwamen, was ruim driekwart Limburger. Van de nieuwe Nederlandse mijnwerkers was zelfs 85 procent in Limburg geboren. Het aandeel van de 'mijnstrekers' onder de Limburgers steeg eveneens fors naar 74 procent.

$\mathrm{Na}$ de oorlog nam het aandeel van geboren Limburgers in de nieuwe mijnwerkers af. Het bleef echter op een aanzienlijk hoger niveau dan in de fase van opbouw. In de naoorlogse jaren was bijna de helft van de nieuwe mijnwerkers Limburger. Van de groep Nederlanders was 7 I procent in een Limburgse gemeente geboren. Ruim 68 procent van die Limburgers was geboortig in de mijnstreek.

In de volgende paragrafen worden de subperioden specifiek behandeld. Met name zal worden gekeken naar patronen in de herkomst en naar het wervings- en selectiebeleid van de mijnbedrijven.

\section{DE OPBOUW VAN EEN MIJNWERKERSBESTAND, I900-I930}

\section{Personeelsvoorziening op een rurale arbeidsmarkt}

Het probleem met de personeelsvoorziening van de mijnen in de beginjaren was niet de aanwezigheid van alternatieve werkgelegenheid in Limburg zelf. ${ }^{9}$ Sedert de laatste decennia van de negentiende eeuw was het met de werkgelegenheid in Limburg niet best gesteld. De landbouw, traditioneel de grootste sector van de Limburgse beroepsbevolking, kampte sedert de grote crisis van de jaren I875-I895 met een grote uitstoot van arbeidskrachten. Voor het Midden-Limburgse dorp Heythuysen is de achteruitgang van de werkgelegenheid in de landbouw onderzocht. ${ }^{\text {Io }}$ Het tekort aan arbeidsplaatsen steeg er van 28 procent in de periode $\mathrm{I} 855$-I 869 tot 38 procent tussen 1870 en 1889 . De grotere boeren moesten onder druk van dalende inkomsten bezuinigen op de kosten van arbeid. In die situatie zagen vele dagloners en landarbeiders, maar ook kleine zelfstandige boeren en middenstanders zich genoodzaakt om te zien naar alternatieve middelen van bestaan. ${ }^{\text {II }}$ Sommige agrarische gebieden hadden in deze jaren een vertreksaldo van meer dan tien promille van de bevolking. Velen verlieten het dorp en trokken weg naar de stad in de hoop er werk te vinden. Steden als Sittard, Roermond en Maastricht tekenden tussen I 876 en I 885 overwegend vestigingsoverschotten op. ${ }^{12}$

9 Dieteren, Migratie, 6-9.

Io J.H.M. Janssen, 'Van lokale markt tot internationale handel. De commercialisatie van de landbouw in Heythuysen, I850-I9I4', SSEGL XXXIII (1988) 62-99.

II Serge Langeweg, 'Werken over de grens. Limburgers naar Duitsland, I870-1914', SSEGL XLVII (2002) 27-48, aldaar 30.

12 Wachelder, 'De migratie', tabel 7, 179 en tabel 9, I82; Voor Maastricht zie ook: Ch. Gemmeke, Maastricht. Een bijdrage aan de demografisch-historische studie in het byzonder over de periode 1830-1930 (Leuven I96I) Ioo. 
GRAFIEK 4.2 DE BEVOLKING EN DE AANVRAGEN VAN NATIONALITEITSBEWIJZEN IN DE OOSTELIJKE MIJNSTREEK ALS PERCENTAGE VAN HET LIMBURGSE TOTAAL, I875-I9I4

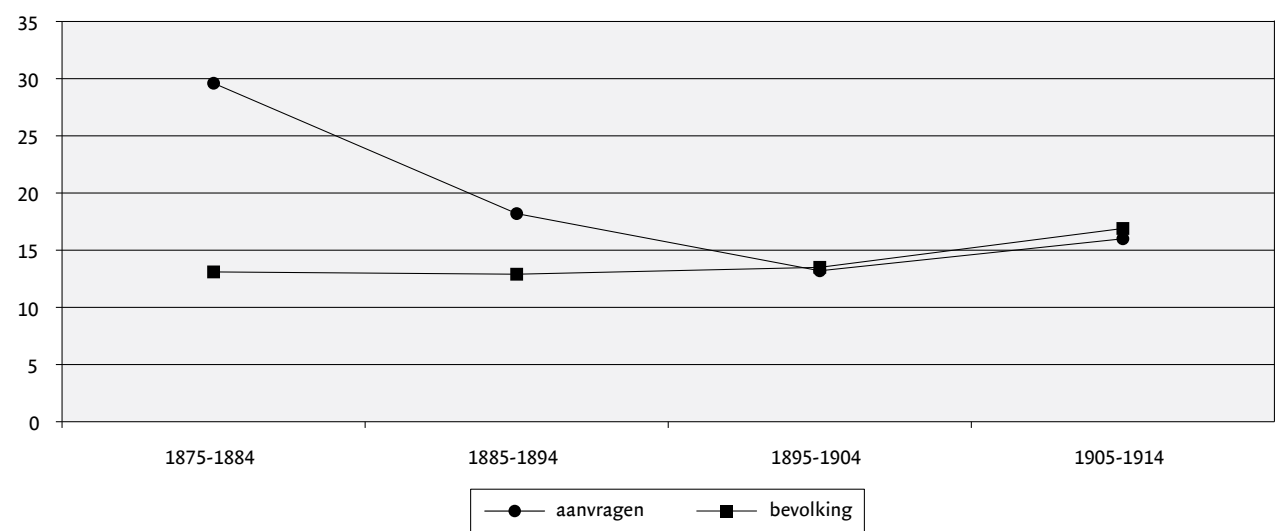

Bron: Eigen berekening op basis van een steekproef uit de aanvraagformulieren. RHCL, Provinciaal Archief, inv. nrs. 6895-7283: aanvragen voor nationaliteitsbewijzen, I875-1914 (zie bijlage 9).

Niet iedereen zocht echter heil in de eigen provincie. Ook de naburige Duitse industriegebieden vormden de bestemming van menige migrant uit Limburg. Vooral voor de inwoners van de streek rond Kerkrade en Heerlen was de Duitse arbeidsmarkt een vaak gekozen optie. Dat blijkt bijvoorbeeld uit het aantal nationaliteitsbewijzen dat in de (latere) oostelijke mijnstreek werd aangevraagd. ${ }^{13}$ In grafiek 4.2 is zowel het bevolkingsaantal als het aantal aanvragen voor nationaliteitsbewijzen in de oostelijke mijnstreek (uit een steekproef, zie bijlage 9) uitgezet als percentage van het Limburgse totaal. Het blijkt dat de oostelijke mijnstreek tot het eind van de negentiende eeuw aanzienlijk meer arbeidsmigranten telde dan op basis van het bevolkingsaantal mocht worden aangenomen. Tot 1894 hadden de gemeenten in de oostelijke mijnstreek samen steeds ongeveer 13 procent van de totale Limburgse bevolking binnen hun grenzen. In het decennium I875-I884 was daarentegen 30 procent van de Limburgse arbeidsmigranten naar Duitsland uit de oostelijke mijnstreek afkomstig. In de volgende periode van tien jaar daalde dit aandeel tot I8 procent, niettemin nog steeds hoger dan het aandeel in de Limburgse bevolking. Pas na 1895 ging het aantal uitgereikte nationaliteitsbewijzen in de pas lopen met de bevolkingsontwikkeling.

Onder de arbeidsmigranten naar Duitsland bevonden zich veel seizoenwerkers. ${ }^{\mathrm{I}}{ }^{\mathrm{J}} \mathrm{Jaar}-$ lijks rond Pasen trokken deze arbeiders de grens over naar het Rijnland of het Ruhrgebied om daar tijdelijk in de zomermaanden te gaan werken als brikkenbakker, bouwvakarbeider, meid of knecht op een landbouwbedrijf. Dankzij de hoge lonen daar, was er een grote uitstroom uit de Limburgse arbeidsmarkt. De trek naar Duitsland was meer dan alleen een crisisverschijnsel. 'Duizenden en nog eens duizenden van de vlijtigste en krachtigste werklie-

I3 Nationaliteitsbewijzen waren bewijzen van Nederlanderschap. Voor wie werk in Duitsland zocht en daar ook (tijdelijk) wilde verblijven, was een nationaliteitsbewijs verplicht. Zie bijlage 9 .

I4 Waarschijnlijk waren niet alle Limburgse seizoensarbeiders in Duitsland in het bezit van een nationaliteitsbewijs. Vooral in beroepen waarvoor moeilijk arbeiders te krijgen waren, liet de controle op de vereiste papieren wel eens na. 
den uit deze streken [Limburg, SL] gaan in Duitsland in de zomer kost en onderhoud voor de komende winter verdienen', schreef rapporteur Beekers aan de commissie die in I886 de toestand van de Nederlandse landbouw onderzocht. ${ }^{\text {I5 }}$ Zijn collega-rapporteur H. Dautzenberg schatte het aantal Limburgers dat jaarlijks in Duitsland werk vond, op tienduizend. Alleen al uit Voerendaal, een dorp van nauwelijks I.9oo zielen, werkten meer dan honderd inwoners in Duitsland. ${ }^{16}$ De landbouwleraar F.R. Corten kwam in zijn onderzoeksverslag zelfs tot een aantal van twintigduizend Limburgse arbeiders in Duitsland. ${ }^{17}$ Twintig jaar later bleek de toestand niet veranderd. In een verslag over de toestand van de Limburgse landarbeiders dat in 1908 verscheen, werd nog steeds geconstateerd dat er in de provincie, vooral in de zomermaanden, een groot tekort aan arbeidskrachten bestond. Als voornaamste oorzaak werd de zuigkracht van de Duitse arbeidsmarkt aangemerkt. ${ }^{18}$

Voor de personeelsvoorziening van de mijnen was de Duitse arbeidsmarkt dus een geduchte concurrent. De concurrentiepositie van de mijnen op de arbeidsmarkt werd verder bemoeilijkt door de beeldvorming over het beroep van mijnwerker. Alleen in Kerkrade was de beroepsbevolking van oudsher bekend met mijnarbeid. Aan het eind van de negentiende eeuw was Kerkrade de enige plaats in Limburg waar het mijnwerkersberoep ingeburgerd was en van generatie op generatie werd doorgegeven. Zo had de zoon uit een mijnwerkersgezin, wanneer de vader stierf, voorrang bij het innemen van de opengevallen plaats in de mijn. ${ }^{19}$ Hoezeer mijnarbeid in Limburg tot diep in de negentiende eeuw een vrijwel exclusief Kerkraads fenomeen was, wordt duidelijk uit een onderzoek naar de opgegeven beroepen van bruidegoms in de huwelijksakten.

TABEL 4.2 HUWELIJKSSLUitingen, WAARBIJ DE BRUIDEGOM MIJNWERKER WAS

\begin{tabular}{|c|c|c|c|c|c|c|c|c|}
\hline & \multicolumn{2}{|c|}{ vóór 1890} & \multicolumn{2}{|c|}{ 1890-1899 } & \multicolumn{2}{|c|}{ 1900-1909 } & \multicolumn{2}{|c|}{ I910-1919 } \\
\hline & $\mathbf{N}$ & $\%$ & $\mathbf{N}$ & $\%$ & $\mathbf{N}$ & $\%$ & $\mathbf{N}$ & $\%$ \\
\hline Kerkrade & 628 & 92,6 & 355 & 76,7 & 747 & $54, \mathrm{I}$ & I.093 & 28,5 \\
\hline Heerlen & I5 & 2,2 & 39 & 8,4 & 248 & 17,9 & 613 & I6,o \\
\hline Ubach over Worms & - & - & 24 & 5,2 & 45 & 3,3 & 97 & 2,5 \\
\hline Schaesberg & - & - & 20 & 4,3 & 58 & 4,2 & I65 & 4,3 \\
\hline Nieuwenhagen & - & - & - & - & 37 & 2,7 & III & 2,9 \\
\hline Maastricht & - & - & - & - & - & - & 258 & 6,7 \\
\hline Sittard & - & - & - & - & - & - & I35 & 3,5 \\
\hline Hoensbroek & - & - & - & - & - & - & 99 & 2,6 \\
\hline overig & 35 & 5,2 & 25 & 5,4 & 247 & 17,8 & $\mathrm{I} .269$ & 33,0 \\
\hline totaal & 678 & 100,0 & 463 & 100,0 & 1.382 & 100,0 & 3.840 & 100,0 \\
\hline
\end{tabular}

Bron: RHCL, Huwelijksaktes, I795-I922.

I5 Uitkomsten van het onderzoek naar den toestand van den landbouw in Nederland ('s-Gravenhage I8go) Rapport XCIII, gemeente Schinnen, I3-I4.

I6 Idem, Rapport XCIV, gemeente Voerendaal, 8-9.

17 Idem, Rapport XCII, gemeente Beek, I5.

I8 Verslag betreffende den toestand der landarbeiders in Limburg ('s-Gravenhage 1908) 360.

19 Dieteren, Migratie, 59. 
Vóór I89o werd in de provincie Limburg 92,6 procent van de huwelijken, waarbij de mannelijke partner aangaf mijnwerker te zijn, in Kerkrade gesloten. Hoewel dat percentage na I89o tengevolge van de regionale uitbreiding van de mijnbouw snel afnam, bleef Kerkrade zeker tot omstreeks I920 de Limburgse mijnstad bij uitstek.

Het belang van de mijnbouw voor de plaatselijke beroepsbevolking komt ook tot uiting in de beroepstellingen van die tijd. Van de in totaal I.I62 mijnwerkers die in I889 in de provincie Limburg werden geteld, woonden er 95I (8I,8 procent) in Kerkrade. Dat kwam neer op ruim 47 procent van de mannelijke beroepsbevolking. Heerlen volgde op zeer ruime afstand met slechts 39 mijnwerkers, 2,5 procent van de mannelijke beroepsbevolking. De overige 172 mijnwerkers woonden in dorpen met minder dan vijfduizend inwoners die bij de beroepstelling van 1889 niet verder werden gespecificeerd. ${ }^{20}$

Buiten Kerkrade was het beroep van mijnwerker met mysterie omgeven. Die geheimzinnigheid was het gevolg van de 'onzichtbaarheid' van het ondergrondse productieproces voor de buitenwereld. Het mijnwerkersberoep was slechts bekend uit de vaak gekleurde verhalen uit de tweede hand en niet uit eigen waarneming. ${ }^{21}$ Bovendien betekende mijnarbeid een breuk met de aard van de werkgelegenheid en het arbeidsritme waarmee de bevolking van Zuid-Limburg vertrouwd was. Mijnarbeid werd niet gedicteerd door de wisselingen van jaargetijden zoals werk in de landbouw of in de kleine ambachtelijke bedrijfjes. Mijnarbeid kende het hele jaar door dag-, middag- en nachtdiensten. Er heerste een minder persoonlijke manier van leiding geven, er waren andere beloningsmaatstaven, nieuwe arbeidsmethoden en andere arbeidsvoorwaarden. ${ }^{22}$ Die negatieve beeldvorming werd nog versterkt door de omstandigheid dat tot in de jaren 1920 huisvesting in de omgeving van de mijnbedrijven schaars was en de verbindingen met de Limburgse dorpen slecht waren. ${ }^{23}$

Mijnarbeid was vaak een laatste redmiddel, dat men pas aangreep wanneer er nergens anders werk te krijgen was. Velen bleven liever in de lente en de zomer in de Duitse brikkenbakkerijen werken, dan dat men mijnwerker in Limburg werd. Een ploegbaas van een groep brikkenbakkers merkte in 1908 op: 'in de brikkenbakker schuilt geen mijnwerker. Is de campagne voorbij, wanneer zij met zeer zware arbeid een mooi stuk geld verdiend hebben, dan zoeken zij hier of daar wat los werk, knutselen zelf wat thuis en brengen ook een week of wat in rust door, om, als de campagne begint, weer naar de brikkenbakkerijen te gaan. De mijnen in gaan zij niet; een enkele mag misschien zijn oude levenswijze laten varen, maar van de brikkenbakkers mijnwerkers maken, dat hoeft men niet te proberen, die poging mislukt stellig. Geen van ons denkt eraan in de mijnen te gaan werken' ${ }^{24}$ Kreukels heeft er op gewezen dat zelfs Limburgers die wél besloten de mijn in te gaan, dat tot diep in de jaren twintig veelal niet als een definitieve keuze beschouwden. Velen hielden een stuk bouwland in pacht. De verwachting nog ooit zelfstandig landbouwer te worden, bleef bij hen leven. ${ }^{25}$ Anderen combineerden mijnarbeid aanvankelijk met een nevenfunctie, zoals landarbeid op een eigen bedrijfje of met een ander beroep, een ambachtsbedrijfje, een han- 


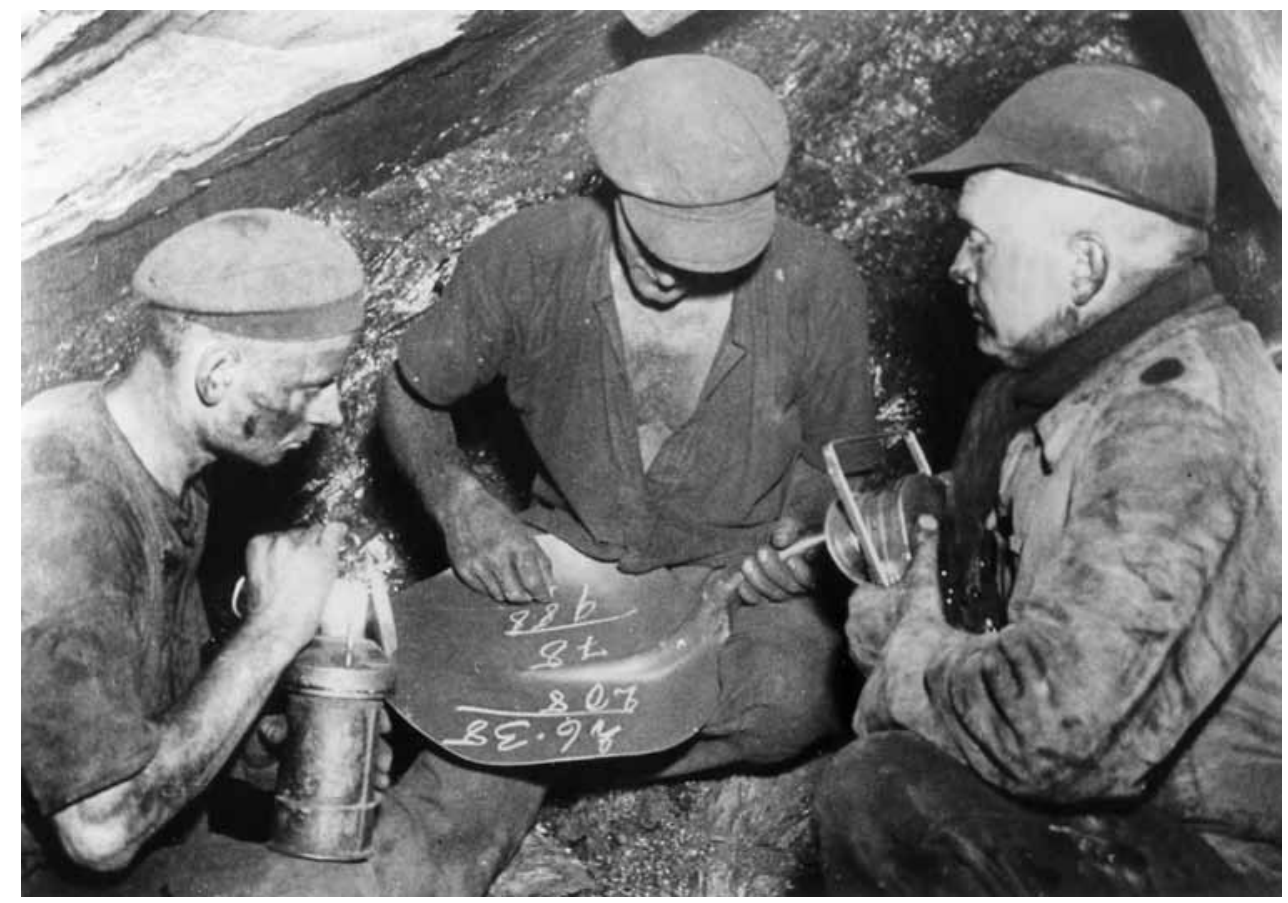

Mijnwerkers van de Domaniale Mijn berekenen op de schop het loon voor de maandafrekening. Omstreeks 1928. Collectie Continium Kerkrade F2417.

deltje of een café. ${ }^{26}$ Ook werd mijnarbeid wel ingepast in een jaarlijkse arbeidscyclus, die verder in de oogstmaanden seizoensarbeid bij de boer omvatte. ${ }^{27}$

Het probleem van de onbekendheid met mijnarbeid speelde ook elders in Nederland. Al vroeg was geprobeerd arbeiders buiten Limburg te werven. Pogingen van de Oranje-Nassau Mijnen, van Laura \& Vereeniging en van Staatsmijnen in de jaren I908-I909 om in NoordBrabant en boven de grote rivieren arbeiders te rekruteren hadden echter minimaal resultaat opgeleverd. ${ }^{28}$ Het gevolg was dat het aantal Nederlanders in de mijnen weliswaar steeg, maar dat hun aandeel in de totale personeelsbezetting geleidelijk afnam (grafiek 4.I).

Dat mijnarbeid voor veel arbeiders pas een serieuze optie werd wanneer alternatieven om aan de kost te komen ontbraken of wegvielen, bleek toen in de loop van de Eerste Wereldoorlog de werkloosheid buiten de mijnbouw sterk toenam. Bij Staatsmijnen, waar de toename van het aantal in Limburg geboren mijnwerkers in de jaren I913-1916 had geschommeld rond de 650 man per jaar, accelereerde die groei in 1917 en 1918 naar respectievelijk ruim I.00o en ruim I.200 mijnwerkers van Limburgse geboorte. Ook op nationale schaal deed zich deze ontwikkeling voor. Vanaf I9I5 nam het aantal onervaren Nederlandse arbeiders dat zich als ondergronder bij de Limburgse mijnbouw aanbood, sterk toe. Terwijl hun

26 B.P.A. Gales, H. van den Hoogen, G. Legebeke en J. de Roos, Bedrijfsvoering, arbeidsverhoudingen in de Limburgse mijnen, $1920-1940$ (doctoraalscripties, Nijmegen z.j.) 6-7.

27 'Annalen van de Willem-Sophia', Steenkool (maart 1948) ro8-rog.

28 Gales e.a., Bedrijfsvoering, I4-I5; Kreukels, Mijnarbeid, 82. 
aandeel in de jaren I908-I9I4 rond een kwart van het totaal aantal in dienst genomen ondergronders had bedragen, steeg dat tot ruim 57 procent in I9I8. Absoluut gezien verdrievoudigde het aanbod van Nederlandse arbeiders zonder mijnervaring tussen I9I3 en I9I8 (bijlage I2).

Ook na de Eerste Wereldoorlog had het grootste deel van de nieuwe Nederlandse ondergronders geen ervaring in mijnarbeid. Tussen I9I9 en I925 was gemiddeld 88 procent van de nieuwe ondergrondse mijnwerkers zonder eerdere ervaring in de steenkolenwinning Nederlander. Uit verschillende bronnen blijkt dat de ambitie voor mijnarbeid van de meesten van hen niet groot was en dat hun lichamelijke conditie in veel gevallen onvoldoende was voor het ondergrondse werk. Een voorbeeld is een groep van vijftien arbeiders uit Oss die zich in 1922 voor mijnarbeid aanmeldde. Van hen werd bijna de helft voor mijnarbeid afgekeurd, terwijl de overigen binnen acht dagen uit de mijn verdwenen waren, omdat de arbeid te zwaar was. ${ }^{29}$ Drie jaar later bleek een groep Maastrichtenaren weinig te zien in mijnarbeid. Via tussenkomst van de directeur van de arbeidsbeurs van Maastricht werden 69 kandidaten opgeroepen voor werk bij Staatsmijnen. Van hen reageerden er slechts twintig, waarvan er acht voor mijnarbeid werden goedgekeurd. Uiteindelijk gingen zes van hen daadwerkelijk bij Staatsmijnen aan de slag. ${ }^{30}$ Op II augustus I929 schreef het Algemeen Handelsblad: 'Voor de Nederlanders is het gaan werken in de mijnen vaak een wanhoopsdaad. Door hoogste nood gedwongen gaat men de diepte in, met het vaste voornemen zodra mogelijk te deserteren. De hier te werk gestelde werklozen uit Emmen trekken zodra mogelijk weg. Dergelijke mensen verzinnen het uiterste om maar afgekeurd te worden en sommen de dokter allerlei kwalen op waaraan ze lijden'. ${ }^{3 \mathrm{I}}$ Werk in de mijn was voor een groep arbeiders nog steeds een negatieve keuze in een situatie dat alternatieven om aan de kost te komen niet meer voorhanden waren.

\section{Herkomst}

Vanaf I9I2 zijn gegevens voorhanden over de herkomst van Nederlandse mijnwerkers. Tot I9I9 betreft dit echter enkel de personeelsbezetting bij Staatsmijnen. Een ruime meerderheid kwam uit Limburg, al nam het percentage Limburgers onder de Nederlandse mijnwerkers wel af, van driekwart in de jaren onmiddellijk vóór de Eerste Wereldoorlog tot 6I,4 procent in I9I9..$^{32} \mathrm{Bij}$ de gezamenlijke mijnen bedroeg het aandeel Limburgers onder de Nederlandse mijnwerkers in dat jaar 66,7 procent, een indicatie voor de relatieve aantrekkingskracht van Staatsmijnen op Nederlanders van buiten Limburg. ${ }^{33}$ In een volgende paragraaf wordt hierop nader ingegaan.

Vanaf I9I9 is aan de hand van de steekproef uit de inschrijvingen in het AMF de herkomst van nieuwe mijnwerkers te volgen (tabel 4.I). Duidelijk blijkt dat de Nederlandse arbeidsmarkt voor mijnwerkers in de jaren I9I9-I930 nog steeds te krap was om aan de vraag vanuit

29 Jaarverslag Arbeidsbeurs Limburgsche Mijnstreek 1922, 5.

30 Caspar Cillekens, Arbeidsmarkt, werklozenzorg en werkloosheidsbestrijding te Maastricht 1914-1939 (doctoraalscriptie, Nijmegen I980)

IIO.

3I Geciteerd bij Dieteren, 'Moeizame weg', 3i.

32 Jaarverslag van het bedrijf der Staatsmijnen in Limburg over het jaar 1919, I6.

33 Jaarverslag AMF 1919-1920, 2 I. 
de mijnbedrijven te voldoen. Slechts een minderheid (40,8 procent) van de nieuwe mijnwerkers kwam uit Nederland. Van de Nederlanders maakten Limburgers met 59,4 procent het merendeel uit. Binnen Limburg was het de eigenlijke mijnstreek, die de meeste mijnwerkers leverde: van elke tien mijnwerkers kwamen er zes uit een van de 39 mijnstreekgemeenten (bijlage Io). Buiten Limburg scoorden de provincies Noord-Brabant en Gelderland het hoogst, op enige afstand gevolgd door Drenthe. De eerste twee genoemde provincies hadden de voorkeur van de mijndirecties, daarin gesteund door de katholieke geestelijkheid, omdat er veel katholieken woonden. Arbeiders, afkomstig uit Noord-Brabant of Gelderland zouden de minste aanpassingsproblemen in de mijnstreek hebben. Dat zou vooral gelden voor arbeiders van het platteland. ${ }^{34}$ De Limburgse clerus en de christelijke vakbond van mijnwerkers hielpen zelfs actief mee om arbeiders uit katholieke streken in Nederland te interesseren voor arbeid in de mijnen. Het liefst zag men dat de aanhang naar Staatsmijnen ging. Daar zouden de arbeidsvoorwaarden en -omstandigheden het beste zijn. Zo bezocht Poels in I9I3 Noord-Brabant om mijnwerkers te rekruteren en was er ook in de jaren daarna geregeld contact tussen de Limburgse geestelijkheid en dorpspastoors en -kapelaans elders in Nederland om parochianen in ieder geval niet af te raden om mijnwerker in Limburg te worden. ${ }^{35}$ Het resultaat van de rekruteringsactiviteiten van de geestelijkheid was pover. ${ }^{36}$ Maar dat de concurrentie tussen de mijnondernemingen op de arbeidsmarkt groot was, blijkt uit de reactie van de directie van Oranje-Nassau Mijnen. Door de acties van de geestelijkheid om arbeiders naar Staatsmijnen te bemiddelen, werd de personeelsvoorziening bij de grootste particuliere mijnonderneming bemoeilijkt. ${ }^{37}$

Voor de Drenten - en in mindere mate ook voor de migranten uit de overige provincies in het noordoosten van Nederland - speelden push-factoren een grotere rol. De turfwinning die daar in de jaren I880-I920 een bloeiperiode had gekend, zakte na de Eerste Wereldoorlog in elkaar. De werkgelegenheid in de veenderijen nam fors af. In Drenthe tussen I920 en 1930 met 35 procent. $3^{8}$ Alternatieven waren er in Drenthe nauwelijks: de landbouw kon de overtollige arbeidskrachten niet opnemen en de traditionele trekarbeid naar Duitsland bood door de economische en monetaire ontreddering van begin jaren twintig evenmin soelaas. ${ }^{39}$ De werkloosheid in de veenstreken van de vier noordoostelijke provincies werd bestreden door werkverschaffing met steun van de rijksoverheid. Het besef dat dit geen structurele oplossing voor het werkloosheidsprobleem bood, leidde tot de optie van migratie naar industriegebieden elders in Nederland, waar wel vraag naar arbeidskrachten bestond. De rijksoverheid verplichtte het aanvaarden van mijnarbeid zelfs op straffe van inhouding van de werkloosheidsuitkering. ${ }^{40}$ Vanaf 1924 trokken arbeiders met hun gezinnen uit het veen naar bijvoorbeeld Philips in Eindhoven, naar Enka in Ede, naar de textiel-

34 Kreukels, Mijnarbeid, 29I.

35 Ibidem, 82; Dieteren, 'Moeizame weg', 31.

36 Dieteren, Migratie, 56; Dieteren, 'Moeizame weg', 3 I.

37 Oranje-Nassau Groep Amsterdam, ArchiefOranje-Nassau Mijnen, doos 303i, Correspondentie met De Wendel, eind igrz.

38 J. Heringa, D.P. Blok, M.G. Buist, H.T. Waterbolk (ed.), Geschiedenis van Drenthe (Meppel/Amsterdam I985) 632. In I930 bedroeg de werkgelegenheid in de vervening nog $8.487,9,8$ procent van de beroepsbevolking.

39 De trekarbeid richtte zich vooral op de landbouw en op de bouw van infrastructurele werken. Zie bijvoorbeeld: Michael Kösters-Kraft, Großbaustelle und Arbeitswanderung. Niederländer beim Bau des Dortmund-Ems-Kanals 1892-1900 (Osnabrück 2000) I62I8o.

40 Dieteren, 'Moeizame weg', 31. 
nijverheid in Twente en naar de Limburgse mijnen. ${ }^{4 \mathrm{I}}$ Het belang van de werkgelegenheid in de mijnen voor de Drentse bevolking wordt onderstreept door de constatering dat Drenthe - buiten uiteraard Limburg - zelfs de enige provincie was waar het aandeel mijnwerkers groter was dan op basis van het inwonertal mocht worden aangenomen. ${ }^{42}$

\section{Nederlanders uit Duitse mijnen}

Hierboven bleek dat de aard van de mijnarbeid en het gemis aan ervaring in de steenkolenwinning de personeelsvoorziening op de Nederlandse arbeidsmarkt parten speelde. In de groep Nederlanders bevonden zich echter ook mijnwerkers met ervaring, opgedaan in buitenlandse mijnen. In de praktijk betrof dit vooral Duitse mijnen. ${ }^{43}$ Voor de mijndirecties was dit een heel belangrijke groep, omdat die de Nederlandse nationaliteit koppelde aan ervaring. Die ervaring hadden ze in veel gevallen opgedaan in het Ruhrgebied.

De ontwikkeling van het Ruhrgebied tot industriegebied begon omstreeks I840. Gaandeweg schoof de geïndustrialiseerde zone met aanvankelijk voornamelijk steenkolenmijnen van de oevers van de Ruhr in noordwaartse richting op. Omstreeks I855 was het gebied bereikt langs de Hellweg, een oude heerbaan die van west naar oost de plaatsen Duisburg, Essen, Bochum en Dortmund verbond. ${ }^{44}$ De steenkolenlagen in deze streek bestonden vooral uit vetkool, waarvan hoogovencokes kon worden vervaardigd. Voor het smelten van een ton erts waren in die tijd minstens twee ton cokes nodig. Het was dus goedkoper de ertsen naar de kolen te vervoeren dan andersom. In de Hellweggordel ontwikkelde zich als gevolg daarvan tevens een belangrijke ijzer- en staalindustrie. Mijnbouw en ijzer- en staalindustrie werden de pijlers waarop de economie van het Ruhrgebied ging berusten. Duisburg, Essen, Bochum en Dortmund ontwikkelden zich al in de tweede helft van de negentiende eeuw tot belangrijke industriesteden met een explosief toenemende bevolking.

Nog voor het begin van de twintigste eeuw schoof de industrialisatie van het Ruhrgebied verder naar het noorden op. In de jaren I860 en I87o kwam het gebied langs de rivier de Emscher tot ontwikkeling. Hier ontstonden belangrijke mijnbouwsteden als Recklinghausen, Gelsenkirchen, Bottrop en Oberhausen. De meest noordelijke locatie bereikte de industrie in het Ruhrgebied omstreeks I9oo in de Lippezone, met plaatsen als Marl en Hamm. Alleen aan de westzijde van de Rijn, rondom de stad Moers, ontstond kort na I9oo nog de zogenaamde Rijnzone. 45

De snelle ontwikkeling van de industrie in het Ruhrgebied had een grote vraag naar arbeid tot gevolg. Tot omstreeks I86o kon die worden opgevangen door de arbeidsreserve in de streken waar de nieuwe mijnen en fabrieken ontstonden, maar daarna was arbeidsmi-

\footnotetext{
4I Heringa e.a. (ed.), Geschiedenis van Drenthe, 632-637.

42 Zie bijlage 14.

43 Het aantal Nederlandse mijnwerkers in de Belgische mijnen in het begin van de twintigste eeuw was te verwaarlozen. Volgens de Volkstelling van I9Io werkten slechts 67 Nederlanders in de Belgische steenkolenmijnbouw (op een totaal van 5.045 buitenlandse mijnwerkers). Population-Recensement Général du 31 Décembre 1910. In 1922 waren het er nog steeds niet meer dan I84 (op een totaal van 4.320 buitenlanders). Revue du Travail (Bruxelles 1930) 940.

44 Wilhelm Brepohl, Der Aufbau des Ruhrvolkes im Zuge der Ost-West-Wanderung. Beiträge zur deutschen Sozialgeschichte des 19. und 20. Jahrhunderts (Recklinghausen I948) 33-I37.

45 Ben de Pater, 'Nederlanders naar en in het Ruhrgebied', in: Kinie Hoogers, Jaap Hoogeveen en Roel Visser (ed.), 100 Jaar Nederlandse Kerk in Duitsland (Duisburg-Ruhrort 2002) 17-28, aldaar 21-22.
} 
gratie van verder weg noodzakelijk. ${ }^{46}$ Er kwam een migratiestroom naar het Ruhrgebied tot stand, die vooral vanaf I 890 massale vormen aannam. De meest tot de verbeelding sprekende migratiestroom in die tijd was die van etnische Polen uit Oost-Pruisische provincies, de zogenaamde Ruhrpolen. In I9I3 werd hun aantal in het industriegebied van de Rijnprovincie en Westfalen geschat op 400.000.47 Daarnaast nam ook de migratie van buitenlandse arbeiders naar het Ruhrgebied sterk toe. ${ }^{4^{8}}$ In I9I3 waren er ongeveer 360.000 buitenlandse arbeiders in de Rijnprovincie en in Westfalen, de twee provincies waarover het Ruhrgebied zich uitstrekte. ${ }^{49}$ Die kwamen hoofdzakelijk uit de Donaumonarchie (ca. 120.000), Italië (ca. I00.000) en Nederland (ca. I07.000)..$^{50}$ Van alle Nederlanders in Duitsland werkte in die tijd ongeveer 90 procent in de Rijnprovincie of in Westfalen..$^{51}$ Dit waren vooral migranten uit de provincies langs de Duitse grens. ${ }^{22}$

Van de Nederlandse mannen in de Rijnprovincie en in Westfalen was in de jaren Igo6I9I4 8 procent mijnwerker. ${ }^{53}$ Zij maakten in die tijd ongeveer ${ }^{5}$ procent uit van het aantal buitenlandse mijnwerkers. Daarmee kwamen ze, na de mijnwerkers uit de Donaumonarchie, op de tweede plaats. ${ }^{54}$ De sterke aanwezigheid van juist deze groepen is mede verklaarbaar door een in 1899 door het Oberbergamtsbezirk Dortmund uitgevaardigde verordening, waarin stond dat buitenlandse mijnwerkers enige kennis van de Duitse taal moesten hebben. ${ }^{55}$ Oostenrijkers en Nederlanders konden makkelijker aan deze eis voldoen dan migranten uit Polen, Rusland of Italië. Een meerderheid van de Nederlandse mijnwerkers in Duitsland werkte in de Rijnprovincie, het gedeelte dat het dichtst bij de Nederlandse grens was gelegen. Vooral het westelijke gedeelte van de Hellweg- en de Emscherzone kende een belangrijke concentratie Nederlanders. ${ }^{56}$ In 1907 werd het grootste aantal Nederlanders in één mijn - I3 I - geteld in de mijn Osterfeld, in de gelijknamige plaats nabij Oberhausen. De mijn Westende in Meiderich, een stadsdeel van Duisburg, had 127 Nederlanders in dienst. ${ }^{57}$

In absolute aantallen ging het in I893 om I.334 Nederlandse mijnwerkers in het Ruhrgebied. Daarna steeg de Nederlandse aanwezigheid snel via ongeveer 3.000 in de eerste jaren van de twintigste eeuw naar ruim 5.000 aan de vooravond van de Eerste Wereldoorlog..$^{8}$

\footnotetext{
46 Brepohl, Aufbau, 62.

47 Hans-Ulrich Wehler, 'Die Polen im Ruhrgebiet bis I9ı9', in: Hans-Ulrich Wehler (ed.), Moderne deutsche Sozialgeschichte (Köln/ Berlin I966) 437-455, aldaar 442-443.

48 Klaus J. Bade, " "Preußengänger” und "Abwehrpolitik”. Ausländerbeschäftigung, Ausländerpolitik und Ausländerkontrolle auf dem Arbeitsmarkt in Preußen vor dem Ersten Weltkrieg', Archiv für Sozialgeschichte XXIV (I984) 9I-I62, aldaar 97-98.

49 De grens tussen beide provincies lag ter hoogte van Essen. Essen en het westelijke deel van het Ruhrgebied behoorden tot de Rijnprovincie. Het oostelijke deel lag in Westfalen.

50 Klaus J. Bade (ed.), 'Arbeiterstatistik zur Ausländerkontrolle: die Nachweisungen der preußischen Landräte über den Zugang, Abgang und Bestand der ausländische Arbeiter im preußischen Staate I906-I9I4', Archiv für Sozialgeschichte XXIV (I984) I63-285, aldaar 240-244.

$5 \mathbf{I}$ Kösters-Kraft, Gro $\beta$ baustelle, 53.

52 P.R.D. Stokvis, 'Nederland en de internationale migratie, $1815-1960$ ', in: F.L. van Holthoon (ed.), De Nederlandse samenleving sinds 1815 . Wording en samenhang (Assen/Maastricht 1985) 7I-92, aldaar 87.

53 Bade, 'Arbeiterstatistik', tabellen Nachweisungen 179-253.

54 Brepohl, Aufbau, 243.

55 Adolf Wennemann, Arbeit im Norden. Italiener im Rheinland und Westfalen des späten 19. und frühen 20. Jahrhunderts (Osnabrück I997) I20-I2I.

56 De Pater, 'Nederlanders', 25.

57 De Nederlander in Duitschland, $\mathrm{nr}$ I8, 28 augustus Igog.

58 Zie ook: Sigismund Gargas, 'Die niederländische Auswanderung', Economisch-Historisch Jaarboek XIV (I928) I79-28I, aldaar 195. Dit aantal is hoogstwaarschijnlijk exclusief de door Gargas vermelde I.26I Nederlandse mijnwerkers in het Wormbekken, bijna allemaal Limburgse pendelaars.
} 


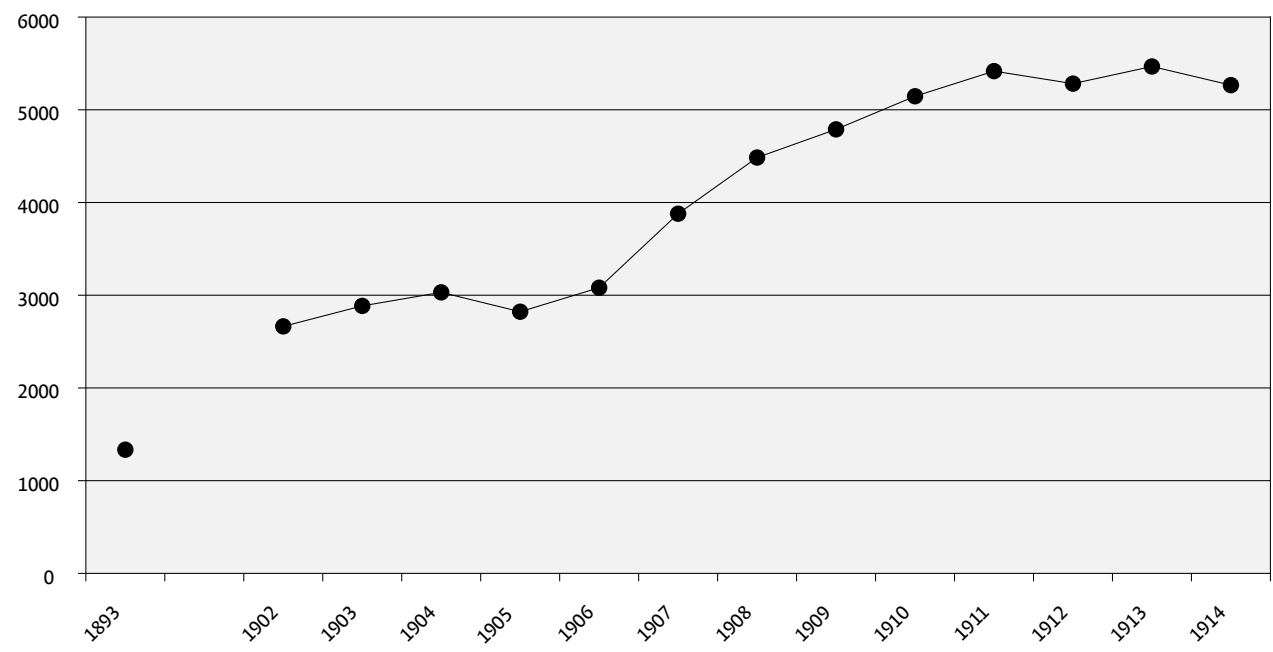

Bron: Brepohl, Aufbau (I893-I906); Bade, 'Arbeiterstatistik', tabellen Nachweisungen, I79-253 (I907-19I4).

Deze aantallen betreffen echter steeds momentopnames aan het eind van het jaar. Zeker is in ieder geval dat de mijnen in de Rijnprovincie en in Westfalen tot I9I4 een aantrekkingskracht op Nederlandse arbeiders hebben uitgeoefend, arbeiders die ook meteen naar de Limburgse mijnen hadden kunnen gaan. Die aantrekkingskracht nam weliswaar licht af getuige tabel 4.3, maar niettemin besloten elk jaar ongeveer 2.500 Nederlanders mijnwerker te worden in een Duitse mijn.

Mijnwerkers waren echter een mobiele beroepsgroep. Bij de Nederlandse mijnwerkers in Duitsland uitte zich dat in de eerste plaats in hun geringe geneigdheid zich permanent in de buurt van hun werkgelegenheid te vestigen. Slechts I9,4 procent van de Nederlandse mijnwerkers die vóór I9I4 in Duitsland werkte, deed dat. Hun vestigingsgedrag week daarmee sterk af van dat van de Nederlandse fabrieksarbeiders in Duitsland, die in driekwart van de gevallen besloten tot permanente vestiging. ${ }^{59}$ Binnen een jaar was het verloop onder de mijnwerkers aanzienlijk, zodat het werkelijke aantal Nederlanders dat met de mijnbouw in Duitsland in aanraking kwam, aanmerkelijk groter was.

Tabel 4.3 laat zien dat in de periode 1907 tot I9I4 per jaar gemiddeld de helft van de bezetting vertrok. In die jaren waren ongeveer 20.000 Nederlanders voor korte of wat langere tijd in dienst van een mijn in de Rijnprovincie of in Westfalen, waar ze ervaring in mijnarbeid hadden kunnen opdoen.

Van oudsher bevond zich onder de Nederlandse mijnwerkers in Duitsland een aanzienlijke groep Limburgers. Reeds de Commissie voor de Mijnen van I899 had er haar hoop op gevestigd dat deze mijnwerkers, die vertrouwd waren met de Limburgse samenleving, zouden terugkeren. Verwacht mocht immers worden, volgens de Commissie, 'dat het verrijzen eener krachtige mijnindustrie den stroom van arbeiders die nu over de grenzen in hun on- 
TABEL 4.3 HeT VERLOOP ONDER NEDERLAN DSE MIJNWERKERS IN DE RiJNPROVINCIE EN IN WESTFALEN, I907-I9I4

\begin{tabular}{|l|c|c|c|c|}
\hline & intreders & uittreders & $\begin{array}{c}\text { bezetting } \\
\text { einde jaar }\end{array}$ & $\begin{array}{c}\text { uittreders als \% } \\
\text { van bezetting }\end{array}$ \\
\hline I907 & 3.294 & 2.238 & 3.666 & $6 \mathrm{I}, 0$ \\
\hline I908 & 3.386 & 2.567 & 4.485 & 57,2 \\
\hline I909 & 2.645 & $2.34 \mathrm{I}$ & 4.789 & 48,9 \\
\hline I9I0 & 2.432 & 2.075 & 5.146 & 40,3 \\
\hline I9II & 2.403 & 2.132 & 5.417 & 39,4 \\
\hline I9I2 & 2.795 & 2.930 & 5.282 & 55,5 \\
\hline I9I3 & 2.619 & 2.434 & 5.467 & 44,5 \\
\hline I9I4 & 2.287 & 2.488 & 5.266 & 47,2 \\
\hline
\end{tabular}

Bron: Eigen berekening op basis van Bade, 'Arbeiterstatistik', tabellen Nachweisungen, 179-253.

derhoud gaan voorzien, ten voordeele van de Limburgsche ontginningen zal keeren. Het is toch niet wel aan te nemen, dat de Limburgsche arbeider, bij huis werk vindende, op den duur naar Duitschland zal blijven gaan'. ${ }^{\circ 0}$

Grenspendel van Limburgse arbeiders naar vooral de mijnen in de streek rond Aken makte onderdeel uit van de hierboven beschreven migratiestroom vanuit deze provincie. Pendel naar de Duitse steenkolenmijnen kwam vooral voor vanuit de mijnwerkersstad Kerkrade. De grenspendel blijkt al uit vergelijking van het aantal mijnwerkers volgens de beroepstelling van 1889 (I.I62) en de werkgelegenheid in de twee Limburgse mijnen, die op dat moment niet meer dan vierhonderd arbeidsplaatsen bedroeg. ${ }^{6 \mathrm{I}}$

In de winter en het voorjaar van 1899 vroeg de Commissaris der Koningin in de provincie Limburg, Gustave Ruys de Beerenbrouck, schriftelijk aan de burgemeester van Kerkrade om een opgave van het aantal pendelaars uit diens gemeente, dat zich dagelijks of wekelijks naar de mijnen en fabrieken rond Aken begaf. ${ }^{62}$ Het antwoord van burgemeester Karl Ignatz Daelen, tevens kassier op de mijn Voccart in Herzogenrath, leert dat er dat jaar 893 Kerkradenaren in Akense mijnen werkten. De Kerkraadse mijnwerkers waren tussen de I6 en 55 jaar oud en pendelden dagelijks naar Duitsland. Degenen die op de mijn Anna in Alsdorf werkten, konden gebruik maken van een speciale arbeiderstrein. De mijnwerkers die in dienst waren bij mijnen vlak over de grens maakten elke dag de reis te voet.

In I9I 2 werd in Kerkrade opnieuw een overzicht opgesteld. ${ }^{63}$ In totaal werden er nu I.434 pendelaars geteld. Van hen waren er 836 mijnwerker. De Kerkraadse mijnwerkers maakten het leeuwendeel uit van de in totaal elfhonderd Limburgers die begin I9I2 dagelijks naar de mijnen van het Wurmrevier pendelden. De anderen kwamen voornamelijk uit Eygelshoven,

6o Rapport Commissie voor de Mijnen, 20.

6I RHCL, Archief Staatstoezicht op de Mijnen o7Io2, inv. nr. 768: Jaarverslag Staatstoezicht I898.

62 Gemeentearchief Kerkrade, Archief Gemeentesecretarie, nr. 3809, Correspondentie tussen Commissaris der Koningin en burgemeester Kerkrade, I899.

63 Gemeentearchief Kerkrade, Archief Gemeentesecretarie, nr. 3809, 'Opgave van het aantal arbeiders die in de gemeente Kerkrade wonen en elken dag in Duitschland gaan werken', I januari ıوı2. 
Nieuwenhagen en Waubach (gemeente Ubach over Worms). ${ }^{64}$ Belangrijke concentraties Kerkraadse mijnwerkers werkten op de mijn Nordstern in Merkstein (200), op de mijnen Anna I en II in Alsdorf (22I) en op de Voccart in Herzogenrath (220). In de mijn van Mariendorf (gemeente Höngen bij Aken) werkten 47 Kerkradenaren. Het is opvallend dat het aantal pendelende Kerkraadse mijnwerkers, ondanks de grote uitbreiding van de Limburgse mijnbouw die inmiddels had plaatsgevonden, sinds I899 nagenoeg gelijk was gebleven. Kennelijk was werken in Duitsland voor deze groep nog steeds te prefereren boven werkgelegenheid in eigen provincie.

Niet alle Limburgse arbeiders in Duitse mijnen waren echter pendelaars. Er waren er ook die ervoor kozen zich in Duitsland te vestigen. Evenals andere Nederlanders die zich, al dan niet tijdelijk, in Duitsland wilden vestigden, hadden zij een nationaliteitsbewijs nodig (zie bijlage 9). Uit analyse van de aanvraagformulieren voor nationaliteitsbewijzen blijkt dat het percentage Limburgers dat bij de aanvraag als beroep mijnwerker opgaf in de loop van de tijd sterk toenam (tabel 4.4). In het decennium I875-I884 gaf in de provincie Limburg I,3 procent van de migranten naar Duitsland het beroep van mijnwerker op. In de periode I905I9I4 bleek het percentage al bijna verdubbeld naar 2,4. In de oostelijke mijnstreek was het aandeel mijnwerkers onder de vertrekkers naar Duitsland steeds groter dan in de provincie als geheel, maar was ook de toename in de loop van tijd groter: van 2,8 procent in I875-I884 naar I0,7 procent in I905-I9I4. Sinds het decennium I895-I904 vormden de mijnwerkers zelfs het grootste contingent industriearbeiders onder de migranten uit de oostelijke mijnstreek.

TABEL 4.4 HET AAN DEEL MIJNWERKERS IN DE AANVRAGEN VAN NATIONALITEITSBEWIJZEN, I875-I9I4 (IN PERCENTAGES VAN HET TOTAAL AANTAL AANVRAGEN)

\begin{tabular}{|c|c|c|c|c|c|c|c|c|}
\hline & \multicolumn{2}{|c|}{$1875-1884$} & \multicolumn{2}{|c|}{$1885-1894$} & \multicolumn{2}{|c|}{ I895-1904 } & \multicolumn{2}{|c|}{ 1905-1914 } \\
\hline & $\%$ & 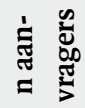 & $\%$ & 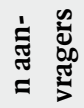 & $\%$ & 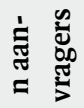 & $\%$ & 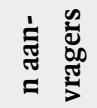 \\
\hline Limburg & $\mathrm{I}, 3$ & $3 \cdot 397$ & 0,6 & 6.169 & 0,9 & 8.879 & 2,4 & I0. 628 \\
\hline oostelijke mijnstreek & 2,8 & I.023 & 2,6 & I.I 48 & 3,9 & $\mathrm{I} .285$ & I0,7 & I. 792 \\
\hline
\end{tabular}

Bron: Berekening op basis van steekproef aanvragen nationaliteitsbewijzen (zie bijlage 9 ).

Ook zij zochten het in meerderheid dicht bij huis in een mijn in het Wormbekken rond Aken, al nam aan het eind van de negentiende eeuw het belang van het Ruhrgebied als plaats van vestiging toe (tabel $4 \cdot 5$ ).

Hoewel het potentieel er dus wel degelijk was - de 20.000 voormalige Nederlanders in Duitse mijnen alleen al vormden in aantal meer dan het drievoudige van de toename van de werkgelegenheid in de Limburgse mijnen tot I9I4-lukte het nauwelijks hen te interesseren voor mijnarbeid in Nederland. De opmerkingen van de Hoofdingenieur in Igog wezen daar al op. ${ }^{65}$ Ook de journalist Theodoor Vianen, die het jaar daarvoor in een vlammende artike-

64 Staatscommissie over de Werkloosheid deel IX Eindverslag ('s-Gravenhage 19I4) 543.

65 Jaarverslag van den Hoofd-Ingenieur der Mijnen over 1909, I-4. 
TABEL 4.5 DE OPGEGEVEN BESTEMMING VAN MIJNWERKERS UIT DE PROVINCIE LIMBURG EN UIT DE OOSTELIJKE MIJNSTREEK, DIE EEN NATIONALITEITSBEWIJS AANVROEGEN, I875-I9I4 (IN PROCENTEN)

\begin{tabular}{|c|c|c|c|c|c|c|c|c|c|c|}
\hline \multirow[b]{2}{*}{ bestemming } & \multicolumn{2}{|c|}{ I875-I9I4 } & \multicolumn{2}{|c|}{$1875-1884$} & \multicolumn{2}{|c|}{$1885-1894$} & \multicolumn{2}{|c|}{ I895-1904 } & \multicolumn{2}{|c|}{$1905-1914$} \\
\hline & 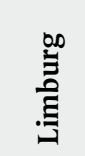 & 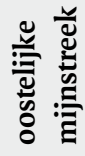 & 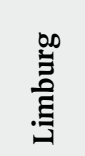 & 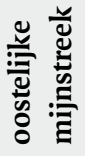 & Do & 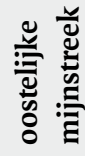 & 告 & 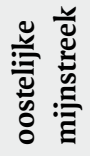 & 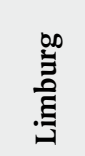 & 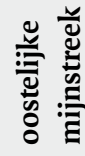 \\
\hline Wormbekken & 43,3 & 49,3 & 56,8 & 86,2 & 64,9 & 85,2 & 45,2 & 56,0 & $37, \mathrm{I}$ & 37,0 \\
\hline Ruhrgebied & 34,9 & 22,5 & $34, \mathrm{I}$ & 13,8 & 27,0 & II,I & 42,6 & 28,0 & 32,8 & 24,0 \\
\hline onbekend & $2 \mathrm{I}, 8$ & 28,2 & $9, \mathrm{I}$ & - & $8, \mathrm{I}$ & 3,7 & $\mathrm{I} 2,2$ & I6,0 & 30,1 & 39,0 \\
\hline totaal & 100,0 & 100,0 & 100,0 & 100,0 & 100,0 & 100,0 & 100,0 & 100,0 & 100,0 & 100,0 \\
\hline absoluut & 455 & 298 & 44 & 29 & 37 & 27 & II5 & 50 & 259 & 192 \\
\hline
\end{tabular}

Bron: Berekening op basis van steekproef aanvragen nationaliteitsbewijzen (zie bijlage 9 ).

lenreeks de sociale toestand in de mijnstreek aan de kaak had gesteld, was pessimistisch. Hij verwachtte dat hooguit een honderdtal ongehuwde Nederlandse arbeiders hun werk in de Duitse mijnen zouden willen verruilen voor werk in de Limburgse mijnen. ${ }^{66}$

Hoeveel Nederlanders vóór de Eerste Wereldoorlog daadwerkelijk vanuit een Duitse mijn naar Limburg zijn gekomen, is bij gebrek aan bronnen nauwelijks te bepalen. Volgens Dieteren zou enkel ten gevolge van de grote mijnwerkersstaking in het Ruhrgebied in I905, waarbij veel buitenlandse stakers werden ontslagen en uitgewezen, een groter contingent Nederlandse arbeiders uit de Duitse mijnen naar Nederland zijn gekomen. Onder hen zou zich ook een aantal Limburgers hebben bevonden. ${ }^{67}$ Aantallen noemt hij echter niet.

Slechts voor de Domaniale Mijn in Kerkrade zijn enkele cijfers bekend over de herkomst van in dienst genomen mijnwerkers. ${ }^{68}$ Tussen 1907 en I9I4 was 5 procent van de mijnwerkers die bij het bedrijf in dienst traden Nederlander die voordien in het Ruhrgebied had gewerkt. Nog eens 16 procent was Nederlander en gaf als laatste werkgever een bedrijf op in het Duitse grensgebied (het Duitse deel van de huidige Euregio Maas-Rijn). In de meeste gevallen ging het om een mijn. Getalsmatig komt dit neer op 335 man uit het Ruhrgebied en I.072 man uit het Duitse grensgebied. Gemiddeld per jaar kon de Domaniale dus rekenen op 40 Nederlanders uit het Ruhrgebied en I34 uit het Duitse grensgebied. Of deze cijfers representatief zijn voor de hele Limburgse mijnstreek, is echter de vraag. De Domaniale Mijn lag pal op de Nederlands-Duitse grens en de Duitse invloed was er van oudsher groot. Dat resulteerde onder meer in een grote grensoverschrijdende arbeidsmobiliteit.

Voor de gezamenlijke Limburgse mijnen is alleen het aantal nieuwe aanmeldingen bekend van ondergronders, afkomstig van een Duitse mijn.

66 Vianen, Bevolkingstoestanden, 8-ı.

67 Dieteren, 'Moeizame weg', 25.

68 Achim Korres, 'Arbeitsmigration in der Euregio Maas-Rhein im I9. und 20. Jahrhundert. Problemstellungen und Ergebnisse eines Forschungsprojektes', Vom 'Hollandgänger zum EU-Bürger: Migration und Wahrnehmung im deutsch-niederländisch-belgischen Grenzraum in historische und aktueller Perspektive. Themaheft Interregiones ro (200I) I5-6I, aldaar 49-52. 
GRAFIEK 4.4 HET AANTAL NIEUWE AANMELDINGEN VOOR WERK ON DERGRONDS

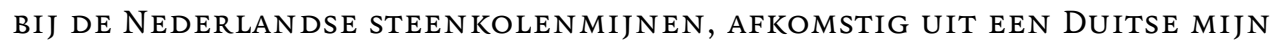
EN HET AANTAL DUITSERS IN DIENST BIJ DE NEDERLANDSE STEENKOLENMIJNEN OP 3I DECEMBER, I9O5-I9I8

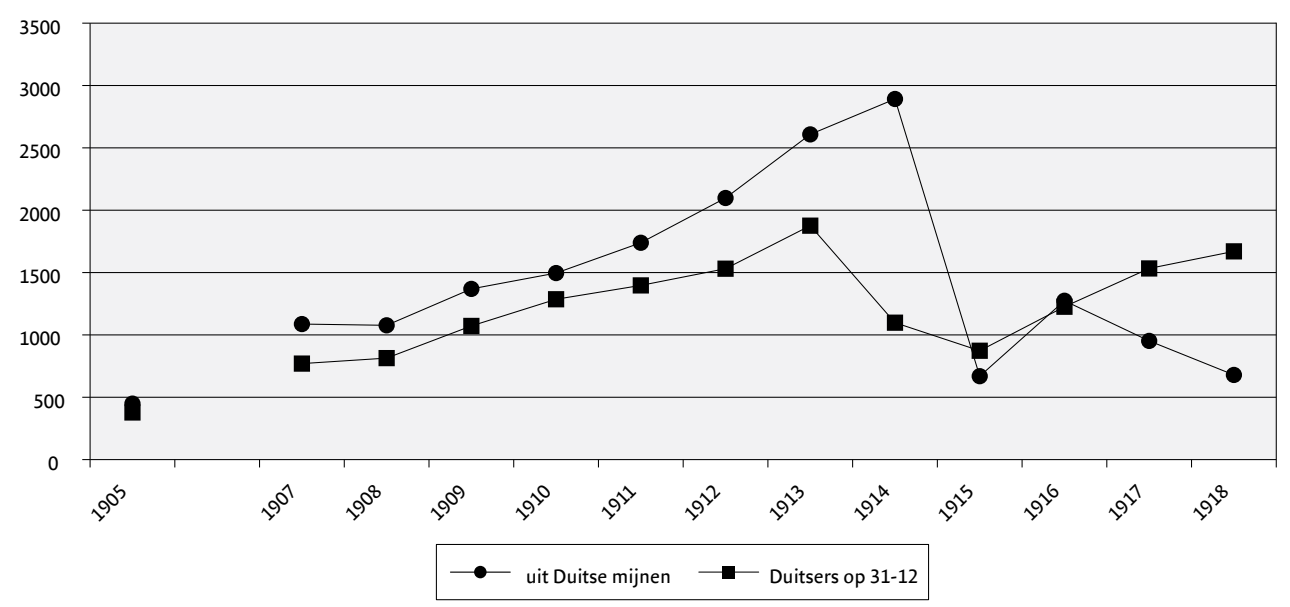

Bron: (Jaar)verslagen (Hoofd-)Ingenieur der Mijnen, I905-I9I8. Zie ook bijlagen II, I2 en I3.

Tot I9I4 nam dat van jaar tot jaar toe, om in I9I5 scherp te dalen. Het is echter niet uit de cijfers op te maken of het om Duitsers, Nederlanders of wellicht nog andere nationaliteiten ging. Het aantal Duitsers in de Limburgse mijnen steeg tot I9I3 ook voortdurend - netto met gemiddeld bijna tweehonderd per jaar - en van hen zullen ongetwijfeld de meesten ervaring hebben opgedaan in een Duitse mijn. Het feit dat het aantal jaarlijkse nieuwe aanmeldingen veel hoger ligt dan de toename van het aantal Duitsers, zou aanleiding kunnen zijn om te veronderstellen dat er dus ook een belangrijk contingent niet-Duitsers (lees: Nederlanders, want het aantal buitenlanders met een andere dan de Duitse nationaliteit was op dat moment nog te verwaarlozen) uit Duitse mijnen naar Limburg zou zijn gekomen. Maar door het enorme verloop onder nieuwe mijnwerkers was het aantal nieuwkomers in een gegeven jaar een veelvoud van de daadwerkelijke toename van het aantal bezette arbeidsplaatsen.

Pas in I9I4 daalde het aantal Duitse mijnwerkers in Limburg scherp, een gevolg van het uitbreken van de Eerste Wereldoorlog en de mobilisatie van het Duitse leger. Het aantal aanmeldingen uit Duitse mijnen steeg in I9I4 echter verder. Aangenomen mag worden dat voor het eerst een belangrijke groep Nederlandse mijnwerkers uit Duitse mijnen naar Limburg kwam.

Voor het geringe succes van de Limburgse mijnen bij het aantrekken van in Duitse mijnen geschoolde Nederlandse mijnwerkers vóór de Eerste Wereldoorlog is een aantal verklaringen te geven. Op de eerste plaats kan worden gewezen op de traditie onder veel inwoners van Kerkrade en omstreken om over de grens te werken. Het was vaak van vader op zoon gebruik geworden om naar een Duitse mijn te gaan. Men voelde zich er thuis. Men sprak de taal en werd in Duitsland mede daardoor niet als vreemdeling gezien. Men had er vrienden en kennissen gemaakt, en die opgebouwde contacten verbrak men niet graag om 
in de Limburgse mijnbouw te gaan werken. Temeer niet, omdat ze hun in Duitsland opgebouwde rechten ten aanzien van sociale verzekeringen verloren als ze overstapten naar een Nederlandse mijn. Nederlandse mijnen erkenden die in het buitenland opgebouwde rechten in het algemeen niet. Bovendien waren in Duitsland de sociale verzekeringen voor mijnwerkers per mijnbekken geregeld, en niet, zoals in Nederland in die tijd, per mijn. Elk Duits mijnbekken had zijn eigen Knappschaftskasse, die zorgde voor uitkering van ouderdoms-, invaliditeits-, weduwen- en wezenpensioenen. Door die centrale regeling konden mijnwerkers in Duitsland makkelijker desgewenst van mijn naar mijn overstappen. Die traditionele Freizügigkeit van ervaren mijnwerkers was in de Limburgse mijnstreek moeilijker, omdat de mijnen de bij een andere mijnonderneming opgebouwde rechten op sociale verzekering niet erkenden. ${ }^{69}$ Dat zou pas veranderen met de oprichting van het Algemeen Mijnwerkersfonds van de Steenkolenmijnen in Limburg in augustus I9Ig.

Een andere reden was de loonhoogte. In 1912 bedroeg het gemiddelde dagloon in de Duitse mijnen 5,05 Mark (bij een achturige werkdag) en in de Limburgse mijnen 4,25 Mark (bij een tienurige werkdag). Weliswaar was het Duitse prijspeil ook hoger, maar dat was voor de pendelaars, die hun inkomen immers in het relatief goedkope Nederland besteedden, geen probleem..$^{7}$ Wellicht hebben deze verschillen in lonen en prijzen aan beide zijden van de grens het grensoverschrijdend arbeidsmarktgedrag zelfs bevorderd. In grensstudies wordt in dit verband gewezen op de paradox van de grens. ${ }^{71}$

Een belangrijke oorzaak van het niet terugkeren van Nederlandse pendelaars uit de Duitse mijnen was ook gelegen in de gebrekkige infrastructuur. De mijnen in het Wormbekken waren vaak beter te bereiken dan veel van de nieuwe mijnen die in Limburg waren verrezen. Vooral voor de Kerkraadse pendelaars gold dat: 'Zoo kan de Kerkraadsche arbeider met gemak de verschillende Duitsche mijnen bereiken, terwijl hij, om de meest nabijgelegen Nederlandsche mijn te bereiken, op minstens een uur loopens is aangewezen (de mijn van Kerkrade zelf blijft hier vanzelf buiten beschouwing). Wil hij naar Heerlen of Schaesberg, dan moet hij van den trein gebruik maken en moet hij soms 2 uur op een trein wachten, ongerekend den afstand van het station Kerkrade naar het dorp, die ook nog drie kwartier bedraagt', aldus de Staatscommissie die aan de vooravond van de Eerste Wereldoorlog de Nederlandse werkloosheid onderzocht. ${ }^{2}$ Pas na de oorlog zou dat verbeteren door de oprichting van de Limburgsche Tramweg Maatschappij (LTM) in 1919, die een netwerk ven tramverbindingen zou aanleggen en door de opkomst - in de jaren I920 - van de autobus.

Ten slotte speelde nog de ontoereikende huisvesting in de Limburgse mijnstreek een rol. Hoewel er vanaf het begin van de twintigste eeuw driftig werd gebouwd door de mijnondernemingen zelf en door woningbouwverenigingen bestond er in 1914 nog steeds grote woningnood, die in het algemeen de werving van nieuwe arbeidskrachten door de mijnen parten speelde.

Van de Limburgse mijnen zelf ging dus weinig aantrekkingskracht uit op Nederlandse mijnwerkers in Duitsland. Het waren vooral externe factoren die Nederlandse mijnwer-

69 Staatscommissie Werkloosheid, 544, 546-547.

70 Ibidem, 544-547.

7I Hastings Donnan en Thomas M. Wilson, Borders; Frontiers of identity, nation and state (Oxford/New York 200I) 87. Voor de Limburgse casus is het mechanisme van de grensparadox uitgewerkt in: Ad Knotter, 'Paradoxen van de grens. Ongelijke ontwikkeling, grensoverschrijdende mobiliteit en de vergelijkende geschiedenis van de Euregio Maas-Rijn', SSEGL XLVI (200I) I59-174. 72 Staatscommissie Werkloosheid, 544 . 
kers uit Duitse mijnen naar Limburg brachten. De mijnwerkersstaking in het Ruhrgebied in I905 werd al gememoreerd. Maar vooral het uitbreken van de Eerste Wereldoorlog in augustus I9I4 makkte alles anders. Mijnwerkers werden opgeroepen voor het Nederlandse leger, toen dat mobiliseerde. De mobilisatieoproep gold ook voor mijnwerkers in de Duitse mijnen, die terug naar Nederland moesten. Na de demobilisering van het Nederlandse leger in I9I6 konden of wilden ze niet terug naar Duitsland en traden ze in dienst van de Nederlandse mijnen. ${ }^{73}$ De grensoverschrijdende vervoersmogelijkheden werden ernstig beperkt door het uitbreken van de oorlog. Voor veel pendelaars was het niet langer mogelijk hun werk in Duitsland te bereiken. Ook voor hen zat er vaak niet veel anders op dan een baan in Limburg te zoeken.

De toenemende inflatie in Duitsland na het uitbreken van de vijandelijkheden deed de rest. Naarmate de duurte van eerste levensbehoeften in Duitsland toenam, werd het voor Nederlanders steeds aantrekkelijk terug te keren. ${ }^{74}$ Uit Westfalen volgde een uittocht van Nederlandse mijnwerkers. Via de Nederlandse Arbeidsbeurs in Oberhausen en de Arbeidsbeurs voor de Limburgsche Mijnstreek in Heerlen konden ervaren houwers gegarandeerd aan de slag bij de Limburgse mijnen. ${ }^{75}$

Precieze aantallen ontbreken, maar opgaven van de Arbeidsbeurs voor de Limburgsche Mijnstreek geven wel een indicatie voor de toename van het aanbod van Nederlandse mijnwerkers uit Duitsland. De bij de arbeidsbeurs ingeschreven houwers en leerhouwers waren 'voor het meerendeel Hollanders, welke voorheen in Duitsche mijnen werkten en van de beurs gebruik maakten om weer in hun vaderland terug te keeren'. ${ }^{6}$ Het aantal ingeschreven houwers en leerhouwers steeg tussen I9I2 en I9I6 tot het achtvoudige; vooral na I9I3 was de toename groot.

TABEL 4.6 Het AANTAL INSCHRIJVINGEN VAN HOUWERS EN LEERHOUWERS BIJ De Arbeidsbeurs voor de Limburgsche MijnstreEk in HeErLEN, I9I2-I9i6

\begin{tabular}{|l|c|}
\hline & aantal ingeschreven houwers en leerhouwers \\
\hline I9I2 & I8 \\
\hline I9I3 & 30 \\
\hline I9I4 & $\cdot$ \\
\hline I9I5 & 84 \\
\hline I9I6 & I48 \\
\hline
\end{tabular}

Bron: Arbeidsbeurs voor de Limburgsche Mijnstreek. Verslag over [1913-1916].

In werkelijkheid zal de terugkeer van Nederlandse arbeiders uit de Duitse mijnen beduidend groter zijn geweest dan de cijfers in tabel 4.6 suggereren. Zoals in een volgende paragraaf zal blijken, was de allocatie van mijnwerkers via de arbeidsbeurs in Heerlen marginaal. Zo blijkt uit vergelijking tussen het aantal inschrijvingen voor mijnwerkers bij de Heerlense ar-

73 Arbeidsbeurs voor de Limburgsche Mijnstreek. Verslag over 1916, ro en idem over 1917, 9.

74 Langeweg, 'Werken over de grens', 45.

75 F.K.Th. van Iterson, 'Woningbouw in verband met steenkolenontginning bij de Staatsmijnen te Heerlen', De Ingenieur XXXIV nummer 2 (I9I9) I7-I9, aldaar I7.

76 Arbeidsbeurs voor de Limburgsche Mijnstreek. Verslag over 1913, 6. 


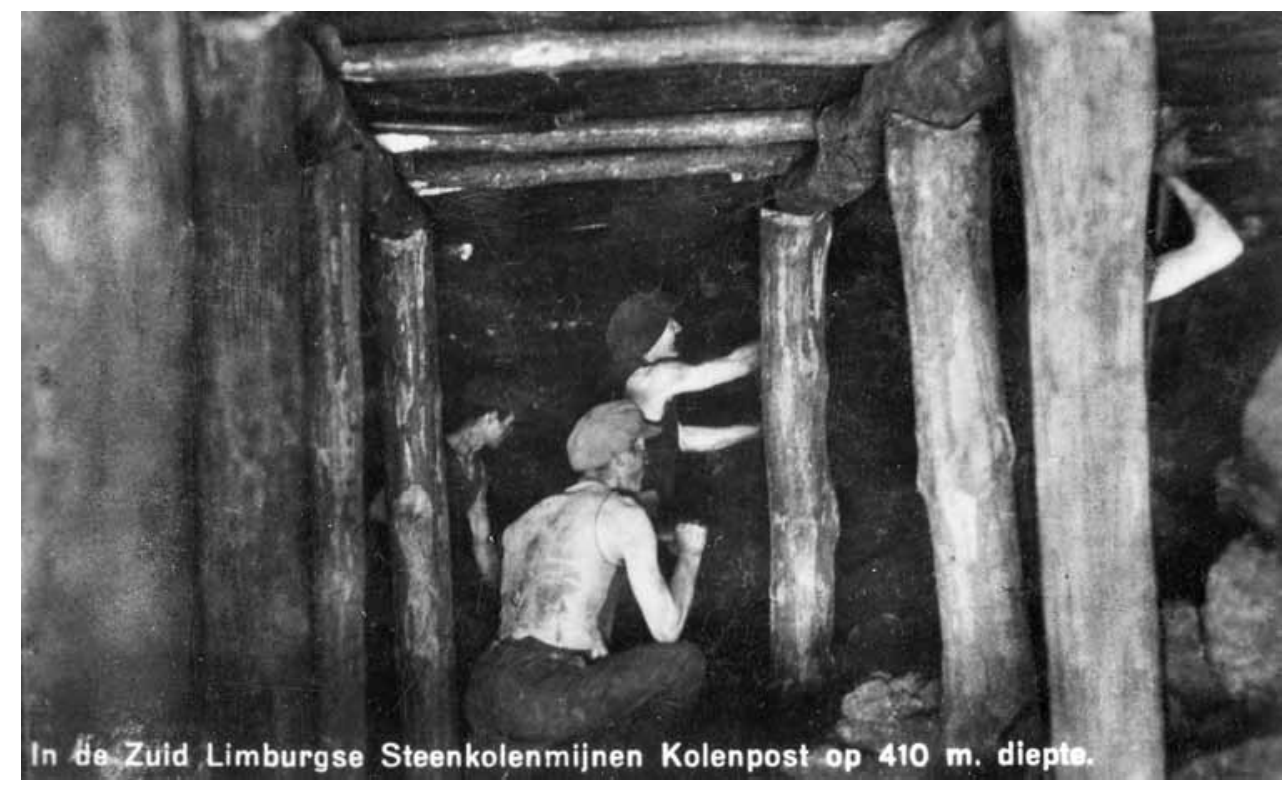

Een pijler in een van de Limburgse mijnen. Omstreeks 1920. Bron: Fotocollectie Continium Kerkrade, F4796.

beidsbeurs in I9I3 en het totaal in dat jaar door de gezamenlijke Limburgse mijnen aangenomen personeel, dat meer dan 95 procent van de werving niet via de arbeidsbeurs liep. ${ }^{77}$

Door de economische en monetaire chaos waarin Duitsland na het einde van de oorlog belandde, waren weinig Nederlanders bereid hun oude baan in een Duitse mijn weer op te nemen. Vergeleken met de jaren vóór de oorlog waren er in de jaren twintig aanzienlijk minder Nederlanders als mijnwerker in Duitsland actief. In I922 werkten er in het Ruhrgebied nog ongeveer tweeduizend Nederlandse mijnwerkers. In I930 was de aanwezigheid van Nederlanders in de mijnen van het Ruhrgebied verder afgenomen tot 750 man..$^{7}$

\section{Selectie}

Door het grote tekort aan arbeidskrachten konden de mijnen zich vóór de jaren twintig eigenlijk geen systematische selectie van personeel permitteren. ${ }^{79}$ Desondanks namen de mijnbouwondernemingen maatregelen om beter zicht te krijgen op de antecedenten en kwalificaties van degenen die men in dienst wilde nemen. Zo vroeg Staatsmijnen vanaf igo9 een bewijs van goed gedrag, afgegeven door de burgemeester of de politiecommissaris van de laatste woonplaats. Ook kregen de rekruteringsbeambten opdracht inlichtingen over de aan te nemen arbeiders in te winnen, eventueel bij de veldwachter. Verder werd in I9I5 een onderzoek ingesteld naar het veelvuldig voorkomen van contractbreuk, overtreding van het

77 Kreukels, Mijnarbeid, 68-69; Serge Langeweg, Van Adreskantoor tot Arbeidsvoorziening. Arbeidsbemiddeling en arbeidsmarkt in ZuidLimburg, 1904-1994 (Leeuwarden/Mechelen I994) I25.

78 De Pater, 'Nederlanders', 25.

79 Dieteren, Migratie, I3I. 
in 1909 bij de particuliere mijnen ingesteld arbeidsreglement. Het onderzoek leidde tot het aanleggen van zwarte lijsten van mijnwerkers die zich aan contractbreuk hadden bezondigd. De lijsten werden onderling tussen de mijnen uitgewisseld. Met deze maatregel probeerden de mijnondernemingen te verhinderen dat mijnwerkers die contractbreuk hadden gepleegd, onmiddellijk weer bij een andere mijn in dienst konden treden. ${ }^{80}$ Maar dergelijke maatregelen waren doorgaans weinig effectief en werden minder stringent nageleefd al naar gelang de arbeidsmarkt krapper was. In het algemeen nam men aan wie men krijgen kon.

Dat neemt niet weg dat al in de eerste jaren van de twintigste eeuw initiatieven werden genomen die een meer systematisch selectiebeleid beoogden. Het eerste initiatief ging uit van het mijnbedrijf zelf. Bij de oprichting van Staatsmijnen behoorde selectie tot het personeelsbeleid: het bedrijf zou alleen Nederlandse mijnwerkers in dienst nemen. Het tweede initiatief kwam uit de koker van de katholieke geestelijkheid, die via de oprichting van een arbeidsbeurs tot selectie van mijnwerkers wilde komen. Beide initiatieven worden hier besproken.

\section{Een eerste poging tot selectie: Staatsmijnen}

Het selectiebeginsel bij Staatsmijnen om alleen Nederlands personeel in dienst te nemen, was ingegeven door de vrees dat bij een te snelle industrialisatie van Limburg de regio overspoeld zou worden door vreemdelingen op zoek naar werk. De Staatscommissie die in I899 de kwestie in opdracht van minister Lely onderzocht, baseerde haar oordeel ten aanzien van de personeelsvoorziening mede op ervaringen die in het buitenland waren opgedaan. De Commissie onderscheidde het Westfaalse en het Saarlandse model. ${ }^{8 \mathrm{I}}$ In Westfalen (het Ruhrgebied) had de mijnbouwsector, die in private handen was en in de tweede helft van de negentiende eeuw sterk expandeerde, in belangrijke mate een beroep gedaan op arbeiders afkomstig van buiten de eigen streek. ${ }^{82}$ In sociaal opzicht had het aantrekken van die vreemde 'elementen' volgens de Commissie ernstige gevolgen gehad voor de stabiliteit van de samenleving. Daartegenover stond de situatie in het Saarland. De steenkolenmijnen waren daar in bezit van de Staat en de ontwikkeling van de mijnbouwsector was daardoor geleidelijker en harmonieuzer verlopen. In het Saarland was een gezeten en aan de streek gebonden mijnwerkersbevolking ontstaan. ${ }^{8}{ }_{3}$ De Commissie pleitte daarom voor een selectiebeleid dat het Saarlandse model als voorbeeld had. De naar schatting van de Commissie ongeveer 9.000 nieuwe mijnwerkers die nodig zouden zijn om het voor staatsexploitatie aangewezen deel van de Limburgse steenkolenvoorraad te ontginnen, moesten worden gerekruteerd uit de bevolking in eigen streek en uit degenen, die zich daar gaandeweg zouden vestigen. Daarmee zou Staatsmijnen de weg van de geleidelijkheid bewandelen en het benodigde personeel op de Nederlandse arbeidsmarkt kunnen rekruteren.

Uit analyse van het aandeel Nederlanders bij het Staatsmijnbedrijf enerzijds en de particuliere mijnen anderzijds blijkt dat Staatsmijnen inderdaad met meer succes Nederlandse arbeiders wist te rekruteren. Het selectiecriterium van uitsluitend Nederlanders kon het bedrijf echter niet lang volhouden (grafiek 4.5). Het wegvallen van de kolenimport uit de

8o Gales e.a., Bedrijfsvoering, 38-40.

8I Rapport Commissie voor de Mijnen, 32.

82 Klaus Tenfelde, Sozialgeschichte der Bergarbeiterschaft an der Ruhr im 19. Jahrhundert (Bonn-Bad Godesberg I77) $238-246$.

83 Klaus-Michael Mallmann, Lohn der Mühen. Geschichte der Bergarbeiter an der Saar (München I989) 53-54. 


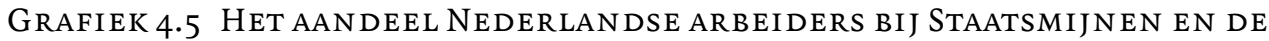
PARTICULIERE MIJNEN, I9O5-I938

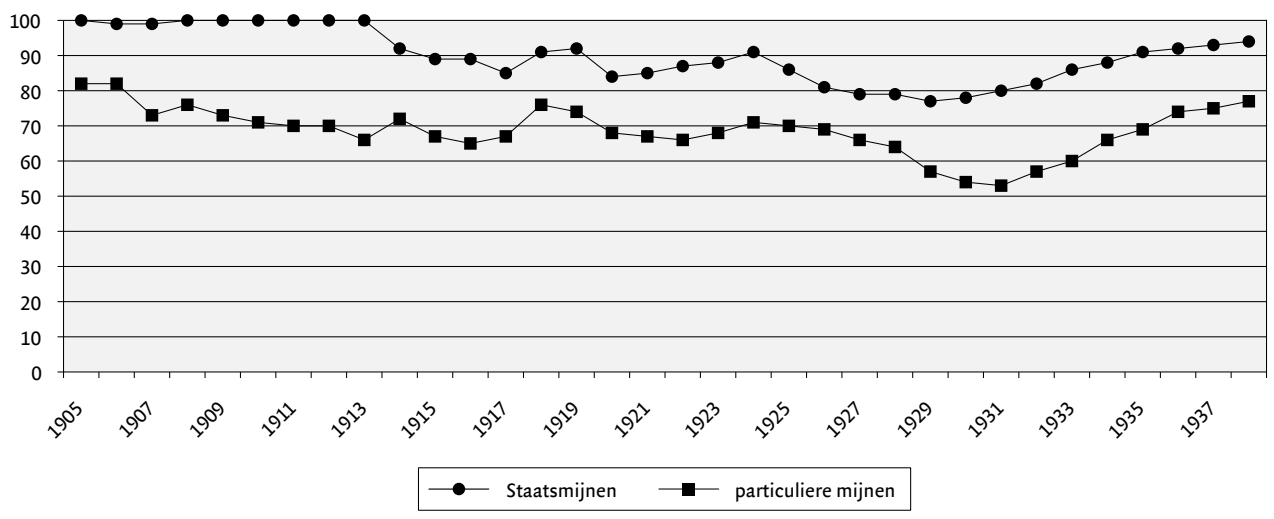

Bron: Jaarverslagen Staatsmijnen; (Jaar)verslagen (Hoofd-) Ingenieur / Inspecteur-Generaal der Mijnen, 1905-1938.

oorlogvoerende landen in de jaren I9I4-I9I8 noodzaakte Staatsmijnen, om nationaal-economische redenen, tot een geforceerd groeiproces. De weg van de geleidelijkheid moest worden verlaten en dat betekende dat het bedrijf niet meer kon volstaan met het aantrekken van arbeiders op de Nederlandse arbeidsmarkt. Toch bleef het aandeel Nederlanders in het arbeidersbestand van Staatsmijnen steeds relatief hoog. Meer dan de particuliere mijnen richtte het Staatsbedrijf zich via actieve wervingsacties op Nederlandse arbeiders, zowel in Limburg als daarbuiten, die werden gelokt met goede arbeidsvoorwaarden. Nadrukkelijk profileerde Staatsmijnen zich als een modelbedrijf dat niet alleen technisch vooruitstrevend was, maar ook goed voor zijn arbeiders zorgde. ${ }^{84}$

Tussen 1905 en 1925 betrok Staatsmijnen ruim driekwart van de ondergrondse arbeiders op de Nederlandse arbeidsmarkt. De particuliere mijnen slaagden er in slechts 60 procent van de ondergronders op de Nederlandse arbeidsmarkt te werven. ${ }^{85}$ Het grotere succes van Staatsmijnen op de Nederlandse arbeidsmarkt gold voor zowel ervaren als onervaren krachten. Meer mijnwerkers maakten de overstap van de particuliere mijnen naar Staatsmijnen, dan omgekeerd (tabel 4.7).

Ook bij de werving van nieuwe arbeiders zonder mijnervaring op de binnenlandse arbeidsmarkt had Staatsmijnen meer succes dan de particuliere mijnbouwondernemingen. Tot I925 was bij Staatsmijnen gemiddeld meer dan de helft van de nieuwe ondergrondse arbeiders zonder eerdere ervaring als mijnwerker afkomstig van de Nederlandse arbeidsmarkt. Bij de particuliere mijnen was dat 36,2 procent (bijlage I3).

Door zijn rekruteringsbeleid roomde het Staatsmijnbedrijf de Nederlandse arbeidsmarkt voor mijnwerkers af, met als gevolg dat de particuliere mijnen, die evenzeer een voorkeur hadden voor jonge autochtone mijnwerkers, in ruimere mate een beroep moesten doen op mijnwerkers uit het buitenland. ${ }^{86}$

84 B.P.A. Gales en J.P. Smits, 'Een Nederlands scheppingsverhaal', in: J.W. Schot e.a, Techniek in Nederland in de twintigste eeuw II (Zutphen 2000) 29-43, aldaar 37.

85 Zie bijlage 13 .

86 Peet en Rutten, Oranje-Nassau Mijnen, ro9. 


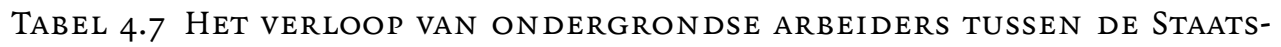
MIJNEN EN DE PARTICULIERE MIJNEN, I905, I9I3-I925

\begin{tabular}{|l|c|c|}
\hline & $\begin{array}{c}\text { particuliere mijnen naar } \\
\text { Staatsmijnen }\end{array}$ & $\begin{array}{c}\text { Staatsmijnen naar } \\
\text { particuliere mijnen }\end{array}$ \\
\hline I905 & 39 & II \\
\hline I913 & 584 & 501 \\
\hline I9I4 & 744 & 460 \\
\hline I915 & 865 & 642 \\
\hline I9I6 & 712 & 759 \\
\hline I917 & 478 & 539 \\
\hline I918 & 756 & 726 \\
\hline I919 & I.003 & 546 \\
\hline I920 & 560 & 376 \\
\hline I92I & 342 & 203 \\
\hline I922 & I24 & 286 \\
\hline I923 & 212 & I73 \\
\hline I924 & 541 & 203 \\
\hline I925 & 822 & 368 \\
\hline totaal & 7.782 & 5.793 \\
\hline
\end{tabular}

Bron: Onderzoek naar de mijnwormziekte. (Jaar)verslagen (Hoofd-)Ingenieur der Mijnen, I905-I925.

Selectie door de katholieke geestelijkheid: de Arbeidsbeurs voor de Limburgsche Mijnstreek De benoeming van dr. H.A. Poels tot aalmoezenier van sociale werken in de mijnstreek in I9Io was het startsein tot de oprichting van een scala aan katholieke sociale organisaties om de gevolgen van de snelle industrialisatie van de regio in goede, dat wilde zeggen katholieke, banen te leiden. Het voornaamste doel was het katholieke karakter van de streek te beschermen tegen liberale en socialistische denkbeelden. Als overkoepelend orgaan van de katholieke sociale beweging functioneerde de Limburgse RK Werkliedenbond, een standsorganisatie van arbeiders, die in december I9II werd opgericht. Al tijdens de oprichtingsvergadering van de Werkliedenbond kwam Poels met het voorstel om op korte termijn een arbeidsbeurs voor de mijnstreek op te richten. ${ }^{87}$ Nauwelijks een maand later, op I4 januari I9I2, nam het districtsbestuur van de Werkliedenbond in de mijnstreek het formele besluit tot oprichting van een Arbeidsbeurs voor de Limburgsche Mijnstreek. Op I februari I9I2 begon de beurs haar werkzaamheden in twee lokalen van het kantoor van de Werkliedenbond aan de Stationstraat in Heerlen. Dépendances, sedert I9I6 correspondentschappen genoemd, kwamen er in Kerkrade en Sittard. 
Uit de voortvarende wijze waarop de arbeidsbeurs tot stand kwam, bleek het belang dat in katholieke kring aan een dergelijke instelling werd gehecht. Niet alleen kon een bemiddelingskantoor de arbeidsallocatie bevorderen en daardoor de werking van de arbeidsmarkt versoepelen, belangrijker nog in de optiek van de geestelijkheid was dat de arbeidsbeurs een selectieinstrument was. Men hoopte dat de grote toevloed van arbeiders, die de mijnstreek had te verwerken, door de arbeidsbeurs kon worden gecontroleerd. Het kon immers 'niemand, zeker niet den katholieken Limburger, onverschillig laten, van welk gehalte die arbeiders zijn. Ons streven is om in de grote behoefte aan arbeidskrachten in de mijnstreek te voorzien door er brave en degelijke werklieden heen te trekken' ${ }^{88}$ In ieder geval moesten '[...] buitenlandsche sujetten, die geheel de streek onveilig maken en [...] menschen, die door hunne revolutionnaire beginselen een gevaar zijn voor de samenleving' worden geweerd. ${ }^{89}$ Het liefst zag de geestelijkheid dat de vele Limburgers die in Duitsland werkten, terugkeerden en zich aanmeldden bij de Nederlandse mijnen. De arbeidsmarktproblematiek in de mijnstreek werd dus gezien als nauw verbonden met de arbeidsmigratie naar Duitsland. Al omstreeks I9oo was de geestelijkheid zich grote zorgen gaan maken over de trek van katholieke arbeiders naar Duitsland, waar ze onttrokken waren aan het wakend oog van pastoor en kapelaan. Het niet naleven van godsdienstige plichten en het bijbehorende morele verval was de grote vrees van de clerus. Poels zelf drukte die zorg al in I903 in een veelgeciteerde uitspraak als volgt uit: 'De lente is nog niet in het land of onze Limburgsche metselaars en brikkenbakkers trekken met gansche troepen het groote Pruisen in. Eerst tegen den winter komen zij in de Heimath weer; en hebben zij geen gaten meer in de kousen en in de beurs, zij kregen dikwerf een leelijk gat in hun braaf, echt-Limburgsch volkskarakter'.$^{\circ \circ}$

De geestelijkheid probeerde het gevaar te beteugelen door via de preekstoel de parochianen te waarschuwen voor de gevaren die er in Duitsland op de loer lagen. Parochianen van wie bekend was dat ze naar Duitsland gingen vertrekken, konden rekenen op huisbezoek van de pastoor of de kapelaan. Ter behartiging van de stoffelijke en geestelijke belangen van de katholieke Nederlandse arbeiders in Duitsland richtte het Nederlandse Episcopaat op I4 december 1907 het Sint-Jozefcomité op, met afdelingen in zowel Duitse als in Nederlandse plaatsen. ${ }^{9 \mathrm{r}}$ Maar de beste remedie leek toch te voorkómen dat Limburgers naar Duitsland gingen door nadrukkelijk de werkgelegenheid die er dicht bij huis in de mijnbouw was te propageren. Wanneer Limburgers bereid bleken het beroep van mijnwerker te kiezen, werd daarmee tevens voorkomen dat vreemdelingen de Limburgse samenleving overspoelden. En zo sneed het mes aan twee kanten.

Van begin af aan waren de mijndirecties huiverig over de doelstellingen van de Heerlense arbeidsbeurs. ${ }^{92}$ Men vreesde dat de arbeidsbeurs als onderdeel van een werkliedenvereniging niet objectief zou zijn, en de neiging zou hebben de belangen van de werknemers voorop te stellen. De mijndirecties hadden grote moeite met de selectiecriteria die de Arbeidsbeurs voor de Limburgsche Mijnstreek hanteerde. Woordvoerder van deze oppositie was mr A. Haex, lid van de directie van de Oranje-Nassau Mijnen. De kritiek van Haex richtte

\footnotetext{
88 Jaarverslag over 1910/1911 van de Limburgse RK Werkliedenbond, I6-I7.

89 Limburger Koerier, I8 december I9II.

90 H.A. Poels, 'Tijdig', Een zestal redevoeringen (z.p. z.j.) 23-69, aldaar 28.

9I Het Sint-Jozefcomité gaf een periodiek uit; De Nederlander in Duitschland. In dit orgaan verscheen tussen mei rgog en maart IgIo een reeks artikelen, waarin de ontstaansgeschiedenis en de doelstellingen van het Comité werden behandeld.

92 Langeweg, Van Adreskantoor, 35-37.
} 
zich met name op de voorwaarden die de arbeidsbeurs voor bemiddeling stelde als uitvloeisel van haar doelstelling 'slechte elementen' uit de regio te weren. Wie zich als werkzoekende wilde laten inschrijven, diende een bewijs van goed gedrag over te leggen. Dit document kon worden afgegeven door de plaatselijke zielzorger of het bestuur of de geestelijk adviseur van een rooms-katholieke of christelijke vereniging. Haex was van oordeel dat de arbeidsbeurs zou 'gaan maken eene selectie, eene scheiding tusschen schapen en bokken; alleen de schapen zal zij aan werk helpen, de bokken daarentegen weeren' ${ }^{93}$ Dat deze scheiding op verantwoorde manier zou plaatsvinden, betwijfelde hij sterk. De initiatiefnemers van de arbeidsbeurs hamerden volgens hem te veel op het katholiek houden van de mijnstreek en het weren van andersdenkende, maar overigens betrouwbare en bruikbare arbeiders. Haex was zeker geen voorstander van een ongecontroleerde intocht van vreemde arbeiders. Hij zag die controle echter als een taak van de politie, bij voorkeur de mijnpolitie, die hij grotendeels zelf controleerde. De arbeidsbeurs moest zich beperken tot de zuivere arbeidsbemiddeling.

De bedenkingen tegen de objectiviteit van de arbeidsbeurs zouden geregeld de kop blijven opsteken. Het bestuur van de arbeidsbeurs bleef echter vasthouden aan de oorspronkelijke doelstellingen. Pas het inwerkingtreden van de Arbeidsbemiddelingswet 1930 betekende dat particuliere arbeidsbeurzen geen recht van bestaan meer hadden. ${ }^{94} \mathrm{De} \mathrm{Ar}-$ beidsbeurs voor de Limburgsche Mijnstreek werd per I januari 1932 als Districtsarbeidsbeurs Heerlen overgedragen aan de gemeente Heerlen. Inmiddels was in 1928 , ten gevolge van de snelle ontwikkeling van de westelijke mijnstreek rond Staatsmijn Maurits, het correspondentschap Sittard gepromoveerd tot zelfstandige districtsarbeidsbeurs. ${ }^{95}$

TABEL 4.8 HET AANTAL DOOR DE STEEN KOLENMIJNEN AANGENOMEN MIJNWERKERS EN HET AANTAL PLAATSINGEN VAN MIJNWERKERS VIA DE (DISTRICTS-)ARBEIDSBEURZEN VAN HEERLEN EN SITTARD, I9I3-I930

\begin{tabular}{|c|c|c|c|c|c|}
\hline & $\begin{array}{c}1 \\
\text { in dienst- } \\
\text { genomen }\end{array}$ & $\begin{array}{c}2 \\
\mathrm{AB} \\
\text { Heerlen }\end{array}$ & $\begin{array}{c}3 \\
\mathrm{AB} \\
\text { Sittard }\end{array}$ & $\begin{array}{c}4 \\
\text { Heerlen } \\
\text { en Sittard }\end{array}$ & $\begin{array}{c}5 \\
\text { \% kolom } \\
4 \text { van kolom I }\end{array}$ \\
\hline I9I3 & 6.762 & 233 & & 233 & 3,4 \\
\hline I9I9 & 13.080 & 423 & & 423 & 3,2 \\
\hline I925 & 10.485 & 625 & & 625 & 6,0 \\
\hline I930 & $6.57 \mathrm{I}$ & 260 & 50 & 310 & 4,7 \\
\hline
\end{tabular}

Bron: Kreukels, Mijnarbeid (kolom I); Jaarverslagen Arbeidsbeurs Limburgsche Mijnstreek / Arbeidsbeurs Heerlen, I9I3-I930 (kolom 2); Jaarverslag Arbeidsbeurs Sittard 1930 (kolom 3 ).

De bedenkingen van de mijnbedrijven tegen het functioneren van de arbeidsbeurs komen duidelijk aan het licht wanneer wordt nagegaan welk percentage van het nieuwe personeel door tussenkomst van arbeidsbemiddeling tot stand kwam. Tot 1930 was dat hooguit 6 pro-

93 Geciteerd bij: Remigius Dieteren, Mens en mijn. Een halve eeuw strijd, groei en bloei van de Nederlandse Katholieke Mijnwerkersbond (Heerlen 1953) 93.

94 Rob Hoffius en Babette Vriend, De geschiedenis van de openbare arbeidsbemiddeling in Nederland (afstudeerscriptie Sociale en Organisatiepsychologie, Leiden 1987) 37-46.

95 Langeweg, Van Adreskantoor, 44-46. 


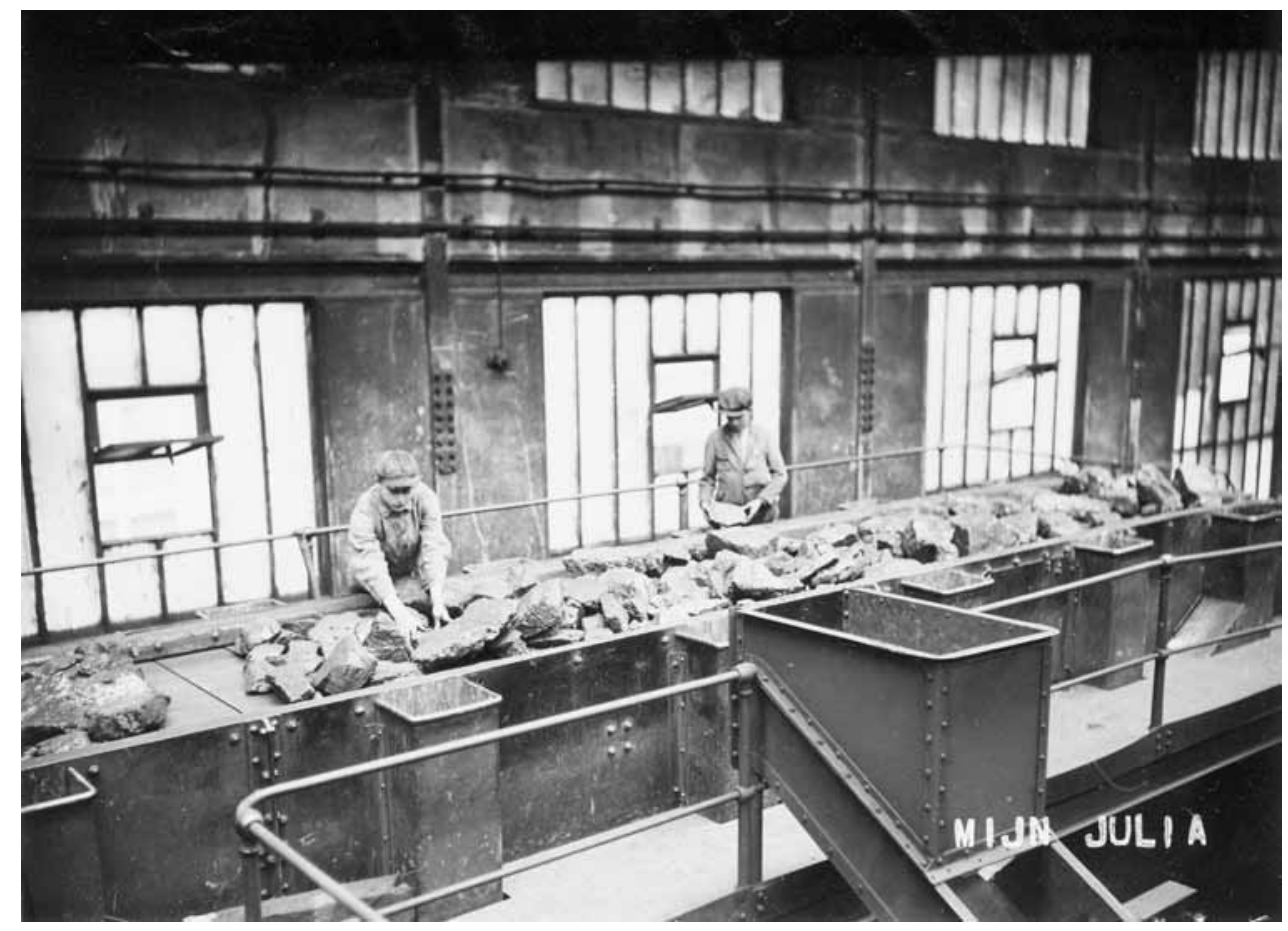

Arbeiders aan de leesband in het bovengrondse bedrijf van de Julia. Aan de leesband werden steen en onzuivere kool handmatig verwijderd. 1930. Bron: Fotocollectie Continium Kerkrade, F2742.

cent per jaar. De mijndirecties hadden een afspraak met de Heerlense arbeidsbeurs dat een ieder die zich voor mijnarbeid bij de bemiddelingsinstantie aanbood, en daarvoor de fysieke kwaliteiten bleek te bezitten, bij de mijnen aan de slag kon. Dit is af te leiden uit de manier van registratie van het aantal vacatures voor mijnwerkers bij de arbeidsbeurs en het aantal arbeiders dat door de beurs bij de mijnen werd geplaatst. Het aantal vacatures werd aan het eind van het jaar door de beursdirectie gelijkgesteld aan het aantal in de mijnen geplaatste arbeiders. Het aantal vacatures zegt dan ook niet veel over het aantal arbeiders dat de mijndirecties nodig hadden, maar des temeer over het gebrek aan bereidheid en fysieke kwaliteiten bij de ingeschreven werkzoekenden om mijnarbeid te verrichten. Vooral ongeschoolde arbeiders die zich via de arbeidsbeurs voor mijnarbeid aanboden, hadden een slechte reputatie bij de mijndirecties. Niet zelden waren dat werklozen die door gemeentebesturen uit het hele land met het dreigement van intrekking van de steun die ze ontvingen, werden aangespoord om werk te zoeken in de Limburgse mijnen. Noch de motivatie, noch de voor mijnarbeid vereiste specifieke capaciteiten waren bij hen in voldoende mate aanwezig. De slechte ervaringen met arbeiders die via de arbeidsbeurs werden geworven, droegen er toe bij dat de mijndirecties een ongunstig oordeel hielden over de waarde van de arbeidsbeurs voor hun personeelsvoorziening. Veel liever namen ze arbeiders aan, die zich spontaan bij de mijnzetels aanmeldden of stuurden ze eigen wervingsagenten op pad..$^{6}$ 
Vanaf 1923 gingen de gezamenlijke mijnen een meer systematisch selectiebeleid voeren. Dat uitte zich in een verplichte medische keuring van nieuw personeel, uitgevoerd door een gemeenschappelijke Geneeskundige Dienst met mijnartsen voor alle Limburgse mijnondernemingen en een striktere controle op antecedenten. ${ }^{97}$ Slechts sporadisch kozen de mijnondernemingen ervoor die selectie door de arbeidsbeurs te laten uitvoeren. In I927 hielden de Nederlandse werkgeversverenigingen een enquête onder hun leden over het functioneren van de arbeidsbemiddeling. De gezamenlijke Limburgse mijnen hadden in de eerste drie kwartalen van dat jaar in totaal 7.858 arbeiders in dienst genomen, waarvan slechts 148 (net geen 2 procent) door bemiddeling van de Heerlense arbeidsbeurs..$^{98}$ In I930 konden de districtsarbeidsbeurzen van Heerlen en Sittard samen 3 Io werkzoekenden naar een mijnonderneming bemiddelen, minder dan 3 procent van het totaal aantal werkzoekenden dat zich bij de beurzen had ingeschreven voor een baan in de nijverheidssector (exclusief de bouw). ${ }^{99}$

\section{0: een tussenbalans}

In 1930 bleek de ontwikkeling van de personeelsvoorziening anders dan drie decennia eerder was gehoopt: de weg van de geleidelijkheid was verlaten; het Saarlandse model van arbeidsvoorziening had men losgelaten en ingewisseld voor een mengvorm met het Westfaalse model. Aan de vooravond van de grote crisis van de jaren I930 was de mijnwerkerspopulatie minder Limburgs en Nederlands en meer internationaal dan ooit tevoren: het percentage Limburgers was afgenomen tot 43,4 en dat van de Nederlanders uit de rest van het land tot 15,7 . Nederlanders die waren geboren in het buitenland makten 9 procent van de mijnwerkersbevolking uit. Bijna 32 procent was buitenlander. ${ }^{100}$

\section{CRISIS EN OORLOG, I93I-I944}

\section{Werving en selectie in de jaren dertig}

Tengevolge van de economische crisis die in de loop van 1930 in de Limburgse mijnbouw voelbaar werd, ${ }^{\text {ro }}$ kwamen de mijndirecties voor een onbekend probleem te staan. Voor het eerst was in het personeelsbeleid de aandacht niet primair gericht op de werving van nieuwe mijnwerkers, maar op inkrimping van het personeelsbestand. De vermindering van het aantal mijnwerkers was onderdeel van bedrijfseconomisch beleid dat kostenreductie beoogde. De post loonkosten maakte in het mijnbedrijf een zeer hoog aandeel uit van de totale productiekosten. Medio jaren dertig bedroeg het tussen de 50 en 60 procent. ${ }^{102}$ In een poging dat aandeel te verminderen gingen de mijnen in de jaren dertig versneld door met

97 Ibidem, I52-I56.

98 SHCL, Archief GSL, nr. 802 Vereeniging Centraal Overleg 1927.

99 Langeweg, Van Adreskantoor, I25-I27 tabellen 24 en 25.

Ioo Jaarverslag AMF 1930, I4.

IOI Jaarverslag van den Hoofdingenieur der Mijnen over het jaar 1930, 9 .

I02 Rapport Staatscommissie 1946, I03 en tabel XVIIa I84. 
rationalisering en mechanisering van het productieproces, een beleid waarmee al een decennium eerder een begin was gemaakt. ${ }^{\mathrm{I} 3}$ In toenemende mate vervingen machines en meer efficiënte winningsmethoden menselijke arbeid. Bij een dalende afzet van steenkool en verhevigde internationale concurrentie ten gevolge van de algehele economische malaise, leidde dat tot het inleggen van verzuimdiensten en tot massaontslagen. ${ }^{\text {104 }}$

Al in I93 legden de Limburgse mijnen de eerste verzuimdiensten of Feierschichten in, een vorm van onbetaalde tijdelijke arbeidstijdverkorting. Tijdens de crisisjaren nam het aantal verzuimdiensten fors toe, zoals blijkt uit tabel 4.9 waarin een overzicht wordt gegeven van het jaarlijkse aantal werkvrije dagen. Het hoogste aantal werd tijdens het dieptepunt van de crisis in 1935 bereikt. Pas in de tweede helft van 1936 was de economische situatie zodanig verbeterd dat de verzuimdiensten konden worden afgeschaft. ${ }^{105}$

TABel 4.9 Het aANTAl WERKVRije Dagen in DE Nederlandse STEENKolenMIJNBOUW, I93I-I936

\begin{tabular}{|l|r|r|r|r|r|r|}
\hline & I93I & I932 & I933 & I934 & I935 & I936 \\
\hline totaal mijnen & 57 & $37 \mathrm{I}$ & 479 & 579 & 684 & $4 \mathrm{I} 2$ \\
\hline totaal Staatsmijnen & $\mathrm{I}$ & 42 & 32 & $3 \mathrm{I}$ & $\mathrm{I} 44$ & 85 \\
\hline gemiddeld per Staatsmijnzetel & 0,25 & $\mathrm{II}$ & 8 & 8 & 36 & $2 \mathrm{I}$ \\
\hline totaal particuliere mijnen & 56 & 329 & 447 & 548 & 540 & 327 \\
\hline gemiddeld per particuliere mijnzetel & 7 & $4 \mathrm{I}$ & 56 & 69 & 68 & $4 \mathrm{I}$ \\
\hline
\end{tabular}

Bron: Rapport Staatscommissie 1946, IoI.

Vooral de arbeiders bij de particuliere mijnen werden geconfronteerd met Feierschichten. De problemen bij de particuliere mijnen waren groot, omdat de afzet van de daar geproduceerde magere huisbrandkool ernstige moeilijkheid ondervond. ${ }^{106}$ Ook Staatsmijn Wilhelmina, de enige Staatsmijnzetel die huisbrand produceerde, kende die problemen. Tussen I93I en I936 was de Wilhelmina verantwoordelijk voor een derde van het totaal aantal werkvrije dagen bij de vier Staatsmijnzetels. Dat aantal werd nog beperkt door in I933 een aantal mijnwerkers van de Wilhelmina over te plaatsen naar de vetkoolmijnen Hendrik, Emma en Maurits. ${ }^{107}$

In totaliteit was Staatsmijnen door zijn gemengd bedrijf van vetkoolmijnen en nevenbedrijven op basis van veredeling van die vetkool - cokes, gas, chemische producten en stikstofmeststoffen - minder conjunctuurgevoelig en daardoor beter in staat slechte jaren door te komen dan de particuliere mijnen. ${ }^{108}$ Staatsmijnen ging pas in 1935 over tot inkrimping van de kolenproductie, terwijl de particuliere mijnen daar al in 1932 mee begonnen waren. Behalve de betere positie van vetkolen op de kolenmarkt, speelde een rol dat Staatsmijnen

I03 Gales, 'Himmel', I6I-2I5.

I04 Rapport Staatscommissie 1946, 97-98.

I05 G.C.M. Vromen, 'Personeelsbeleid bij de Nederlandse mijnen tijdens de jaren dertig', SSEGL XXXII (I987) 27-79, aldaar 35-36.

Io6 Peet en Rutten, Oranje-Nassau Mijnen, I82-I83, I90-I9I.

I07 Jaarverslag Hoofdingenieur der Mijnen over 1933, 30.

Io8 Rapport Staatscommissie 1946, 79, IOI-IO2. 
bereid was tot voorraadvorming over te gaan en zeer lage prijzen te accepteren. ${ }^{109} \mathrm{Bij}$ de particuliere mijnen lag dat lastiger, omdat aldus de Staatscommissie, 'het particuliere bedrijf ook met de rechtmatige belangen van de kapitaalverschaffers, die een redelijk inkomen en behoud van hun eigendom wensen, rekening moet houden'. ${ }^{\text {Io }}$

Het inleggen van verzuimdiensten ging hand in hand met massaontslagen. Het ontslagbeleid van de mijnen komt in hoofdstuk 6 aan de orde in het kader van het personeelsverloop. Hier wordt volstaan met de mededeling dat tussen eind 1930 en eind 1935 het aantal arbeidsplaatsen bij de Limburgse mijnondernemingen met bijna 9.000 afnam.

Toch betekende de crisis niet dat de mijnen overgingen tot een absolute personeelsstop. Ook in deze moeilijke jaren namen de mijnen personeel aan, zij het uiteraard veel minder dan voorheen. Zo schreef het AMF in de periode I93I-I935 per jaar gemiddeld I.668 nieuwe mijnwerkers in, terwijl dat tussen I9I9 en 1930 nog gemiddeld 7.400 nieuwelingen per jaar was. ${ }^{\text {III }}$ Tijdens de crisisjaren traden voornamelijk Nederlanders bij de mijnen in dienst (tabel 4.Io). Gemiddeld had in deze periode 77 procent van de nieuwe mijnwerkers de Nederlandse nationaliteit. ${ }^{\mathrm{II2}}$

TABEL 4. IO HET AANTAL IN DIENST GENOMEN MIJNWERKERS NAAR NATIONALITEIT BIJ DE GEZAMENLIJKE NEDERLAN DSE STEEN KOLENMIJNEN, I93I-I939

\begin{tabular}{|l|c|c|c|}
\hline & Nederlanders & buitenlanders & totaal \\
\hline I93I & 2.706 & I.585 & $4.29 \mathrm{I}$ \\
\hline I932 & I.230 & 338 & I.568 \\
\hline I933 & I.I98 & 233 & I.43I \\
\hline I934 & I.36I & I4I & I.502 \\
\hline I935 & I.609 & I37 & I.746 \\
\hline I936 & 2.168 & I42 & 2.310 \\
\hline I937 & 3.869 & 404 & 4.273 \\
\hline I938 & I.999 & 75 & 2.074 \\
\hline I939 & 3.502 & 85 & 3.587 \\
\hline
\end{tabular}

Bron: Vromen, 'Personeelsbeleid', 69; SHCL, ArchiefWillem-Sophia 603, 09-05-02.

De groep nieuwe mijnwerkers bestond in hoofdzaak uit twee categorieën: Nederlandse arbeiders die in Duitsland hadden gewerkt en jonge Limburgse arbeiders. De eerste groep was ten gevolge van de crisis in Duitsland ontslagen en werd onder druk van de Nederlandse regering in dienst genomen. De Nederlandse Arbeidsbeurs in Oberhausen, ooit opgericht om Nederlandse werkzoekenden op de Duitse arbeidsmarkt behulpzaam te zijn, speelde nu een rol in omgekeerde richting. De mijnondernemingen selecteerden uit het aanbod van de arbeidsbeurs de meest geschikten, wat in de praktijk neerkwam op ervaren

Io9 Vromen, 'Personeelsbeleid', 32; Peet en Rutten, Oranje-Nassau Mijnen, I83.

IIO Rapport Staatscommissie 1946, I8.

III Jaarverslagen AMF [I9I9-I935]; zie ook bijlage I8.

12 Het verschil tussen het aantal door het AMF ingeschreven mijnwerkers en het totaal aantal door de gezamenlijke mijnen in dienst genomen arbeiders wordt verklaard, doordat in de AMF-cijfers geen rekening werd gehouden met het verloop tussen de mijnen onderling. 


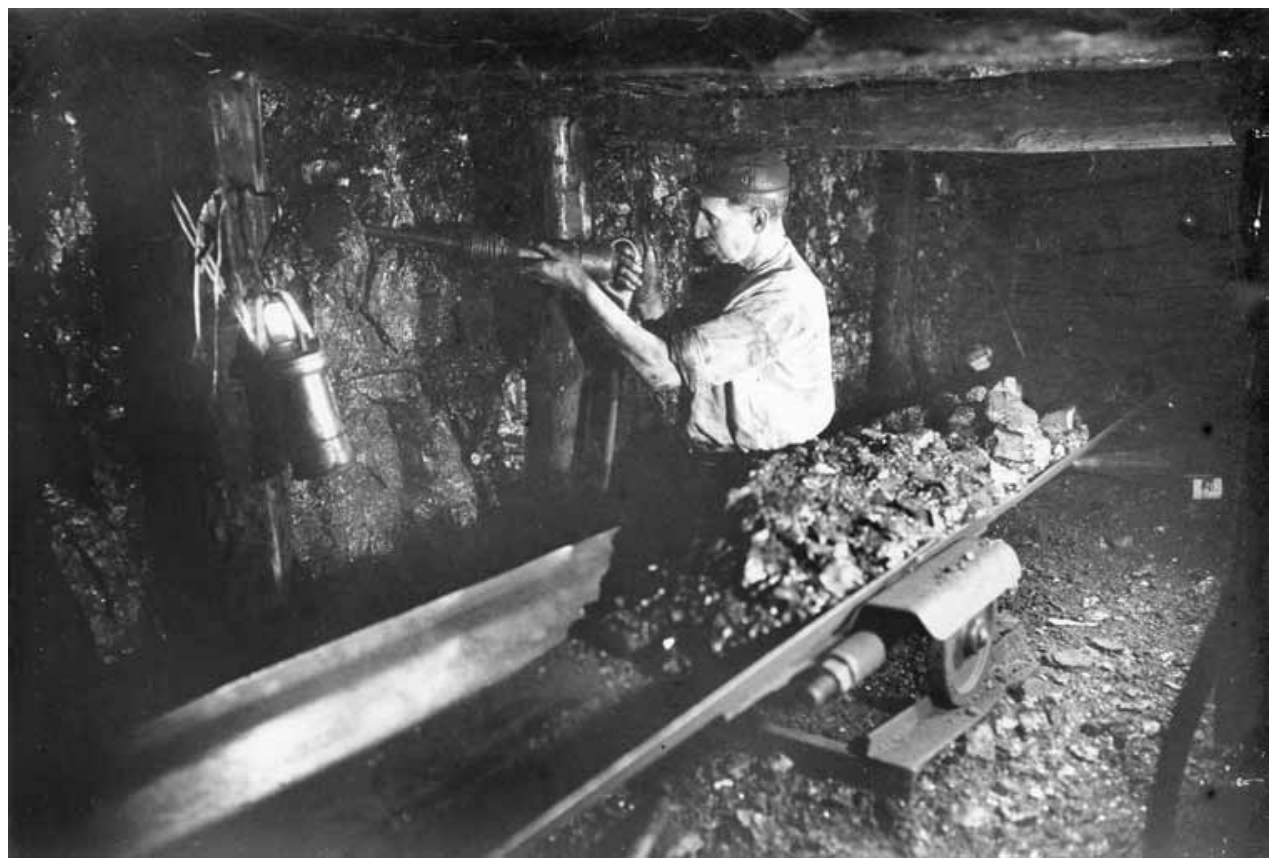

Een houwer in de pijler aan het werk met een afbouwhamer. Op de voorgrond de schudgoot die de kolen uit de pijler transporteert. 1930. Bron: Fotocollectie Continium Kerkrade, F2814.

mijnwerkers. Zolang het om ervaren mijnwerkers ging, wilden de mijnen wel meewerken aan allocatie via de arbeidsbeurs in Oberhausen. Zelfs waren de mijnen bereid om voor deze Nederlanders plaats te maken door buitenlanders te ontslaan. In 1934 sloeg de welwillende houding van de mijndirecties echter om door negatieve ervaringen die waren opgedaan met de laatste lichtingen Nederlandse mijnwerkers die via Oberhausen waren betrokken. Bovendien was het stadium bereikt, dat er uit bedrijfsbelang geen buitenlandse mijnwerkers meer ontslagen konden worden. De stroom Nederlanders uit Duitsland naar de Limburgse mijnen droogde daarmee op. ${ }^{113}$

De grootste groep nieuwe mijnwerkers bestond uit jonge Limburgse arbeiders, die men plaatste op de inmiddels ingestelde leesjongensopleidingen, waar de nieuwelingen werden voorbereid op het werk in de mijn. ${ }^{\mathrm{II} 4}$ In de jaren tussen I93I en I935 was 65 procent van de nieuwe mijnwerkers in Limburg geboren. De vakopleiding van jonge mijnwerkers vond in die jaren voortgang, werd zelfs uitgebreid. Aan de inpassing van jonge arbeiders in het mijnbedrijf werd grote waarde gehecht. ${ }^{115}$ Gewaarborgd moest worden '... dat de groei van Nederlandsche mijnwerkers ten opzichte van de buitenlanders blijft voortgaan. Nog steeds toont het mijnwerk de sporen van een voor Nederland betrekkelijk jonge nijverheid. Dit is de reden van de aanwezigheid van de nog steeds talrijke geschoolde buitenlandse mijnwerkers. Daar het mijnwerk bij uitstek geschoold werk is, is de vakopleiding van hooge waar-

II3 Vromen, 'Personeelbeleid', 67-69.

II4 A.J. Ritt, Statistische gegevens opleiding leesjongens (z.p. I962).

II5 Rapport Staatscommissie 1946, 88-89. 
de. [...] Om een goed ondergrondsch mijnwerker te worden, behoort men jong, beneden de 20 jaren, te beginnen' ${ }^{116}$ Duidelijk is dat de mijndirecties van de ruimere arbeidsmarkt tijdens de jaren dertig gebruik maakten om de samenstelling van het personeelsbestand in de door hen gewenste richting te wijzigen. De opzet was de mobiele, vreemde mijnwerkers te vervangen door arbeiders, geworteld in de eigen streek en daardoor met een verwachte grotere geneigdheid om werk in de mijn als een langjarige carrière te beschouwen. Voor het eerst in hun geschiedenis konden de mijnen bij hun aannamebeleid selectief zijn. Duidelijk is dat preferentiebeleid af te lezen aan de leeftijden van de in dienst genomen mijnwerkers.

TABEL 4.II DE GEMIDDELDE LEEFTIJD VAN INTREDERS BIJ HET AMF, I92I-I965

\begin{tabular}{|l|c|c|c|c|}
\hline cohort & alle mijnwerkers & Nederlanders & Limburgers & buitenlanders \\
\hline I92I-I925 & 23,7 & 22,3 & $2 \mathrm{I}, 2$ & 25,5 \\
\hline I926-I930 & 24,7 & $2 \mathrm{I}, 8$ & $2 \mathrm{I}, 2$ & $26, \mathrm{I}$ \\
\hline I93I-I935 & I9,0 & I8,4 & I7,9 & 23,3 \\
\hline I936-I940 & I9,7 & I9,8 & I9,3 & I8,0 \\
\hline I94I-I945 & 20,7 & 20,9 & 20,0 & I9,0 \\
\hline I946-I950 & $22, \mathrm{I}$ & $2 \mathrm{I}, 3$ & 20,3 & 26,3 \\
\hline I95I-I955 & $2 \mathrm{I}, 0$ & 20,9 & $\mathrm{I} 9,5$ & 23,7 \\
\hline I956-I960 & I9,6 & I8,0 & I6,9 & 22,8 \\
\hline I96I-I965 & 24,8 & I9,0 & I7,5 & 29,2 \\
\hline
\end{tabular}

Bron: Steekproef AMF. NB Tussen I93I en 1945 namen de mijnen weinig buitenlandse arbeiders aan. In de steekproef zijn in die periode slechts enkele buitenlanders opgenomen: respectievelijk 7, 4 en II in de cohorten I93I-I935, I936-I940 en I94I-I 945.

De gemiddelde leeftijd van de nieuwe mijnwerkers nam in de jaren dertig sterk af, vergeleken met het voorgaande decennium. De voorkeur voor met name jonge Limburgers blijkt uit de lage leeftijd van deze groep mijnwerkers.

Het personeelsbeleid van de mijnen tijdens de crisis, dat was gebaseerd op enerzijds bescherming van met name Limburgse arbeiders bij ontslag en anderzijds voorkeursbeleid ten aanzien van deze groep bij het aannemen van nieuwe mijnwerkers, leidde tot een toename van het percentage geboren Limburgers in de mijnen. Terwijl het percentage geboren Limburgers in de Limburgse mijnen na I9I9 gestaag was afgenomen, steeg dit vanaf I93I fors. In 1935 was 55 procent van de mijnwerkers Limburger, een toename van I2 procent vergeleken met 1930 .

$\mathrm{Na}$ de crisis zetten de mijnen het eenmaal ingezette beleid voort. De situatie op de arbeidsmarkt bleef gunstig voor de mijndirecties: dankzij de demografische ontwikkeling bleef het aanbod van arbeidskrachten de vraag overtreffen en behielden de mijnen de mogelijkheid om te selecteren op basis van hun preferenties. Ondanks druk van de regering en van de arbeidsbeurzen werden degenen die in de crisisjaren waren ontslagen, over het algemeen niet opnieuw aangenomen. ${ }^{117}$ De argwaan van de mijndirecties ten aanzien van het 
Grafiek 4.6 Het PERCENTAge Limburgers in de Nederlandse STEEN KolenMIJNEN, I9I9-I935

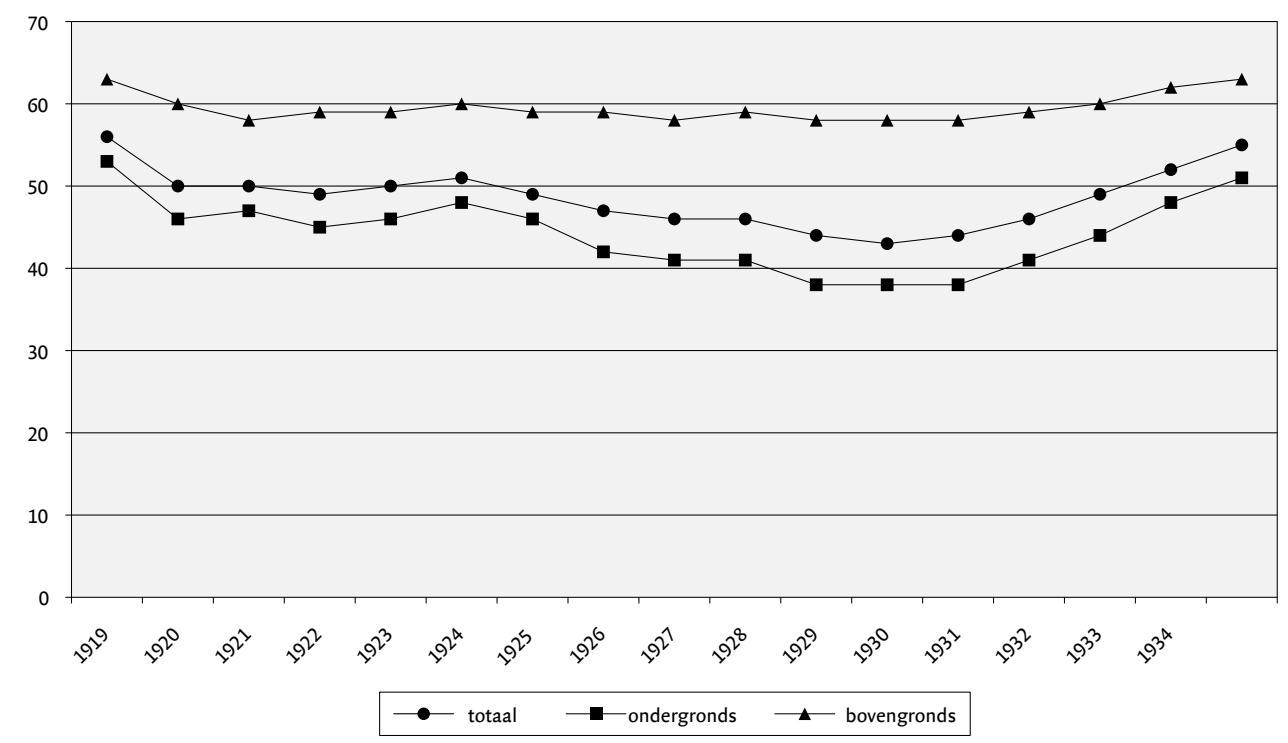

Bron: Jaarverslagen AMF, [1919-1935].

personeelsaanbod van de arbeidsbeurzen was nog lang niet verdwenen. In 1938 en 1939 lieten de mijnen de bij de Limburgse arbeidsbeurzen ingeschreven werkloze mijnwerkers onderzoeken. Voor de mijndirecties waren de resultaten negatief: het overgrote merendeel werd ongeschikt bevonden voor mijnarbeid om medische redenen, leeftijd, invaliditeit, persoonlijke eigenschappen, politieke gezindheid of gedrag. ${ }^{\mathrm{I} 8}$

Het stringente selectiebeleid van de Limburgse mijndirecties en hun uitgesproken ideeën over de kwaliteiten van bij de arbeidsbeurzen ingeschreven werklozen blijken eens te meer uit de bereidheid van Duitse en Belgische mijnen om wél Limburgse werklozen via de arbeidsbeurzen te betrekken. De arbeidsbeurs van Sittard speelde een coördinerende rol in deze internationale arbeidsbemiddeling. De vraag naar mijnwerkers kwam er via Belgische en Duitse arbeidsbemiddelingsinstituten binnen en de Sittardse beurs nam vervolgens met andere arbeidsbeurzen in Limburg en oostelijk Noord-Brabant contact op om arbeiders te rekruteren. ${ }^{\text {I9 }} \mathrm{Na}$ I936 nam die bemiddeling naar het buitenland fors toe, zoals tabel 4.I2 laat zien.

Duidelijk is dat de Limburgse mijnen het liefst hun eigen boontjes dopten als het om personeelsvoorziening ging. De mijnen bleven opteren voor Nederlandse, liefst in Limburg geboren en getogen jongeren, die ze zelf selecteerden. Ook in de tweede helft van de jaren dertig bleef de gemiddelde leeftijd van de nieuwe mijnwerkers laag. Van hen was tussen 1936 en 194086,5 procent geboren in Limburg. ${ }^{120}$ De meesten van hen begonnen hun carrière in het mijnbedrijf op de leesjongensopleidingen, die in de tweede helft van de jaren dertig ook bij particuliere mijnen werden opgericht.

II8 Ibidem, 76-77.

119 Langeweg, Van Adreskantoor, 55.

120 Berekend op basis van de steekproef uit de AMF-inschrijvingen. 
TAbel 4.I2 Het aAntal en percentage plaAtsingen in België en DuitsLAN D VIA DE DISTRICTSARBEIDSBEURS SITTARD, I936-I939

\begin{tabular}{|l|r|r|r|c|}
\hline & België & Duitsland & totaal & $\begin{array}{c}\text { in \% van } \\
\text { totaal aantal } \\
\text { plaatsingen }\end{array}$ \\
\hline $\mathrm{I} 936$ & 48 & $\mathrm{I}$ & 49 & 0,7 \\
\hline $\mathrm{I} 937$ & $\mathrm{I} .675$ & 205 & $\mathrm{I} .880$ & 22,6 \\
\hline $\mathrm{I} 938$ & 580 & $\mathrm{I} .8 \mathrm{I} 8$ & 2.398 & 29,2 \\
\hline $\mathrm{I} 939$ & 548 & 855 & $\mathrm{I} .403$ & $\mathrm{I} 6,2$ \\
\hline
\end{tabular}

Bron: Jaarverslag van de Arbeidsbeurs Sittard, [1936-1939].

\section{Bezetting}

De Duitse bezetting van de Limburgse mijnstreek (Io mei I940 tot 5 oktober I944) betekende geen fundamentele breuk in het door de mijnen gevoerde personeelsbeleid. ${ }^{12 \mathrm{I}}$ Onder Duitse druk om de kolenproductie te verhogen nam het personeelsbestand tussen 3 I december 1939 en 3 I december 1943 met 8.200 man toe. Van de nieuwe mijnwerkers die tussen I juni I940 en I oktober I944 in dienst traden, was 7I procent in Limburg geboren en 23 procent in de rest van Nederland. Zes procent had een buitenlandse nationaliteit. ${ }^{122}$ Nog steeds was het leeuwendeel van de nieuwelingen dus Limburger, waarmee de mijndirecties voortgingen op de weg, die in de jaren dertig was ingeslagen. Vergeleken met de tweede helft van de jaren dertig was het aandeel nieuwe Limburgers echter wat gedaald ten faveure van de overige Nederlanders. Specifieke oorlogsomstandigheden hebben hierbij hoogstwaarschijnlijk een rol gespeeld.

In juni I940 kreeg een deel van de mijnen te maken met Duits toezicht. Oberbergrat Johow werd aangesteld tot Verwalter over de particuliere mijnen die met buitenlands kapitaal werkten (Oranje-Nassau Mijnen, Laura \& Vereeniging en Willem-Sophia). Staatsmijnen en de Domaniale Mijn werden aanvankelijk ongemoeid gelaten. De geringe belangstelling van de Duitsers voor de Nederlandse mijnen kan worden verklaard door de kleine productie in perspectief van de totale kolenproductie in Duitsland en de bezette gebieden. Vergeleken met de ruim 300 miljoen ton die de mijnen in Silezië, Tsjecho-Slowakije, Frankrijk, België en Duitsland zelf jaarlijks produceerden, waren de I2 à I 3 miljoen ton van de Nederlandse mijnen inderdaad een druppel op een gloeiende plaat. ${ }^{123}$

Toch bleek ook de Nederlandse kolenproductie in de loop van de bezettingsperiode voor de Duitsers steeds belangrijker te worden, reden waarom de Duitse autoriteiten de controle op de mijnen intensiveerden. De pensionering van de Staatsmijndirecteuren W.F.J. Frowein en F.K.Th. van Iterson aan het eind van I94I werd door de Duitsers aangegrepen om

I2I Tegen 20 september 1944 was Zuid-Limburg op Vaals, Kerkrade en Eygelshoven na bevrijd. Dat gebied werd tijdelijk frontgebied bij de verovering van Aken. Op 5 oktober werd Kerkrade als laatste Zuid-Limburgse gemeente bevrijd. Fred Cammaert, 'De Tweede Wereldoorlog', Het Land van Herle nummer 2 (2008) 5I-66, aldaar 63-64.

122 Berekend op basis van de steekproef uit de AMF-inschrijvingen.

I23 Cammaert, 'Tweede Wereldoorlog', 52. 
ook Staatsmijnen en de Domaniale Mijn onder beheer te stellen. ${ }^{\mathrm{I} 24}$ Verwalter was inmiddels Hermann Wilhelm Bruch, een geschoold mijnbouwkundige, die Johow in december I94I was opgevolgd. ${ }^{125}$

In november 1940 hadden de Duitsers al bij de Nederlandse mijndirecties aangedrongen op verhoging van de jaarproductie tot 15 miljoen ton. De mijndirecties hadden die eis met succes weten te pareren met het argument dat er te weinig geschoolde arbeidskrachten beschikbaar waren door de mobilisatie van Duitse mijnwerkers die in Limburg hadden gewerkt en de zuigkracht van de hogere lonen die werden betaald bij projecten die in opdracht van de Wehrmacht in Nederland werden uitgevoerd. ${ }^{226}$ De Duitse druk om de productie te verhogen bleef de volgende jaren aanhouden. Via een reeks van maatregelen trachtten de Duitse autoriteiten dat doel te bereiken. In een aantal stappen werd de arbeidstijd verlengd. Nadat in november 1940 de arbeidstijd op zaterdagen was verlengd van zes naar acht uur, werd twee jaar later voor bovengronders de 54-urige werkweek ingevoerd en werd, naar analogie van de praktijk in de Duitse mijnen, de werktijd voor ondergronders van acht uur gebracht op acht uur en 45 minuten. Ook voerden de Duitsers werkzondagen in. Na een mislukte poging in juni I94I werd dit in het voorjaar van I942 opnieuw geprobeerd, ditmaal met door represailles afgedwongen succes. Vanaf september 1942 moest er zelfs tweemaal per maand op zondag worden gewerkt. ${ }^{127}$ Daarnaast probeerden de Duitsers - vergeefs - via invoering van het zogenaamde éénmansakkoord de individuele prestaties van de mijnwerkers te verhogen, ${ }^{128}$ golden er beperkingen voor het ontslaan van mijnwerkers en mochten mijnwerkers sinds I94I na hun pensioengerechtigde leeftijd blijven doorwerken. ${ }^{\text {I29 }}$ Het aannemen van nieuw personeel paste ook in het streven om de productie te verhogen.

$\mathrm{Al}$ snel na de Duitse inval was duidelijk geworden dat werk in de mijnen praktische voordelen bood. Allereerst voor werklozen. Op 25 juni I940 besloot de secretaris-generaal van Sociale Zaken dat werklozen die weigerden werk in Duitsland te aanvaarden, geen steun meer zouden krijgen. ${ }^{130}$ Dat betekende dat degenen die aan werk in Duitsland wilden ontkomen, gedwongen werden in Nederland een baan te vinden. Hoewel cijfers ontbreken, leidt het geen twijfel dat in de eerste maanden van de bezetting, toen de werkloosheid in $\mathrm{Ne}$ derland tot recordhoogten steeg, ${ }^{13 \mathrm{I}}$ menigeen een toevluchtsoord vond in de mijnen. Daar was werk genoeg. Een vast dienstverband bij een mijnonderneming bood, naast een relatief hoog loon, bovendien de nodige extra's. Mijnwerkers hadden recht op deputaatkolen, waarmee de jaarlijkse behoefte aan brandstof doorgaans makkelijk kon worden vervuld. Daarnaast kregen ze extra levensmiddelenbonnen en hadden de mijnen gaarkeukens ingericht die onder meer belegde boterhammen en koffie verstrekten. Mijnwerkerskleding en

\footnotetext{
124 Staatsmijnen in Limburg. Gedenkboek bij gelegenheid van het vijftigjarig bestaan (Heerlen 1952) 98-99.

I25 Van Buren, 'Kolenwinning', I36-137.

I26 J. Mensink, De kolenvoorziening van Nederland tijdens den tweeden wereldoorlog (Amsterdam 1946) 30.

I27 Van Buren, 'Kolenwinning', I44-I5r.

I28 Dit betekende dat honderd procent van het in akkoord geregelde loon afhankelijk werd gesteld van de individuele prestatie. Het éénmansakkoord werd slechts in enkele pijlers ingevoerd, omdat de mijndirecties er afwijzend tegenover stonden. Invoering zou de noodzakelijke solidariteit ondergronds in gevaar brengen.

129 Ron Eussen, Akkomodatie en verzet bij de Nederlandse steenkolenmijnen tijdens de Duitse bezetting, mei 1940-september 1944 (doctoraalscriptie VU, Amsterdam 1984) 9o; Verslag van de Inspecteur-Generaal der Mijnen over de jaren 1940-1945, 6-7.

130 Hein A.M. Klemann, Nederland 1938-1948. Economie en samenleving in de jaren van oorlog en bezetting (Amsterdam 2002) 267.

I3I Cijfers van het CBS doen vermoeden dat in juni 194026 procent van de afhankelijke beroepsbevolking werkloos was. Dat kwam neer op 740.000 personen, meer dan op enig moment tijdens de depressie van de jaren I930. Klemann, Nederland 19381948, 65 .
} 
-schoenen konden buiten het normale bonnensysteem verstrekt worden, evenals fietsbanden voor diegenen die met de fiets naar het werk kwamen. Door dergelijke voordelen aangelokt, probeerden arbeiders uit heel Nederland op een mijn geplaatst te worden. ${ }^{32}$

Omdat deze spontane aanmeldingen tekortschoten, werd door de Duitse autoriteiten en de mijndirecties daarnaast een actief wervingsbeleid gevoerd. Dat beleid richtte zich vooral op de Limburgse arbeidsmarkt. Toen in I94I enkele mijnen hun benodigde nieuwe personeel in onvoldoende mate in Limburg konden vinden, werd een begin gemaakt met de werving en selectie van arbeidskrachten elders in Nederland. De mijndirecties bleven echter kieskeurig bij de selectie van nieuwkomers. Het beleid dat in de jaren dertig was ingezet, werd niet gewijzigd. Het was in deze periode zeker niet zo dat iedereen die dat wilde bij de mijnen aan de slag kon. Veel sollicitanten uit de rest van Nederland werden afgekeurd om medische redenen of omdat ze anderszins niet geschikt werden bevonden voor het zware werk ondergronds. De herinnering van Raedts, dat ongeschoolde en improductieve arbeidskrachten, waarvan een aantal 'nauwelijks aan lichamelijke arbeid gewoon was' ${ }^{133}$ na medische keuring, zonder meer te werk werden gesteld, is waarschijnlijk onjuist. Uit overwegingen van veiligheid bij het werk ondergronds moesten de mijndirecties eisen stellen aan de fysieke capaciteiten van degenen die zich voor mijnarbeid aanboden. Blijkbaar was het aantal afgekeurden zelfs zo groot, dat de mijndirecties in oktober I94I besloten de selectie voortaan op de plaats van rekrutering af te handelen, zodat nodeloze kosten en teleurstellingen zoveel mogelijk werden voorkomen. ${ }^{\mathrm{I} 4}$

Dat de mijndirecties een zekere mate van speelruimte hadden bij het aantrekken van nieuw personeel bleek ook uit hun afwijzing van de ruim 2.000 Nederlanders die in de mijnen bij Aken werkten. In februari 1942 drong Verwalter Bruch er bij de Nederlandse mijnen op aan deze geschoolde mijnwerkers in dienst te nemen. De gezamenlijke mijndirecties waren echter pertinent tegen het aannemen van deze grensgangers. Volgens hen waren het uitsluitend werkkrachten die ze eerder hadden afgestoten, omdat ze om verschillende redenen niet voldeden. Ook de Akense mijnen waren tegen, want die konden de mijnwerkers niet missen. Uiteindelijk ging de overplaatsing niet door. ${ }^{135}$ Voorts verzetten de Nederlandse mijnen zich met succes tegen het plan van Bruch om vrouwen en invaliden in het bovengrondse bedrijf van de mijnen te plaatsen, waardoor arbeidskrachten beschikbaar zouden komen voor het werk ondergronds. Uitvoering van het dreigement van de Verwalter om dan maar van Russische krijgsgevangenen in te zetten, zoals in de kolenbekkens van de Kempen, Luik $\mathrm{K}^{136}$ en Aken in groten getale gebeurde, konden de Nederlandse mijndirecties net lang genoeg tegenhouden. De bevrijding voorkwam dat de Duitsers het plan daadwerkelijk konden uitvoeren. ${ }^{\mathrm{I} 7}$

De mijn als toevluchtsoord voor hen die arbeid in Duitsland wilden ontlopen, kreeg een nieuwe dimensie toen de Duitsers in de loop van 1942 de Arbeitseinsatz uitbreidden tot Ne-

\footnotetext{
132 C.E.P.M. Raedts, 'Het mijnwerkersverzet tijdens de Tweede Wereldoorlog', SSEGL XXIV (1979) I-23, aldaar I2-I4.

I33 Ibidem, 2I.

134 Eussen, Akkomodatie, 60.

I35 Willibrord Rutten, 'Russen niet gewenst: de mislukte inzet van Russische dwangarbeiders in de Nederlandse steenkoolmijnen in de Tweede Wereldoorlog', SSEGL XLIX (2004) I65-19o, aldaar 172-174.

136 Leen Roels, 'Où sont les mineurs belges? Het probleem van het arbeidstekort in de Luikse mijnen tijdens en na de Tweede Wereldoorlog' (manuscript, 2009) I3-I4.

I37 Rutten, 'Russen niet gewenst', I75-Igo.
} 
derlandse arbeiders die niet werkloos waren. ${ }^{13^{8}}$ Overal in het land werden bedrijven die in de ogen van de Duitsers van geen belang voor de oorlogsindustrie waren, gesloten. Andere werden gedwongen het personeelsbestand in te krimpen. In 1943 moesten voormalige militairen terug in krijgsgevangenschap en werden in de zogenaamde jaargangenactie mensen geboren tussen 1920 en 1924 opgeroepen zich bij de arbeidsbureaus te melden. Die verplichting gold ook voor een groep studenten. De op deze wijze vrijgekomen arbeidskrachten werden vervolgens verplicht in Duitsland tewerkgesteld. ${ }^{139}$ Mijnwerkers moesten zich ook melden, maar als zij ondergronds werkten, ontvingen ze doorgaans een stempel op hun distributiekaart en een vrijstellingsbewijs. ${ }^{140}$ Bovengronders liepen een groter risico, zeker wanneer zij ongeschoold waren. Zij kregen in lang niet alle gevallen vrijstelling. Zo vertrokken in 1943 minstens vijfhonderd jonge bovengrondse Nederlandse mijnwerkers verplicht naar Duitsland. ${ }^{\mathrm{I} 4 \mathrm{I}}$

In de praktijk betekende werk als ondergronder een redelijke zekerheid niet naar Duitsland te worden gedeporteerd. De Duitse druk om de kolenproductie op te voeren bleef onverminderd groot en van de direct bij de kolenwinning betrokken arbeiders kon niemand worden gemist. Sterker nog: het tekort aan personeel bleef groot. In maart 1943 gaven de gezamenlijke Limburgse mijnen een tekort op van I.544 arbeidskrachten: 50 procent houwers, 24 procent leerhouwers en 26 procent leerjongens. ${ }^{142}$ Voor de mijndirecties bood de eis van productieverhoging dus de mogelijkheid mensen aan te nemen. Maar in principe moesten die wel geschikt zijn voor de zware mijnarbeid. De bezetter in de persoon van Verwalter Bruch keek voortdurend mee, en de mijnen moesten de toename van het personeelsbestand kunnen rechtvaardigen met stijging van de productie. Dat lukte niet. Tot en met 1943 bleef de productie stabiel op een niveau van I2 à I 3 miljoen ton per jaar (bijlagen 2 en 3). Bovendien daalde de arbeidsproductiviteit voortdurend. In 1938 en 1939 bedroeg de nettoprestatie per arbeider en per ondergrondse dienst 2,37 ton. In I 943 was dat afgenomen tot $\mathrm{I}, 74$ ton. ${ }^{\mathrm{I} 43}$ Oorzaken van de afnemende arbeidsproductiviteit en de stagnerende productie waren het tekort aan geschoolde mijnwerkers en het sterk toegenomen verzuim.

In Duitse ogen werd dat laatste voor een deel veroorzaakt door ongeoorloofd verzuim. Uit tabel 4.I3 blijkt dat in de loop van de bezetting willekeurig verzuim fors toenam. Toch was het willekeurig verzuim marginaal vergeleken met het verzuim wegens ziekte. Naast een toename van ziektegevallen door het steeds kariger voorzieningenniveau in de loop van de oorlog, ging in het ziekteverzuim waarschijnlijk echter veel willekeurig verzuim schuil. Zeker nadat de Duitsers in 1942 onder dreiging met strafvervolging de verplichte zondagdiensten hadden ingevoerd, nam op doordeweekse dagen het aantal ziekmeldingen sterk toe. ${ }^{\mathrm{I} 44}$ Duidelijk is dat in 1943 het verzuim verdubbeld was in vergelijking met het begin van de bezetting.

138 Klemann, Nederland 1938-1948, 269-27I.

139 B.A. Sijes, De Arbeidsinzet. De gedwongen arbeid van Nederlanders in Duitsland, 1940-1945 ('s-Gravenhage (I990²) 280 e.v.

140 A.P.M. Cammaert, Het verborgen front. Een geschiedenis van de georganiseerde illegaliteit in de provincie Limburg tijdens de Tweede Wereldoorlog (Leeuwarden/Mechelen 1994) 507-508.

I4I Cammaert, 'Tweede Wereldoorlog', 63 .

142 Eussen, Akkommodatie, go.

143 SHCL, ArchiefGSL, Statistiek V-I.

I44 Van Buren, 'Kolenwinning', I47-15I. 


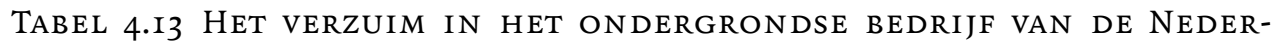
LAN DSE STEEN KOLENMIJNEN, I938-I947 (IN PROMILLE VAN HET AANTAL MOGELIJKE DIENSTEN)

\begin{tabular}{|l|c|c|c|c|c|}
\hline & $\begin{array}{c}\text { verzuim } \\
\text { totaal }\end{array}$ & ziekte & ongevallen & $\begin{array}{c}\text { willekeurig } \\
\text { verzuim }\end{array}$ & overig \\
\hline I938 & 85 & 40 & I2 & I & 32 \\
\hline I939 & 94 & 47 & I2 & I & 34 \\
\hline I940 & I00 & 48 & I3 & 2 & 37 \\
\hline I94I & I37 & 79 & I9 & 7 & 32 \\
\hline I942 & I70 & I02 & 26 & 6 & 36 \\
\hline I943 & I97 & I26 & 32 & 9 & 30 \\
\hline I944 & 271 & I7I & 35 & 28 & 37 \\
\hline I945 & 209 & II4 & 22 & I7 & 56 \\
\hline I946 & I76 & 86 & 25 & I6 & 49 \\
\hline I947 & I53 & 73 & $2 I$ & II & 48 \\
\hline
\end{tabular}

Bron: SHCL, ArchiefGSL, Statistiek.

In het voorjaar van 1943 werd daarom met de mijndirecties afgesproken dat alle nieuw geworven arbeidskrachten - met uitzondering van de jeugdige mijnwerkers - die niet tegen de eisen van de mijnarbeid bleken opgewassen, ontslagen zouden worden. Datzelfde gold voor de mijnwerkers die bij herhaling ongemotiveerd verzuimden. Volgens een opgave van Bruch werden in I943 niet minder dan 2.669 'onaangepaste elementen' ontslagen. Dat lijkt aan de hoge kant, omdat uit cijfers van het AMF blijkt, dat er in I943 slechts $\mathbf{2 . 2 0 0 ~ m i j n w e r - ~}$ kers wegens ontslag werden uitgeschreven. ${ }^{145}$ Degenen die werden ontslagen, werden nagenoeg allemaal in Duitsland verplicht tewerkgesteld. ${ }^{\mathrm{I} 46}$

Uit de cijfers van het AMF blijkt dat de arbeidsmarkt voor mijnwerkers in de loop van I943 was afgeroomd. Vergeleken met 1942 daalde het aantal nieuw ingeschreven mijnwerkers met bijna 40 procent. In 1943 nam het arbeidersbestand bij de gezamenlijke mijnen zelfs met 150 man af. Was voor menigeen mijnarbeid een aanvaardbaar alternatief voor werk in Duitsland, voor iedereen gold dat niet. 300.000 Nederlandse arbeiders doken in I942 en 1943 onder en werden op die manier onttrokken aan de officiële arbeidsmarkt. ${ }^{\mathrm{I} 7}$ De personeelsnood bij de mijnen werd in de loop van 1943 zo groot dat de Nederlandse mijnen in oktober van dat jaar toestemming kregen om Nederlandse arbeiders, die ongeoorloofd hun werk in Duitsland hadden verlaten, zonder verdere strafvervolging aan te nemen. ${ }^{\mathrm{I} 48}$ Hoeveel nieuwe mijnwerkers die toezegging opleverde, is niet bekend. In januari I944 stelde Bruch zelfs voor om onderduikers in dienst te nemen, met de belofte dat ze niet gestraft zouden worden. De mijndirecties wimpelden het voorstel als onuitvoerbaar af. Het

145 Jaarverslag AMF 1943

146 Eussen, Akkommodatie, 92-93.

I47 Klemann, Nederland 1938-1948, 85-88.

I48 Eussen, Akkommodatie, 98. 
zou onmogelijk zijn de onderduikers te bereiken en bovendien zouden zij toch niet zo naïef zijn zich op basis van een simpele toezegging aan te melden. ${ }^{\mathrm{I}}{ }^{4}$

Over het aantal Nederlandse arbeiders dat tijdens de bezettingsjaren zijn toevlucht in de mijnen zocht en daardoor deportatie naar Duitsland voorkwam, lopen de schattingen uiteen. Beheerder C.Th. Groothoff sprak in juli 1945 tijdens een persconferentie in Heerlen over 'honderden onderduikers'. ${ }^{5 \circ}$ Een paar jaar later kwam de Commissie-Couvée in haar rapport zelfs tot een aantal van 8.000. ${ }^{151}$

Het grote verschil tussen beide schattingen hangt hoogstwaarschijnlijk samen met de definiëring van het begrip 'onderduiker'. Tijdens de bezetting was er enerzijds sprake van een groep administratieve onderduikers, personen die de Arbeitseinsatz ontliepen door officieel een baan te nemen in een sector met weinig risico om voor werk in Duitsland opgeroepen te worden. Daarnaast was er een groep onderduikers die ook administratief verdween. Deze groep 'illegalen' werd door organisaties als de Landelijke Organisatie voor de Hulp aan Onderduikers (LO) bemiddeld naar clandestien werk, dat voornamelijk werd gevonden op het platteland of bij kleine ambachtelijke bedrijfjes. Wellicht dat de mijnen, net als bij andere grote bedrijven zoals Philips gebeurde, ook een aantal van deze groep 'illegalen' tewerk hebben gesteld. ${ }^{152}$

Zeker is dat een aanzienlijk aantal Nederlanders dankzij een baan in de mijnen aan dwangarbeid in Duitsland wist te ontkomen en dat de mijndirecties, zeker nadat vanaf $\mathrm{I} 942$ de jacht op arbeiders scherper werd, daar welwillend aan hebben meegewerkt. Het Duitse toezicht en de risico's, onlosmakelijk verbonden met het werk ondergronds, hadden echter tot gevolg dat niet iedereen die zijn toevlucht in de mijnen dacht te vinden, ook daadwerkelijk geplaatst of gehandhaafd kon worden. Vooral vreesden de mijndirecties dat het Duitse toezicht zou verscherpen. Verwalter Bruch was geen scherpslijper en de mijndirecties hadden enige speelruimte. Die vrees lag ook ten grondslag aan de halsstarrigheid waarmee de mijndirecties probeerden te voorkomen dat Russische krijgsgevangenen aan het werk zouden worden gezet. De komst van de Russen zou ook de komst van Duitse bewakingstroepen betekenen en meer controle konden de mijndirecties niet gebruiken. ${ }^{53}$

\section{WEDEROPBOUW, 1945-1965}

\section{Rekruteringsmoeilijkheden}

Zoals in hoofdstuk 2 reeds werd behandeld, steeg de arbeidersbezetting bij de Limburgse mijnen in de jaren 1950 sterk. De mijnen werden gezien als motor van de wederopbouw. De

\footnotetext{
149 Rutten, 'Russen niet gewenst', 177.

I50 Keesings Historisch Archief 8-I4 juli I945, 6356.

I5 Rapport Staatscommissie 1946, 70.

152 Klemann, Nederland 1938-1948, 2 I8 en 257. Overigens maakten de Arbeidsbureaus van Heerlen en Maastricht in de loop van de bezetting, toen de Duitse jacht op Nederlandse arbeiders voor de Duitse oorlogsindustrie steeds scherper werd, gebruik van de vrijstelling voor de arbeidsinzet die mijnwerkers inmiddels genoten. Op de arbeidsbureaus werden valse bedrijfspassen uitgereikt, waarmee men kon bewijzen op de mijn te werken. Alleen al door het Gewestelijk Arbeidsbureau Heerlen zouden er vijfhonderd van dergelijke valse documenten rechtstreeks zijn uitgereikt, terwijl er daarenboven nog 450 passen aan verschillende verzetsorganisaties werden doorgespeeld. Verslag van de werkzaamheden van het Gewestelijk Arbeidsbureau Heerlen in de jaren 1940-1944, 9.

153 Rutten, 'Russen niet gewenst', 189-190.
} 
kolenproductie moest omhoog en ondanks toenemende mechanisering van de kolenwinning betekende dat het werven van nieuw personeel op een arbeidsmarkt die in het algemeen als krap gold. ${ }^{154}$ Bovendien ontstond onmiddellijk na de bevrijding een grote vervangingsvraag toen duizenden arbeidskrachten die tijdens de oorlog een veilig heenkomen in de mijnen hadden gezocht, de bedrijven weer verlieten. Het preferentiebeleid betreffende de herkomst van nieuwe mijnwerkers werd niet verlaten. Al in 1945 sprak de directie van het Gewestelijk Arbeidsbureau in Heerlen die voorkeur uit bij de aanwerving van nieuwe arbeidskrachten voor de mijnen. Het liefst zag de bemiddelingsinstantie Limburgers in de mijn, maar gezien de nationale opdracht de kolenproductie op te voeren 'kan niet worden afgezien van een beroep op alle beschikbare Nederlandsche arbeidskrachten' ${ }^{155}$ Arbeidskrachten uit Limburg en uit de rest van Nederland, daar ging het nog steeds om. De mijndirecties waren het met die opvatting van harte eens.

Bij de werving van arbeidskrachten op de Nederlandse arbeidsmarkt hadden de mijnen te maken met een aantal hardnekkige problemen. In de eerste plaats speelde het gebrek aan huisvesting de mijnen parten. Door het grote tekort aan eengezinswoningen waren de mijnen gedwongen nieuw personeel te rekruteren binnen een straal rond het bedrijf waarbinnen woon-werkverkeer redelijkerwijs mogelijk was. Wie van verder kwam dan de eerder genoemde twaalf- of dertienurengrens moest verhuizen. Deze groep binnenlandse migranten bestond hoofdzakelijk uit jonge ongehuwde arbeiders, die in gezellenhuizen werden ondergebracht. De huisvestingsproblematiek was een belangrijke reden dat de wervingsacties van de mijnen het grootste succes hadden in de provincie Limburg. Deze mijnwerkers konden meestal blijven wonen in hun vertrouwde omgeving. De mijnen zetten pendelbussen in die hen naar hun werk brachten. Van de nieuwe mijnwerkers in de naoorlogse periode was bijna de helft in Limburg geboren. Van de Nederlanders was driekwart geboren in een Limburgse gemeente.

Een tweede structureel probleem was het aanzien van het mijnwerkersberoep. Hoewel dat in de loop van de tijd verbeterde, mede dankzij de relatief hoge lonen en de goede secundaire arbeidsvoorwaarden, was en bleef mijnarbeid een zwaar beroep. De keuze daarvoor was niet zelden negatief gemotiveerd in een situatie dat er geen ander werk te krijgen was. Dat gold ook in de naoorlogse periode en zeker voor de wervingsgebieden buiten de eigenlijke mijnstreek. Zo bleek uit onderzoek dat Staatsmijnen in I957 liet uitvoeren naar het arbeidspotentieel voor de in aanleg zijnde mijnzetel Beatrix, dat in de Midden- en Noord-Limburgse gemeenten Broekhuizen, Meerlo, Horst, Sevenum, Helden, Meijel, Weert en Nederweert bij ongeschoolde arbeiders en landbouwers de animo voor mijnarbeid gering was. Algemeen bestond de vrees dat mijnarbeid de gezondheid zou schaden. ${ }^{156}$

Het succes van werving van Nederlands personeel werd sterk bepaald door de algemene stand van de arbeidsmarkt. Was er genoeg alternatieve werkgelegenheid, dan merkten de mijnen dat onmiddellijk aan de terugloop van het aantal spontane aanmeldingen, de slechtere resultaten van de actieve wervingsacties en de toename van het personeelsverloop. ${ }^{57}$

I54 Rapport van de Commissie Verhoging Kolenproductie (z.p. z.j.).

155 Verslag GAB Heerlen 1945, 29.

I56 Messing, Geschiedenis van de mijnsluiting, I73-174.

I57 Voor het verloop: zie hoofdstuk 6. 
Alternatieven op de arbeidsmarkt werden aantrekkelijker naarmate in de loop van de jaren vijftig de lonen in de mijnen en in andere industrieën naar elkaar toe groeiden..$^{158}$

Een derde steeds terugkerend probleem was de grensligging van de Limburgse mijnstreek. Het niveau van lonen en arbeidsvoorwaarden in het omringende buitenland waren van directe invloed op de personeelsvoorziening bij de Limburgse mijnen. ${ }^{159}$ Een hoger loonpeil in de nabije Belgische en Duitse mijnen had onmiddellijk een trek over de grens van Limburgse arbeidskrachten tot gevolg. In de jaren vijftig en zestig bestond er een aanzienlijke uitgaande pendel naar de mijnen in beide buurlanden. Tot halverwege de jaren vijftig waren het vooral de Belgische mijnen in Luik en de Kempen die Limburgse arbeiders lokten. ${ }^{160}$ Vanaf het midden van de jaren vijftig verlegde zich de pendelstroom richting Duitsland. ${ }^{16 \mathrm{r}}$ Ongetwijfeld had de aantrekkingskracht van de naburige Belgische en Duitse arbeidsmarkt gevolgen voor de wervingsacties van de mijnen. Het grootste probleem was echter dat de mijnen in de grensstreek ervaren arbeidskrachten uit de Nederlandse mijnen losweekten. Vooral het personeelsverloop werd erdoor vergroot. Om die reden wordt de grenspendel verder in hoofdstuk 6 aan de orde gesteld.

\section{Werving en selectie}

De resultaten van de werving van personeel op de Nederlandse arbeidsmarkt werden voor een belangrijk deel bepaald door conjuncturele schommelingen en de daarmee samenhangende ruimte op de arbeidsmarkt. Tot I95I hadden de mijnen grote moeite om hun personeel op de Nederlandse arbeidsmarkt te vinden. Hoe groot de opgave was om op korte termijn de bedrijven te voorzien van een werkbare bezetting blijkt wel uit de samenwerking die de Beheerder van de mijnen al in 1945 aanging met de openbare arbeidsbemiddeling. ${ }^{162}$ Vóór de oorlog hadden de mijndirecties weinig op gehad met de arbeidsbeurzen, maar nu was de nood hoog. De mijnen en het Gewestelijk Arbeidsbureau (GAB) Heerlen organiseerden vanaf september 1945 regelmatig gemeenschappelijke wervingsacties op de Nederlandse arbeidsmarkt. Voor elke wervingsactie werd een team samengesteld, bestaande uit een beambte van het Beheer der Mijnen, ${ }^{163}$ één ondergronds mijnwerker en één ambtenaar van het GAB in Heerlen. Aan het wervingsteam werd een beambte van de mijnpolitie toegevoegd, die met het onderzoek naar de antecedenten, politieke betrouwbaarheid en maatschappelijk gedrag van de sollicitanten werd belast. ${ }^{164}$

Op verschillende plaatsen in het land werden bijeenkomsten belegd, waar geïnteresseerden werden voorgelicht over het werk in de mijn. In de advertenties en affiches waarmee

158 Roemen e.a., Verkenning, 83-85.

159 Jaarverslag van de Inspecteur-Generaal over 1957, I2.

I60 Willibrord Rutten, 'Buitenbeentjes. Nederlandse kompels in de Luikse kolenmijnen na de Tweede Wereldoorlog'. Concept (2010) te verschijnen in SSEGL LVI (20II).

I6I Sophie Bouwens, Over de streep. Grensarbeid vanuit Zuid-Limburg naar Duitsland, 1958-2001 (Hilversum 2008).

I62 Bij een reorganisatie van de openbare arbeidsbemiddeling in I94I waren de Districtsarbeidsbeurzen vervangen door Gewestelijke Arbeidsbureaus. De mijnstreek werd voortaan bediend door het Gewestelijk Arbeidsbureau Heerlen. Langeweg, Van Adreskantoor, 74-75.

I63 Na de beëindiging van het Beheer per I januari I 949 vervangen door een vertegenwoordiging van de Gezamenlijke Steenkolenmijnen in Limburg (GSL).

I64 Jaarverslag GAB Heerlen 1946, 7 . 
ongehuwde jongemannen tussen de 18 en 30 jaar werden uitgenodigd dergelijke informatiebijeenkomsten te bezoeken, werden de positieve kanten van het beroep van mijnwerker breed uitgemeten. Mijnarbeid werd daarin omschreven als een interessant, echt mannelijk beroep met hoog loon, goede sociale voorzieningen, een pensioen op relatief jonge leeftijd, extra distributiebonnen voor de aanschaf van allerlei goederen die vlak na de oorlog nog niet vrij verkrijgbaar waren ${ }^{165}$ en een ruim verlof. Andere affiches verwezen naar de wens van veel Nederlanders na de oorlog om te emigreren en elders een nieuwe toekomst op te bouwen. ${ }^{166}$ 'Emigreer in eigen land' werd door de mijnen als alternatief aangeboden. Ook in de mijnbouw zou een goed bestaan en een rijke toekomst te vinden zijn. ${ }^{\mathrm{I} 7}$

De acties strekten zich gaandeweg uit over het hele land, alhoewel op last van de Minister van Sociale Zaken aanvankelijk niet geworven werd in de door de oorlog zwaar geteisterde gebieden in Zeeland en Noord- en Midden-Limburg. ${ }^{168}$ De beste resultaten leverde de rekrutering op in de mijnstreek zelf en in Noord-en Midden-Limburg (waar vanaf 1946 weer werd gerekruteerd). De acties in de rest van Nederland waren teleurstellend. Dat wordt geillustreerd door een overzicht dat het GAB Heerlen eind I950 opstelde van de zogenaamde intergewestelijke mijnbemiddeling: de bemiddeling van arbeiders van buiten het gewest Heerlen naar een baan in de mijn. ${ }^{169}$ Tussen I oktober 1945 en 3I december 1950 hadden zich 13.445 personen via de kanalen van de arbeidsbemiddeling aangemeld voor mijnarbeid. Van hen waren er 7.56o afgewezen of hadden zich vrijwillig teruggetrokken. 5.65I Arbeiders waren daadwerkelijk in dienst getreden, terwijl 234 sollicitaties nog in behandeling waren. Op 3I december 1950 waren daarvan nog slechts I.53I arbeiders in de mijn werkzaam: een uiteindelijk resultaat van niet meer dan II procent. ${ }^{170}$

In totaliteit leverden de acties van de tweede helft van de jaren veertig te weinig nieuwe mijnwerkers op. Vooral ondergronds bleven de tekorten groot. Naast de inzet van Poolse ex-militairen en displaced persons en de aanwerving van uit Indonesië gerepatrieerde Nederlandse militairen werden ook politieke delinquenten als ondergronder ingezet. ${ }^{17 \mathrm{I}} \mathrm{Zij} \mathrm{moch}$ ten vrijwillig daarvoor kiezen als invulling van de hen opgelegde straf. Beheerder Groothoff stond erop dat de delinquenten alleen op basis van vrijwilligheid medewerking verleenden. Na gedane arbeid in de mijn werden zij opgesloten in speciale gevangenkampen die onder toezicht stonden van het Directoraat-Generaal Bijzondere Rechtspleging. Het voordeel van tewerkstelling in de mijnen was voor Justitie dat de delinquenten zelf de kosten van levensonderhoud tijdens hun detentie terugverdienden en voor de gemeentelijke sociale diensten dat zij konden besparen op uitkeringen aan de gezinnen van deze delinquenten. En natuurlijk was de inzet van politieke delinquenten in het belang van de opvoering van de kolenproductie.

I65 In het kader van de Stichting Mijnwerkersvoorziening (SMV).

I66 Herman Obdeijn en Marlou Schrover, Komen en gaan. Immigratie en emigratie in Nederland vanaf 1550 (Amsterdam 2008) I96-228.

I67 Continium Discovery Center Kerkrade, Wervingsaffiches 'Hier is Uw kans', 'Een nieuwe toekomst, een nieuw bestaan', 'Emigreer in eigen land'.

I68 Jaarverslag GAB Heerlen 1945, 25-28.

I69 Het gewest Heerlen van de arbeidsbemiddeling omvatte het gebied dat globaal overeenkwam met de oostelijke en westelijke mijnstreek.

I70 Jaarverslag Inspecteur-Generaal 1950, II-I2.

I7I A.D. Belinfante, In plaats van bijltjesdag. De geschiedenis van de Bijzondere Rechtspleging na de Tweede Wereldoorlog (Assen I978) 306309; Marcel Krutzen, 'Over strafkampen voor “foute Nederlanders” en het mijnkamp Julia te Eygelshoven [I947-I957]', Land van Herle 60: 4 (2010) I47-I62. 
In augustus 1945 werd er mee begonnen bij de Willem-Sophia. ${ }^{122}$ Aan het eind van dat jaar waren er bij de gezamenlijke mijnen 244 politieke delinquenten als ondergronder tewerkgesteld. In I946 en I947 nam dat aantal tot het tienvoudige toe (tabel 4.I4). Hoewel de delinquenten vaak in ongunstige pijlers werden geplaatst, zette hun tewerkstelling veel kwaad bloed bij de Limburgse mijnwerkers. Mijnarbeid werd kennelijk op één lijn gesteld met gevangenisstraf. Aan de toch al niet al te beste reputatie van het mijnwerkersvak in de jaren vlak na de oorlog werd nog meer afbreuk gedaan. ${ }^{173}$ Bij de troonwisseling in december 1948 werd aan veel politieke delinquenten amnestie verleend. Door de amnestieregeling verlieten ruim 750 politieke delinquenten de mijn. ${ }^{174}$ In de eerste helft van de jaren I950 nam het aantal politieke delinquenten verder af.

TABEL 4.I4 ONDERGRONDS TEWERKGESTELDE POLITIEKE DELINQUENTEN BIJ DE NEDERLAN DSE STEEN KOLENMIJNEN, I945-I957

\begin{tabular}{|c|c|c|}
\hline & totale ondergrondse bezetting & waarvan politieke delinquenten \\
\hline I945 & I9.043 & 244 \\
\hline 1946 & 23.435 & 2.486 \\
\hline 1947 & 25.272 & 2.523 \\
\hline I948 & 25.427 & I. 238 \\
\hline 1949 & $26.8 \mathrm{I} 7$ & 784 \\
\hline 1950 & 27.248 & 322 \\
\hline I95I & $29 \cdot 336$ & 238 \\
\hline 1952 & 30.521 & 104 \\
\hline 1953 & 30.420 & 37 \\
\hline 1954 & $30.66 \mathrm{I}$ & 17 \\
\hline 1955 & $30.44 \mathrm{I}$ & I9 \\
\hline 1956 & 30.766 & I9 \\
\hline 1957 & 31.505 & I \\
\hline
\end{tabular}

Bron: SHCL, ArchiefGSL, Statistiek.

De korte algemene conjuncturele inzinking in de jaren I95I en 1952 bleek gunstig voor de personeelsvoorziening van de mijnen. In I95I was voor het eerst sinds de bevrijding het Nederlandse aanbod voor ondergrondse mijnarbeid bevredigend. 'Door de minder gunstige perspectieven op de arbeidsmarkt [...] was de trek naar de mijnen bijzonder groot', noteerde het GAB Heerlen in I95I. Het aanbod voor mijnarbeid was met 4.535 aanmeldingen van buiten Zuid-Limburg meer dan het viervoudige van $1950 .{ }^{175}$ Ook in 1952 leverden spontane aanmeldingen en binnenlandse wervingsacties betere resultaten op dan in de tweede helft

\footnotetext{
172 Jaarverslag GAB Heerlen 1945, 3I.

173 Cammaert, 'Tweede Wereldoorlog', 66.

174 Jaarverslag Inspecteur-Generaal over 1946, 1947 en 1948, I2.

175 Jaarverslag GAB Heerlen 1951, 7.
} 
van de jaren veertig. ${ }^{176}$ Dankzij het toegenomen aanbod op de Nederlandse arbeidsmarkt konden de tekorten voor een deel worden weggewerkt (tabel 2.2, hoofdstuk 2).

$\mathrm{Na}$ twee mindere jaren trok landelijk de werkgelegenheid in 1953 weer aan. ${ }^{177}$ Ook op de nabije Belgische arbeidsmarkt waren ruime alternatieven voorhanden. ${ }^{178}$ De mijnen merkten dat onmiddellijk doordat het aantal spontane aanmeldingen afnam en ook de wervingsacties minder resultaat opleverden. ${ }^{179}$ Slechts een wervingsactie van Staatsmijnen, weer in samenwerking met de Gewestelijke Arbeidsbureaus, in Noord-Limburg en oostelijk Noord-Brabant, leverde in 1953 en 1954 bevredigende resultaten op: I.305 personen konden in dienst worden genomen, waarvan I.I92 ondergronds. Aangezien echter ook het vertrek van personeel toenam doordat er ruimere alternatieven op de arbeidsmarkt waren, leverde de wervingsactie per saldo weinig op. ${ }^{180}$ Tot de kolencrisis van 1958 schoot de Nederlandse arbeidsmarkt tekort om aan de onverminderd grote vraag vanuit de mijnbedrijven te voldoen. Ondanks verbetering van de arbeidsvoorwaarden, zoals verhoging van de kinderbijslag en de kerstgratificatie, en het toekennen van allerlei premies, liepen de tekorten aan mijnwerkers in deze jaren op tot 6 à 7 procent van de arbeidersbezetting. ${ }^{18 \mathrm{I}} \mathrm{In}$ toenemende mate deden de mijnen daarom een beroep op zogenaamd aannemerspersoneel: door aannemers uitgeleend personeel, waarmee tekorten in het bovengrondse mijnbedrijf werden aangevuld. Doorgaans werden ze op de losvloer of in de zeverijen tewerkgesteld, samen met de arbeiders in eigen dienst. ${ }^{82}$ In juni 1956 werkten bij de gezamenlijke mijnen 783 personen via aannemers. Het overgrote deel van dit personeel kwam uit ZuidLimburg, maar de mijnindustrie trok ook aannemerspersoneel aan uit de rest van Nederland. Meestal betrokken de mijnen dit personeel van verschillende bedrijven. Uitzondering waren de Oranje-Nassau Mijnen, die het grootste deel van het ingeleende personeel betrok van één enkel bouwbedrijf, de firma Lemmens in Brunssum. ${ }^{\mathrm{I} 3}$ Daarnaast namen de mijnen in 1955 voor het eerst sinds het eind van de jaren veertig voor het ondergrondse werk weer grotere contingenten arbeiders uit het buitenland aan. Het werd als een noodoplossing beschouwd: 'Hoewel er van moet worden uitgegaan dat een gezonde ontplooiing van de mijnindustrie in de allereerste plaats moet steunen op Nederlandse arbeidskrachten, moest, teneinde een behoorlijk functioneren van de bedrijven te waarborgen, gelet op de krappe arbeidsmarkt hier te lande en in Limburg in het bijzonder, in stijgende mate een beroep worden gedaan op buitenlandse arbeidskrachten zodat naast wervingsacties in eigen land ook in het buitenland een actieve werving plaats vond', noteerde de Inspecteur-Generaal der Mijnen in $1956 .{ }^{184}$ Tussen 1955 en 1957 liep daardoor het percentage Nederlanders in de mijnen terug van 93 naar 89 procent.

Desondanks werd anno I957 in een in opdracht van de Hoge Autoriteit van de EGKS verricht onderzoek met optimisme gesproken over de toekomstige arbeidsvoorziening van de

I76 Idem 1952, 3.

177 Roemen e.a., Verkenning, 65-66.

I78 Rutten, 'Buitenbeentjes'.

179 Jaarverslag GAB Heerlen 1953, 3-6.

I80 Jaarverslag Inspecteur-Generaal 1954, 17.

I8I Zie ook hoofdstuk 2, tabel 2.2.

I82 Jaarverslag Inspecteur-Generaal $1955,60$.

I83 Peet en Rutten, Oranje-Nassau Mijnen, 270-272.

I84 Jaarverslag Inspecteur-Generaal 1956, I6. 


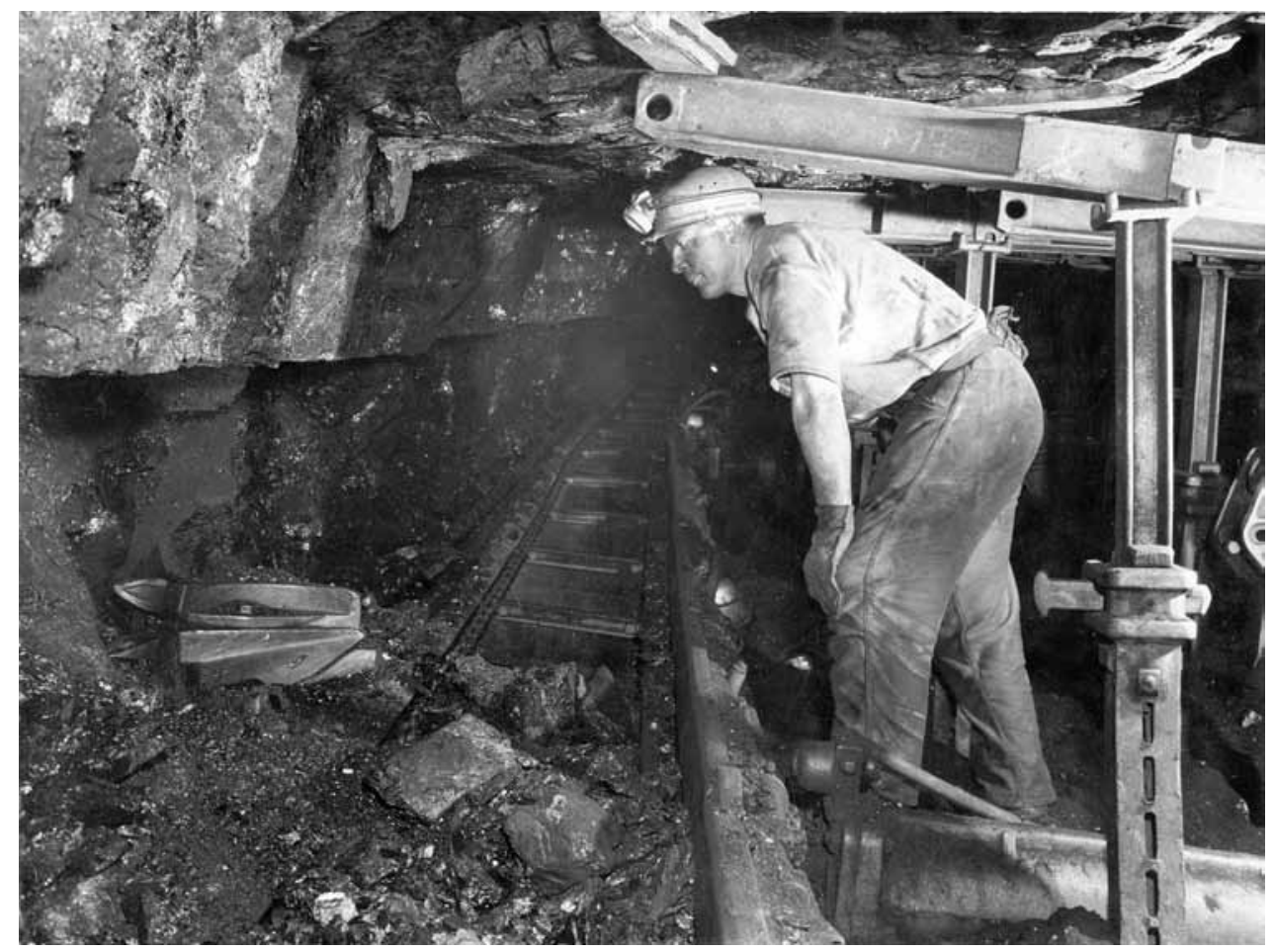

Een mechanische pijler in de Julia. De kolen wordt losgebroken met een schaafinstallatie (links) en via een kettingtransporteur (midden) uit de pijler vervoerd. De ondersteuning moest echter nog handmatig worden verplaatst. 1958. Bron: Fotocollectie Continium Kerkrade, F3993.

Nederlandse mijnen. De grote schaarste aan regionale arbeidskrachten en de stroeve aanwerving zouden van tijdelijke aard zijn. In dat kader werd gewezen op de gunstige demografische ontwikkeling van de provincie Limburg. Limburg had een jonge bevolking en de (mannelijke) beroepsbevolking zou de komende jaren groeien. ${ }^{185}$ Naar verwachting zouden daardoor omstreeks 1965 de personeelstekorten van de mijnen voorbij zijn. Zelfs achtten de auteurs van het onderzoeksverslag het niet onmogelijk dat het regionale aanbod van mijnpersoneel zich dusdanig zou ontwikkelen, dat, naast Staatsmijn Beatrix die in aanleg was, in Midden-Limburg nog één of twee nieuwe mijnen konden worden geopend. ${ }^{186}$

Spoedig na het verschijnen van het onderzoeksverslag diende zich de kolencrisis aan die de toekomst van de Nederlandse mijnbouw in een ander perspectief plaatste. Voor het eerst sinds de bevrijding kwam de afzet van steenkool onder druk te staan. Bij de noodzakelijke inkrimping van het personeelsbestand kwam het preferentiebeleid weer duidelijk naar voren: mijnwerkers uit Limburg en de rest van Nederland werden ontzien. ${ }^{87}{ }^{87}$ Buitenlandse mijnwerkers betaalden ook nu weer het gelag van de crisissituatie. Eind 1960 was het percentage Nederlanders weer op het niveau van 1955.

I85 Zie ook hoofdstuk 3.

I86 Roemen e.a., Verkenning, I04.

I87 Messing, Geschiedenis van de mijnsluiting, I30. 


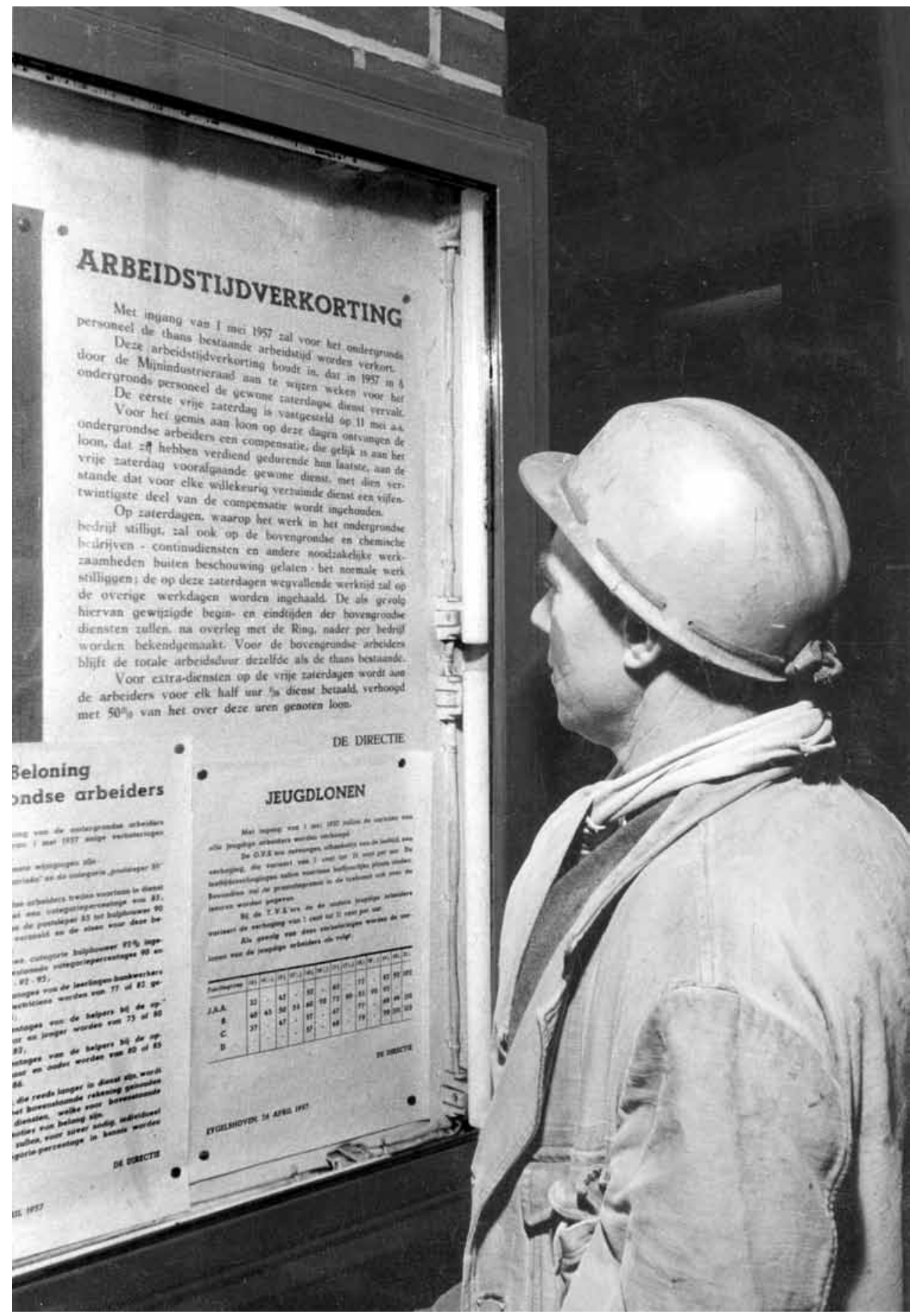

Een mijnwerker van de Laura/Julia leest de aankondiging van de invoering van één vrije zaterdag per maand. De regeling ging in op 1 mei 1957. Het was het begin van een arbeidstijdverkorting die tussen 1957 en 1961 geleidelijk werd doorgevoerd. 1957. Bron: Fotocollectie Continium Kerkrade, F2455. 
Vanaf I960 was opnieuw sprake van een krappe Nederlandse arbeidsmarkt en waren er weer grote moeilijkheden om Nederlandse arbeiders voor de mijnen te werven. De personeelstekorten werden des temeer gevoeld door de geleidelijke invoering, op initiatief van de Mijnindustrieraad, van de vrije zaterdag tussen 1957 en I96r ${ }^{\text {I88 }}$ Daarnaast ging de uittocht van Nederlanders uit de mijnen versneld door nu de kolencrisis had aangetoond dat de dagen van de steenkool waren geteld. Omdat jonge arbeidskrachten de beste kansen hadden op de arbeidsmarkt vertrok net deze categorie. Hoewel tussen 1946 en I96o de gemiddelde leeftijd van nieuwe mijnwerkers daalde van ruim 22 tot ruim ig jaar (tabel 4.II), vooral ten gevolge van het aantrekken van leerlingen voor de Ondergrondse Vakscholen (OVS), verouderde het totale personeelsbestand snel. In I944 was 50,2 procent van de ondergronders 30 jaar of ouder, in 1959 was dat 59 procent, in 1964 zelfs 66,8 procent. De jonge aanwas was in aantal niet voldoende om het grote verloop van de meest productieve mijnwerkers te compenseren. Vooral de allocatie via de OVS liet na 1958 steeds meer te wensen over. ${ }^{189}$ De veroudering van het personeel had ernstige consequenties voor de mijnbedrijven. De productiviteit en daarmee de rentabiliteit kwam in gevaar, en dat net in een tijd dat de mijnen alle zeilen moesten bijzetten om de internationale concurrentie op de energiemarkt het hoofd te kunnen bieden. Uiteindelijk zou het gebrek aan jonge arbeiders een belangrijke reden zijn voor het regeringsbesluit de Limburgse mijnen te sluiten.

\section{BESLuit}

Staatsmijnen en de particuliere mijnen waren het eens over het beginsel dat mijnwerkers bij voorkeur op de Nederlandse, en liefst Limburgse, arbeidsmarkt gerekruteerd moesten worden. In dit hoofdstuk stond de vraag centraal in hoeverre de mijnondernemingen in dit beleid slaagden.

Over het geheel genomen had het preferente rekruteringsbeleid succes. Gemiddeld genomen waren tussen 1900 en ${ }_{9} 965$ van elke tien aangenomen mijnwerkers er zeven Nederlander. Van de Nederlanders kwam gemiddeld een ruime meerderheid van bijna 75 procent uit Limburg. Binnen de provincie scoorde de mijnstreek het hoogst met 68 procent. Dit rekruteringspatroon had tot gevolg dat op het moment dat in december 1965 minister Den Uyl de sluiting van de mijnen aankondigde, 85 procent van de totale mijnwerkerspopulatie Nederlander was. Zelfs ondergronds, waar de personeelsproblemen altijd het grootst waren, was 84 procent Nederlander. Hoewel cijfers over de regionale herkomst van de mijnwerkerspopulatie op het moment van de sluiting ontbreken, mag op grond van de rekruteringscijfers worden aangenomen dat van de Nederlanders een ruime meerderheid afkomstig was uit de regio. Deze percentages autochtonen waren hoog, zeker in vergelijking met de naburige mijnbekkens in Aken, de Belgische Kempen en vooral Luik. ${ }^{190}$

Dat succes kwam niet vanzelf, maar was een gevolg van een in de loop van de tijd opgebouwde wervingspolitiek. Na moeilijkheden in de periode van opbouw kreeg het preferen-

I88 Math Akkermans, De publiekrechtelijke bedriifsorganisatie in de Nederlandse steenkolenmijnindustrie (doctoraalscriptie UVA, Amsterdam i986) $7 \mathrm{I}-72$.

I89 Voor de rol van de Ondergrondse Vakscholen bij de opbouw van een stabiele kern van mijnwerkers zie hoofdstuk 6.

190 Knotter, 'Inleiding', 28-29. 


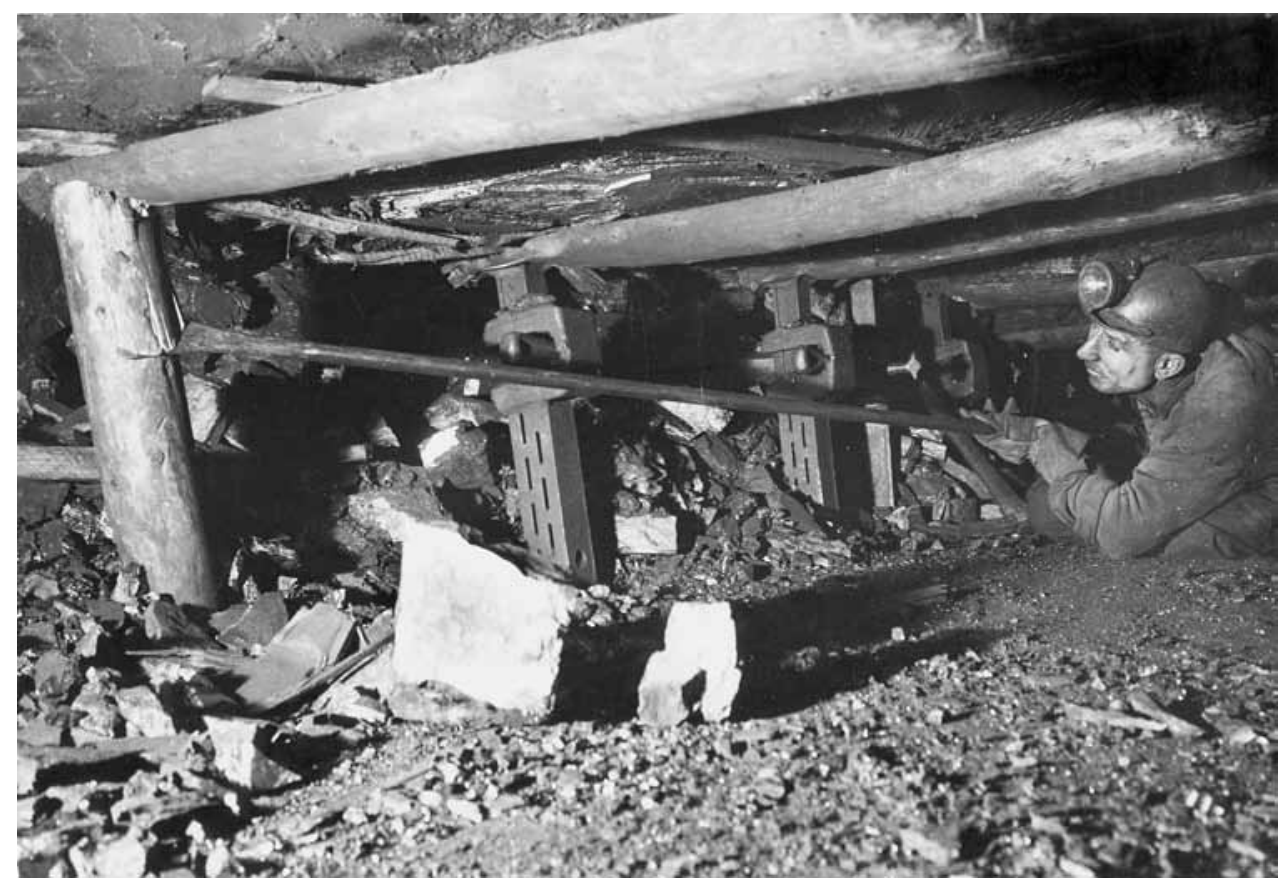

Houwer J. Meertens van de Julia bezig met 'roven': het weghalen van de ondersteuning in een ontkoolde pijler. Omstreeks 1960. Bron: Fotocollectie Continium Kerkrade, F3969.

tiebeleid van de mijnen bij de personeelsvoorziening tijdens de crisisjaren de wind mee. De mijnen maakten gebruik van de conjuncturele neergang en de ruimere arbeidsmarkt om de minst preferente groepen te vervangen door jonge en in de streek gewortelde arbeidskrachten.

Na de oorlog probeerden de mijnondernemingen dit personeelsbeleid te consolideren. Tot het midden van de jaren vijftig lukte dat: voor een belangrijk deel kwam de nieuwe instroom in het ondergrondse bedrijf van jonge Limburgse arbeidskrachten die scholing in mijnarbeid hadden genoten in door de mijnbedrijven opgezette interne opleidingen.

In de tweede helft van de jaren vijftig begon het preferentiebeleid echter spaak te lopen door toenemende alternatieven op de arbeidsmarkt en in opleidingsmogelijkheden buiten de mijnbouw. Desondanks bleek het nog een tijdlang mogelijk om een meerderheid van de nieuwe mijnwerkers te rekruteren op de Nederlandse en Limburgse arbeidsmarkt. In de periode I945-1965 kwam nog steeds bijna de helft van de nieuwe mijnwerkers uit Limburg en 67 procent uit heel Nederland. Pas toen begin jaren zestig het vertrouwen in de toekomst van de mijnbouw, bij een arbeidsmarkt die in het algemeen zeer krap was, snel afnam, keerden Nederlandse arbeidskrachten zich en masse van de mijnen af. Vooral nieuwe intredingen namen sterk af. Zoals in het volgende hoofdstuk zal blijken, moesten de mijnondernemingen na 196r het wervingsbeleid verleggen naar buitenlandse arbeidsmarkten. Het aantal Nederlandse mijnwerkers in dienst van de mijnen bleef echter relatief groot. 


\section{Hoofdstuk 5 \\ Buitenlandse arbeiders in de Nederlandse steenkolenmijnen}

In het vorige hoofdstuk werden de pogingen van de mijnondernemingen besproken om de meest preferente groepen, Limburgers en arbeidskrachten uit de rest van Nederland, voor mijnarbeid te rekruteren. Zoals we zagen, waren die pogingen redelijk succesvol, maar zonder aanvulling van arbeidskracht uit het buitenland konden de Nederlandse steenkolenmijnen niet. De achtergronden van de tewerkstelling van buitenlandse arbeidsmigranten komen in dit hoofdstuk aan de orde.

In de fases van opbouw, consolidatie en neergang van de arbeidsmarkt voor mijnwerkers, die onlosmakelijk waren verbonden met de levenscyclus van de mijnbedrijven, speelden arbeidsmigranten met een niet-Nederlandse nationaliteit steeds een rol. De vraag is of, en in hoeverre de specifieke positie die arbeidsmigranten van over de grens in het Nederlandse mijnbedrijf hadden, in de loop van die ruim zes decennia veranderde. Daarbij is het van belang een onderscheid te maken tussen de kwantitatieve en kwalitatieve functie van arbeidsmigratie voor het mijnbedrijf.

De positie van migranten op de arbeidsmarkt is veelvuldig thema van historisch onderzoek geweest. ${ }^{I}$ Een belangrijke factor in de verklaring van de rol van arbeidsmigranten is het inzicht dat de arbeidsmarkt niet homogeen is, maar bestaat uit een aantal segmenten of deelmarkten. Zo gaat de theorie van de dubbele arbeidsmarkt ervan uit dat er enerzijds sprake is van een intern segment met vaste werkgelegenheid en stabiele arbeidsmarktverhoudingen, en anderzijds een extern segment van wisselende omvang en samenstelling met tijdelijke arbeidscontracten. ${ }^{2}$ Het externe of secundaire segment heeft een bufferfunctie, waarmee werkgevers conjuncturele fluctuaties in de vraag naar arbeidskrachten kunnen opvangen. Bovendien worden de functies in dit externe segment vaak gekenmerkt door fysiek zware, ongezonde, ongeschoolde en eentonige werkzaamheden. ${ }^{3}$ Herkomst blijkt een van de factoren die bepalen tot welk segment een werknemer behoort. ${ }^{4}$ In veel gevallen belanden buitenlandse migranten in het secundaire segment, waar ze die banen vervullen waarvoor conjuncturele vraag bestaat, of die door plaatselijke arbeidskrachten zó onaantrekkelijk worden gevonden dat er een structureel tekort dreigt of zelfs al bestaat. ${ }^{5}$ In deze categorie viel ook mijnarbeid. De inzet van buitenlandse migranten als mijnwerker was daarom regelmatig noodzakelijk.

\footnotetext{
I Voor een recent overzicht zie: Klaus J. Bade, P.C. Emmer, L. Lucassen e.a. (ed.), Enzyklopädie Migration in Europa: vom 17. Jahrhundert bis zur Gegenwart (Paderborn/München 2008). De rol van buitenlandse arbeidskrachten op de arbeidsmarkt voor mijnwerkers werd uitgebreid belicht in: Knotter (ed.), Themanummer 'Arbeidsmigranten en grensarbeiders'.

2 Knotter, Economische transformatie, 16.

3 Klaus J. Bade, Europa in Bewegung. Migration vom späten 18. Jahrhundert bis zur Gegenwart (München 2000) I09-II3.

4 Noordegraaf, 'Arbeid en arbeidsmarkt', 362.

5 Kösters-Kraft, Großbaustelle, 55-57.
} 
Migratie kan echter nog een andere functie voor de arbeidsmarkt hebben dan het leveren van (tijdelijke) arbeidskrachten voor zwaar fysieke ongeschoolde werkzaamheden. Arbeidsmigranten kunnen ook een belangrijke rol spelen bij de overdracht van kennis en vaardigheden die in de omgeving waar ze zich vestigen niet of in onvoldoende mate aanwezig zijn. ${ }^{6}$ De transfer van hun deskundigheid kan zowel direct en indirect verlopen. Direct, doordat ze door hun ervaring meteen volwaardig kunnen worden ingezet in het productieproces en indirect, doordat ze op de werkplek optreden als opleiders die hun ervaring overdragen op ongeschoolde collega's. ${ }^{7}$ Door hun ervaring en de onmisbare positie die ze innemen in (startende) ondernemingen, kunnen deze arbeidsmigranten gerekend worden tot het interne of primaire segment van de arbeidsmarkt. Het belang van de aanwezigheid van ervaren arbeidskrachten geldt des te meer als het een sector betreft als de steenkolenmijnbouw, met zijn zeer specifieke arbeidsomstandigheden, waar een goede training van ongeschoolde krachten essentieel is. ${ }^{8}$

De hierboven geformuleerde onderzoeksvraag naar de (veranderende) positie van buitenlandse migranten in de Nederlandse mijnen zal worden beantwoord door het aantal en aandeel buitenlanders in de mijnbouw over een tijdsbestek van ruim zes decennia te volgen. Hierdoor komen zowel de structurele aanwezigheid van deze groep arbeiders als conjunctureel bepaalde schommelingen in de loop van de tijd aan het licht. De (structurele) positie op de arbeidsmarkt voor mijnwerkers wordt onderzocht door na te gaan in welke mate buitenlandse arbeiders, in vergelijking met hun Nederlandse collega's, op specifieke plaatsen binnen de mijnbedrijven terechtkwamen. Conjuncturele schommelingen in de rekrutering van mijnwerkers worden opgespoord door de jaarlijkse groeivoet van het aantal buitenlandse en Nederlandse arbeiders binnen het ondergrondse bedrijf van de mijnen te vergelijken. Ook wordt de herkomst van de arbeidsmigranten uit het buitenland in kaart gebracht en verklaard. Op de achtergrond is steeds het overheidsbeleid inzake de toelating van vreemdelingen op de Nederlandse arbeidsmarkt aanwezig. De vraag is of veranderende regelgeving op dit gebied de rekruteringsmogelijkheden van buitenlandse arbeidsmigranten voor de mijnondernemingen heeft beïnvloed.

Uiteindelijk zal de analyse die in dit hoofdstuk wordt gepresenteerd antwoord geven op de vraag waarom en in welke omstandigheden de directies van de Nederlandse steenkolenmijnen besloten om een beroep te doen op buitenlandse arbeidskrachten, de in principe minst preferente groep op de arbeidsmarkt.

Ook bij de kwantitatieve gegevens die in dit hoofdstuk worden gepresenteerd, gaat het steeds om de arbeidersbezetting. Een tweede kanttekening geldt de definiëring van het begrip 'buitenlandse arbeidskracht'. Uitgegaan wordt van de nationaliteit van de betrokkenen. Buitenlander is dan iedereen die niet de Nederlandse nationaliteit bezit.

6 Bade, Europa in Bewegung, $\mathrm{II}_{3}$.

7 M.C.M. van Elteren, Staal en arbeid. Een sociaal-historische studie naar industriële accommodatieprocessen onder arbeiders en het desbetreffend bedriifsbeleid bij Hoogovens IJmuiden, 1924-1966 (Leiden I986) I-I2, II4-II6.

8 Franz-Josef Brüggemeier, Leben vor Ort. Ruhrbergleute und Ruhrbergbau 1889-1919 (München I983) 99-102. 


\section{BUITENLANDERS IN DE MIJN}

Uiteraard is de ontwikkeling van het aantal buitenlandse arbeidskrachten in de Nederlandse steenkolenmijnen het spiegelbeeld van de aanwezigheid van Nederlandse arbeiders. In grafiek 5.I is de absolute en relatieve aanwezigheid van buitenlandse mijnwerkers in beeld gebracht. Het verloop van de lijnen in de grafiek kan zowel door structurele als door conjuncturele factoren worden verklaard. De structurele aanwezigheid van mijnwerkers met een buitenlandse nationaliteit bij de Nederlandse mijnen was het gevolg van het feit dat een aantal van hen in de loop van de tijd geworteld raakte in de Limburgse samenleving en ging behoren tot de vaste arbeidersstam, waardoor ze stegen op de preferentieladder. Voor een ander gedeelte moet de aanwezigheid van buitenlandse mijnwerkers worden verklaard door jaarlijkse schommelingen in de vraag naar en het aanbod van arbeidskrachten uit de meer preferente groepen. Uit tabel 4.I bleek al dat het percentage van buitenlandse arbeiders in de rekruteringen van de mijnen in verschillende periodes sterk varieerde. De achtergronden van die schommelingen kunnen ook van jaar tot jaar worden bekeken. Wanneer het aantal buitenlandse mijnwerkers gedurende een bepaald jaar stijgt, mag worden aangenomen dat er een tekort bestond aan Nederlandse arbeiders voor de mijnen. Dat is a fortiori het geval wanneer het groeipercentage van het aantal vreemde arbeiders binnen het bedrijf groter is dan dat van de autochtone personeelsbezetting. Het omgekeerde is het geval bij een negatief groeipercentage. In grafiek 5.2 zijn die jaarlijkse groeipercentages voor de periode 1920-1965 uitgezet voor het segment van de arbeidsmarkt waar steeds de grootste discrepanties bestonden: de ondergrondse mijnarbeid. Gegevens uit deze jaren werden aange-

GRAFIEK 5.I HET AANTAL EN PERCENTAGE BUITEN LANDERS IN HET ARBEIDERSBESTAND VAN DE NEDERLANDSE STEEN KOLENMIJNEN, I905-I965

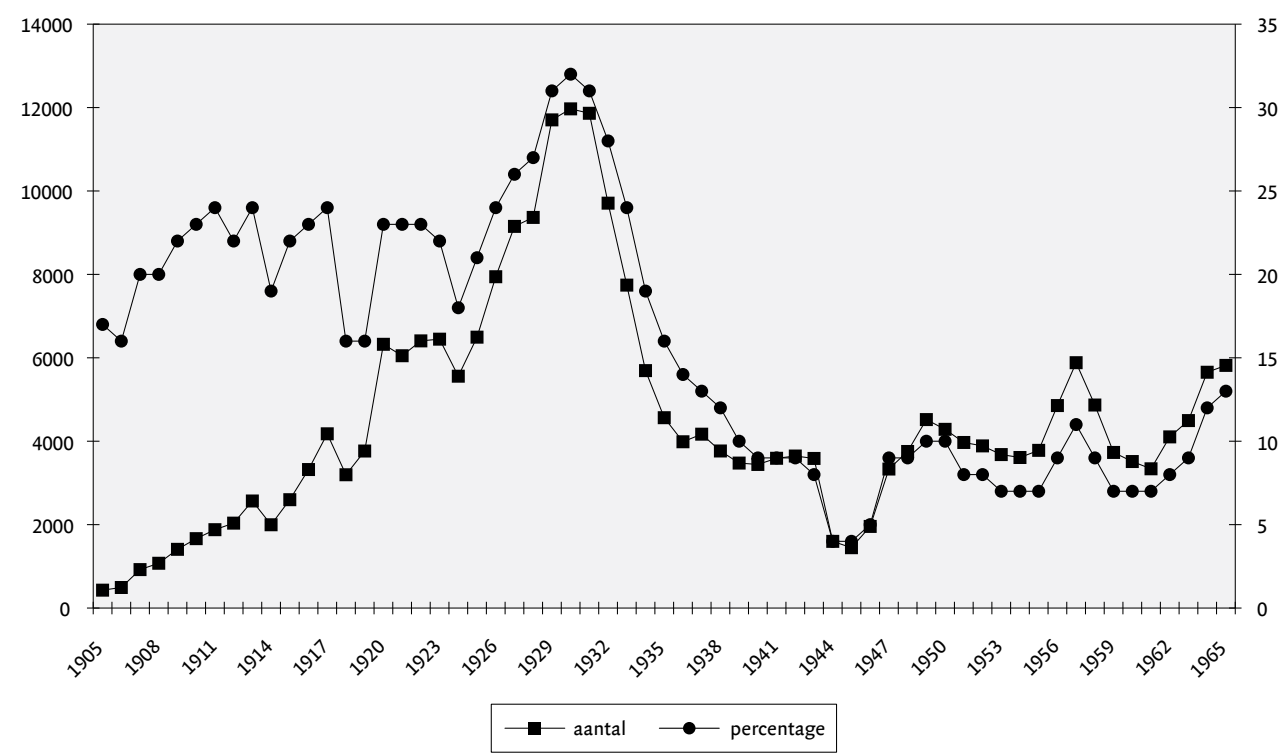

Bron: (Jaar)verslagen (Hoofd-)Ingenieur / Inspecteur-Generaal der Mijnen, I905-I965. 
GRAFIEK 5.2 Het JAARLIJKSE GROEIPERCENTAGE VAN DE ONDERGRONDSE BEZETTING IN DE NEDERLANDSE STEENKOLENMIJNEN: NEDERLANDERS EN BUITENLAN DERS, I906-I965 (I9O6-I9I9 TOTALE BEZETTING)

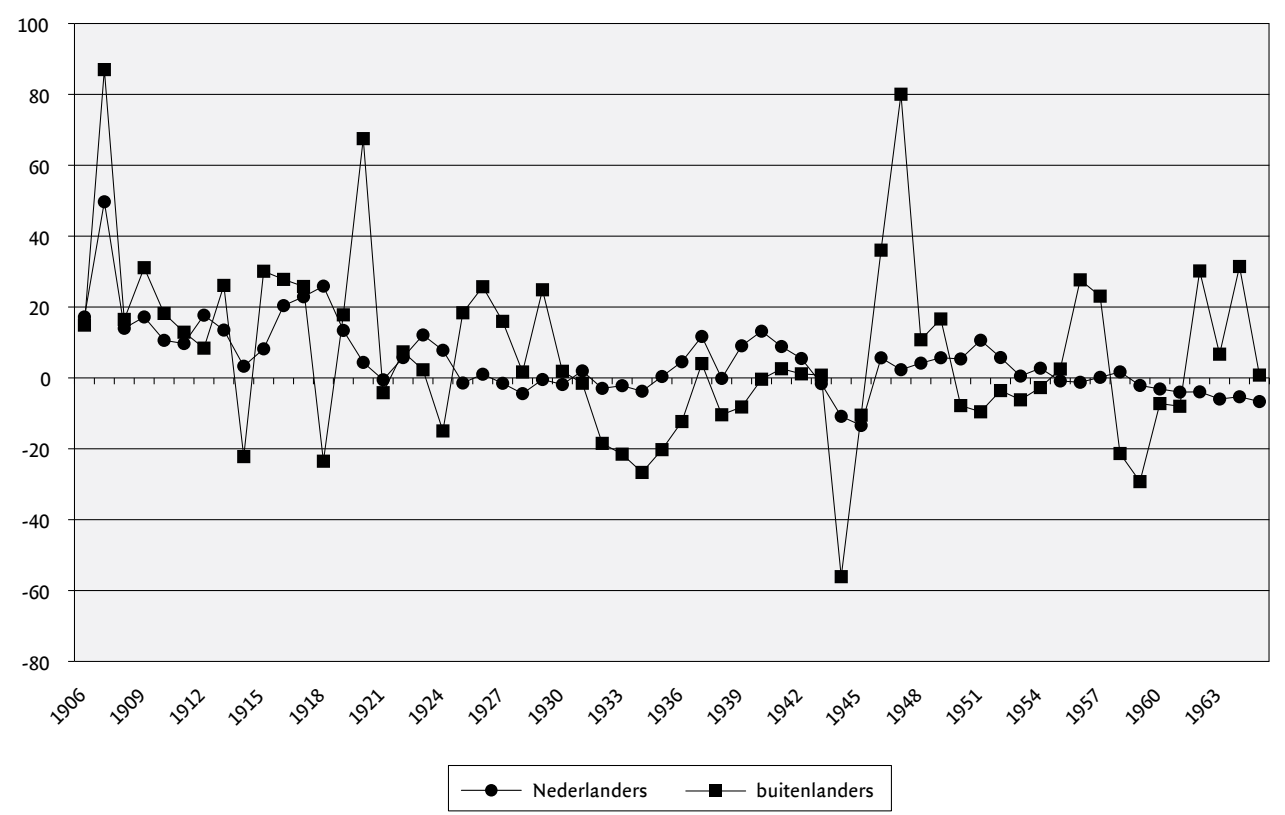

Bron: Eigen berekening op basis van: (Jaar)verslagen (Hoofd-)Ingenieur / Inspecteur-Generaal der Mijnen, I905-1965.

vuld met gegevens over de totale bezetting tijdens de eerste twee decennia van de twintigste eeuw, waarvoor specifieke cijfers over nationaliteiten van ondergronders ontbreken. Net als in het vorige hoofdstuk wordt de onderzochte periode onderverdeeld in drie subperiodes: opbouw (I900-I930), crisis en bezetting (I93I-I944) en wederopbouw (I945-I965). In het kort kunnen de drie te onderscheiden perioden als volgt worden gekarakteriseerd: de periode van opbouw wordt gekenmerkt doordat het groeipercentage van de buitenlandse ondergronders doorgaans boven dat van de Nederlandse bezetting lag. De jaren van crisis en oorlog vormden daarentegen een periode van krimp. Het groeipercentage buitenlanders was meestal negatief en lag beneden dat van de Nederlandse mijnwerkers. Het tijdperk I945I965 wordt gekenmerkt door korte periodes van drie tot vijf jaar met afwisselend positieve en negatieve groeisaldi van de buitenlandse ondergronders.

De rol die de buitenlandse arbeiders speelden op de arbeidsmarkt voor mijnwerkers, was in die drie tijdvakken verschillend van aard. Ook werden er steeds nieuwe buitenlandse wervingsgebieden aangeboord. De periodes worden hieronder meer in detail besproken. 


\section{DE PERIODE VAN OPBOUW, I900-I930}

\section{De jaren vóór de Eerste Wereldoorlog}

Nederlandse arbeidskrachten konden in de opbouwfase van de Limburgse steenkolenwinning niet voldoen aan de grote vraag van de mijnen, zo bleek in het vorige hoofdstuk. Vooral voor het werk ondergronds waren de tekorten groot. Voor mijnwerkers met ervaring waren de Limburgse mijnondernemingen in belangrijke mate afhankelijk van arbeidsmigranten uit het buitenland. Zelfs Staatsmijnen, het bedrijf dat alleen Nederlandse arbeidskrachten zou aannemen, moest in I9I4 overstag. Ten gevolge van de sterk toegenomen vraag naar arbeiders voor de pas geopende Staatsmijn Emma was het bedrijf voor het eerst genoodzaakt ook buitenlandse arbeidskrachten te rekruteren. Op 3i december van dat jaar werkten er 340 mijnwerkers met een vreemde nationaliteit bij het Staatsmijnbedrijf. ${ }^{9}$

De vraag naar ervaren buitenlandse mijnwerkers blijkt uit de hoge groeipercentages. Daardoor nam zowel hun absolute als relatieve aanwezigheid geleidelijk aan toe (grafiek 5.I). Werkten er eind I905 - eerdere cijfers zijn er niet - 429 buitenlanders in de Limburgse mijnen, eind I9I3 waren het er al ruim 2.500. Het aandeel van de buitenlanders in de totale arbeidersbezetting steeg in die jaren van 17 naar 24 procent. Ondergronds was het percentage buitenlanders eind I9I 328 procent. Op datzelfde moment was 86,8 procent van alle buitenlanders ondergronds werkzaam. Van alle Nederlanders in dienst van de gezamenlijke mijnen, was dat percentage niet hoger dan 68,7 procent. ${ }^{\text {IO }}$

De betekenis van buitenlanders in verband met de vraag van de mijnen naar ervaren krachten blijkt uit de gegevens uit het mijnwormonderzoek dat elke nieuwe ondergronder bij een Limburgse mijn moest ondergaan (bijlagen II, I2 en I3). Mijnwerkers met ervaring waren in meerderheid afkomstig uit buitenlandse mijnen (grafiek 5.3). Deze groep vormde tot I9I5 gemiddeld meer dan de helft van de nieuwe mijnwerkers die in de Limburgse mijnen ondergronds werden tewerkgesteld. ${ }^{11}$ Het ging hierbij niet noodzakelijkerwijs om mijnwerkers met een buitenlandse nationaliteit, maar aangezien in het vorige hoofdstuk bleek dat vóór I9I4 weinig Nederlanders uit buitenlandse mijnen naar Limburg kwamen, kan veilig worden aangenomen dat het aanbod uit buitenlandse mijnen vooral uit mijnwerkers met een vreemde nationaliteit bestond. Daarentegen waren buitenlanders in de minderheid als het ging om nieuwe ondergronders zonder eerdere ervaring in de mijnbouw (grafiek 5.4).

Over de wijze van rekrutering in deze beginperiode is weinig bekend. In de literatuur wordt veelal aangenomen dat de komst van buitenlandse arbeidsmigranten vooral spontaan gebeurde en soms werd gevolgd door kettingmigratie van familieleden, vrienden, kennissen en collega's. ${ }^{12}$ Volgens Vianen meldden zich bij de Oranje-Nassau Mijnen vooral Duitsers uit het Ruhrgebied aan, terwijl het bij de dichter aan de grens gelegen WillemSophia, Laura en Domaniale voornamelijk ging om mijnwerkers uit nabijgelegen mijnen in het Wurmrevier en uit aangrenzende Duitse gemeenten. ${ }^{\mathrm{I}}{ }^{3}$ Wel konden incidentele pushfacto-

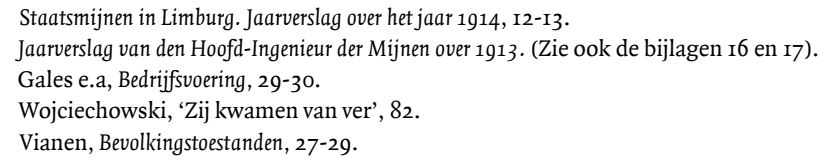


GRAFIEK 5.3 ERVAREN ONDERGRONDERS, AFKOMSTIG VAN NEDERLANDSE EN BUITENLAN DSE MIJNEN, I905-I925

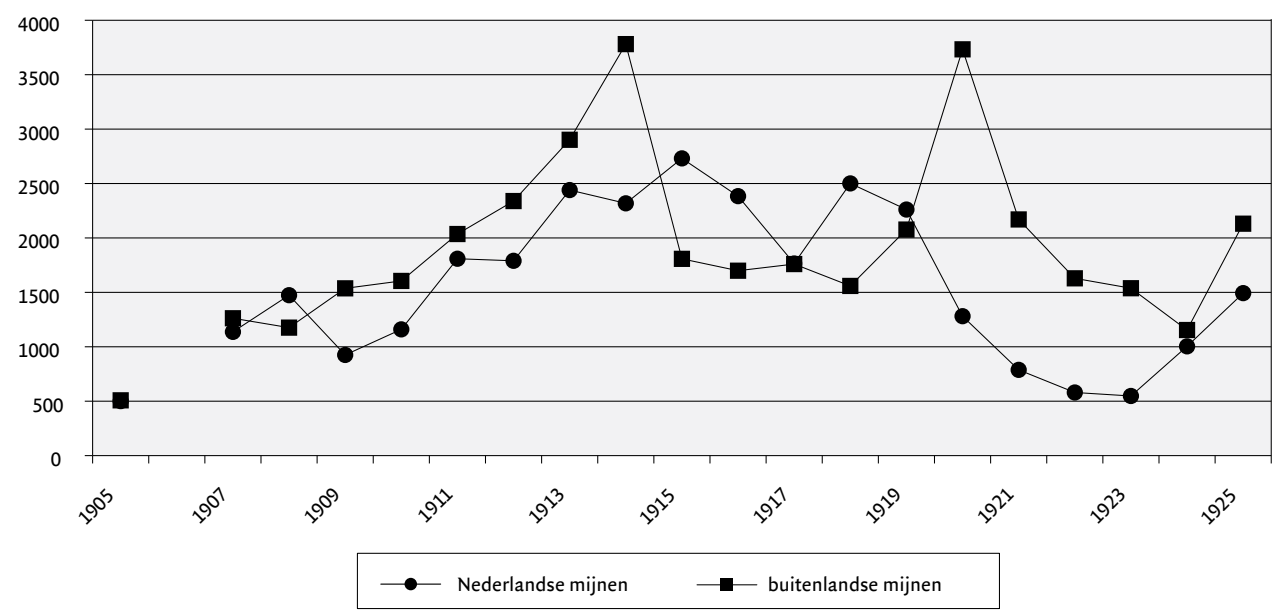

Bron: Onderzoek naar de mijnwormziekte, (Jaar)verslagen (Hoofd-)Ingenieur der Mijnen, I905-I925. Zie ook bijlage I2.

GRAFIEK 5.4 ARBEIDERS ZONDER EERDERE MIJNBOUWERVARING, AFKOMSTIG UIT NEDERLAN D EN HET BUITENLAND, I905-I925

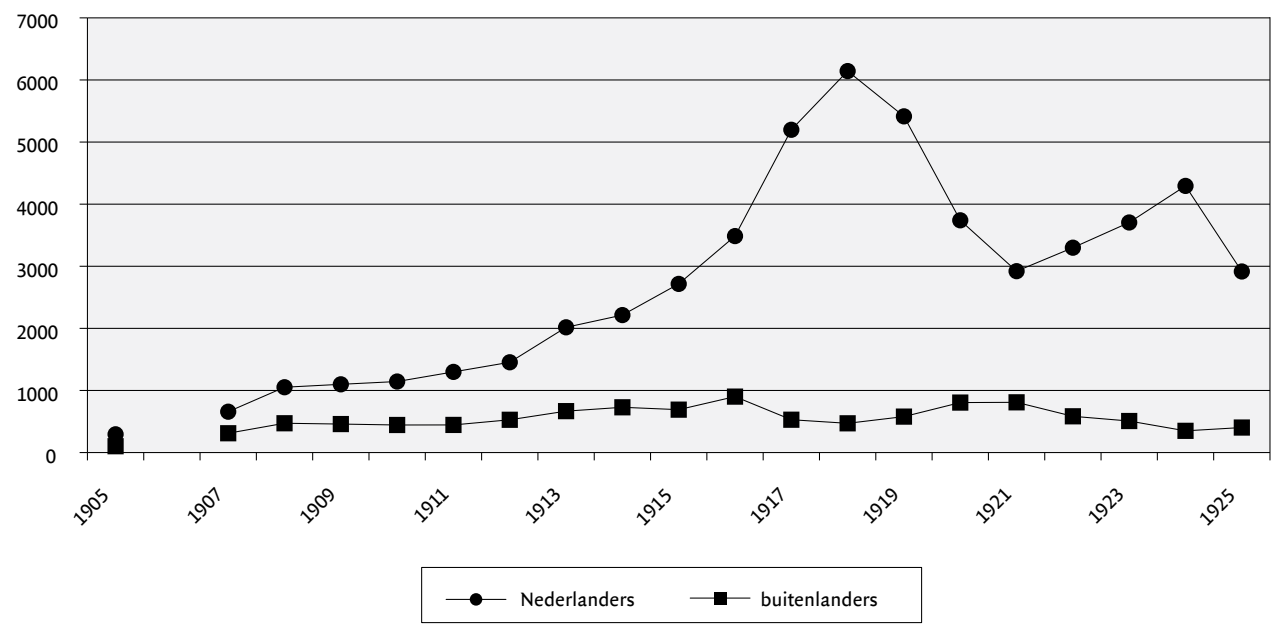

Bron: Onderzoek naar de mijnwormziekte, (Jaar)verslagen (Hoofd-)Ingenieur der Mijnen, I905-I925. Zie ook bijlage I2.

ren bij de komst van mijnwerkers uit het buitenland een rol spelen. Al eerder is gewezen op de betekenis van de grote staking in de mijnen van het Ruhrgebied in 1905, die naast Nederlanders ook veel Duitsers naar de Limburgse mijnen zou hebben gebracht. ${ }^{14}$ 


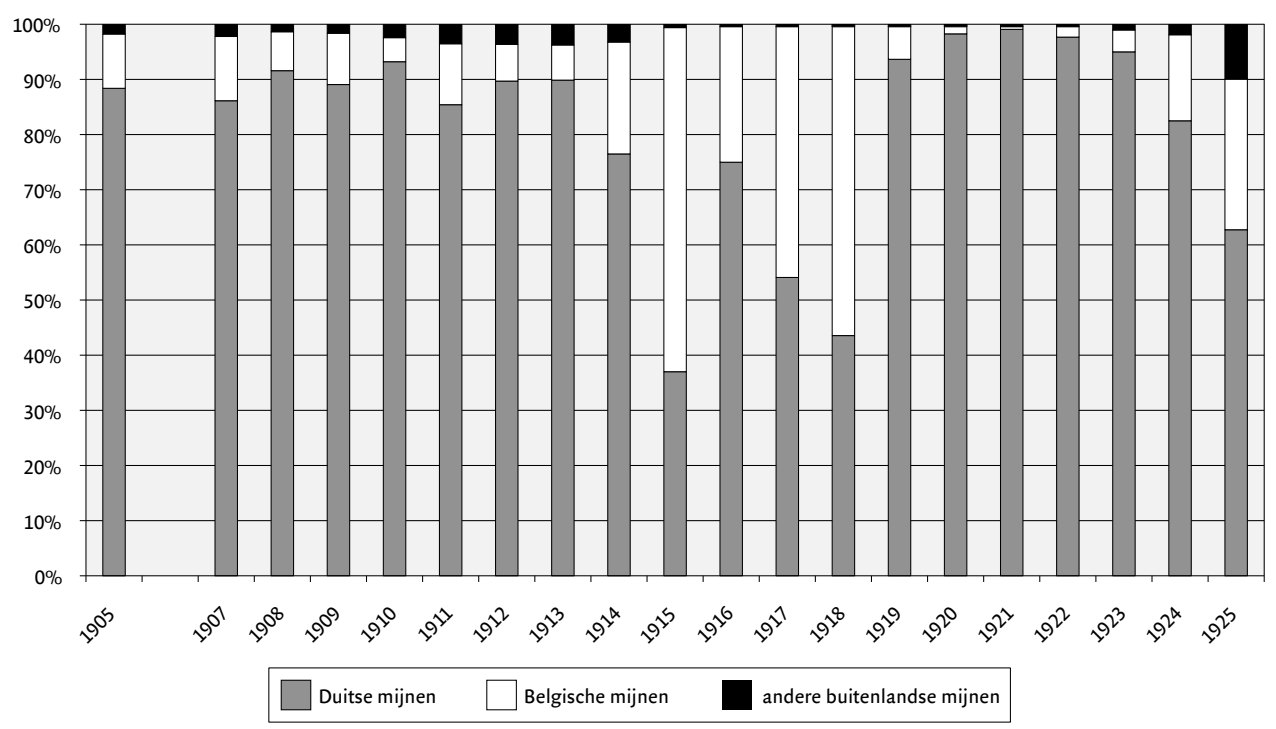

Bron: Onderzoek naar de mijnwormziekte, (Jaar)verslagen (Hoofd-)Ingenieur der Mijnen, I905-I925. Zie ook bijlage I2.

Van georganiseerde werving in het buitenland was nauwelijks sprake. ${ }^{15}$ Bemiddelingsorganisaties in het buitenland, zoals de Nederlandse Arbeidsbeurs in Oberhausen, werden vooral gebruikt bij de pogingen om Nederlanders vanuit Duitsland voor de Limburgse mijnen te werven.

Dat Duitsland met zijn nabije kolenbekkens rond Aken en in het Ruhrgebied een belangrijke rol speelde als land van herkomst van de buitenlandse arbeiders blijkt uit grafiek $5 \cdot 5$. Tussen 1905 en I9I3 kwam 90 procent van de aangeworven ondergronders die ervaring hadden opgedaan in het buitenland, van een Duitse mijn. In diezelfde periode had aan het eind van elk jaar tussen 70 tot 90 procent van de buitenlandse mijnwerkers in de Limburgse mijnen de Duitse nationaliteit. De overige nationaliteiten werden vooral gevormd door Oostenrijkers en Belgen (grafiek 5.6).

$\mathrm{Al}$ voor de Eerste Wereldoorlog deden ook mijnwerkers van Poolse en Sloveense herkomst hun intrede in de Nederlandse mijnen. Omdat er vóór I9I8 geen nationale Poolse en Sloveense (Joegoslavische) staat bestond, zijn ze niet als afzonderlijke nationaliteiten in de registratie van de mijnen opgenomen. Veel is er over deze eerste groepen Polen en Slovenen niet bekend. Etnische Polen hadden meestal de Duitse nationaliteit. In de meeste gevallen ging het om Polen uit Oost-Pruisische provincies die in de tweede helft van de negentiende eeuw als arbeidsmigrant in de mijnen van het Ruhrgebied waren beland. De eersten van deze zogenaamde Ruhrpolen arriveerden waarschijnlijk al rond I9oo in Limburg, waar ze bij de Oranje-Nassau Mijnen gingen werken. Een tweede contingent zou zich onder de Duitsers hebben bevonden, die in 1905 na de stakingen in het Ruhrgebied naar de Nederlandse 
GRAFIEK 5.6 DE VERDELING VAN BUITENLANDSE NATIONALITEITEN IN DE NEDERLANDSE STEENKOLENMIJNEN, I905-I9I3 (ONDERGRONDS EN BOVENGRONDS)

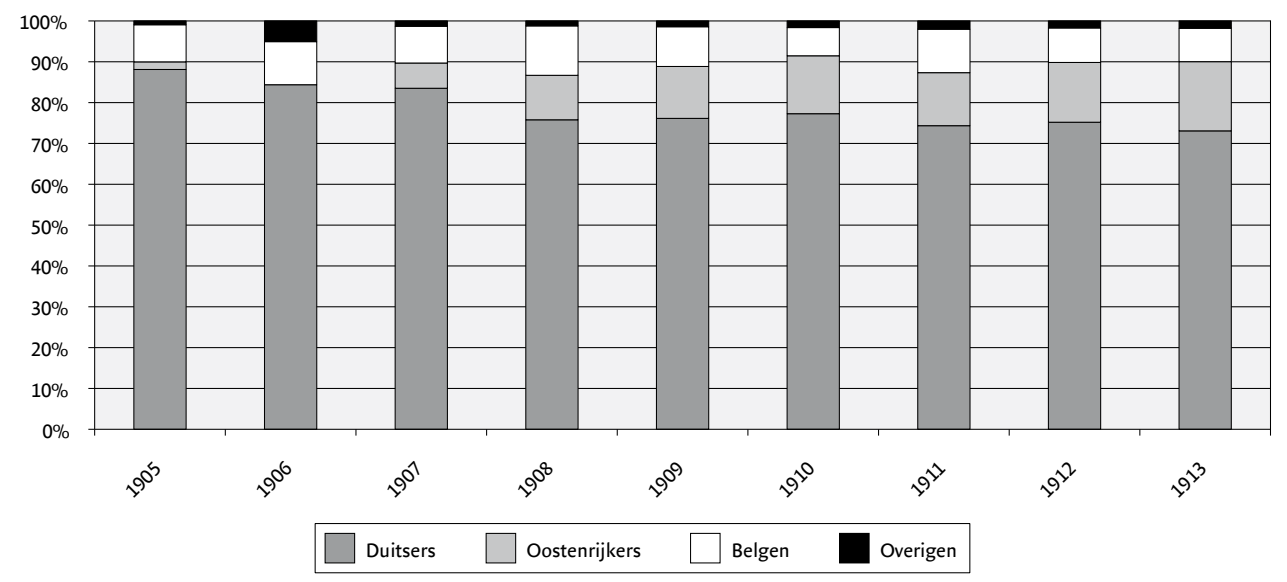

Bron: (Jaar)verslagen (Hoofd-)Ingenieur der Mijnen, I905-1913. Zie ook bijlage I5.

mijnen kwamen. Daarnaast kwam er in de jaren I907-I9Io een groep Poolse contractarbeiders van Russische en Oostenrijkse herkomst uit Duitsland, waar ze een jaarcontract hadden gehad. Zij prefereerden werk in de Limburgse mijnen boven terugkeer naar huis. Deze Polen kwamen vooral terecht in de Domaniale en de Laura. ${ }^{16}$ Kort voor de Eerste Wereldoorlog telde de Poolse gemeenschap in de Limburgse mijnstreek ongeveer tweehonderd gezinnen. ${ }^{\mathrm{I}}$

Mijnwerkers van Sloveense afkomst hadden veelal het Oostenrijkse staatsburgerschap. De eerste Slovenen zouden in I905 uit Duitsland naar Limburg zijn gekomen, mogelijk ook als gevolg van de stakingen in het Ruhrgebied. Volgens mondelinge overlevering kwamen ook uit de regio Aken al voor de Eerste Wereldoorlog Slovenen naar Limburg, waar ze in dienst traden van de Domaniale Mijn in Kerkrade. ${ }^{18}$

Voor het uitbreken van de Grote Oorlog in augustus I9I4 ondervonden buitenlanders nauwelijks belemmeringen bij het passeren van de grens en het aanvaarden van een baan in Nederland. De periode tussen circa I86o en I9I4 is wel omschreven als 'het paspoortloze tijdperk' ${ }^{19}$ Hoewel identiteitsbewijzen in het grensoverschrijdend verkeer zeker niet waren afgeschaft, genoten loonarbeiders in Europa in het algemeen bewegingsvrijheid tussen verschillende nationale staten. Veel overheidsbemoeienis met de arbeidsmarkt was er niet. Dat betekende dat vreemdelingen doorgaans weinig in de weg werd gelegd als ze zich op de arbeidsmarkt aanboden. ${ }^{20}$

I6 Brassé en Van Schelven, Assimilatie, 34.

17 Wojciechowski, Voor brood en urijheid, I9-2I.

I8 Mulders, Met de buik het brood achterna, i8.

I9 Leo Lucassen, 'A many-headed monster: The evolution of the passport system in the Netherlands and Germany in the long nineteenth century', in: John Torpey \& Jane Caplan (ed.), Documenting individiual identity: the development of state practices in the modern world (Princeton 2000).

20 Leslie Page Moch, Moving Europeans. Migration in western Europe since 1650 (Bloomington/Indianapolis I992) 107. 
Dat gold ook in Nederland. De Vreemdelingenwet uit I849, die in principe beoogde de migratie te reguleren, onder meer door een systeem van paspoorten, werd in de loop van de negentiende eeuw nauwelijks meer nageleefd. Vanaf het begin van de jaren I86o werden alle vreemdelingen zonder vertoon van een buitenlands paspoort toegelaten; bovendien raakte ook het verstrekken van een reis- en verblijfspas aan vreemdelingen in onbruik. Vreemdelingen konden overal werken en werden stilzwijgend gedoogd. ${ }^{21}$ Tijdens de economische depressie van 1907-I909 werd de eerste voorzichtige bemoeienis van de Nederlandse overheid met de arbeidsmarkt zichtbaar. Die aandacht leidde tot meer interesse in de arbeidsbemiddeling en tot de oprichting van de Vereniging van Nederlandse Arbeidsbeurzen in I908. Een verdere impuls kwam van de Staatscommissie voor de Werkloosheid, ingesteld in I909. Maatregelen om de arbeidsmarkt te beschermen tegen immigranten achtte de Staatscommissie in haar rapport, dat in I9I4 verscheen, niet nodig. ${ }^{22}$ Pas de Eerste Wereldoorlog zou overal aanleiding geven tot intensivering van de grenscontroles en het beschermen van de arbeidsmarkt door nationale overheden.

\section{Belgische vluchtelingen en geïnterneerden}

Ten gevolge van de oplopende internationale spanningen in de zomer van I9I4 kwam de personeelsvoorziening van de Nederlandse mijnen in moeilijkheden. Veel arbeidskrachten in de mijnen kregen een oproep voor mobilisatie in het leger van hun vaderland. Tussen $3 \mathrm{I}$ december I9I3 en I5 augustus I9I4 daalde de personeelsbezetting in de gezamenlijke Limburgse mijnen van I0.728 naar 7.350. ${ }^{23}$ Onder hen waren de nodige buitenlanders, zo blijkt uit het sterk negatieve groeipercentage in I9I4 (grafiek 5.2). Een overzicht naar nationaliteit in de zomer van I9I4 ontbreekt, maar op 3I december van dat jaar was het aantal Duitsers vergeleken met eind december I9I3 met bijna 800 man teruggelopen, terwijl de Oostenrijkse bezetting met ruim 200 man was afgenomen. Bijna 94 procent van de vertrokken Duitsers en Oostenrijkers werkte ondergronds (bijlagen I5 en I6).

Voor de Limburgse mijnen betekende dit vertrek van veel ervaren krachten een gevoelige aderlating. Niet alleen moesten de vertrokken arbeiders worden vervangen. Door uitbreiding van de ondergrondse werkzaamheden met het oog op uitbreiding van de productie door een dreigend kolentekort was er veel extra vraag naar arbeidskrachten. ${ }^{24}$ Het traditionele aanbod van ervaren buitenlandse mijnwerkers uit Duitse mijnen nam echter sterk af. Volgens opgaaf van de Hoofdingenieur der Mijnen konden de gezamenlijke Limburgse mijnen vóór september I9I4 maandelijks rekenen op ongeveer 400 ondergrondse arbeiders uit Duitse mijnen. Sinds september I9I4 was dat aantal tot ro procent daarvan teruggelopen. ${ }^{25}$ Niettemin slaagden de mijnen er in de personeelsbezetting aan het eind van I9I4 weer nagenoeg op het peil van een jaar eerder te krijgen. Behalve aan de Nederlandse mijnwerkers die uit Duitsland terugkeerden, was dat te danken aan succesvolle aanwerving van onge-

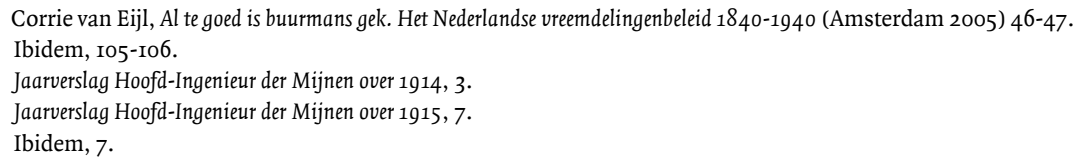


Grafiek 5.7 De verdeling VAN BUitenlandse nationaliteiten in DE NeDERLANDSE STEENKOLENMIJNEN, I9I4-I9I8 (ONDERGRONDS EN BOVENGRONDS)

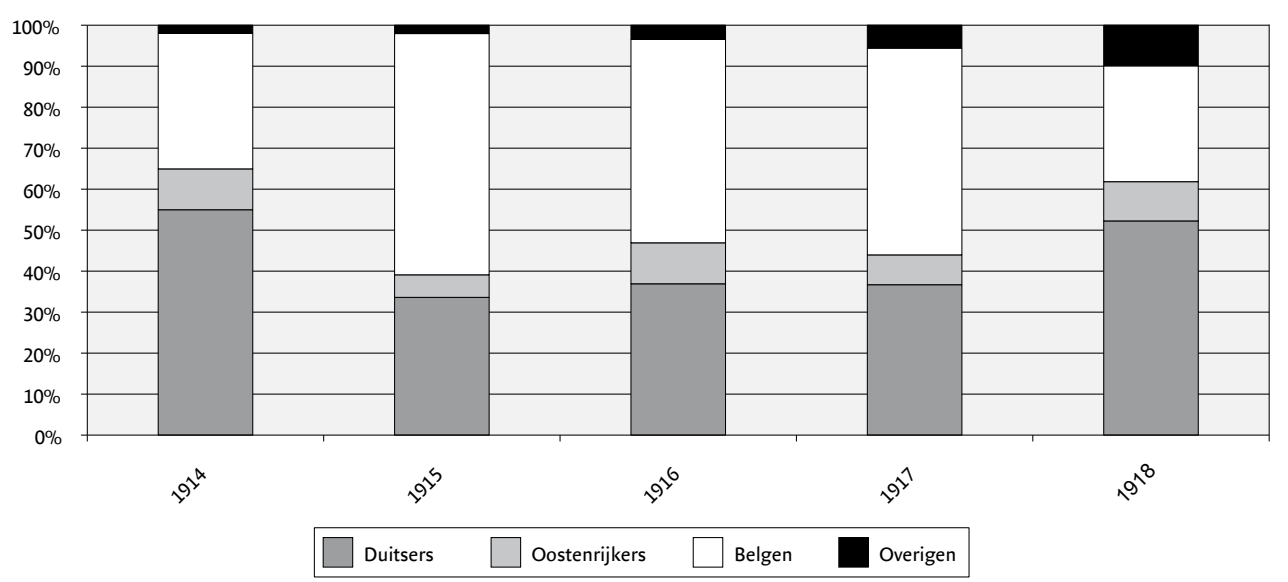

Bron: (Jaar)verslagen (Hoofd-)Ingenieur der Mijnen, I9I4-I9I8. Zie ook bijlage I5.

schoolde Nederlandse arbeiders (zie bijlage I2). Een andere belangrijke rekruteringsbron waren vluchtelingen uit de Belgische burgerbevolking en Belgische militairen, die na de opmars van de Duitse legers dwars door België hun heil in Nederland hadden gezocht. ${ }^{26}$ Het belang van de Belgen tijdens de Eerste Wereldoorlog blijkt uit grafiek 5.7. Tussen I9I5 en I9I7 makkten ze zelfs meer dan de helft uit van de buitenlandse bezetting in de Nederlandse mijnen.

Aanvankelijk meldden veel burgervluchtelingen, die zich bij het uitbreken van de oorlog in Maastricht of omgeving hadden gevestigd, zich spontaan bij de mijnen aan, of werden door de Heerlense arbeidsbeurs geplaatst. De door de Nederlandse regering eind I9I4 aan de arbeidsbeurzen uitgevaardigde richtlijn, dat ze alle Belgische vluchtelingen weliswaar moesten inschrijven, maar hen uitsluitend mochten plaatsen als er geen geschikte Nederlandse arbeidskrachten waren en als het loon niet lager was dan het standaardloon, ${ }^{27}$ was in het geval van ervaren mijnwerkers een wassen neus. Ervaren Nederlandse ondergronders waren er veel te weinig en dus waren Belgische mijnwerkers over het algemeen op de arbeidsmarkt niet concurrerend voor werkloze Nederlandse arbeidskrachten. Bovendien was de beloning voor Nederlandse en buitenlandse arbeiders in de Nederlandse mijnbouw gelijk bij gelijk werk.

Vanaf het eind van I9I4 ging de mijnbouwsector ook over op een meer gestructureerde werving. Op verzoek van de minister van Landbouw, Nijverheid en Handel stelde de Hoofdingenieur der Mijnen zich eind I9I4 in verbinding met de vluchtelingenkampen en vluchtelingencomités in verschillende plaatsen omtrent de plaatsing op de Limburgse mijnen van uitgeweken Belgische mijnwerkers. Meteen konden er ongeveer 350 worden geplaatst.

\footnotetext{
26 M. Hendrickx-van der Avert, 'Vlucht en opvang van de burgerbevolking', in: M. Bossenbroek en J.B.C. Kruishoop, Vluchten voor de Groote Oorlog. Belgen in Nederland 1914-1918 (Amsterdam 1988) 22-30, aldaar 22-26.

27 Van Eijl, Al te goed is buurmans gek, 105. Dit was de eerste keer dat werkgelegenheid en werkloosheid overwegingen waren om voorwaarden te stellen aan arbeid van immigranten.
} 
Vanwege de taal gaf men hierbij de voorkeur aan Vlamingen. Omstreeks I april I9I5 was het aantal geplaatste Belgische vluchtelingen al opgelopen tot ruim I.000 man. ${ }^{28}$

Dat de meesten van hen ervaring hadden in het werk ondergronds blijkt uit de sterke stijging van het aantal uit Belgische mijnen afkomstige arbeiders, die op de mijnwormparasiet werden onderzocht. Terwijl het in de jaren vóór de Eerste Wereldoorlog gemiddeld om I35 ervaren Belgische arbeiders per jaar ging, met een maximum van 225 in I9II, bedroeg het in I9I4 767, en in I9I5 zelfs I.I28 man (bijlage I2).

In juli I9I5 verschenen ook richtlijnen voor de tewerkstelling van geïnterneerde militairen. Sinds het uitbreken van de oorlog in augustus I9I4 waren honderden Belgische militairen vanuit de regio Luik naar Nederland gevlucht. Het grootste contingent kwam na de val van Antwerpen op ro oktober I9I4. Meer dan 32.00o Belgische militairen vluchtten naar Nederland om aan Duits krijgsgevangenschap te ontkomen. ${ }^{29}$ Op basis van artikel II van het 'Verdrag nopens de rechten en verplichtingen der onzijdige mogendheden en personen ingeval van oorlog te land' was Nederland verplicht deze militairen te interneren. ${ }^{3^{\circ}}$ Dat betekende dat ze een verblijfplaats kregen aangewezen die ze niet mochten verlaten. Aanvankelijk werden ze ondergebracht in kazernes, maar in januari I9I5 kwamen barakkenkampen - zogenaamde depots - beschikbaar in Zeist, Harderwijk, Oldenbroek en Gaasterland. ${ }^{3}$ Onder de Belgische geïnterneerden waren veel mijnwerkers. ${ }^{32}$

De richtlijnen voor de tewerkstelling van geïnterneerden hielden in dat tewerkstelling een gunst was, geen recht, en pas mogelijk na toestemming van de opperbevelhebber en na het afleggen van de belofte niet te zullen vluchten. De tewerkstelling mocht de belangen van Nederlanders niet schaden en moest geschieden onder de gebruikelijke arbeidsvoorwaarden. De militairen kregen geen loon, maar een verhoogd zakgeld; het resterende loon werd aan het eind van de internering uitbetaald. Werkgevers die meer dan vier geïnterneerden in dienst namen, moesten zorgen voor bewaakte huisvesting. Bovendien was vanaf I9I6 toestemming nodig van de Rijksdienst der Werkloosheidsverzekering en Arbeidsbemiddeling. Die toestemming werd via de districtsarbeidsbeurzen voor bepaalde tijd verstrekt en verlengd als bleek dat er nog geen geschikte Nederlandse arbeidskrachten konden worden gevonden. ${ }^{33}$ Direct na het verschijnen van deze richtlijnen kregen de mijnen toestemming voor de tewerkstelling van Belgische geïnterneerden. Op 27 juli I9I5 meldde de Limburger Koerier dat er eerstdaags een aantal geïnterneerden in de mijnen tewerkgesteld zouden worden. ${ }^{34}$

In zekere zin gaf de rekrutering van geïnterneerden aan hoe groot de vraag naar ervaren mijnwerkers was. In tegenstelling tot de eerder in dienst genomen Belgische burgervluchtelingen, was een overgrote meerderheid (circa 90 procent) van de geïnterneerden van Waalse origine en de Nederlandse taal niet of nauwelijks machtig. Dat was de reden

\footnotetext{
28 Jaarverslag Hoofd-Ingenieur der Mijnen over 1914, II.

29 Evelyn de Roodt, Oorlogsgasten. Vluchtelingen en krijgsgevangenen in Nederland tijdens de Eerste Wereldoorlog (Zaltbommel 2000) 25-26.

30 Het verdrag kwam, samen met andere verdragen over de rechten en plichten van neutrale staten in tijd van oorlog, tot stand tijdens de Tweede Haagse Vredesconferentie in 1907. Nederland ratificeerde die verdragen bij wet van I juli I909.

$3 \mathbf{I}$ J. Laugs, De tewerkstelling van geïnterneerde Belgische militairen in de Limburgse Mijnstreek 1915-1918 (doctoraalscriptie, Nijmegen 1988) 3-4.

32 Fernand Baudhuin, Histoire economique de la Belgique 1914-1939. Tome premier: Grandeurs et misères d'un quart de siècle (Bruxelles I944) 44 .

33 Van Eijl, Al te goed is buurmans gek, 107.

34 Laugs, Tewerkstelling, II-I2.
} 
GrAFIEK 5.8 AANGEWORVEN BELGISCHE GEÏNTERNEERdEN VOOR ONDERGRONDSE ARBEID IN DE NEDERLANDSE STEENKOLENMIJNEN, I9I6-I9I8

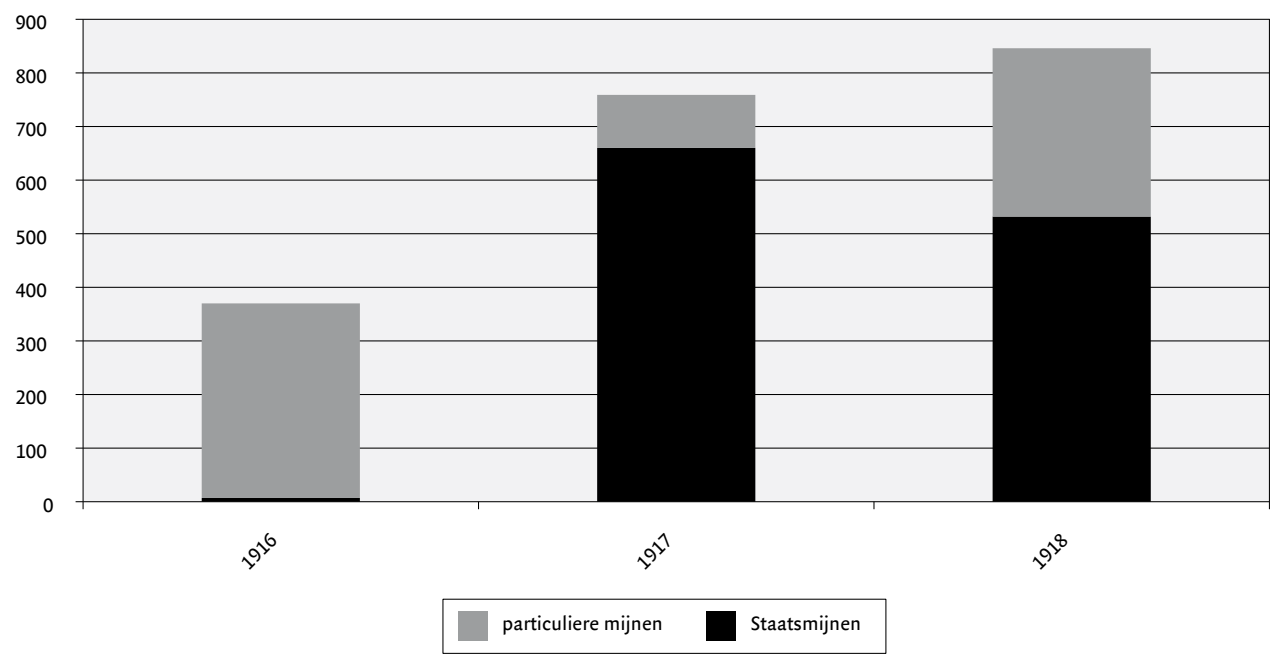

Bron: Onderzoek naar de mijnwormziekte, (Jaar)verslagen (Hoofd-)Ingenieur der Mijnen, I9I6-I9I8. Zie ook bijlage I3.

dat Staatsmijnen aanvankelijk nauwelijks geïnterneerden in dienst nam. ${ }^{35}$ Pas in de loop van I9I7 was het tekort aan ervaren mijnwerkers ook bij het staatsbedrijf zo groot, dat men tot de rekrutering van geïnterneerden overging. Ontegenzeggelijk schiep het taalprobleem moeilijkheden bij hun tewerkstelling. Ze werden in groepen in de mijn aan het werk gezet en stonden onder toezicht van opzichters die de Franse taal beheersten. Ook moesten voor hen reglementen en voorschriften in het Frans worden vertaald. Desalniettemin waren de mijnen, zeker tot de staking van I9I7, waaraan nog al wat Belgische geïnterneerden deelnamen, over het geheel genomen tevreden over zowel hun prestaties als hun gedrag. ${ }^{36}$ In het begin van I9ı 6 waren er al ruim 700 geïnterneerde Belgische militairen bij de mijnen in dienst, tegen het eind van de oorlog waren het er 3.155. ${ }^{37}$ Ze waren aanvankelijk in vier kampen ondergebracht: Beersdal voor de geïnterneerden die bij de ON I werkten, Schaesberg voor de ON II, Eygelshoven voor de Laura en Spekholzerheide voor de Willem-Sophia en Staatsmijn Wilhelmina. In de loop van IgI7 kwam er een vijfde kamp bij in Rumpen, voor de militairen die bij de Staatsmijnen Emma en Hendrik werkten. ${ }^{8}$

Vanaf IوI6 werden de geïnterneerden als groep onderscheiden in de statistiek betreffende het mijnwormonderzoek. Tot in het laatste oorlogsjaar nam het aantal gerekruteerde geïnterneerde Belgen voortdurend toe (grafiek 5.8). Duidelijk is in de grafiek te zien dat Staatsmijnen aanvankelijk nauwelijks geïnterneerden in dienst nam, maar sinds I9I7 het grootste gedeelte van hen opnam. Door de uitbouw van de grote Staatsmijn Emma en de opening van Staatsmijn Hendrik in I9I7 bestond er bij Staatsmijnen in die jaren een groot

35 Ibidem, 23.

36 Jaarverslag Hoofd-Ingenieur der Mijnen over 1915, 8.

37 G. Laporte, 'Sociale en politieke actie', in: Bossenbroek en Kruishoop, Vluchten voor de Groote Oorlog, 58-63, aldaar 58.

38 Laugs, Tewerkstelling, II-I2. 
tekort aan ervaren mijnwerkers. Het is in dit verband tekenend dat zelfs de mijnwerkersstaking van juni I9I7 niet het einde van de rekruteringen betekende. De geïnterneerden die aan de staking hadden deelgenomen, werden door de mijnen ontslagen en teruggevoerd naar het depot in Zeist. ${ }^{39} \mathrm{Na}$ afloop van de staking liet de minister van Oorlog aan de mijndirecties weten, dat hij in het belang van de Nederlandse kolenvoorziening bereid was de ontslagen militairen opnieuw voor tewerkstelling in de mijnen beschikbaar te stellen. Eigenlijk voelden de mijndirecties daar niets voor - in die opvatting gesteund door geestelijke en wereldlijke autoriteiten die socialistische sympathieën bij de geïnterneerden vermoedden - maar ze stonden met de rug tegen de muur, omdat ze de ervaren Belgen eenvoudigweg niet konden missen. $4^{\circ}$ Begin augustus 1917 was tweederde van de ontslagen geïnterneerden teruggekeerd in de mijnen..$^{4}$

Pas na de wapenstilstand van november I9I8 verlieten de geïnterneerden definitief de mijnen. Op 2, 3 en 4 december vertrokken de Belgische militairen uit Limburg naar de grote interneringskampen boven de grote rivieren, en van daaruit terug naar België.4²

\section{Duitse en Belgische grensarbeiders}

Wat betreft de verdeling van de buitenlandse nationaliteiten in de Nederlandse mijnen keerde na november I9I8 de vooroorlogse toestand snel terug. De Belgische geïnterneerden gingen naar huis, Oostenrijkers en vooral Duitsers meldden zich weer bij de Nederlandse mijnen aan. In de eerste helft van de jaren 1920 maakten beide nationaliteiten samen ongeveer 90 procent uit van alle buitenlanders in de Nederlandse mijnen, een percentage dat ook al voor de Eerste Wereldoorlog was bereikt. In de administratie van de mijnen verschenen nieuwe nationaliteiten als Polen en Joegoslaven uit staten die na de Eerste Wereldoorlog waren ontstaan. Gaandeweg de jaren 1920 nam het aandeel van deze nationaliteiten in het arbeidersbestand van de Nederlandse mijnen toe.

In het begin van de jaren I920 nam de aantrekkingskracht van de Nederlandse mijnen op Duitse arbeiders buitengewone proporties aan door de economische situatie in Duitsland. Tengevolge van de Eerste Wereldoorlog en de herstelbetalingen die de Republiek van Weimar in het Verdrag van Versailles kreeg opgelegd, werd de economisch-monetaire situatie in het begin van de jaren twintig snel slechter. Voor Duitsers uit het grensgebied werd het erg aantrekkelijk om in de Nederlandse mijnen te gaan werken. Daar werd het salaris uitbetaald in harde Nederlandse guldens in plaats van in waardeloze Reichsmarken. 'De Duitse arbeider, welke [...] zijn loon in marken omzet, is als bij tooverslag millionair geworden en ruilt zijn weekgeld niet met den President der Duitsche Republiek', zo vatte Nic. Grootjans, de directeur van de arbeidsbeurs in Heerlen, het valutavoordeel samen. ${ }^{43}$ De koopkracht in Duitsland van het in guldens verdiende mijnwerkersloon bedroeg ongeveer het drievoudige van het loon dat in de Duitse mijnen werd verdiend. Het gevolg was een toestroom van

39 Kreukels, Mijnarbeid, 237.

40 Laporte, 'Sociale en politieke actie', 59 .

4I Laugs, Tewerkstelling, I9-2I, 29-30.

42 Ibidem, 32.

43 Jubileumboek uitgegeven ter gelegenheid van het 25-jarig bestaan der RK Werkliedenvereeniging in Heerlen 1905-1930 (z.p. z.j.) $5 \mathrm{I}$. 
GRAFIEK 5.9 DE VERDELING VAN BUITENLANDSE NATIONALITEITEN IN DE NEDERLANDSE STEENKOLENMIJNEN, I9I9-I930 (ONDERGRONDS EN BOVENGRONDS)

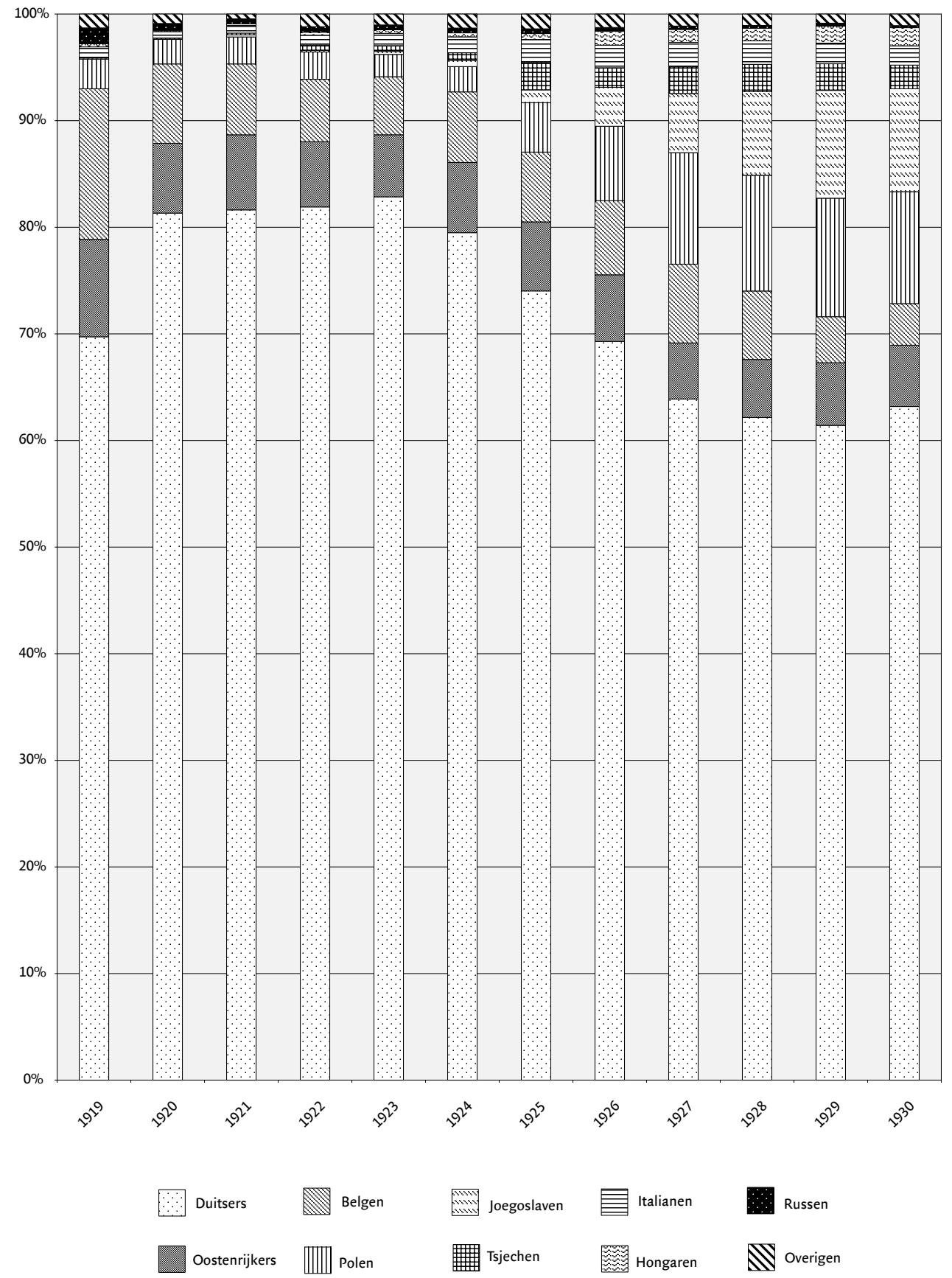

Bron: Jaarverslagen Hoofdingenieur der Mijnen, I919-1930. Zie ook bijlage I5. 
zogenaamde valuta-arbeiders naar de Limburgse mijnen. De directie van de Eschweiler Bergwerks Verein (EBV), die de uittocht van veel ervaren mijnwerkers uit de Akense mijnen met lede ogen aanzag, protesteerde zonder veel succes bij de Nederlandse mijndirecties tegen het aannemen van de grensarbeiders. ${ }^{44}$ De Nederlandse overheid nam wel enkele maatregelen om de toestroom af te remmen. Sinds oktober 1920 moesten werkgevers die grensarbeiders uit het buitenland wilden aantrekken, beschikken over een verklaring van de districtsarbeidsbeurs dat geen bezwaar bestond tegen hun indienstneming. Voor visumplichtige buitenlanders die zich in Nederland wilden vestigen, was die verplichting al anderhalf jaar eerder ingevoerd. Het oogmerk was de bescherming van Nederlanders tegen concurrentie van buitenlanders op de arbeidsmarkt. Hoe groot de problemen van de mijnen met hun arbeidsvoorziening waren, blijkt wel uit het feit dat dat zij werden uitgezonderd van de nieuwe maatregel.45 De buitenlandse mijnwerkers werden zonder paspoort in Nederland toegelaten, mits zij in het bezit waren van een zogenaamde vrijstelling. Die kregen ze alleen als ze konden bewijzen dat ze op een van de Nederlandse mijnen werk hadden gevonden. Vooral grenspendelaars kregen zo'n vrijstelling, al waren er ook wel klachten dat vanuit heel Duitsland arbeidskrachten zich bij de Nederlandse autoriteiten aan de grens meldden als grensbewoner. Zelfs zou in een van de Duitse grensgemeenten een Zentrale bestaan, die tegen betaling grenspassen vervalste..$^{6}$ De komst van de grensarbeiders naar de mijnen leidde tot protesten in de Limburgse pers en bij de vakbonden. In de Tweede Kamer werden er door de katholieke Limburgse afgevaardigde Henri Hermans zelfs vragen over gesteld. De belangrijkste beschuldiging was dat de Duitsers zich voor lagere lonen zouden aanbieden en daardoor Nederlandse arbeidskrachten verdringen. De voorkeur voor goedkopere Duitse arbeiders zou zelfs zo ver gaan, dat de eisen voor de medische aanstellingskeuring voor hen waren verlaagd. Ook werd gevreesd voor socialistische en revolutionaire infiltratie in de mijnbedrijven. ${ }^{47}$

Voor minister P.J.M. Aalberse was de kwestie aanleiding in november 1922 naar Heerlen te komen voor overleg met de betrokkenen. ${ }^{8}$ De vertegenwoordigers van de mijnwerkersbonden herhaalden daar hun belangrijkste grief dat de Duitse valuta-arbeiders de Nederlandse mijnwerkers 'het broode uit den mond stooten', zoals voorzitter C. van der Bilt van de Algemene Nederlandse Mijnwerkersbond het uitdrukte. Zijn collega H.J. Stins van de Algemene Bond van Christelijke Mijnwerkers voegde daar aan toe dat buitenlanders alleen nog aangenomen zouden mogen worden na toestemming van de arbeidsbeurs, waarmee hij dus bepleitte dat de uitzonderingssituatie waarin de mijnarbeid was geplaatst, zou worden opgeheven. De vertegenwoordigers van de mijnen weerlegden de geuite kritiek. De grieven zouden allemaal geweldig overtrokken zijn. Directeur W. Frowein van Staatsmijnen wees er op dat de bepalingen in de cao voor het mijnbedrijf aan Nederlandse en buitenlandse arbeiders gelijke lonen en arbeidsvoorwaarden voorschreven. Ook de keuringseisen

\footnotetext{
44 Kristin Klank, 'Secondary labour force or permanent staff? Foreign workers in the Aachen coal mines', TSEG V nummer 3 (2008) I26-I54, aldaar I40-I4I.

45 Van Eijl, Al te goed is buurmans gek, I28-129.

46 Jaarverslag van de Arbeidsbeurs voor de Limburgsche Mijnstreek over 1920, 5-7 en idem 1921, 6-7.

47 Piet Hermens, Buitenlandse arbeiders in het Zuid-Limburgse kolendistrict, in het bijzonder de rol van de Duitse arbeiders in de mijnen 19001930 (scriptie, z.p. 1983) 36-37.

48 RHCL, Centraal Archief DSM 17.26/06A inv. nr. 57 Verslag bijeenkomst ter bespreking van het vraagstuk der tewerkstelling van vreemde arbeidskrachten in de Limburgsche mijnindustrie, gehouden Dinsdag 28 November 1922 ten raadhuize van Heerlen.
} 
Grafiek 5.Io Het aANTAl GRENSARbeiders, WOONACHTIG IN DUITSLANd EN BELGIË, ONDERGRONDS EN BOVENGRONDS IN DE NEDERLANDSE STEEN KOLEN-

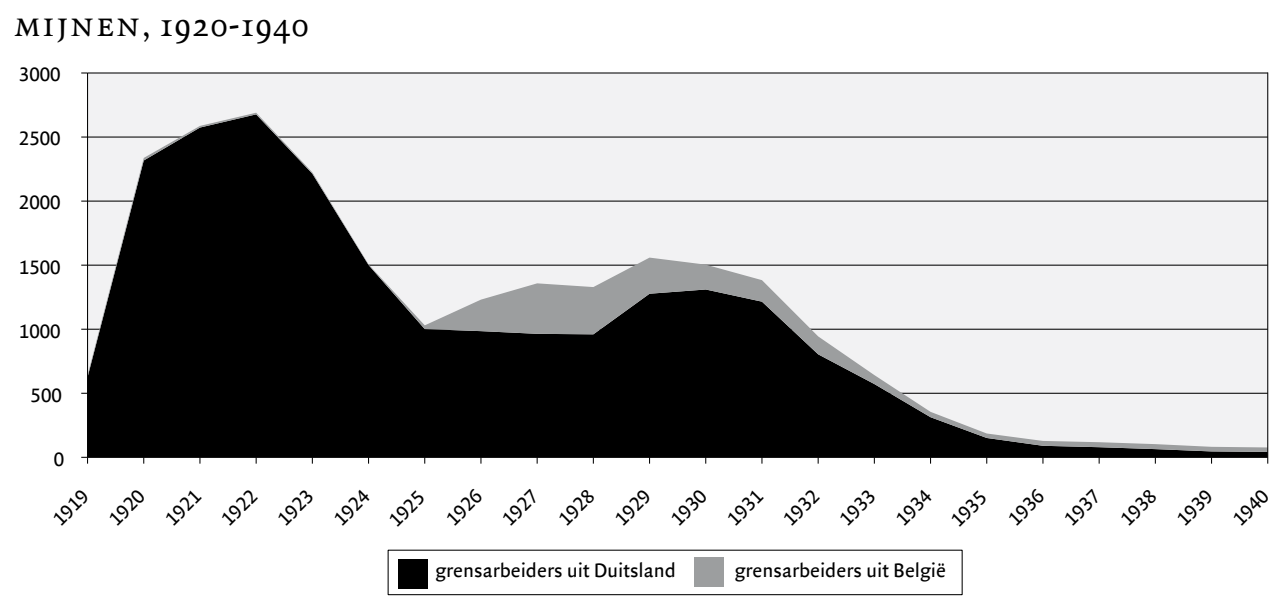

Bron: (Jaar)verslagen AMF, I920-1940.

lagen vast en die golden voor iedereen die zich voor mijnarbeid aanbood, ongeacht nationaliteit of herkomst. De mijnen waren echter gedwongen Duitse en andere buitenlandse arbeiders in dienst te nemen, omdat de Nederlandse arbeidsmarkt tekort schoot. Wanneer er geschikte Nederlandse arbeiders beschikbaar waren, zouden die door de mijnen worden aangenomen. Frowein benadrukte dat het de mijnondernemingen te doen was om het 'verkrijgen en uitbreiden van een gevestigde mijnwerkersbevolking' en dat de gezamenlijke mijnen zich terdege realiseerden dat 'de aanneming van inheemsche arbeidskrachten hiervoor veel meer bevorderlijk is dan de indienstneming van vreemdelingen, die door den stand der valuta hierheen worden gelokt'. In de vergadering werd zelfs gesuggereerd dat de Duitse grensarbeiders verplicht zouden moeten worden zich metterwoon in Nederland te vestigen; dat zou immers de stabiliteit van de mijnwerkersbevolking ten goede komen!

De geografische ligging van de mijnen werkte de komst van Duitse grensarbeiders in de hand. Volgens directeur A. Haex van de Oranje-Nassau Mijnen was dat de voornaamste reden voor de aanwezigheid van veel Duitsers op de particuliere mijnen. De mijnondernemingen waren 'dientengevolge zeer gemakkelijk toegankelijk en als het ware aangewezen op Duitsche arbeiders'. Dat de Duitsers zich op grote schaal schuldig zouden maken aan smokkel of blijk zouden geven van revolutionaire praktijken, zoals in de pers was beweerd, werd door de mijndirecteuren overigens ten stelligste ontkend. Hun gedrag week in geen enkel opzicht af van dat van de overige mijnwerkers.

De selectie en werving van mijnwerkers zou echter hoe dan ook een zaak van de mijnondernemingen zelf moeten blijven. Inmenging van de arbeidsbeurs was ongewenst, waarmee Frowein nog maar weer eens een keer het wantrouwen verwoordde dat er bij de mijnondernemingen bestond tegen het functioneren van de geïnstitutionaliseerde arbeidsbemiddeling in de mijnstreek.

De minister liet zich overtuigen door de argumenten van de mijndirecties. De vrijstellingsregeling voor de mijnondernemingen bleef bestaan. Grensarbeiders konden zonder 
voorafgaande vergunning van de districtsarbeidsbeurs in dienst worden genomen. Ten tijde van de vergadering in Heerlen was het maximale aantal wel zo ongeveer bereikt. Zoals in grafiek 5.Io blijkt, werd op 3I december 1922 het hoogste aantal grensarbeiders uit Duitsland bereikt van 2.677 personen, waarvan 2.223 ondergronders. Dit aantal kwam neer op II, 2 procent van de ondergrondse bezetting. Het gros van de Duitse pendelaars was afkomstig uit plaatsen in de Landkreis Aken, direct grenzend aan de oostelijke mijnstreek. Kohlscheid en Herzogenrath leverden steeds de meeste pendelaars, op gepaste afstand gevolgd door Alsdorf, Bardenberg, Merkstein, Richterich, Würselen en de stad Aken. ${ }^{49}$ In november I923 kwam in Duitsland met de stabilisering van de Reichsmark een eind aan de naoorlogse periode van hyperinflatie..$^{\circ}$ Voor veel Duitse mijnwerkers waren de genormaliseerde monetaire verhoudingen aanleiding om naar het eigen land terug te keren. Dat effect is duidelijk af te lezen in de grafieken 5.2 en 5.9: het jaar 1924 vertoont een negatief groeipercentage van de categorie buitenlandse arbeiders, terwijl het aandeel van de Duitsers in de totale arbeidersbezetting van de mijnen afnam.

Voor Belgische grensarbeiders ontstond in de jaren 1926-1929 een gunstige valutaverhouding tengevolge van de devaluatie van de Belgische frank. Belgische grensarbeiders konden zonder belemmeringen werk in Nederland accepteren, nadat in de eerste helft van de jaren 1920 tussen België en Nederland vrijwel alle beperkingen in het grensoverschrijdend verkeer van personen waren opgeheven. ${ }^{\text {I }}$ De komst van Belgen was echter lang niet zo massaal als die van de Duitsers een paar jaar eerder. Van protesten tegen hun komst is niets bekend. Het maximale aantal grensarbeiders uit België werd op 3I december 1927 bereikt: 394 personen, waaronder 38I ondergronders: I, I procent van de totale bezetting. Belgen kwamen vooral uit de (Belgische) provincie Limburg. Helaas zijn alleen de woonplaatsen bekend met meer dan tien Belgische grensarbeiders. In deze categorie was 86 procent woonachtig in een Belgisch-Limburgse gemeente, vooral in Maasmechelen, Maaseik, Stokkem en Eisden. 47 Belgische grensarbeiders pendelden uit Gemmenich en La Calamine in de provincie Luik, plaatsen onmiddellijk ten zuiden van Vaals. ${ }^{52}$

De grenspendel van Belgische en vooral Duitse mijnwerkers liep in de crisisjaren sterk terug en werd marginaal (grafiek 5.Io).

\section{Naar georganiseerde werving: de jaren twintig}

Tussen 1919 en 1930 nam bij de Limburgse mijnen het aantal buitenlandse mijnwerkers sterker toe dan het Nederlandse deel van de bezetting. Bijna 6o procent van de nieuwe mijnwerkers had in die periode een buitenlandse nationaliteit (tabel 4.I). Eind I930 was 32 procent van alle mijnwerkers in Nederland buitenlander, terwijl dat eind IgI8 nog slechts I6 procent was geweest. De buitenlandse arbeiders kwamen vooral ondergronds terecht. Eind I9I8 was 20 procent van de ondergrondse bezetting van buitenlandse origine, eind I930 was dat verdubbeld tot 40 procent (bijlage I6). In de periode vóór de Tweede Wereld-

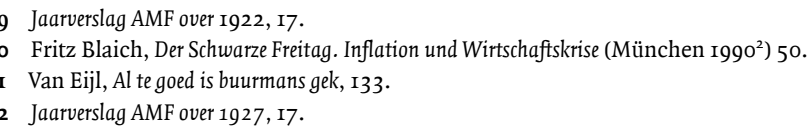


oorlog werkten 85 tot 90 van elke honderd buitenlanders ondergronds. Bij mijnwerkers uit verder weg gelegen landen als Polen, Joegoslavië, Tsjecho-Slowakije en Italië lag dat percentage nog aanzienlijk hoger. Eind 1930 was 96 procent van hen ondergronds aangesteld. ${ }^{53}$ Ter vergelijking: bij de Nederlandse mijnwerkers was het percentage ondergronders 60 à 70 .

Dat de mijnen in toenemende mate een beroep moesten doen op buitenlandse arbeiders duidt er op dat de Nederlandse arbeidsmarkt was opgedroogd. Vooral gold dat voor de jaren tussen 1925 en I930. De tweede helft van de jaren twintig werd gekenmerkt door een grote vraag naar mijnwerkers. Drie nieuwe mijnen kwamen in die jaren in productie, waaronder de zeer groot opgezette Staatsmijn Maurits in Geleen. Bovendien hadden de oudere mijnen hun maximale productiecapaciteit nog niet bereikt; daardoor konden ze voortdurend mijnwerkers gebruiken. Grafiek 5.2 laat die ontwikkeling duidelijk zien: de groeipercentages van de buitenlanders in dienst van de mijnen lagen jaarlijks ruim boven die van de $\mathrm{Ne}$ derlandse bezetting. Het groeipercentage van de Nederlandse ondergronders was meestal negatief.

Ook de Nederlandse arbeidsmarkt voor ongeschoolde arbeiders schoot in de tweede helft van de jaren twintig tekort. De jaarverslagen van de districtsarbeidsbeurs in Heerlen maakten voortdurend melding van het grote tekort aan slepers. ${ }^{54}$ Pas in 1930 kon directeur Grootjans in zijn jaarverslag opmerken dat er bij de mijnen geen behoefte meer was aan ongeschoolde arbeidskrachten en ze voor hun personeelsvoorziening in voldoende mate konden putten uit het arbeidsaanbod in de regio. ${ }^{55}$ De mijndirecties moesten daarom na 1925 in toenemende mate ook onervaren mijnwerkers uit het buitenland rekruteren. ${ }^{6}{ }^{6}$ Versteegh toonde aan dat van de Poolse arbeiders die in de periode I927-I930 door de mijnzetel Oranje Nassau II werden gerekruteerd, 53,2 procent als ongeschoold kon worden aangemerkt. In I920 was dat percentage slechts 32,6 geweest. ${ }^{57}$ Ondergronds werden deze ongeschoolde mijnwerkers ingezet als sleper.

De toenemende werving van ongeschoolde buitenlanders kan echter ook worden toegeschreven aan de veranderende rol van deze categorie arbeiders in het mijnbedrijf. ${ }^{8} \mathrm{Op}$ basis van interviews met oud-mijnwerkers van Poolse, Sloveense en Italiaanse herkomst concludeerden Brassé en Van Schelven dat de ervaren mijnwerkers uit het buitenland aanvankelijk een belangrijke rol speelden als opleider. Nederlandse mijnwerkers leerden in de ondergrondse praktijk het houwersvak van hun ervaren buitenlandse collega's. In de loop van de tijd bouwden de Limburgse mijnen op die manier een vaste kern van geschoolde Nederlandse mijnwerkers op. Daarmee verdween langzamerhand de afhankelijkheid van de Nederlandse mijndirecties van de ondergrondse vakman uit het buitenland.

Het is verleidelijk een relatie te veronderstellen tussen het gewijzigde wervingsbeleid ten aanzien van arbeidskrachten uit het buitenland en de ontwikkeling van de mechanisering en de arbeidsorganisatie in het ondergrondse bedrijf in de jaren twintig. Tengevolge van de introductie van de schudgoot en de pneumatische afbouwhamer onderging de organisatie

53 Jaarverslag van den Hoofd-Ingenieur der Mijnen over 1930.

54 Jaarverslag van de Arbeidsbeurs voor de Limburgsche Mijnstreek 1926.

55 Idem 1930.

56 Brassé en Van Schelven, Assimilatie, 146.

57 Versteegh, Onvermijdelijke afkomst, 225.

58 Brassé en Van Schelven, Assimilatie, I45-I47. 
van de winning en het transport van de steenkool belangrijke wijzigingen. ${ }^{59}$ Schaalvergroting kwam tot uiting in de vervanging van de traditionele koppijler, waar kleine groepjes mijnwerkers de steenkolen met de hak uit de laag braken en in wagentjes schepten, door de lange pijler, waarin soms enkele tientallen mijnwerkers naast elkaar met behulp van de afbouwhamer de steenkool dolven, die via de schudgoot gemechaniseerd uit de pijler werd gevoerd. Het vakmanschap van de houwer wijzigde. Waar voorheen veel afhing van de ervaring om bij het losmaken van de kolen gebruik te maken van zogenaamde splijtvlakken (zwakke plekken in de laag), werd dat bij het gebruik van de krachtige afbouwhamer minder belangrijk. Bovendien werd de houwer bij zijn werk in de lange pijler geholpen door de grotere druk van het gesteente, die als het ware de kolen uit de laag perste. Mijningenieurs wezen er op dat het gebruik van de afbouwhamer het gevaar inhield van het verloren gaan van het 'ouderwetse' vakmanschap van de houwer. Ook nam door de komst van de lange pijler de specialisatie toe. De arbeidsdag werd ingedeeld in drie diensten: een kooldienst, waarin de steenkool werd gewonnen, een omlegdienst, waarin de schudgoot naar het kolenfront werd verplaatst en een vul- of roofdienst, waarin men de ontkoolde pijler met stenen vulde of gecontroleerd liet instorten. ${ }^{60}$

Het is denkbaar dat de gewijzigde eisen die aan het vakmanschap van de houwer werden gesteld, de introductie van een nieuwe arbeidsorganisatie in de lange pijler, alsmede het ontstaan van nieuwe functies door de introductie van het dienstensysteem, ook de afhankelijkheid van in het buitenland opgedane ervaring heeft verminderd. Naarmate de techniek voortschreed, kon kennis en kunde niet meer op de werkplek al doende aan jonge collega's worden overgebracht. Eind jaren twintig werd daarom ook de opleiding van jonge mijnwerkers geïnstitutionaliseerd. ${ }^{6 r}$

De toegenomen werving van ongeschoolden in het buitenland betekende niet dat ervaren buitenlanders niet langer welkom waren. Ook in de tweede helft van de jaren twintig rekruteerden de mijnen geschoolde buitenlanders. Dat blijkt zowel uit de wervingsafspraken die de mijnen met buitenlandse autoriteiten maakten (zie hieronder) als uit berichten van de arbeidsbeurs in Heerlen dat zich regelmatig geschoolde mijnwerkers met een niet-Nederlandse nationaliteit aanboden en door de mijnen in dienst genomen werden. ${ }^{62}$ Evenmin werden geschoolde buitenlanders die al in dienst waren, afgedankt. Ervaren mijnwerkers waren altijd gewenst, ongeacht nationaliteit. Menig ervaren buitenlandse ondergronder die in de jaren twintig was gerekruteerd, bracht het tot een langjarige carrière in de Limburgse mijnbouw. ${ }^{6}$ Uit een steekproef uit de inschrijvingen bij het Algemeen Mijnwerkersfonds (AMF) bleek bijvoorbeeld dat bij een op de vier buitenlandse arbeiders die in de periode 1920-I93I bij de Nederlandse mijnen in dienst trad, een dienstverband van vijf jaar of meer volgde..$^{64}$

Gelijke carrièrekansen hadden de buitenlandse mijnwerkers doorgaans niet. Duitsers hadden nog de beste kansen: zij konden het in de praktijk soms brengen tot opzichter, de

59 B.P.A. Gales, J.P. Smits en R. Bisscheroux, 'Steenkolen', Techniek in Nederland in de twintigste eeuw II: Delfstoffen, energie, chemie (Zutphen 2000) 45-65, aldaar 45-53.

6o Ben Gales, 'De techniek ondergronds', Weet je nog, koempel? De mijnen in Limburg (Zwolle 2004) 153-176, aldaar I62-167.

6I Rob Wolf, Mijnbouw, techniek en onderwijs. De ondergrondse vakscholen van de Staatsmijnen (doctoraalscriptie, Nijmegen 1978 ) deel III, 29-34.

62 Jaarverslag van de Arbeidsbeurs voor de Limburgsche Mijnstreek 1927; idem 1928; idem 1929.

63 Zie bijvoorbeeld: Wojtkowiak, Je moet weten hoe haas hupt.

64 AZL Heerlen, ArchiefAMF, inschrijvingskaarten I9I9-ca I97I. 
Grafiek 5.II Het Aantal NATURAlisaties TOT NEDERLANDER VAN MiJNWERKERS IN LIMBURG, I9O6-I933

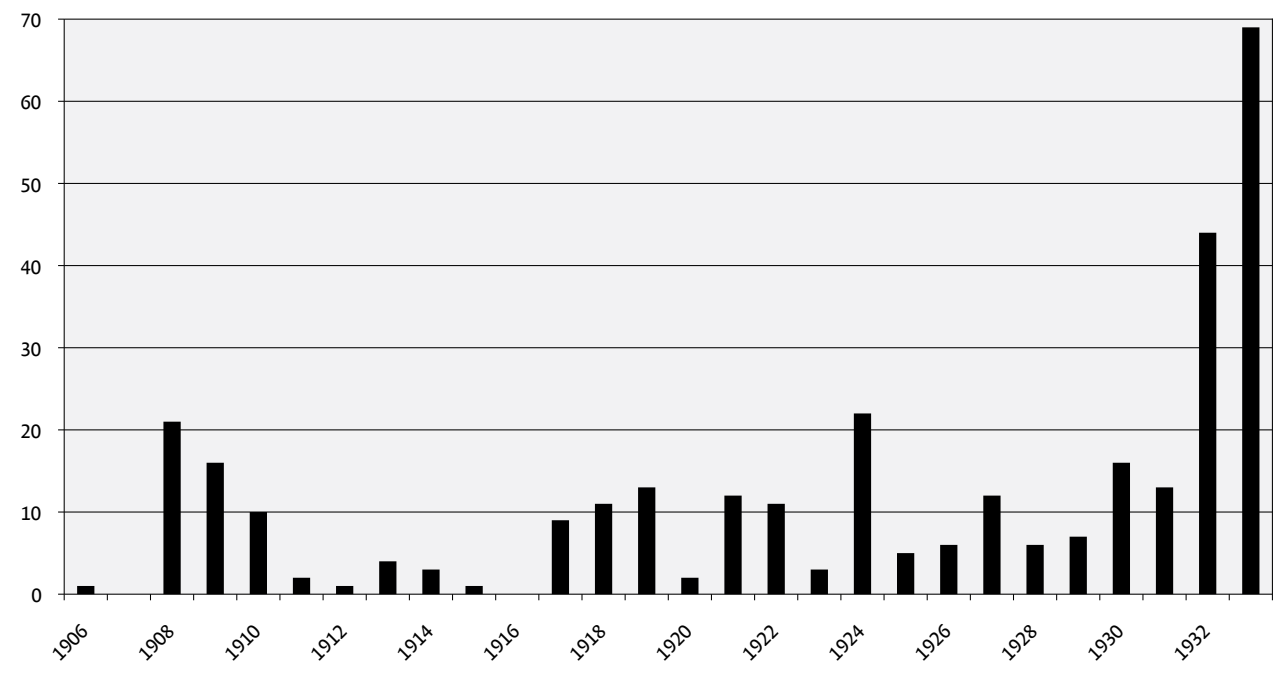

Bron: Staatsblad, I906-1933. Het bestand van ruim Ir.000 vreemdelingen die zich in de periode 1850-1933 hebben laten naturaliseren tot Nederlander is beschikbaar gemaakt op www.shgv.nl. Hieruit werden voor de jaren na I905 de aan mijnbouw gerelateerde beroepen van de betrokkenen gefilterd. Met dank aan dr. Willibrord Rutten (Sociaal Historisch Centrum voor Limburg in Maastricht).

laagste rang van beambte. Dit gold met name voor particuliere mijnen als de Domaniale en de Oranje-Nassau, waar het Duitse element vanouds sterk vertegenwoordigd was. Voor immigranten uit Oost- en Zuid-Europa was het opklimmen tot beambte slechts bij zeer hoge uitzondering weggelegd. ${ }^{65}$ Niet alleen hadden zij een taalprobleem, hetgeen hun opleiding op de mijnschool bemoeilijkte, maar ook was het beleid van vooral Staatsmijnen erop gericht om bij voorkeur Nederlanders voor kaderfuncties in aanmerking te laten komen. Uit onderzoek naar de arbeidspositie van Polen bij de Oranje-Nassau Mijnen bleek dat hun kansen om het tot opzichter te brengen gering waren. ${ }^{66}$ Ook uit interviews met Sloveense (oud-)mijnwerkers kwam naar voren dat voor hen het opklimmen tot een beambte-functie nagenoeg uitgesloten was. Hun herinneringen werden bevestigd door toenmalig bedrijfsingenieur C. Raedts van de Oranje-Nassau Mijnen: promotie tot beambte was alleen mogelijk als iemand genaturaliseerd was tot Nederlander. ${ }^{67}$ Vanwege de hoge kosten kwam onder mijnwerkers naturalisatie tot Nederlander, zeker vóór de Tweede Wereldoorlog, echter erg weinig voor (zie grafiek 5.II). ${ }^{68}$

De werving en selectie van buitenlandse arbeidskrachten gebeurde vanaf de eerste helft van de jaren twintig op een meer gestructureerde manier dan tot dan toe gebruikelijk was geweest. Het vertrouwen in voldoende spontane toeloop van ervaren buitenlandse mijnwerkers makte meer en meer plaats voor een actiever rekruteringbeleid, waarbij een betere se-

65 Brassé en Van Schelven, Assimilatie, I45-I46.

66 Versteegh, Onvermijdelijke afkomst, 228-229.

67 Mulders, Met de buik het brood achterna, 50.

68 Brassé en Van Schelven, Assimilatie, I26-гіг. 
lectie vooraf mogelijk was. ${ }^{69}$ Aanvankelijk betekende de meer actieve wijze van werving en selectie in het buitenland dat de mijnondernemingen wervingsagenten naar buitenlandse mijndistricten stuurden. Zo stuurde Staatsmijnen eind 1924 wervingsbeambten naar het Franse mijnbouwgebied van de departementen Nord en Pas-de-Calais om er ervaren ondergronders te werven. Dat leverde de Nederlandse mijnen een aantal Poolse ondergronders op, die na de Eerste Wereldoorlog vanuit het Ruhrgebied in Noord-Frankrijk waren beland..$^{70}$ Ook de particuliere mijnen hadden wervingsagenten in dienst. De Oranje-Nassau Mijnen deden daarnaast een beroep op zogenaamde aannemers. Deze functioneerden als particuliere arbeidsbemiddelaars en boden losse arbeidskrachten aan..$^{71}$ Dit soort bemiddelingsbureaus werkte niet altijd even bonafide. Met name in Noord-Frankrijk bleken bureaus met een bedenkelijke reputatie te functioneren. Een daarvan gaf zich zelfs ten onrechte uit als agentschap van de mijnonderneming Laura \& Vereeniging. Tegen betaling konden in Noord-Frankrijk mijnwerkers zich inschrijven voor werk in Nederland, waarbij werd voorgewend dat plaatsing al verzekerd was. ${ }^{72}$

Meestal was de praktijk van de werving in het buitenland dat de mijnen actief samenwerkten met officiële instellingen voor arbeidsbemiddeling in de betreffende landen. Aanvankelijk waren het Ruhrgebied en het Saarland de aangewezen regio's om mijnwerkers te werven. ${ }^{73}$ De economisch-monetaire chaos waarin de jonge Republiek van Weimar tot 1924 verkeerde, maakte velen werkloos en stimuleerde vertrek naar het buitenland. ${ }^{74}$ Onder hen waren ook naar schatting 150.000 Ruhrpolen, die moesten omzien naar een betrekking in het buitenland. ${ }^{75}$ De Nederlandse Arbeidsbeurs in Oberhausen werd door de mijnen als samenwerkingspartner gebruikt, evenals het Niederländisches Arbeitsamt in Bochum, dat van daaruit de arbeidsbemiddeling voor Staatsmijnen leidde. ${ }^{76}$ Ook de particuliere Laura \& Vereeniging en Oranje-Nassau Mijnen wierven actief in het Ruhrgebied.

De wervingsacties zijn zichtbaar in de resultaten van het mijnwormonderzoek, die in bijlage 13 zijn gepresenteerd. De instroom uit buitenlandse mijnen was in 1925 met ruim 30 procent van het totaal aan nieuw personeel voor het ondergrondse bedrijf aanzienlijk hoger dan sinds een aantal jaren gebruikelijk was. Verder valt op dat het aandeel van de mijnen in België en in het 'overige buitenland' (in de praktijk waren dat voornamelijk de Franse mijnen van Nord en Pas-de-Calais) in 1925 belangrijker werd, al bleef de instroom uit Duitse mijnen onverminderd prominent. Tussen I 919 en I 924 was gemiddeld per jaar 25,9 procent van de ervaren ondergronders afkomstig uit een Duitse mijn. In 1925 was dat I 19,3 procent. De mijnen in België en het overige buitenland hadden in de jaren I919-1924 een marginale rol gespeeld bij de rekrutering van ervaren mijnwerkers voor de Nederlandse mijnen. Gemiddeld per jaar was I, I procent van de ondergronders afkomstig uit een Belgische mijn en 0,2 procent uit een mijn in het overige buitenland. In 1925 waren die percentages belangrijk gestegen tot respectievelijk 8,4 en 3, I procent (bijlage I2).

69 Kreukels, 'Vreemd gespuis', 72.

70 Wojtkowiak, Je moet weten hoe haas hupt, 75.

7I Versteegh, Onvermijdelijke afkomst, 23I.

72 Gales e.a., Bedrijfsuoering, 126.

73 Dieteren, Migratie, I3I.

74 Brassé en Van Schelven, Assimilatie, 36-37.

75 Dorota Praszalowicz, 'Polen', in: Bade e.a. (ed.), Enzyklopädie, 258-271, aldaar 263; Brian McCook, 'Polnische industrielle Arbeitswanderer im Ruhrgebiet (Ruhrpolen) seit dem Ende des I9. Jahrhunderts', in: ibidem, 870-879, aldaar 877-878.

76 Gales e.a., Bedriifsvoering, 123. 
In de tweede helft van de jaren twintig bleek steeds duidelijker dat de werving in het Ruhrgebied onvoldoende mijnwerkers opleverde. In I929 was het resultaat van een wervingsactie voor houwers en slepers, waarvoor de bedrijfsleiding van de Oranje-Nassau Mijnen een hoofdopzichter van de ON III naar het Ruhrgebied stuurde, praktisch nihil. De autoriteiten weigerden medewerking, omdat er in het Ruhrgebied zelf een tekort aan ervaren mijnwerkers was ontstaan. ${ }^{77}$ Die geleidelijke opdroging van de Duitse arbeidsmarkt had de Nederlandse mijnen er al een paar jaar eerder toe gebracht ook rechtstreeks te gaan werven in Centraal-, Oost- en Zuid-Europa. Deze wervingscampagnes brachten groepen Tsjechen en Italianen naar Limburg, samen met nieuwe contingenten Oostenrijkers, Joegoslaven en Polen. Een belangrijke overweging om mijnwerkers in hun vaderland te gaan werven, was de overtuiging dat zij minder 'ontworteld' waren dan degenen die al in vele mijnen in verschillende landen hadden gewerkt en er aan gewend waren geraakt om nergens lang te blijven. Volgens De Mijnwerker, het blad van de Nederlandse Katholieke Mijnwerkersbond, hadden de buitenlandse arbeiders die rechtstreeks in hun vaderland werden geworven 'nog niet hun raseigenschappen verloren', zoals dat doorgaans wel was gebeurd met degenen die al in andere kolenbekkens hadden gewerkt. De resultaten van de nieuwe wijze van werven waren volgens het blad dan ook bevredigend te noemen. ${ }^{78}$ Niettemin gingen de mijnondernemingen zelf er vanuit dat de aanwezigheid van de nieuwkomers in Limburg tijdelijk zou zijn. Niet voor niets was de rekruteringsstrategie er op gericht de arbeiders te werven in landbouwgebieden. De groepen uit het eind van de jaren twintig waren 'halve landbouwers die ernaar streefden zich als zelfstandigen in hun eigen land te kunnen vestigen met behulp van het geld dat zij als mijnwerker konden sparen'. ${ }^{79}$ Van in ieder geval de groep Polen die in deze tijd in Nederland arriveerde, is bekend dat zij een tijdelijk arbeidscontract kregen, met werkzekerheid voor maximaal twaalf maanden. ${ }^{80}$

Onderdeel van het wervingsbeleid van de Limburgse mijnondernemingen was ook dat men zich richtte op katholieke landen. Ten gevolge van de ongestructureerde komst van vreemde arbeiders was Limburg sedert het begin van de eeuw minder homogeen katholiek geworden. In I900 was meer dan 99 procent van de bevolking katholiek. In I920 was dat afgenomen tot 86 procent; in Heerlen en Brunssum, waar zich relatief veel nieuwkomers vestigden, zelfs tot 75 procent. ${ }^{81}$ Voor zover het bedrijfsbelang zich er niet te veel tegen verzette, wilden de mijndirecties wel rekening houden met de katholieke identiteit van Limburg en dus katholieke mijnwerkers rekruteren. Dat zou naar verwachting minder aanpassingsproblemen met zich meebrengen voor de migranten, omdat die konden worden opgenomen in het op katholieke leest geschoeide Limburgse maatschappelijke bestel. ${ }^{82}$ Uiteraard was dat ook het belang van de mijnondernemingen. Zo sprak Laura \& Vereeniging bij de werving in Joegoslavië van mijnwerkers voor de mijnzetel Julia een duidelijke voorkeur uit voor 'onberispelijke katholieke arbeiders'.$^{83}$

77 Ibidem, 126.

78 De Mijnwerker, 5-4-I930, geciteerd bij Brassé en Van Schelven, Assimilatie, 29.

79 Kreukels, Mijnarbeid, 293.

8o Versteegh, Onvermijdelijke afkomst, 232.

8I Dieteren, Migratie, 38.

82 Mulders, Met de buik het brood achterna, 30.

83 SHCL, Archief Laura \& Vereeniging, inv. nr. 534: Brief van Laura \& Vereeniging aan het Joegoslavische Auswanderungs Emissariat in Düsseldorf, 8-7-I929. 
Daarnaast was de taal van belang. Tijdens de Eerste Wereldoorlog hadden de mijnondernemingen bij de tewerkstelling van de Waalse geïnterneerden moeilijkheden ervaren die samenhingen met een onvoldoende beheersing door arbeiders van een taal die in de mijnen gangbaar was. De rekrutering richtte zich in de jaren twintig daarom op landen of regio's waar arbeiders in ieder geval het Duits min of meer machtig waren: naast Duitsland zelf op Oostenrijk, of op Duitssprekende gebieden in Polen, Tsjecho-Slowakije en Joegoslavië. ${ }^{84}$ In ieder geval moesten ze voldoende Duits begrijpen om zich bij het werk verstaanbaar te kunnen maken. ${ }^{85}$ Voor Laura \& Vereeniging was enige kennis van het Duits, naast de onberispelijkheid van gedrag en het katholiek-zijn, zelfs een derde harde eis die het bedrijf aan de te werven arbeiders in Joegoslavië stelde. ${ }^{86}$ In de Limburgse mijnstreek was door de veelvuldige contacten met Duitsland het Duits van oudsher ingeburgerd. Dat gold ook voor het mijnbedrijf. Veel benamingen waren er ontleend aan de Duitse taal, omdat het kader zijn opleiding vaak in Duitsland had genoten en veel van de arbeidskrachten Duitsers waren. Ook al de eerste groepen Polen en Slovenen die al vóór de Eerste Wereldoorlog in de Nederlandse mijnen waren beland, spraken Duits. Zij hadden de taal leren begrijpen in het Ruhrgebied, vanwaar de meesten van hen direct of indirect afkomstig waren. ${ }^{87}$

Ondanks alle moeite lukte het niet altijd om enkel Duitssprekende arbeidskrachten in de wervingslanden te vinden. Staatstoezicht constateerde in I929 dat communicatieproblemen tussen ondergronders tot gevaarlijke situaties op de werkplek aanleiding konden geven. De mijndirecties beaamden de taalmoeilijkheden en beloofden arbeidskrachten die het Nederlands of het Duits niet machtig waren samen te laten werken met collega's die als tolk konden optreden. ${ }^{88}$

De georganiseerde werving van mijnwerkers verliep ook in Centraal-, Oost- en Zuid-Europese landen via tussenkomst van officiële kanalen. Voor de werving in Polen, die vooral voor Staatsmijnen en de Oranje-Nassau Mijnen van belang was, werkten de mijnondernemingen nauw samen met de Emigratie Commissie in Warschau en met mr. F.G. van der Kroon, de honorair-consul van Polen in Heerlen. ${ }^{89}$ De contacten met de Joegoslavische arbeidsmarkt liepen via het Auswanderungs Emissariat des Königreiches der Serben, Kroaten und Slovenen in Düsseldorf, dat op zijn beurt in nauwe verbinding stond met arbeidsbemiddelingsinstanties in Joegoslavië..$^{\circ}$ De rekrutering van Oostenrijkers vond plaats via bemiddeling van het Wanderungsamt in Wenen, ${ }^{91}$ in Tsjecho-Slowakije speelde de Société Tchèque de Colonisation in Praag een belangrijke rol bij de bemiddeling van arbeiders naar de Nederlandse mijnen (vooral naar Staatsmijnen en de Oranje-Nassau Mijnen). ${ }^{92}$ Vaak kon de werving niet zonder

84 RHCL, ArchiefOranje-Nassau Mijnen I7.05J, inv. nr. Io: Tewerkstelling Tsjechen, I929; inv. nr. II: Tewerkstelling Oostenrijkers, I929.

85 RHCL, Centraal ArchiefDSM 17.26/06A, inv. nr. 63: Brief van de directie van Staatsmijnen aan de bedrijfsingenieurs van de mijnzetels, 5-II-I929.

86 SHCL, Archief Laura \& Vereeniging, inv. nr. 534: Brief van Laura \& Vereeniging aan het Joegoslavische Auswanderungs Emissariat in Düsseldorf, 8-7-I929.

87 Brassé en Van Schelven, Assimilatie, I42-I43.

88 Jaarverslag van den Hoofd-Ingenieur der Mijnen over het jaar 1929, 98.

89 Versteegh, Onvermijdelijke afkomst, 232-233; Brassé en Van Schelven, Assimilatie, 38-45.

90 SHCL, Archief Laura \& Vereeniging, inv. nr. 534: Brieven Auswanderungs Emissariat in Düsseldorf aan Laura \& Vereeniging, 10-3I929 en 2-4-I929.

91 RHCL, ArchiefOranje-Nassau Mijnen, 17.05J, inv. nr. Ir: BriefWanderungsamt in Wenen aan Oranje-Nassau Mijnen, 17-8-1929. 92 RHCL, Archief Oranje-Nassau Mijnen, 17.05J, inv. nr. Io: Brief Société Tchèque de Colonisation in Praag aan Oranje-Nassau Mijnen, september 1929 . 
de medewerking van officiële instanties, omdat de betreffende landen toestemming voor vertrek naar Nederland moesten geven in de vorm van een paspoort met uitreisvisum. Het 'paspoortloze tijdperk' met vrij verkeer van personen was met het uitbreken van de Eerste Wereldoorlog geëindigd. Ook voor de binnenkomst en tewerkstelling in Nederland van vreemdelingen waren de regels sindsdien aangescherpt. Voor Polen, Tsjechen, Joegoslaven en andere Zuid- en Oost-Europeanen bestond er een visumplicht, die in de praktijk vooral diende ter bescherming van de arbeidsmarkt door de Nederlandse staat. Een visum werd slechts verstrekt als de Rijksdienst der Werkloosheidsverzekering en Arbeidsbemiddeling (via de districtsarbeidsbeurs in de betreffende regio) had verklaard dat er in het beroep waarin de aanvrager ging werken geen Nederlanders beschikbaar waren. Verblijfsvergunning en arbeidscontract waren aan elkaar gekoppeld. Wanneer het arbeidscontract werd beëindigd, verviel tevens de verblijfsvergunning. Om tegen te gaan dat buitenlanders met een visum van beroep veranderden en in een beroep terechtkwamen waarvoor geen toestemming zou zijn verkregen, werd vanaf I januari I924 naast de verklaring van de arbeidsbeurs ook een werkgeversverklaring geëist. ${ }^{93}$ Hoewel de Limburgse mijnondernemingen eenvoudig konden aantonen dat de Nederlandse arbeidsmarkt onvoldoende mijnwerkers opleverde en de Rijksdienst steeds meewerkte aan de wervingsacties in het buitenland, kwamen ze niet onder de nieuwe formele richtlijnen uit.

Aan de basis van de georganiseerde rekrutering van buitenlandse arbeiders stond meestal een contract dat was opgesteld in samenspraak tussen de Nederlandse mijnen en de autoriteiten in het buitenland, die immers de belangen van hun onderdanen op hun nieuwe werkplek in Nederland gegarandeerd wilden zien. De overeenkomst bevatte afspraken over de eisen die aan de te werven arbeiders werden gesteld, de arbeidsvoorwaarden die bij de Nederlandse mijnen voor hen zouden gelden en de procedure van selectie en werving. Op enkele kleine punten van verschil na, bestond tussen de contracten met de verschillende wervingslanden grote overeenkomst.

Het sprak welhaast vanzelf dat de arbeiders van onbesproken gedrag moesten zijn. Als bewijs daarvan dienden de kandidaten die voor tewerkstelling bij de mijnen in aanmerking wilden komen, te beschikken over een bewijs van goed gedrag, afgegeven door de plaatselijke politie in de gemeente van herkomst en een verklaring over de duur en aard van eventuele vorige dienstbetrekkingen. Hieruit moest in ieder geval blijken dat de laatste dienstbetrekking met instemming van de werkgever was beëindigd. ${ }^{94}$ Ook moesten de sollicitanten, ter controle van de opgegeven personalia, een geboortebewijs overleggen. Wellicht ten overvloede gaf de Poolse regering daarnaast bij monde van honorair-consul Van der Kroon de verzekering dat alleen 'bekwame en ordelievende werkkrachten' naar Nederland zouden worden gezonden. ${ }^{95}$

Omdat de arbeidskrachten in het buitenland uitsluitend werden geworven voor ondergrondse arbeid, hechtten de mijnondernemingen veel belang aan hun fysieke gesteldheid. Daarom werd overeengekomen dat er twee medische keuringen zouden voorafgaan aan de definitieve tewerkstelling. Een eerste vrij oppervlakkig onderzoek in het land van werving

93 Van Eijl, Al te goed is buurmans gek, 128 .

94 RHCL, Archief Oranje-Nassau Mijnen 17.05J, inv. nr. 9: Brief van Van der Kroon aan Oranje-Nassau Mijnen, I-7-I929.

95 RHCL, Archief Oranje-Nassau Mijnen 17.05J, inv. nr. 9: Brief van Staatsmijnen aan Van der Kroon, 24-I0-I927; Brief van OranjeNassau Mijnen aan Van der Kroon, 15-6-1929. 
en een tweede, uitgebreidere check-up door de mijnarts van het bedrijf bij aankomst in $\mathrm{Ne}$ derland. De kosten van de medische keuringen kwamen voor rekening van het mijnbedrijf. Wanneer bij de tweede keuring in Nederland de geworven arbeider alsnog voor mijnarbeid werd afgekeurd, volgde repatriëring naar het land van herkomst. Ook die kosten werden door de mijn betaald..$^{6}$

Een leeftijdsindicatie maakte eveneens deel uit van de selectievoorwaarden. De maximumleeftijd bij werving was veertig jaar. Staatsmijnen en de Oranje-Nassau Mijnen maakten daarbij geen onderscheid in ervaring van de arbeider. ${ }^{97}$ Laura \& Vereeniging daarentegen hanteerde de leeftijdsgrens van 40 jaar alleen voor houwers. Slepers, onervaren arbeidskrachten die nog moesten worden opgeleid tot volleerd mijnwerker, mochten niet ouder zijn dan 30 jaar..$^{8}$

Aan de burgerlijke staat werden geen eisen gesteld: zowel ongehuwden als gehuwden werden geworven. Gehuwden konden desgewenst hun gezin mee naar Nederland nemen, al raadde Laura \& Vereeniging aan dat pas te doen als ook de medische keuring in Nederland had uitgewezen dat de arbeidsmigrant in dienst kon worden genomen. ${ }^{99} \mathrm{Wie}$ ervoor koos zijn gezin in het vaderland achter te laten, werd wel geacht een deel van zijn in Nederland verdiende geld regelmatig naar huis over te maken. De Tsjechische autoriteiten achtten het gewenst een bepaling daarover in de overeenkomst op te laten nemen: 'De arbeider [...] verklaart er genoegen mee te nemen, dat voor het geval hij voor zijne in het vaderland achter gebleven familie niet zorg draagt, hem een door den Tsjechoslowaakschen Gezantschap of Consulaat vast te stellen deel van zijn loon wordt ingehouden, om aan zijn familie door bemiddeling van den Tsjechoslowakkschen Gezantschap of Consulaat te worden afgedragen'. ${ }^{100}$

Voor de arbeidsmigranten golden de arbeidsvoorwaarden, zoals die in de cao voor het Nederlandse mijnbedrijf waren vastgelegd. Onderscheid met Nederlandse mijnwerkers werd dus niet gemaakt. In het contract van de Oranje-Nassau Mijnen met de Poolse autoriteiten stond zelfs expliciet vermeld dat de Poolse arbeiders niet zouden worden achtergesteld, omdat ze de taal niet beheersten: 'Het niet op de hoogte zijn met de Nederlandsche taal kan bij gelijke arbeidsprestatie geen reden zijn noch voor loonsvermindering noch voor het opdragen van zwaarder werk' ${ }^{\text {Ior }}$

Voor degenen die naar de Nederlandse mijnen kwamen, werd goede huisvesting gegarandeerd: gezinswoningen voor gehuwden en een plaats in een gezellenhuis voor ongehuwden. ${ }^{\text {102 }}$ Dat die garantie geen loze belofte was, bleek in september 1929 toen Oranje-

96 SHCL, Archief Laura \& Vereeniging, inv. nr. 435: Brief van Laura \& Vereeniging aan het Auswanderungs Emissariat in Düsseldorf, 8-7-1929.

97 RHCL, ArchiefOranje-Nassau Mijnen I7.05J, inv. nr. 9: Brief van Van der Kroon aan Oranje-Nassau Mijnen, I-7-I929.

98 SHCL, Archief Laura \& Vereeniging, inv. nr. 435: Brief van Laura \& Vereeniging aan het Auswanderungs Emissariat in Düsseldorf, 8-7-1929.

99 SHCL, Archief Laura \& Vereeniging, inv. nr. 435: Brief van Laura \& Vereeniging aan het Auswanderungs Emissariat in Düsseldorf, 8-7-1929.

Ioo RHCL, Archief Oranje-Nassau Mijnen 17.05J, inv. nr. Io: Brief van Société Tchèque de Colonisation in Praag aan Oranje-Nassau Mijnen, september 1929 .

I0I RHCL, ArchiefOranje-Nassau Mijnen 17.05J, inv. nr. 9: Brief van Van der Kroon aan Oranje-Nassau Mijnen, 25-6-I929. Het standaard arbeidscontract waarover de mijnondernemingen met de Poolse autoriteiten tot overeenstemming waren gekomen, is als bijlage bij deze brief gevoegd.

I02 SHCL, Archief Laura \& Vereeniging, inv. nr. 534: Brief van Laura \& Vereeniging aan het Auswanderungs Emissariat in Düsseldorf, 8-7-1929. 
Nassau Mijnen de werving in Polen tijdelijk opschortte vanwege gebrek aan huisvesting. ${ }^{103}$

Over de procedure van werving en selectie werd doorgaans afgesproken dat de autoriteiten in het buitenland ervoor zorgden dat belangstellenden voor werk in de Nederlandse mijnen werden gezocht, al stuurden de Nederlandse mijnen soms hun vertegenwoordigers om bij de eerste selectie te assisteren. Wervingsagenten van Laura \& Vereeniging bijvoorbeeld bezochten dorpen in Slovenië. In het dorpscafé, waar de mannen zich na de zondagse hoogmis verzamelden, hielden de Nederlandse beambten een praatje over het werk in de Limburgse mijnen en benadrukten hoeveel er kon worden verdiend. ${ }^{104}$ Vervolgens werden de kandidaten die zich aanmeldden op centrale plaatsen bijeengebracht. Daar konden de gevolmachtigden van de mijnen geschikte kandidaten rekruteren. ${ }^{105}$ Op de verzamelplaatsen vond ook de eerste algemene medische keuring plaats. Wanneer die geen fysieke ongeschiktheid voor mijnarbeid aan het licht bracht en de door de mijnen vereiste documenten met betrekking tot goed gedrag en personalia konden worden overlegd, volgde een voorlopig bewijs van indienstneming. Op basis van die tewerkstellingsverklaring konden de reisdocumenten in orde worden gemaakt.

De mijnbedrijven betaalden de visumkosten die de buitenlandse arbeider moest maken. Verder kwamen ook de kosten van de reis naar Nederland, inclusief de voeding tijdens de reis en het geneeskundig onderzoek voor rekening van de mijnbedrijven. De mijnen verplichtten zich de repatriëring na afloop van het arbeidscontract te bekostigen. Tijdens de groepsgewijze reis naar Nederland werden de geworven arbeidsmigranten begeleid door een wervingsagent van de Nederlandse mijnen. ${ }^{106}$ Soms maakten de mijnen daarbij gebruik van een landgenoot van de geworven arbeiders, die al langer bij de mijn in dienst was. ${ }^{107}$

De overgang naar georganiseerde werving betekende niet dat spontane aanmelding van buitenlanders tot het verleden behoorde. Waarschijnlijk heeft de toenemende aanwezigheid van buitenlandse arbeiders in de Nederlandse mijnen kettingmigratie van dorpsgenoten, familieleden, vrienden en oud-collega's gestimuleerd. Individueel en in groepsverband arriveerden ook in de tweede helft van de jaren twintig buitenlanders op de bonnefooi in Limburg. Ze kwamen via een omweg van een mijn in Duitsland, Frankrijk of België, maar ook rechtstreeks uit hun geboorteland. ${ }^{108}$ Dat men zelf moest zorgen voor de vereiste papieren en de reis naar Nederland uit eigen zak moest betalen, namen deze spontane arbeidsmigranten voor lief. Hoe in de jaren twintig de verhouding lag tussen georganiseerde en spontane arbeidsmigratie naar de Limburgse mijnen, valt bij gebrek aan bronnen niet na te gaan.

Als gevolg van de intensieve werving werd de samenstelling van de buitenlandse arbeidersbezetting na I924 diverser (grafiek 5.9). Duitsers maakten weliswaar nog steeds de meerderheid uit, maar hun aandeel nam zienderogen af. In I93o had 63 procent van de buitenlandse mijnwerkers de Duitse nationaliteit, waar dat zes jaar eerder nog 8o procent was geweest. Daarentegen was de aanwezigheid van vooral Polen en Joegoslaven belangrijker geworden.

\footnotetext{
I03 RHCL, ArchiefOranje-Nassau Mijnen 17.05J, inv. nr. 9: Brief van Oranje-Nassau Mijnen aan de consul van Polen, 26-9-I929.

104 Mulders, Met de buik het brood achterna, 33.

I05 RHCL, ArchiefOranje-Nassau Mijnen I7.05J, inv. nr. 9: Brief van Van der Kroon aan Oranje-Nassau Mijnen, 25-6-I929.

Io6 Gales e.s., Bedrijfsuoering, I29-Izo.

107 RHCL, ArchiefOranje-Nassau Mijnen 17.05J, inv. nr. I2: Brief van het Auswanderungs Emissariat in Düsseldorf aan Oranje-Nassau Mijnen, 8-Io-I929.

Io8 Mulders, Met de buik het brood achterna, 22-29, 34; Versteegh, Onvermijdelijke afkomst, 49-50.
} 
Een bewoner van het gezellenhuis Heisterberg in Hoensbroek legt een kaartje. Omstreeks 1956. Bron:

Fotocollectie Continium Kerkrade, F596.

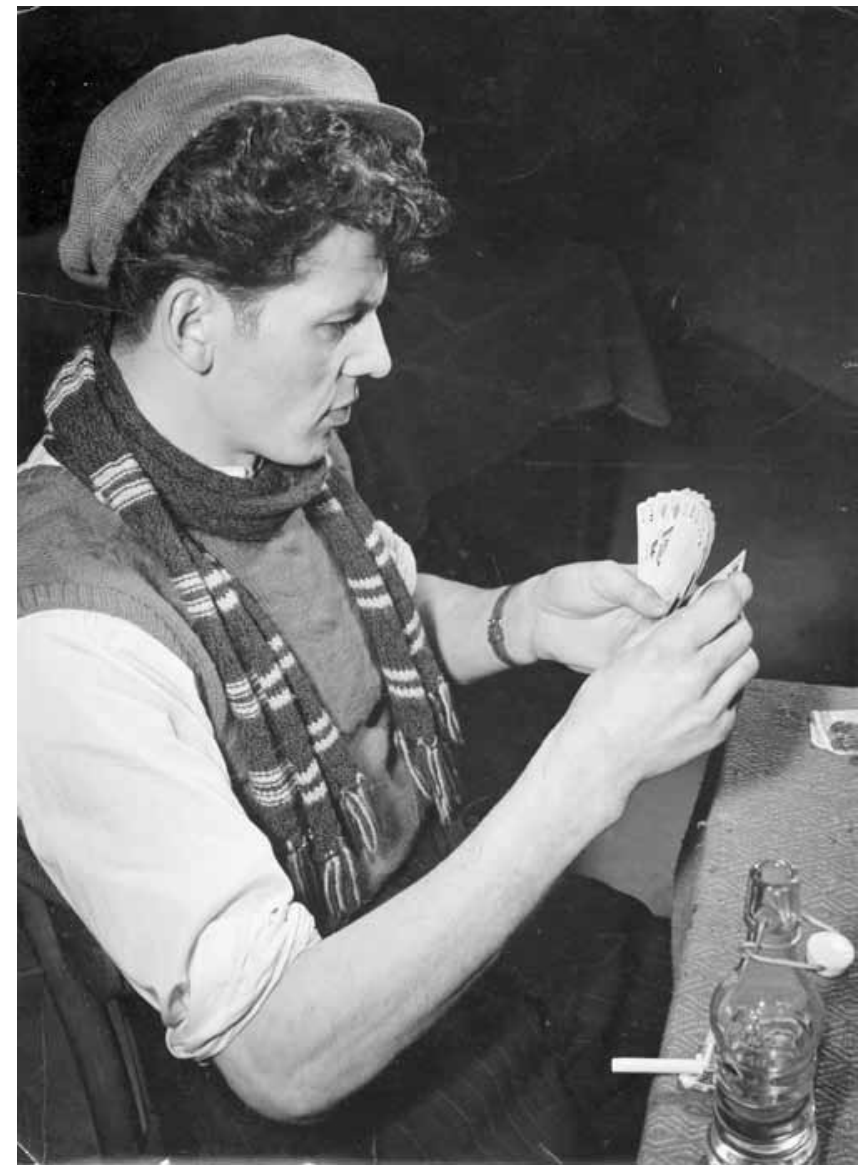

CRISIS EN OORLOG, I93I-I944

\section{Ontslaggolven}

In het vorige hoofdstuk kwam al ter sprake dat de mijnondernemingen in de crisisjaren de personeelsbezetting sterk inkrompen. Tussen eind I930 en eind I935 nam de werkgelegenheid in de Nederlandse mijnen met bijna 9.000 arbeidsplaatsen af, ruim 20 procent van de arbeidersbezetting aan het eind van $1930 .{ }^{\text {I09 }}$ Voor de buitenlandse arbeiders bij de mijnen hadden de ontslaggolven desastreuze gevolgen. Van jaar tot jaar nam het aantal mijnwerkers met een niet-Nederlandse nationaliteit af, getuige grafiek 5.2: van I93 I tot en met I936 was het groeipercentage buitenlanders voortdurend negatief en lag het beneden dat van de Nederlandse bezetting. Terwijl er eind 1930 nog II.969 niet-Nederlandse arbeiders op de loonlijsten van de mijnen stonden, was dat aantal vijf jaar later gedaald tot 4.564 , een afname van 62 procent. In diezelfde periode nam ook het aantal Nederlandse mijnwerkers 
af, maar slechts met 5,3 procent. De mate waarin de inkrimping van de personeelsbezetting werd afgewenteld op arbeidskrachten uit het buitenland, krijgt vooral reliëf wanneer de Nederlandse mijnstreek wordt vergeleken met de situatie in de omringende mijnbouwbekkens van de Kempen en Luik. Beide Belgische regio's ontkwamen evenmin aan de crisis: in de Kempen nam het aantal mijnwerkers tussen I930 en I935 af met 3.270 man (I5 procent van de bezetting in 1930). ${ }^{\text {I0 }}$ Het aantal mijnwerkers in de Luikse mijnen bedroeg in I935 8.455 man minder dan in I930, een daling van 26 procent. ${ }^{\text {III }}$ Opvallender is de grote mate waarin in Nederland de afnemende werkgelegenheid ten koste ging van buitenlandse werknemers. De situatie in de Kempen kwam nog het dichtst bij de Nederlandse praktijk: bij de Belgen nam het aantal arbeidsplaatsen af met 9 procent, terwijl de buitenlandse bezetting afnam met 27 procent. ${ }^{112}$ In Luik daarentegen nam het aantal Belgische mijnwerkers tijdens deze periode zelfs sterker af dan de buitenlandse personeelsbezetting: 22,7 procent tegen $\mathrm{I} 6,2$ procent. ${ }^{\mathrm{II} 3}$

De Nederlandse mijndirecties konden buitenlanders zonder veel problemen ontslaan, omdat het karakter van de ondergrondse arbeid was veranderd en daarmee de rol van de ervaren mijnwerker uit het buitenland. Bovendien hadden de mijnen, dankzij de opleidingsfunctie die ervaren ondergronders uit het buitenland hadden uitgeoefend, een kern van goed gekwalificeerde Nederlandse mijnwerkers kunnen opbouwen. 'Na twintig jaar van ons de kunst van het kolen maken te hebben afgekeken kunnen ze [de Limburgse mijnwerkers] dat nu zelf wel, daar hebben ze ons niet meer bij nodig', merkte een Poolse mijnwerker in het begin van de jaren dertig op. ${ }^{\text {I4 } 4}$ Zeker bij de laatst aangeworven groepen buitenlandse arbeiders was de vakbekwaamheid niet groter dan die van Nederlandse mijnarbeiders. Nederlandse arbeidskrachten kunnen 'in de huidige situatie alleszins de vreemde arbeidskrachten vervangen wat technische kennis en ervaring betreft', verwoordde in I933 een politiebeambte van Staatsmijnen het standpunt van zijn werkgever. ${ }^{15}$ Bij de gewenste ontslagen hadden de mijndirecties aanvankelijk dus iets te kiezen en de keuze voor ontslag ging uit naar de minst preferente groep.

Er werden meer buitenlandse mijnwerkers ontslagen dan strikt genomen noodzakelijk was. ${ }^{116}$ Tijdens de crisisjaren gold geen absolute personeelsstop. Een zekere vervangingsvraag bleef bestaan. Naarmate de crisis langer duurde, kwamen buitenlandse arbeiders steeds minder in aanmerking om door de mijnen in dienst te worden genomen. Had in I93 I nog 37 procent van de nieuwe mijnwerkers een niet-Nederlandse nationaliteit, in 1936 was dat nog slechts 6 procent. Getalsmatig ging het in 1936 om niet meer dan 142 man. ${ }^{\text {II7 Van }}$ actieve werving was geen sprake. Hoogstwaarschijnlijk waren deze nieuwe mijnwerkers buitenlandse arbeiders die al langer in Nederland verbleven of kinderen van in Nederland

II Bart Delbroek, 'Op zoek naar koolputters. Buitenlandse mijnwerkers in Belgisch-Limburg in de twintigste eeuw', TSEG V nummer 3 (2008) 80-103, aldaar 89.

III Annales des Mines de Belgique 1930 en 1935.

112 Delbroek, 'Op zoek naar koolputters', 89-90; Pluymers, De Limburgse mijnwerkers, 75.

II3 Langeweg en Roels, 'Buitenlandse arbeiders', Ior.

II4 Wojtkowiak, Je moet weten hoe haas hupt, II3.

II5 RHCL, Centraal Archief DSM 17.26/o6A, inv. nr. 62: Brief van de inspecteur van politie van Staatsmijnen aan de Procureur-Generaal bij het Gerechtshof in Den Bosch, 22-II-I933.

II6 RHCL, Centraal ArchiefDSM 17.26/06A, inv. nr. 62: Brief van de minister van Sociale Zaken aan de minister van Waterstaat, I6I-I934.

II7 Vromen, 'Personeelsbeleid', 69; zie ook tabel 4.Io. 
woonachtige vreemdelingen, die als nieuwkomers de arbeidsmarkt betraden. Jonge, autochtone Limburgers gingen voor, zo bleek al in het vorige hoofdstuk. De mijnen profiteerden volop van het mechanisme dat mijnarbeid aantrekkelijker werd naarmate er minder alternatieve werkgelegenheid beschikbaar was. In het volgende hoofdstuk zal blijken dat ook het verloop in de crisisperiode sterk afnam.

Nationaliteit, in combinatie met de vaste-stampolitiek, was het leidende principe bij het ontslagbeleid, maar niet alle buitenlandse arbeidskrachten stonden op de nominatie om te worden ontslagen. Twee categorieën immigranten werden in het algemeen niet met ontslag bedreigd. Zij die met een Limburgse vrouw waren getrouwd, een gezin hadden gesticht en daardoor in de mijnstreek waren ingeburgerd, behoorden volgens de mijndirecties tot de 'vaste mijnwerkersstam' die men niet graag zag vertrekken. ${ }^{\mathrm{II} 8}$ Ook hun zonen waren welkom als ze zich voor mijnarbeid aanmeldden. ${ }^{\text {1r9 }}$ Daarnaast moest de mijnwerker van buitenlandse afkomst worden beschouwd als onmisbaar voor het mijnbedrijf. Dat hield in dat hij bewezen moest hebben over grote vakbekwaamheid te beschikken en tot hoge prestaties in staat te zijn. ${ }^{\mathrm{I2}}$ Door de ontslagpolitiek van de mijnondernemingen werd de druk op buitenlandse mijnwerkers om bovenmaats te presteren, tot grote hoogte opgevoerd. Zo hard mogelijk werken leek een garantie om van ontslag gespaard te blijven. Omdat de verblijfsvergunning in Nederland voor buitenlandse mijnwerkers (voor zover ze visumplichtig waren) gekoppeld was aan het dienstverband bij de mijn, betekende ontslag niet alleen dat men zijn inkomen kwijt raakte, maar in veel gevallen ook dat men het land uit moest. Nog jaren later blikten veel (oud-)mijnwerkers vol afschuw terug op deze periode van 'jagen en drijven', zoals de Pool F. Walkowiak: 'Je moest honderd procent mijnwerker zijn en kei- en keihard werken. Ziek zijn was verboden. Iedere aanleiding was voldoende om je te ontslaan. Voor Nederlanders was het toen ook geen prettige tijd, maar voor ons was de hel losgebroken' ${ }^{\text {.2I }}$

Andere buitenlandse mijnwerkers probeerden hun werkzekerheid via het traject van naturalisatie tot Nederlander veilig te stellen. Voor iedereen was duidelijk dat Nederlanders zo veel mogelijk werden ontzien, dus nam het aantal aanvragen van buitenlandse mijnwerkers om tot Nederlander te worden genaturaliseerd, in de eerste helft van de jaren dertig toe, ondanks de hoge kosten (zie grafiek 5.II). ${ }^{\mathrm{I} 22}$ Deze ontwikkeling gaf aanleiding tot een correspondentie tussen Staatsmijnen, de Procureur-Generaal bij het Gerechtshof in Den Bosch en de ministeries van Justitie, Sociale Zaken en Waterstaat. De betrokken instanties waren het er over eens dat naturalisatie geen verzekering tegen ontslag mocht betekenen. 'Uit een onderhoud van een mijner ambtenaren met vertegenwoordigers van de directie der Staatsmijnen in Limburg en van de Oranje-Nassau Mijnen is mij gebleken, dat bij deze directies niet

II8 RHCL, Centraal Archief DSM 17.26/06A, inv. nr. 64: Brief van de directie van Staatsmijnen aan de minister van Waterstaat, 2-I1936.

II Er was nog een bijkomende reden om een categorie buitenlandse mijnwerkers met een gezin niet bij voorkeur te ontslaan. Buitenlanders die kinderen hadden uit een huwelijk met een Nederlandse vrouw konden ingevolge artikel i9 van de Vreemdelingenwet I849 niet worden uitgezet. Dat betekende dat zij bij ontslag, net als Nederlandse collega's die werden ontslagen, ten laste kwamen van Nederlandse uitkeringsinstanties. Andere buitenlanders daarentegen werden in geval van ontslag doorgaans uitgeleid. Van Eijl, Al te goed is buurmans gek, 24; RHCL, Centraal ArchiefDSM 17.26/06A, inv. nr. 62: Brief van de Procureur-Generaal bij het Gerchtshof in Den Bosch aan de minister van Justitie, 27-II-I934.

I20 Vromen, 'Personeelsbeleid', 53-54.

I2I Limburgs Dagblad, 2I-7-I979, geciteerd bij Brassé en Van Schelven, Assimilatie, I62.

122 Volgens een Sloveense zegsman van Brassé en Van Schelven bedroegen de kosten van naturalisatie in 1936 ruim tweehonderd gulden. Ter vergelijking: het gemiddelde houwersloon bedroeg in dat jaar $f_{5, \mathrm{I}} 8$ per dienst. SHCL, Archief GSL, Statistiek (lonen). 
het voornemen bestaat om aan vreemdelingen, die thans naturalisatie aanvragen of haar verkregen hebben, geen ontslag te geven. Het al of niet in dienst houden van deze personen zal van andere factoren afhangen, byv. langen diensttijd, byzondere bekwaamheid, enz.', schreef de minister van Sociale Zaken aan zijn collega van Waterstaat. ${ }^{123}$ Naturalisatie zou des te meer ongewenst zijn, omdat genaturaliseerde mijnwerkers na ontslag niet meer konden worden uitgeleid en ze in aanmerking zouden komen voor ondersteuning door Nederlandse instanties. Bovendien werden vraagtekens geplaatst bij het motief voor naturalisatie. 'Dat in den laatsten tijd zeer vele vreemdelingen zich willen laten naturaliseeren is uitsluitend en alleen - behoudens een sporadische uitzondering - om het ontslag te voorkomen. Deze vreemdelingen blijven echter in hun hart vreemdeling, zij hebben nimmer gedurende hun verbliif hier te lande aan naturalisatie gedacht en vragen dit slechts aan uit materiële motieven', merkte de inspecteur van het politiekorps van Staatsmijnen op. Van vreemdelingen had deze politiebeambte geen hoge pet op. Ze waren niet altijd politiek betrouwbaar gebleken: het waren communisten, socialisten en nationaal socialisten. Ook was volgens hem 'het moreel gehalte van veel vreemdelingen schadelijk voor de mijnbevolking'. ${ }^{124}$

De bedoeling was duidelijk: nu de conjunctuur het mogelijk maakte, wilden de mijnen zoveel mogelijk van hun vreemde arbeidskrachten af. Naturalisatie mocht dat streven niet in de weg staan. Toch wilde Staatsmijnen van geval tot geval bezien. Het bedrijf sprak met de minister van Sociale Zaken af, dat het van elke aanvraag voor naturalisatie van een van zijn buitenlandse werknemers van het ministerie mededeling zou ontvangen. 'Wij zullen dan berichten, of ons een gunstig advies op deze naturalisatieverzoeken met het oog op de belangen van het bedrijf of wegens bijzondere omstandigheden gewenscht is' ${ }^{125}$

De mijnbedrijven wilden ook in de crisisjaren de personeelsvoorziening in eigen hand houden. Dat bleek in het vorige hoofdstuk al uit hun huiver om met de Nederlandse arbeidsbureaus in zee te gaan. Dat bleek ook uit de reactie op pogingen van de rijksoverheid om de arbeidsmarkt te reguleren. Aanvankelijk hadden de mijnondernemingen weinig reden om te protesteren tegen het overheidsbeleid, dat de eerste tijd goeddeels beperkt bleef tot pogingen werkgevers op hun plicht te wijzen en voorrang te geven aan Nederlandse arbeidskrachten. ${ }^{126}$ Dat gebeurde ook bij de mijnen, die door de overheid werden bestookt met verzoeken om buitenlandse arbeiders te vervangen door Nederlanders die in Duitsland waren ontslagen. Zolang het bedrijfsbelang zich daar niet tegen verzette en er geen onmisbare buitenlandse arbeidskrachten ontslagen hoefden te worden, waren de mijnen daar in het algemeen toe bereid, omdat het paste in hun eigen vaste-stampolitiek. De protesten tegen de druk van de overheid namen in de loop van de crisisjaren echter toe, zeker toen in 1936 ook buitenlandse ondergronders onder een vergunningenstelsel voor buitenlandse werknemers gingen vallen. Aanvankelijk waren mijnwerkers uitgezonderd geweest van de Vreemdelingenarbeidswet uit 1934 die het vergunningenstelsel instelde. ${ }^{\mathrm{I27}}$ Voortaan was voor te-

I23 RHCL, Centraal Archief DSM 17.26/o6A, inv. nr. 62: Brief van de minister van Sociale Zaken aan de minister van Waterstaat, I6-I-I934.

I24 RHCL, Centraal Archief DSM 17.26/06A, inv. nr. 62: Brief van de inspecteur van politie van Staatsmijnen aan de Procureur-Generaal bij het Gerechtshof in Den Bosch, 22-II-I933.

125 RHCL, Centraal ArchiefDSM 17.26/06A, inv. nr. 62: Brief van Staatsmijnen aan de minister van Waterstaat, 5-2-1934.

I26 Van Eijl, Al te goed is buurmans gek, I54.

I27 'Wet van den I6den Mei 1934, tot regeling van het verrichten van arbeid door vreemdelingen (Vreemdelingenarbeidswet)' Staatsblad I934, nr. 257. 
werkstelling van buitenlandse mijnwerkers een vergunning vereist, die door de Rijksdienst der Werkloosheidsverzekering en Arbeidsbemiddeling alleen werd verstrekt als er geen geschikte werkloze Nederlanders voor de functie beschikbaar waren. De regeling gold voor zowel nieuwe arbeidskrachten als voor degenen die al bij de mijnen werkzaam waren.

Het doel van de regering was het aantal allochtonen in dienst van de mijnen, dat eind 1934 nog 5.693 personen bedroeg, terug te dringen tot $1.000 .{ }^{128}$ Dat doel mislukte: aan het eind van 1939 waren er nog steeds bijna 3.500 buitenlanders bij de Nederlandse mijnondernemingen werkzaam.

Protesten van de mijnondernemingen tegen deze inmenging in het personeelsbeleid hadden succes. In de praktijk werd rekening gehouden met de belangen van de mijnindustrie. Tussen de Rijksdienst en de mijnen bestond een mondelinge afspraak dat voor de buitenlandse bezetting de vergunningen telkens automatisch voor één jaar werden verlengd, op grond van bedrijfsbelangen, langdurig verblijf in Nederland of met het oog op familieverhoudingen. De Rijksdienst concludeerde dan ook dat de mijnen het zelf in de hand hadden om ontslag van de buitenlanders te voorkomen, als die uit bedrijfstechnisch oogpunt onontbeerlijk waren. ${ }^{\mathrm{I} 29}$ De mijnen konden het personeelsbeleid dus zelf bepalen, en daar ging het hen om. Ook in 1936 en daarna waren buitenlandse mijnwerkers niet zonder meer verzekerd dat ze hun baan zouden behouden. Over de maanden maart tot juli 1936 bleef een lijst bewaard van ontslagen buitenlandse arbeidskrachten bij Staatsmijn Emma met de redenen voor ontslag. ${ }^{130}$ Daaruit blijkt dat de ontslagpolitiek nog steeds verder ging dan louter het bedrijfsbelang. Persoonlijke bijzonderheden legden doorgaans meer gewicht in de schaal dan de kwalitatieve beoordeling als arbeidskracht. 'Goede werklieden' werden ontslagen als ze wegens persoonlijke omstandigheden 'ongewenscht' waren. Een criterium van ongewenst zijn was nog steeds het aantal verzuimen, dat nauwkeurig op de lijsten was genoteerd. Ongewenst waren ook degenen die op zedelijk gebied ongunstig bekend ston-

TABEL 5.I BUITENLANDSE ONDERGRONDERS IN DE NEDERLANDSE STEENKOLENMIJNEN, I93O EN I938

\begin{tabular}{|l|c|c|c|c|}
\hline & $\begin{array}{c}\text { aantal op } \\
\text { 3I-I2-I930 }\end{array}$ & $\begin{array}{c}\text { aantal op } \\
\text { 3I-12-I938 }\end{array}$ & $\begin{array}{c}\text { absolute } \\
\text { afname }\end{array}$ & $\begin{array}{c}\text { afname, \% van } \\
\text { 3I-I2-I930 }\end{array}$ \\
\hline Duitsers & 6.548 & I.5I5 & 5.033 & 76,9 \\
\hline Polen & I.2I2 & 437 & 775 & 63,9 \\
\hline Joegoslaven & I.I25 & 276 & 849 & 75,5 \\
\hline Italianen & 209 & II4 & 95 & 45,5 \\
\hline Oostenrijkers & 656 & I24 & 532 & $8 \mathrm{I}, \mathrm{I}$ \\
\hline overigen & 936 & 756 & $\mathrm{I} 80$ & $\mathrm{I9,2}$ \\
\hline totaal & I0.686 & $\mathbf{3 . 2 2 2}$ & 7.464 & 69,8 \\
\hline
\end{tabular}

Bron: Jaarverslag Hoofdingenieur over het jaar 1930 en 1938 . Zie ook bijlage i6.

128 Vromen, 'Personeelsbeleid', 55.

129 Ibidem, 55-56.

130 RHCL, Centraal Archief DSM 17.26/o6A, inv. nr. 64: Staatsmijn Emma, Personeel hetwelk ingaande [I maart tot en met I juli 1936] het dienstverband is opgezegd, wegens slapte in het bedrijf. 
GRAFIEK 5.I2 DE VERDELING VAN BUITENLANDSE NATIONALITEITEN IN DE NEDERLANDSE STEENKOLENMIJNEN, I93I-I939 (ONDERGRONDS EN BOVENGRONDS)

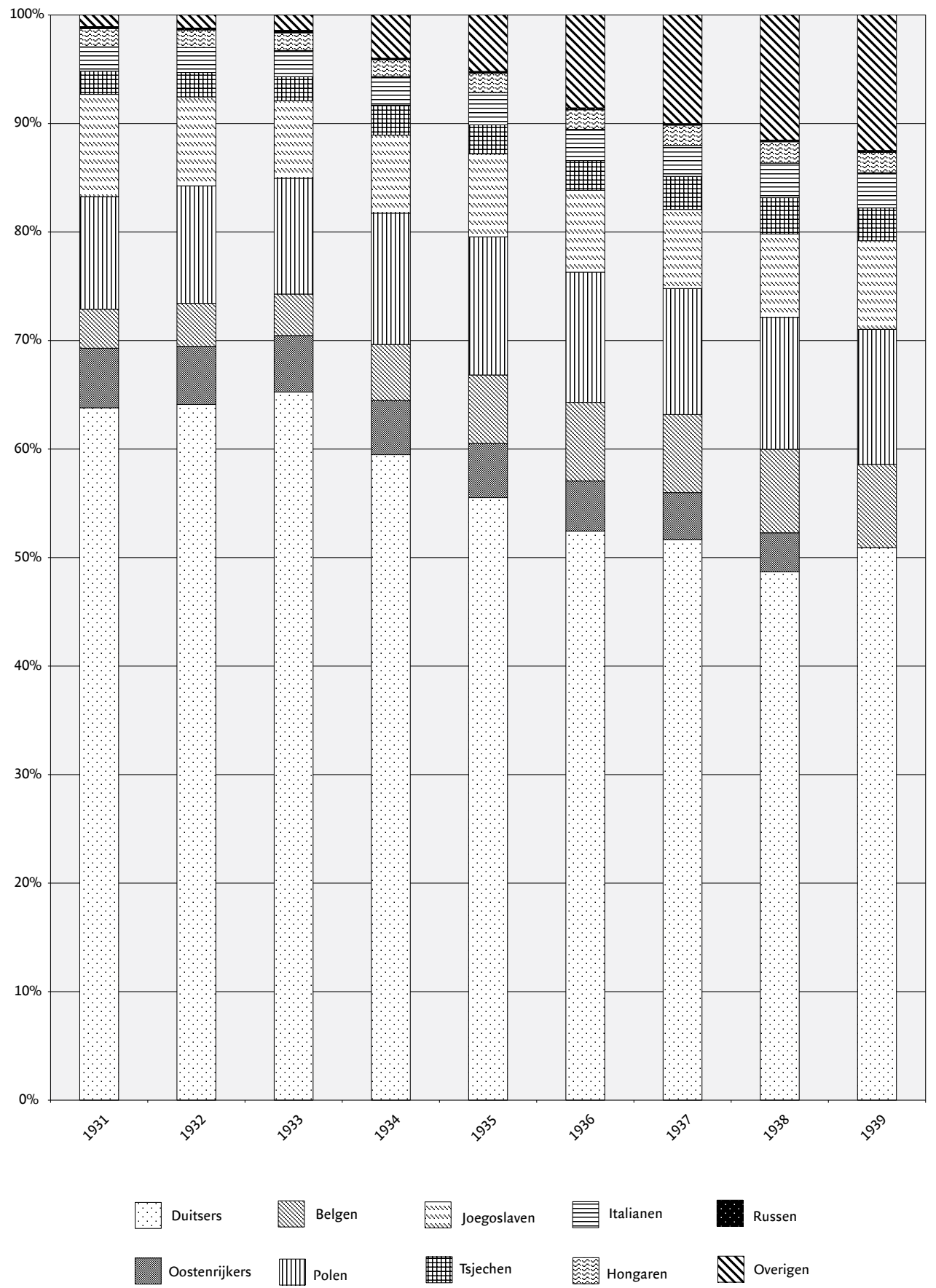

Bron: Jaarverslagen Hoofdingenieur / Inspecteur-Generaal der Mijnen, I93I-I939. Zie ook bijlage I5. 
den. Dat kon de mijnwerker zelf zijn, maar ook diens vrouw of gezin. De meeste ontslagenen op de lijst waren in de jaren 1925-1929 in dienst getreden.

In 1937 was de vraag naar arbeid weer zo groot geworden, dat de mijnen, naast vooral jonge Limburgse arbeidskrachten, ook weer enkele honderden buitenlanders aantrokken (tabel 4.Io). Het was een tijdelijke opleving van het aantal buitenlandse arbeiders in de Nederlandse mijnen in de tweede helft van de jaren dertig. Als gevolg van de oorlogsdreiging en mobilisering in Europa in 1938 en 1939 verlieten veel buitenlanders de Nederlandse mijnen en keerden terug naar hun land van herkomst. Die tendens is ook te zien in de scherpe daling van het aantal buitenlanders dat bij de Nederlandse mijnen in die jaren in dienst trad. In 1939 had nog slechts 2,4 procent van de in dat jaar in dienst getreden mijnwerkers een niet-Nederlandse nationaliteit.

Van alle buitenlandse ondergronders nam het aantal Duitsers het sterkste af. Dat had niet alleen met het ontslagbeleid van de mijndirecties te maken, maar ook met vrijwillig vertrek. Ook Oostenrijkers en Joegoslaven werden relatief vaak ontslagen. Het aantal mijnwerkers met de Poolse en de Italiaanse nationaliteit nam minder sterk af. Wellicht is dat in het geval van de Polen verklaarbaar uit het feit dat deze groep mijnwerkers vaak al langere tijd in de Limburgse mijnen werkzaam was en daardoor een sterkere positie in het mijnbedrijf had opgebouwd. ${ }^{13 \mathrm{I}}$ Van de Italianen is bekend dat zich onder hen relatief veel ervaren en gespecialiseerde mijnwerkers bevonden. Dat gold ook voor de laatste groepen Italianen die in 1930 en 193 I vanuit Istrië naar de Nederlandse mijnen kwamen. De ervaring hadden ze opgedaan in kolenmijnen in hun geboortestreek. Een andere groep Italianen was gespecialiseerd in steenwerk en werd daarom onmisbaar geacht bij de aanleg van galerijen. ${ }^{132}$ Dergelijke vaklieden werden in het belang van het bedrijf pas in het uiterste geval ontslagen.

De relatief geringe afname van de restcategorie 'overigen' is verklaarbaar door het aantal statelozen dat er deel van uitmaakt. In de jaren dertig nam het aandeel van deze categorie in de niet-Nederlandse arbeidersbezetting van de mijnen toe.

Duidelijk kwamen in de jaren dertig de beide functies van buitenlandse arbeiders voor de Nederlandse mijnen aan het licht: enerzijds een harde kern van ervaren en geschoolde ondergronders met vaste werkgelegenheid en anderzijds een groep die als het ware een reserveleger van arbeiders vormde waarmee conjuncturele fluctuaties konden worden opgevangen. Uit deze laatste groep, die voornamelijk bestond uit ongeschoolde arbeidskrachten die in de tweede helft van de jaren twintig op basis van tijdelijke arbeidscontracten waren gerekruteerd, blijkt het bestaan van een dubbele arbeidsmarkt in de Nederlandse mijnbouw.

\section{Bezetting}

Het aantal buitenlanders dat in mei 1940 ondergronds bij de Nederlandse mijnen in dienst was, bleef gedurende de bezettingstijd nagenoeg ongewijzigd. Dat gold voor alle buitenlandse nationaliteiten. Behalve de omstandigheid dat tijdens de oorlog de grensoverschrij-

I3I Pater Wilhelm Hoffmann, zielzorger van de Poolse gemeenschap in Limburg, wees hierop in een pleidooi bij Staatsmijnen om Poolse arbeiders in dienst te houden. RHCL, Centraal ArchiefDSM 17.26/06A, inv. nr. 6r: Brief van Pater W. Hoffmann aan de directie van Staatsmijnen, I-8-1933.

132 Brassé en Van Schelven, Assimilatie, 86. 
Grafiek 5.I3 DE VERdELING VAN BUITENLANDSE NATIONALITEITEN IN DE NeDERLANDSE STEENKOLENMIJNEN, I94O-I944 (ONDERGRONDS EN BOVENGRONDS)

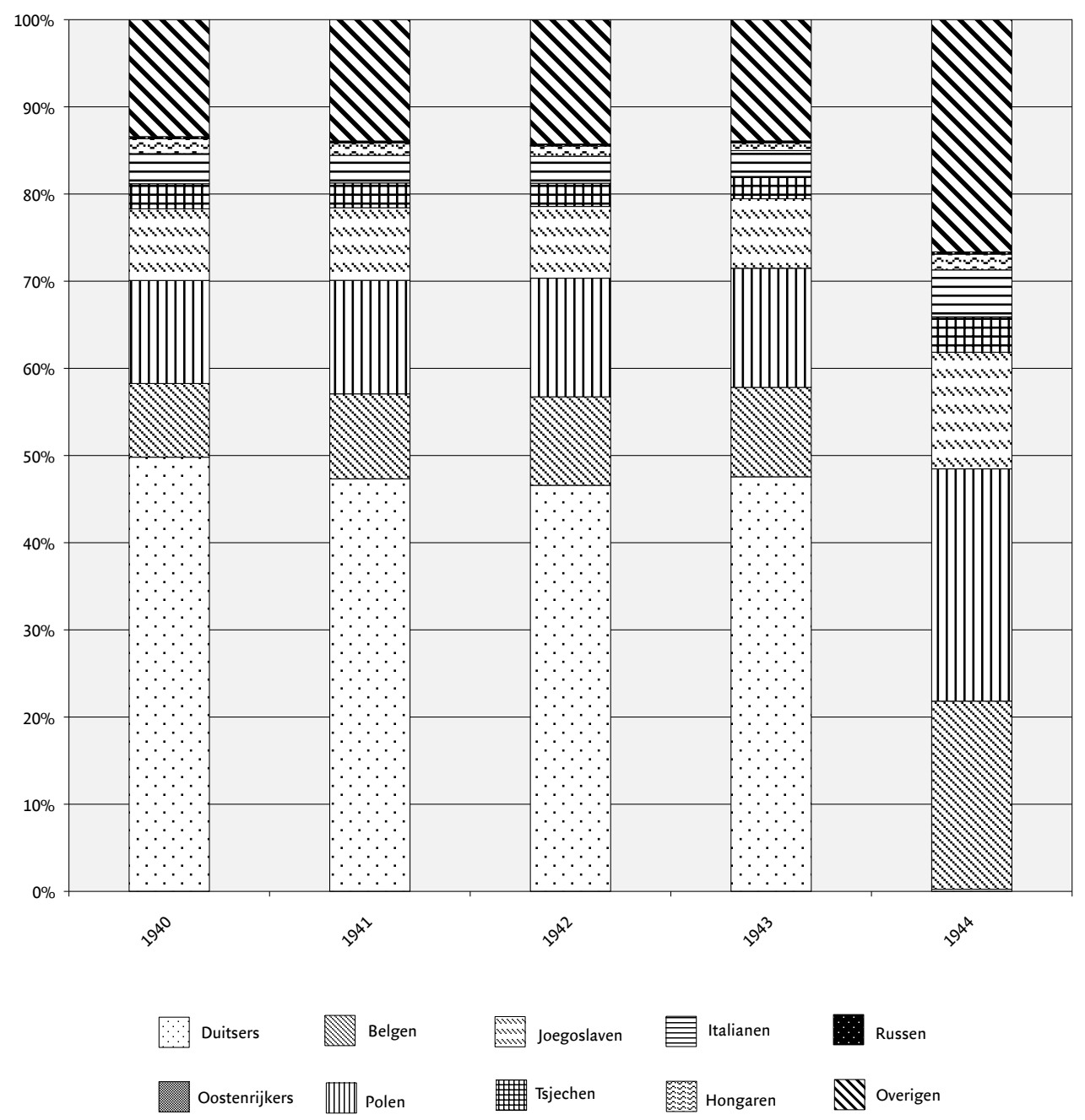

Bron: Jaarverslagen Inspecteur-Generaal der Mijnen, 1940-1944. Zie ook bijlage I5.

dende mobiliteit ernstig werd bemoeilijkt, speelde daarbij de bescherming die het beroep van mijnwerker bood een rol. Zo kregen Duitse mijnwerkers in Nederland, die net als andere Rijksduitsers dienstplichtig waren, vrijstelling van militaire dienst. ${ }^{133}$ Waarschijnlijk gold hetzelfde voor de Italiaanse mijnwerkers, toen in I94I en 1942 Italiaanse mannen werden opgeroepen om hun dienstplicht in Italië te komen vervullen. ${ }^{134}$ De contingenten Polen en Joegoslaven bleven gedurende de bezettingsjaren ook gelijk in aantal. Zelfs het vertrek

133 Jan Sintermaartensdijk en Yfke Nijland, Operatie Black Tulip. De uitzetting van Duitse burgers na de oorlog (Amsterdam 2009) 36-37.

134 Brassé en Van Schelven, Assimilatie, 94. 
in 1943 van een groep Duitsgezinde Slovenen naar Duitsland had nauwelijks invloed op de Joegoslavische personeelsbezetting van de mijnen. ${ }^{135}$ De kleine mutaties in de buitenlandse arbeidersbezetting van jaar tot jaar kunnen worden verklaard uit natuurlijk verloop. Ook in de verdeling van de niet-Nederlandse nationaliteiten kwam tijdens de oorlogsjaren nauwelijks verandering. Steeds was ongeveer de helft van de buitenlanders Duitser.

Deze status quo staat in opvallend contrast met de ontwikkeling van de personeelssamenstelling van de mijnen in de naburige bekkens van Aken en de Kempen. De buitenlandse personeelsbezetting nam daar toe, vooral omdat onder druk van de Duitse autoriteiten de mijnondernemingen in belangrijke mate buitenlandse dwangarbeiders tewerkstelden.

In het kader van de inzet van dwangarbeiders uit de bezette gebieden waarmee de Duitse overheid de oorlogseconomie gaande probeerde te houden, nam het aantal buitenlanders in de Akense mijnen in de loop van de bezetting fors toe. Begin I944 werkten er 2.000 Ostarbeiter, ${ }^{136} 5.600$ krijgsgevangenen uit vooral de Sovjet-Unie, 3.500 Italiaanse politieke gevangenen en 2.500 à 3.000 burgerarbeiders van verschillende nationaliteit. ${ }^{137}$ Van deze laatste groep waren ruim I.ooo arbeiders Nederlander, waaronder waarschijnlijk de meesten grensarbeider. ${ }^{13^{8}}$ In totaal vormden de buitenlandse arbeidskrachten in 1944 bijna de helft van de personeelsbezetting in de Akense mijnen. In I939 was het aandeel van buitenlandse mijnwerkers in het Akense bekken niet meer dan 4 procent geweest. ${ }^{139}$

Ook in Belgische mijnen nam de inzet van buitenlandse dwangarbeiders in de loop van de bezettingsjaren toe. Vooral in de vetkoolmijnen van de Kempen was dat het geval, omdat de productie van deze voor de industrie zeer belangrijke kolensoort werd gestimuleerd. In de Belgisch-Limburgse mijnen waren in 19446.852 dwangarbeiders actief, voornamelijk Russische krijgsgevangenen en civiele Ostarbeiter. ${ }^{10}$ Het percentage buitenlanders in de Kempense mijnen nam toe van 20 procent in 1939 naar 26 procent eind $1943{ }^{\mathrm{I}}{ }^{\mathrm{II}}$ De Luikse mijnen ontkwamen evenmin aan indienstneming van buitenlandse dwangarbeiders. De inzet bleef hier beperkt tot ruim 300 Russische krijgsgevangenen, die in 1943 arriveerden. ${ }^{142}$

Het uitblijven van contingenten buitenlandse dwangarbeiders in de Nederlandse mijnen werd onderzocht door Willibrord Rutten. ${ }^{143}$ Ook in Nederland hadden de Duitse autoriteiten al in 1942 plannen voor de plaatsing van Russische krijgsgevangenen. Door de inzet van extra arbeidskrachten hoopte de Duitse Verwalter van de mijnen de productie en de productiviteit omhoog te krijgen. ${ }^{144}$ De mijndirecties wisten de uitvoering van de plannen echter met succes tegen te houden. In de zomer van I944 kwam bij de mijn Oranje-Nassau IV een barakkenkamp gereed, waar de Russische dwangarbeiders zouden worden ondergebracht, maar de bevrijding in september voorkwam dat daadwerkelijk Russen naar Lim-

135 Mulders, Met de buik het brood achterna, I32. Zie ook: Milena Mulders, 'Sloveense migranten in de Limburgse mijnstreek: verenigingsleven en internationale politiek', SSEGL LIV (2009) 7I-I00, aldaar 85.

I36 Burger-dwangarbeiders uit vooral Rusland, Wit-Rusland en Oekraïne.

137 Klank, 'Secondary labour force', $\mathbf{1 4 5}$.

138 Thomas Müller, 'Dwangarbeid aan de grens. Regionale aspecten van de dwangarbeid in het grensgebied bij Aken in de nazitijd', SSEGL XLVII (2002) 49-60, aldaar 5I-55.

139 Berekend op basis van Klank, 'Secondary labour force', grafiek 4, I4I en grafiek 6, I44.

I40 Delbroek, 'Op zoek naar koolputters', 94.

I4I Ibidem, grafiek I, gr.

142 Roels, Où sont les mineurs belges, I3-I4.

143 Rutten, 'Russen niet gewenst'.

I44 Zie hiervoor hoofdstuk 4 . 
burg kwamen. De mijndirecties hadden niet zo zeer principiële bezwaren tegen de komst van Russische dwangarbeiders. Ze hadden vooral praktische bedenkingen. De praktijk in de Belgische mijnen had inmiddels uitgewezen dat de Russische krijgsgevangenen over het algemeen ongeschoold waren, terwijl voor de stijging van de productie en de productiviteit ervaren mijnarbeiders nodig zouden zijn. In tegenstelling tot de mijnen in de Kempen en in Luik, waar de problemen met de arbeidsvoorziening al voor de oorlog groter waren, hadden de Nederlandse mijnen tijdens de bezettingsjaren geen gebrek aan ongeschoolde mijnwerkers. De Nederlandse arbeidsmarkt kon daar in voldoende mate in voorzien, zeker toen bleek dat een baan in de mijnbouw een verzekering tegen de Arbeitseinsatz betekende. Daarnaast wezen de Nederlandse mijndirecties op het taalprobleem dat zou ontstaan. Dat leek misschien wat ver gezocht, ${ }^{\mathrm{I} 45}$ maar was het waarschijnlijk niet. Weliswaar hadden de mijnen in het verleden mijnwerkers gerekruteerd in Oost- en Zuid-Europa, maar daarbij had men er toch zoveel mogelijk op gelet dat de arbeiders die naar Limburg kwamen in ieder geval voldoende Duits begrepen om op de werkplek basaal te kunnen communiceren. Of dat bij de Russen het geval zou zijn, was op zijn minst twijfelachtig. Zelfs toen de komst van de Russen begin 1944 nog slechts een kwestie van tijd leek, bleven de mijnen praktische obstakels opwerpen. Zo probeerde de directie van de Oranje-Nassau Mijnen de Duitsers duidelijk te maken dat de komst van de Russen pas zin had als eerst de technische uitrusting van de mijnen werd aangevuld met materialen als transportbanden, motoren, stutten en stempels, waar op dat moment in de oorlog niet meer aan te komen was. ${ }^{146}$

De echte reden waarom de mijndirecties tegen de tewerkstelling van Russen in het geweer bleven komen, zelfs toen de Duitsers begin 1944 eindelijk definitief daartoe besloten hadden, was volgens Rutten echter de bescherming van de illegaliteit in Limburg, dat tijdens de bezetting een veilige haven was voor onderduikers uit alle delen van Nederland. ${ }^{47}$ Ook de mijnen zelf boden een wijkplaats aan menigeen die aan de Arbeitseinsatz wilde ontkomen. De mijndirecties vreesden terecht dat de komst van SS-troepen ter bewaking van de Russische dwangarbeiders ook het illegale werk in gevaar zou brengen.

De bevrijding van de Limburgse mijnstreek in september 1944 gaf aanleiding tot een exodus van buitenlanders. Wie op de hand van de Duitsers was geweest, vluchtte het land uit of werd gearresteerd. Vrijwel alle Duitsers werden op zijn minst als verdacht beschouwd en aan hen werd door de mijndirecties of door de zuiveringscommissies die onmiddellijk na de bevrijding in de mijnbedrijven actief waren de toegang tot de mijn ontzegd. ${ }^{\mathrm{I}}{ }^{8} \mathrm{Zo}$ werden de Duitse werknemers van de Oranje-Nassau Mijnen - een enkele bonafide persoon uitgezonderd - al op 18 september geschorst of ontslagen. ${ }^{\text {I49 }}$ Eind 1944 hadden de gezamenlijke mijnen nog zegge en schrijve vier arbeidskrachten met de Duitse nationaliteit in dienst. Ook de Joegoslavische personeelsbezetting nam de eerste tijd na de bevrijding relatief sterk af. Onder meer ten gevolge van het vertrek van een groep Slovenen was eind 1945 het contingent Joegoslavische mijnwerkers met 39 procent afgenomen ten opzichte van eind 1943 .

145 Rutten, 'Russen niet gewenst', 176.

I46 Ibidem, I82. Zie ook Peet en Rutten, Oranje-Nassau Mijnen, 223-224.

I47 Rutten, 'Russen niet gewenst', I89-Igo.

148 Wim van der Linde, 'De naoorlogse zuiveringen in het mijnbedrijf als reactie op sociale en religieuze tegenstellingen', SSEGL XLIX (2004) I9I-2I3, aldaar 195.

I49 Peet en Rutten, Oranje-Nassau Mijnen, 227. 
Hoeveel Duitse mijnwerkers in het kader van de Operatie Black Tulip (september I946-november I948) werden uitgewezen, is niet duidelijk. Zeker is dat ook mijnwerkers zijn opgepakt en naar Duitsland uitgeleid. ${ }^{150}$ Het is echter niet aannemelijk dat het er erg veel zijn geweest. In de jaren I946-I948 nam het aantal Duitse mijnwerkers in Limburg zelfs weer toe tot bijna vijfhonderd. Onder hen bevonden zich mijnwerkers waarvan was komen vast te staan dat ze zich tijdens de bezettingsjaren niet 'on-Nederlands' hadden gedragen en daarom weer in genade werden aangenomen. Een ander contingent bestond uit 'niet-bonafide Duitsers' die, net als Nederlandse politieke delinquenten, in de gelegenheid werd gesteld op basis van vrijwilligheid hun straf in te vullen door mijnarbeid te gaan verrichten. ${ }^{\text {i5r }}$

Bovendien werd bij de uitzetting van Duitsers een aantal uitzonderingen gemaakt. Onder meer werd vergunning tot tijdelijk voortgezet verblijf in Nederland verleend aan personen van Duitse nationaliteit 'wier voortgezet verblijf in Nederland noodzakelijk wordt geacht in het algemeen Nederlandse belang'. ${ }^{152}$ Dat de Nederlandse steenkolenproductie onder de noemer van 'algemeen Nederlands belang' viel, werd in die tijd door weinigen betwijfeld.

\section{WEDEROPBOUW, $1945-1965$}

\section{Rekruteringsgolven van buitenlandse arbeidskrachten}

De periode 1945 -I965 werd gekenmerkt door korte tijdvakken van drie tot vijf jaar die afwisselend een positief en negatief groeisaldo van de buitenlandse arbeidersbezetting vertoonden. Op langere termijn steeg het percentage buitenlanders bij de mijnondernemingen, zonder de percentages van omstreeks 1930 ook maar te benaderen. Het bedroeg 5 procent in 1946 , schommelde in de jaren vijftig tussen 7 en II procent en steeg ten slotte naar 13 procent in $\mathrm{I}_{965}$. Getalsmatig ging het eind $\mathrm{I}_{9} 65 \mathrm{om} 5.8 \mathrm{I} 8$ mijnwerkers. Dat was minder dan de helft van het aantal buitenlandse arbeidskrachten dat in 1930 in dienst van de mijnen was geweest. Vergeleken met omliggende mijnbouwgebieden was dat een laag percentage. In de Kempen was in het midden van de jaren zestig ongeveer 40 procent van de mijnwerkers

TABEl 5.2 Het PERCENTAge Nederlanders EN BUitenlanders, WerkZAAM ONDERGRONDS, I950, I957, I965

\begin{tabular}{|l|c|c|}
\hline & Nederlanders & buitenlanders \\
\hline 1950 & $57 \%$ & $84 \%$ \\
\hline 1957 & $54 \%$ & $75 \%$ \\
\hline 1965 & $52 \%$ & $68 \%$ \\
\hline
\end{tabular}

Bron: Jaarverslagen Inspecteur-Generaal der Mijnen, I950, I957 en 1965.

I50 Sintermaartensdijk en Nijland, Operatie Black Tulip, 73.

I5I Verslag van de Inspecteur-Generaal der Mijnen over 1946-1947-1948, 9.

152 Sintermaartensdijk en Nijland, Operatie Black Tulip, 62-63. 


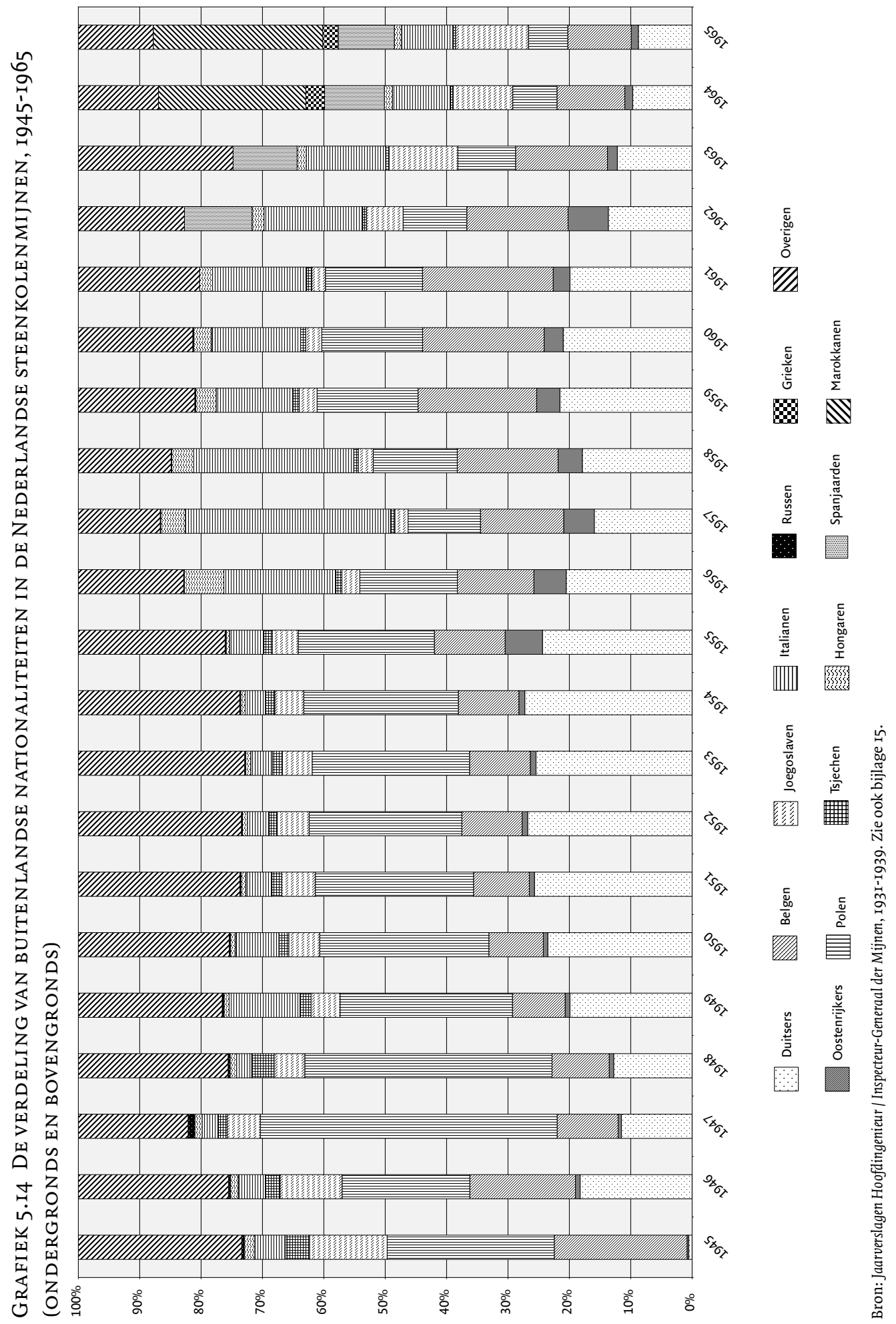




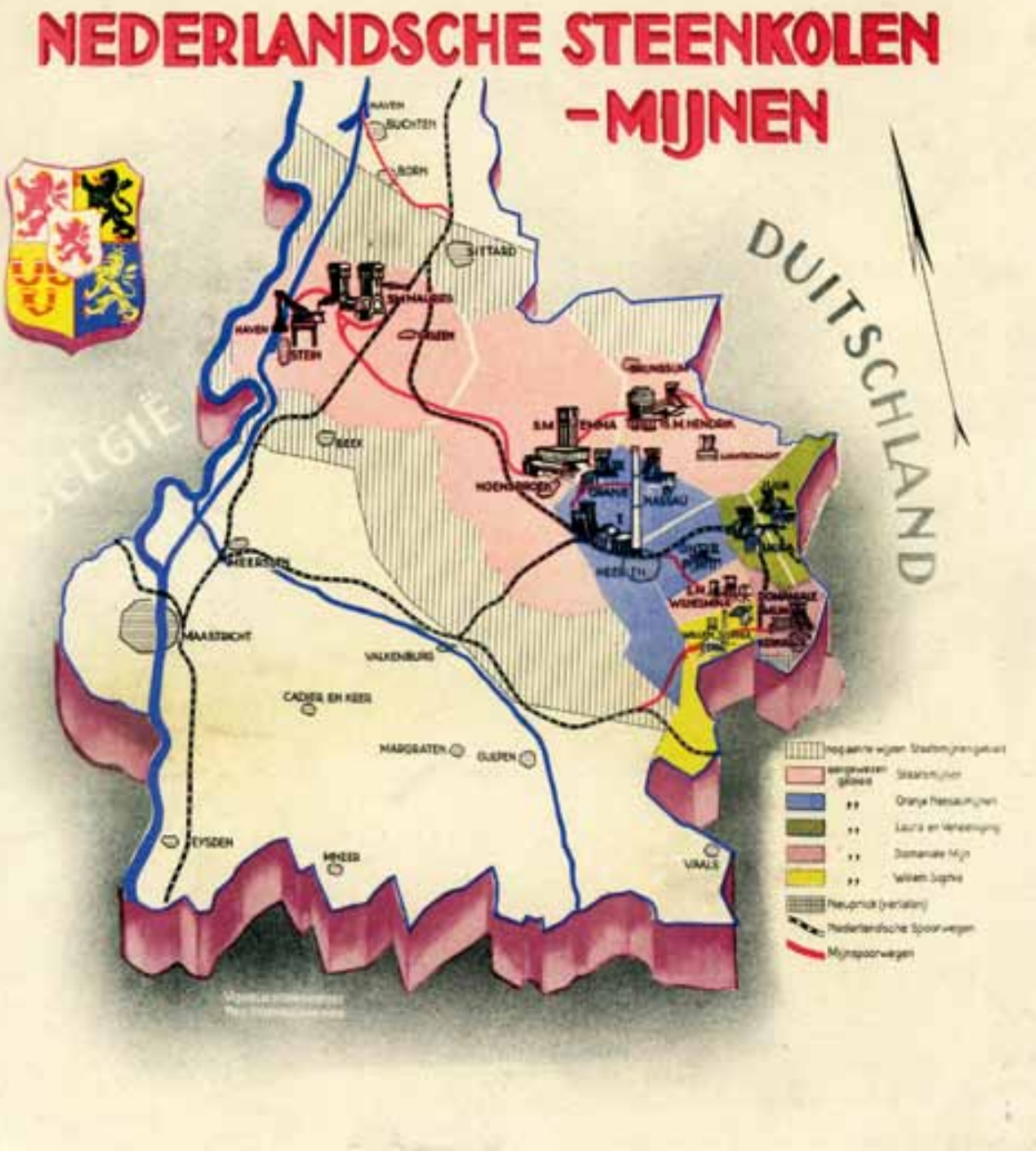

Kaartje met de concessiegebieden van de vijf mijnbouwondernemingen die in Nederland actief waren. Omstreeks 1940. Collectie Continium Kerkrade. 


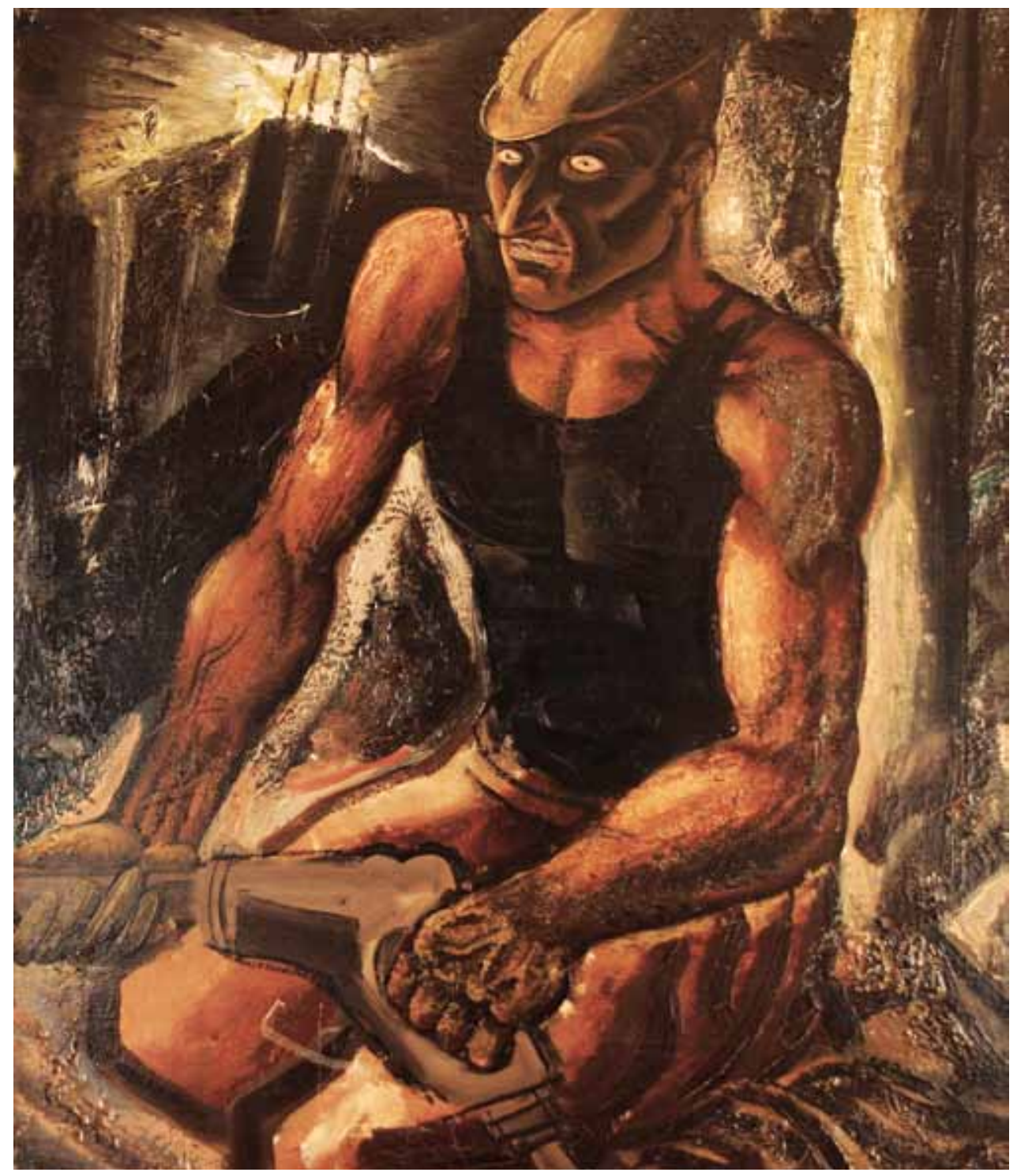

De mijnwerker. Charles Eyck. Olieverf op doek. Omstreeks 1930. Een sterk gelijkend tafereel is onderdeel van een wandschildering die Eyck maakte in de Vincentius à Paolokerk in Brunssum-Rumpen. Collectie Continium Kerkrade 064962 . 


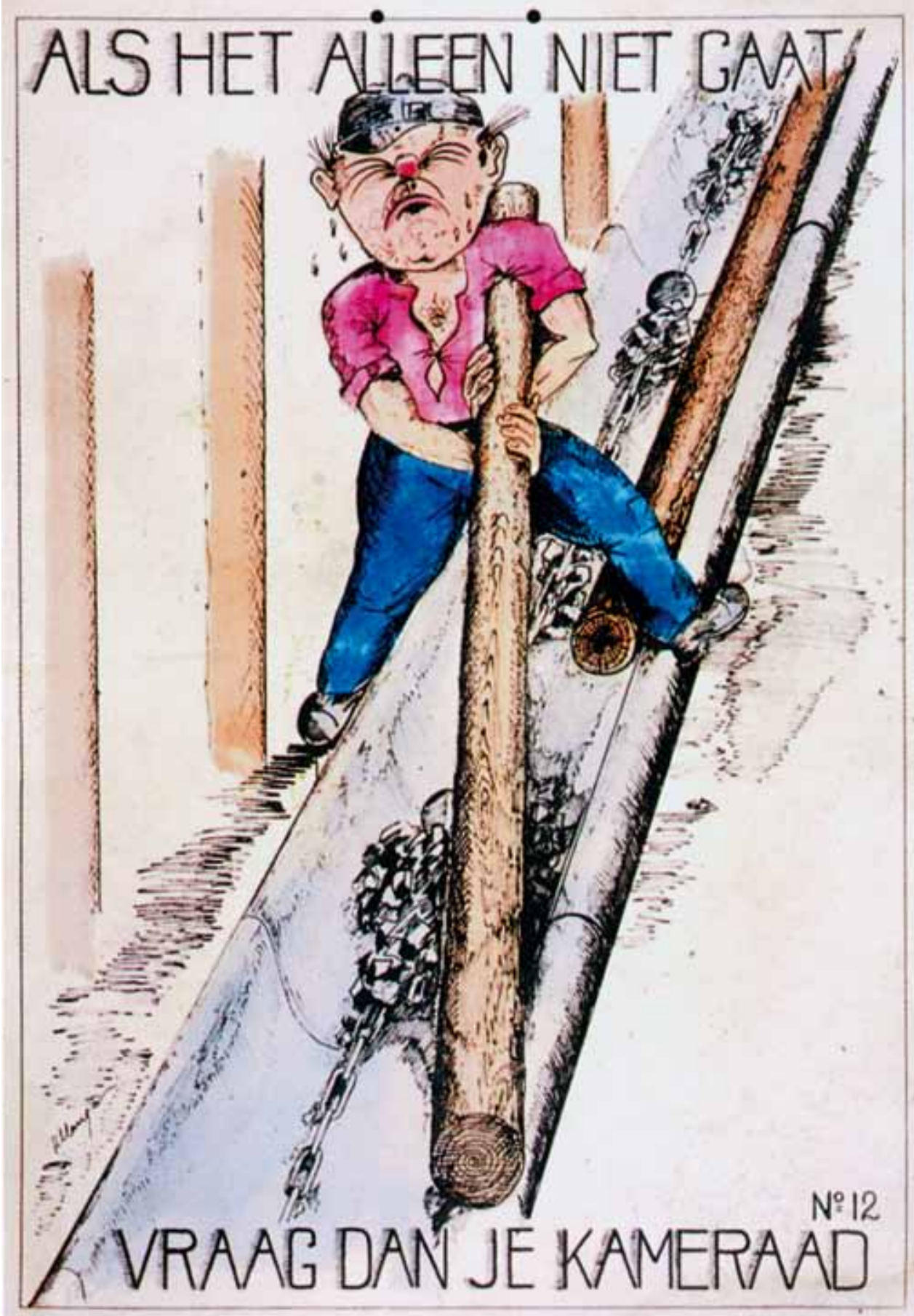

Affiche ter bevordering van veilig werken ondergronds. Omstreeks 1950. Collectie Continium Kerkrade 058835.01. 


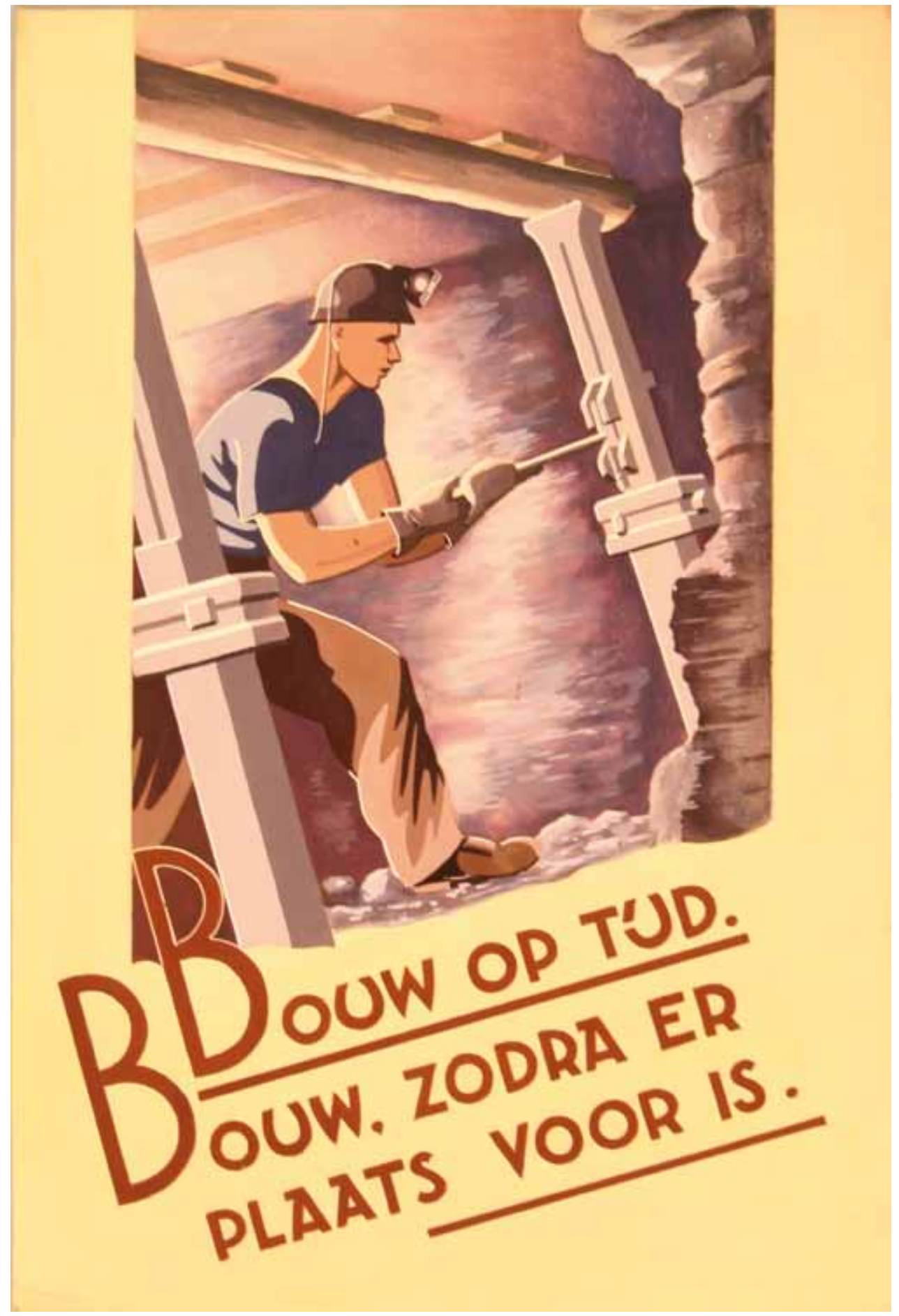

Affiche ter bevordering van veilig werken ondergronds. Omstreeks 1950. Collectie Continium Kerkrade. 


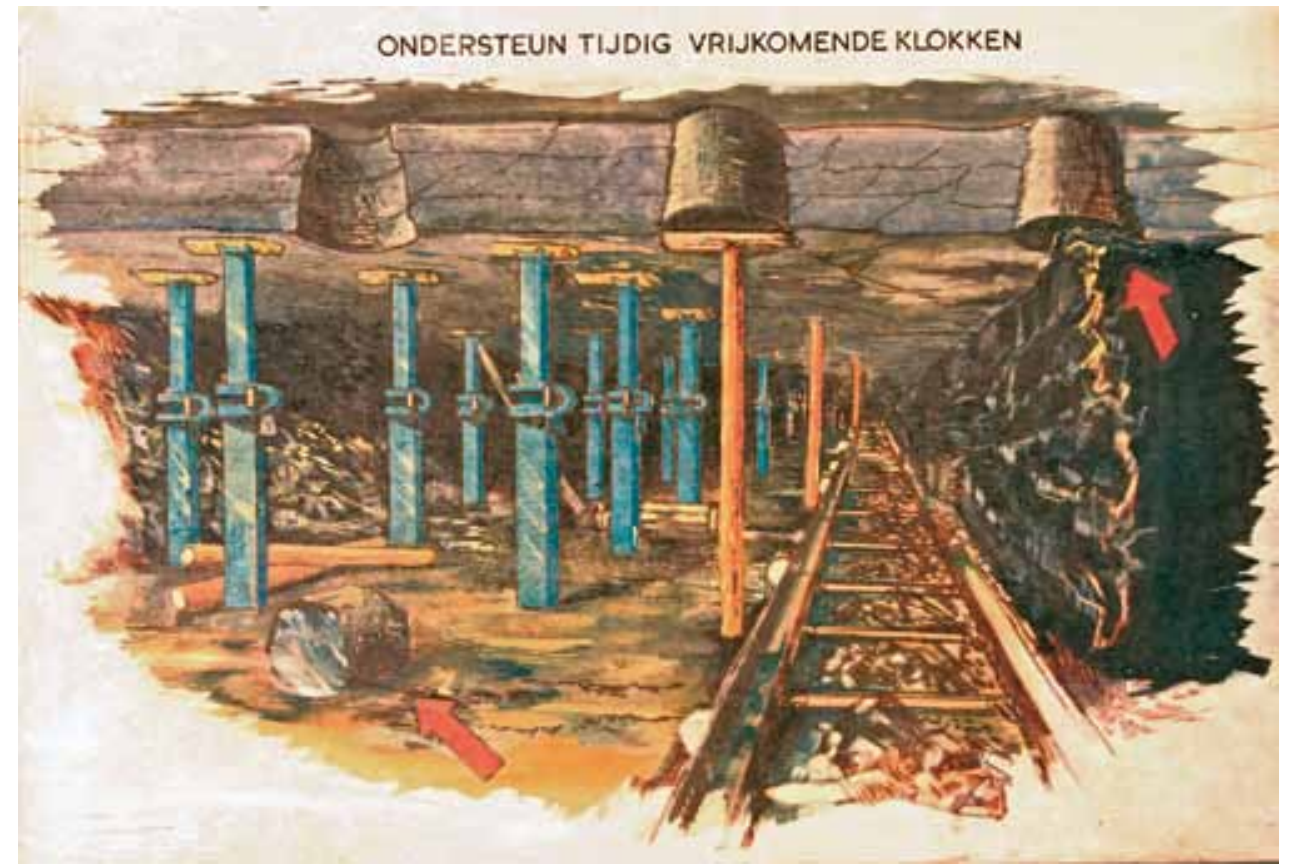

Affiche ter bevordering van veilig werken ondergronds. Loszittend gesteente was een gevaar voor de mijnwerker en moest dus zorguuldig ondersteund worden. Omstreeks 1950. Collectie Continium Kerkrade 058840.

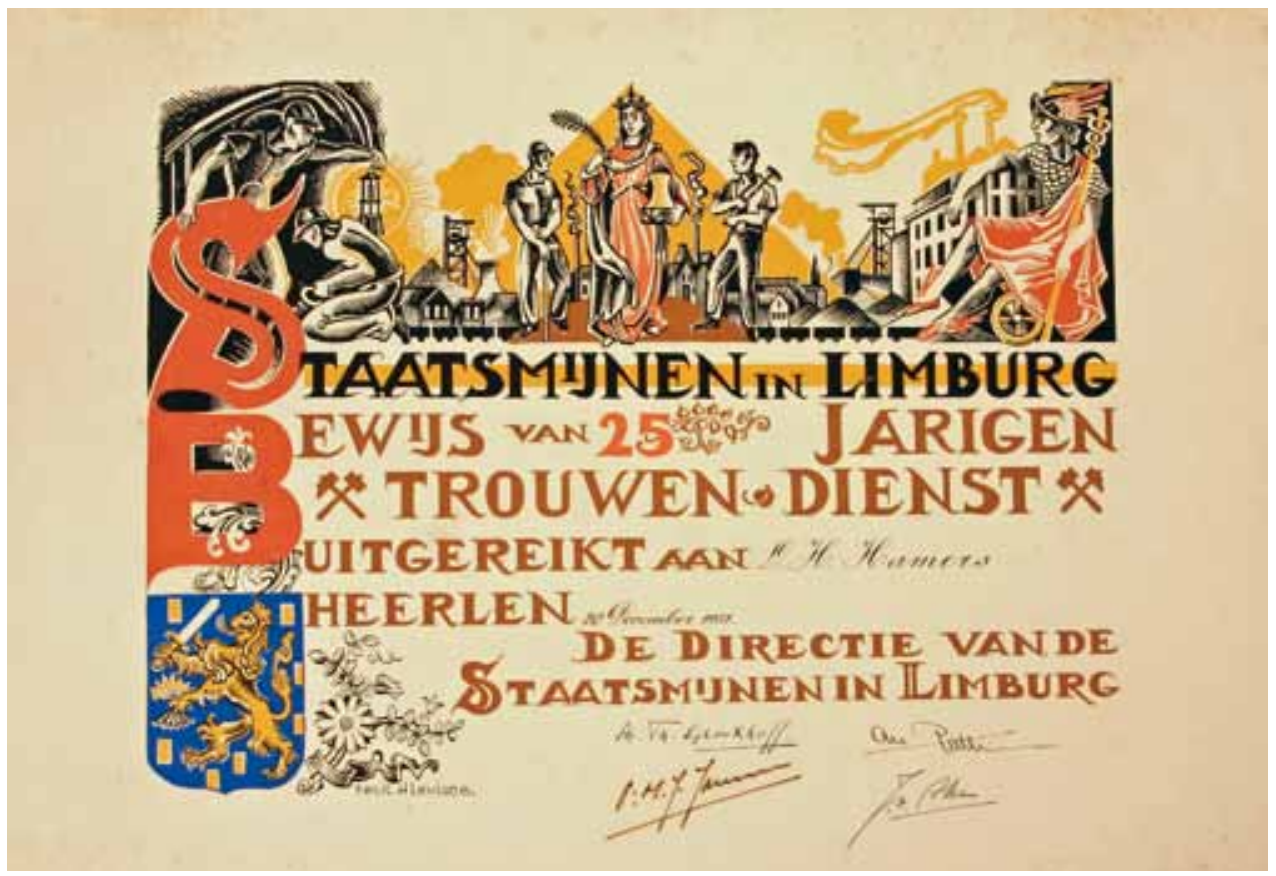

Getuigschrift, uitgereikt aan L.H. Hamers te Heerlen bij gelegenheid van zijn 25-jarig dienstjubileum bij Staatsmijnen. 1951. Collectie Continium Kerkrade o64114. 


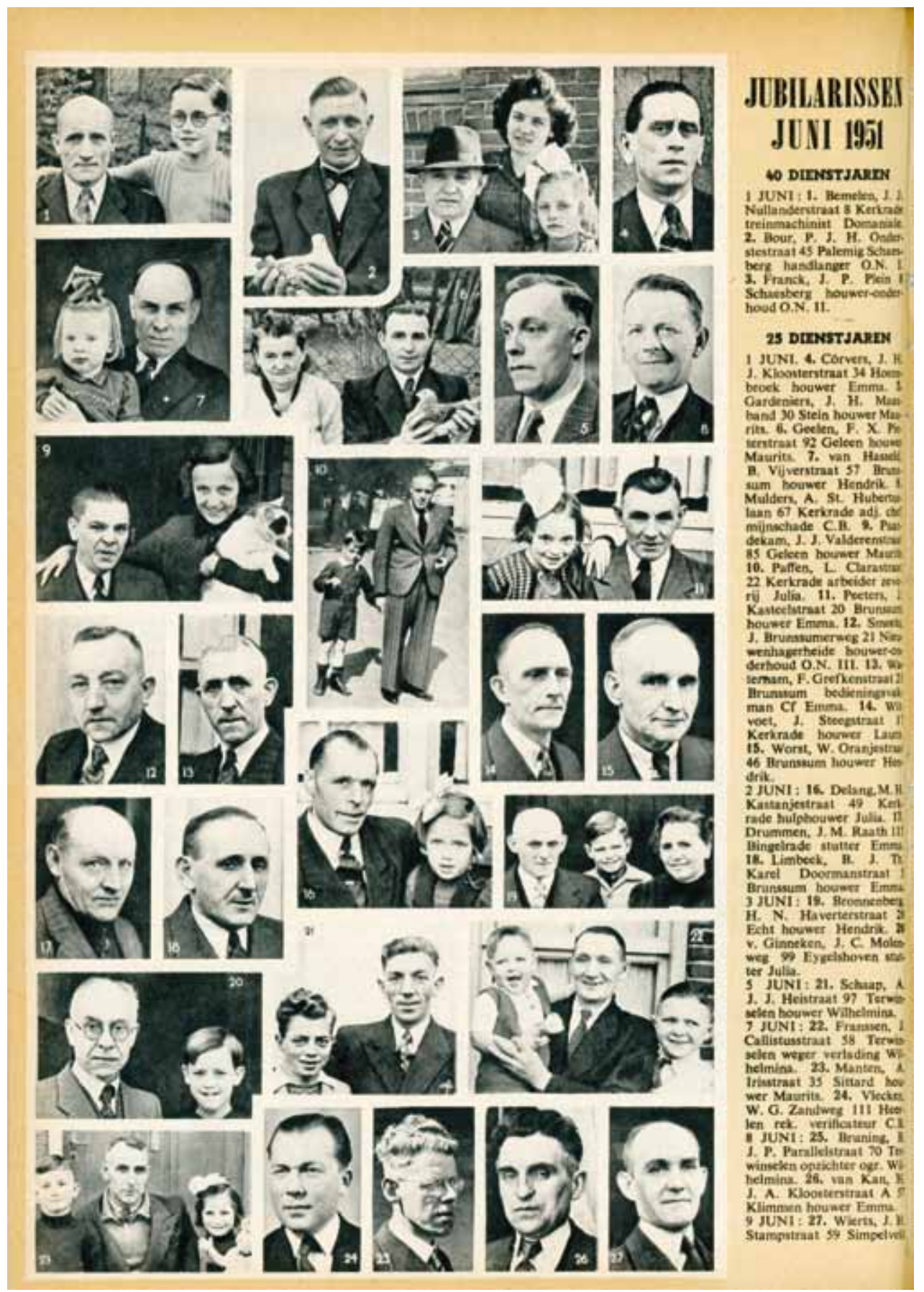

Maandelijks publiceerde het blad Steenkool een overzicht met portretfoto's van jubilarissen met 25 of 40 dienstjaren in de Nederlandse mijnbouw. Bron: Steenkool, mei 1951, p. 224. 


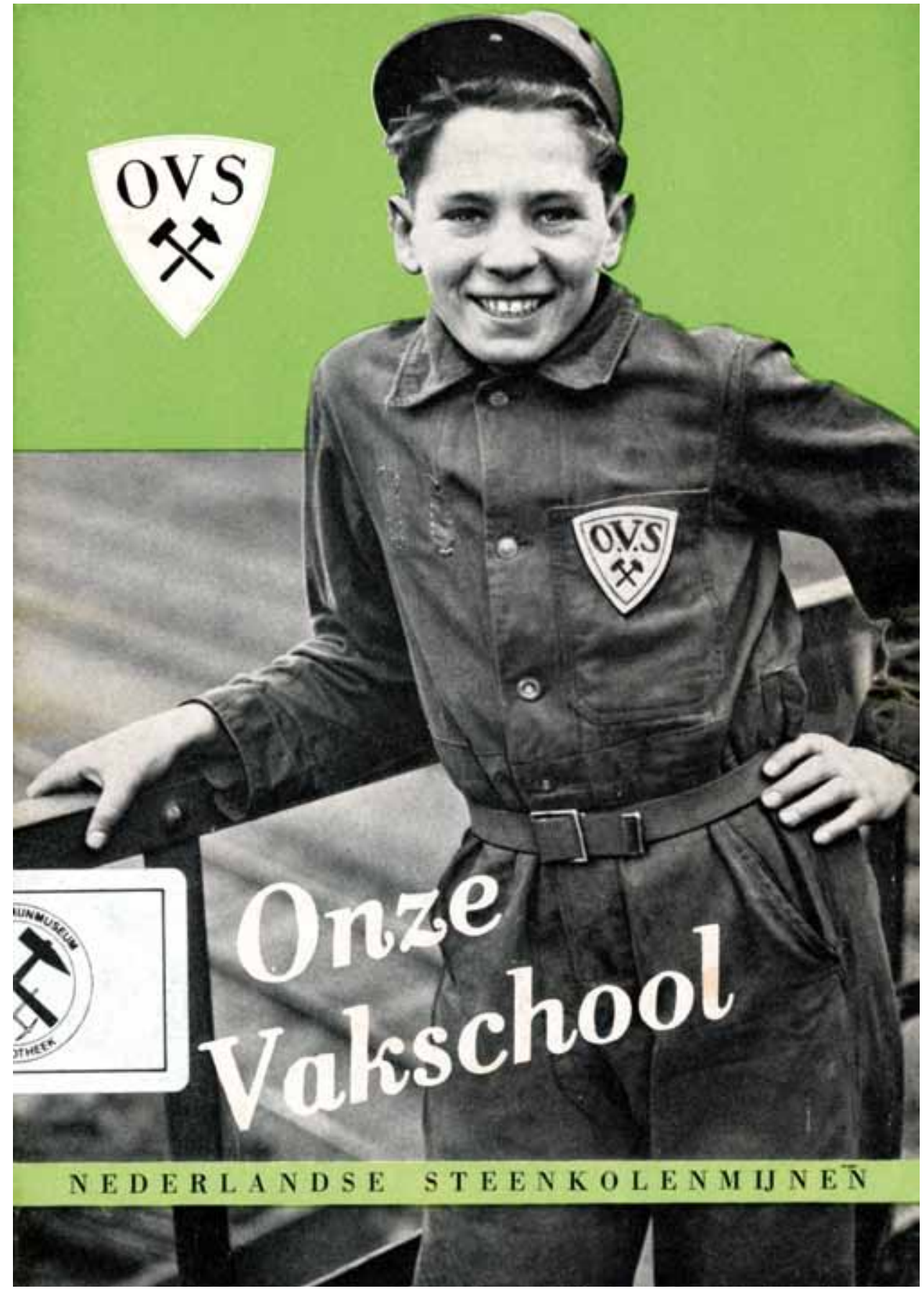

Informatiefolder over de Ondergrondse Vakscholen. Omstreeks 1955. Collectie Continium Kerkrade. 


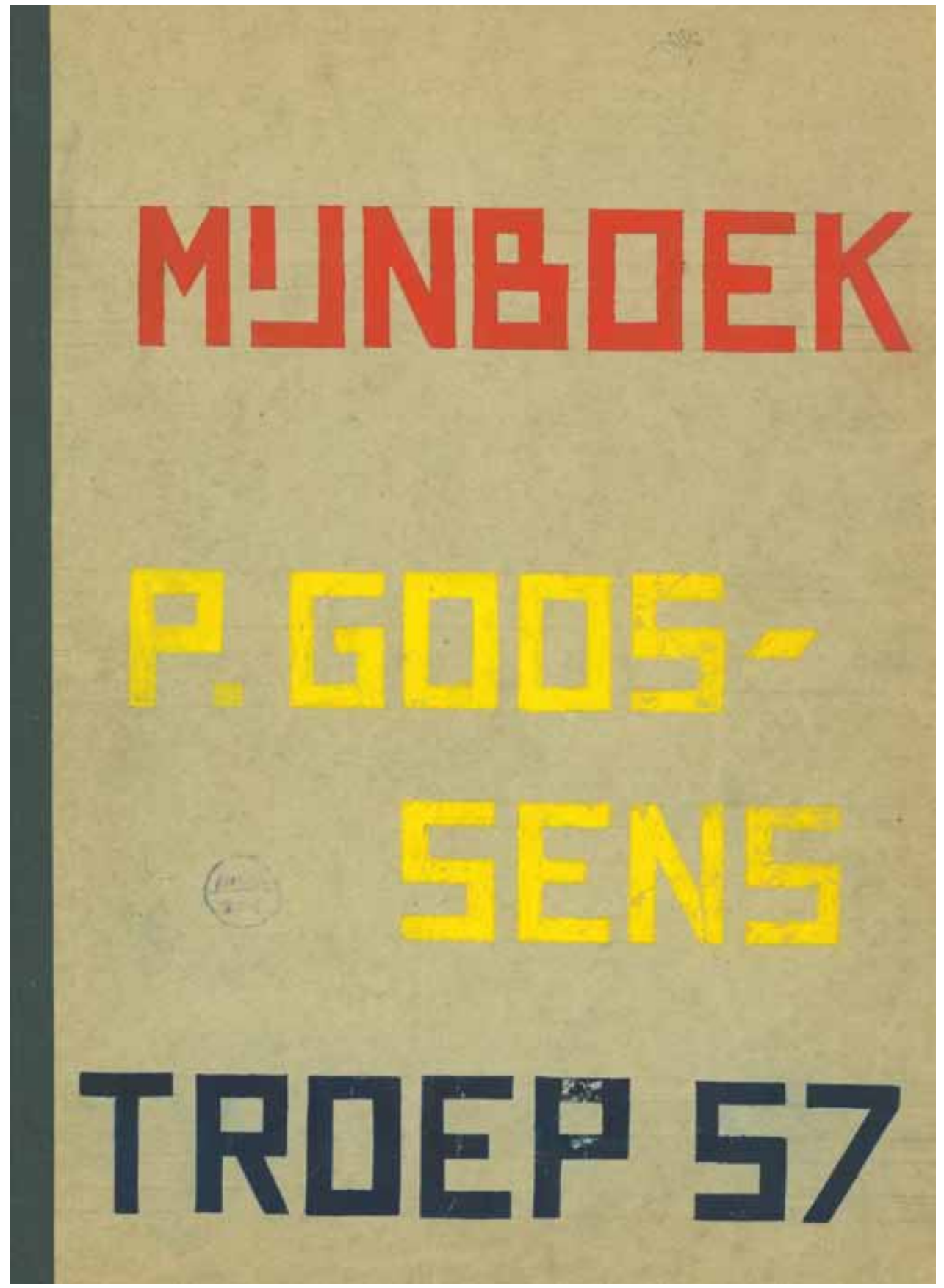

Omslag van het 'Mijnboek' dat OVS-leerling P. Goossens in het eerste jaar van zijn opleiding bijhield. Omstreeks 1955. Collectie Continium Kerkrade booog3. 

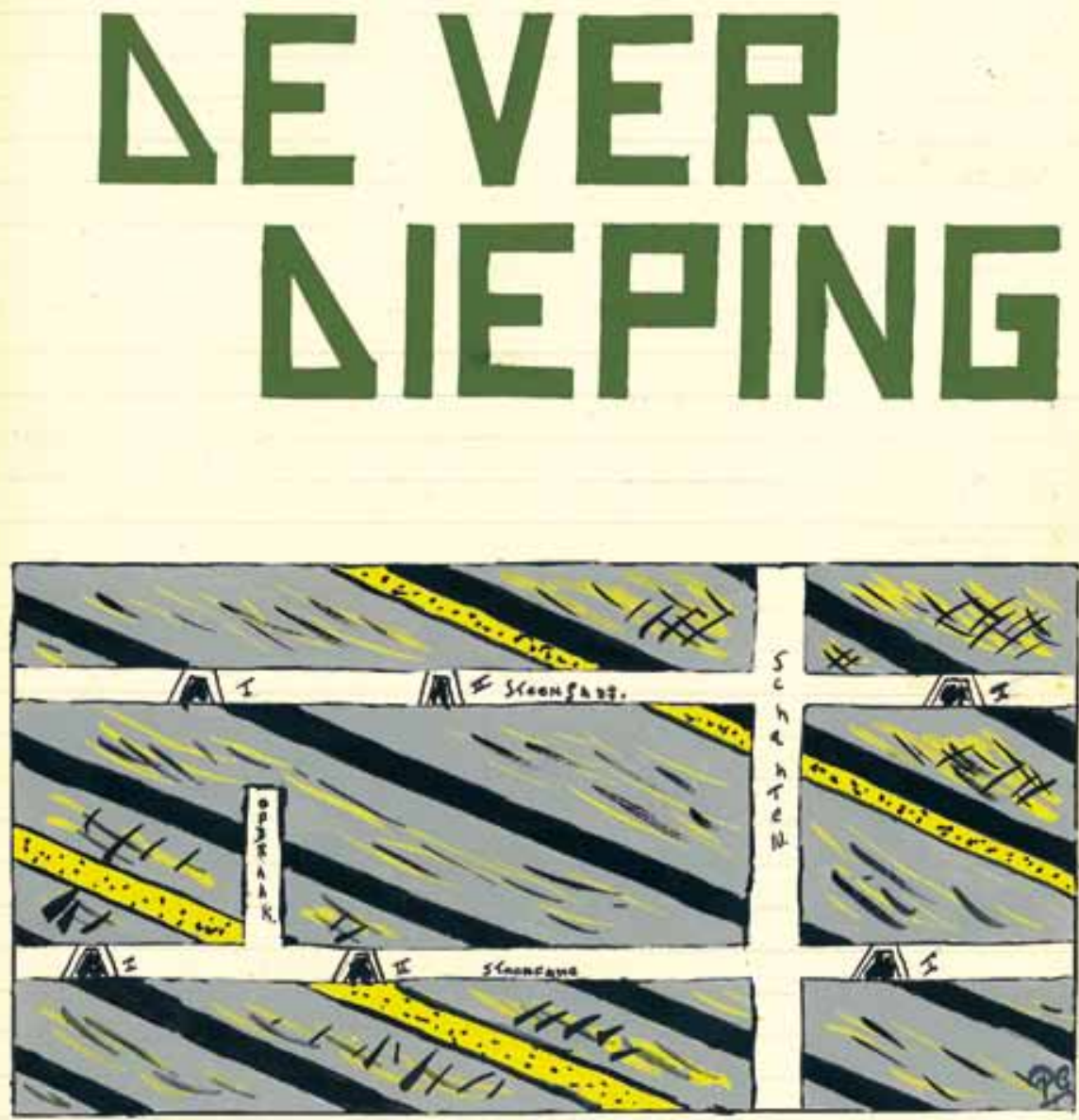

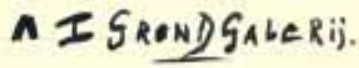

$$
n=\text { Sterenglerij. }
$$

$$
\begin{aligned}
& \text { ZANI STEeN. } \therefore: \because: \\
& \text { Leisficen. Dex }
\end{aligned}
$$

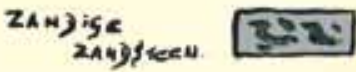

Pagina uit het 'Mijnboek' dat OVS-leerling P. Goossens in het eerste jaar van zijn opleiding bijhield. Omstreeks 1955. Collectie Continium Kerkrade booog3. 


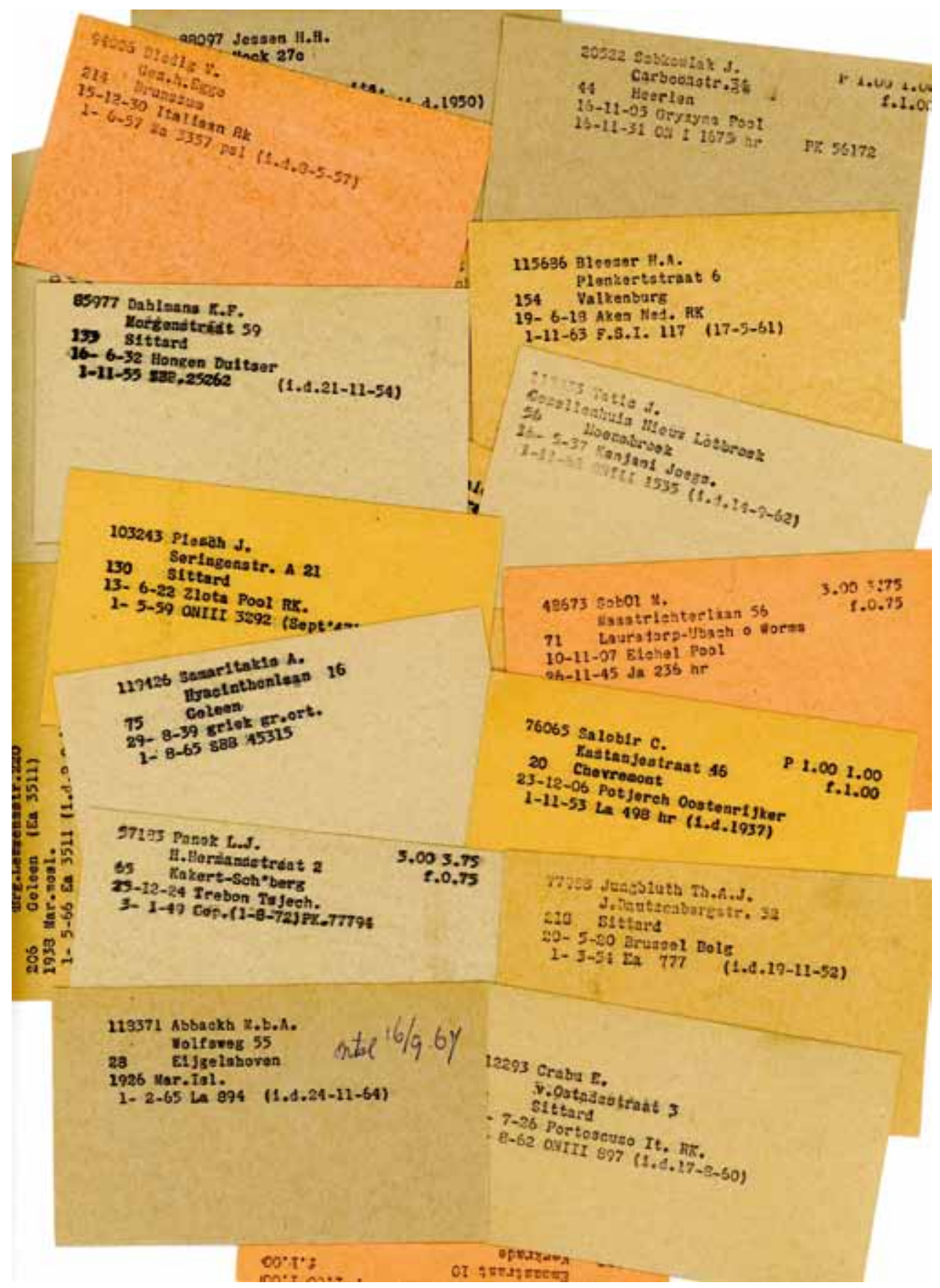

Ook buitenlandse mijnwerkers konden lid worden van de Nederlandse Katholieke Mijnwerkersbond. Een keuze uit het ledenbestand. De kaartjes vermelden onder andere naam, adres, geboortedatum en -plaats, nationaliteit, religie, aanvang lidmaatschap, aanvang dienstverband (indien afwijkend), mijnzetel, functie. Bron: SHCL, Archief NKMB, ledenkaartenbestand. 


\section{c’è lavoro per voi nelle}

\section{miniere olandesi}

di carbone

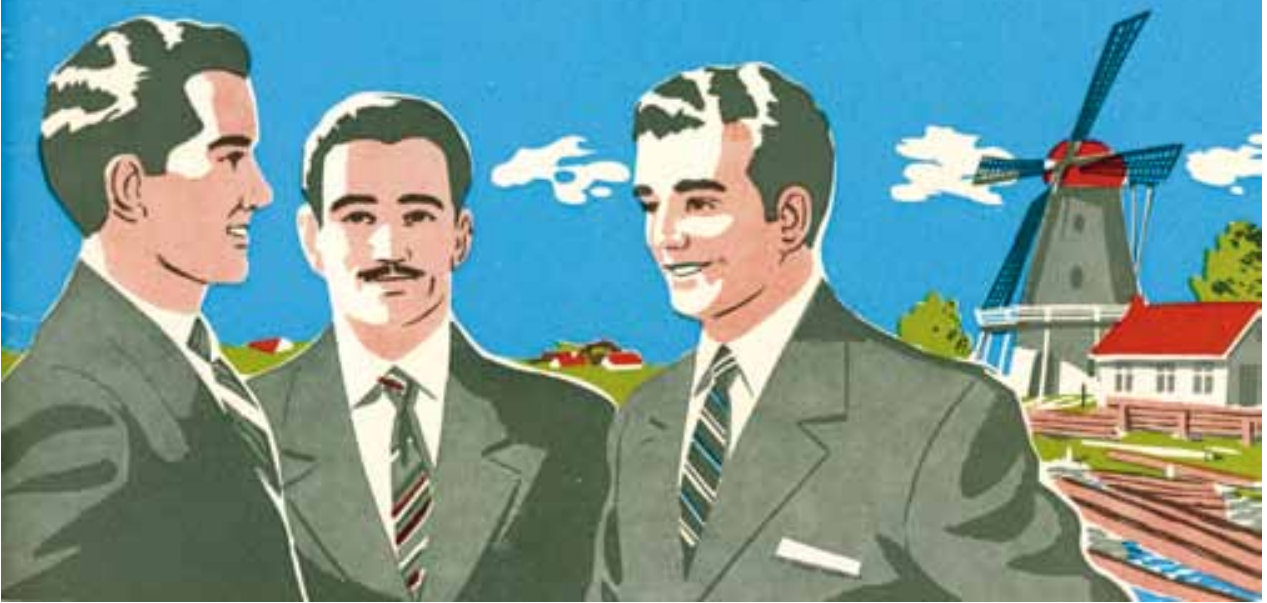

Italiaanse wervingsbrochure voor werk in de Nederlandse mijnen. Omstreeks 1956. Collectie Continium Kerkrade. 


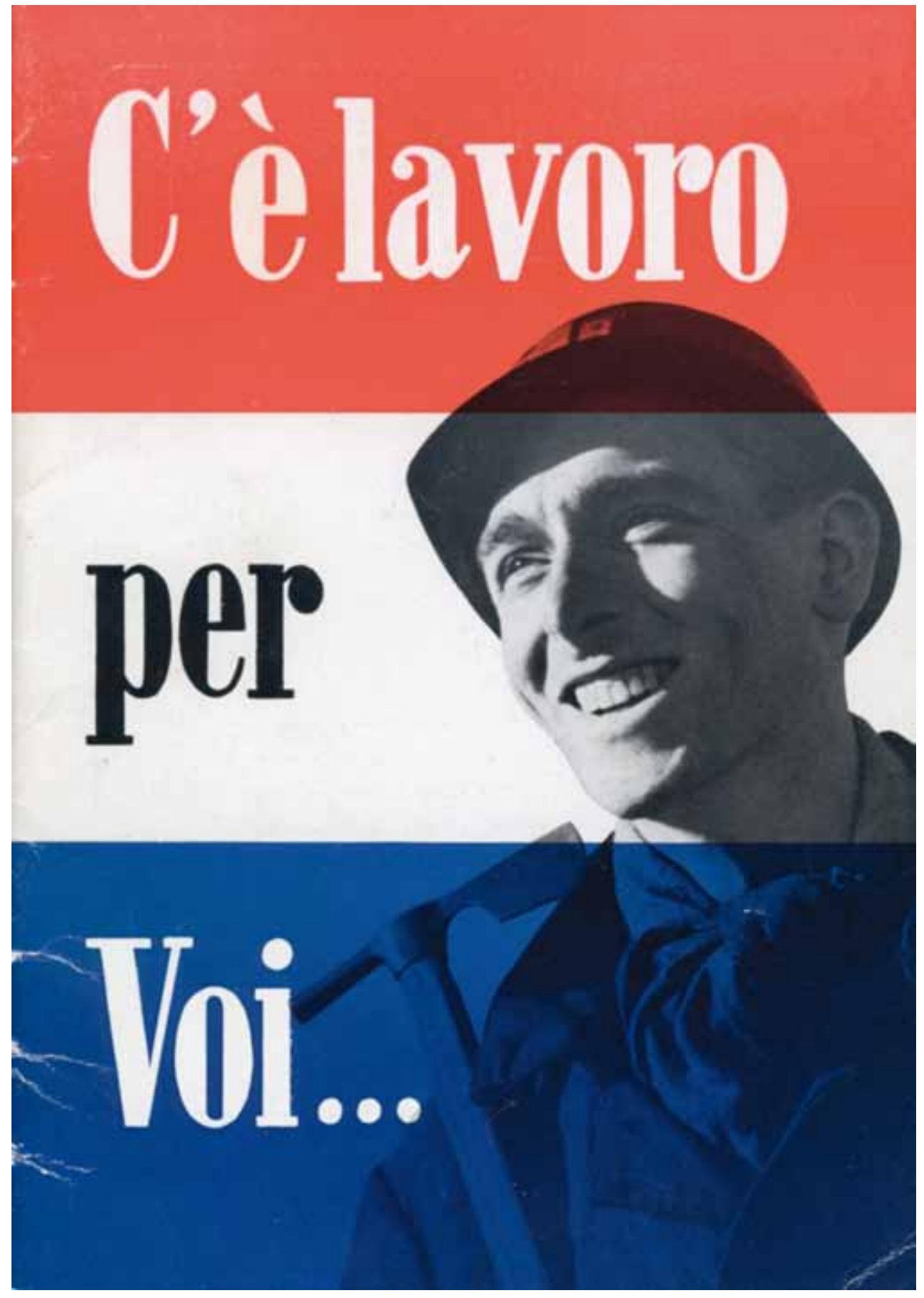

Italiaanse wervingsbrochure voor werk in de Nederlandse mijnen. 1949. Collectie Continium Kerkrade. 


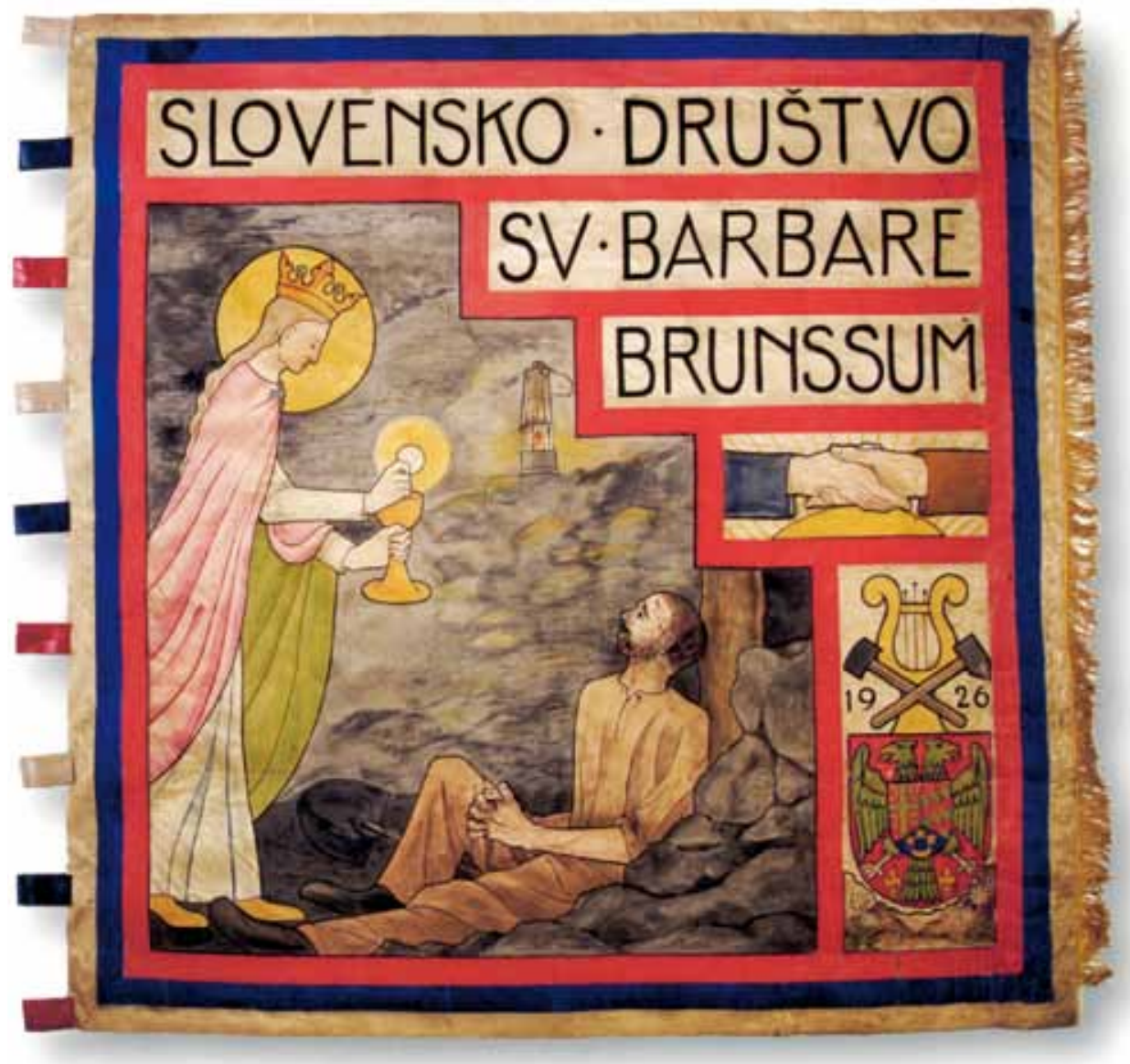

Vlag van een vereniging van Sloveense mijnwerkers in Limburg. De vereniging is vernoemd naar Sint-Barbara, de patroonheilige van de mijnwerkers. Vervaardigd door M.A.T.H. Lommen te Schaesberg in 1925 . Collectie Continium Kerkrade 054976. 


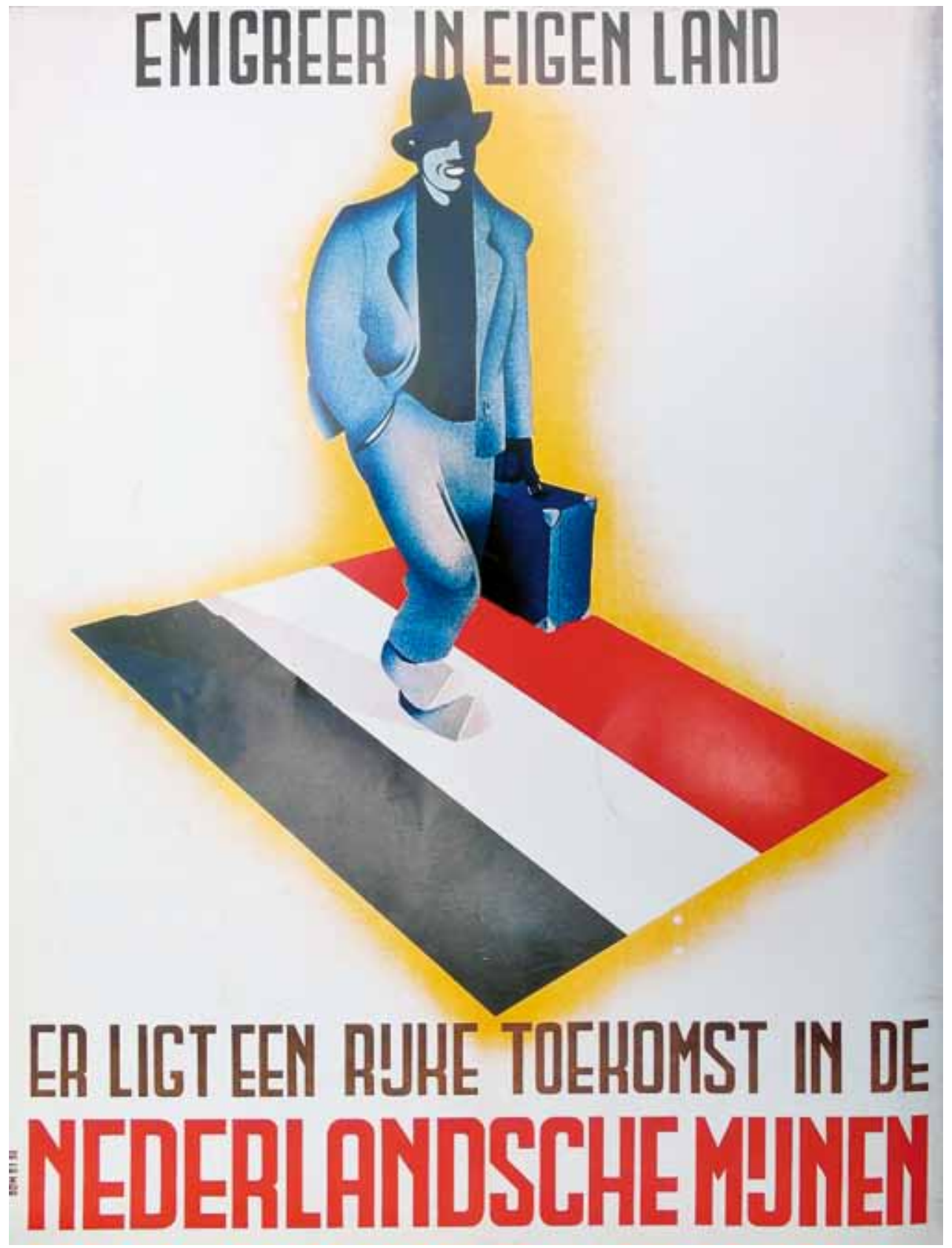

Wervingsaffiche van de Nederlandse mijnen. Migratie in eigen land (naar de Limburgse mijnen) als alternatief voor overzeese emigratie. Omstreeks 1950. Collectie Continium Kerkrade. 


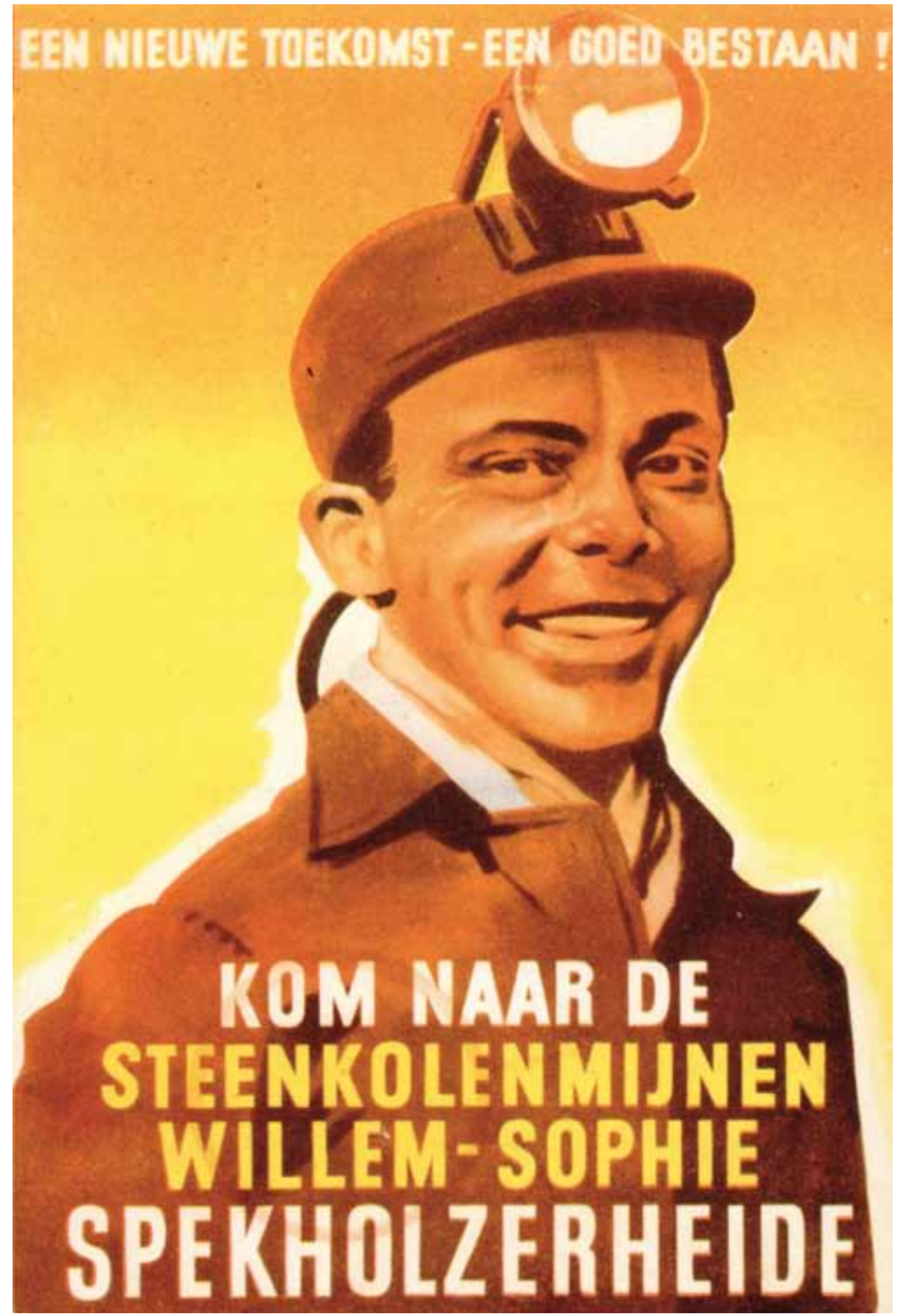

Wervingsaffiche van de mijn Willem-Sophia in Kerkrade. Dit affiche werd bij arbeidsbureaus in Nederland opgehangen. Omstreeks 1953. Collectie Continium Kerkrade 064088. 


\title{
HIEF IS
}
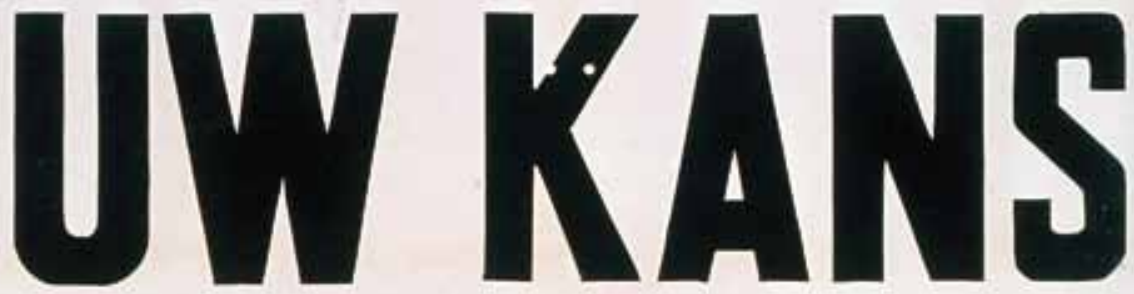

Woor flinke jongemannen ligt een mooie toekomst in de Mijnstreek. $\mathrm{Zij}$, die zich door interessante, echt mannelijhe arbeid een goed bestaan willen veroveren, kunnen daar vooruit komen! Werken in 't mijnbedrijf beteekent:

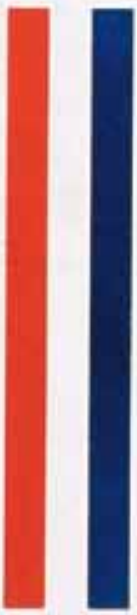

\author{
HOOG LOON \\ SOCIALE ZEKERHEID \\ VROEG PENSIOEN \\ RUIM VERLOF \\ BEHOORLIJKE HUISVESTING \\ SPECIALE \\ EXTRA BONNEN
}

Alle ongehuwde jongemannen in den leeftijd van $18-30$ jaar, die hierover méér wenschen te weten, worden uitgenoodigd, tot het bezoeken van een groote vergadering, welke gehouden zal worden in

Alle inlichtingen zullen $U$ daar worden gegeven! Vergeet niet, om met Uw vrienden deze belangrijke vergadering te bezoeken. Het gaat om Uw toekomst!

Wervingsaffiche van de Nederlandse mijnen. Ongehuwde mannen tussen 18 en 30 jaar werden uitgenodigd voor informatiebijeenkomsten over het werken in de mijn, die op veel plaatsen werden georganiseerd. Omstreeks 1950. Collectie Continium Kerkrade. 
buitenlander, in Luik liep dat aandeel zelfs op tot 70 procent. ${ }^{153}$ Dat geringe Nederlandse percentage is opmerkelijk en duidt er op dat de mijnen sinds de crisisjaren beter in staat waren hun personeel te rekruteren op de Nederlandse arbeidsmarkt, waar zich de meest preferente groepen bevonden. Nog steeds werkten buitenlanders vaker ondergronds dan Nederlanders, zoals blijkt uit tabel 5.2.

Ook in de naoorlogse jaren grepen de personeelsdiensten van de mijnen terug op de rekrutering van buitenlandse mijnwerkers wanneer het regionale, provinciale en nationale aanbod te gering was. ${ }^{154}$ De jaarlijkse groeipercentages die in grafiek 5.2 zichtbaar zijn gemaakt, geven een indruk wanneer zich een dergelijke situatie voordeed. De verdeling van vreemde nationaliteiten in de personeelsbezetting (grafiek 5.I4) laat zien waar nieuwe contingenten buitenlanders vandaan kwamen.

De eerste periode dat buitenlandse mijnwerkers in versterkte mate werden geworven, waren de jaren onmiddellijk na de bevrijding. Die acties brachten voornamelijk Poolse exmilitairen en zogenaamde displaced persons, oorspronkelijk afkomstig uit Oost-Europese landen, naar de Nederlandse mijnen. Tot halverwege de jaren vijftig vormden Polen en statelozen (die het grootste gedeelte van de categorie 'overigen' in grafiek 5.I4 vormen) belangrijke groepen onder de buitenlandse arbeidersbezetting. Volgende golven van buitenlandse rekruteringen vonden plaats in de jaren 1955-1957 en in de periode I96I-1965. Deze arbeidskrachten waren vooral afkomstig uit Oostenrijk en uit mediterrane landen: Italië, Joegoslavië, Spanje en Marokko. Ook de komst van deze groepen is in grafiek 5.I4 goed te volgen.

\section{Poolse ex-militairen en displaced persons}

Door verschillende oorzaken, zoals vrijwillig of gedwongen ontslag, aanmelding of oproeping voor militaire dienst, was het aantal mijnwerkers aan het eind van 1944 scherp gedaald. ${ }^{155}$ De mijnen stonden voor de opgave het personeelstekort op korte termijn aan te vullen. Dat kon alleen lukken door ook een beroep te doen op de buiten-Nederlandse arbeidsmarkt. Vooral de jaren 1946 en 1947 laten spectaculaire groeipercentages van de groep buitenlandse ondergronders zien. Die toename was het gevolg van de georganiseerde werving van twee groepen arbeiders in het buitenland: gedemobiliseerde Poolse militairen en zogenaamde displaced persons, ontheemden uit vooral Polen, maar ook uit andere Oost-Europese landen, die na de oorlog in opvangkampen in Duitsland waren beland. Beide groepen konden of wilden om uiteenlopende redenen niet terug naar hun door de Sovjet-Unie bezette landen. De Nederlandse regering verklaarde zich al op 8 oktober 1945 bereid alle Poolse ex-militairen uit de Eerste Poolse Pantserdivisie van generaal Stanislaw Maczek, die onder meer Breda had bevrijd, uit dankbaarheid in Nederland toe te laten. Aanvankelijk bleef deze toelating beperkt tot de militairen uit deze divisie die zich op het moment van het regeringsbesluit nog daadwerkelijk in Nederland bevonden. Toen bleek dat het merendeel van deze divisie zich inmiddels in Duitsland bevond, werd in augustus 1946 besloten de toebedachte

153 Knotter, 'Inleiding', 28.

I54 H. Römkens, Problemen bij tewerkstelling van buitenlandse arbeiders (scriptie Sociale Academie, Sittard I965) I6-26.

I55 Jaarverslag van den Inspecteur-Generaal der Mijnen over de jaren 1946, 1947 en 1948, 9. 
beloning in de vorm van een verblijfsvergunning uit te breiden tot de Poolse militairen die in Duitsland verbleven. Door uitstel van de demobilisatie van de divisie en langdurige administratieve procedures om uit Duitsland te vertrekken, arriveerden pas begin 1947500 à 600 Poolse militairen in Nederland. ${ }^{156}$ Waarschijnlijk kwamen niet meer dan enkele tientallen van hen in de Limburgse mijnen terecht. ${ }^{157}$

Wat meer succes hadden de Limburgse mijnen bij een tweede groep Poolse ex-militairen: het Tweede Poolse Legerkorps van generaal Wladyslaw Anders, dat in de oorlog onder Brits commando had gestreden. In 1946 bevonden zich onderdelen van dit legerkorps in Engeland, Frankrijk en Italië. Op II maart 1946 besloot de Nederlandse regering om in te gaan op het Engelse verzoek een deel van de te demobiliseren Poolse militairen uit dit legerkorps op te nemen. Was het eerdere besluit van de Nederlandse ministerraad om de leden van de Eerste Poolse Pantserdivisie toe te laten vooral voortgekomen uit dank voor hun rol in de bevrijding, bij de toelating van de Poolse militairen uit het leger van Anders stond het economisch belang voorop. Besloten werd 2.00o Poolse militairen uit dit leger toe te laten en in te zetten in de mijnen, om het grote personeelstekort dat daar bestond, weg te werken. ${ }^{158}$

Begin mei 1946 reisde in opdracht van de ministerraad een delegatie onder leiding van ir A. Paulen, ${ }^{59}$ hoofdbedrijfsingenieur bij Staatsmijnen, naar Frankrijk en Italië om met de geallieerde legerautoriteiten besprekingen te voeren over de rekrutering van te demobiliseren Poolse militairen voor de Nederlandse mijnen. Paulen vernam dat de Engelse militaire autoriteiten, onder wie het Poolse legerkorps ressorteerde, pas tot demobilisatie wilden overgaan als er voor de Poolse militairen die niet naar Polen terug wilden in andere landen vestigingsmogelijkheden waren gevonden. ${ }^{160}$ Dat leek mogelijkheden te bieden voor de Nederlandse mijnen. Daags nadat Paulen schriftelijk verslag van zijn bevindingen had uitgebracht, verzocht de Beheerder der Mijnen C.Th. Groothoff aan de minister van Verkeer en Energie om bij de Britse regering officieel toestemming te vragen om circa 3.000 Poolse arbeiders voor de mijnen te mogen werven uit het te demobiliseren legerkorps. ${ }^{161}$ De Nederlandse regering stemde in met het aantal van 3.000 aan te werven mijnwerkers, I.00o meer dan aanvankelijk was besloten. Bij deze verhoging van het aantal toe te laten Polen speelden de grote personeelstekorten waarmee de mijnen in 1946 nog te kampen hadden een belangrijke rol.

De onderhandelingen met de Britten verliepen stroef. De oorzaak daarvan was vooral dat ook de Engelse mijnen grote personeelstekorten hadden. Probleem was echter dat de Engelse mijnondernemingen niet met de vakbonden tot overeenstemming konden komen

\footnotetext{
I56 C.K. Berghuis, Geheel ontdaan van onbaatzuchtigheid. Het Nederlandse toelatingsbeleid voor vluchtelingen en displaced persons van 1945 tot 1956 (Amsterdam I999) 43-46.

157 RHCL, Centraal Archief DSM 17.26/06B, inv. nr. 19: Werving buitenland, niet gedateerd (waarschijnlijk 1948).

158 Berghuis, Geheel ontdaan van onbaatzuchtigheid, 45-48.

I59 De voormalige Olympische atleet Adriaan Paulen was sinds 1929 als mijnbouwkundig ingenieur in dienst bij Staatsmijnen. In september 1944 maakte hij bij de Amerikaanse en Britse legerautoriteiten naam, toen hij vanwege zijn talenkennis dienst deed als gids voor de oprukkende Amerikaanse troepen. A.P.M. Cammaert, Het verborgen front. Een geschiedenis van de georganiseerde illegaliteit in de provincie Limburg tijdens de Tweede Wereldoorlog (Leeuwarden/Mechelen 1994) 925-926. Leden van de Britse strijdkrachten zouden Paulen hebben ontmoet tijdens Operation Market Garden. Het lijdt geen twijfel dat Paulen door zijn goede contacten bij de legerautoriteiten werd beschouwd als de aangewezen man om de wervingsacties onder gedemobiliseerde militairen en displaced persons te leiden. I6o RHCL, Centraal Archief DSM 17.26/06B, inv. nr. 17: Verslag van een reis naar Frankrijk en Italië van kol. ir A. Paulen en kap. ir C.W. Baïs, 6-5-1946.

I6I RHCL, Centraal Archief DSM 17.26/06B, inv. nr. I7: Brief van Groothoff aan de minister van Verkeer en Energie, 7-5-1946.
} 
over de werving van Poolse ex-militairen. ${ }^{{ }^{62}}$ In afwachting van die overeenstemming wilde de Engelse regering de meest geschikte Poolse arbeidskrachten niet naar het buitenland laten vertrekken. De Nederlandse mijnen werden, zoals Paulen het uitdrukte 'van het kastje naar de muur [gestuurd]' ${ }^{.63}$ Pas in oktober 1946 nam de Engelse regering een beslissing en die was niet gunstig voor de Nederlandse mijnen. In afwachting van een akkoord tussen de mijnondernemingen en de vakbonden zouden de Poolse mijnwerkers in Engeland blijven: 'As a result of very careful consideration by the Ministry of Fuel and Power it has now been finally decided that the coal production position in this country is such that we shall need to employ here all the available Polish miners who have been serving under British Command', lieten de Britten aan de Nederlandse regering weten. De slotsom van Berghuis dat er dus niemand uit het leger van generaal Anders naar de Nederlandse mijnen is gekomen, is echter onjuist. ${ }^{164}$ Uit een opgave van de mijnondernemingen blijkt dat er in I947 ongeveer 300 Poolse ex-militairen in Engeland werden gerekruteerd. Daarnaast arriveerden nog enkele tientallen Poolse militairen uit het Franse legerkamp La Courtine. De Polen kwamen terecht in de staatsmijnzetels Emma en Hendrik, en de Oranje-Nassau Mijn IV. ${ }^{165}$ Wel kan uit de formulering van de Engelse regering worden afgeleid dat de Engelse autoriteiten de meest ervaren mijnwerkers selecteerden voor tewerkstelling in de eigen mijnen.

Omdat de wervingsacties onder de militairen van het Tweede Poolse Legerkorps achter bleven bij de verwachtingen, kwam het ministerie van Sociale Zaken in januari 1947 met het plan om ongeveer 2.000 arbeidskrachten te rekruteren onder Poolse militairen die bij de Engelse marine hadden gediend. Het zou moeten gaan om 500 geschoolde metaalarbeiders, textielarbeiders en bouwvakkers, naast ongeveer I.500 ongeschoolde mijnwerkers. Een Nederlandse commissie vertrok in februari naar Engeland om de Poolse arbeidskrachten te selecteren. Eind oktober 1947 waren er ongeveer I.Ioo Poolse ex-marinemensen geworven. Of er van deze derde lichting Poolse ex-militairen arbeidskrachten in de mijnen zijn terechtgekomen, is onduidelijk. Het overzicht dat begin I948 van het aantal door de mijnen geworven ex-militairen en displaced persons werd opgesteld, vermeldt deze categorie arbeidskrachten in ieder geval niet. ${ }^{166}$

Behalve Poolse ex-militairen wierven de mijnen in 1947 en 1948 displaced persons in Duitsland. Ook deze rekruteringen van buitenlandse arbeidskrachten werden mogelijk gemaakt door een besluit van de Nederlandse regering. In de ministerraad van I 2 augustus I 946 werd voor het eerst gesproken over de eventuele opname in Nederland van displaced persons. Naast argumenten van humanitaire aard speelde ook het heersende tekort aan arbeidskrachten een rol in de beraadslagingen. Een maand later werd de 'Commissie inzake toelating van Displaced Persons' ingesteld, onder voorzitterschap van de chef van de afdeling Arbeidsvoorziening van het Rijksarbeidsbureau van Sociale Zaken. De commissie had als taak via contacten met de bezettingsautoriteiten in Duitsland het aantal toe te laten displaced persons

I62 Kenneth Lunn, 'The employment of Polish and European volunteer workers in the Scottish coalfields, I945-I950', in: Tenfelde (ed.), Towards a social history of mining, 582-592, aldaar 586 .

I63 RHCL, Centraal Archief DSM 17.26/o6B, inv. nr. I9: A. Paulen, Gegevens betreffende de werving van nieuwe arbeiders voor de Nederlandse mijnindustrie, 3I-7-I947.

I64 Berghuis, Geheel ontdaan van onbaatzuchtigheid, 46. In januari 1947 ging de National Union of Mineworkers akkoord met de tewerkstelling van Poolse ex-mitairen in de Britse mijnen.

I65 RHCL, Centraal Archief DSM 17.26/06B, inv. nr. I9: Werving buitenland, niet gedateerd [waarschijnlijk begin I948].

I66 RHCL, Centraal ArchiefDSM 17.26/o6B, inv. nr. I9: Werving buitenland, niet gedateerd [waarschijnlijk begin I948]. 
te onderzoeken, waarbij een zekere selectie op gezondheid en arbeidscapaciteit moest worden toegepast. Bij de bepaling van het maximaal op te nemen aantal ontheemden hield de commissie rekening met het tekort dat er in Nederlandse takken van industrie bestond. In maart 1947 kwam de commissie met een nota, waarin werd voorgesteld in totaal 8.500 displaced persons toe te laten, onder wie 3.000 mannen. Daarvan zou ongeveer de helft bestemd zijn voor de mijnen. ${ }^{167}$

De commissie bepaalde ook de voorwaarden voor toelating in Nederland van de te rekruteren arbeidskrachten. Een struikelblok voor de werving zou de voorwaarde worden dat de arbeidskrachten ongehuwd moesten zijn. Die eis werd beargumenteerd door te wijzen op het grote tekort aan huisvesting in Nederland in de naoorlogse periode. Het tekort werd in mei 1945 berekend op ongeveer 300.000 woningen. ${ }^{168}$ In de praktijk bleken werkgevers het over het algemeen met die eis eens, vooral omdat zij zelf moesten zorgen voor woonruimte voor de aan te werven arbeidskrachten. Ook Staatsmijnen was die mening toegedaan. Het bedrijf wees erop dat ook op de Nederlandse arbeidsmarkt buiten de eigenlijke mijnstreek gehuwden door de mijnen geweerd werden door gebrek aan woonruimte. In de mijnstreek bestond anno I947 een tekort van 7.000 woningen. Het aanbod van de Amerikaanse bezettingsautoriteiten in Duitsland om prefab-woningen voor te rekruteren gehuwde displaced persons ter beschikking te stellen, werd door Staatsmijnen afgewezen, uit vrees voor een negatieve reactie van de Nederlandse bevolking. ${ }^{169}$ Feit is dat veel displaced persons door de eis van het ongehuwd zijn, afvielen voor bemiddeling naar Nederland. De mijnen ontdekten dat zelf ook. Het wervingsteam dat de mijnen in samenwerking met het Rijksarbeidsbureau in de zomer van 1947 naar het opvangkamp in Meppen stuurde, moest om die reden veel potentiële kandidaten afwijzen. ${ }^{170}$

De andere voorwaarden die de 'Commissie inzake toelating van Displaced Persons' formuleerde, gaven minder aanleiding tot discussie. Er mocht geen discriminatie naar nationaliteit zijn, 'slechts de behoefte van de arbeidsmarkt zal de keuze [...] bepalen'. De leeftijdsbegrenzing werd voor mannen bepaald tussen de 20 en 30 jaar, gespecialiseerde arbeidskrachten mochten tot 40 jaar oud zijn. De aan te werven arbeidskrachten dienden arbeidsgeschikt en bekwaam te zijn, over een goede gezondheid te beschikken en mochten geen politieke of criminele antecedenten hebben. ${ }^{17 \mathrm{I}}$

Op basis van de inhoud van de opgestelde nota bezochten in april en mei I947 leden van de commissie een aantal opvangkampen voor displaced persons in de Amerikaanse bezettingszone. Op 5 mei kon een overeenkomst worden gesloten tussen de Nederlandse regering en de Intergovernmental Committee on Refugees (IGCR), een internationaal comité dat onder meer de opvang en hervestiging van displaced persons en vluchtelingen coördineerde. Afgesproken werd dat Nederland displaced persons zou opnemen uit kampen in de Amerikaanse bezettingszone. Aan de displaced persons werden dezelfde arbeids-, levens- en sala-

I67 De precieze omvang van het contingent voor de mijnen is niet helemaal duidelijk. Het uitgangspunt was een totaal aantal van 2.000 displaced persons voor de mijnen, maar dat was inclusief de Poolse ex-militairen die door de mijnondernemingen waren geworven.

I68 Berghuis, Geheel ontdaan van onbaatzuchtigheid, I3.

I69 Ibidem, 89-9r.

I70 RHCL, Centraal Archief DSM 17.26/06B, inv. nr. I7: Reis naar Meppen dd 7, 8 en 9 juli 1947 in verband met aanwerving van Poolse arbeidskrachten, 9-7-1947.

I7I Berghuis, Geheel ontdaan van onbaatzuchtigheid, 89 . 
risvoorwaarden gegarandeerd als aan Nederlanders. Het verblijf in Nederland was echter gebonden aan een tijdelijk arbeidscontract voor twee jaar. Daarna kon de verblijfsvergunning met telkens een jaar worden verlengd. Wie voor mijnarbeid was geworven, mocht niet in andere sectoren in Nederland gaan werken. Bij ontslag uit de mijn vóór de beëindiging van het arbeidscontract volgde uitzetting naar de Amerikaanse bezettingszone in Duitsland. Een uitzondering werd gemaakt voor degenen die in de loop van de contractduur voor mijnarbeid werden afgekeurd. In dat geval kon men door bemiddeling van het Gewestelijk Arbeidsbureau elders in Nederland worden tewerkgesteld. ${ }^{172}$

In augustus 1947 vertrokken twee Nederlandse wervingsteams naar de 400 opvangkampen in de Amerikaanse zone. De teams bestonden uit vertegenwoordigers van de Rijksvreemdelingendienst, het Rijksarbeidsbureau, medici en grote Nederlandse werkgevers. De Nederlandse mijnen verspreidden niet minder dan 30.000 wervingsfolders met informatie over de arbeidsvoorwaarden en de levensomstandigheden in Limburg in de hoop minstens 2.000 arbeidskrachten te kunnen rekruteren. ${ }^{173}$ Kennelijk vertrouwden de mijnondernemingen erop dat het mogelijk zou zijn meer arbeidskrachten te werven dan het contingent dat hen officieel was toegestaan. Een van de informanten van Brassé en Van Schelven beschreef de manier waarop hij en zijn collega's naar Nederland werden gelokt: 'In augustus 1947 kwam een wervingscomité uit Holland naar Bamberg, waar ik in een kamp zat. Die commissie bestond uit zeven man, waaronder doktoren en personeelschefs, zowel van de mijnen als van Philips. We kregen films te zien met mooie meisjes, tulpen en natuurlijk talloze fietsen. Bijna alle aanwezigen, dat waren zo'n 500 man, hebben zich toen opgegeven'. ${ }^{174}$

Ondanks de intensieve wervingscampagne viel het resultaat tegen. Het aantal van 2.000 man dat de mijnen gehoopt hadden te kunnen werven, werd niet gehaald. De grootste groep kwam in de tweede helft van 1947. Het betrof I.I39 man. Naast enkele tientallen Russen en kleine groepjes van verschillende nationaliteiten en statelozen, waren dit voor het merendeel Polen. Zij werden tewerkgesteld op de staatsmijnzetels Maurits, Emma en Hendrik, de Oranje-Nassau Mijnen II en III, de Domaniale en de Willem-Sophia. ${ }^{175}$ Op 3I december 1947, toen de Inspecteur-Generaal der Mijnen zijn jaarlijkse momentopname van het arbeidersbestand van de gezamenlijke mijnen bepaalde, waren de meesten van hen nog in de mijnen werkzaam, getuige de toename van het aantal Polen, Russen en statelozen, vergeleken met eind 1946 (zie bijlage 15).

In 1948 nam het resultaat van de wervingsacties onder de displaced persons af. Het aantal Polen in dienst van de mijnen daalde in de loop van het jaar. Aan het eind van 1948 bedroeg het honderd man minder dan een jaar eerder. Uit de archieven van de mijnondernemingen blijkt niet dat er in 1948 nog nieuwe displaced persons uit de Amerikaanse bezettingszone in Limburg zijn gearriveerd. Dat lijkt onwaarschijnlijk. De cijfers die er voor heel Nederland bestaan, geven weliswaar aan dat het aantal toegelaten displaced persons in de eerste helft van I948 ongeveer halveerde ten opzichte van de tweede helft van 1947, maar er kwamen toch

172 RHCL, ArchiefOranje-Nassau Mijnen 17.05J, inv. nr. I5: Richtlijnen betreffende afvoer van in Duitsland geworven buitenlandse arbeiders (DP's), die niet meer in een der Nederlandse Steenkolenmijnen werken, I-Io-I948.

173 RHCL, Centraal Archief DSM 17.26/06B, inv. nr. I9: A. Paulen, Gegevens betreffende de werving van nieuwe arbeiders voor de Nederlandse mijnindustrie, 31-7-1947.

174 Brassé en Van Schelven, Assimilatie, 7I.

175 RHCL, Centraal Archief DSM 17.26/06B, inv. nr. 20: Werving buitenland, niet gedateerd [waarschijnlijk begin 1948]. 
nog steeds ontheemden uit de Amerikaanse bezettingszone in Nederland aan. In de tweede helft van 1947 kwam ongeveer 45 procent van de binnengekomen displaced persons in de mijnbouw terecht. Als we dit percentage ook voor de eerste helft van I 948 hanteren, zou dat betekenen dat er wellicht nog ongeveer 400 à 500 ontheemden bij de mijnen zijn tewerkgesteld. De afname van het totale aantal Polen in dienst van de mijnen in I948 zou dan verklaard kunnen worden door het grote verloop. Uit de steekproef uit de AMF-inschrijvingen is af te leiden dat van de Polen die in 1947 werden aangeworven ongeveer de helft binnen een jaar weer was vertrokken. Op grond van deze verlooppercentages mag worden aangenomen dat van het cohort dat in I 947 was gekomen in de loop van I 948600 à 700 man de Limburgse mijnen verlieten. Vanaf de zomer van 1948 was de komst van displaced persons naar Nederland van weinig betekenis meer.

Het resultaat in 1948 viel vooral tegen, omdat de werving in de Britse zone op een fiasco uit liep. Net zoals eerder in de Amerikaanse zone was gebeurd, moest de Nederlandse regering in de Britse zone een overeenkomst sluiten met de bezettingsautoriteiten en de International Refugee Organization (IRO), de opvolger van de IGCR. De door de Britse autoriteiten opgestelde concept-overeenkomst vermeldde echter dat ook gehuwden en familieleden in Nederland zouden worden toegelaten. De Nederlandse regering wilde met die eis niet akkoord gaan. ${ }^{17}$ Een andere oorzaak voor het moeizame verloop van de onderhandelingen was de slechte verhouding tussen de Nederlandse regering en de autoriteiten in de Britse bezettingszone, die aan Nederland grensde. Vanaf het eind van de oorlog ruzieden de Nederlandse en Britse autoriteiten over door Nederland uitgewezen illegale vreemdelingen en ongewenste Rijksduitsers, die de Engelse autoriteiten vervolgens weigerden in hun bezettingszone toe te laten. ${ }^{177}$

Door al die moeilijkheden werd pas op 27 oktober 1947 een overeenkomst tussen Nederland, de Britse bezettingsautoriteiten en de IRO gesloten, op basis waarvan de mijnen hoopten opnieuw 2.00o arbeiders te kunnen rekruteren. ${ }^{178}$ De concurrentie met de Franse, Belgische en vooral Engelse mijnen, die ook onder de displaced persons in de Britse zone wierven, was echter groot. Het was een nadeel dat de Nederlandse mijnen in een vrij laat stadium in de opvangkampen in dit deel van Duitsland op het toneel verschenen. De Engelsen hadden al ruimschoots kunnen selecteren en ook de Belgische mijnen waren al sinds september 1947 in de Britse zone actief. ${ }^{179}$ De arbeidskrachten waaruit men nog kon kiezen, waren veelal 'gehuwd, of te oud, of ziek', en dus ongeschikt om naar de Nederlandse mijnen te komen. ${ }^{180}$ Bovendien kwamen in de Britse zone veel Polen niet in aanmerking voor toelating in Nederland, omdat ze in Duitse krijgsdienst waren geweest. Voor zeer jeugdige Polen werd soms een uitzondering gemaakt, omdat kon worden aangenomen dat ze gedwongen waren geweest dienst te nemen. Polen die hadden gediend in het Duitse leger in Nederland werden in alle gevallen uitgesloten. ${ }^{18 \mathrm{r}}$ Volgens eigen opgave van de mijnondernemingen zou-

176 Berghuis, Geheel ontdaan van onbaatzuchtigheid, 92-93.

177 Sintermaartensdijk en Nijland, Operation Black Tulip, 75-78.

I78 Het totale toegestane contingent zou daarmee op 4.000 komen. Niet geheel duidelijk is echter of het om 2.000 extra arbeidskrachten ging, of om vervanging van inmiddels weer uit de mijnen vertrokken displaced persons.

179 Idesbald Goddeeris, De Poolse migratie in België 1945-1950. Politieke mobilisatie en sociale differentiatie (Amsterdam 2005) I48-I49. I80 RHCL, Centraal Archief DSM 17.26/06B, inv. nr. 20: Rapport over de werving van DP's voor tewerkstelling en herplaatsing in Nederland, afkomstig uit de Britse zone in Duitsland, niet gedateerd [waarschijnlijk zomer 1948].

I8I Berghuis, Geheel ontdaan van onbaatzuchtigheid, 93. 
den er tot de late zomer van 1948 slechts 62 mijnwerkers uit de Engelse bezettingszone in Nederland zijn gearriveerd. ${ }^{182}$

Als oplossing voor het grote tekort aan personeel waren de Poolse ex-militairen en displaced persons welkom, maar de komst van de vreemdelingen uit de opvangkampen in Duitsland leverde voor de mijnen ook moeilijkheden op. Vooral de taal was een probleem. Omdat de nieuwe arbeidskrachten het Nederlands doorgaans niet machtig waren, waren de mijnen verplicht instructeurs op te leiden die de taal van de nieuwkomers spraken. Vaak werden voor die taak landgenoten van de nieuwelingen uitgekozen die al lang in de Limburgse mijnen werkten en de ervaring bezaten om de nieuwkomers te begeleiden op de ondergrondse werkplek. De meeste nieuwelingen waren ongeschoold in mijnarbeid. Cijfers voor de Nederlandse mijnen ontbreken, maar het percentage geschoolden zal niet veel hebben afgeweken van het aandeel van deze categorie in de groep displaced persons die in de Belgische mijnen terechtkwam. In de mijnen van de kolenbekkens van Mons, het Centre en de Kempen had niet meer dan 2 à 3 procent van de displaced persons ervaring als mijnwerker. ${ }^{183}$ Groepen nieuwkomers werden onder leiding van de ervaren landgenoot in aparte pijlers tewerkgesteld. ${ }^{184}$

Concluderend kan worden aangenomen dat de Limburgse mijnen in de jaren 1947 en 1948 ongeveer 2.000 Poolse ex-militairen en displaced persons hebben geworven..$^{185}$ Dat kwam neer op ongeveer $\mathrm{I} 4$ procent van het totaal aan indiensttredingen in die jaren ${ }^{\mathrm{I}}{ }^{66}$ Eind 1947 was 3 à 4 procent van de arbeidskrachten in de Nederlandse mijnen voormalig Pools militair of displaced person. Dat was een gering percentage in vergelijking met de naburige Belgische bekkens. In 1947 was in de Kempen 15,5 procent van de personeelsbezetting displaced person; in Luik was dat 12,4 procent. ${ }^{187}$ Dat grote verschil is ook een aanwijzing dat de personeelstekorten bij de Nederlandse mijnen minder urgent waren dan in de naburige Belgische kolenbekkens. Dat er op dat moment in de Belgische mijnen, naast de displaced persons, al vele tienduizenden Italiaanse gastarbeiders werkten, duidt daar ook op. ${ }^{188}$

\section{Regulering}

Bij het indienstnemen van arbeiders met een niet-Nederlandse nationaliteit kregen de mijnen na de oorlog meer dan ooit tevoren te maken met arbeidsmarktregulering door overheden. Nationale en later ook supranationale wet- en regelgeving beoogden het toelatingsbeleid van arbeidsmigranten in Nederland te bepalen. ${ }^{189}$ Voorwaarden voor werving en selectie in het buitenland werden veelal vastgelegd in bilaterale wervingsovereenkomsten die de $\mathrm{Ne}$ derlandse overheid met een toenemend aantal landen sloot.

\footnotetext{
182 RHCL, Centraal Archief DSM 17.26/o6B, inv. nr. 20: Rapport over de aanwerving en herplaatsing van DP's in Nederland afkomstig uit de Britse zone van Duitsland, I6-8-1948.

I83 Goddeeris, Poolse migratie, I57-I58.

I84 Brassé en Van Schelven, Assimilatie 72; Zie ook: Wojtkowiak, Je moet weten hoe haas hupt, 323.

I85 Zie ook: Wojciechowski, Voor brood en vrijheid, 82-83; 'Hun tweede vaderland', Steenkool (maart I95I) I03.

I86 Jaarverslag AMF over 1947, idem over 1948.

187 Roels, 'Buitenlandse arbeiders', II7.

188 Idem, Où sont les mineurs belges, 26.

I89 Zie voor een uitgebreide analyse vooral: Tesseltje de Lange, Staat, markt en migrant. De regulering van arbeidsmigratie naar Nederland 1945-2006 (z.p. 2007) en Simone Goedings, Labor migration in an integrating Europe: national migration policies and the free movement of workers, 1950-1968 (Den Haag 2006).
} 
Uit vrees voor terugkeer van de vooroorlogse werkloosheid bleef op nationaal niveau na I945 de Vreemdelingenarbeidswet uit I934, die sinds 1936 ook voor alle mijnarbeid gold, van kracht. De wet reguleerde arbeidsmigratie van vreemdelingen door een stelsel van arbeids- en verblijfsvergunningen. Doel was vooral om de arbeidsmarktpositie van Nederlanders te beschermen, al werd in de jaren vijftig de toelatingseis, dat buitenlanders alleen mochten worden aangenomen als er geen Nederlanders voor de betreffende functie beschikbaar waren, ruimer geformuleerd door te spreken van algemeen economisch belang dat met de komst van arbeidsmigranten gediend moest zijn. De werkgever moest de arbeidsvergunning aanvragen bij het Rijksarbeidsbureau (Directoraat-Generaal voor de Arbeidsvoorziening) van het ministerie van Sociale Zaken. Op vertoon van een arbeidsvergunning kreeg de arbeidsmigrant vervolgens een verblijfsvergunning. De Vreemdelingenarbeidswet bleef tot 1969 van kracht.

Op supranationaal niveau kwamen in respectievelijk I948, I95I en I957 de Benelux-, EGKS- en EEG-verdragen tot stand. De verdragen beoogden vrij verkeer van arbeidskrachten tussen de lidstaten. In de onderzochte periode waren de verdragen voor de rekrutering door de mijnbedrijven nog van weinig belang. Van de betrokken landen was alleen Italië een emigratieland. Bovendien was in het EGKS-verdrag alleen sprake van vrij verkeer van geschoolde mijnwerkers (en metaalarbeiders), terwijl de mijnen hoofdzakelijk ongeschoolde arbeidskrachten wierven. De EEG-bepalingen over vrij verkeer van werknemers werd pas op I juli I968 van kracht. ${ }^{190}$ De Europese landen regelden de internationale arbeidsmigratie vooralsnog in bilaterale wervingsverdragen. ${ }^{191}$

Tot I96o had Nederland alleen bilaterale sectorale wervingsovereenkomsten met Italië. De eerste overeenkomst kwam tot stand in de periode direct na de Tweede Wereldoorlog en was alleen van toepassing op arbeiders voor de mijnindustrie. ${ }^{192}$ Toen eind I947 bleek dat de resultaten van werving in Nederland en onder Poolse ex-militairen en displaced persons ontoereikend waren om het grote personeelstekort in de Limburgse mijnen op te lossen, kwam Staatsmijnen met de optie om, in navolging van België, een wervingscontract met de Italiaanse overheid te sluiten. ${ }^{193}$ Begin 1948 richtte Staatsmijnen daartoe een Commissie Oriëntatie Tewerkstelling Italiaanse Arbeidskrachten op, waarin Staatsmijnen en het Rijksarbeidsbureau vertegenwoordigd waren. ${ }^{194}$ De Commissie besprak in juli 1948 in Rome met vertegenwoordigers van de Italiaanse ministeries van Arbeid en Buitenlandse Zaken de voorwaarden waaronder de aanwerving zou geschieden. In Nederland werd vervolgens de concept-wervingsovereenkomst voorgelegd aan de betrokken ministeries en aan de Mijnindustrieraad. Toen bleek dat er geen bezwaren tegen het concept bestonden, ondertekende de Nederlandse regering de overeenkomst op 4 december I948. Omdat op basis van deze overeenkomst vrijwel alle Italianen voor de Nederlandse mijnen werden geworven en de overeenkomst met Italië ook diende als model voor wervingscontracten met andere landen,

I90 René Leboutte, 'Coal mining, foreign workers and mine safety: steps towards European integration, 1945-85', in: Berger, Croll en Laporte (ed.), Towards a comparative history, 219-237, aldaar 23I-232.

19I Christoph Rass, Institutionalisierungsprozesse auf einem internationalen Arbeitsmarkt: Bilaterale Wanderungsverträge in Europa zwischen 1919 und 1974 (Paderborn/München/Wien/Zürich 2010) 296-304.

192 De tweede kwam in 1955 tot stand en gold de metaalsector.

193 RHCL, Centraal Archief DSM 17.26-o6B, inv. nr. 20: Brief van hoofdbedrijfsingenier A. Paulen van Staatsmijnen aan Beheerder Ch.Th. Groothoff, 2I-II-I947.

194 De Lange, Staat, markt en migrant, 67-70. 
is het zinvol hier de inhoud kort te bespreken. ${ }^{195}$ De overeenkomst begon met de wijze van werving en selectie. De werving in Italië geschiedde in eerste instantie door de Italiaanse arbeidsbemiddelingsinstanties. De mijnen gaven daarvoor wel enkele algemene richtlijnen: kandidaten moesten, uit oogpunt van tekort aan woonruimte in Nederland, bij voorkeur ongehuwd zijn. Wie gehuwd was, kon worden aangenomen, onder voorwaarde dat zijn gezin in Italië bleef. De kandidaat-mijnwerkers moesten een goede gezondheid hebben en tussen de I 9 en 30 jaar oud zijn. Voorts moesten ze politiek betrouwbaar zijn (dat wil zeggen: geen communistische sympathieën hebben), gealfabetiseerd en ze mochten niet met justitie in aanraking zijn geweest. Een selectiecommissie met vertegenwoordigers van de mijnen, het Rijksarbeidsbureau en een aantal tolken besliste uiteindelijk, na een eerste medische keuring in Italië, over definitieve indienstneming van de kandidaten.

Voor elke arbeidskracht die daadwerkelijk naar de Nederlandse mijnen vertrok, betaalden de Nederlandse mijnen een bedrag aan de Italiaanse autoriteiten. Dat bedrag zou later in een separate overeenkomst worden bepaald op 55 gulden per arbeider. ${ }^{196}$ Met name Beheerder Groothoff verklaarde zich zeer ingenomen met deze bepaling. Het impliceerde namelijk dat het in het belang van de Italiaanse regering zou zijn de voorselectie zo goed en zo volledig mogelijk binnen de door de mijnen uitgestippelde wervingsrichtlijnen te verrichten. ${ }^{197}$ Dat de uiteindelijke selectie van arbeidskrachten door de Nederlandse commissie zou geschieden, was een harde eis van de mijnen geweest in de onderhandelingen. De ondernemingen wilden zelf kunnen bepalen wie ze in dienst namen, een opvatting die het personeelsbeleid van de mijnen vanouds kenmerkte. De Italianen waren met die eis akkoord gegaan onder voorwaarde dat de Nederlandse regering zich verplichtte te zorgen voor de regelmatige overdracht van spaargelden die de Italiaanse arbeidskrachten naar huis wilden zenden, alsmede van gezins- en kindertoeslagen en pensioenen. De mijnen zegden toe desgevraagd een deel van het salaris over te maken naar Italië.

De mijnen stelden zich ook garant voor huisvesting. Die was niet gratis. Italianen betaal$\operatorname{den} \mathrm{f} I, 40$ per dag voor volledig pension in een gezellenhuis. Wie langer dan drie maanden in dienst bleef, hoefde de eerste maand geen kostgeld te betalen. Met deze maatregel beoogden de mijnondernemingen het verloop tegen te gaan, dat, zoals in het volgende hoofdstuk nog zal blijken, vooral in de eerste maanden van tewerkstelling doorgaans erg groot was. De mijnen betaalden de reis naar Nederland. Ook de kosten van repatriëring na afloop van het arbeidscontract kwamen ten laste van de mijnen.

Italianen kregen een arbeidscontract voor één jaar, dat echter van jaar tot jaar, steeds na toestemming van het Rijksarbeidsbureau, kon worden verlengd. De Nederlandse arbeidsvergunning was gekoppeld aan de verblijfsvergunning in Nederland en gold alleen voor de mijnbouwsector. Overeengekomen werd dat de Italiaanse arbeidskrachten dezelfde arbeidsvoorwaarden zouden hebben als hun Nederlandse collega's in de mijn.

Dit wervingscontract bleef geldig tot de Nederlandse overheid in I96o een nieuw akkoord

195 Voor een afschrift van de overeenkomst: SHCL, Archief Laura \& Vereeniging, inv. nr. 537: Overeenkomst op 4 december 1948 te Rome tussen de Regeringen van het Koninkrijk der Nederlanden en van de Italiaanse Republiek gesloten, betreffende de aanwerving van Italiaanse arbeiders voor de ondergrondse bedrijven der Nederlandse Steenkolenmijnen.

I96 SHCL, Archief Laura \& Vereeniging, inv. nr. 537: Rapport Sociaal Technische Dienst Laura \& Vereeniging inzake Italianen, 206-1949.

I97 SHCL, Archief Laura \& Vereeniging, inv. nr. 537: Brief Beheerder Ch.Th. Groothoff aan Laura \& Vereeniging, II-II-I948. 
met Italië sloot, datvoor alle sectoren gold. ${ }^{198}$ Dat akkoord was de opmaat voor wervingsverdragen die Nederland in het volgende decennium zou afsluiten met andere mediterrane landen: Spanje (I96r), Portugal (I963), Turkije (I964), Griekenland (I966), Marokko (I969) en Joegoslavië en Tunesië (I970). Hoewel de details van land tot land konden verschillen, weken de overeenkomsten niet veel af van de Nederlands-Italiaanse overeenkomst uit I948: de wervingslanden selecteerden de arbeidskrachten op leeftijd, gezondheid en vakbekwaamheid. Onder toezicht van de Nederlandse overheid zorgden de werkgevers ervoor dat de arbeidsvoorwaarden in overeenstemming waren met wat in de bedrijfstak gebruikelijk was en regelden ze huisvesting en voeding. ${ }^{199}$ Nederlandse werkgevers moesten hun aanvraag om een bepaald contingent arbeidskrachten in het buitenland te mogen rekruteren, indienen bij het Rijksarbeidsbureau/Directoraat voor de Arbeidsvoorziening, die de aanvraag beoordeelde op de bekende criteria van de stand van de Nederlandse arbeidsmarkt en het algemene economische belang. De daadwerkelijke werving en selectie gebeurde vervolgens conform de door de overheden afgesloten wervingsovereenkomst.

\section{Gastarbeiders}

\section{Italianen (1948-1951)}

Op basis van het Nederlands-Italiaanse contract uit december I 948 hoopten de mijnen tussen de I.000 en 2.000 Italiaanse arbeidskrachten te kunnen werven. Uit oogpunt van de opnamecapaciteit in de mijnen en de huisvesting zouden die in groepen van honderd naar Limburg worden gebracht, een beginsel dat de mijnen ook bij de werving van volgende groepen buitenlandse arbeiders zouden hanteren. De wervingsactie was geen groot succes: op I oktober I950 waren in totaal 679 Italianen aangetrokken. De groep bestond merendeels uit boerenzonen en ongeschoolde arbeiders uit het noorden van het land. Van hen waren er echter op I oktober 1950 slechts 2I5 overgebleven. De rest was al weer vertrokken. ${ }^{200}$ Hoewel de mijnen ervan uit gingen dat de meesten na afloop van hun arbeidscontract naar Italië zouden terugkeren - het waren gastarbeiders - viel het verloop toch tegen. Velen dienden hun arbeidscontract niet uit.

De mijnondernemingen hadden over het algemeen geen ongunstig oordeel over de Italiaanse arbeidskrachten. Hoewel ze bij hun komst in Nederland doorgaans geen enkele ervaring in mijnarbeid hadden, presteerden ze gemiddeld. Ze werden in de mijnondernemingen opgeleid onder leiding van een ervaren landgenoot. Speciaal voor dat doel waren de Oranje-Nassau Mijnen bereid ervaren Italiaanse houwers uit te lenen aan Staatsmijnen. ${ }^{201}$

Het geringe succes van de werving, de organisatorische moeilijkheden die de komst van de Italianen met zich bracht en de hoge kosten van werving werd door de mijnen aangegrepen om de werving van Italianen in I95I te stoppen. ${ }^{202}$ De belangrijkste reden om de rekrutering te beëindigen was echter dat in I95I de werving van mijnwerkers op de Nederlandse

198 SHCL, Archief Laura \& Vereeniging, inv. nr. 538: Intern rapport Laura \& Vereeniging inzake Italianen, I-I2-I96I.

199 Will Tinnemans, Een gouden armband. Een geschiedenis van mediterrane immigranten in Nederland (1945-1994) (Utrecht 1994) 64.

200 De Lange, Staat, markt en migrant, 69-70; 'Italiaanse gezellen', Steenkool (april 195I) I5I-I52.

201 RHCL, ArchiefOranje-Nassau Mijnen I7.05J, inv. nr. I6: Brief van Staatsmijnen aan de Oranje-Nassau Mijnen, I3-6-I949.

202 SHCL, ArchiefOranje-Nassau Mijnen 17.05J, inv. nr. I6: Brief van de Gezamenlijke Steenkolenmijnen in Limburg aan het Gewestelijk Arbeidsbureau in Heerlen, 19-4-1951. 
arbeidsmarkt door een korte conjuncturele inzinking bevredigende resultaten opleverde. De minst preferente groep was daardoor tijdelijk niet nodig.

\section{Oostenrijkers en Italianen (1955-1957)}

In de zomer van 1954 was de toegenomen krapte op de Nederlandse arbeidsmarkt opnieuw voor de mijnen aanleiding hun toevlucht te nemen tot de aanwerving van buitenlandse gastarbeiders. De mijnen zagen de tekorten als een tijdelijk probleem. Door de snel toenemende beroepsbevolking en de voortgezette woningbouw waren de vooruitzichten voor de rekruteringsmogelijkheden op termijn niet zorgwekkend. Gewezen werd op de analogie met de jaren I948-I950, toen de schaarste op de arbeidsmarkt tijdelijk was doorbroken door de tewerkstelling van Italianen. Een dergelijk scenario stond de mijnen ook dit keer voor ogen. ${ }^{203}$ Door het inmiddels ondertekende Verdrag van Parijs, dat de oprichting van de EGKS regelde, had het voor de hand gelegen dat de Nederlandse mijnen zich in eerste instantie weer hadden gericht op Italië, het enige land in het EGKS-verband waar grote aantallen arbeidsmigranten beschikbaar waren. Toch gebeurde dat niet. De ervaringen met de eind jaren veertig geworven Italianen waren niet in alle opzichten positief geweest. De arbeiders bleken niet makkelijk te aarden in de Limburgse samenleving en in de mijn was de communicatie met de enkel Italiaans sprekende arbeiders problematisch en bracht de nodige kosten met zich mee. ${ }^{204}$ Als men tijdelijk buitenlanders moest aannemen, ging de voorkeur daarom uit naar Duitssprekenden uit een land waar werkloosheid heerste en de bevolking 'unter den gleichen Verhältnisse lebt wie hier' ${ }^{205}$ De directie van de Oranje-Nassau Mijnen nam daarom in september 1954 contact op met de Oostenrijkse consul in Eindhoven, met het verzoek behulpzaam te willen zijn bij de werving van geschoolde mijnwerkers of ongeschoolde arbeiders in zijn land. In overleg met het Rijksarbeidsbureau, de Rijksvreemdelingendienst en het Bundesministerium für Soziale Verwaltung in Oostenrijk werd overeengekomen dat er 200 arbeiders in Oostenrijk zouden worden geworven. De voorwaarden waaronder dat mocht gebeuren, waren ontleend aan de Nederlands-Italiaanse overeenkomst uit $1948 .{ }^{206}$ In december 1954 reisde een wervingsteam voor het eerst naar Oostenrijk af, waar bij arbeidsbureaus in Wenen, Graz, Klagenfurth en Linz een eerste contingent arbeidskrachten werd geselecteerd. Eind januari 1955 waren alle formaliteiten in Oostenrijk geregeld en volgde de reis naar Nederland van ongeveer I50 man. Zij werden met een arbeidscontract voor twee jaar tewerkgesteld bij de ON III. ${ }^{207}$ Tussen de eerste contacten en de aankomst in Heerlen was bijna een half jaar verlopen, een indicatie voor de duur van de wervingsprocedures. Tot april 1955 kwamen bij de Oranje-Nassau Mijnen ongeveer 250 en bij Laura \& Vereeniging circa 60 Oostenrijkers terecht. ${ }^{208}$ Hoewel oorspronkelijk ook was

203 RHCL, Centraal Archief DSM 17.26/o6C, inv. nr. 48: Staatsmijnen afdeling arbeiderspersoneel, Rapport naar de mogelijkheden van de noodzakelijke uitbreiding van arbeiderspersoneel, 22-9-1953.

204 SHCL, Archief Laura \& Vereeniging, inv. nr. 538: Brief van Laura \& Vereeniging aan de Minister van Economische Zaken, I4-6I949.

205 RHCL, Archief Oranje-Nassau Mijnen I7.05J, inv. nr. II: Brief Oranje-Nassau Mijnen aan de Consul van Oostenrijk in Eindhoven, 7-9-1954.

206 RHCL, ArchiefOranje-Nassau Mijnen I7.05J, inv. nr. II: Brieven van de Oranje-Nassau Mijnen aan de directeur van het GAB in Heerlen, I-IO-I954; Bundesministerium für Soziale Verwaltung Republik Österreich aan Oranje-Nassau Mijnen, 8-II-I954; Rijksvreemdelingendienst aan Oranje-Nassau Mijnen, 23-II-I954.

207 RHCL, ArchiefOranje-Nassau Mijnen I7.05J, inv. nr. II: Verslag van de inspecteur van Mijnpolitie van de Oranje-Nassau Mijnen, 26-I-I955.

208 Begin 1955 had het Directoraat voor de Arbeidsvoorziening toestemming verleend om het contingent Oostenrijkers voor de 
uitgegaan van de werving van ervaren mijnwerkers, waren de nieuwkomers over het algemeen ongeschoolde arbeiders. Ze werden, na een korte introductieperiode, ondergronds als sleper aangesteld. ${ }^{209}$

Omdat de werving van Oostenrijkers de mijnen goed beviel, niet in de laatste plaats omdat Oostenrijkers in de Limburgse mijnen geen taalproblemen hadden, besloot het bestuur van de Gezamenlijke Steenkolenmijnen in Limburg (GSL) om gezamenlijk te gaan werven in Oostenrijk. Voor I.00o Oostenrijkers vroeg de GSL een werkvergunning aan. De nieuwe arbeidskrachten zouden volgens een verdeelsleutel (Staatsmijnen 450, Oranje-Nassau Mijnen 300 , Laura \& Vereeniging 200 en Willem-Sophia 50) bij de mijnbedrijven worden ondergebracht. De wervingskosten werden naar rato door de betrokken mijnondernemingen gedeeld. ${ }^{210}$ Sociale Zaken had geen bezwaar tegen de gezamenlijke rekrutering van I.000 arbeidskrachten, maar achtte het op grond van politieke overwegingen (het EGKS-verdrag) noodzakelijk daaraan de voorwaarde te verbinden, dat ook een aantal Italiaanse arbeiders zou worden geworven. De mijnondernemingen protesteerden hevig tegen deze voorwaarde. Uiteindelijk werden Sociale Zaken en de GSL het erover eens dat van de I.00o aan te werven buitenlandse arbeidskrachten er 150 Italiaan zouden zijn, die de Duitse taal machtig waren. ${ }^{2 \mathrm{II}}$ De mijnen spraken af, dat de acties in Oostenrijk vanuit Nederland zouden worden georganiseerd door de Oranje-Nassau Mijnen en Laura \& Vereeniging, terwijl Staatsmijnen de werving in Italië voor zijn rekening zou nemen. ${ }^{212}$ Het kostenaspect van de buitenlandse werving lag aan deze afspraak ten grondslag.

Het coördinatiepunt in Oostenrijk bij de gezamenlijke werving van de GSL was het Landesarbeitsamt in Wenen, dat de activiteiten van provinciale arbeidsbureaus in Kärnten, OberÖsterreich, Nieder-Österreich, Salzburg en Steiermark overkoepelde. De propaganda werd door de Oostenrijkse arbeidsbureaus gedaan, daarbij geholpen door de informatiefolders die de mijnen hadden opgesteld. De uiteindelijke selectie en de indienstneming zou in Oostenrijk plaatsvinden door vertegenwoordigers van de Nederlandse mijnondernemingen. ${ }^{213}$ De gezamenlijke wervingsactie begon in september 1955. Het werd echter een mislukking, vooral omdat al in oktober de Oostenrijkse regering actieve medewerking aan de wervingsacties weigerde in verband met de inmiddels opgetreden krapte op de Oostenrijkse arbeidsmarkt. ${ }^{214}$ Tussen I januari en I augustus 1956 kwamen er slechts IoI, veelal ongeschoolde, Oostenrijkers bij de Limburgse mijnen aan. ${ }^{215}$ In 1957 zouden er nog ruim 200 bij de Nederlandse mijnen arriveren (tabel 5.3). ${ }^{216}$ De opdroging van de Oostenrijkse arbeidsmarkt was

Nederlandse mijnen te verhogen tot 350 man. RHCL, ArchiefOranje-Nassau Mijnen 17.05J, inv. nr. II: Brief van de Oranje-Nassau Mijnen aan het GAB in Heerlen, 5-3-1955.

209 Dat blijkt onder meer uit de inschrijvingskaarten bij de Nederlandse Katholieke Mijnwerkersbond, waarvan de nieuwkomers uit het buitenland in veel gevallen lid werden. Op de kaarten staat de functie bij intreding in het mijnbedrijf vermeld. SHCL, Archief Nederlandse Katholieke Mijnwerkersbond, lidmaatschapsformulieren.

210 RHCL, ArchiefOranje-Nassau Mijnen, I7.05J, inv. nr. II: Brief van de GSL aan de Oranje-Nassau Mijnen, 25-4-I955.

2II RHCL, ArchiefOranje-Nassau Mijnen, I7.05J, inv. nr. Ir: Brief van de GSL aan de Limburgse mijnondernemingen, 26-5-I955.

212 RHCL, Archief Oranje-Nassau Mijnen, I7.05J, inv. nr. Ir: Brief van de Oranje-Nassau Mijnen en Laura \& Vereeniging aan de minister van Economische Zaken, I9-I-I956.

213 RHCL, ArchiefOranje-Nassau Mijnen, 17.05J, inv. nr. II: Brief van de GSL aan de Limburgse mijnondernemingen, I6-6-1955.

214 RHCL, ArchiefOranje-Nassau Mijnen, I7.05J, inv. nr. II: Brief van het Landesarbeitsamt Wien aan de Oranje-Nassau Mijnen, 7-IOI 955 .

215 RHCL, ArchiefOranje-Nassau Mijnen, I7.05J, inv. nr. Ir: Rapport Werving Oostenrijkers, I4-9-1956.

216 Daarnaast konden de mijnen eind 1956 in Oostenrijkse kampen ongeveer 400 Hongaarse vluchtelingen rekruteren. Jaarverslag van de Inspecteur-Generaal der Mijnen over 1956, I6. 


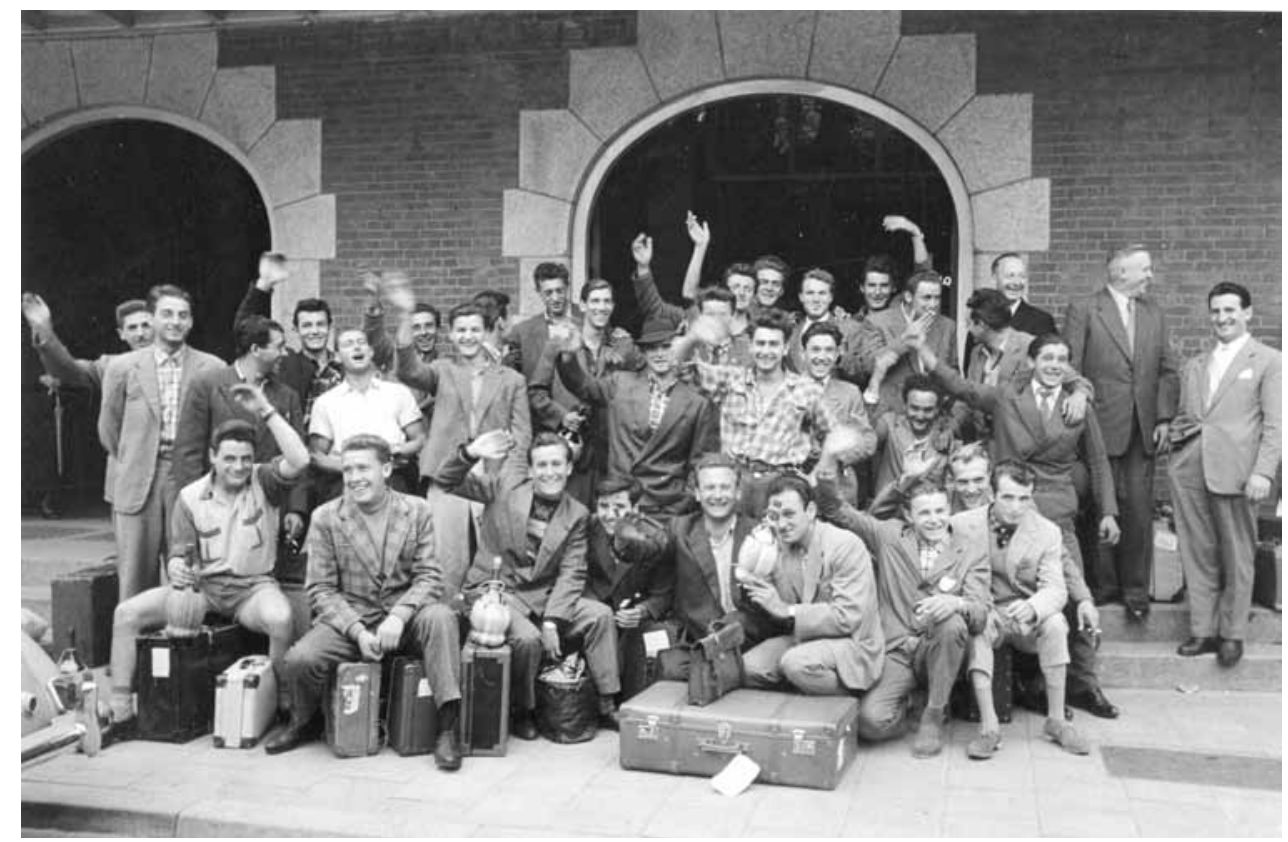

Op 6 juli 1956 arriveerde een groep van 31 Italiaanse gastarbeiders voor de Julia op station Maastricht. Bron: Fotocollectie Continium Kerkrade, F4764.

echter de reden dat al begin 1956 besloten werd zich meer op Italianen te gaan richten. De verdeling van het toegestane contingent buitenlanders werd gewijzigd in 700 Italianen en 300 Oostenrijkers. ${ }^{217}$

In augustus I955 vonden in Italië besprekingen plaats tussen een Nederlandse delegatie onder leiding van de Directeur-Generaal voor de Arbeidsvoorziening en de Italiaanse autoriteiten. Afgesproken werd de overeenkomst uit I 948 als leidraad bij de werving te gebruiken. ${ }^{218}$ Een afwijkende bepaling was dat de Italiaanse arbeidsmigranten deze keer een arbeidscontract voor twee jaar kregen. De reden hiervoor was dat de kosten die de mijnen moesten maken om de nieuwkomers te werven en op te leiden, voor een contract van twee jaar meer rendement opleverde. Volgens een berekening uit 1956 ging een Italiaanse arbeidsmigrant gemiddeld pas na 5,6 maanden rendement opleveren. ${ }^{219}$

De mijnen hoopten in eerste instantie arbeidskrachten te kunnen werven in Duitstalige gebieden in het noorden van Italië. Toen het contingent werd verhoogd van 150 naar 700 man, bleek het noorden te weinig mensen te kunnen leveren. De concurrentie in dat gedeelte van Italië was groot, vooral omdat ook de Belgische mijnondernemingen er al vanaf 1946 actief waren. De Italiaanse autoriteiten raadden de Nederlandse mijnen daarom ook Sardinië als wervingsregio aan. Daar was reeds geruime tijd gebrek aan werkgelegenheid en de

217 RHCL, Archief Oranje-Nassau Mijnen, I7.05J, inv. nr. II: Brief van het Directoraat voor de Arbeidsvoorziening aan de GSL, I02-1956.

218 RHCL, ArchiefOranje-Nassau Mijnen 17.05J, inv. nr. I6: Verslag van de besprekingen in Italië van 18 tot en met 25 Augustus over de werving van Italiaanse arbeiders, 25-8-1955.

219 RHCL, Centraal ArchiefDSM 17.26/06C, inv. nr. 48: Rapport Personeelsvoorziening in de mijnindustrie, 1956. 
uitkeringsduur van veel werklozen was inmiddels verstreken. Er zou dus ongetwijfeld veel animo zijn om in Nederland te gaan werken. Veel concurrentie van de Belgen was er niet te duchten. De Belgische mijnen hadden een slechte reputatie in dit deel van Italië door klachten van Italiaanse arbeidsmigranten over de huisvesting, de veiligheid en vooral de wijze waarop ze door opzichters werden behandeld. In dat kader achtten de Italiaanse autoriteiten het gewenst de Nederlandse mijnondernemingen een typering van de Sardijnse arbeider te geven: 'een harde en intelligente werker met een lichtelijk overdreven rechtvaardigheidsgevoel en erg sensibel. De Nederlandse mijnen zullen hiermede rekening moeten houden wil men van slagen verzekerd zijn. Als de arbeider wordt gestraft moet hem het motief van bestraffing worden duidelijk gemaakt, zo niet, dan verdwijnt hij zonder meer' ${ }^{220}$ Misschien mede dankzij deze goede raad verliep de rekrutering van Italiaanse arbeiders voorspoedig. Eind 1955 werkten er 2II Italianen in de gezamenlijke Nederlandse mijnen, eind 1956886 en eind I957 zelfs I.966. ${ }^{221}$ Die cijfers geven al aan dat het toegestane contingent van 700 in overleg met Arbeidsvoorziening was verhoogd tot uiteindelijk 2.00o. Dat contingent was eind 1957 dus nagenoeg bereikt.

De cijfers aan het eind van het jaar verhullen echter dat het verloop onder de Italianen groot was. Voor de toename in 1956, die 665 man bedroeg, hadden de mijnen I.200 arbeidskrachten moeten aannemen. ${ }^{22}$ Ook in 1957 was het verloop groot. Bij keuring door de mijnarts in Nederland moesten Italianen regelmatig wegens medische ongeschiktheid worden teruggestuurd en tijdens de instructieperiode moesten anderen na enkele dagen naar huis terugkeren wegens mijnvrees of aanpassingsmoeilijkheden. Dergelijke arbeidskrachten telden mee voor de bepaling van de omvang van het toegestane contingent arbeidsmigranten, maar voor de kolenproductie waren ze van geen enkele betekenis. De mijnen wisten Arbeidsvoorziening ervan te overtuigen dat er moest worden uitgegaan van het aantal Italianen dat daadwerkelijk in de mijnen werkte. In de praktijk betekende de gewijzigde berekening dat een arbeidsmigrant die de mijn voor het verstrijken van zijn arbeidscontract verliet, door een andere vervangen mocht worden. ${ }^{223}$

Net zoals hun Oostenrijkse collega's hadden de meeste Italiaanse arbeiders geen ervaring als mijnwerker. Ook zij kregen, na een introductiecursus in het bedrijf, de functie van sleper. ${ }^{224}$ Ondergronds werden ze begeleid door ervaren landgenoten die Italiaans spraken.

De ongeschooldheid en de tijdelijkheid van het arbeidscontract van de Oostenrijkers en Italianen duiden op een bufferfunctie op de arbeidsmarkt. Zij werden de voornaamste slachtoffers van de kolencrisis van I958-i96o die de mijnen noodzaakte de personeelsbezetting in te krimpen en de tijdelijke contracten van de recent aangeworven buitenlandse arbeiders niet te verlengen. ${ }^{225}$ Een aantal Italianen kon in Nederland aan ander werk wor-

220 RHCL, Archief Oranje-Nassau Mijnen I7.05J, inv. nr. I6: De werving van Italiaanse arbeiders. Resultaat van de besprekingen in Italië in de periode van 28 oktober tot Io november 1955.

22I Zie bijlage I5.

222 Jaarverslag van de Inspecteur-Generaal der Mijnen over 1956, I6.

223 RHCL, Archief Oranje-Nassau Mijnen 17.05J, inv. nr. I6: Brief van de GSL aan de Directeur-Generaal voor de Arbeidsvoorzie-

ning, 2I-4-1956.

224 SHCL, Archief Nederlandse Katholieke Mijnwerkersbond, lidmaatschapsformulieren.

225 Messing, Geschiedenis van de mijnsluiting, IzO. 
den geholpen. ${ }^{226}$ Binnen de gezamenlijke Nederlandse mijnen werd de Italiaanse bezetting gehergroepeerd. Enkele tientallen Italiaanse arbeiders van Staatsmijnen werden overgeplaatst naar de huisbrandkolenmijnen Oranje-Nassau en Laura \& Vereeniging, die wat minder last van de crisis ondervonden. ${ }^{227}$ Een grotere groep Italianen van wie de contracten niet werden verlengd, werd mede door bemiddeling van de mijnen via de arbeidsbureaus elders tewerkgesteld. Een aantal van hen kwam in de mijnen van de Franse departementen Nord en Pas-de-Calais terecht. ${ }^{228}$

TABEL 5.3 INDIENSTGETREDEN EN VERTROKKEN ITALIAANSE EN OOSTENRIJKE ARBEIDERS BIJ DE NEDERLAN DSE STEEN KOLENMIJNEN, I957-I959

\begin{tabular}{|c|c|c|c|c|}
\hline \multirow{2}{*}{} & \multicolumn{4}{|c|}{ Italianen } \\
\cline { 2 - 5 } & $\begin{array}{c}\text { sterkte begin van } \\
\text { het jaar }\end{array}$ & in dienst getreden & vertrokken & sterkte ultimo jaar \\
\hline $\mathrm{I} 957$ & 776 & $\mathrm{I} .85 \mathrm{I}$ & 755 & $\mathrm{I} .872$ \\
\hline $\mathrm{I} 958$ & $\mathrm{I} .872$ & 42 & $73 \mathrm{I}$ & $\mathrm{I} .183$ \\
\hline $\mathrm{I} 959$ & $\mathrm{I} .183$ & $\mathrm{I} 7$ & $8 \mathrm{I} 5$ & 385 \\
\hline
\end{tabular}

\begin{tabular}{|c|c|c|c|c|}
\hline & \multicolumn{4}{|c|}{ Oostenrijkers } \\
\cline { 2 - 5 } & $\begin{array}{c}\text { sterkte begin van } \\
\text { het jaar }\end{array}$ & in dienst getreden & vertrokken & sterkte ultimo jaar \\
\hline I957 & $22 \mathrm{I}$ & 236 & 200 & 257 \\
\hline I958 & 257 & 48 & I54 & I5I \\
\hline I959 & I5I & - & 48 & 103 \\
\hline
\end{tabular}

Bron: Verslag GSL aan MIR, [1957-1959].

In totaal verlieten in de jaren I958 en I959 ruim I.500 Italianen en bijna 200 Oostenrijkers de Nederlandse mijnen (tabel 5.3). Die ontslaggolf van buitenlandse arbeiders is in grafiek 5.2 zichtbaar in de negatieve groeipercentages in de periode 1958 -1960.

$$
\text { Italianen, Spanjaarden, Joegoslaven en Marokkanen (1961-1965) }
$$

De zeer krappe regionale en nationale arbeidsmarkt in de jaren $196 \mathrm{I}-\mathrm{I}_{9} 6_{5}$ was voor de mijndirecties aanleiding opnieuw een beroep te doen op arbeiders van niet-Nederlandse afkomst. Naarmate duidelijk werd dat de wervingsacties in Nederland nauwelijks nog resultaat opleverden, de belangstelling van jongeren voor de opleidingen van de mijnen afnam en het verloop onder de Nederlanders voortdurend steeg (zie hoofdstuk 6), legden de gezamenlijke mijnen meer en meer het accent op tewerkstelling van buitenlandse arbei-

226 Van Elteren, Staal en arbeid, 805-806.

227 Verslag GSL aan MIR, 23.

228 RHCL, ArchiefOranje-Nassau Mijnen I7.05J, inv. nr. I6: Brief van de GSL aan de Hoge Autoriteit van de EGKS, 24-2-1959. 
GRAFIEK 5.I5 INDIENSTGENOMEN ONDERGRONDSE MIJNWERKERS NAAR HERKOMST, I960-I964

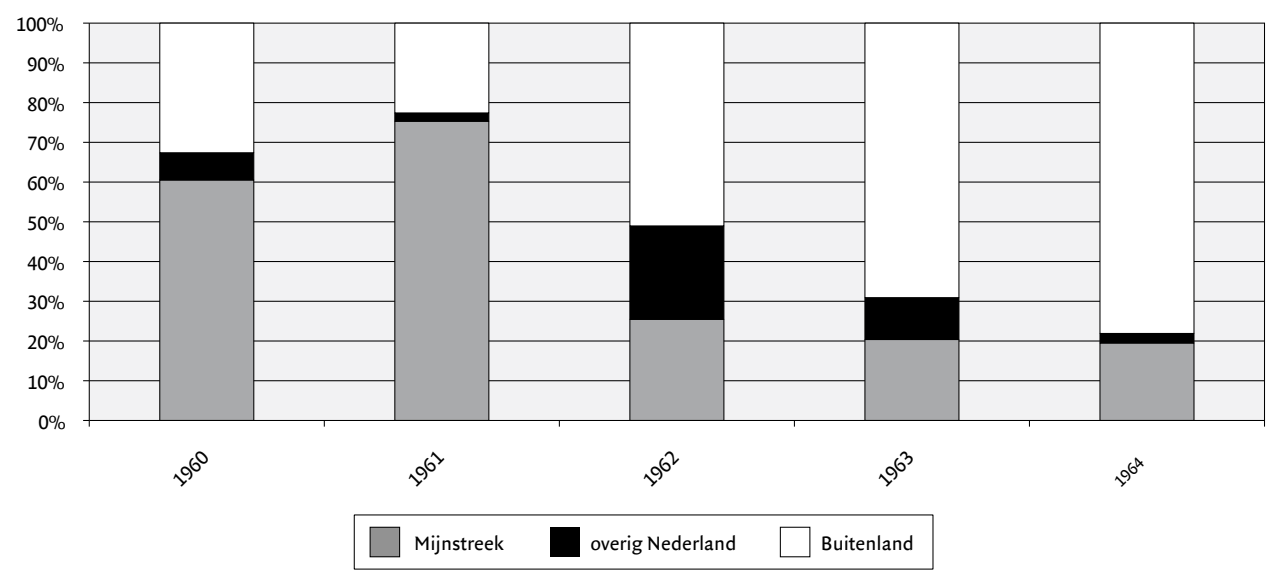

Bron: Verslag GSL aan MIR, [1960-1964].

ders. ${ }^{229}$ De jaren tot aan de aankondiging van de mijnsluitingen in december 1965 werden gekenmerkt door een sterke vertegenwoordiging van buitenlanders onder de indienstgenomen ondergronders. Vooral vanaf I 962 was de toename van nieuwkomers van buitenlandse herkomst groot. In 1964 was 80 procent van de nieuwe ondergronders buitenlander. Het cohort buitenlandse arbeiders dat tussen I96I en I965 in de Nederlandse mijnen arriveerde, bestond hoofdzakelijk uit Spanjaarden, Joegoslaven en Marokkanen (grafiek 5.I4), nadat pogingen om een nieuw contingent Italianen aan te trekken goeddeels waren mislukt.

Aanvankelijk was het de bedoeling de buitenlandse arbeiders alleen te werven in EEGlanden. Hiervan kwam uitsluitend Italië in aanmerking. ${ }^{230}$ Eind I96r besloten de mijnondernemingen opnieuw arbeiders in Italië te werven. Inmiddels was op 6 augustus ig6o een nieuwe wervingsovereenkomst tussen Nederland en Italië tot stand gekomen. Voor de mijnen had dit tot gevolg dat ze geen directe zeggenschap meer hadden in de selectie in Italië, maar slechts hun normen en eisen konden doorgeven aan de Nederlandse Selectie Commissie in Milaan die namens de Nederlandse overheid de selectie van de arbeidskrachten verzorgde. ${ }^{23}$ De mijnen vreesden dat de selectie problemen kon geven als ze er niet rechtstreeks bij betrokken zouden zijn, gezien de specifieke aard van de werkzaamheden in de mijn. De overheid kwam enigszins aan dit bezwaar van de mijnen (en andere werkgevers) tegemoet door een vertegenwoordiger van de bedrijfstak waar de geworven Italiaan zou worden tewerkgesteld, toe te laten in het wervingsbureau in Milaan. ${ }^{232}$

De mijnen spraken de voorkeur uit voor arbeiders uit Sardinië en vervolgens uit de provincie Abruzzen, dezelfde regio's waar men ook in de tweede helft van de jaren vijftig had

229 Messing, Geschiedenis van de mijnsluiting, 183.

230 RHCL, ArchiefOranje-Nassau Mijnen 17.05J, inv. nr. I2: Nota betreffende werving voor directies GSL ten behoeve van bespreking in de MIR, I9-IO-I962.

23I RHCL, ArchiefOranje-Nassau Mijnen I7.05J, inv. nr. I6: Briefvan de GSL aan de directies van de mijnondernemingen, 8-I2-I96I.

232 Tinnemans, Een gouden armband, 32. 
geworven. De eisen die aan de arbeidskrachten werden gesteld, bleven ongewijzigd: ongehuwd en een leeftijd tussen de I8 en 30 jaar. Vakbekwaamheid in het werk ondergronds was niet vereist, de mijnen zorgden voor de noodzakelijke opleiding. Conform het NederlandsItaliaanse wervingsverdrag kregen de Italianen een arbeidscontract voor één jaar, met de mogelijkheid van verlenging met hetzij één jaar, hetzij voor onbepaalde tijd. Aangedrongen werd op een strenge eerste keuring in Italië. ${ }^{233}$

De mijnen verwachtten 100 à 150 arbeiders per maand te kunnen aantrekken. In maart 1962 kreeg de GSL toestemming om in totaal 900 Italiaanse arbeiders te werven. De Italiaanse werving bleek echter onvoldoende arbeidskrachten op te leveren om de toenemende personeelstekorten op te vullen. In de februarizitting 1962 van het Europees Parlement werd al opgemerkt, dat Italië als gevolg van de snelle economische expansie in de nabije toekomst zou ophouden een leverancier van arbeidskrachten te zijn en men dus steeds meer een beroep zou moeten doen op arbeidskrachten van buiten de EEG. ${ }^{234}$ Bovendien was er grote concurrentie in Italië van vooral de Duitse en Belgische mijnen. Wat ook niet meehielp was het feit dat de Italianen de minimumleeftijd voor emigratie op 2I jaar stelden, in verband met het vervullen van de dienstplicht. ${ }^{235}$ In maart 1962 zette Rome bovendien de werving van mijnwerkers voor Nederland tijdelijk stop, omdat er geen gehuwde arbeiders werden geworven. ${ }^{236}$ Tot begin april 1963 konden de gezamenlijke mijnen in totaal slechts 238 Italianen werven. ${ }^{237}$ Daarna leverde de Italiaanse arbeidsmarkt nauwelijks nog arbeidskrachten op. In september 1963 oordeelde Staatsmijnen dat de wervingsmogelijkheden in Italië konden worden verwaarloosd. Wel verwachtte men nog iets van de werving in Spanje en Joegoslavië.. ${ }^{23}$

In april I96I tekenden Nederland en Spanje een wervingsovereenkomst naar het model van het Nederlands-Italiaanse akkoord van een jaar eerder. Pas in de zomer van 1962, toen duidelijk werd dat de werving in Italië ver achterbleef bij de verwachtingen, meldden de Nederlandse mijnen zich op de Spaanse arbeidsmarkt. Dat was rijkelijk laat. Door die late komst verkeerden de mijnen in een ongunstige positie. Duitse en Belgische mijnondernemingen waren er al sinds begin $196 \mathrm{r}$ actief en ook andere grote Nederlandse werkgevers rekruteerden al langer in Spanje. ${ }^{239}$ Dergelijke ondernemingen hadden dus al de nodige contacten op de Spaanse arbeidsmarkt opgebouwd.

De wervingsactie van de mijnen was aanvankelijk gericht op 750 arbeiders. In de loop van 1962 en 1963 kreeg de GSL toestemming het contingent tot 2.250 man te verhogen. ${ }^{240}$

233 RHCL, Archief Oranje-Nassau Mijnen 17.05J, inv. nr. I6: Brief van de GSL aan de Directeur-Generaal voor de Arbeidsvoorziening, 8-12-196r.

234 RHCL, Archief Oranje-Nassau Mijnen 17.05J, inv. nr. I2: Nota betreffende werving voor directies GSL ten behoeve van bespreking in de MIR, I9-IO-I962.

235 RHCL, Archief Oranje-Nassau Mijnen I7.05J, inv. nr. I6: Verslag besprekingen in Italië t.b.v. de wervingsactie in de priode 9-I5 februari I962, I6-2-I962.

236 RHCL, ArchiefOranje-Nassau Mijnen 17.05J, inv. nr. I6: Brief van de GSL aan de mijnbouwondernemingen, 19-3-1962.

237 SHCL, Archief Laura \& Vereeniging, inv. nr. 538: Nota van Staatsmijnen ten behoeve van de directies van de GSL betreffende tewerkstelling van buitenlanders, $\mathrm{I} 2-4-\mathrm{I}_{9} 63$.

238 RHCL, Centraal Archief DSM 17.26/o6C inv. nr. 48: Staatsmijnen in Limburg, Personeelsvoorziening ondergrondse bedrijven en de huisvesting van de geworven arbeiders, 6-9-1963.

239 SHCL, Archief Laura \& Vereeniging, inv. nr. 538: Verslag reis van A. Paulen naar Madrid, 8-6-1962. Zie ook: Geertje van Os, Ik kwam met een koffer van karton. Spanjaarden in Zuidoost-Brabant 1961-2006 (Alphen aan de Maas 2006) I2 e.v.; Marlou Schrover, Judith ten Broeke, Ronald Rommes, Migranten bij de Demka-staalfabrieken in Utrecht (1915-1983) (Utrecht 2008) 69-70; Van Elteren, Staal en arbeid, $823-828$.

240 RHCL, Archief Oranje-Nassau Mijnen 17.05J, inv. nr. I9: Brief van de GSL aan de Directeur-Generaal voor de Arbeidsvoorziening, 5-I-I963. 


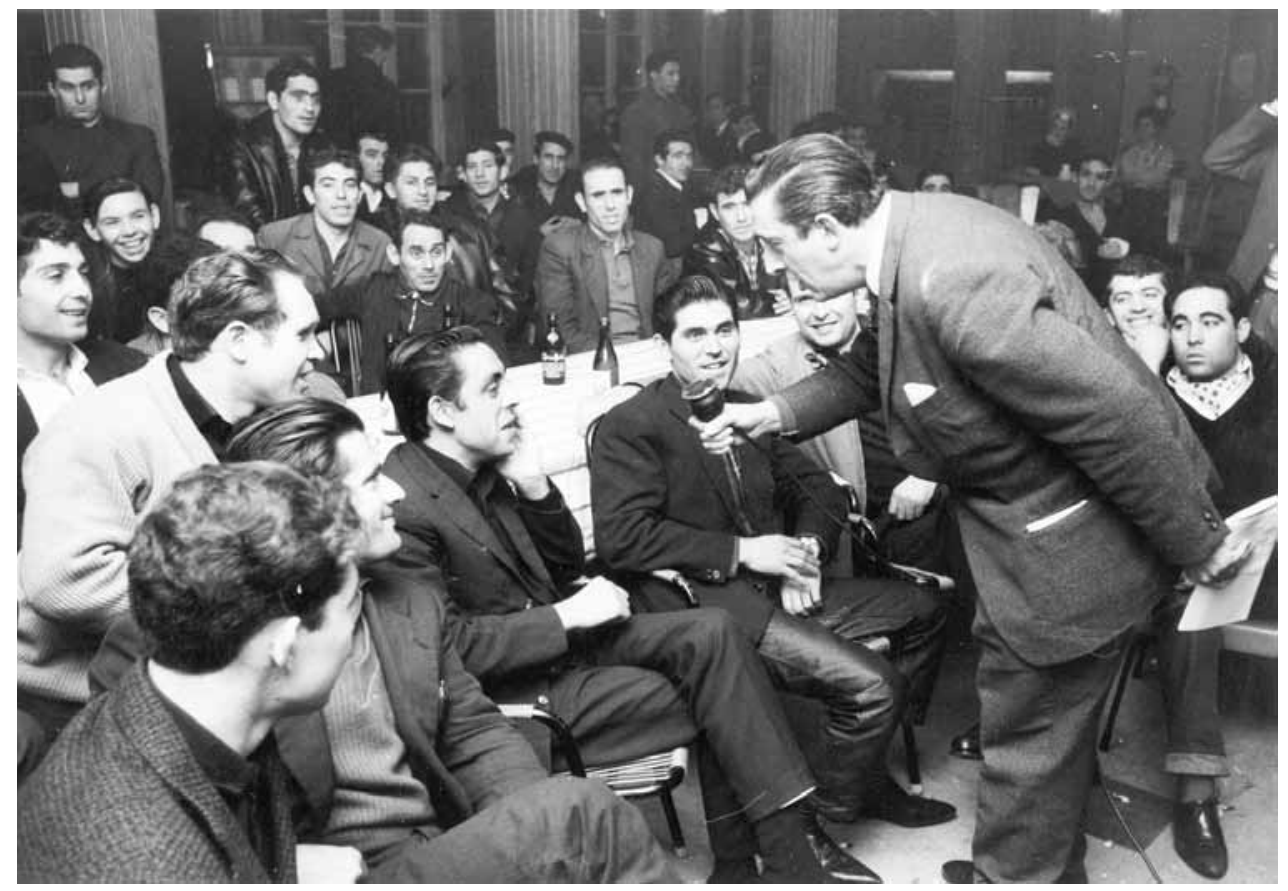

De Wereldomroep op bezoek in het gezellenhuis Eygelshoven. Spaanse mijnwerkers van de Laura en Julia mochten de groeten aan het thuisfront doen. 1963. Bron: Fotocollectie Continium Kerkrade, F4769.

Dat aantal werd lang niet gehaald. Tot begin april 1963 kwamen in totaal 835 Spanjaarden naar de Nederlandse mijnen. ${ }^{241}$ Precieze aantallen voor de volgende jaren zijn niet bekend, maar uit de jaarlijkse opgaven van de personeelsbezetting op 3I december van de Inspecteur-Generaal der Mijnen kan worden opgemaakt dat er tot eind ${ }_{19} 65$ hooguit enkele honderden per jaar zijn gerekruteerd. ${ }^{242}$ Het tegenvallende resultaat was mogelijk mede te wijten aan een incident in april I963. Staatsmijnen had toen circa 200 Spaanse mijnwerkers die in staking waren gegaan omdat de verzorging in de gezellenhuizen Leijenbroek (Sittard) en de Egge (Brunssum) volgens hen niet goed was, op staande voet ontslagen. ${ }^{243}$ Bemiddelingspogingen van onder meer de Spaanse viceconsul mislukten en uiteindelijk vertrokken naar aanleiding van het conflict 283 Spaanse mijnwerkers. Nieuw aangeworven Spanjaarden werden voorshands alleen bij de particuliere mijnen tewerkgesteld. ${ }^{244}$

Inmiddels was ook de werving van Joegoslaven ter hand genomen. Het plan daartoe stamde uit juni $1962 .{ }^{245}$ De GSL constateerde dat de werving in Italië zeer moeizaam verliep en de eerste resultaten van de opgezette wervingsactie in Spanje pas over enkele

24I SHCL, ArchiefLaura \& Vereeniging, inv. nr. 538: Nota van Staatsmijnen ten behoeve van de directies van de GSL betreffende tewerkstelling van buitenlanders, $12-4-1963$.

242 Zie bijlage 15.

243 SHCL, Archief Laura \& Vereeniging, inv. nr. 538: Nota van Staatsmijnen ten behoeve van de directies van de GSL betreffende tewerkstelling van buitenlanders, I2-4-1963. Hierin opgenomen een uitgebreide verslaglegging van de aanleiding, het verloop en de nasleep van de staking.

244 RHCL, Archief Oranje-Nassau Mijnen 17.05J, inv. nr. I9: Brief van de GSL aan de Directeur-Generaal voor de Arbeidsvoorziening, 10-4-1963.

245 RHCL, ArchiefOranje-Nassau Mijnen I7.05J, inv. nr. I2: Brief GSL aan Minister van Economische Zaken, 20-6-1962. 


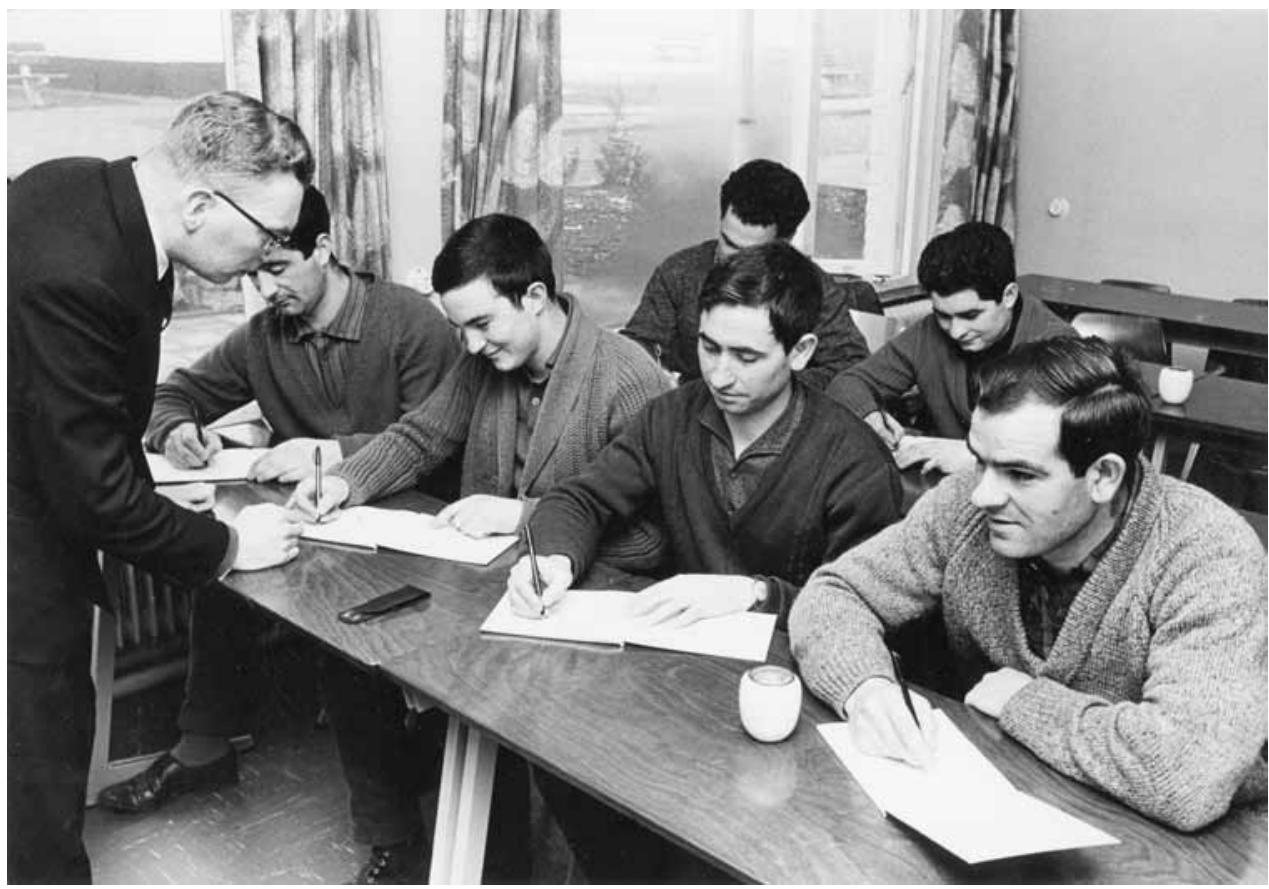

Spaanse mijnwerkers van de Laura en Julia krijgen Nederlandse les. 1964. Bron: Fotocollectie Continium Kerkrade, F4772.

maanden duidelijk zouden worden. Zo lang konden de mijnen niet wachten. Het personeelstekort werd geraamd op 2.700 man, waardoor de productiecapaciteit van de mijnondernemingen niet volledig kon worden benut. Het bleek echter mogelijk om op korte termijn in Joegoslavië te gaan werven. Joegoslavië was een aantrekkelijke optie voor de mijnen: er bestond een ruim aanbod en snelle wervingsmogelijkheden van veelal geschoolde mijnwerkers waren mogelijk. De arbeidskrachten konden worden geworven in Kroatië en waren afkomstig uit bauxietmijnen bij de plaatsen Drnis en Varazdin, die aan het eind van hun exploitatie waren gekomen. Bijkomend voordeel was dat de opleiding voor deze mijnen vrijwel dezelfde was als voor de Nederlandse steenkolenmijnen. ${ }^{246} \mathrm{Naar}$ verwachting konden de nieuwkomers in Nederland snel worden ingepast, vooral omdat er nog veel Joegoslaven van oudsher in de Nederlandse mijnbouw werkzaam waren. Voor de mijnen was verder van groot belang, dat de ondernemingen de selectie in Joegoslavië, in tegenstelling tot in Italië en Spanje, volledig in eigen hand hadden. ${ }^{247}$ Een wervingsteam bestaande uit een personeelsfunctionaris, een beambte van de mijnpolitie en een tolk nam in Zagreb de mijnwerkers aan. ${ }^{24}$ Een Joegoslavische arts verrichtte een eerste medische keuring. Bij de eerste wervingen moesten de mijnen nog de Joegoslavische overheidsin-

246 SHCL, Archief Laura \& Vereeniging, inv. nr. 538: Intern rapport Laura \& Vereeniging inzake aantrekking van Yougo-Slavische arbeiders, 26-5-1962.

247 RHCL, ArchiefOranje-Nassau Mijnen 17.05J, inv. nr. 12: Nota betreffende werving voor de directies van de mijnondernemingen ten behoeve van bespreking in de MIR, I9-I0-I962.

248 SHCL, Archief Laura \& Vereeniging, inv. nr. 538: Intern rapport Laura \& Vereeniging inzake aantrekking van Yougo-Slavische arbeiders, 26-5-1962. 
stanties benaderen, maar later mocht men rechtstreeks onderhandelingen voeren met vertegenwoordigers van de bauxietmijnen.

Omdat er geen wervingsverdrag tussen Nederland en Joegoslavië bestond, hadden de mijnen voor de uitvoer van hun plannen toestemming nodig van de Nederlandse regering. Die ging akkoord, al twijfelden sommige bewindslieden vanwege de vermeende communistische ideologie van de Joegoslavische arbeidskrachten. Uiteindelijk liet de ministerraad het belang van de mijnen om voldoende jonge houwers aan het kolenfront te kunnen plaatsen prevaleren. ${ }^{249}$ Daarnaast moesten de mijnen zelf de formaliteiten regelen met het Rijksarbeidsbureau voor de werkvergunningen, alsmede met de Rijksvreemdelingendienst en de Binnenlandse Veiligheidsdienst voor het vereiste antecedentenonderzoek. ${ }^{250}$

De GSL kreeg aanvankelijk toestemming voor de aanwerving van 200 geschoolde Joegoslaven. Het ministerie van Justitie bepaalde de algemene voorwaarden voor de komst naar Nederland. Degenen die zich voor mijnarbeid in Nederland aanmeldden, moesten in het bezit zijn van een Joegoslavisch paspoort, voorzien van een terugkeervisum dat nog minstens twee jaar geldig was. Wanneer een onderzoek naar de politieke en justitionele antecedenten niets belastends opleverde, kreeg de betrokkene een voorlopige verblijfsvergunning van de Nederlandse ambassade in Belgrado. Bij aankomst in Nederland was de plaatselijke politie gemachtigd een definitieve verblijfsvergunning voor de duur van het arbeidscontract te verlenen. ${ }^{251}$ Het arbeidscontract was voor de duur van twee jaar. De werkvergunning in Nederland was alleen geldig voor de mijnbouwsector. Aanvankelijk was de werving beperkt tot ongehuwde arbeidskrachten, maar toen bleek dat die voorwaarde de rekrutering belemmerde, ging het ministerie van Justitie akkoord met de werving van gehuwde Joegoslaven. ${ }^{252}$

In maart I963 was het toegestane contingent van 200 Joegoslaven bereikt. ${ }^{253}$ Aangezien de Nederlandse mijnen tevreden waren over de Joegoslavische mijnwerkers, vooral omdat het verloop onder deze groep arbeiders opmerkelijk gering was, ${ }^{254}$ werd in de loop van ${ }_{1} 963$ het contingent verhoogd tot in totaal I.ooo man. De komst van nieuwe Joegoslaven was van groot belang omdat de werving in andere landen vrijwel was beëindigd. ${ }^{255}$

Het zat de mijnen niet mee. De voortgang van de werving in Joegoslavië liep ernstige vertraging op, doordat de Joegoslavische regering bij decreet van 23 oktober 1963 besloot tot coördinatie van de werving van arbeidskrachten. Er werden inmiddels door diverse landen zoveel arbeiders aan Joegoslavië onttrokken dat de Joegoslavische regering van mening was, dat de buitenlandse wervingsploegen niet meer op de oude voet verder konden gaan. Pas nadat de Joegoslavische regering een volledig zicht op de eigen arbeidsmarkt en de behoefte aan arbeiders had verkregen, besliste zij verder over de werving van arbeidskrach-

\footnotetext{
249 Messing, Geschiedenis van de mijnsluiting, 184.

250 RHCL, ArchiefOranje-Nassau Mijnen 17.05J, inv. nr. I2: Brief GSL aan Minister van Economische Zaken, 20-6-1962.

25I RHCL, ArchiefOranje-Nassau Mijnen 17.05J, inv. nr. I2: Brief van de Minister van Justitie aan de GSL, 27-7-1962.

252 RHCL, ArchiefOranje-Nassau Mijnen 17.05J, inv. nr. I2: Brief van de Minister van Justitie aan de GSL, 27-8-1962.

253 SHCL, Archief Laura \& Vereeniging, inv. nr. 538: Nota van Staatsmijnen ten behoeve van de directies van de GSL betreffende tewerkstelling van buitenlanders, $12-4-1963$.

254 Messing, Geschiedenis van de mijnsluiting, 183.

255 RHCL, Archief Oranje-Nassau Mijnen 17.05J, inv. nr. I2: Brieven van de GSL aan de Directeur-Generaal voor de Arbeidsvoorziening, 2-8-1963; de Directeur-Generaal voor de Arbeidsvoorziening aan de GSL, 22-I0-1963 en van de Minister van Justitie aan de GSL, 22-I0-1963.
} 


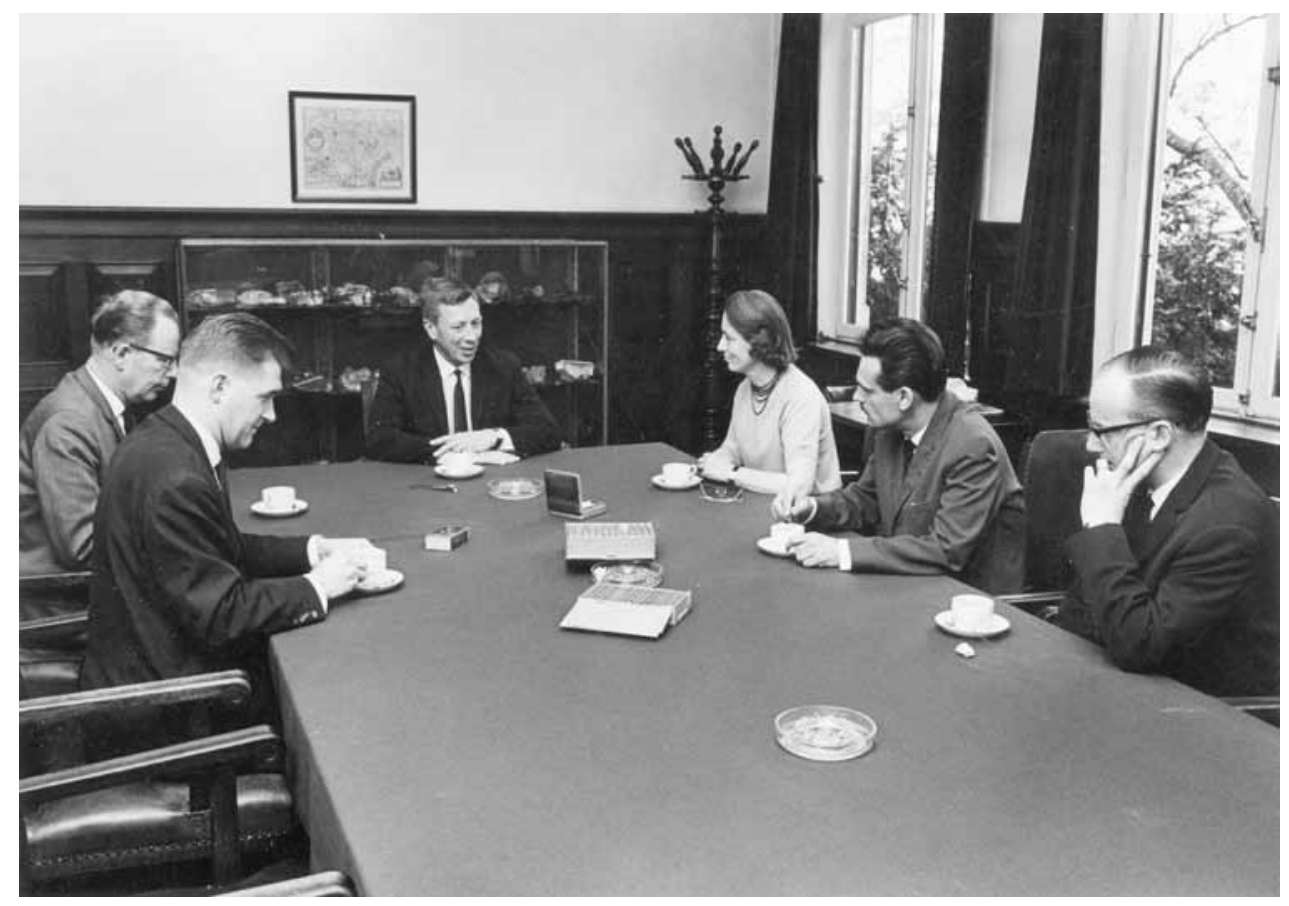

De directeur en een juriste van het arbeidsbureau in Zagreb ( $2^{e}$ en $3^{e}$ van rechts) op bezoek bij Laura \& Vereeniging. 1965. Bron: Fotocollectie Continium Kerkrade, F4779.

ten door buitenlandse wervingsteams. ${ }^{256}$ Bijna een half jaar lag de werving stil. Pas in maart I964 gingen de Joegoslavische autoriteiten akkoord met voortzetting van de werving op basis van een nieuwe overeenkomst met de GSL. Het akkoord kwam in grote lijnen overeen met de bepalingen die eerder met andere landen waren overeengekomen. Het was geldig tot I965 en kon daarna telkens voor een jaar worden verlengd. ${ }^{257}$ Het contingent aan te werven Joegoslaven was in de overeenkomst verhoogd tot 2.000 man. ${ }^{25} 8$

Het duurde nog tot oktober 1964 voordat de eerste groep van 77 Joegoslaven in Limburg arriveerde. De rest van dat jaar en in 1965 kwamen naar schatting nog 200 à 300 Joegoslaven bij de Nederlandse mijnen terecht. Nadat in 1966 de particuliere mijnen nog een aantal Joegoslaven hadden geworven, zegde de GSL per I-I-Ig68 het wervingscontract met het Centraal Arbeidsbureau in Zagreb op. ${ }^{259}$

In de loop van de jaren zestig nam het aantal buitenlanders dat zonder tussenkomst van een wervingscontract naar Nederland kwam toe. Deze spontane migranten kwamen als 'toerist' naar Nederland en zochten zelf, vaak via familie, vrienden of kennissen, werk. Als ze eenmaal een baan hadden, kregen ze meestal probleemloos een werk- en verblijfsvergunning. ${ }^{260}$ Spontane arbeidsmigranten hadden als grootste voordeel voor werkgevers

256 SHCL, Archief Nederlandse Katholieke Mijnwerkersbond, inv. nr. I332: Brief van de Commissie Werving aan de MIR, 16-7-1963.

257 RHCL, ArchiefOranje-Nassau Mijnen 17.05J, inv. nr. I2: Brief van SL aan het Centraal Arbeidsbureau in Zagreb, 30-10-1964.

258 RHCL, ArchiefOranje-Nassau Mijnen 17.05J, inv. nr. I2: Brief Centraal Arbeidsbureau Zagreb aan GSL, I8-3-1964.

259 RHCL, ArchiefOranje-Nassau Mijnen 17.05J, inv. nr. I2: Brief van GSL aan het Centraal Arbeidsbureau in Zagreb, 3-5-1967.

260 Jan Lucassen en Rinus Penninx, Nieuwkomers, nakomelingen, Nederlanders. Immigranten in Nederland 1500-1993 (Amsterdam 1999³) 80. 
dat ze onmiddellijk beschikbaar waren, terwijl op degenen die via de officiële wervingskanalen kwamen, soms maanden moest worden gewacht. ${ }^{26 r}$ Hoeveel Italianen, Spanjaarden of Joegoslaven buiten de officiële kanalen om bij de Limburgse mijnen zijn beland, is niet bekend. De spontane arbeidsmigranten naar de mijnen waren met zekerheid in overgrote meerderheid Marokkanen.

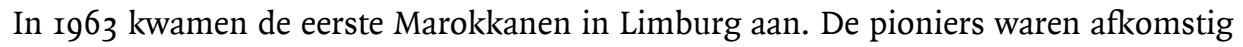
uit kolenbekkens in België en Noord-Frankrijk, waar mijnen sloten. Bovendien gingen er geruchten dat de lonen in de Nederlandse mijnen hoger waren, de werkomstandigheden beter en de leefomstandigheden in de gezellenhuizen aangenamer. ${ }^{262}$ Via het mechanisme van kettingmigratie volgden anderen, ook rechtstreeks uit Marokko. ${ }^{2{ }_{3}} \mathrm{Al}$ snel werden Marokkanen die reeds in dienst waren door de mijnen aangespoord om kennissen en familie in Marokko, België en Frankrijk te werven. De mijnen gaven er zelfs een premie voor. Dat leverde zoveel reacties op, dat mijnondernemingen die aansporingen moesten matigen. H. Moritz, destijds werkzaam bij de personeelsdienst van Laura \& Vereeniging herinnerde zich: 'Aan familieleden en kennissen die in België of Noord-Frankrijk verbleven, schreven zij [de Marokkanen die al bij het bedrijf in dienst waren, SL] over de mogelijkheden die hier waren. Het is menigmaal gebeurd dat's morgens als we op het kantoor van de personeelsdienst arriveerden 20 tot 30 Marokkanen zaten te wachten die om werk ondergronds kwamen vragen. Een en ander nam zo'n extreme vormen aan dat we de Marokkanen met klem moesten verzoeken geen familieleden of kennissen in België of Frankrijk meer te animeren'. ${ }^{264}$ De mijn Willem-Sophia liet in verschillende Franse kranten advertenties plaatsen, waarin mijnwerkers werden opgeroepen om in Limburg te komen werken. De reis naar Limburg werd door de mijn vergoed, huisvesting werd gegarandeerd en de arbeidsvoorwaarden waren krachtens MIR-verordening gelijk aan die van de Nederlandse mijnwerkers. De eerste groepen Marokkanen kwamen terecht bij de Oranje-Nassau Mijnen, Laura \& Vereeniging en de Willem-Sophia. Het Staatsmijnbedrijf, dat voorkeur had om arbeidsmigranten via de officiële wervingskanalen te rekruteren, nam pas in de loop van 1964 , toen bleek dat de werving in Joegoslavië te weinig resultaten opleverde, Marokkanen aan. ${ }^{265}$

Door hun ervaring als mijnwerker werden de Marokkanen doorgaans graag door de mijnen in dienst genomen. Bij Laura \& Vereeniging bleken ze zelfs heel vaak de bij het bedrijf toegepaste afbouwmethode via mechanische kolenwinning volledig te beheersen. ${ }^{266}$ De uitvoerige introductie in het ondergrondse werk die als regel werd gegeven aan nieuwkomers uit andere landen, was daarom voor veel Marokkanen niet nodig. De communicatie binnen het bedrijf was op te lossen door de inschakeling van Franssprekende personeelsleden. Bij Laura \& Vereeniging hanteerde men de volgende selectiecriteria voor de Marokkanen die zich aanmeldden: goed Frans kunnen spreken, minstens vier jaar lager onderwijs, minstens een jaar ondergrondse mijnervaring, leeftijd 2I tot 25 jaar en medische geschiktheid

\footnotetext{
26I Tinnemans, Een gouden armband, 64-69.

262 Tanja Cranssen, "Sjöppe, sjöppe!" Marokkaanse mijnwerkers in de Nederlandse steenkolenmijnen 1963-1975 (doctoraalscriptie, Leiden z.j.) r6. Een bewerking van de scriptie verscheen onder de titel 'Marokkaanse mijnwerkers in Limburg, I963-I975', SSEGL XLVIII (2003) I2I-I 48.

263 Annemarie Cottaar, Nadia Bouras m.m.v. Fatiha Laouikili, Marokkanen in Nederland. De pioniers vertellen (Amsterdam 2009) 77-89.

264 H. Moritz, Marokkaanse gastarbeiders bij de mijnen Laura en Julia (scriptie Sociale Akademie, Sittard z.j.) I5.

265 Cranssen, "Sjöppe, sjöppe", 20-22.

266 Moritz, Marokkaanse gastarbeiders, 9-Io.
} 


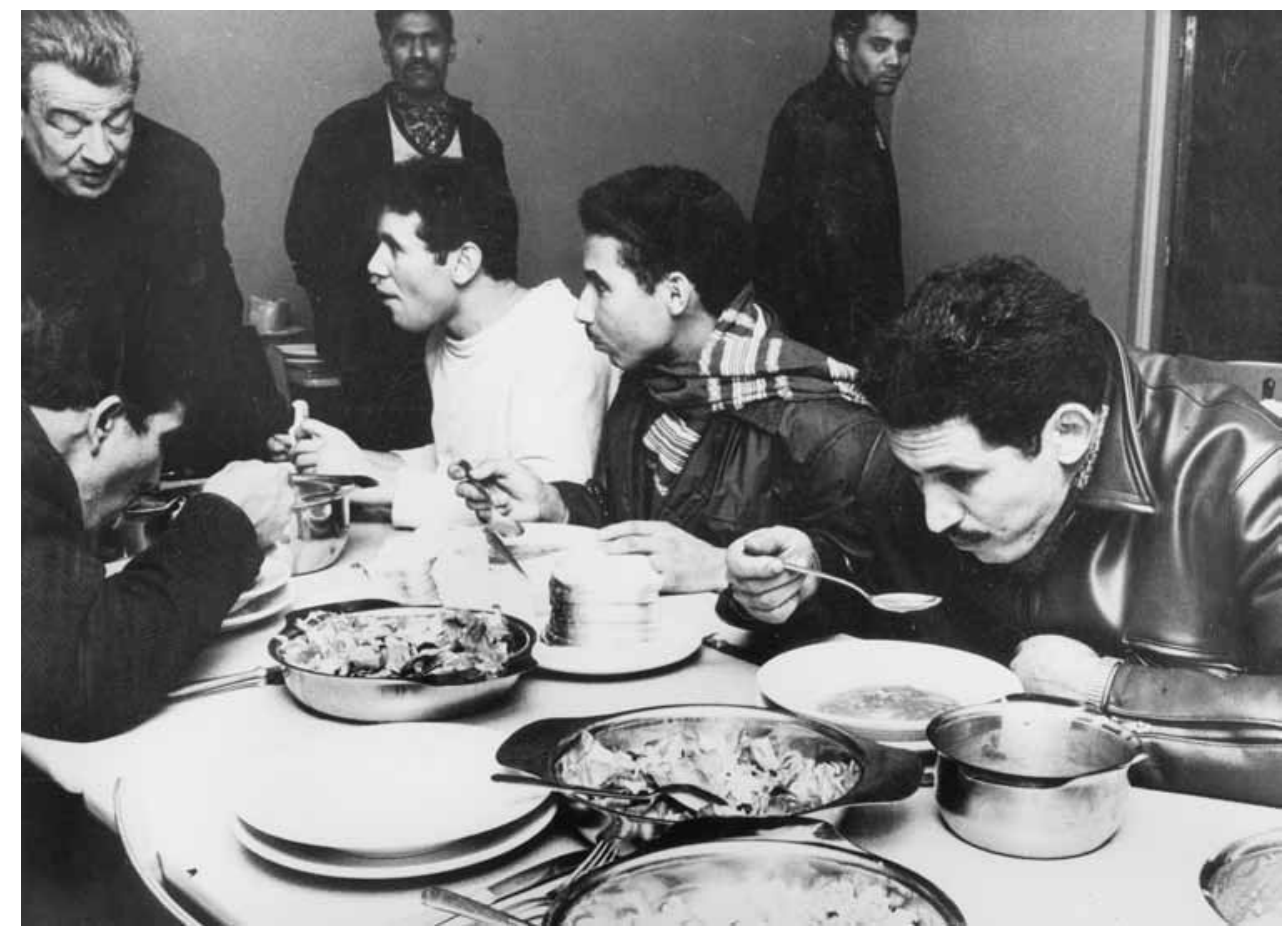

Marokkaanse mijnwerkers aan de maaltijd in het gezellenhuis. Omstreeks 1965. Bron: Fotocollectie Continium Kerkrade.

voor ondergrondse mijnarbeid. Het arbeidscontract werd aangegaan voor een jaar. Bij gebleken geschiktheid werd de overeenkomst met nog eens een jaar verlengd. Na dat tweede jaar volgde een verlenging voor onbepaalde tijd. ${ }^{267}$

Volgens schatting van Tanja Cranssen namen de gezamenlijke Limburgse mijnen in de jaren ${ }^{9} 963$ tot en met I 965 tussen de 3.000 en 4.000 Marokkanen aan. ${ }^{268}$ Het verloop onder hen was aanzienlijk. Voor de Marokkaanse arbeidskrachten bij Laura \& Vereeniging rekende Moritz uit dat 45 procent binnen een jaar vertrok. ${ }^{269} \mathrm{Op} 3$ I december 1965 hadden de gezamenlijke mijnen nog r.607 Marokkanen in dienst. Dit was met een aandeel van 28 procent de grootste groep in de buitenlandse personeelsbezetting. Van hen werkte 85 procent ondergronds. ${ }^{270}$

\section{BESLUIT}

Buitenlandse arbeiders behoorden tot de minst preferente groepen in het rekruteringsbeleid van de Nederlandse mijnondernemingen. De buitenlanders vormden het segment op

267 Ibidem, 20-2I.

268 Cranssen, "Sjöppe, sjöppe", 39-4I.

269 Moritz, Marokkaanse gastarbeiders, 50-5I.

270 Zie de bijlagen 15 en 16. 
de arbeidsmarkt dat tijdelijke discrepanties tussen vraag en aanbod moest opvangen. De mijnen streefden naar de vorming van een stabiele personeelsbezetting, bestaande uit arbeiders die een baan als mijnwerker zouden gaan beschouwen als een permanente betrekking. Die arbeidskrachten probeerde men in eerste instantie te vinden op de regionale en nationale arbeidsmarkt. In die opzet slaagde het Staatsmijnbedrijf beter dan de particuliere mijnbouwondernemingen. Echter, er waren vrijwel voortdurend spanningen tussen vraag en aanbod op de regionale arbeidsmarkt voor mijnwerkers. De tekorten traden vooral op in het ondergrondse bedrijf. In de hele onderzochte periode kwamen buitenlandse arbeidskrachten vooral in dat gedeelte van de mijnondernemingen terecht. Vóór de economische crisis van de jaren dertig waren de discrepanties op de arbeidsmarkt vooral van kwalitatieve aard. Er waren grote tekorten aan ervaren ondergronders. Die tekorten verklaren de absolute en relatieve stijging van het aantal buitenlandse ondergronders in de opbouwfase van de Nederlandse mijnen. De grootste groep onder de niet-Nederlanders werd in die periode gevormd door Duitse mijnwerkers, die zich in de meeste gevallen spontaan bij de Limburgse mijnen aanmeldden.

Buitenlandse mijnwerkers speelden in het tijdvak voor de crisisjaren een belangrijke rol bij de praktijkopleiding van Nederlandse ondergronders. Aan het eind van de jaren twintig hadden de mijnbouwondernemingen op die manier een kern van vakbekwame Nederlandse ondergronders kunnen opbouwen. Bovendien hadden de toegenomen mechanisatie en rationalisatie aan het kolenfront ertoe geleid dat de opleiding van nieuwe mijnwerkers niet meer op de werkplek kon gebeuren. De scholing tot ondergronder werd geïnstitutionaliseerd. De rol van de ervaren buitenlandse houwer als opleider raakte daarmee uitgespeeld. Bij de noodzakelijk inkrimping van het personeelsbestand tijdens de crisisjaren konden de mijnen zich daardoor permitteren de autochtone arbeiders, de meest preferente groep, zo veel mogelijk te ontzien. Het waren buitenlanders die massaal werden ontslagen. Alleen een vrij kleine groep van ervaren buitenlandse arbeidskrachten met een lang dienstverband en een gezin in de mijnstreek, ontsprong de dans. Zij werden gezien als onderdeel van de vaste kern van mijnwerkers.

Voor vakbekwaamheid waren de Nederlandse mijnen na de oorlog veel minder van buitenlandse mijnwerkers afhankelijk geworden. De vaste kern van geschoolde Nederlandse ondergronders werd in de jaren vijftig en zestig geconsolideerd door de verdere uitbouw van het systeem van bedrijfsinterne opleidingen, waarvoor met redelijk succes jonge arbeiders uit de regio werden aangeworven. Dit verklaart voor een belangrijk deel het lage percentage buitenlandse ondergronders in vergelijking met de periode vóór I930. Bij nieuwe aanwervingen van buitenlanders ging het in de naoorlogse jaren voornamelijk om ongeschoolde arbeiders die gerekruteerd werden in mediterrane landen. Zij werden beschouwd als tijdelijke arbeidskrachten, als gastarbeiders.

Meer dan ooit tevoren probeerde de overheid in de naoorlogse periode de komst van buitenlandse arbeidskrachten te reguleren. De bestaande vreemdelingenwetgeving werd echter zeer soepel toegepast. ${ }^{271}$ Door het belang van de kolenproductie voor de Nederlandse economie werd altijd ruimhartig medewerking verleend aan verzoeken van de mijnonder-

27I Zie ook: Leo Lucassen, 'Agent of koopman? Theorie en praktijk van de controle op arbeidsmigratie in Nederland, I918-1980', in: Marjolein 't Hart, Jan Lucassen en Henk Schmal (ed.), Nieuwe Nederlanders. Vestiging van migranten door de eeuwen heen (Amsterdam I996) I5I-I68, aldaar I6I. 
nemingen om arbeidsmigranten uit het buitenland aan te trekken. De wervingscampagnes in het buitenland waren echter omslachtig en duur. Bovendien was ook de inschakeling in het bedrijf van de buitenlandse arbeidskrachten door de communicatie en de opleiding niet zonder moeilijkheden. Om die redenen werd een te groot percentage buitenlanders onwenselijk geacht voor de bedrijfseconomische gang van zaken. ${ }^{272}$ Pas wanneer er ernstige personeelstekorten waren, gingen de mijndirecties over tot werving in het buitenland. Die tekorten traden op naarmate de werkgelegenheid in andere sectoren groeide en Nederlanders geneigd waren een baan buiten de mijn te prefereren. Dat gebeurde vooral nadat de kolencrisis van de jaren I958-I96o duidelijk had gemaakt dat de dagen van de Nederlandse steenkolenwinning waren geteld. De wervingsacties in het buitenland verliepen echter steeds moeizamer. Omdat buitenlandse mijnondernemingen en andere Nederlandse werkgevers ook in mediterrane landen wierven, was de concurrentie groot. In I964 was de Europese arbeidsreserve nagenoeg uitgeput. De mijnen slaagden er vaak niet in de in principe toegestane aantallen arbeidskrachten daadwerkelijk te werven. Dat tegenvallende resultaat werd voor een belangrijk deel gecompenseerd door Marokkaanse arbeidsmigranten, die zich buiten de officiële werving om spontaan bij de Nederlandse mijnen aanmeldden.

Vergeleken met aangrenzende mijngebieden bleef in de laatste jaren van de Nederlandse mijnen de inzet van arbeidsmigranten uit het buitenland beperkt. Toch speelden ze een belangrijke rol. De veelal jonge houwers uit het buitenland zorgden ervoor dat de mijnen lang genoeg open konden blijven zodat veel oudere Nederlandse arbeiders hun pensioengerechtigde leeftijd als mijnwerker konden halen. 


\section{Hoofdstuk 6 \\ Binding aan de mijn}

In de vorige hoofdstukken werd duidelijk dat de mijnen in hun arbeidsvoorzieningsbeleid een hiërarchie van preferente groepen hanteerden. Mijnstrekers, overige Limburgers, overige Nederlanders en buitenlanders, dat was de volgorde van voorkeur. De nieuwkomers dienden niet alleen te worden geïnteresseerd voor arbeid in de Nederlandse mijnen, eenmaal geworven moesten ze worden ingepast binnen een specifieke arbeidssituatie, die niet voor iedereen even bekend was. In dit hoofdstuk komt aan de orde in hoeverre deze preferentievolgorde bepalend was voor het succes van de inpassing in het bedrijf. Het proces van inpassing en - van de nieuwkomers uit bezien - aanpassing, is door Van Elteren omschreven als 'industriële accommodatie'. ${ }^{\mathrm{I}}$ Doel van het accommodatieproces is het opbouwen van een vaste kern van arbeiders, die zich gebonden voelt aan het bedrijf. Door vooral moeilijk vervangbare krachten aan het bedrijf te binden, wordt de afhankelijkheid van de arbeidsmarkt verminderd. ${ }^{2}$ In het mijnbedrijf kwam dit streven tot uiting in de 'vaste-stampolitiek' van de ondernemingen. Onderzocht wordt welke beleidsinstrumenten de Nederlandse mijnbedrijven gebruikten om het ideaal van een stabiele kern van mijnwerkers te bereiken en in hoeverre de ondernemers in deze opzet slaagden. Van Hoof spreekt in dit verband van bindingsstrategieën, een pakket van beleidsinstrumenten op basis van specifieke hulpbronnen die actoren op de arbeidsmarkt ter beschikking staan. ${ }^{3}$ Die hulpbronnen kunnen worden beschouwd als het potentieel aan marktmacht dat op de arbeidsmarkt kan worden gemobiliseerd in het streven een zo gunstig mogelijk resultaat te bereiken. In het geval van de mijnondernemingen was dat de opbouw van een stabiele kern van arbeidskrachten. In het geheel van hulpbronnen spelen de zogenaamde lokmiddelen een grote rol. Hiermee worden de materiële en immateriële beloningen bedoeld die verbonden waren met het arbeidscontract. Te denken valt aan de hoogte van het loon en eventuele andere salarisbestanddelen, sociale voorzieningen, werkzekerheid, de mogelijkheid een opleiding te volgen en de aanwezigheid van (bedrijfs)huisvesting. Ook het aantrekkelijker maken van de arbeidsomstandigheden hoort bij deze categorie van hulpbronnen.

Het beleid van de mijnondernemingen kwam tot stand binnen de context van nauwelijks te beïnvloeden algemene economische, sociale en culturele omstandigheden. ${ }^{4}$ Van grote invloed was de algemene situatie op de arbeidsmarkt. In het voorgaande kwam al ter sprake dat de mijnondernemingen door de aard van de ondergrondse arbeid in een ongun-

\footnotetext{
I Van Elteren, Staal en arbeid.

2 A.W.F. Corpeleijn, 'Arbeidsmobiliteit en werkgelegenheidsstructuur. Oorzaken van sectorale verschillen in personeelsverloop', Economisch Statistische Berichten LXV nummer 3239 (23-I-I980) 88-92, aldaar 89.

3 Van Hoof, Arbeidsmarkt, I9o-I99.

4 Uiteraard gold dat ook voor andere ondernemingen, die voor de zelfde opgave stonden. Van Elteren, Staal en arbeid Ir.
} 
stige concurrentiepositie verkeerden. Die ongunstige positie was van invloed op het succes van de werving, maar ook op het verloop en daarmee dus ook op het succes van de binding aan het bedrijf. Kreukels kwam voor de periode tot I940 tot de conclusie dat de vraag naar arbeid in andere bedrijven in belangrijke mate bepalend was voor het personeelsverloop in de mijnbouwsector. ${ }^{5} \mathrm{Na}$ de Tweede Wereldoorlog was het niet anders. Zodra elders alternatieven beschikbaar kwamen met ongeveer gelijke arbeidsvoorwaarden nam het verloop toe. ${ }^{6}$ De bindingsstrategie van de mijnondernemingen kwam hier in conflict met een autonomiestrategie van arbeidskrachten, die door arbeidsmobiliteit hun onafhankelijkheid van het mijnbedrijf demonstreerden. ${ }^{7}$ In buitenlandse mijnbouwdistricten is hetzelfde verschijnsel geconstateerd. ${ }^{8}$

Daarnaast speelde een rol wat Segers in navolging van de Duitse sociologen B. Lutz en F. Weltz noemt de waarneming van de arbeidsvoorwaarden..$^{9}$ Vooral voor nieuwkomers in de mijnbouw speelde dit een voorname rol, omdat het werk, de werkomstandigheden en aspecten van de arbeidsvoorwaarden, zoals het voor buitenstaanders ondoorzichtige akkoordstelsel bij de loonberekening, in het ondergrondse bedrijf grotendeels buiten de waarnemingssfeer lagen. Pas wanneer men ondergronds ging, werd men direct geconfronteerd met de fysieke arbeidsomstandigheden en met een loonberekening die soms teleurstellend kon uitvallen. Dat het meeste verloop plaatsvond in de eerste maanden van het dienstverband illustreert de grote aanpassingsmoeilijkheden aan de onbekende omstandigheden ondergronds. Het was daarom van belang dat bij de werving en selectie van nieuwe arbeidskrachten goede informatie werd verstrekt over het werk in de mijn, dat de kandidaten gekeurd werden op fysieke en psychische geschiktheid voor het ondergrondse werk en er een degelijke introductie in het bedrijf plaatsvond. ${ }^{\text {1o }}$

Uiteraard konden ook individuele factoren een rol spelen bij het succes dat de mijnen hadden om arbeiders aan het bedrijf te binden. Persoonlijke karakterkenmerken van mijnwerkers waren bepalend voor de wijze waarop de aanpassing aan de nieuwe werkomgeving, en soms ook woonomgeving, gestalte kon krijgen. ${ }^{\text {II }}$ Dit individuele niveau van aanpassing blijft verder buiten beschouwing.

Het verloop onder de mijnwerkers kan dienen als indicator voor de mate van binding aan het bedrijf. Immers: hoe geringer de geneigdheid van mijnwerkers om hun baan op te zeggen, hoe groter de stabiliteit van de personeelsbezetting. Onder verloop wordt hier, in navolging van de definitie van de mijnondernemingen zelf, verstaan de verbreking van de band tussen het bedrijf en een aantal werknemers in een bepaald tijdvak. ${ }^{12}$ Een deel van het verloop was onvermijdelijk. Elk jaar verliet een aantal arbeidskrachten de mijn tengevolge van zogenaamd natuurlijk verloop: pensionering, medische ongeschiktheid of overlijden. Een ander deel van het verloop zoals dat uit de cijfers van de mijnen blijkt, was louter administratief. Zo werden arbeidskrachten die bevorderd werden tot beambte, officieel als ar-

5 Kreukels, Mijnarbeid, 66-67.

6 Bardoul, Personeelsverloop, 22.

7 Van Hoof, Arbeidsmarkt, I98.

8 Knotter, 'Inleiding', 16.

9 J.H.G. Segers, Het personeelsverloop in het ondergronds mijnbedriff. Methoden en resultaten (Heerlen I968) 8-9.

Io Van Elteren, Staal en arbeid, 9. Specifiek voor het mijnbedrijf zie: Bardoul, Personeelsverloop, 23-24.

II Segers, Personeelsverloop, 6-II; Zie ook: Reumkens, Onderzoek, 3.

12 Zie bijvoorbeeld: RHCL, Centraal Archief DSM 17.26/o6C, inv. nr. 48: Rapport betreffende personeelsvoorziening Staatsmijnen I954, bijlage verloop mijnbedrijven ondergronds, I930-I954. 
Grafiek 6.i De REDENEN VAN UitTreding Uit Het AlgEMEen MijnWERKersFONDS, I920-I960 (ALS PERCENTAGE VAN HET TOTALE AANTAL UITTREDERS)

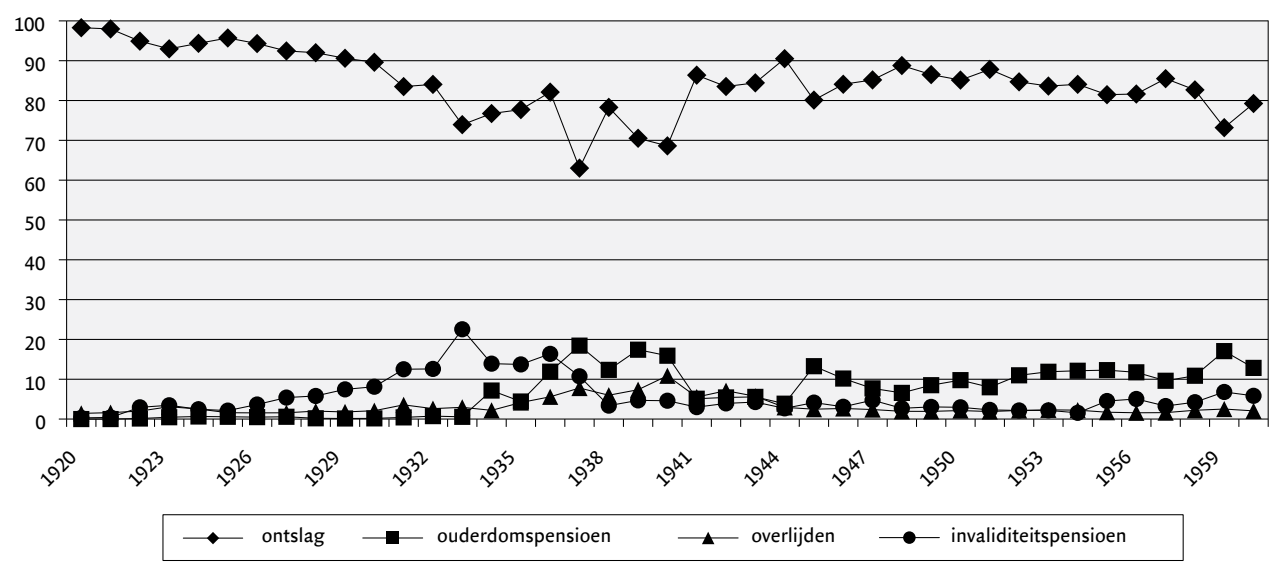

Bron: Jaarverslagen AMF, 1920-1960.

beider ontslagen en daarna weer als beambte aangesteld. Ook overplaatsingen binnen het bedrijf werden soms in de verloopcijfers opgenomen. De categorie verloop waarbij het in het kader van de binding aan het bedrijf om gaat, betreft de ontslagen. Idealiter zou er een onderscheid gemaakt moeten worden tussen gedwongen verloop (ontslag door het bedrijf) en spontaan verloop (ontslag op eigen verzoek door de werknemer). ${ }^{13}$ Het spontane verloop geeft een zuiverder beeld van de mate van binding aan het mijnbedrijf, omdat bij vrijwillig ontslag de werknemer kennelijk niet in het bedrijf vond wat hij ervan verwachtte. ${ }^{\text {I4 }}$

Helaas is deze differentiatie op basis van de beschikbare cijfers niet voor de hele periode te maken. Uit gegevens van omstreeks I96o blijkt dat ruim 75 procent van het ontslag bestond uit vrijwillig vertrek. Het andere kwart was ontslag door het bedrijf of wegens contractbreuk van in het buitenland geworven arbeidskrachten. ${ }^{15} \mathrm{Wel}$ is voor de hele periode duidelijk dat het totale 'ontslag' (gedwongen plus spontaan) steeds met afstand de belangrijkste categorie vertrekkers uit het mijnbedrijf vormde (grafiek 6.I).

Niet alle verloop was ongewenst. Een zekere mate van verloop was in het belang van de mijnbedrijven. Verloop kon zorgen voor het in stand houden van een goede leeftijdspiramide in het bedrijf. Daarnaast maakten fluctuaties in de werkgelegenheid voor mijnwerkers als gevolg van de conjuncturele ontwikkeling naast een stabiele kern van mijnwerkers ook een vlottend segment onder het personeel wenselijk, waarmee die schommelingen konden worden opgevangen. Een harde kern van mijnwerkers kon op die manier in dienst worden gehouden, hetgeen de stabiliteit van het mijnwerkersbestand op lange termijn bevorderde. 


\section{HET VERLOOP}

In de jaren vijftig en zestig verscheen een aantal onderzoeken naar de achtergronden van het personeelsverloop in de Nederlandse mijnen. In deze studies werden twee methodes gebruikt om het verloop te kwantificeren. ${ }^{16}$ Diezelfde methodes zullen hier worden gebruikt om de ontwikkeling van het verloop over een langere periode inzichtelijk te maken.

$\mathrm{Bij}$ de eerste en meest gangbare methode wordt als kengetal voor het verloop aangegeven het aantal uitgetredenen in een bepaald tijdvak (bijvoorbeeld gedurende een jaar), uitgedrukt als percentage van de gemiddelde personeelsbezetting in dat tijdvak. Het percentage geeft aan welk gedeelte van het personeel elk jaar moest worden vervangen. ${ }^{17}$

$\mathrm{Bij}$ de tweede methode wordt een groep nieuwe intreders gevolgd en wordt genoteerd op welk moment ze het bedrijf verlaten. Op bepaalde momenten (bijvoorbeeld na een jaar) kan vervolgens worden nagegaan welk percentage van het cohort intreders dat wordt gevolgd, nog in dienst is. Dat percentage wordt vaak aangeduid als het overlevingspercentage. Deze tweede methode heeft het voordeel dat kan worden nagegaan op welk moment in de carrière van een werknemer het verloop plaatsvond. Een bijkomend voordeel in de casus van de Nederlandse mijnbouw is dat deze methode het mogelijk maakt, op basis van de steekproef uit het ledenbestand van het AMF (zie bijlage 8), te differentiëren naar nationaliteit en geboorteplaats van de betrokkenen. De methode van berekening van de overlevingspercentages geeft de duur van het dienstverband aan en zegt daarmee iets over de stabiliteit van het in een bepaalde periode aangetrokken personeelscohort.

In grafiek 6.2 wordt voor de periode I9II-I965 het jaarlijkse vertrek van arbeidskrachten uit de mijnen getoond. De grafiek is samengesteld aan de hand van verschillende gegevens. De eerste reeks komt uit het proefschrift van Kreukels, waarin de auteur op basis van de jaarverslagen van Staatsmijnen en opgaven van de particuliere mijnen aan de Vereeniging tot Behartiging van de Belangen der Limburgsche Mijnindustrie tabellen presenteert over het verloop in de jaren I9II-I939. ${ }^{18}$ Die cijfers betreffen alle vertrek, dus ook het onderlinge verloop tussen de mijnondernemingen. ${ }^{19}$

Een tweede reeks van gegevens over het verloop is afkomstig uit de jaarverslagen van het Algemeen Mijnwerkersfonds (AMF) en beslaat de periode I9I9-I960. Deze cijfers zijn lager dan die van Kreukels, omdat het verloop tussen de Limburgse mijnen buiten beschouwing blijft. Wie naar een andere Limburgse mijn overstapte, bleef lid van het AMF en werd dus niet uitgeschreven. Pas wanneer men de mijnbouwsector verliet, volgde uitschrijving uit de AMF-administratie.

Ook de cijfers uit de derde reeks - van de Gezamenlijke Steenkolenmijnen in Limburg (GSL) over de jaren I955-1965 - verstaan onder uittreding het verlaten van de mijnbouwsector. Ook hier blijft het verloop tussen de mijnen buiten beschouwing. Niettemin kon dit - vooral in de periode van opbouw van de Limburgse mijnindustrie - aanzienlijk zijn, zoals uit een meer gedetailleerde analyse hieronder nog zal blijken.

I6 Zie voor deze methodes in studies over het personeelsverloop in de Nederlandse mijnen vooral: Segers, Personeelsverloop; Reumkens, Onderzoek.

17 Deze methode om het verloop te bepalen werd ook gebruikt in: P.W.N.M. Dehing, '... Eene soort dynastie van spoorwegbeambten.' Arbeidsmarkt en spoorwegen in Nederland 1875-1914 (Hilversum 1989) 86-87; zie ook: Corpeleijn, 'Arbeidsmobiliteit', 89-9o.

I8 Kreukels, Mijnarbeid, 68-69 (tabellen ig en 20).

19 SHCL, ArchiefGSL, Statistische gegevens betreffende verloop en verzuim van het arbeidspersoneel [1915-I937]. 
GrafiEK 6.2 JAARLIJKS VERTROKKEN ARbEIDERS, AbSOLUUT EN ALS PERCENTAGE VAN DE GEMIDDELDE ARbEIDERSBEZETTING BIJ DE GEZAMENLIJKE NEDER-

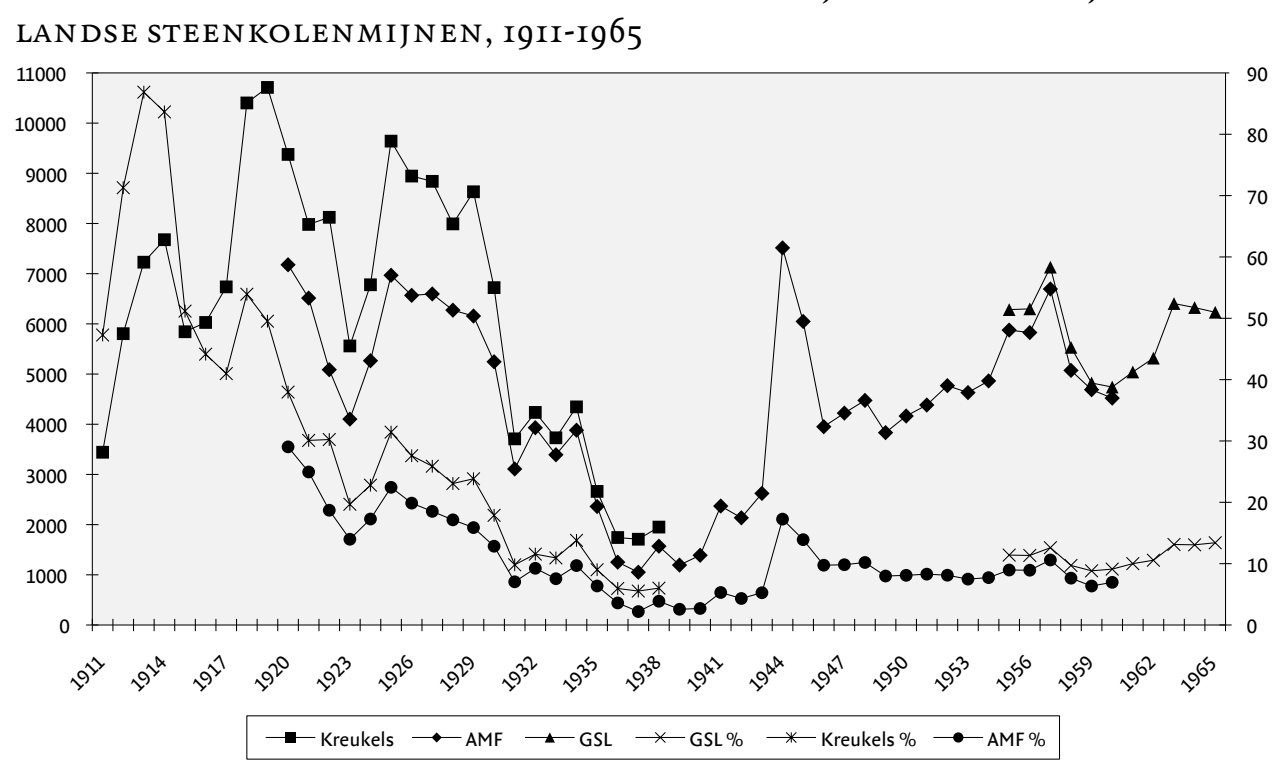

Bron: I9II-I939: Kreukels, Mijnarbeid, 68-69; I920-I960: Jaarverslagen AMF, 1920-1960; I955-I965: Verslagen GSL aan MIR, 1955 -1965.

Grafiek 6.2 geeft aanleiding tot een aantal conclusies. De eerste is dat het jaarlijkse verloop grote schommelingen in de tijd vertoonde. Het verloop was in het algemeen het grootst in de periode van opbouw van de Limburgse mijnbouw, dus tot ongeveer 1930. Jaarlijks verlieten gemiddeld ruim 8.000 arbeiders de mijnbouwondernemingen, maar er waren grote uitschieters. Vooral in de jaren voor de Eerste Wereldoorlog nam het verloop massale vormen aan. Zo moesten de gezamenlijke mijnen in I9I3 bijna 9o procent van de personeelsbezetting vervangen. Over de hele termijn gezien zette tijdens de Eerste Wereldoorlog een dalende tendens in, die tot het eind van de jaren dertig aanhield. Die tendens werd doorbroken in jaren met opvallende pieken. Duidelijk zichtbaar in de grafiek is de uittocht aan het eind van de Eerste Wereldoorlog van arbeidskrachten die hun verblijf in de mijnen als tijdelijk hadden gezien, zoals Belgische geïnterneerden en arbeidskrachten die een baan als mijnwerker hadden genomen bij gebrek aan alternatieven. Ook het vertrek van Duitse grensarbeiders na de normalisering van de valutaverhoudingen in de Republiek van Weimar na I923 is herkenbaar.

Opvallend is dat de ontslaggolven van de eerste helft van de jaren dertig nauwelijks in de loop van de grafieklijnen zijn terug te vinden. Slechts tussen 1932 en I934 zien we een relatief kleine toename. Kreukels wees er al eerder op dat het spontane verloop uit de mijnen in de periode van opbouw vele malen groter was dan het gedwongen vertrek in de crisisjaren. ${ }^{20}$ In 1937 bereikte het verloop, zowel in absolute als in relatieve zin, een historisch dieptepunt. Slechts I.00o arbeiders verlieten in dat jaar de Limburgse mijnbouw, nauwelijks 2 procent van de personeelsbezetting. 
GRAFIEK 6.3 HET OVERLEVINGSPERCENTAGE VAN DE ARBEIDSKRACHTEN IN DE NEDERLAN DSE STEEN KOLENMIJNEN, I9I9-I960

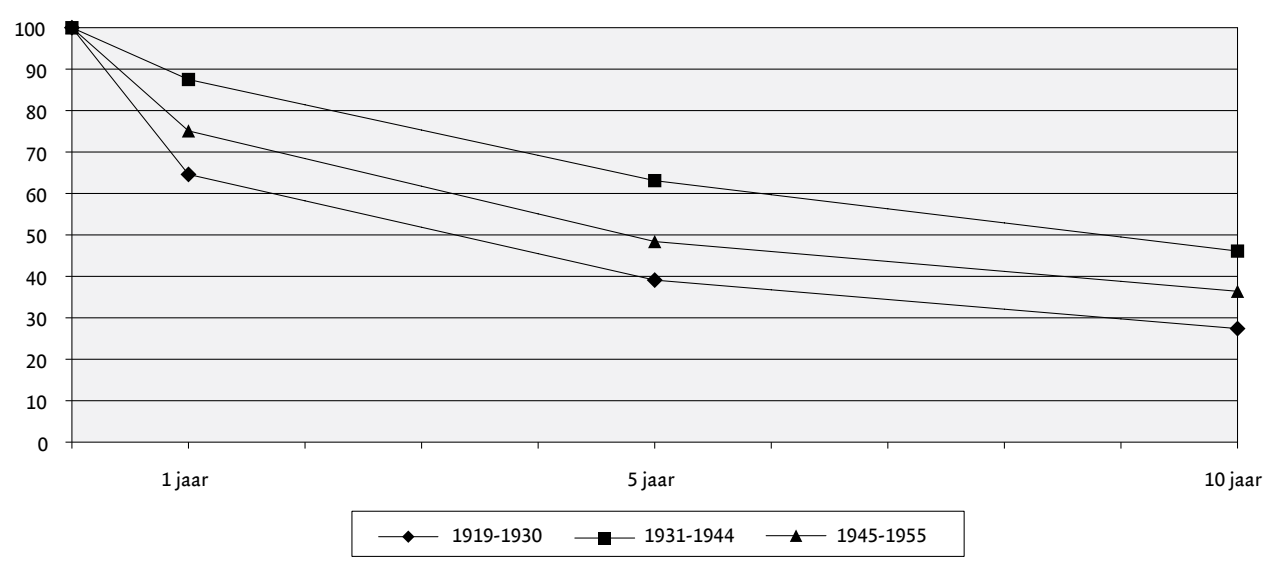

Bron: Steekproef uit lidmaatschapskaarten AMF. Zie ook bijlage 8.

Zelfs wanneer we de exceptionele jaren 1944 en 1945 buiten beschouwing laten, vertoonde het verloop in de periode na de Tweede Wereldoorlog opnieuw een stijgende tendens. Vooral tot aan de kolencrisis van 1958 was de stijging sterk. In I957 en na een tijdelijke daling opnieuw in 1963 was het verloop weer op het niveau van de tweede helft van de jaren I920 beland. Het percentage arbeiders dat elk jaar de mijnbouw verliet, schommelde in de naoorlogse periode rond de ro procent. Omdat inmiddels de personeelsbezetting sterk was uitgebreid, was dat percentage lager dan in de jaren twintig, toen het meestal tussen de I5 en 20 procent was.

Grafiek 6.3 geeft een globaal beeld van het overlevingspercentage in de perioden van opbouw, crisis en oorlog, en wederopbouw. In de gemiddelde duur van de dienstverbanden bestonden belangrijke verschillen tussen de onderscheiden perioden. ${ }^{21}$ De grootste neiging om mijnwerker te blijven, vertoonden degenen die intraden in de periode I93I-I944. Van hen was gemiddeld 87,5 procent na een jaar nog in de mijnbouwsector werkzaam, na vijf jaar was van deze groep nog 63, I procent mijnwerker en tien jaar na intrede was nog steeds bijna de helft (46, I procent) in een van de Limburgse mijnen actief.

In haar arbeidsmarktgedrag verschilde deze groep aanzienlijk met het cohort dat was ingetreden in de opbouwfase van de Limburgse mijnbouw. Van degenen die tussen rgr9 en I930 voor het eerst hun opwachting maakten in de mijnbouwsector, was na een jaar gemiddeld nog 64 procent mijnwerker, na vijf jaar was nog slechts 39, I procent over en na tien jaar niet meer dan 27 , I procent.

De groep intreders tussen I945 en I955 nam een tussenpositie in. Van hen was na een jaar nog 75, I procent in dienst van een Limburgse mijn. Na vijf jaar was nog 48,4 procent over; na tien jaar bedroeg het overlevingspercentage 36,4 . 
Uit tabel 6.I blijkt dat in alle cohorten de kans om in het eerste jaar te vertrekken het grootst was. Uit onderzoek naar het verloop bij de Oranje-Nassau Mijnen in de eerste helft van de jaren I950 kwam naar voren dat binnen een maand na indiensttreding zelfs al 20 procent het bedrijf verliet. ${ }^{22}$ De aanpassingsmoeilijkheden kwamen in de eerste tijd van het dienstverband duidelijk naar voren. Men moest wennen aan nieuwe collega's, het arbeidsritme, de specifieke arbeidsomstandigheden in het mijnbedrijf en eventueel aan een nieuwe woonomgeving. Wie het eerste jaar in de mijn 'overleefde' had een veel grotere kans een lange carrière in de mijnbouwsector tegemoet te gaan, dan op het moment dat het dienstverband een aanvang nam. Ook hier valt het onderscheid tussen de verschillende periodes op.

TABEL 6.I VERTREK UIT DE MIJNBOUWSECTOR, GEMIDDELD PER JAAR, I9I9-I955 (IN PERCENTAGE VAN AANTAL INTREDERS PER COHORT)

\begin{tabular}{|l|c|c|c|}
\hline cohort van intreding & vertrek eerste jaar & $\begin{array}{c}\text { vertrek tussen } \\
\text { I en 5 jaar } \\
\text { (gemiddeld per jaar) }\end{array}$ & $\begin{array}{c}\text { vertrek tussen } \\
\text { 5 en Io jaar } \\
\text { (gemiddeld per jaar) }\end{array}$ \\
\hline I9I9-I930 & 36,0 & 6,5 & 2,2 \\
\hline I93I-I944 & I2,5 & $4, \mathrm{I}$ & 3,4 \\
\hline I945-I955 & 24,9 & 6,7 & 2,4 \\
\hline
\end{tabular}

Bron: Steekproef uit lidmaatschapskaarten AMF. Zie ook bijlage 8.

De gevonden resultaten uit de steekproef maken het ook mogelijk te differentiëren naar nationaliteit en herkomst van de mijnwerkers (grafieken 6.4 tot en met 6.6). Onderscheid kan worden gemaakt tussen mijnwerkers geboren in Limburg, overige Nederlanders en buitenlanders.

GRAFIEK 6.4 Het OVERLEVINGSPERCENTAGE VAN DE INTREDERS IN HET AMF, I9I9-I930

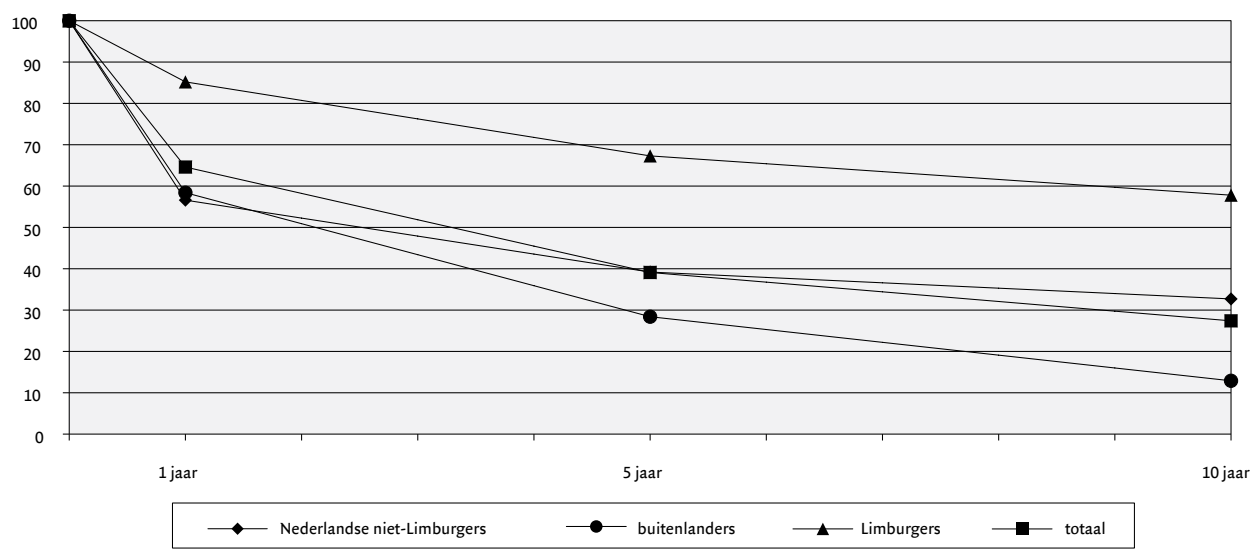

Bron: Steekproef uit lidmaatschapskaarten AMF. Zie ook bijlage 8. 
GRAFiEK 6.5 Het OVERLEVINGSPERCENTAGE VAN DE INTREDERS IN HET AMF, I93I-I944

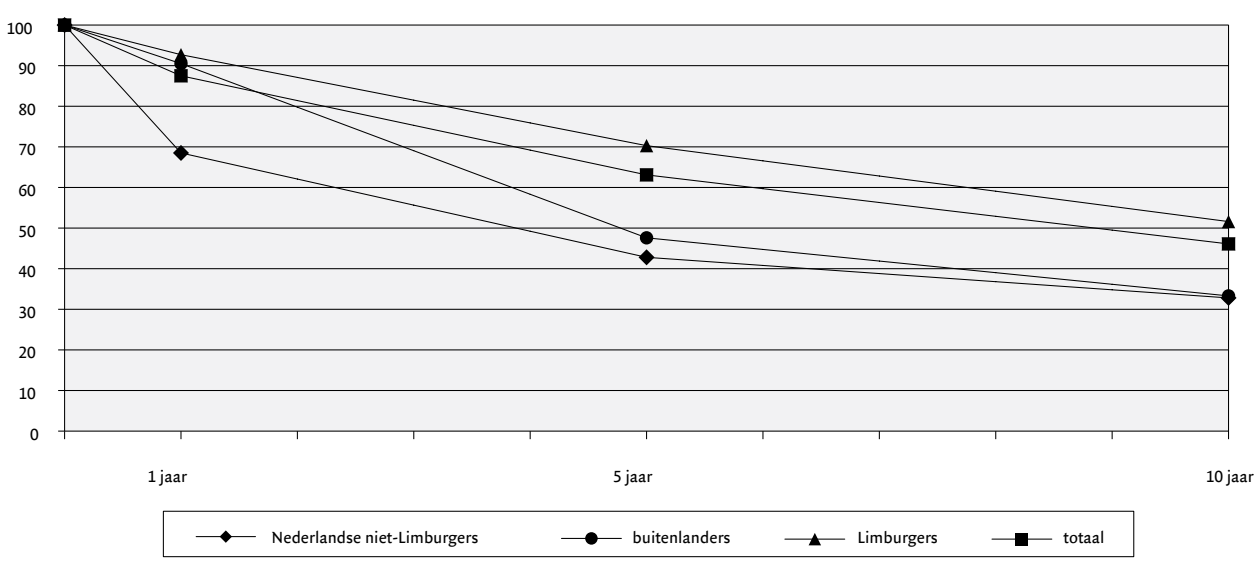

Bron: Steekproef uit lidmaatschapskaarten AMF. Zie ook bijlage 8 .

GRAFiek 6.6 Het OVERLEVINGSPERCENTAGE VAN DE INTREDERS IN HET AMF, I945-I955

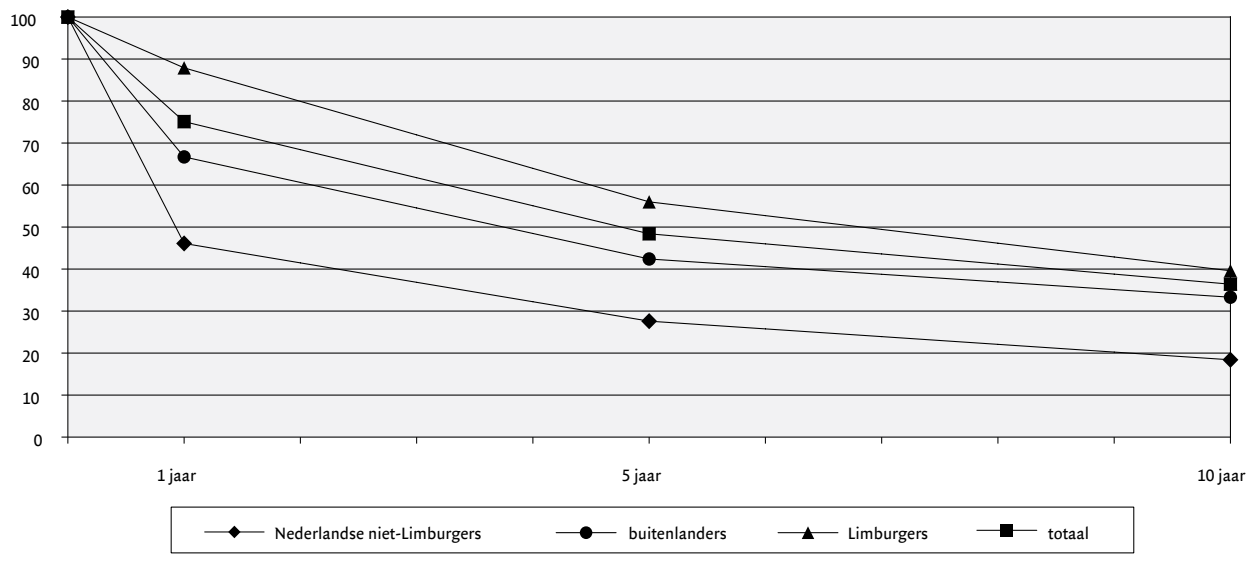

Bron: Steekproef uit lidmaatschapskaarten AMF. Zie ook bijlage 8.

Voor alle cohorten gold dat Limburgse mijnwerkers in het algemeen het trouwste aan de mijnbouwsector waren. Zowel na een, vijf en tien jaar was het overlevingspercentage van Limburgse mijnwerkers steeds boven het gemiddelde van de hele arbeidersbezetting. In de periode van opbouw waren de buitenlandse arbeiders in het algemeen degenen die het snelst vertrokken. In de tijdvakken I93I-I944 en I945-I955 waren het daarentegen de niet in Limburg geboren Nederlandse mijnwerkers die de minste stabiliteit vertoonden.

Vooral in de opbouwfase van de mijnindustrie bleken de verschillen tussen de groepen groot. Het verschil kwam vooral tot uiting in het overlevingspercentage na een jaar. Van de 
Limburgse intreders tussen I9I9 en I930 was na een jaar nog 85,2 procent in de mijnbouw werkzaam, tegen 56,6 procent van de Nederlanders en 58,4 procent van de buitenlanders. Opvallend is dat dit verschil in het volgende cohort (sterk) afnam. Tussen I93I en I944 bedroeg het verschil in overlevingspercentage van Limburgers met niet in Limburg geboren Nederlanders nog 24,2 procent en met buitenlandse mijnwerkers zelfs niet meer dan 2,2 procent. Niet-Limburgse mijnwerkers uit Nederland waren in het eerste jaar van het dienstverband nog steeds de meest mobiele groep, al waren ook deze mijnwerkers wat meer geneigd om in dienst te blijven dan in de jaren voor I93. Opvallend is ook de mate waarin het overlevingspercentage van Limburgse en buitenlandse mijnwerkers nivelleerde. Ongetwijfeld speelde een rol dat de weinige buitenlanders die in deze periode werden aangenomen waarschijnlijk al langer in de regio verbleven, bijvoorbeeld omdat ze tweede generatie migranten waren.

In de periode van wederopbouw nam het verschil tussen het overlevingspercentage van Limburgers en de andere twee groepen weer toe. Nederlanders van buiten de provincie Limburg waren het meest mobiel. De duur van hun carrières in de mijnen waren gemiddeld genomen zelfs korter dan in de opbouwfase. Het verschil in overlevingspercentage na een jaar tussen Limburgers en buitenlanders nam fors toe tot 2I,2 procent, waarmee het weer in de buurt kwam van de verhoudingen in de opbouwfase van de mijnbouw, toen het verschil tussen beide groepen 28,2 procent had bedragen.

Wat betekenen deze bevindingen voor de binding aan het mijnbedrijf? Het creëren van een vaste stam van arbeiders, die zich gebonden voelden aan het mijnbedrijf was in de periode van opbouw een moeizaam proces. Het jaarlijkse verloop was groot en de overlevingspercentages van de aangetrokken arbeidskrachten waren laag. De mijnbedrijven moesten dus voortdurend blijven investeren in de werving en inpassing van nieuwe arbeidskrachten. Zoals in de vorige hoofdstukken bleek, was in de jaren I9I9-I930 een minderheid van de aangeworven arbeidskrachten in Limburg geboren. Net bij deze schaarse categorie arbeidskrachten was de kans op binding aan de mijnbouwsector het grootst.

In de exceptionele jaren van crisis en oorlog vond er een omslag plaats. De binding aan de mijn werd veel groter. Tijdens de ontslagrondes van de eerste helft van de jaren dertig was het verloop aanzienlijk geringer dan in de twee à drie decennia die daaraan voorafgingen. Het daalde in de jaren vlak voor de Tweede Wereldoorlog tot een historisch dieptepunt. In alle categorieën mijnwerkers nam het overlevingspercentage toe.

Na de Tweede Wereldoorlog kon dit niet worden uitgebouwd. Het jaarlijkse verloop nam opnieuw toe - zij het dat de percentages van vóór I930 niet werden bereikt - terwijl het overlevingspercentage daalde. Die daling gold voor zowel de momentopnames na één, na vijf en na tien jaar. De achtergronden van de beschreven ontwikkelingen op lange termijn worden hierna voor de drie te onderscheiden perioden nader uitgewerkt. Welke maatregelen namen de mijndirecties om de binding te bevorderen, in hoeverre was de algemene sociaal-economische context van invloed op de realisering van dat beleidsvoornemen en hoe verhield zich de bindingsstrategie van de mijnbedrijven tot de autonomiestrategie van de mijnwerkers? 


\section{DE PERIODE VAN OPBOUW, I900-I930}

\section{Wandervögel}

De hoop bij de oprichting van Staatsmijnen om de benodigde arbeidskrachten uitsluitend aan te kunnen trekken uit de regio en uit de groep Nederlanders die uit de Duitse mijnen zouden terugkeren, was al binnen een decennium verkeken. Een geleidelijke uitbouw van de Limburgse mijnindustrie, die het mogelijk zou maken uit 'de bestaande bevolking, en hen die zich gaandeweg vestigen langzamerhand, eene krachtige mijnbevolking te vormen', bleek niet mogelijk. ${ }^{23}$ De Nederlandse arbeidsmarkt schoot te kort en ervaren buitenlandse arbeiders uit vooral de Duitse mijnen bleken onmisbaar. Door de grote vraag kon van selectie nauwelijks sprake zijn. De groepen buitenlandse mijnwerkers kenmerkten zich door een enorme mobiliteit, een verschijnsel dat in snel groeiende industriecentra in het algemeen kan worden geconstateerd. ${ }^{24}$ In de Duitse mijnbouwsector - en vaak ook al daarbuiten - hadden de arbeidsmigranten in veel gevallen al een zwerftocht langs vele ondernemingen achter de rug. Dit mobiele arbeidsmarktgedrag werd bevorderd door de strijd die deze groepen arbeiders tegen mijndirecties hadden gevoerd. Een van hun belangrijkste strijdvormen was die van de organisierte Arbeitsplatzwechsel, waarbij men door (dreiging met) massaal vertrek naar een andere mijn betere arbeidsvoorwaarden probeerde af te dwingen. ${ }^{25}$ Ongebondenheid aan het bedrijf, de Freizügigkeit, werd beschouwd als een verworven recht en als een van de mogelijkheden om optimaal gebruik te kunnen maken van de in de mijnen steeds bestaande vraag naar ervaren en vakkundige arbeidskrachten. ${ }^{26}$ Ook onder onervaren nieuwkomers was het verloop groot. Dat werd vooral veroorzaakt door de onbekendheid met mijnarbeid. Aangelokt door lonen, die zeker in vergelijking met de verdiensten in de landbouwsector zeer hoog waren, werden velen onaangenaam verrast door de specifieke arbeidsomstandigheden in het ondergrondse mijnbedrijf. ${ }^{27}$ Voor alle nieuwkomers, ervaren en onervaren, waren er aanpassingsmoeilijkheden en teleurstellingen in de nieuwe omgeving, die vooral samenhingen met de volstrekt ontoereikende huisvesting. Om die reden hadden de mijnondernemingen al in een vroeg stadium aandacht voor uitbreiding van de woningvoorraad in de mijnstreek, zoals in hoofdstuk 3 werd besproken.

Voor de Nederlandse mijndirecties was het grote verloop problematisch, omdat voortdurend nieuwelingen in het bedrijf moesten worden ingepast. Dat kostte veel tijd en geld, en van de gewenste binding aan het bedrijf kwam niet veel terecht. Bovendien stonden lonen en andere arbeidsvoorwaarden daardoor voortdurend onder druk. ${ }^{28}$ De aanzet die de mijnbedrijven al omstreeks Igoo gaven tot de bouw van bedrijfswoningen en de relatief hoge lonen die werden betaald, konden voor de Eerste Wereldoorlog de binding aan het bedrijf niet positief beïnvloeden.

23 Rapport Commissie voor de Mijnen, 32.

24 Kreukels, Mijnarbeid, 67; Knotter, 'Inleiding', i6.

25 Gales e.a., Bedrijfsvoering, I2.

26 Kreukels, Mijnarbeid, 66-67.

27 Kreukels berekende dat in 1908 bovengrondse mijnwerkers ongeveer drie keer zo veel verdienden dan landarbeiders in de mijnstreek. Het gemiddelde loon van een ondergronder was zelfs vijf keer dat van een landarbeider. Kreukels, Mijnarbeid, Ioo-IoI. 28 Ibidem, 105-106. 
Ook in de samenleving was het komen en gaan van de Wandervögel, zoals de arbeidsmigranten werden genoemd, een bron van onrust. De journalist Theodoor Vianen typeerde mobiele arbeidsmigranten als 'cosmopolieten van de slechtste soort', die zich te buiten zouden gaan aan liederlijk en crimineel gedrag en daarmee verantwoordelijk zouden zijn voor aantasting van de traditionele waarden en normen in de mijnstreek. ${ }^{29}$ Dergelijke uitlatingen over het gedrag van de nieuwkomers versterkten het imago van het beroep van mijnwerker niet. Mogelijk had dat ook gevolgen voor de bereidheid van de voor de mijnbedrijven meer preferente groepen om mijnwerker te worden of te blijven.

Desondanks waren voor Limburgers de aanpassingsproblemen het minst groot. Velen van hen konden in de vertrouwde omgeving blijven wonen, al moest menigeen door het weinig ontwikkelde openbare vervoer daarvoor dagelijks een omslachtige reis naar en van de mijn maken. ${ }^{30}$ Cijfers die een indruk kunnen geven van de binding aan de mijn voor verschillende groepen naar herkomst, zijn voor deze vroege periode schaars. De inschrijvingen in het AMF op het moment dat dit fonds van start ging (I augustus I9I9) geven een indicatie (tabel 6.2).

TABEL 6.2 DE CARrière OP I AUGUSTUS I9I9 VAN DE INTREDERS IN HET AMF

\begin{tabular}{|l|r|c|c|}
\hline & n & $\begin{array}{c}\text { gemiddelde diensttijd in } \\
\text { mijnbouwsector } \\
\text { (op I-8-I9I9) }\end{array}$ & $\begin{array}{c}\text { gemiddeld aantal dienst- } \\
\text { verbanden in de mijn- } \\
\text { bouwsector (op I-8-19I9) }\end{array}$ \\
\hline Limburgers & $\mathbf{2 2 0}$ & 34 maanden & $\mathrm{I}, 7$ \\
\hline niet-Limburgse Nederlanders & 97 & $\mathbf{2 8}$ maanden & $\mathrm{I}, 7$ \\
\hline alle Nederlanders & 317 & 32 maanden & $\mathrm{I}, 7$ \\
\hline buitenlanders & 49 & $\mathbf{2 2}$ maanden & $\mathrm{I}, 9$ \\
\hline totaal & $\mathbf{3 6 6}$ & $\mathbf{3}$ I maanden & $\mathbf{I , 7}$ \\
\hline
\end{tabular}

Bron: Eigen berekening op basis van de steekproef uit de AMF-kaarten. Zie ook bijlage 8 .

Gemeten naar hun relatief lange diensttijd leken Limburgers zich in het algemeen het best aan de mijnbouwsector te binden. De groep buitenlandse arbeidskrachten komt ook in deze tabel als de meest mobiele groep naar voren. Mijnwerkers met een buitenlandse nationaliteit hadden gemiddeld de kortste diensttijd op I augustus I9I9. Ook bleken zij meer dan gemiddeld mobiel binnen de Nederlandse mijnbouwsector.

Indirect blijkt het verschil in binding aan het bedrijf ook uit vergelijking van de verloopcijfers tussen Staatsmijnen en de particuliere mijnen. Bij het Staatsmijnbedrijf, waar het Nederlandse aandeel in het personeelsbestand steeds groter was dan bij de particuliere mijnen, was het arbeidersverloop van jaar tot jaar geringer (grafiek 6.7). Vooral in de jaren vóór de Eerste Wereldoorlog waren de verschillen aanzienlijk. De toenadering van beide lijnen vanaf $19{ }_{15}$, maar vooral in de jaren twintig, is mede verklaarbaar doordat ook Staatsmijnen in toenemende mate arbeidskrachten uit het buitenland moest aannemen, waar- 
GRAFIEK 6.7 Het ARBEIDERSVERLOOP BIJ STAATSMIJNEN EN DE PARTICULIERE MIJNEN, I9II-I938 (JAARLIJKS VERTREK ALS PERCENTAGE VAN DE GEMIDDELDE ARBEIDERSBEZETTING)

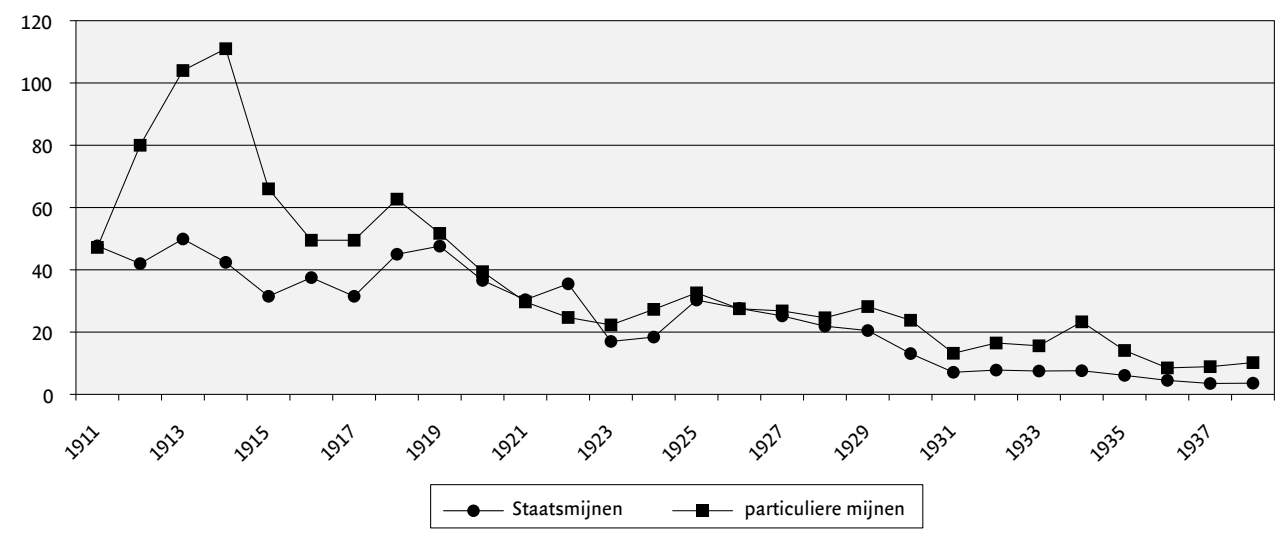

Bron: Kreukels, Mijnarbeid, 68-69.

door het aandeel van de groepen met een in het algemeen meer stabiel arbeidsmarktgedrag afnam. ${ }^{3 \mathrm{I}}$

\section{De Eerste Wereldoorlog}

De vermindering van het verloop tijdens de Eerste Wereldoorlog was deels het gevolg van een verandering in de personeelssamenstelling. Een belangrijk gedeelte van de meest mobiele groep, de buitenlandse mijnwerkers, vertrok in de zomer van I9I4. Zij werden in de loop van de oorlog vervangen door groepen arbeidskrachten die in het algemeen een meer stabiel arbeidsmarktgedrag vertoonden: Limburgers en arbeidskrachten uit de rest van $\mathrm{Ne}$ derland. De Belgische vluchtelingen en geïnterneerde militairen hadden veel minder bewegingsvrijheid dan de buitenlandse mijnwerkers die ze vervingen..$^{32}$ Bovendien waren veel van de nieuwe Nederlandse mijnwerkers ongeoefend in mijnarbeid. Dat gemis aan vakbekwaamheid bemoeilijkte de overstap naar een andere mijn. Zoals uit grafiek 6.8 blijkt, nam het verloop tussen de Nederlandse mijnen tijdens de oorlogsjaren af.

Door de oorlog werden de mogelijkheden voor de arbeidskrachten om van mijn of van werk te veranderen duidelijk ingeperkt. In andere bedrijven was de vraag naar arbeiders tijdens de oorlog in het algemeen minder geworden. Het verband tussen het aanbod van mijnarbeid en de algemene stand van de arbeidsmarkt werd in de Eerste Wereldoorlog duidelijk. Op momenten dat er sprake was van een ruime arbeidsmarkt, vielen meer arbeidskrachten terug op de werkzekerheid die de mijn bood. De mijnen merkten dat niet alleen aan het arbeidsaanbod, maar ook aan dalende vertrekpercentages. Veel van de arbeidskrachten die

3 Zie ook grafiek 4.5.

32 Gales e.a., Bedrijfsuoering, 32. 
GRAFIEK 6.8 HET TOTAAL AANTAL MUTATIES VAN ARBEIDSKRACHTEN TUSSEN NEDERLANDSE MIJNZETELS, I907-I925 (ALS PERCENTAGE VAN DE JAARLIJKSE ARBEIDERSBEZETTING OP 3I DECEMBER)

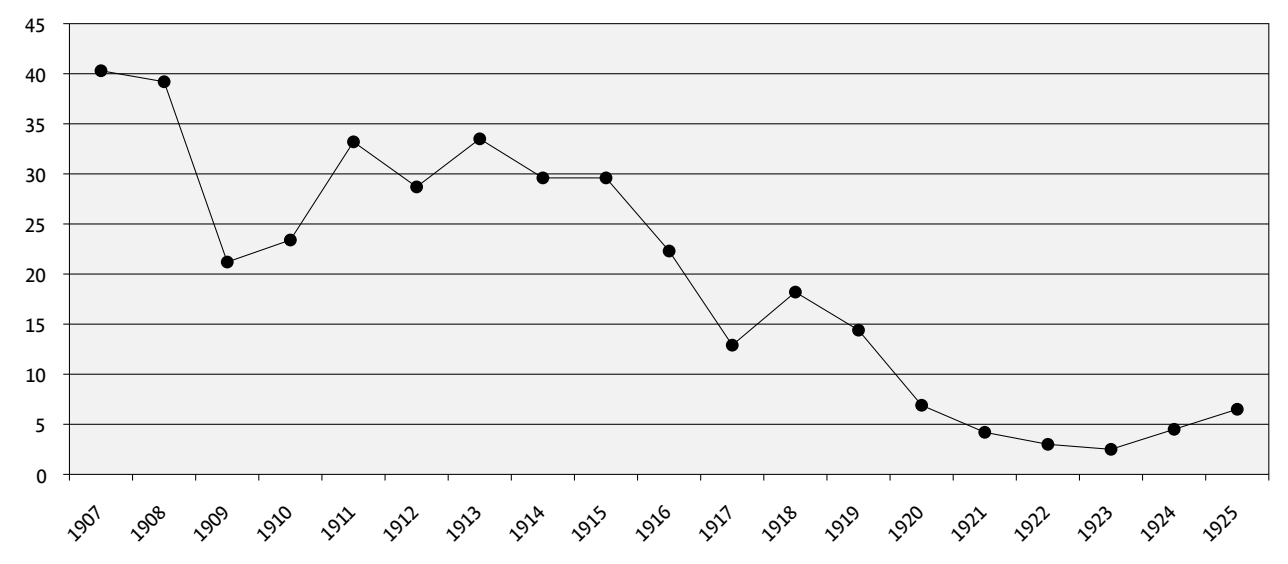

Bron: Onderzoek naar de mijnwormziekte. Zie ook bijlage II en Gales e.a., Bedrijfsvoering, tabellen X, XIII en XVII.

werk in de mijn als een strategische optie hadden gebruikt bij gebrek aan alternatieven, verlieten in I9I8 of IgI9 de mijnen. De uittocht is zichtbaar in de pieken die de lijn van de absolute aantallen in grafiek 6.2 vertoont. Maar de uittocht was kleiner dan wellicht te verwachten was. In I9I8 was het vertrekpercentage bij de totale Limburgse mijnindustrie ten opzichte van I9I3 gedaald met bijna 40 procent. Dieteren neemt daarom aan dat de Eerste Wereldoorlog de aanzet vormde voor meer stabiliteit onder de mijnwerkersbevolking in de jaren twintig, mede dankzij de woningbouw die in deze jaren tot stand kwam in de vorm van gezinswoningen en gezellenhuizen. ${ }^{33}$

\section{De jaren twintig: naar meer stabiliteit}

Vanaf het eind van de Eerste Wereldoorlog werden de beleidsinstrumenten die de mijnen inzetten om de binding aan de mijnbouwsector te bevorderen uitgebreid. Uniformering en institutionalisering van arbeidsvoorwaarden en arbeidsverhoudingen kregen vorm in een Contact-Commissie voor het Mijnbedrijf, waarin de mijndirecties en de vakbonden arbeidsvoorwaarden bespraken en regelden in de vorm van collectieve arbeidsovereenkomsten, en de oprichting van het Algemeen Mijnwerkersfonds van de Steenkolenmijnen in Limburg, waar verzekeringen tegen ziekte, invaliditeit en ouderdom werden ondergebracht. Een belangrijke schakel in de selectie van nieuw personeel was de oprichting van een Gemeenschappelijke Geneeskundige Dienst, die het verrichten van aanstellingskeuringen als taak kreeg opgedragen. Op bedrijfsniveau zagen in de periode na de Eerste Wereldoorlog steeds meer sociale voorzieningen voor mijnwerkers het licht. Die varieerden van gezelligheidsverenigingen tot werkplaatsen waar invalide mijnwerkers een nieuwe ar- 
beidsplaats konden vinden. Last but not least investeerden de mijnbedrijven in allerlei initiatieven op sociaal gebied van voornamelijk katholieke organisaties. Hieronder worden deze beleidsinstrumenten kort besproken.

\section{De Contact-Commissie voor het Mijnbedrijfen de cao}

Het geïnstitutionaliseerde overleg tussen de mijnondernemers en de vakbonden kreeg zijn beslag in de Contact-Commissie voor het Mijnbedrijf, die op II augustus I9I7 voor het eerst bij elkaar kwam. Taak van de Commissie was regelmatig overleg te voeren over alle aangelegenheden betreffende de arbeidsvoorwaarden. ${ }^{34}$ Een van de beweegredenen voor de instelling van de Contact-Commissie was het grote personeelsverloop, dat werd gestimuleerd door het gebrek aan uniforme arbeidsvoorwaarden bij de verschillende mijnbedrijven. Bij Staatsmijnen waren de arbeidsvoorwaarden en lonen over het algemeen gunstiger dan bij de particuliere mijnen. De gemiddelde lonen lagen er hoger en in 1917 werd bij Staatsmijnen de ondergrondse verblijftijd teruggebracht van 8,5 naar acht uur, terwijl de particuliere mijnen dat voorbeeld pas in I9I9 volgden. ${ }^{35}$ De mijnwerkers konden in hun arbeidsmarktgedrag gebruikmaken van deze concurrentie. In hoofdstuk 4 kwam al aan de orde dat daardoor het verloop van de particuliere mijnen naar Staatsmijnen groter was dan andersom.

Het verloop speelde niet alleen het mijnbedrijf parten, maar ook het werk van de vakbonden werd er door gefrustreerd. Ledenwerving en ledenadministratie waren ten gevolge van het grote verloop onder de leden onbegonnen werk. Voortdurend wisselden de leden en, wat volgens Dieteren nog veel erger was, de propagandisten. ${ }^{36}$

Het eerste belangrijke resultaat van het overleg in de Contact-Commissie was de totstandkoming in februari 1920 van een uniform arbeidsvoorwaarden- en loonbeleid, vastgelegd in een collectieve arbeidsovereenkomst voor de gehele Limburgse mijnindustrie. De cao betekende een ordening van de arbeidsmarkt: de concurrentie op de arbeidsmarkt tussen de Limburgse mijnondernemingen nam af, al bleven wel loonverschillen bestaan, vooral door het akkoordstelsel. ${ }^{37}$ Voorts kan ook de invoering van een minimumloon de binding aan het mijnbedrijf hebben bevorderd. In de cao werd het zogenaamde garantieloon vastgelegd. De hoogte daarvan werd bepaald op 80 procent van het gemiddelde loon van de functie die de betreffende arbeidskracht uitoefende. Aangezien de meeste ondergrondse arbeiders in akkoord werkten, was in de cao bepaald dat het akkoord zodanig moest zijn, dat bij normale prestatie het gemiddelde loon werd behaald. Wanneer in het overleg over de hoogte van het akkoord geen overeenstemming werd bereikt, had de ondergronder recht op het garantieloon..$^{8}$

Voorts bepaalde de cao de arbeidsduur voor bovengronders op acht uur per dag. Voor ondergronders gold een verblijfsduur ondergronds van acht uur per dag en zes uur op zaterdag. ${ }^{39}$

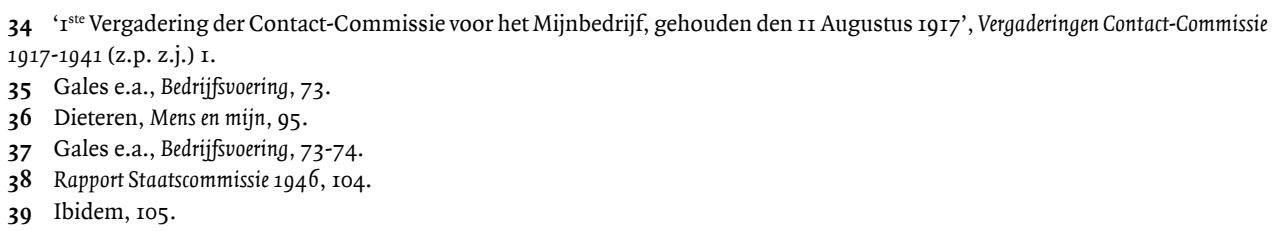


De cao betekende dat de loonhoogte bij de verschillende mijnen meer dan voorheen bekend werd. Was de beslissing om ontslag te nemen voorheen vaak gedeeltelijk gebaseerd op geruchten en vermoedens dat elders meer verdiend kon worden, na het inwerkingtreden van de cao konden die geen rol meer spelen. De verwachting was dat de binding aan het bedrijf daardoor zou worden bevorderd.

Zoals bleek uit grafiek 6.7 nam het verloop tussen de mijnen in het algemeen na de Eerste Wereldoorlog verder af. De harmonisering van de arbeidsvoorwaarden in een cao heeft daarbij een rol gespeeld. De eerste cao had ontegenzeglijk een belangrijke nivellerende werking. Die uitte zich vooral in het kleiner worden van de verschillen tussen de lonen bij Staatsmijnen en de particuliere mijnen na I920. In de jaren vóór de cao bedroeg het verschil tussen het gemiddelde loon per werktijd bij Staatsmijnen en de afzonderlijke particuliere mijnen ro à 15 procent. Na de totstandkoming van de cao werd het verschil veel kleiner. Tot I930 bedroeg het gemiddeld nog slechts 3 procent. De verschillen in loon tussen de particuliere mijnen waren gering, omdat grote verschillen het verloop zouden hebben bevorderd..$^{\circ}$ Eigenmachtig optreden buiten de cao-afspraken om werd scherp in de gaten gehouden. Zo protesteerden de directies van de overige particuliere mijnen in I923 tegen een voornemen van Laura \& Vereeniging om 150.000 gulden als gratificatie onder het personeel te verdelen. De maatregel zou zijn bedoeld om de binding van de arbeidskrachten aan het bedrijf te bevorderen, maar deze doorbreking van het uniforme loonbeleid werd door de andere mijnen niet geaccepteerd. Laura \& Vereeniging loste het probleem op door het gereserveerde bedrag niet als gratificatie uit te keren, maar te gebruiken ter verbetering van de pensioenen van de mijnwerkers. Op die manier hoopte het bedrijf toch de doelstelling van binding aan het bedrijf te bereiken.

De besprekingen in de Contact-Commissie betekenden niet dat loonsverlagingen konden worden voorkomen. Het globale beeld van de jaren tussen I92I en I927 was er een van dalende lonen. Mijnwerkerslonen bleken gevoelig voor conjuncturele schommelingen. In de tweede helft van de jaren twintig bleven de gemiddelde jaarlonen van mijnwerkers ruim 25 procent onder het peil van I920. ${ }^{4 \mathrm{I}}$ Daarbij moet worden bedacht dat tussen oktober 1925 en januari 1927 de zesurendienst op zaterdag voor ondergronders tijdelijk werd verlengd tot acht uur. Ondanks de in het algemeen licht dalende kosten van levensonderhoud daalde de koopkracht van de mijnwerkerslonen. ${ }^{42}$ Waarschijnlijk was die daling zelfs sterker dan in andere beroepsgroepen. De voorsprong die de mijnwerkerslonen in de jaren I9I4-I920 hadden behaald op het loonniveau in andere takken van industrie, ging echter na I920 niet verloren. De mijnwerkers bleven voortdurend behoren tot de best betaalde Nederlandse industriearbeiders. ${ }^{43}$

Opvallend genoeg gingen de dalende lonen en verslechterde arbeidsvoorwaarden in de jaren twintig over het algemeen samen met een afname van het jaarlijkse vertrekpercentage uit de mijnbouwsector. Het loonniveau in vergelijking tot dat in andere sectoren was zeker niet alléén bepalend voor de mate van binding aan de mijnbouwsector. Ook de tijdelijke toe-

40 Kreukels, Mijnarbeid, 86-89.

4I Ibidem, 293-298.

42 CBS, Vijfennegentig jaar statistiek in tijdreeksen 1899-1994 ('s-Gravenhage 1994) I8I.

43 Erik Nijhof, 'Bespreking van L. Kreukels, Mijnarbeid en strijdbaarheid. Geschiedenis van de arbeidsverhoudingen in de Nederlandse steenkolenmijnen, I900-I940, Assen/Maastricht I986', Tijdschrift voor Sociale Geschiedenis XVI (I990) 94-96. 
name van het vertrekpercentage in de jaren I924-I925 was niet in de eerste plaats te wijten aan verslechterde arbeidsvoorwaarden in de Nederlandse mijnbouw, maar aan de terugkeer naar Duitsland van veel Duitse mijnwerkers na de normalisering van de monetaire en economische verhoudingen in de Republiek van Weimar.

Dat wil niet zeggen dat de loonhoogte geen enkele rol speelde. Zo vreesde de directie van Staatsmijnen dat een salarisdaling die in april 1925 in de mijnbouwsector van kracht werd, tot gevolg zou hebben dat gekwalificeerde arbeiders de mijnen verlieten. Het staatsbedrijf zou daardoor in problemen komen. Ook in de jaren I927-I929 voelde Staatsmijnen weinig voor loonsverlagingen, omdat de personeelstekorten na de opening van de Maurits groot waren. Menigmaal weigerden mijnwerkers de aangeboden akkoorden en verlieten zij het bedrijf. 44

\section{Het Algemeen Mijnwerkersfonds van de Steenkolenmijnen in Limburg}

In navolging van de Domaniale Mijn en de Neuprick richtten de mijnbedrijven die vanaf I899 in exploitatie kwamen voor hun arbeiders ondersteuningsfondsen op, waaraan deelname verplicht was. De fondsen waren aan het bedrijf gebonden. De regelingen waren niet bij elke mijn hetzelfde en lieten vaak te wensen over. ${ }^{45}$ Alleen bij de Domaniale Mijn, de Oranje-Nassau Mijnen en Staatsmijnen (sinds I9II) bestond de verzekering uit een ziekenkas, een ziekenfonds en een pensioenfonds. De overige mijnen kenden alleen een ziekenkas en ziekenfonds.

$\mathrm{Al}$ sinds het begin van de twintigste eeuw was door de mijnwerkersorganisaties gepleit voor de totstandkoming van één algemeen ondersteuningsfonds voor alle mijnen. Hierdoor zou het bezwaar worden ondervangen dat mijnwerkers die van de ene naar een andere mijn overgingen hun recht op uitkering verloren. Bovendien zou de arbeidsmarktpositie van de Limburgse mijnbouwsector ten opzichte van de Duitse mijnen met hun Knappschaftskassen door een algemeen ondersteuningsfonds worden bevorderd. ${ }^{46}$ In I9I 6 werd de Commissie-Nolens ingesteld, die de minister adviseerde over de wijze waarop een uniforme regeling voor de hele mijnbouwsector tot stand zou kunnen komen. ${ }^{47}$ Op I6 december I9I8 ondertekenden de mijndirecties en de vakorganisaties de notariële stichtingsakte van het Algemeen Mijnwerkersfonds van de Steenkolenmijnen in Limburg (AMF). Het AMF trad op I augustus I9I9 in werking. Het kende een ziekenfonds, dat bij ziekte van de mijnwerker of van zijn gezinsleden geneeskundige behandeling en geneesmiddelen verstrekte, een ziekenkas, die een uitkering garandeerde aan mijnwerkers die door ziekte niet in staat waren te werken en een pensioenkas, die uitkeerde bij ouderdom of invaliditeit van de mijnwerker. ${ }^{4}$ De bijdragen van de drie kassen werden voor de helft door de mijnondernemingen en voor de helft door de mijnarbeiders gezamenlijk opgebracht. ${ }^{49}$ Het bestuur van het AMF was paritair samengesteld uit vertegenwoordigers van werkgevers en werknemers. Alleen arbei-

44 Kreukels, Mijnarbeid, 296-298.

45 Jaarverslag AMF over 1919-1920, 3.

46 Jaarverslag van den Hoofd-Ingenieur der Mijnen over 1910, 2.

47 SHCL, ArchiefGSL, inv. nr. 34I: Verslag van de Commissie, ingesteld bij beschikking van den minister van landbouw, nijverheid en handel van 4 april I916 no 2751, afdeeling nijverheid, tot het uitbrengen van advies over de wijze, waarop een algemeen mijnwerkersfonds zal kunnen worden tot stand gebracht ('s-Gravenhage igi8).

48 Rapport Staatscommissie 1946, IIO-II4.

49 Jaarverslag AMF over 1919-1920, 13. 
ders waren verplicht lid. Ondersteuningsfondsen voor beambten zouden nog lang op bedrijfsniveau blijven geregeld. Pas op I januari 1953 trad een Beambtenfonds voor het Mijnbedrijf (BFM) in werking..$^{\circ}$

Net als de totstandkoming van de eerste cao betekende de oprichting van het AMF voor de mijnondernemingen vermindering van de onderlinge concurrentie op de arbeidsmarkt. ${ }^{51}$ De verschillen tussen de eerdere bedrijfsgebonden regelingen hadden het verloop in de hand gewerkt. Vooral Staatsmijnen had daarvan geprofiteerd: net als veel andere arbeidsvoorwaarden stak het Ondersteuningsfonds van de Staatsmijnen in Limburg gunstig af bij de sociale fondsen van de particuliere mijnen. Het reglement van het AMF werd sterk geënt op het fonds van Staatsmijnen. ${ }^{2}$ Hoewel de uniforme regeling in theorie het verloop tussen de mijnen bevorderd kan hebben - mijnwerkers namen vanaf augustus I9Ig hun opgebouwde rechten mee als ze naar een andere mijn vertrokken - viel dat in de praktijk mee, zoals bleek uit grafiek 6.8. Belangrijker was dat de Limburgse mijnbouwsector als geheel aantrekkelijker werd door de verbetering van de sociale verzekeringen..$^{53}$ De Commissie-Nolens was al van oordeel geweest dat goede sociale fondsen een positieve invloed zouden hebben op de binding aan het bedrijf. Het grote verloop van de jaren vlak voor de Eerste Wereldoorlog zou zich niet blijven voordoen, 'althans niet onder de arbeiders die noemenswaardige pensioen-aanspraken te verliezen hebben' ${ }^{54}$ Herman Stins, die als voorzitter van de Christelijke Mijnwerkersbond nauw betrokken was geweest bij de totstandkoming van het AMF, sprak van 'het beste fonds in ons land'. Het bestuur van de sociaaldemocratische Algemene Nederlandse Mijnwerkersbond was eveneens positief gestemd over hetgeen bereikt was. 55 Voor de binding aan de mijnbouwsector is het AMF ongetwijfeld belangrijk geweest.

\section{De Geneeskundige Dienst der Nederlandse Steenkolenmijnen}

Tot 1918 liet de medische verzorging van ongevalsslachtoffers in de mijnen te wensen over. Eerste hulp was in handen van verbandmeesters. Bij ernstige gevallen werd een beroep gedaan op de huisarts of op het Sint-Jozefziekenhuis in Heerlen, dat daartoe met financiële steun van de mijnen zijn capaciteit al voor de Eerste Wereldoorlog uitbreidde. ${ }^{6}$ De mijnen constateerden echter dat de bestaande praktijk een doeltreffende medische verzorging in de weg stond met een stijging van de arbeidsongeschiktheid als gevolg. In het begin van I9I6 overwoog Staatsmijnen of het bedrijf niet moest beschikken over eigen bedriifsartsen, zoals ook bij Philips in Eindhoven het geval was. Daar bleek dat een eigen bedrijfsarts de 'ware belangen van het personeel behartigt en in vele gevallen bovendien voor den ondernemer voordeelig is' ${ }^{57}$ Een hervorming van de medische praktijk in het mijnbedrijf zou leiden tot 'vermindering van invaliditeit en beperking van lichamelijke minderwaardigheid als gevolg van ongevallen', waardoor voor het bedrijf de 'uitgaven die de sociale zorg voor

50 Verslag van de Inspecteur-Generaal der Mijnen over het jaar 1952, 39.

5I Gales e.a., Bedrijfsuoering, 85.

52 Dieteren, Mens en mijn, I75-I82.

53 Gales e.a., Bedrijfsuoering, 84 .

54 SHCL, ArchiefGSL, inv. nr. 34I: Verslag Commissie advies algemeen mijnwerkersfonds, 43.

55 De Mijnwerker, 9 maart igr8 en idem, 30 maart i9ı8.

56 Rob Wolf, Mijn ziekenhuis. 100 Jaar ziekenhuiszorg in Parkstad Limburg (Heerlen 2004) 28-29.

57 Geciteerd bij Bart Gielen, In het belang van het mijnbedrijf? Een onderzoek naar het functioneren van de Geneeskundige Dienst der Nederlandse Steenkolenmijnen en de rol van hoofdmijnarts A.H. Vossenaar, 1918-1939 (doctoraalscriptie, Amsterdam 2003) 30. 


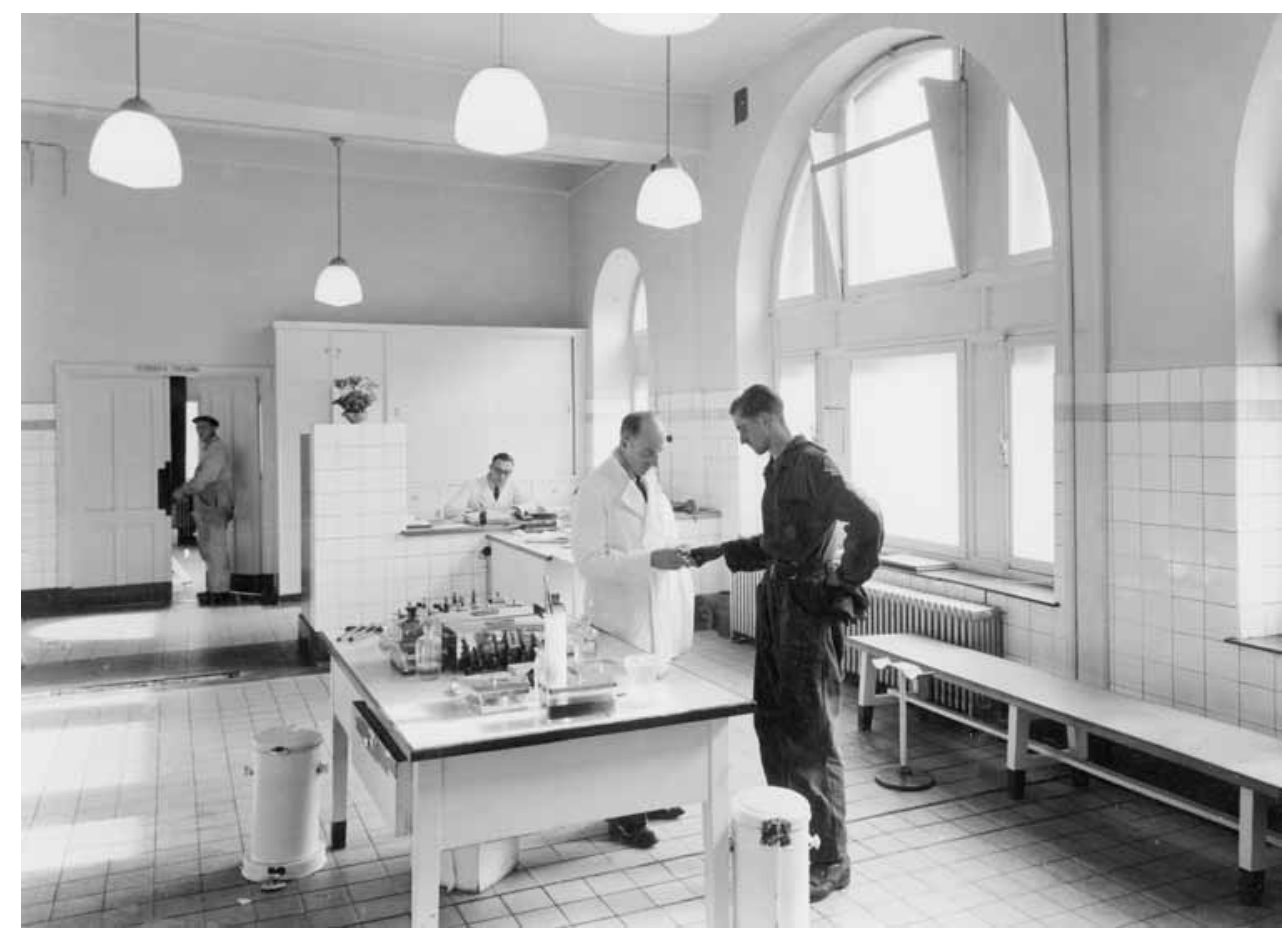

Hoofdverbandmeester J. v.d. Schuren met een patiënt in de verbandkamer van de Julia. Omstreeks 1955. Bron: Fotocollectie Continium Kerkrade, F2547.

de arbeiders vordert', zouden worden beperkt..$^{8}$ Nadat de Oranje-Nassau Mijnen zich bij de opvattingen van Staatsmijnen hadden aangesloten, schreef de gezamenlijke directie van beide bedrijven in september 1917 een brief naar de Rijksverzekeringsbank (die de uitvoering van de Ongevallenwet 1903 in handen had), waarin werd gewezen op de dringende behoefte die er bestond aan hervorming en verbetering van de wijze waarop de behandeling van de eerste hulp in de steenkolenmijnen was geregeld. Tevens verzocht de directie aan de Rijksverzekeringsbank om A.H. Vossenaar, controlerend geneesheer in Zwolle, tijdelijk vrij te stellen voor een onderzoek naar de medische toestanden in de mijn. Het rapport dat Vossenaar opstelde, zou de basis worden voor de Geneeskundige Dienst der Nederlandse Steenkolenmijnen, die in juli I 918 van start ging. ${ }^{59}$ Aanvankelijk was de nieuwe dienst voorbehouden aan Staatsmijnen en de Oranje-Nassau Mijnen, maar in 1922 en 1923 sloten ook de andere Nederlandse mijnondernemingen zich aan. Bij de mijnzetels werden mijnartsen aangesteld, die onder leiding stonden van een hoofdmijnarts. Tot 1939 nam Vossenaar die taak op zich. De kern van de geneeskundige dienst werd het Sint-Jozefziekenhuis in Heerlen, waar een speciaal voor de mijnen bestemde ongevallenafdeling werd ingericht, waarvan de hoofdmijnarts de leiding had. De medische verzorging van minder ernstig letsel 
geschiedde als vanouds in de verbandkamer. De verbandmeesters waren voortaan ondergeschikt aan de mijnarts.

Tot de taak van de nieuwe dienst behoorde ook de medische keuring van alle in dienst tredende arbeiders. Eerder gebeurde dat door huisartsen. Voor de mijnbedrijven was het van groot belang dat ze de aanstellingskeuringen in eigen hand kregen. Na I920 werd meer en meer ingezien dat selectie een van de belangrijke middelen was om vroegtijdig verloop tegen te gaan. De aanstellingskeuringen, die algemeen strenger werden, hebben daarin een voorname plaats ingenomen. ${ }^{60}$

De professionalisering van de geneeskundige dienst van de mijnen heeft er zeker toe bijgedragen dat de medische zorg verbeterde. In die zin bevorderde de instelling van de Geneeskundige Dienst de binding aan het bedrijf. Dat neemt niet weg dat er ook kritiek kwam uit de kringen van het AMF en van de vakbonden op de nauwe band van de verantwoordelijke medici met de mijnbedrijven. Vaak werd de onafhankelijkheid van de mijnartsen ter discussie gesteld. ${ }^{6 r}$ Hoofdmijnarts Vossenaar verzette zich bijvoorbeeld in de jaren 1930 lang tegen erkenning van silicose als beroepsziekte. Voor de mijnondernemingen zou erkenning hebben kunnen leiden tot financiële aanspraken en dat wilden Vossenaar en zijn ondergeschikten voorkomen. ${ }^{62}$

\section{Sociale voorzieningen op bedrijfsniveau}

De directies van de mijnbedrijven hechtten veel belang aan de opbouw van een verenigingsleven voor hun personeelsleden. Ze moesten ook wel, want qua vrijetijdsbesteding was er in de nieuwe mijnstreken vrijwel niets te doen. In de boerendorpen was er nauwelijks geld en interesse om zich met andere zaken als werk, gezin en kerk bezig te houden. Slechts hier en daar bestond een harmonie of fanfare, waaraan soms een zangkoor verbonden was. ${ }^{63}$

Toch achtten de mijnen de aanwezigheid van mogelijkheden tot vrijetijdsbesteding van groot belang. Het kon arbeidskrachten immers doen besluiten zich in het gebied te vestigen en er ook te blijven. In een tijd dat arbeidskrachten schaars waren, kon dit daarom in de ogen van de mijnondernemers een belangrijk instrument zijn bij de opbouw van een vaste kern van personeel. Voor de beambten en kaderleden kwamen er tennisclubs, symfonieorkesten, kaatsbalverenigingen, bridgeclubs en kunstkringen. Voor de arbeiders gold dat er alternatieven moesten zijn voor het ontmoetingspunt bij uitstek: de kroeg. Dus opteerden de mijndirecties voor in hun ogen meer zinvolle vormen van vrijetijdsbesteding als voetbalclubs, harmonieën, duiven-, zangvogel- en visclubs en zang-, dans- en toneelverenigingen.

Naast de voetbalclub was vooral de harmonie of fanfare de prestigevereniging van de mijnbedrijven. De muziekvereniging werd financieel en materieel gesteund. De mijnen zorgden voor een repetitieruimte, uniformen en muziekinstrumenten. Het grootste voordeel van een lidmaatschap was dat de leden vaak beter werk kregen. Alleen maar dagdiensten bijvoorbeeld en een enkele maal bovengronds werk. Hierdoor konden de leden deelnemen aan de noodzakelijke repetities. ${ }^{64}$

6o Gales e.a, Bedriifsuoering, 86-87.

6I Gielen, Belang mijnbedriif, 38 .

62 Bart Gielen, 'Sjtub'. Hoofdmijnarts Vossenaar en stoflongen als beroepsziekte', Skript historisch tijdschrift XXV nummer 3 (2003)

5-I9.

6370 Jaar FSI, fonds voor sociale instellingen. (http://www.stichtingfsi.nl).

64 Oranje-Nassau Post, juni I970, I3. 


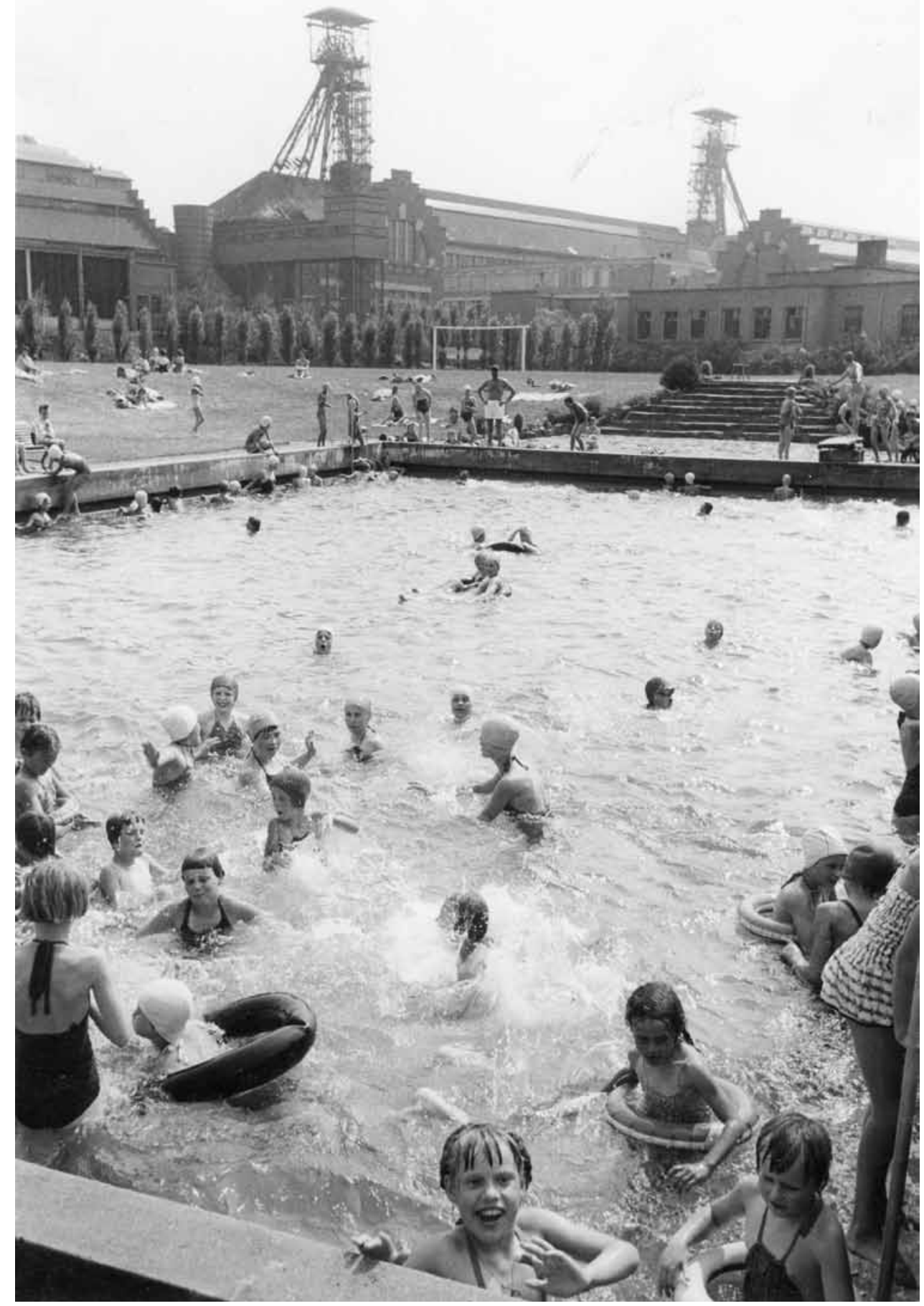

Zwemmen onder de rook van de mijn. Het zwembad van de Julia was oorspronkelijk alleen bedoeld voor de leerlingen van de OVS. Later mochten op bepaalde dagen ook andere personeelsleden en hun kinderen er gebruik van maken. 1959. Bron: Fotocollectie Continium Kerkrade, F2466. 
Onmiddellijk na het begin van de kolenproductie uit de eerste mijnzetel begonnen de Oranje-Nassau Mijnen met de opbouw van een verenigingsleven ten behoeve van het personeel. Het De Wendel-concern, de onderneming die de Oranje-Nassau Mijnen in Igo8 overnam, hechtte veel belang aan dit soort voorzieningen als beleidsinstrument om de binding aan het bedrijf te bevorderen. Bij de Franse bedrijven van De Wendel was dat beleid succesvol gebleken en het werd daarom ook bij de Oranje-Nassau Mijnen geïntroduceerd. ${ }^{65}$ Dit resulteerde in de oprichting van onder meer de sportvereniging ONS. Een voetbalvereniging, een atletiekvereniging, een korfbalclub en een gymnastiekvereniging met klaroenkorps maakten er deel van uit. Ook werd een mannenkoor opgericht, dat uiteindelijk tachtig leden telde. In het Oranje-Nassau-symfonieorkest musiceerden 55 medewerkers van het bedrijf. Daarnaast hadden de Oranje-Nassau Mijnen een Harmonieorkest, opgericht in I9I4. ${ }^{66}$

Staatsmijnen bouwde eveneens al voor de Eerste Wereldoorlog een eigen verenigingsleven op om het sociale en culturele leven van het personeel te bevorderen. Deze activiteiten werden per II februari I9I8 ondergebracht in het toen opgerichte Fonds voor Sociale Instellingen (FSI). Ook initiatieven van de zogenaamde arbeiderscommissies in de vorm van coöperatieve winkels en gaarkeukens, in de loop van de Eerste Wereldoorlog opgericht met als doel te voorzien in materiële noden van de arbeiders van Staatsmijnen, werden in het verband van het FSI opgenomen. ${ }^{67}$

Het doel van het FSI was de belangen van de arbeidskrachten te bevorderen door het exploiteren van gaarkeukens en gezellenhuizen, het houden van winkels, het oprichten van bibliotheken en het verlenen van geldelijke subsidies aan initiatieven die het culturele en ontspanningsleven van de arbeidskrachten beoogden te bevorderen: buurthuiswerk, muziek- en zangverenigingen, eigen muziekkorpsen, schooltuinwerk, oranjefeesten, recreatieparken, Barbaravieringen, concerten, toneel- en filmvoorstellingen. ${ }^{68}$

In 1927 riep het FSI als onderafdeling een speciaal instituut in het leven: Werkverschaffing aan Invalide Mijnwerkers der Staatsmijnen (WIM), bedoeld voor voormalige mijnwerkers die door ziekte of ongeval hun oude beroep niet meer konden uitoefenen. ${ }^{69}$ Daartoe werden een rietvlechterij, timmerwerkplaatsen, schoenmakerijen en een zadelmakerij opgericht. Daarnaast werd aan gezinsleden van mijnwerkers werk verschaft, waartoe Staatsmijnen deelnam in enkele ondernemingen die mijnkleding, regenkleding en tricotage vervaardigden. ${ }^{70}$

De Oranje-Nassau Mijnen exploiteerden eveneens winkels zonder winstoogmerk, de zogenaamde economaten. Ook exploiteerde het bedrijf een schoenmakerij met het doel werk te verschaffen aan invalide mijnwerkers. ${ }^{7 \mathrm{I}}$ De andere particuliere mijnen gaven aan invalide mijnwerkers gelegenheid om lichte werkzaamheden in het bovengrondse bedrijf te verrichten, waarmee het invaliditeitspensioen kon worden aangevuld. ${ }^{72}$

65 Peet en Rutten, Oranje-Nassau Mijnen, 95-96.

66 Oranje-Nassau Post, december 1970, 30-34.

6770 Jaar FSI, 9-Io.

68 Voor een overzicht zie: Harry Strijkers, Van sociaal pionier tot cultuursponsor. Kroniek Fonds voor Sociale Instellingen 1918-2008 (Geleen 2009).

69 De naam werd in 1934 gewijzigd in 'Werkplaatsen voor Invalide Mijnwerkers'.

70 Rapport Staatscommissie 1946, II8-irg.

7I Peet en Rutten, Oranje-Nassau Mijnen, I30.

72 Rapport Staatscommissie 1946, II8-IIg. 
Ten slotte dient kort te worden gewezen op de opbouw van een netwerk van sociale organisaties en initiatieven door met name de katholieke geestelijkheid. Onder de koepel van de in I9II opgerichte Limburgse Rooms-Katholieke Werkliedenbond, de standsorganisatie van de arbeiders, werkten tientallen sociale organisaties en instellingen, met honderden plaatselijke afdelingen. ${ }^{73}$ Het katholieke sociale verzorgingsstelsel omvatte uiteenlopende activiteiten als woningbouwverenigingen, coöperatieve winkels, consultatiebureaus en een bureau voor rechtshulp. De mijnbedrijven steunden deze katholieke 'verzorging van de wieg tot het graf' financieel. ${ }^{74}$ Ook verleenden de mijnen subsidies bij de bouw van kerken, scholen en buurthuizen. In de gemeenschappelijke centrale doelstelling om de sociale stabiliteit in de mijnstreek te bevorderen, vonden de mijnen en de katholieke organisaties elkaar. ${ }^{75}$ Hoewel de gemeenschappelijke rol van mijndirecties en katholieke leidsmannen met hun sociale opvattingen en initiatieven in de ontwikkeling van de arbeidsverhoudingen in de mijnstreek aanleiding is geweest tot een heftig debat onder historici, staat buiten kijf dat die gemeenschappelijke doelstelling in de jaren twintig werd bereikt. ${ }^{76}$ In het algemeen verliep de transformatie naar een industriële samenleving in de mijnstreek in relatieve sociale rust.

\section{CRISIS EN OORLOG, I93I-I944}

\section{Ontslagbeleid, personeelsvoorziening en binding aan het bedrijf}

Tussen eind I930 en eind 1935 nam het aantal arbeidsplaatsen bij de Limburgse mijnen met bijna 9.000 af. Omdat de mijnen in het algemeen de productie beperkten (zie ook hoofdstuk 2, grafiek 2.I) vervielen voornamelijk banen bij de direct-productieve ondergronders. ${ }^{77}$ Het ondergrondse bedrijf noteerde 88 procent van het totaal aantal geschrapte banen.

Hiervoor kwam al ter sprake dat desondanks het personeelsverloop in de jaren dertig aanzienlijk lager was dan in de periode van opbouw van de mijnen. De mogelijkheden voor mijnwerkers om arbeidsmobiliteit in te zetten als een autonomiestrategie namen tijdens de crisisjaren drastisch af. De verhoudingen op de arbeidsmarkt keerden om: de mijndirecties konden nu een strenge selectie toepassen en hun bindingsstrategieën verwezenlijken, waar voorheen tijdens de hoogconjunctuur de mijnwerkers keuzes konden maken. ${ }^{78}$

Het leidende principe in het ontslagbeleid van de mijndirecties was dat Nederlandse arbeiders zoveel mogelijk werden ontzien. Wat dat 'zoveel mogelijk' betekende, deed de Hoofdingenieur der Mijnen in 1933 uit de doeken: 'Nederlanders [moeten slechts] wijken voor die buitenlanders, welke door hun speciale taak of door hun bijzondere geschiktheid

\footnotetext{
73 Jac. Jacobs, Het gouden boek der K.A.B. Limburg 1900-1950. Vifftig jaren arbeidersbeweging in Limburg (Heerlen z.j.).

74 Ook initiatieven van de protestantse zuil werden door de mijnen gesteund, zij het meestal veel minder royaal dan de katholieke organisaties. Peet en Rutten, Oranje-Nassau Mijnen, Ioo.

75 Erik Nijhof, Jan Boersma en Gertjan de Groot, 'Regions in transition. An interregional comparison of industrialization, labour market and labour movenment in the Netherlands', TuSG XVIII nummer 2/3 (I992) 294-3II, aldaar 304.

76 Zie voor een bespreking van het debat: Gales en Van Royen, 'Fabrikanten', I53-16o. Zie ook: Ben Gales, 'Houwen en stof bijten? Maakbaarheid in een mijnstreek', SSEGL XLV (2000) 27-64, aldaar 38-47.

77 Vromen, 'Personeelsbeleid', 32.

78 Knotter, 'Inleiding', 17.
} 
moeilijk of niet kunnen worden gemist of wegens andere billijke redenen behoren te worden gehandhaafd'. ${ }^{79}$ Geschiktheid voor het mijnbedrijf speelde dus een belangrijke rol. De mijndirecties maakten van de gelegenheid gebruik zich te ontdoen van minder gewenste arbeiders. Ongewenst waren zij die veel ziek waren of verzuimden, een nevenberoep hadden, wangedrag vertoonden, communistische sympathieën koesterden, zedelijk ongunstig bekend stonden of te weinig presteerden. ${ }^{80}$ 'De eerste honderd die op straat gezet werden, waren kneuzen', merkte C. Raedts, destijds bedrijfsingenieur bij de Oranje-Nassau Mijnen, veel later op. ${ }^{8 \mathrm{r}}$ Intern maakte de bedrijfsleiding van de Oranje-Nassau Mijnen er geen geheim van dat minder geschikte arbeiders ontslagen waren en dat dat beleid had bijgedragen aan een verbetering van de arbeidsproductiviteit. ${ }^{82}$ Volgens Kreukels hadden de particuliere mijnen een grotere neiging om minder gewenste arbeiders te ontslaan dan Staatsmijnen, al maakte ook het staatsbedrijf zeker een selectie op basis van geschiktheid. ${ }^{83}$

Zoals in tabel 6.3 blijkt, ontsloegen zowel Staatsmijnen als Oranje-Nassau Mijnen tijdens de crisisjaren meer buitenlanders dan Nederlanders, hoewel in aantallen de verschillen klein waren. Relatief gezien waren de ontslagen onder de buitenlanders bij Staatsmijnen echter van groter gewicht, omdat de personeelsbezetting er traditioneel minder niet-Nederlanders telde dan bij de particuliere mijnen. Het beleid bij Staatsmijnen was er in het algemeen meer op gericht om Nederlanders voor het bedrijf te behouden. ${ }^{84}$ Zo nam bij de Oranje-Nassau Mijnen het percentage Nederlanders tussen 1930 en 1935 toe van 55 naar 63 procent. ${ }^{85} \mathrm{Bij}$ Staatsmijnen daarentegen steeg dat percentage in dezelfde jaren van 78 naar $9{ }^{8}{ }^{86}$

Naarmate de crisis langer duurde, nam het aantal ontslagen Nederlanders verhoudingsgewijs toe. In 1932 was bij Staatsmijnen 45 procent van de ontslagen arbeiders Nederlander; in 1935 was dat percentage opgelopen tot 5I. Bij Oranje-Nassau Mijnen was het beeld vergelijkbaar: in I932 was 35 procent van de ontslagenen Nederlander, in I935 49 procent. In de loop van de depressiejaren konden de mijnen, in belang van het bedrijf, steeds minder buitenlanders ontslaan en waren in toenemende mate ook Nederlanders aan de beurt bij gedwongen ontslagen.

TAbel 6.3 Nationaliteit van De ontslagen arbeiders bij StaAtsmijnen EN DE ORANJE-NASSAU MIJNEN, I932-I935

\begin{tabular}{|l|c|c|c|c|c|c|c|c|c|c|}
\hline & \multicolumn{2}{|c|}{1932} & \multicolumn{2}{c|}{1933} & \multicolumn{2}{c|}{1934} & \multicolumn{2}{c|}{1935} & \multicolumn{2}{c|}{ totaal } \\
& SM & ON & SM & ON & SM & ON & SM & ON & SM & ON \\
\hline Nederlanders & 675 & 607 & 537 & 508 & 725 & 756 & 539 & 415 & 2.476 & 2.286 \\
\hline buitenlanders & $8 \mathrm{I} 8$ & I.II7 & 763 & 593 & 602 & $8 \mathrm{I} 7$ & 503 & 401 & 2.686 & 2.928 \\
\hline
\end{tabular}

Bron: Vromen, 'Personeelsbeleid' (SHCL, ArchiefGSL, nr I706: Grensverkeer vreemde mijnwerkers, 1939).

79 Jaarverslag van den Hoofdingenieur der Mijnen over het jaar 1933, 28.

8o Vromen, 'Personeelsbeleid', 78.

8I Raedts deed die uitspraak omstreeks I980 in een interview met de sociologen Paul Brassé en Willem van Schelven. Geciteerd

in: Brassé en Van Schelven, Assimilatie, I6I.

82 Peet en Rutten, Oranje-Nassau Mijnen, I8I.

83 Kreukels, Mijnarbeid, $4 \mathrm{I} 6$.

84 Gedenkboek Staatsmijnen, go.

85 RHCL, ArchiefOranje-Nassau Mijnen J46: Centraal Personen Register.

86 Staatsmijnen in Limburg. Jaarverslagen over het jaar 1930 en 1935. 
De belangrijkste verklaring voor het buitenproportioneel hoge ontslagpercentage onder vreemdelingen is de vaste-stampolitiek van de mijnondernemingen, die in de jaren dertig voor het eerst succes leek te hebben. Ontslag van buitenlandse mijnwerkers was daarin een belangrijk element, omdat hun arbeidsmarktgedrag vaak precies het tegenovergestelde was van wat de mijnen graag zagen. Buitenlandse mijnwerkers hadden zich in het verleden vaak geprofileerd als een zeer mobiele groep, die nergens lang bleef. Het streven van de mijndirecties was er vanouds op gericht een vaste kern van mijnwerkers op te bouwen: arbeiders, met vrouw en kinderen geworteld in de regio en met het voornemen een functie bij de mijnonderneming te beschouwen als blijvend middel van bestaan. Mijnwerkerszonen zouden als vanzelfsprekend in de voetsporen van hun vader treden en ook mijnwerker worden. In 1929 had Staatsmijndirecteur W. Frowein het standpunt van de mijnen nog eens onder woorden gebracht: '[...] Voor het aankweeken van een vasten mijnwerkersstam, waaraan de mijnen zoveel gelegen is, is de indienstneming van buitenlandschen arbeiders geenszins bevorderlijk, omdat dergelijke arbeiders over het algemeen na korteren of langeren tijd weer verdwijnen' ${ }^{87}$ De mijndirecties waren sinds de wervingsacties in het buitenland van de tweede helft van de jaren twintig overigens mede debet aan het tijdelijke karakter van het dienstverband van vreemdelingen, omdat die doorgaans een arbeidscontract voor bepaalde tijd kregen. Ook grensarbeiders werden in het algemeen niet beschouwd als behorend tot de vaste stam van mijnwerkers. ${ }^{88}$ De ervaring had geleerd dat de aanwezigheid van grensarbeiders vaak het gevolg was van valutaverschillen aan deze en gene zijde van de grens. Wanneer die verschillen nivelleerden, was het voor deze groep arbeiders financieel niet meer interessant om hun baan in het buitenland te continueren.

De preferenties wat betreft de personeelsvoorziening betekenden dat de groep arbeiders die niet paste in de vaste-stampolitiek van de mijnondernemingen de grootste kans liep voor ontslag in aanmerking te komen. Net als bij de Nederlanders het geval was, vielen onder de buitenlandse mijnwerkers de eerste ontslagen bij degenen met een smetje: arbeiders die regelmatig willekeurig verzuimden of om een of andere reden ongunstig bekend stonden. Verder werden de tijdelijke arbeidscontracten van degenen die eind jaren twintig in het buitenland waren gerekruteerd, niet verlengd. ${ }^{89}$ Polen, Italianen, Oostenrijkers en Joegoslaven werden van dit beleid de dupe. Tabel 6.4 makt de relatie tussen enerzijds nationaliteit en anderzijds lengte van het dienstverband bij ontslag in de eerste helft van de jaren dertig duidelijk. In het algemeen hadden buitenlanders bij ontslag een kortere diensttijd bij de mijnen dan Nederlanders.

Ook grensarbeiders werden vanaf het begin van de ontslagrondes relatief vaak ontslagen. Uit grafiek 5. Io bleek dat tussen eind 1930 en eind 1935 het aantal grensarbeiders decimeerde van I.504 naar I86, een afname van 88 procent, veel meer nog dan de daling van de buitenlandse bezetting als geheel. In de tweede helft van de jaren dertig ging de uittocht van grensarbeiders gewoon door, vooral die van bewoners van het Duitse grensgebied. Hoogstwaarschijnlijk was bij deze groep sprake van veel vrijwillig vertrek. In het algemeen keerden veel Duitsers onder invloed van de nationaal socialistische politiek van stimulering van de conjunctuur en oorlogsvoorbereiding vrijwillig naar Duitsland en een Duitse werkgever te-

87 Geciteerd bij Vromen, 'Personeelsbeleid', 27.

88 Ibidem, 48.

89 Kreukels, Mijnarbeid, 4I4-4I5. 
TABEl 6.4 De DUUR VAN HET DIENSTVERBAND EN HET MOMENT VAN IN DIENSTTREDING VAN IN DE PERIODE I-I-I93I TOT EN MET 3I-I2-I935 ONTSLAGEN MIJNWERKERS

\begin{tabular}{|l|c|c|c|c|c|}
\hline & $\mathbf{t} / \mathbf{m} \mathbf{5}$ jaar & $>\mathbf{5}$ jaar & $\begin{array}{c}\text { in dienst } \\
\text { vóór } \\
\text { I-I-I925 }\end{array}$ & $\begin{array}{c}\text { in dienst } \\
\text { tussen } \\
\mathbf{I}-\mathbf{I}-\mathbf{I} 925 \\
\mathbf{3} \text {-I2-I930 }\end{array}$ & $\mathbf{n}$ \\
\hline Nederlanders & $\mathrm{I} 8 \%$ & $82 \%$ & $73 \%$ & $27 \%$ & 45 \\
\hline buitenlanders & $68 \%$ & $32 \%$ & $\mathrm{II} \%$ & $89 \%$ & 38 \\
\hline
\end{tabular}

Bron: Steekproef uit lidmaatschapskaarten AMF. Zie ook bijlage 8 .

rug. ${ }^{\circ}$ Samen met een categorie mijnwerkers - ongeacht nationaliteit - die om verschillende redenen niet langer gewenst was (zie hoofdstuk 4), vormden de buitenlanders die kort tevoren waren geworven en de grensarbeiders de eerste buffer, die de neerwaartse tendens in de werkgelegenheid moesten opvangen.

Ook de herkomst binnen Nederland vormde een ontslagcriterium. Dat is af te leiden uit de gegevens omtrent de geboorteplaatsen van de Nederlandse arbeiders in de mijnen. De absolute daling van het aantal geboren Limburgers bij de mijnen tijdens de crisisjaren was met 439 man (2,7 procent) gering. Van de Nederlanders werd de groep die buiten Limburg was geboren, het zwaarst getroffen. De sterkte van deze groep mijnwerkers nam af met 8I4 man (I3,9 procent). ${ }^{9 \mathrm{r}}$ Volgens Vromen droegen de slechte ervaringen die de mijndirecties in de jaren twintig in het algemeen hadden opgedaan met Nederlandse mijnwerkers van buiten Limburg (zie hoofdstuk 4) er toe bij dat dezen van de Nederlanders het eerst afvloeiden. ${ }^{92}$ Maar waarschijnlijk speelde ook de wens van de mijndirecties een rol om een gezeten arbeidersstam van geboren en getogen Limburgers te vormen, arbeiders waarvan men mocht verwachten dat ze niet snel weg zouden gaan en een lange carrière als mijnwerker ambieerden.

Behalve op nationaliteit en herkomst berustte het ontslagbeleid van de mijndirecties op gezinspolitiek. De 'billijke redenen' waarover de Hoofdingenieur in 1933 sprak bij het in dienst houden van buitenlandse mijnwerkers, hadden met dat tweede uitgangpunt te maken. Buitenlandse mijnwerkers die met een Nederlandse vrouw waren getrouwd en in de mijnstreek een gezin hadden gesticht, mochten in principe blijven. Toen in toenemende mate ook Nederlanders werden ontslagen, werd het criterium van gezinspolitiek steeds belangrijker. In oktober 1933 stelde bedrijfsingenieur J. Bakker aan de directie van Staatsmijnen voor, bij ontslag jonge, ongehuwde arbeiders die geen kostwinners waren, het eerst te laten afvloeien. Ontslag zou aldus het minste maatschappelijke leed veroorzaken. Pas in tweede instantie zou volgens hem moeten worden gedacht aan oudere arbeidskrachten. ${ }^{93}$

Een verband tussen deze gezinspolitiek en het streven naar binding aan het bedrijf was zeker ook aanwezig. Men nam aan dat mijnwerkers met een gezin meer geworteld in de re-

90 Vromen, 'Personeelsbeleid', 39.

9I Jaarverslagen AMF over [I930-I935].

92 Vromen, 'Personeelsbeleid', 40.

93 Kreukels, Mijnarbeid, $4 \mathrm{I} 5$. 
gio waren dan ongebonden arbeidskrachten. Bovendien waren gehuwde mijnwerkers met zonen voor de mijnen ook op de lange termijn essentieel voor de vorming van een mijnwerkerstraditie die van generatie op generatie zou worden overgedragen. Het gevolg van de gezinspolitiek als criterium voor ontslag blijkt uit de tabellen 6.5 en 6.6.

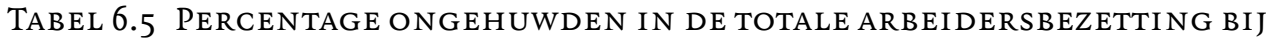
DE NEDERLANDSE STEEN KOLENMIJNEN, I920-I965

\begin{tabular}{|c|c||c|c|}
\hline & \% ongehuwd & & \% ongehuwd \\
\hline I920 & 40,5 & I945 & $3 \mathrm{I}, \mathrm{I}$ \\
\hline $\mathrm{I} 925$ & 39,6 & $\mathrm{I} 950$ & $3 \mathrm{I}, 6$ \\
\hline $\mathrm{I} 930$ & 36,8 & $\mathrm{I} 955$ & 30,9 \\
\hline $\mathrm{I} 935$ & 28,5 & $\mathrm{I} 960$ & 25,8 \\
\hline I940 & 36,6 & $\mathrm{I} 965$ & 20,6 \\
\hline
\end{tabular}

Bron: I920-I945: Jaarverslagen AMF; I950-I965: Tabellen en grafieken MIR.

Tussen 1930 en 1935 nam het percentage ongehuwde mijnwerkers met ruim 8 procent af. Een logisch gevolg van het ontslag van deze categorie arbeiders was, dat de personeelsbezetting verouderde. Zo nam het percentage ondergronders ouder dan 30 jaar tussen 1929 en 1934 met 13 procentpunt toe. Pas aan de vooravond van de aankondiging van de mijnsluitingen, midden jaren zestig, zou dat percentage weer worden bereikt.

Tabel 6.6 Categorie 30-Plussers als percentage van de totale onderGRONDSE ARbEIDERSBEZETTING BIJ DE NederlandSE STEENKOLENMIJNEN, IgI9-Ig64

\begin{tabular}{|c|c||c|c|}
\hline & \% 30-plus & & \% 30-plus \\
\hline I919 & 45,2 & I944 & 50,2 \\
\hline I924 & 44,5 & I949 & 53,7 \\
\hline I929 & 47, I & I954 & 54,6 \\
\hline I934 & 60,3 & I959 & 59,0 \\
\hline I939 & 54,4 & I964 & 66,8 \\
\hline
\end{tabular}

Bron: I9I9-I954: Jaarverslagen AMF; I959-I964: Verslagen GSL aan MIR.

De veroudering van het personeel had nadelen. In 1936 verklaarden de particuliere mijnen dat het ontslagbeleid een 'geenszins gewenschte veroudering van haar personeel tengevolge had'. ${ }^{4}$ Voor de mijndirecties was het financieel ongunstig, met name omdat oudere mijnwerkers verhoudingsgewijs meer ziek waren. Tijdens en na de crisis zouden de mijnen vooral jonge Limburgse arbeiders in dienst nemen. In I939 was het percentage 'ouderen' weer met ruim 6 procent gedaald ten opzichte van vijf jaar eerder. 
Ook dat wervingsbeleid was ingegeven door de wens een gezeten arbeidersstam te creëren. De leesjongensopleiding speelde in dat beleid een prominente rol. ${ }^{95} \mathrm{Bij}$ de oprichting van de leesjongensopleiding eind 1928 was een van de doelstellingen geweest het ontslagpercentage terug te dringen. ${ }^{6}$ Dat beleid was zowel op korte als lange termijn succesvol. In de jaren I930 was het verloop onder de leerlingen van de opleiding relatief laag (tabel 6.7).

TABEL 6.7 Het JAARLIJKSE VERTREKPERCENTAgE Bij DE LEESJONGENSOPLEIDING VAN STAATSMIJNEN (ALS PERCENTAGE VAN HET TOTALE AANTAL IN OPLEIDING IN HET BETREFFENDE JAAR) EN BIJ DE AMF-LEDEN, I929-I944

\begin{tabular}{|c|c|c|c|}
\hline & $\begin{array}{l}\text { bezetting opleiding } \\
\text { per } 3 \mathrm{I}-12\end{array}$ & $\begin{array}{l}\text { vertrekpercentage } \\
\text { leesjongens }\end{array}$ & $\begin{array}{c}\text { vertrekpercentage } \\
\text { AMF-leden }\end{array}$ \\
\hline 1929 & IIO & I2 & I8 \\
\hline 1930 & 453 & $\mathrm{I} 2$ & $\mathrm{I} 4$ \\
\hline I93I & 649 & 8 & 8 \\
\hline 1932 & 805 & IO & II \\
\hline I933 & 822 & 7 & Io \\
\hline I934 & 864 & 7 & I3 \\
\hline I935 & 946 & 7 & 8 \\
\hline 1936 & 982 & 3 & 4 \\
\hline I937 & I. 253 & 4 & 4 \\
\hline 1938 & I. 512 & 3 & 5 \\
\hline I939 & I. 676 & 4 & 4 \\
\hline I940 & I.906 & 4 & 4 \\
\hline I94I & 2.074 & IO & 6 \\
\hline I942 & 2.194 & IO & 5 \\
\hline I943 & 2.018 & I3 & 6 \\
\hline I944 & I. $8 \mathrm{I} 7$ & 20 & I9 \\
\hline
\end{tabular}

Bron: Ritt, Statistische gegevens, 6, 30; Jaarverslagen AMF; zie ook bijlage I9.

Eenmaal ondergronds geplaatst, was de binding aan het bedrijf van de ex-leesjongens groter dan dat van hun collega's die zonder vooropleiding ondergronds bij de mijnen in dienst waren getreden (tabel 6.8).

Na vijf jaar ondergrondse dienst bleek een belangrijk ijkpunt te zijn bereikt. De leesjongens die rond hun achttiende verjaardag ondergronds gingen, waren na vijf jaar doorgaans opgeklommen tot houwer. Wanneer ze die functie hadden bereikt, was de kans dat ze het bedrijf nog zouden verlaten klein geworden. Men had een relatief hoog loon bereikt dat in een andere werkkring moeilijk meer gehaald kon worden. Bovendien was het beroep van houwer exclusief gebonden aan de mijnbouwsector, zodat vertrek betekende dat elders een

95 Zie ook hoofdstuk 4.

96 Ritt, Statistische gegevens, 30. Speciaal voor de leesjongens gaf Staatsmijnen tussen I929 en 1942 het blad Stukkool uit. 
TABEL 6.8 HET OVERLEVINGSPERCENTAGE NA 5 JAAR BIJ EX-LEESJONGENS EN AMF-LEDEN, I929-I944

\begin{tabular}{|l|c|c|c|}
\hline & $\begin{array}{c}\text { leesjongens onder- } \\
\text { gronds geplaatst }\end{array}$ & $\begin{array}{c}\text { overlevingspercentage } \\
\text { ex-leesjongens na 5 jaar }\end{array}$ & $\begin{array}{c}\text { overlevingspercentage } \\
\text { AMF-leden na 5 jaar }\end{array}$ \\
\hline $\mathrm{I} 929$ & 55 & $7 \mathrm{I}$ & 32 \\
\hline $\mathrm{I} 930$ & $\mathrm{I} 87$ & 76 & $3 \mathrm{I}$ \\
\hline $\mathrm{I} 93 \mathrm{I}$ & $\mathrm{I} 86$ & 73 & $4 \mathrm{I}$ \\
\hline $\mathrm{I} 932$ & 259 & 79 & 54 \\
\hline $\mathrm{I} 933$ & $28 \mathrm{I}$ & 79 & 62 \\
\hline $\mathrm{I} 934$ & 315 & 78 & 73 \\
\hline $\mathrm{I} 935$ & 359 & 84 & 74 \\
\hline $\mathrm{I} 936$ & 375 & 83 & 76 \\
\hline $\mathrm{I} 937$ & $4 \mathrm{I} 8$ & 82 & 77 \\
\hline $\mathrm{I} 938$ & 369 & 84 & 77 \\
\hline $\mathrm{I} 939$ & 363 & 84 & 64 \\
\hline $\mathrm{I} 940$ & 405 & $7 \mathrm{I}$ & 56 \\
\hline $\mathrm{I} 94 \mathrm{I}$ & 656 & 58 & 37 \\
\hline $\mathrm{I} 942$ & 362 & 55 & 32 \\
\hline $\mathrm{I} 943$ & $2 \mathrm{I} 8$ & 50 & 57 \\
\hline $\mathrm{I} 944$ & $\mathrm{II} 9$ & 53 & \\
\hline
\end{tabular}

Bronnen: Ritt, Statistische gegevens, 46-48; Jaarverslagen AMF; zie ook bijlage I8.

TABel 6.9 Het Rendement VAN Bij de StAatsmijnzetels Wilhelmina en HENDRIK IN DIENST GETREDEN ONDERGRONDERS ZONDER INTERNE VOOROPLEIDING ('VOLWASSENEN') EN EX-LEESJONGENS/EX-OVS-ERS, I929-I96I

\begin{tabular}{|c|c|c|}
\hline & $\begin{array}{l}\text { volwassenen, ondergronds } \\
\text { in dienst getreden } 1929 \mathrm{t} / \mathrm{m} 1961\end{array}$ & $\begin{array}{l}\text { hiervan nog bij de mijnzetel } \\
\text { ondergronds op 3I-I2-I96I }\end{array}$ \\
\hline SM Wilhelmina & 7.170 & $22 \%$ \\
\hline SM Hendrik & II. 920 & $17 \%$ \\
\hline
\end{tabular}

\begin{tabular}{|l|c|c|}
\hline & $\begin{array}{c}\text { ex-leesjongens, ondergronds } \\
\text { in dienst getreden } \mathbf{1 9 2 9} \mathbf{t} / \mathbf{m} \mathbf{~ 1 9 6 \mathbf { I }}\end{array}$ & $\begin{array}{c}\text { hiervan nog bij de mijnzetel } \\
\text { ondergronds op 32-I2-196I }\end{array}$ \\
\hline SM Wilhelmina & I.I35 & $40 \%$ \\
\hline SM Hendrik & I.607 & $35 \%$ \\
\hline
\end{tabular}




\begin{tabular}{|c|c|c|}
\hline & $\begin{array}{l}\text { ex-leesjongens en ex-OVS-ers, } \\
\text { ondergronds in dienst getreden } \\
1929 \mathrm{t} / \mathrm{m}{ }_{1961}\end{array}$ & $\begin{array}{l}\text { hiervan nog bij de mijnzetel } \\
\text { ondergronds op 3I-I2-I96I }\end{array}$ \\
\hline SM Wilhelmina & 2.157 & $48 \%$ \\
\hline SM Hendrik & 2.767 & $45 \%$ \\
\hline
\end{tabular}

Bron: Ritt, Statistische gegevens, 67-7I.

carrière van voor af aan moest worden opgebouwd. Voorts was van belang dat veel mijnwerkers rond hun $23^{\mathrm{e}}$ levensjaar, dus ook na een dienstverband van een jaar of vijf, een gezin stichtten een ook daardoor niet gauw meer van werkkring veranderden. ${ }^{97}$

In het begin van de jaren I96o werd in een onderzoek bij de staatsmijnzetels Wilhelmina en Hendrik de diensttijd van ex-leesjongens vergeleken met die van ondergronders die zonder een interne vooropleiding in dienst waren gekomen (tabel 6.9). Het rendement van de ex-leesjongens bleek bij beide mijnzetels ongeveer het dubbele. Wanneer ook de voormalige leerlingen van de Ondergrondse Vakscholen (die vanaf 1945 de leesjongensopleidingen vervingen) in de cijfers worden betrokken, blijkt de waarde van de interne opleidingen voor de binding aan het bedrijf nog duidelijker.

\section{Bezetting en nasleep}

Voor een deel van de arbeidskrachten die tijdens de bezettingsjaren bij de mijnen in dienst traden, was mijnarbeid uit nood geboren. De mijn was een toevluchtsoord om uit handen van de Duitsers te blijven. Het personeelsverloop bleef tijdens de jaren I940-I943 dan ook relatief laag. Wanneer er ontslag plaatsvond, gebeurde dat voornamelijk door het bedrijf, al dan niet onder druk van de Duitse toezichthouder (zie hoofdstuk 4). De min of meer gedwongen keuze voor mijnarbeid deed de binding aan het bedrijf van deze groep geen goed. Dat bleek toen bij de bevrijding in september 1944 duizenden arbeidskrachten om uiteenlopende redenen de mijnen verlieten. Alleen al in september I 944 verschenen 6.000 mijnwerkers niet meer op hun werk. ${ }^{8}$

Bij veel arbeiders bestond een zekere afkeer van het werk in de mijn, hetgeen voor een groot deel bepaald was door de grote prestatiedruk die het werk gedurende de jaren van crisis en oorlog had gekenmerkt. Het vertrek uit de mijn werd gestimuleerd doordat de aanwezigheid van Amerikaanse troepen in de regio alternatieve werkgelegenheid bood. Anderen meldden zich aan als oorlogsvrijwilliger.

Naast deze vrij algemene depreciatie van mijnarbeid hadden specifieke groepen mijnwerkers hun eigen redenen om weg te blijven. Een groep van circa duizend arbeiders had geen keus. Zij konden de mijnen niet bereiken, hetzij doordat ze in het nog niet bevrijde deel van Limburg woonden, hetzij door gebrek aan vervoersmiddelen. Het grootste deel van

97 Ritt, Statistische gegevens, $5 \mathrm{I}$.

98 Jaarverslag van het Gewestelijk Arbeidsbureau Heerlen 1945, 24-25. 
deze groep verscheen weer op het werk toen de situatie in de loop van de volgende maanden normaliseerde. Een gedwongen karakter had het vertrek van Rijksduitsers, NSB-ers en (vermeende) collaborateurs. Zij werden voorlopig niet meer op de mijnen toegelaten. ${ }^{99}$

\section{WEDEROPBOUW, 1945-1965}

\section{Binding, conjunctuur en arbeidsmarkt}

Als algemene verklaring voor de stijging van het verloop in de naoorlogse jaren wordt in contemporaine rapporten vaak gewezen op de toenemende aanwezigheid van alternatieven op de arbeidsmarkt. ${ }^{\mathrm{I00}} \mathrm{Op}$ kortdurende conjuncturele neergang in de jaren $195 \mathrm{I}-\mathrm{I} 95^{2}$ en $1957-1958$ na, kon in de periode tot 1965 de arbeidsmarkt als krap tot zeer krap worden beschouwd. In die situatie deed zich het mechanisme voor dat arbeidskrachten het werk in de mijn verruilden voor een baan in een andere sector. ${ }^{101}$ Uit onderzoek naar het personeelsverloop bij de Oranje-Nassau Mijnen bleek dat van degenen die vertrokken 83 procent zijn beroepscarrière voortzette buiten de mijnbouwsector. Van hen koos 29 procent voor fabrieksarbeid, vond 9 procent een nieuwe baan in de bouw en ging 5 procent werken als losse arbeider. De rest vond emplooi in een groot aantal verschillende beroepen of werd werkloos. ${ }^{\text {102 }}$

De neiging tot vertrek gold met name voor beginnende en nog niet geheel geschoolde mijnwerkers. De binding aan de mijn was in het algemeen het grootst bij houwers, volledig opgeleide arbeidskrachten. De GSL onderzocht het personeelsverloop in de maanden april tot september $1957 \cdot{ }^{103}$ In het onderzoek werd gedifferentieerd naar de functies van postsleper, hulphouwer en houwer, de carrièregang die na indiensttreding in het ondergrondse bedrijf gebruikelijk was. In de maanden waarover het onderzoek zich uitstrekte, werden in deze drie groepen in totaal $\mathrm{I.I8} 9$ arbeidskrachten ontslagen.

TABel 6.Io Verloop en GeSCHOOldheid in DE GEZAMENLIJKE NEDERLAN DSE STEEN KOLENMIJNEN, I957

\begin{tabular}{|l|c|c|}
\hline & Aandeel in deze groep & Aandeel in ontslagenen \\
\hline houwers & $56,2 \%$ & $36,9 \%$ \\
\hline hulphouwers & $26,3 \%$ & $25,8 \%$ \\
\hline postslepers & $21,1 \%$ & $37,3 \%$ \\
\hline totaal & $100,0 \%$ & $\mathbf{1 0 0 , 0} \%$ \\
\hline
\end{tabular}

Bron: Eigen berekening op basis van Bardoul, Personeelsverloop, I9.

99 Jaarverslag van den Inspecteur-Generaal der Mijnen over de jaren 1940-1945, 9-10.

Ioo Zie bijvoorbeeld de jaarlijkse Arbeidsmarktbeschrijvingen van de Provincie Limburg van het Districtsbureau voor de Arbeidsvoorziening. In de periode tot 1958 en in de jaren na I96r werd vrijwel jaarlijks geklaagd over het grote verloop van arbeidskrachten bij de steenkolenmijnen, wat werd beïnvloed door de zeer gunstige werkgelegenheid in de mijnstreek in andere bedrijfstakken. Zie ook: Segers, Personeelsuerloop, I68-173.

I0I Roemen e.a., Verkenning, I02.

102 Reumkens, Onderzoek, 59-6o.

I03 Bardoul, Personeelsverloop, I9. 
Uit tabel 6.ro blijkt duidelijk de relatie tussen het verloop en de mate van geschooldheid. De postslepers - de aanvangsfunctie in het ondergrondse bedrijf - namen relatief het vaakste ontslag. Dit hing niet alleen samen met het algemene verschijnsel dat het verloop het grootst was in de eerste maanden van het dienstverband, wanneer de aanpassingsproblemen van de nieuwkomers het grootst waren, maar ook met het feit dat de mijnwerker op dat moment nog nauwelijks had geïnvesteerd in het volgen van een bedrijfsopleiding en daardoor weinig belemmeringen voelde om te vertrekken. ${ }^{104}$ Onder de houwers daarentegen was het ontslagpercentage geringer dan op grond van hun aandeel in de personeelsbezetting mocht worden verwacht. Zij behoorden tot een categorie mijnwerkers die doorgaans al langer in het mijnbedrijf aanwezig was. Pas wanneer een arbeider drie à vier ondergrondse jaren had en 22 of 23 jaar oud was, kon hij tot het houwersexamen worden toegelaten. ${ }^{105}$ Dat betekende dat een houwer al een carrière had gemaakt die hij opgaf wanneer hij uit de mijnbouwsector vertrok. Een houwer kon zijn specifieke beroepskwalificatie alleen in de mijnbouw te gelde maken.

Het onderzoek naar het personeelsverloop van Segers bevestigt deze conclusie. Hij constateerde dat de groep ondergronders die langer dan 58 maanden in de mijnbouwsector werkzaam was, een veel lager dan gemiddeld ontslagpercentage vertoonde. Bij mijnwerkers die langer dan twaalf jaar ondergronds werkten, kwam zelfs nagenoeg geen mobiliteit meer voor. Vooral gold dat voor mijnwerkers die ouder waren dan 35 jaar. Volgens Segers waren er voor deze groep weinig alternatieven op de arbeidsmarkt, te meer daar een aanzienlijk deel van deze oudere mijnwerkers in functie bleek teruggezet, wat verwijst naar een zekere mate van arbeidsongeschiktheid. ${ }^{\text {106 }}$

\section{Lonen en arbeidsverloop}

De aandrang om de mijn vaarwel te zeggen werd groter naarmate in de loop van de jaren vijftig de mijnbouwsector zijn voorsprong in loonniveau zag afnemen. ${ }^{107}$ Lonen in de mijnbouw en in andere industriële sectoren vertoonden een convergerende tendens, hetgeen de concurrentiepositie van de mijnen op de arbeidsmarkt deed afnemen. ${ }^{\text {108 }}$

Door de exclusieve relatie van het houwersberoep met de mijnbouwsector was niet zozeer het naar elkaar toegroeien van de brutolonen van de houwer en de gemiddelde geschoolde arbeider in de nijverheid bepalend voor het verloop. Belangrijker waren de afnemende loonverschillen van beginnende mijnwerkers in vergelijking met ongeschoolde fabrieksarbeiders. Fabrieksarbeid was het onmiddellijke alternatief, waarvoor de beginnende ongeschoolde postsleper zich zag geplaatst. Uit tabel 6.I2 blijkt dat de relatieve loonpositie van de postsleper in verhouding tot de ongeschoolde arbeider in de nijverheid al in de jaren I95I-I954 werd aangetast. Terwijl het indexcijfer van het gemiddelde salaris voor

I04 Roemen e.a., Verkenning, 76-77.

I05 Wolf, Mijnbouw, 76 .

Io6 Segers, Personeelsverloop, 77-78.

I07 Messing, Geschiedenis van de mijnsluiting, 84-85, I64; zie ook J.M.G. Pieters, Lonen en bedrijfsresultaten bij de Nederlandse steenkolenmijnondernemingen in de Gemeenschappelijke Steenkolenmarkt van de EGKS (proefschrift, Rotterdam I98I) 2I5 en tabellen XIV.2, 366 en XIV.3, 367 .

I08 Het vergelijken van lonen is een hachelijke zaak. In de praktijk was sprake van differentiëring naar leeftijdsstructuren, geschooldheid, gemiddelde arbeidstijd, etcetera. Wat de verhouding tussen mijnwerkers en overige industriearbeiders betreft, kwam daar nog bij het beloningssysteem naar diensten en het akkoordstelsel. Daarnaast bestonden er aanmerkelijke verschillen in sociale lasten, toeslagen en secundaire arbeidsvoorwaarden, zoals de verstrekking van deputaatkolen aan de mijnwerkers. Hier wordt slechts een globale tendens gepresenteerd. 
TABEL 6.II INDEXCIJFERS VAN GEMIDDELD VERDIENDE BRUTOLONEN VAN VOLWASSEN MANNELIJKE ARBEIDERS IN DE NIJVERHEID EN VAN HET ONDERGRON DSE MIJNPERSONEEL, I95I-I954

\begin{tabular}{|l|c|c|c|c|c|}
\hline \multirow{2}{*}{} & \multicolumn{3}{|c|}{ weeklonen productiearbeiders nijverheid } & \multicolumn{2}{c|}{$\begin{array}{c}\text { ondergronds personeel } \\
\text { verdiend loon per dienst }\end{array}$} \\
& geschoolden & geoefenden & ongeschoolden & totaal & houwers \\
\hline I95I & I00 & I00 & I00 & I00 & I00 \\
\hline I952 & I02 & I04 & I04 & I02 & I04 \\
\hline I953 & I06 & I06 & I06 & I03 & I05 \\
\hline I954 & I23 & I23 & I23 & II3 & II4 \\
\hline
\end{tabular}

Bron: Roemen, Verkenning, 83 .

TABEL 6.I2 GEMIDDELD VERDIEND WEEKLOON VAN MANNELIJKE ARBEIDERS IN GULDENS, I95I-I954

\begin{tabular}{|c|c|c|c|c|c|c|c|c|c|}
\hline & \multicolumn{3}{|c|}{$\begin{array}{l}\text { weeklonen van arbeiders } \\
\text { in de nijverheid }\end{array}$} & \multicolumn{4}{|c|}{ gemiddeld verdiend loon per 6 diensten in de mijnbouw } & $\begin{array}{l}\text { in de } \mathrm{m} \\
\text { vengron }\end{array}$ & nbouw \\
\hline & 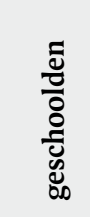 & 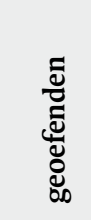 & 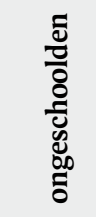 & $\begin{array}{l}0 \\
\vdots \\
\vdots \\
\vdots \\
\vdots\end{array}$ & 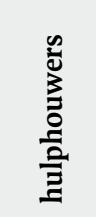 & 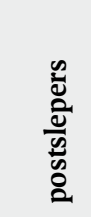 & $\begin{array}{l}\text { चे } \\
\frac{0}{0} \\
\frac{0}{\pi} \\
\frac{\pi}{2}\end{array}$ & 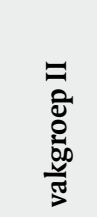 & 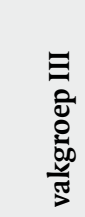 \\
\hline I95I & 61,59 & 56,47 & 53,85 & 92,52 & 85,56 & 72,42 & 67,56 & 59,04 & 53,58 \\
\hline 1952 & 63,47 & 58,46 & 55,79 & • & • & • & • & • & • \\
\hline I953 & 65,46 & 60,02 & 57,20 & 94,30 & 87,78 & 73,02 & 68,94 & 59,70 & 54,12 \\
\hline I954 & 76,35 & 69,57 & 66,18 & 105,48 & 97,86 & 79,32 & 77,94 & 66,24 & 59,58 \\
\hline
\end{tabular}

Bron: Roemen, Verkenning, 84 .

ongeschoolde arbeid steeg van Ioo (I95I) naar I23 (I954), zag de postsleper zijn loon toenemen van IOo (I95I) naar slechts IIo (I954). Voor ongeschoolde bovengronders was de situatie nog ongunstiger. De lonen van de bovengrondse vakgroepen II en III lagen in I954 zelfs al beneden die van ongeschoolde fabrieksarbeiders, zeker wanneer men bedenkt dat in de brutolonen van het mijnpersoneel niet de hoge inhoudingen voor sociale voorzieningen tot uitdrukking kwamen. Weliswaar genoten de mijnwerkers daarvoor bijzondere faciliteiten, zoals een lagere pensioengerechtigde leeftijd ( 55 jaar voor ondergrondse en 60 jaar voor bovengrondse arbeiders) maar daardoor was het nettoloon relatief lager. Voor jonge arbeidskrachten en zeker voor degenen die mijnarbeid als een baan van voorbijgaande aard beschouwden, hadden deze secundaire voordelen weinig waarde. ${ }^{\text {rog }}$ 


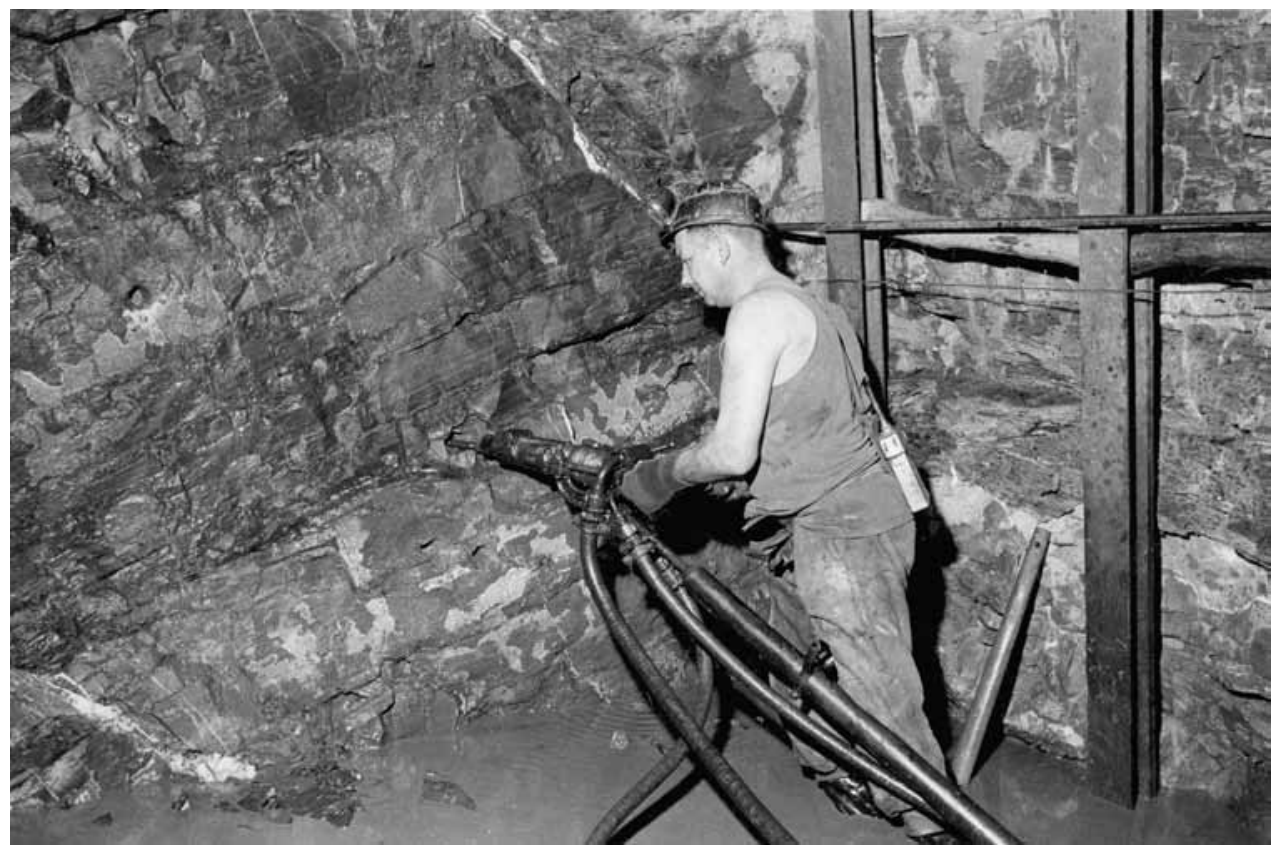

Houwer A. de Jong van de Julia boort een gat in de steenlaag bij de aanleg van een galerij. Vooral na de Tweede Wereldoorlog kwam er meer aandacht voor de gezondheidsrisico's van het werken in een stoffige omgeving. Spoeling met water tijdens het boren moet het steenstof onschadelijk maken. 1956. Bron: Fotocollectie Continium Kerkrade, F3918.

In het algemeen speelde het loon een rol bij het besluit de mijn te verlaten. Dat bleek uit een enquête onder voormalige arbeidskrachten bij de Oranje-Nassau Mijnen. Van alle ondervraagden gaf 15 procent ontevredenheid over het loon op als hoofdreden voor het vertrek. Bardoul kwam tot eenzelfde conclusie op basis van zijn studie naar de achtergronden van het personeelsverloop bij de Julia. ${ }^{\text {IIo }}$ Ook Segers vond dat bij ondergrondse mijnwerkers het loonniveau in vergelijking met dat in andere sectoren een belangrijke rol speelde in de beslissing om de mijn te verlaten. ${ }^{\text {II }}$ Steeds werd benadrukt dat de zeer zware arbeid naar verhouding te slecht betaald werd. De toenemende mechanisatie van de kolenwinning in de jaren na de Tweede Wereldoorlog, die behalve de verhoging van de productie, ook het verlichten van de fysieke belasting van mijnarbeid als doel had, alsmede de toenemende aandacht voor veiligheid en de bestrijding van de risico's op beroepsziekten zoals silicose, hadden dus kennelijk niet geleid tot meer binding aan het bedrijf. ${ }^{\text {II2 }}$

De mijndirecties realiseerden zich in het midden van de jaren vijftig terdege dat de lonen eigenlijk omhoog moesten. ${ }^{\mathrm{Ir} 3}$ Zo constateerde ook Staatsmijnen in 1957 een relatieve achteruitgang van de voorsprong die de arbeidsvoorwaarden van de mijnindustrie hadden ten

IIo Bardoul, Personeelsverloop, 24-25.

III Segers, Personeelsuerloop, I39-I40.

12 H. Muntjewerff, 'Waterinfusie in de Nederlandse steenkolenmijnen (I945-I974)', Erfgoed van Industrie en Techniek V, nummer 2 (I996) 56-64, aldaar 56; zie ook: Messing, Geschiedenis van de mijnsluiting, 64 .

II3 Messing, Geschiedenis van de mijnsluiting, $6_{64}$. 
Een mijnwerker van de Julia strooit calciumchloride in een galerij.

Calciumchloride heeft de eigenschap om water aan de ventilatielucht te onttrekken. Dat water zorgde ervoor dat stofoverlast werd tegengegaan. 1959. Bron: Fotocollectie Continium Kerkrade, F4114.

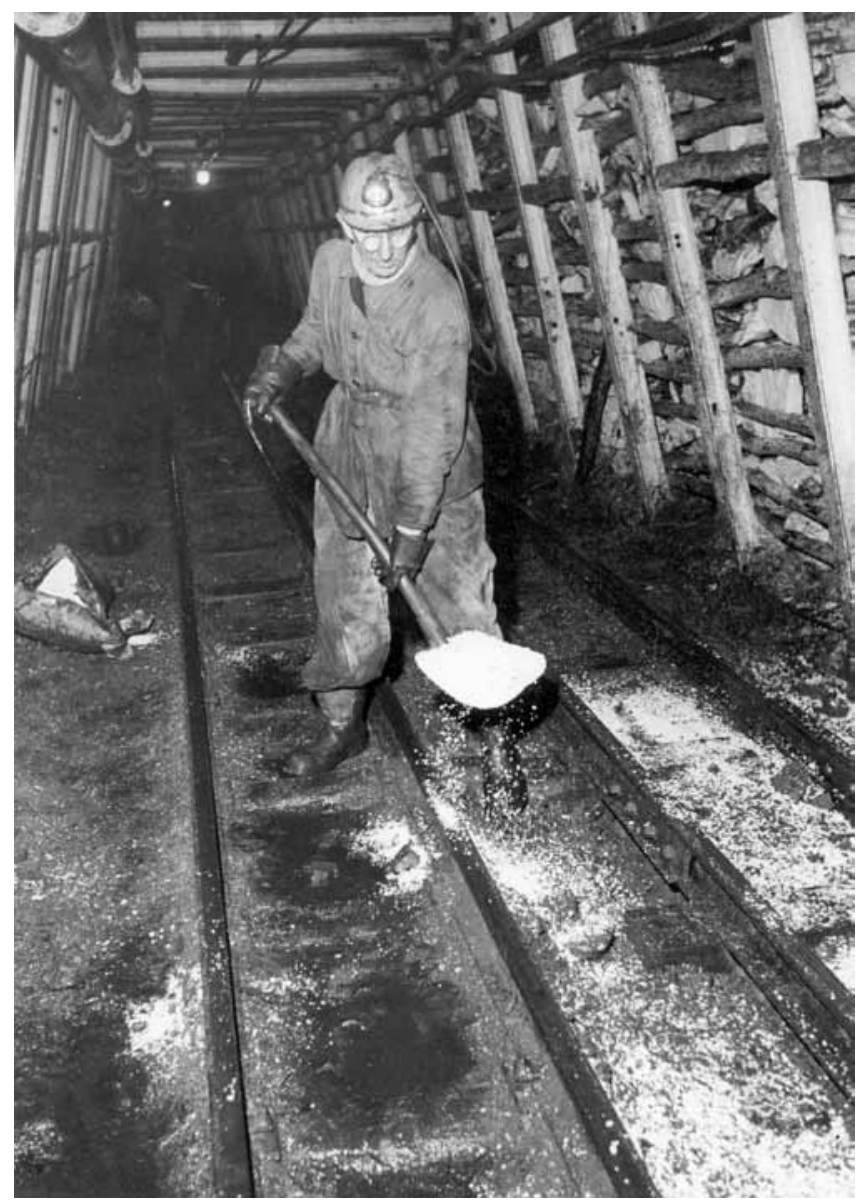

opzichte van andere bedrijfstakken. ${ }^{\text {I4 } 4}$ Door de geleide loonpolitiek van de overheid en de omstandigheid dat de loonkosten zwaar op de bedrijfsresultaten drukten, was het lastig de lonen extra te verhogen. ${ }^{15}$ Uit oogpunt van het vermijden van onderlinge concurrentie tussen de dicht bij elkaar gelegen mijnondernemingen waren de regelingen van lonen en andere arbeidsvoorwaarden in de gehele Nederlandse mijnindustrie gelijk. Na I945 werden ze vastgesteld door de Mijnindustrieraad (MIR), de publiekrechtelijke bedrijfsorganisatie voor het mijnbedrijf, waarin vakbonden en werknemers zitting hadden. ${ }^{116}$ De mijnondernemingen probeerden door het uitkeren van allerlei toeslagen en premies het nettosalaris van de mijnwerkers te verbeteren. ${ }^{117}$ Uit onderzoek bleek dat vooral de door de Rijksoverheid gesubsidieerde zogenaamde aanblijfpremies in 1964 tijdelijk leidden tot een geringe afname

II4 RHCL, Centraal Archief DSM 17.26/o6C, inv. nr. 48: Staatsmijnen afdeling Arbeiderspersoneel, Nota De personeelsvoorziening $1957,2$.

II5 Jan Luiten van Zanden, Een klein land in de $20^{e}$ eeuw. Economische geschiedenis van Nederland 1914-1995 (Utrecht 1997) III e.v. In I959 bijvoorbeeld was bij Staatsmijnen het aandeel van de loonkosten in de totale kosten per ton nettoproductie 50,9 procent; in 1966 was dat verder opgelopen tot 6o,8 procent. Messing, Geschiedenis van de mijnsluiting, 34-35.

II6 Pieters, Lonen en bedrijfsresultaten, I82-I86, 22I-222.

II7 Ibidem, 213. 
van het verloop. ${ }^{\text {I18 }}$ In 1962 kwam er tevens een eind aan het akkoordbeloningssysteem. ${ }^{\text {I9 }}$ In plaats daarvan kwam een stelsel met een vast basisloon voor de verschillende ondergrondse functies en een premie over dit basisloon van gemiddeld circa ro procent, afhankelijk van de wijze waarop de opgedragen taak was vervuld. Daarmee werd het variabele gedeelte van het loon beperkt. In het algemeen pakte dit nieuwe systeem gunstig voor de mijnwerkers uit. ${ }^{\mathrm{I} 20}$ Indirect kwam de tussen 1957 en I96I doorgevoerde arbeidstijdverkorting, die resulteerde in een vrije zaterdag, ook neer op loonsverhoging.

Opvallend is dat de ontevredenheid over de verdiensten onder ex-mijnwerkers uit de mijnstreek en uit overig Zuid-Limburg aanzienlijk groter was dan gemiddeld onder alle mijnwerkers. Bij de Oranje-Nassau Mijnen gaf 29 procent van de mijnstrekers en 27 procent van de arbeidskrachten uit overig Zuid-Limburg het loonniveau als voornaamste reden van vertrek op. Reumkens verklaart dit gegeven door te wijzen op de werkgelegenheid in de naburige Duitse en Belgische mijnen, waar de lonen hoger lagen dan in de Limburgse kolenwinning. Vooral voor arbeidskrachten uit het zuiden van de provincie waren de kolenbekkens vlak over de grens gemakkelijk te bereiken. Van alle mijnwerkers die uit ontevredenheid met het loon de Oranje-Nassau Mijnen hadden verlaten, had een derde een baan in een buitenlandse mijn gevonden. ${ }^{\mathrm{I} 2 \mathrm{I}}$

\section{Grensarbeid}

De paradox van de grens, die in de opbouwfase van de Limburgse mijnbouw een belangrijke rol had gespeeld, oefende ook in de periode van wederopbouw invloed uit op de personeelsvoorziening van de mijnbedrijven. Aangezien in het naburige buitenland de lonen snel stegen, was dat voor menig Limburgse arbeider reden zijn emplooi in België of West-Duitsland te zoeken. Niet alleen boden zich daardoor minder regionale arbeidskrachten aan op de Limburgse arbeidsmarkt voor mijnwerkers, ook nam het vertrek van mijnwerkers uit de Limburgse mijnen toe.

Tot halverwege de jaren vijftig waren het vooral de Belgische mijnen in Luik en in de Kempen die Limburgse arbeiders lokten. De vraag in België naar mijnwerkers was bijzonder groot. De Belgische industrie die uit het verwoeste Europa grote orders kreeg, had dringend behoefte aan steenkool. De mijnen waren vlak na de oorlog echter niet in staat die in voldoende hoeveelheid te leveren, onder meer door het vertrek van een groot aantal ervaren

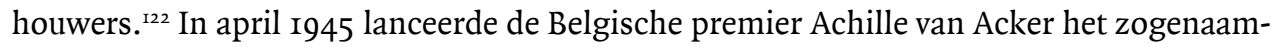
de Mijnwerkersstatuut, waarin allerlei gunstige arbeidsvoorwaarden werden beloofd aan mensen die bereid waren bij de mijnen in dienst te treden. Over het algemeen waren de binnenlandse resultaten van de maatregelen echter teleurstellend. ${ }^{23}$ Aanvulling van het aanbod uit het buitenland bleek noodzakelijk; vooral gold dit voor de Waalse bekkens, waar de verouderde mijnen al sinds de jaren dertig te maken hadden met een vlucht uit het bedrijf

\footnotetext{
II8 Segers, Personeelsuerloop, I27; De aanblijfpremie van duizend gulden werd uitbetaald als een ondergrondse arbeider aan het kolenfront 400 diensten had verricht. Wolf, Mijnbouw, II 89.

II9 Jaarverslag van de Inspecteur-Generaal der Mijnen over 1962, 35 .

I20 Pieters, Lonen en bedrijfsresultaten, 214-215; Wolf, Mijnbouw, II 89.

I2I Reumkens, Onderzoek, 54, 66.

122 Minten e.a., Een eeuw steenkool, I49-I50.

123 Ibidem, 166.
} 
van Belgische mijnwerkers. ${ }^{24}$ Nieuwe mijnwerkers uit het buitenland waren echter veelal ongeschoold en voor Belgische nieuwkomers was pas in I954-I955 gecoördineerd mijnonderwijs beschikbaar. ${ }^{125}$ Aanbod van geschoolde arbeiders uit de Nederlandse mijnen was daarom zeer welkom. De dicht bij de Nederlandse grens gelegen Luikse mijnen organiseerden voor hen in veel gevallen vervoer per autobus. Vanaf I950 gingen de Luikse mijnen er zelfs toe over systematisch Nederlandse grensarbeiders te werven, soms via ronselaars die op verschillende plaatsen in Limburg in zaaltjes en cafés bijeenkomsten hielden. ${ }^{\mathrm{I} 6}$

Uit onderzoek in de pensioenregisters van de Luikse mijnen blijkt dat de Limburgse pendelaars voor de helft afkomstig waren uit de Nederlandse mijnstreek en voor de andere helft uit Maastricht en het heuvelland. Opvallend is dat Maastricht en het heuvelland veel meer grensarbeiders leverden dan op grond van het aandeel in de totale Limburgse mijnwerkerspopulatie mocht worden verwacht. In 1947 woonde 8 procent van de mijnwerkers in de $\mathrm{Ne}$ derlandse mijnen in Maastricht, terwijl in I950 I3 procent van de pendelaars naar de Luikse mijnen in de Limburgse hoofdstad woonde. Voor het heuvelland waren die percentages respectievelijk 5 en $34 \cdot{ }^{\text {I27 }}$ Het is duidelijk dat Maastricht en het heuvelland arbeidsmarkten waren waar de Limburgse mijnbedrijven niet alleen moesten concurreren met de fabrieken in de Limburgse hoofdstad, maar ook met de Luikse kolenproducenten. ${ }^{128}$ Dat de Limburgse mijnen ook bij de werving van jeugdige arbeidskrachten op deze arbeidsmarkten teleurstellende resultaten boekten, zal nog blijken in een volgende paragraaf.

De Nederlandse pendelaars werden vooral aangetrokken door de hoge lonen. De basislonen waren in België 25 à 30 procent hoger dan in Nederland. ${ }^{129}$ Ook de riante kinderbijslag en een goede pensioenvoorziening waren belangrijke pull-factoren voor de Nederlandse grensarbeiders. ${ }^{1{ }^{\circ}}$ Het werd financieel gezien nog aantrekkelijker voor Nederlanders om in een Belgische mijn te gaan werken, toen in 1949 de waarde van de Belgische frank ten opzichte van de gulden steeg. Vooral het Luikse bekken was populair bij de grensarbeiders door de aanzienlijke loonverschillen die er ook tussen de Belgische kolenbekkens bestonden. In de Luikse mijnen, waar de problemen met de arbeidsvoorziening groter waren, lag het loonniveau begin jaren 195035 à 40 procent hoger dan bij de Kempense mijnondernemingen. ${ }^{13 \mathrm{I}}$

Voor honderden Limburgers wogen deze financiële voordelen op tegen de slechte reputatie van de Luikse mijnen. In de eerste helft van de jaren vijftig bestond Io tot I3 procent van de ondergrondse bezetting van de mijnen van Blegny-Trembleur, Cheratte en Queuedu-Bois uit Nederlandse pendelaars. ${ }^{132}$ Eind december 1954 waren er ruim 3.000 Nederlan-

\footnotetext{
124 Roels, 'Buitenlandse arbeiders', II4.

I25 Die Berufsausbildung im Steinkohlenbergbau der Länder der Gemeinschaft. Europäische Gemeinschaft für Kohle und Stahl. Hohe Behörde (Luxemburg 1956) I98 e.v.

126 Rutten, 'Buitenbeentjes'; Willibrord Rutten, 'Alsof de taalgrens niet bestond. Limburgse kompels in de Luikse kolenmijnen na de Tweede Wereldoorlog', Het Land van Herle LIX aflevering 3-4 (2009) II4-I24, aldaar II7.

127 Cijfers over de geografische verdeling van de Limburgse mijnwerkerspopulatie in: Serge Langeweg en Erwin Steegen, 'Het bereik van de mijn. Ruimtelijke aspecten van de arbeidsmarkt voor mijnwerkers in Limburg, I900-I960', Publications de la Société Historique et Archéologique dans le Limbourg/Jaarboek 2008 (Maastricht 2009) 159-200, aldaar I72. Voor de herkomstpercentages van de Limburgse pendelaars in de Luikse mijnen: Rutten, 'Alsof de taalgrens niet bestond', II8.

I28 Rutten, 'Alsof de taalgrens niet bestond', IIg.

129 Leen Roels, 'Arbeidsverloop en geografische mobiliteit' (manuscript 2010) 27.

130 Jaarverslag Inspecteur-Generaal 1950, I2.

I3I Annales des Mines 1950 en 1955.

132 Willibrord Rutten, 'Werken over de grens', Weet je nog, koempel? De mijnen in Limburg (Zwolle 2005) 44I-464, aldaar 447-45I. Zie ook: Langeweg en Roels, 'Buitenlandse arbeiders', III-II2.
} 
ders werkzaam in de Belgische mijnen, van wie de meesten Limburgse grensgangers. ${ }^{133} \mathrm{Ze}$ waren ongeveer gelijk verdeeld over de Luikse en de Kempense mijnen.

De Nederlandse mijnondernemingen voerden een ontmoedigingsbeleid, in samenwerking met de gewestelijke arbeidsbureaus, vakbonden, woningcorporaties, media en kerkgenootschappen. Voor zover het bij de grensgangers ging om arbeidskrachten die men niet geschikt achtte om in de Nederlandse mijnen te werken, hadden de mijndirecties weinig moeite met de grenspendel. Maar vakbekwame arbeiders had men zelf broodnodig, dus die liet men liever niet gaan. Dit betrof ongeveer een derde van het aantal pendelaars naar de Belgische mijnen.

Het ontmoedigingsbeleid van de Nederlandse mijndirecties had succes. Door het aantal pendelaars vanuit Nederlands-Limburg naar Luik te vergelijken met de omvang van de pendelstroom vanuit de Belgische Kempen naar Luik, komt Rutten tot de conclusie dat de pendel vanuit Nederlands-Limburg meeviel. De pendel vanuit Nederland was geringer in omvang, terwijl alleen Nederlanders konden profiteren van de gunstige valutaverschillen. Volgens Rutten moet de verklaring worden gezocht in een mentale drempel bij de Nederlanders. Zij voelden zich niet vrij om in België te gaan werken. De Nederlandse mijnwerkers werden geacht zich in te zetten voor de kolenproductie in eigen land. In hun ontmoedigingsbeleid lieten de mijndirecties niet na hieraan te appelleren. ${ }^{134}$ Eind 1954 was het maximale aantal pendelaars wel bereikt. Dat betekende niet dat de Nederlandse mijnen van het probleem van de grensoverschrijdende pendel waren verlost. Niet alleen bleef er in de eerste helft van de jaren zestig naar de Belgische mijnen een negatief pendelsaldo bestaan (tabel 6.I3), maar vanaf het midden van de jaren vijftig verlegde zich bovendien de pendelstroom richting Duitsland. ${ }^{135}$

In de jaren I950 maakte de Duitse economie een snelle economische groei door, die bekend staat als het Wirtschaftswunder. De vraag naar arbeid was groot en als gevolg daarvan stegen de lonen in West-Duitsland snel. In die situatie nam het aantal Limburgse pendelaars naar West-Duitsland vanaf het midden van de jaren I950 toe. Eind I954 werkten 350 mannen uit de Limburgse mijnstreek in Duitsland, waarvan een deel in de mijnbouw. ${ }^{1{ }^{6}}$ De trek naar Duitsland werd groter toen de West-Duitse regering in oktober 1956 besloot de zogenaamde Bergmannsprämie in te stellen, een belasting- en premievrije toelage op het loon. Dankzij deze toelage steeg het Duitse mijnwerkersloon met ro procent en kwam het flink boven het Nederlandse te liggen. ${ }^{137}$ Het aantal Nederlandse pendelaars in de mijnen rond Aken zou na de invoering van de Bergmannsprämie met 800 man zijn toegenomen. ${ }^{138}$ Nadat in de loop van 1957 de pendelstroom richting Akense mijnen aanvankelijk verder was gestegen, trad in november van dat jaar een kentering op. In de Nederlandse mijnen had een langzaam-aan-actie ertoe geleid dat er ook aan deze zijde van de grens een premie was ingevoerd, waardoor de loonverschillen met de Akense mijnondernemingen waren genivelleerd. Bovendien werd ook in West-Duitsland de arbeidsmarkt ruimer ten gevolge van de

133 Rutten, 'Buitenbeentjes', 19-20. Rutten baseert zich op cijfers van Fédéchar, de gezamenlijke Belgische mijnwerkgevers. Deze cijfers zijn volgens Rutten betrouwbaarder dan de gegevens over grensarbeid van Nederlandse instanties.

134 Ibidem, 20-30, 37.

135 Sophie Bouwens, Over de streep. Grensarbeid vanuit Zuid-Limburg naar Duitsland, 1958-2001 (Hilversum 2008) 50 e.v.

I36 Jaarverslag van de Inspecteur-Generaal 1954, 84.

I37 Ad Knotter, 'Grenzen aan de loonpolitiek. De langzaam-aan-actie van de Nederlandse Katholieke Mijnwerkers Bond (I957) tussen nationale integratie, grensligging en katholiek regionalisme', SSEGL LIII (2008) II7-I57, aldaar I27.

I38 Klank, 'Secondary labour force', I50-15I. 
TABel 6.I3 De pendelbeweging tussen Limburg, België en West-DuitsLAND IN DE MIJNBOUWSECTOR, I960-I965

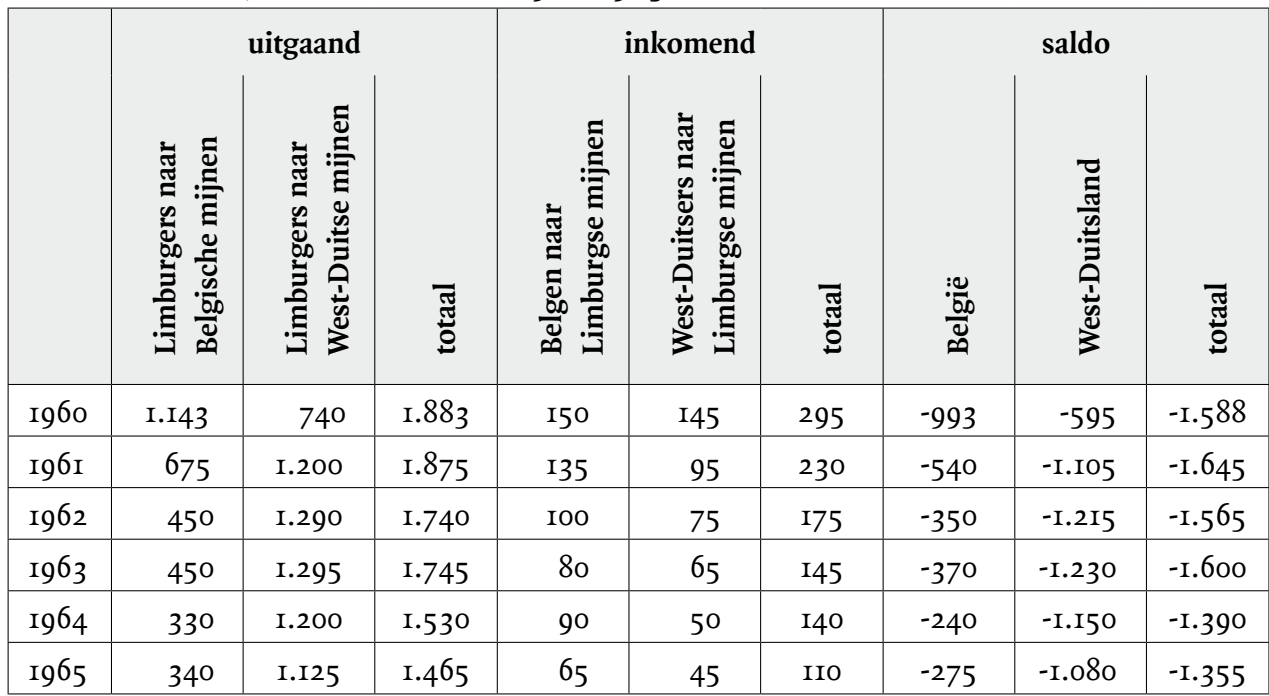

Bron: Arbeidsmarktbeschrijuing van de Provincie Limburg (Districtsbureau voor de Arbeidsvoorziening Limburg [196o-I965].

kolencrisis die eind 1957 merkbaar werd. In I96o bleek de pendelbeweging naar de Duitse mijnbouwsector met 740 man aanmerkelijk afgenomen. ${ }^{139}$

$\mathrm{Na}$ 1960 keerde de hoogconjunctuur terug en nam de uitgaande pendel van Limburgers naar West-Duitsland opnieuw fors toe, zij het dat de omvang niet het niveau haalde dat wellicht kon worden verwacht. Dat blijkt uit onderzoek van Sophie Bouwens, die de omvang van de Limburgse grenspendel naar Duitsland vergeleek met de binnenlandse intergewestelijke pendel. Net als bij de Luikse pendel het geval leek, verklaart zij de relatief lage Duitslandpendel uit een mentale drempel bij de Nederlanders om aan gene zijde van de grens te gaan werken. Hierbij speelde een rol dat pendel naar Duitsland in de publieke opinie negatief werd beoordeeld, vooral omdat die de Nederlandse economie en de Limburgse arbeidsmarkt schade zou berokkenen. ${ }^{\mathrm{I} 0}$

Begin jaren I96o lagen de Duitse lonen 30 à 35 procent hoger dan de Nederlandse. Aangezien in het kader van de geleide loonpolitiek ook de kosten van levensonderhoud in $\mathrm{Ne}$ derland laag werden gehouden, was de koopkracht van de Duitslandpendelaars in eigen land groot. ${ }^{14 \mathrm{I}}$ Doordat de lonen in Duitsland ook hoger waren dan die in België, stapten veel Limburgse grensarbeiders over van een Belgische naar een Duitse werkgever. ${ }^{\mathrm{I} 2}$ Deze tendens werd versterkt door de veelvuldige stakingen in België en de daaruit voortvloeiende politieke onrust. ${ }^{143}$ De pendel trok in de jaren zestig vooral naar de bouw en de metaalindustrie en niet naar de Duitse mijnen. Deze sectoren richtten zich echter veelal op hetzelfde

139 Arbeidsmarktbeschrijuing van de Provincie Limburg 1960, 6r.

I40 Bouwens, Over de streep, 62-63, 78-97.

I4I Ibidem, 50.

142 Arbeidsmarktbeschrijuing van de Provincie Limburg 1962, 38.

143 Roels, 'Arbeidsverloop', 27. Zie ook: Arbeidsmarktbeschrijuing van de Provincie Limburg 1961, 42. 
laaggeschoolde segment van de arbeidsmarkt. ${ }^{\mathrm{I} 4} \mathrm{Al}$ was de Duitslandpendel dan relatief gering, het arbeiderspotentieel voor de Limburgse mijnen nam er wel degelijk door af. Getalsmatig zou alleen al het aantal pendelaars naar de mijnen in Duitsland in de eerste helft van de jaren zestig volstaan hebben om het personeelstekort in de Limburgse mijnen op te lossen (tabel 2.2, hoofdstuk 2 en tabel 6.13). ${ }^{\mathrm{I} 5}$

\section{Herkomst en binding}

De moeite die de mijnen hadden om hun meest preferente groepen te interesseren voor vooral ondergrondse arbeid had een negatieve invloed op het succes van de bindingsstrategieën. ${ }^{146} \mathrm{Er}$ bestond een nauwe relatie tussen binding aan het bedrijf en herkomst van de arbeidskrachten. Reumkens onderscheidde in zijn studie naar de achtergronden van het verloop bij de Oranje-Nassau Mijnen vijf groepen naar herkomst: I) afkomstig uit de mijnstreek, 2) de rest van Zuid-Limburg, 3) Midden- en Noord-Limburg, 4) de rest van Nederland en 5) het buitenland. Uit tabel 6.I4 blijkt dat er grote verschillen waren in het verloop van deze groepen.

TABEL 6.I4 VERLOOP NAAR HERKOMST BIJ DE ORAN JE-NASSAU MIJNEN, I952-I955

\begin{tabular}{|c|c|c|c|}
\hline herkomst & $\begin{array}{c}\text { I } \\
\text { in dienst genomen } \\
1952 \mathrm{t} / \mathrm{m} 1955\end{array}$ & $\begin{array}{c}2 \\
\text { van deze groep } \\
\text { binnen een jaar } \\
\text { ontslagen }\end{array}$ & $\begin{array}{c}3 \\
\text { percentage } 2 \text { van } I\end{array}$ \\
\hline mijnstreek & I.610 & $33 \mathrm{I}$ & $2 \mathrm{I}$ \\
\hline rest van Zuid-Limburg & 358 & II2 & $3 \mathrm{I}$ \\
\hline Midden- en Noord-Limburg & 296 & 156 & 53 \\
\hline rest van Nederland & 387 & 296 & 77 \\
\hline buitenland & 290 & I69 & 59 \\
\hline
\end{tabular}

Bron: Reumkens, Onderzoek, I3.

In het algemeen was de binding aan het bedrijf geringer naarmate de arbeidskrachten van verder weg kwamen. In het geval van de buitenlanders moet daarbij bedacht worden dat het verlooppercentage gedrukt werd door het feit dat zij zich bij rekrutering contractueel verbonden om een vastgestelde periode bij de mijn in dienst te blijven. Nederlandse arbeidskrachten hadden die verplichting niet. Desondanks was ook van de buitenlandse arbeiders meer dan de helft binnen een jaar vertrokken.

In het onderzoek van Segers werden deze conclusies bevestigd. In het algemeen gold: hoe dichter men bij de mijn woonde, hoe minder de geneigdheid tot vertrek. Niet-Limburgse Nederlanders vertoonden de minste binding aan het mijnbedrijf. Ook de buitenlanders waren veelal weer snel vertrokken, met uitzondering van de Joegoslaven, die relatief weinig

144 Bouwens, Over de streep, 55-56.

I45 Het verband tussen pendel en personeelstekorten bij de Limburgse mijnen werd ook door het Districtsbureau voor de Arbeidsvoorziening gelegd. Arbeidsmarktbeschrijuing van de Provincie Limburg $1964,46$.

146 Segers, Personeelsuerloop, 83 . 
verloop kenden. ${ }^{147}$ Waarschijnlijk heeft dit laatste verschijnsel te maken met het uitzonderlijke karakter van de wervingsovereenkomst met Joegoslavië, die enerzijds de mijnwerkers niet de mogelijkheid bood elders werk te zoeken, maar ook de terugkeer naar Joegoslavië vóór afloop van het contract bemoeilijkte. ${ }^{\mathrm{I}}{ }^{8}$

Onbekendheid met het werk in de mijn was ook in de jaren vijftig en zestig een belangrijke oorzaak voor het snelle vertrek van veel nieuwkomers. Ook de mate van bekendheid met het mijnwerkersberoep was nauw verbonden met de herkomst van de arbeidskrachten. Uit vraaggesprekken die Bardoul voerde met ex-mijnwerkers van de mijn Julia bleek dat velen slechts een vage voorstelling hadden van de mijn als ze solliciteerden. Ze hadden vaak moeite met de verschillende diensten en ook het gemis aan buitenlucht werd zwaar gevoeld. Een grote teleurstelling was ook dat door het akkoordstelsel de verdiensten de eerste tijd tegenvielen. ${ }^{149}$ Arbeiders van buiten de mijnstreek waren minder coal minded dan de mijnstrekers, volgens een rapport van Staatsmijnen uit $1950 .{ }^{150}$ Veel van de klachten waren terug te voeren op een gebrekkige informatievoorziening bij de rekrutering. In 1947 of I948 inventariseerden de mijndirecties de klachten van recent aangeworven Poolse arbeidskrachten. ${ }^{\text {I5I }}$ Zij werkten bij de ON IV of bij Staatsmijn Hendrik en waren ondergebracht in het gezellenhuis Ravensbosch bij Valkenburg. De klachten kwamen erop neer dat bij werving de lonen te hoog waren voorgespiegeld. Zo zou niet of niet duidelijk zijn gemeld dat er nog inhoudingen als loonbelasting op in mindering zouden worden gebracht. Voorts was bij de werving soms niet gezegd dat het om werk ondergronds zou gaan. Ook de huisvesting viel tegen: het gezellenhuis was te ver van de mijn verwijderd, zodat men soms tot twaalf uur per dag van huis was. Bovendien waren de slaapzalen te groot, zodat er door het dienstensysteem niet voldoende gerust kon worden. In dezelfde tijd aangeworven Italianen hadden soortgelijke klachten. De voorlichting in Italië was minimaal en vaak te rooskleurig. Zo stonden in de informatiebrochure van Staatsmijnen alleen de brutolonen. Van afdracht van sociale premies en belasting werd ook hier niet gerept. Ook de voorgespiegelde huisvesting kwam niet overeen met de realiteit in Limburg: in plaats van in bungalowachtige woningen die de folder beloofde, werden de Italianen ondergebracht in gezellenhuizen of barakkenkampen. ${ }^{152}$

Het gebrek aan goede huisvesting kwam in de periode van wederopbouw steeds terug als oorzaak van het snelle vertrek van nieuwkomers uit verder weg gelegen streken. Wie elders in Limburg bleef wonen, moest vaak rekenen op lange reistijden voor het woon-werkverkeer. Door het grote tekort aan gezinswoningen was het niet mogelijk het gezin naar de mijnstreek te laten komen. Hoewel tussen 1948 en 1956 de woningvoorraad in Limburg jaarlijks met gemiddeld 5.500 huizen toenam, waren de tekorten aan het eind van de jaren I950 nog steeds aanzienlijk, met name in de regio's Maastricht, Heerlen en het heuvelland. In 1955 bedroeg het tekort in deze gebieden Io à 15 procent van het benodigde volume..$^{153}$

147 Ibidem, 98-ror.

148 RHCL, ArchiefOranje-Nassau Mijnen 17.05J, inv. nr. I2: Tewerkstelling Joegoslaven, krantenknipsels I962.

149 Bardoul, Personeelsuerloop, II-I2.

150 Wolf, Mijnbouw, II 82.

I5I RHCL, Archief Oranje-Nassau Mijnen 17.05J, inv. nr. 9: Rapport over bezoek aan Poolse arbeiders in het gezellenhuis Ravens-

bosch op zondag 27 juli [1947 of I948].

152 Tinnemans, Gouden armband, I7-I8

153 Roemen e.a., Verkenning, 30-32. 
Voor de binding aan de mijn was de woningnood funest. De verdere uitbouw van een vaste stam van Limburgse mijnwerkers vereiste de komst van gezinnen uit andere delen van de provincie. 'Gezinsvaders brengen zonen mee', aldus het Districtsbureau voor de Arbeidsvoorziening in 1952. 'Tevens zouden deze Limburgse werkkrachten in een hun niet wezensvreemde omgeving komen. $\mathrm{Zij}$ scheppen geen problemen ten aanzien van stands- en vakorganisaties. Zij blijven "thuis" onder een volk dat hun volk is. Door arbeidskrachten uit het arsenaal van Noord- en Midden-Limburg aan te trekken lost Limburg tevens zijn problemen op zonder nieuwe problemen te scheppen, want wanneer straks in Midden-Limburg kolenvelden ontsloten zijn, kunnen wellicht de beste Midden- en Noord-Limburgse mijnwerkers uit de oude- en nieuwe mijnstreek de kern gaan vormen van de nieuwste mijnstreek'. ${ }^{154}$ Er werd anno I952, toen net begonnen was met de aanleg van Staatsmijn Beatrix, al met enige zorg naar de toekomst gekeken.

Zolang er een tekort aan gezinswoningen bleef bestaan, moesten gehuwde mijnwerkers, in navolging van hun ongehuwde collega's, worden ondergebracht in gezellenhuizen of particuliere kosthuizen. In de gezellenhuizen werden de mijnwerkers doorgaans geconfronteerd met andere verhoudingen dan men thuis gewend was. Dat gold niet alleen voor Polen of Italianen, maar ook voor arbeidsmigranten uit Nederland. De huisvesting werd door velen als negatief ervaren, vooral omdat in de onpersoonlijke gezellenhuizen de heimwee snel kon toeslaan: 'De meesten lopen door het gebouw als door een fabriek. Men kent elkaar niet of nauwelijks. [...] De sfeer lijkt in het geheel niet op thuis. Tot in zijn vrije uren voelt men al voortdurend de mijn rond zich hangen. Het werk op de mijn is een leven op de mijn'. ${ }^{55}$ Het feit dat de mijnondernemingen een emolumentenregeling instelden, waardoor gehuwde Nederlanders een aantal keren per maand op kosten van de mijn naar hun gezin konden gaan en buitenlandse mijnwerkers een keer per zes maanden voor een korte vakantie naar het land van herkomst mochten, kon de gevoelens van ontheemding bij velen niet wegnemen. ${ }^{156}$ Evenmin slaagden de mijnen erin door betere informatie en strengere selectie het verloop onder buitenlandse mijnwerkers te verminderen.

Uit de verloopcijfers bleek overduidelijk dat de beste remedie voor het creëren van binding het aantrekken van arbeidskrachten uit de regio was. ${ }^{157}$ De verklaring voor het relatief lage verloop bij de groepen uit de nabijheid van de mijnbedrijven werd vooral gezocht in hun geringe aanpassingsmoeilijkheden. Deze arbeidskrachten konden blijven wonen in hun vertrouwde omgeving, waar mijnarbeid veelal een vertrouwd fenomeen was geworden. Vooral was dat het geval in de eigenlijke mijnstreek, waar in de loop van de eeuw de mijnen het economische en sociale leven waren gaan domineren. In hoofdstuk 3 bleek reeds dat in de belangrijkste mijnbouwgemeenten de werkgelegenheid in de steenkolenwinning het karakter van een monocultuur had gekregen. Het gevolg van deze ontwikkeling was dat nagenoeg iedereen wel familie of kennissen in de mijnbouwsector had en informatie over de aard van het beroep en de arbeidsvoorwaarden uit de eerste hand kon krijgen. Omdat ze uit een bekende omgeving kwamen en dezelfde culturele achtergrond

I54 Arbeidsmarktbeschrijuing van de Provincie Limburg 1952, 64.

155 Rapport van een onderzoek naar de aanpassing van immigranten. (z.p. z.j.) 9.

156 RHCL, Archief Oranje-Nassau Mijnen 17.05J inv. nr. Ir: Brief van de GSL aan de mijnondernemingen inzke emolumentenregeling voor nieuw aangeworven Oostenrijkse en Italiaanse arbeiders, I2-I0-1955; idem Nota Werving Oostenrijkers, I4-9-1956.

157 RHCL, Centraal ArchiefDSM 17.26/o6, inv. nr. I56: Brief van Staatsmijnen aan de minister van Economische Zaken, 28-3-1950. 
hadden was de acceptatie van deze nieuwelingen in het mijnbedrijf groot. Door de 'oudere' mijnwerkers werd een nieuwe collega uit een mijnbouwgemeente al snel als 'een van hen' beschouwd. Dit ontstaan van een mijnwerkerstraditie was precies wat de mijndirecties voor ogen stond. ${ }^{158}$

\section{Een mijnwerkerstraditie}

In de opbouwfase tot 1930 waren de mijnen door veel autochtonen gezien als indringers in de traditionele Limburgse samenleving. De weerstand die daarvan het gevolg was, belemmerde de personeelsvoorziening en de opbouw van een stabiele gezeten mijnwerkersstand van geboren en getogen Limburgers. Al vroeg realiseerden de mijnondernemingen zich dat ze werk moesten maken van de wijze waarop de mijnbouwsector zich aan het Limburgse en Nederlandse publiek presenteerde. Na 1945 werd deze politiek van beeldvorming, die er vooral op was gericht de mijnbouw te integreren in de traditionele Limburgse leefwereld, op een systematische manier uitgebouwd. ${ }^{59}$ Nooit werd er met meer energie aan een mijntraditie gebouwd dan in de periode tussen 1945 en 1955 , de jaren dat de kolenproductie in het centrum van de Nederlandse belangstelling stond. Deze creatie van een Limburgse mijnwerkerscultuur, waarin het vanzelfsprekend zou zijn dat een zoon mijnwerker werd omdat zijn vader dat ook was, had alles te maken met propaganda voor de mijn en het werken in de mijn en dus ook met binding aan het bedrijf. ${ }^{160}$

De beeldvorming werd in handen gelegd van hoger opgeleide personen, niet zelden in dienst van het mijnbedrijf. In boeken, brochures en artikelen probeerden auteurs als Paul Frische en Bernard Bekman, beiden professionele voorlichters in dienst van de mijnbedrijven, en C. Raedts, lid van de directie van Oranje-Nassau Mijnen, de mijnbouw een plaats te geven in de Limburgse cultuur. Het blad Steenkool, een door de gezamenlijke mijnen ten behoeve van hun werknemers uitgegeven tijdschrift, speelde in de beeldvorming een belangrijke rol. ${ }^{161}$ Tussen 1945 en 1955 , de periode dat het blad verscheen, publiceerde de redactie talloze artikelen over Limburgse geschiedenis, cultuur en de (vermeende) mijnwerkerstraditie die er van oudsher zou hebben bestaan. Een speciale plaats in de kolommen van Steenkool was weggelegd voor familieportretten en fotogalerijen van jubilarissen. Met graagte publiceerde het bedrijfsblad verhalen en foto's van hele families van mijnwerkers, liefst bestaande uit meerdere generaties. In dergelijke voorbeelden liet het blad zien dat er kennelijk een traditie bestond van mijnwerkersgeslachten, waarin het beroep als vanzelfsprekend op de volgende generatie werd overgedragen. Zo werden in september 1946 de vijf gebroeders Verheyen, afkomstig uit Roggel gepresenteerd. Ze waren omstreeks 1920 in de mijnstreek terecht gekomen, waar ze allen in dienst traden bij Staatsmijn Maurits, toen die in productie kwam. De familie Verheyen was sindsdien een mijnfamilie geworden: 'Dat

158 Bardoul, Personeelsverloop, II-I2.

159 Jos Perry, 'Van vader op zoon', in: Wiel Kusters en Jos Perry, Versteende wouden. Mijnen en mijnwerkers in woord en beeld (Amsterdam r999) 83-96.

I60 Jos Perry, 'Limburg kolenland. Een collage van oud en nieuw', SSEGL XLV (2000) 65-78.

I6I Daarnaast hadden afzonderlijke mijnondernemingen hun eigen bedrijfsbladen: Nieuws van Staatsmijnen/Staatsmijnen Nieuws/ DSM Nieuws (I94I-I974); De Mijn/Nieuws van de steenkolenmijnen Laura en Julia Eijgelshoven/Laura-scope (1956-I974); Anthraciet (WillemSophia, I956-г968). 


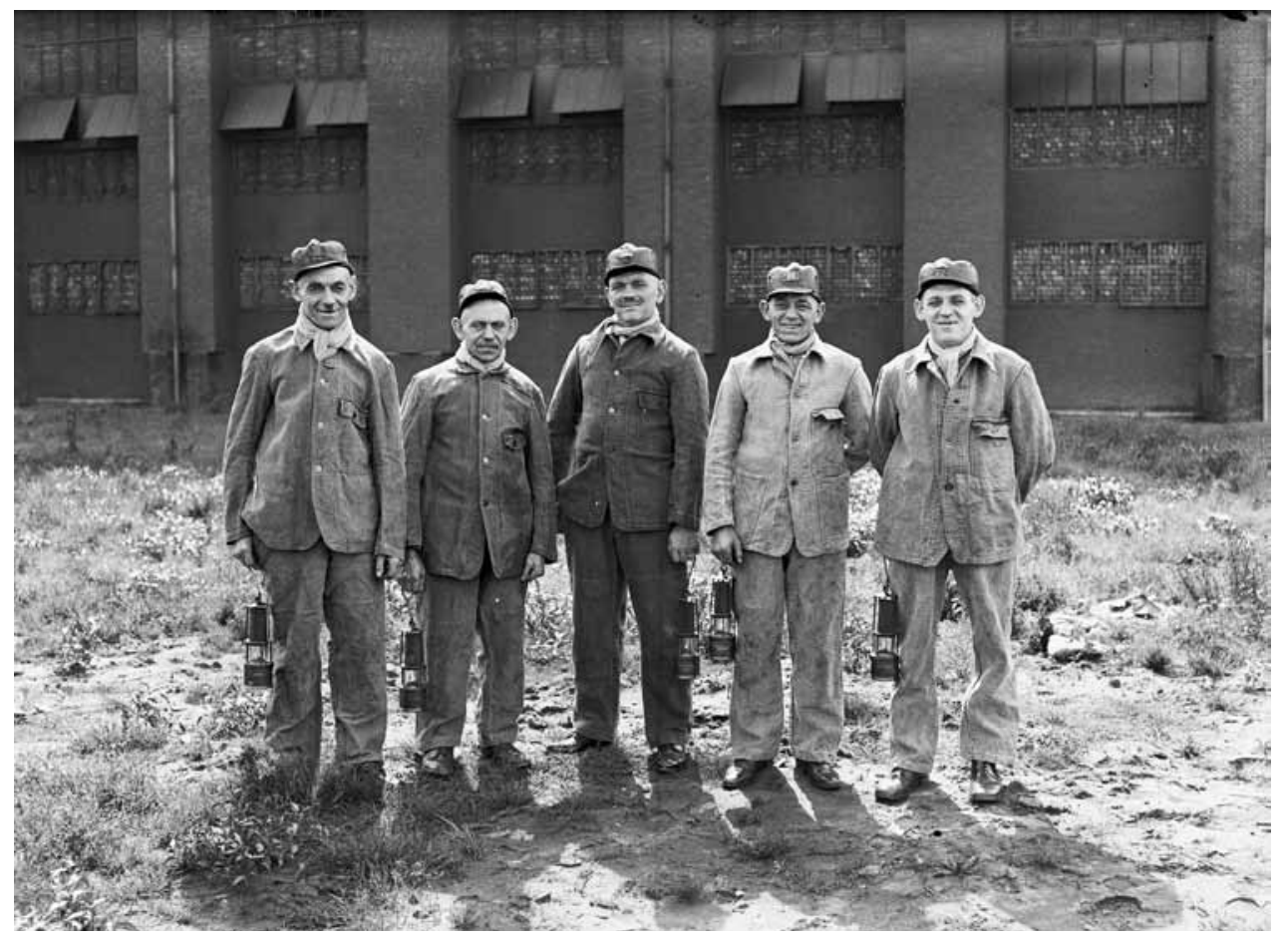

Het blad Steenkool besteedde geregeld aandacht aan mijnbouwfamilies, zoals de vijf gebroeders Verheyen, werkzaam op Staatsmijn Maurits. De vorming van een traditie, waarin mijnarbeid van vader op zoon werd doorgegeven, was een belangrijk doel van de Nederlandse mijnondernemingen. Bron: Steenkool, september 1946, p. 245.

de mijnarbeid in de familie is gaan zitten, blijkt uit het feit dat van de 15 kinderen [van een van de broers] er al 4 op de Maurits aan het werk zijn. En van de I 2 kinderen [van een andere broer] is reeds I zoon op de Maurits aan het werk gegaan' ${ }^{162}$ Een mijnwerkerstraditie was ook ontstaan bij de familie Kirpenstein, van wie grootvader, vader en zoon bij Staatsmijn Hendrik werkten, en bij het gezin Kersten uit Spekholzerheide, waar vader en zeven zonen bij de Willem-Sophia in dienst waren. ${ }^{1{ }^{16}}$ Tevens verscheen elke maand in Steenkool een overzicht van jubilarissen, die 25 of 40 jaar in de Limburgse mijnbouw werkzaam waren. Het waren voorbeelden die moesten worden nagevolgd.

Dankzij dit propagandawerk van de mijnbedrijven, daarbij geholpen door een schare van Limburgse publicisten, schilders, fotografen en filmmakers, verdween de algemene afkeer van de mijn en de mijnarbeid. De stemming sloeg volledig om. Volgens de historicus Jos Perry was er ten tijde van de grootse viering van het gouden bedrijfsjubileum van Staatsmijnen in mei 1952 zelfs sprake van een euforie. Uit de enthousiaste reacties op en de grote deelname aan de vele festiviteiten die in de mijnstreek werden georganiseerd, kon niet anders dan worden geconcludeerd dat Limburg en de mijn zich met elkaar hadden verzoend

I62 Steenkool, nr. 9, september i946, 245 .

I63 Steenkool, nr. I4, september 1947, 360-36r; idem, nr. Io, mei 1949, 2 I9. 
en dat het prestige van het mijnwerkersberoep was gestegen. ${ }^{164}$ Vooral dat laatste was van belang. De mijnondernemingen hoopten vooral meer jongens voor de interne opleidingen te kunnen aantrekken. Niet voor niets werd in de kilometerslange optochten die in het kader van de feestelijkheden door de mijncentra trokken, veel aandacht geschonken aan de opleiding van toekomstige mijnwerkers, de Ondergrondse Vakscholen. De OVS werd gezien als de culturele schakel, die de mijntraditie vestigde en daarmee tevens de binding aan het bedrijf. ${ }^{165}$

\section{Binding door de OVS}

In 1945 werden de leesjongensopleidingen omgevormd tot een in principe driejarige Ondergrondse Vakschool (OVS). ${ }^{166}$ De rijksoverheid steunde het initiatief door een bedrag van twee miljoen gulden ter beschikking te stellen voor de realisatie van de gebouwen waarin de vakscholen werden ondergebracht. ${ }^{167}$ In die tijd van kolenschaarste zag de regering de nieuwe opleidingen als een stimulans voor de keuze voor het beroep van mijnwerker. Mijnarbeid werd daarmee een beroep waarvoor een opleiding vereist was en dat zou het aanzien verhogen. De mijnen onderschreven dat argument, maar zij streefden nog twee andere doelen met de OVS na. De opleidingen zouden zorgen voor scholing in mijnarbeid. Dankzij de opleiding van jonge mijnwerkers '[...] zal er in de toekomst belangrijk toe kunnen worden bijgedragen, dat de Nederlandse steenkolenmijnen de beschikking zullen krijgen over vaklieden, die onder alle omstandigheden voor hun taak berekend zijn', merkte de InspecteurGeneraal der Mijnen vlak na de bevrijding op. ${ }^{168}$ In de praktijk zou de OVS deze doelstelling nauwelijks verwezenlijken, omdat in het lesprogramma vooral aandacht werd besteed aan traditionele technieken van kolenwinning, zoals het werken met de afbouwhamer en het zetten van houten stutten, terwijl de mechanische kolenwinning die in de jaren vijftig en zestig snel opgang maakte, niet of nauwelijks aan bod kwam. ${ }^{169}$ De tweede doelstelling was daarom belangrijker: een eigen opleiding gaf een zekere waarborg dat de arbeider het werk in de mijnbouw als zijn blijvend beroep nastreefde. De opbouw van een stabiele personeelsbezetting werd daardoor bevorderd.

De autochtone jonge arbeiders die voor de OVS werden geworven, waren voor de mijndirecties de meest preferente groep. Het streven was de leerlingen voor de OVS zoveel mogelijk te werven in de mijnstreek en vervolgens in de rest van Limburg. Zoals uit tabel 6.I5 blijkt, had dat beleid over de hele periode genomen succes. Zeven van de tien nieuwe mijnwerkers, jonger dan I8 jaar, waren afkomstig uit de oostelijke of westelijke mijnstreek. Uit overig Limburg leverde vooral het midden van de provincie rond Echt en Roermond een

\footnotetext{
I64 Jos Perry, 'Jubeljaren. Staatsmijnen weerspiegeld in vier jubilea', Publications de la Société Historique et Archéologique dans le Limbourg CXXXIV-CXXXV (1998-1999) 7-84, aldaar 2I-58.

I65 Perry, 'Limburg kolenland', 78.

I66 De OVS bestond uit drie leerjaren. Het eerste en derde leerjaar duurden precies een jaar. De duur van het tweede leerjaar was variabel, afhankelijk van de leeftijd van de OVS-scholier, die op het moment van voltooiing van de hele opleiding achttien jaar moest zijn, want eerder mocht hij niet ondergronds worden tewerk gesteld.

I67 Jaarverslag van den Inspecteur-Generaal der Mijnen over de jaren 1940-1945, I5.

I68 Jaarverslag van den Inspecteur-Generaal der Mijnen over de jaren 1946, 1947 en 1948, 5.

I69 Rob Wolf, 'Tussen Delft en Nijmegen. De Ondergrondse Vakscholen van de Staatsmijnen', Het Land van Herle LIX aflevering 3-4 (2009) I35-I46, aldaar I43-I45.
} 


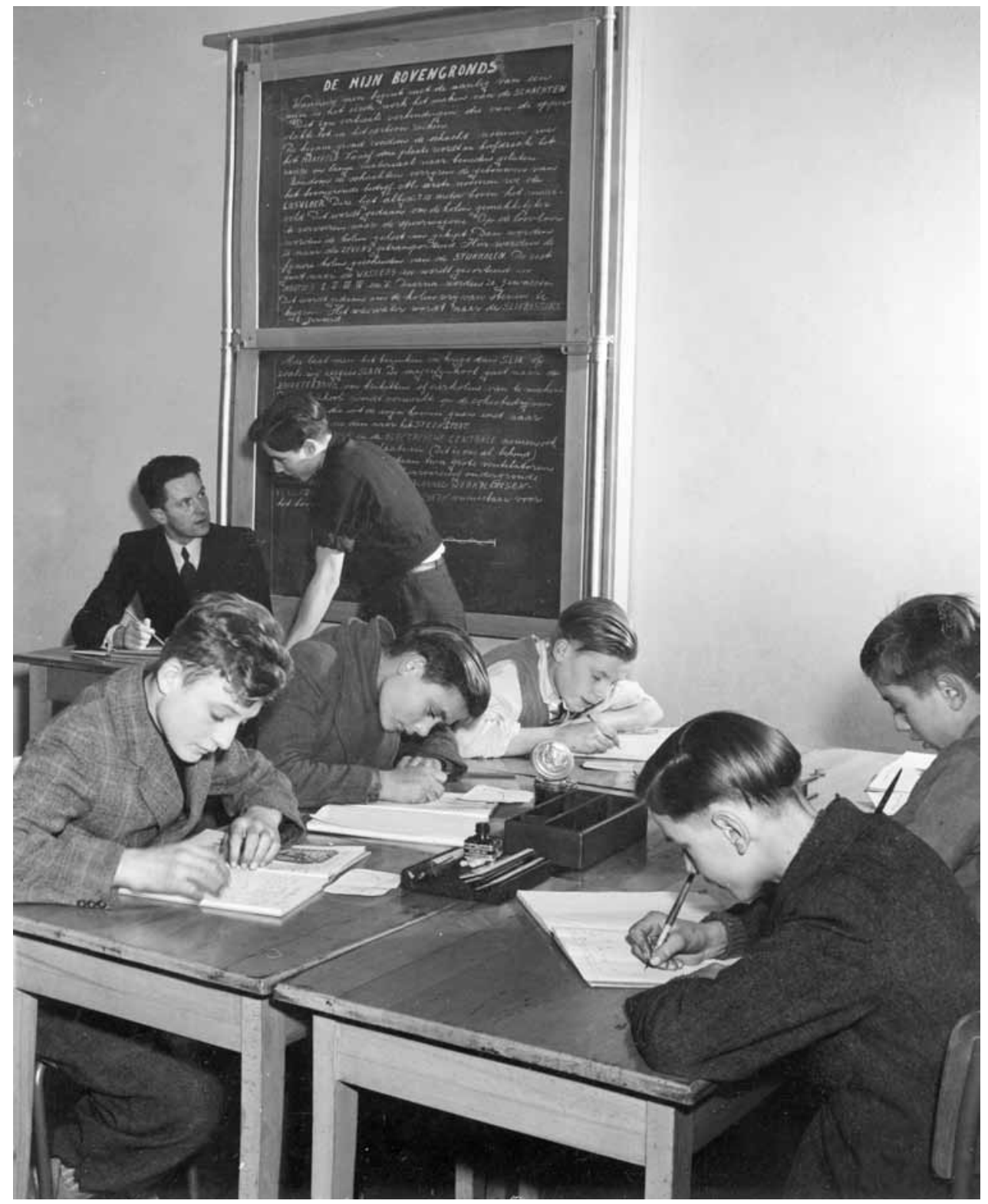

Een groep eerstejaars OVS-leerlingen van de Laura en Julia werkt aan een opdracht van leraar en opzichter Franken. 1950. Bron: Fotocollectie Continium Kerkrade, F4414.

contingent OVS-ers van enig belang. Vooral in dat gebied hoopten de mijnbedrijven de arbeidsmarkt te kunnen uitbreiden. In 1952 was begonnen met de bouw van Staatsmijn Beatrix in Vlodrop en de aanleg in de verdere toekomst van nieuwe mijnen in de zogenaamde Peelvelden stond op de agenda. De verwachting was dat de mijnbouw en de arbeidsmarkt in de toekomst in noordelijke richting zouden opschuiven en het was zaak in een vroeg stadium de beroepsbevolking in die streken vertrouwd te maken met mijnarbeid. Voor deze 
verwachte ontwikkeling had het Districtsbureau voor de Arbeidsvoorziening al in 1952 aandacht gevraagd. In het uiterste zuiden van de provincie (de agglomeratie Maastricht en het heuvelland) vond de werving weinig respons. De Maastrichtse nijverheid slaagde erin de arbeidskrachten in de zuidwestelijke helft van Zuid-Limburg grotendeels voor zich te behouden en aan de werving van de mijnindustrie te onttrekken. ${ }^{170}$ Ook in het noorden van de provincie had de rekrutering van OVS-leerlingen weinig succes. Het deel van de provincie ten noorden van Venlo lag grotendeels buiten de 13-urengrens.

TABEL 6.I5 De GeboortestreEk VAN NiEUWE MiJNWERKERS, JONGER DAN I8 JAAR, IN HET AMF, I945-I965

\begin{tabular}{|l|c|c|}
\hline & aantal & percentage \\
\hline Sittard-Kerkrade (de mijnstreek) & I02 & 69,4 \\
\hline Maastricht en omstreken & Io & 6,8 \\
\hline Het heuvelland & 3 & 2,0 \\
\hline Swalmen-Roermond-Echt & I7 & II,6 \\
\hline Maasbree-Weert-Thorn & 5 & 3,4 \\
\hline Venray-Grubbenvorst & 3 & 2,0 \\
\hline Venlo-Beesel & I & 0,7 \\
\hline overig & 6 & $4, \mathrm{I}$ \\
\hline totaal & I47 & I00,0 \\
\hline
\end{tabular}

Bron: Eigen berekening op basis van steekproef AMF. Zie bijlage 8 .

Voor jeugdigen bestond in de jaren vlak na de oorlog een onbeperkte plaatsingsmogelijkheid bij de OVS. ${ }^{17} \mathrm{Na}$ een aarzelend begin slaagden de mijnen er door uitgekiende wervingsmethoden in het leerlingenaantal van de OVS in de eerste helft van de jaren vijftig fors te laten stijgen (grafiek 6.9). Op voorlichtingsavonden, die de mijnen veelal in samenwerking met plaatselijke afdelingen van de vakbonden, de arbeidsbureaus en de parochiegeestelijkheid verspreid over de provincie organiseerden, werd de betekenis en de inhoud van de OVSopleiding toegelicht, geillustreerd met films en lichtbeelden. Bij deze voorlichtingsbijeenkomsten werd er ook op gewezen dat OVS-ers niet in militaire dienst hoefden. Moeders van potentiële OVS-kandidaten, vaak tevens de echtgenotes van mijnwerkers, werden op speciale 'moederavonden' bijgepraat door de sociaal werksters van de mijnbedrijven. De opbouw van een stabiel personeelsbestand vereiste immers dat het beroep van mijnwerker van generatie op generatie doorgegeven zou worden. Daarnaast speelde huisbezoek een belangrijke rol. Speciale wervingsteams bezochten de ouders van jongens die qua leeftijd in aanmerking kwamen voor de OVS. De adressen werden verstrekt door de hoofden van de lagere school of door de arbeidsbureaus. ${ }^{172} \mathrm{Al}$ in 1948 kon de Inspecteur-Generaal der Mijnen constateren: 'De goede voorlichting aan de ouders van jeugdige personen over de vakopleiding voor ondergrondse mijnwerker, heeft tot gevolg gehad dat de mijnarbeid in de mijnstreek steeds

I70 Roemen e.a., Verkenning, 58.

I7I Zie bijvoorbeeld Jaarverslag GAB Heerlen 1949, 2.

172 Berufsausbildung, 460 . 

OVS-ERS, I945-1965

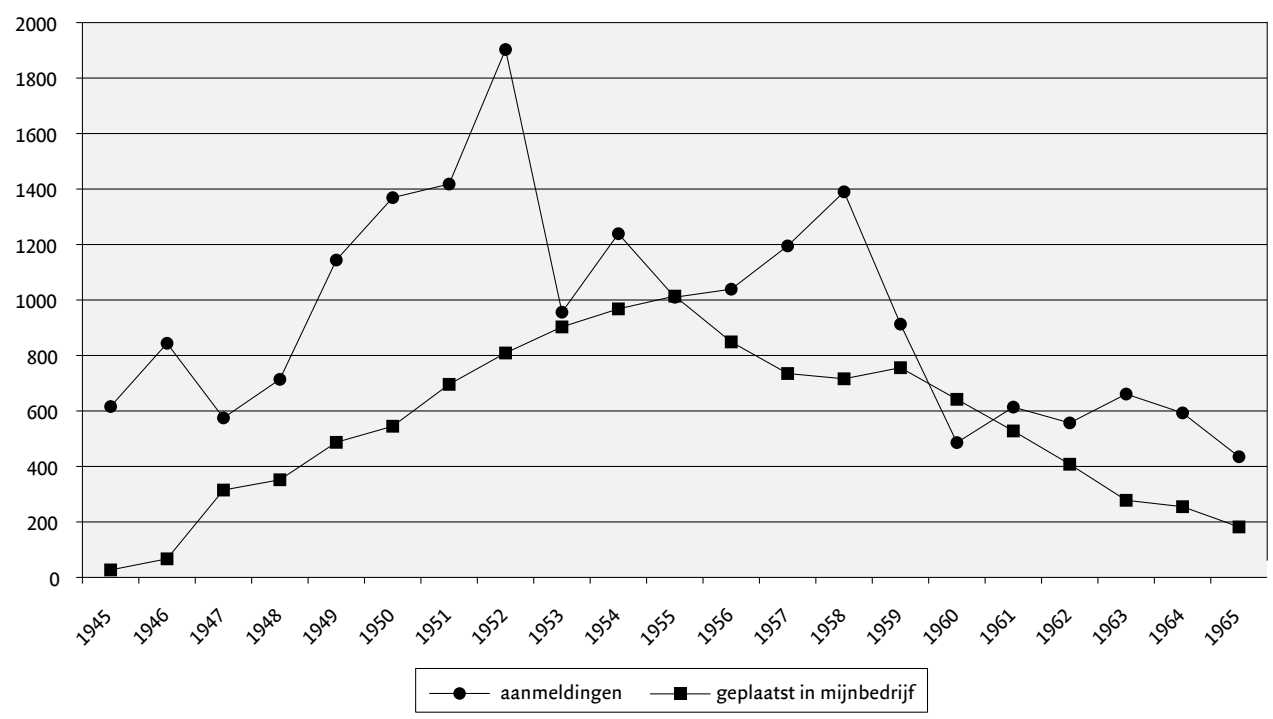

Bron: SHCL, ArchiefGSL, Statistiek. Zie ook bijlage 20.

meer waardering is gaan genieten, waardoor de toevloed van jeugdige personen toenam' ${ }^{173}$

De periode 1948 tot 1952 vormde het hoogtepunt van het succes van de OVS. Het aantal aanmeldingen was groot en het verloop laag (tabel 6.I6). In het begin van de jaren vijftig kwam ontslag op eigen verzoek uit de OVS-opleiding weinig voor. Het bedroeg minder dan 20 procent van het aantal OVS-ers dat de opleiding verliet omdat het doorstroomde naar het ondergrondse bedrijf. Bovendien bleek dat veel van de vakscholieren uit mijnwerkersfamilies afkomstig waren. In 1952 onderzocht Staatsmijnen de familiale achtergrond van de leerlingen die aan de OVS van de Wilhelmina verbonden waren. Van 65 procent van de 240 geënquêteerde leerlingen werkte de vader in een mijn. Van deze groep werkte bijna 8o procent op de Wilhelmina zelf. Ook werd onderzocht hoeveel van de vakscholieren afkomstig waren uit een 'typisch mijnwerkersgezin'. Hiervan was sprake als de vader ondergronds werkte en minstens twee van zijn zonen, waaronder de betreffende OVS-er zelf, eveneens bij de mijn in dienst waren. Twintig procent van de vakscholieren voldeed aan het criterium van het 'typische mijnwerkersgezin'. Waarschijnlijk gaat het te ver uit deze cijfers te concluderen dat er een mijnwerkerstraditie bestond, ${ }^{174}$ maar voor de mijndirecties was het wel duidelijk dat ze op de goede weg waren. Door die goede resultaten kwam eind 1952 de oorspronkelijke doelstelling van de OVS-opleiding voor de mijnen binnen bereik. De gezamenlijke mijnbedrijven streefden naar een totale OVS-bezetting van 3.600 leerlingen. Dat aantal werd voldoende geacht om te voorzien in 70 à 80 procent van de jaarlijks benodigde ondergronders. ${ }^{175}$ Eind 1952 werd dat streefaantal overschreden: aan de OVS-opleiding

173 Jaarverslag Inspecteur-Generaal over de jaren 1946, 1947 en 1948, 75.

174 Wolf, Mijnbouw, II 95.

175 Berufsausbildung, 468 . 
stonden op dat moment 3.812 leerlingen ingeschreven. ${ }^{176}$ In april 1953 kon Th. Rutten, de Nijmeegse hoogleraar in de psychologie die aan de wieg had gestaan van de OVS, aan de directie van Staatsmijnen schrijven: 'Door de OVS is mogelijk geworden de personeelsbezetting van de Limburgse mijnen vrijwel geheel te betrekken uit de autochtone bevolking. Dat betekent niet alleen een belangrijke vermindering van de kosten en de moeite die aan werving van ondergronds personeel moet worden besteed, doch ook dat het ontstaan van ongezonde sociale toestanden in belangrijke mate kan worden voorkomen' ${ }^{177}$ Ook de directie van Staatsmijnen was die mening toegedaan. Na analyse van de gewenste omvang van de OVS met het oog op de toekomstige behoefte aan ondergronders, werd zelfs geconstateerd dat een inkrimping van de opleiding noodzakelijk was. ${ }^{178}$

TABEL 6.I6 VERTREK OP EIGEN VERZOEK VAN OVS-ERS, I95I-I965

\begin{tabular}{|l|c|c|c|}
\hline & I & $\begin{array}{c}\text { 2 } \\
\text { vertrek tgv } \\
\text { ontslag eigen } \\
\text { verzoek }\end{array}$ & 2 als \% van I \\
\hline I95I & 983 & I82 & I8,5 \\
\hline I952 & I.098 & I74 & I5,8 \\
\hline I953 & I.330 & 320 & $24, \mathrm{I}$ \\
\hline I954 & I.49I & 449 & $30, \mathrm{I}$ \\
\hline I955 & I.50I & 429 & 28,6 \\
\hline I956 & I.258 & 361 & 28,7 \\
\hline I957 & I.102 & 325 & 29,5 \\
\hline I958 & I.090 & 194 & I7,8 \\
\hline I959 & I.120 & 282 & 25,2 \\
\hline I960 & I.300 & 533 & $4 \mathrm{I}, 0$ \\
\hline I96I & I.038 & 406 & $39, \mathrm{I}$ \\
\hline I962 & 819 & 263 & $32, \mathrm{I}$ \\
\hline I963 & $69 \mathrm{I}$ & 308 & 44,6 \\
\hline I964 & 716 & 298 & $4 \mathrm{I}, 6$ \\
\hline I965 & 549 & 299 & 54,5 \\
\hline
\end{tabular}

Bron: SHCL, ArchiefGSL, Statistiek. Zie ook bijlage 20.

Al het volgende jaar werd het besluit van de Staatsmijndirectie achterhaald door de economische situatie. Net als bij de werving in het algemeen, bleken conjuncturele schommelingen van invloed op de mate waarin jongens konden worden geïnteresseerd voor de OVSopleiding. De arbeidsmarkt werd snel krapper en het aantal aanmeldingen voor de OVS vertoonde na 1952 een dalende tendens. Ook nam het verloop fors toe, vooral bij de onder- 


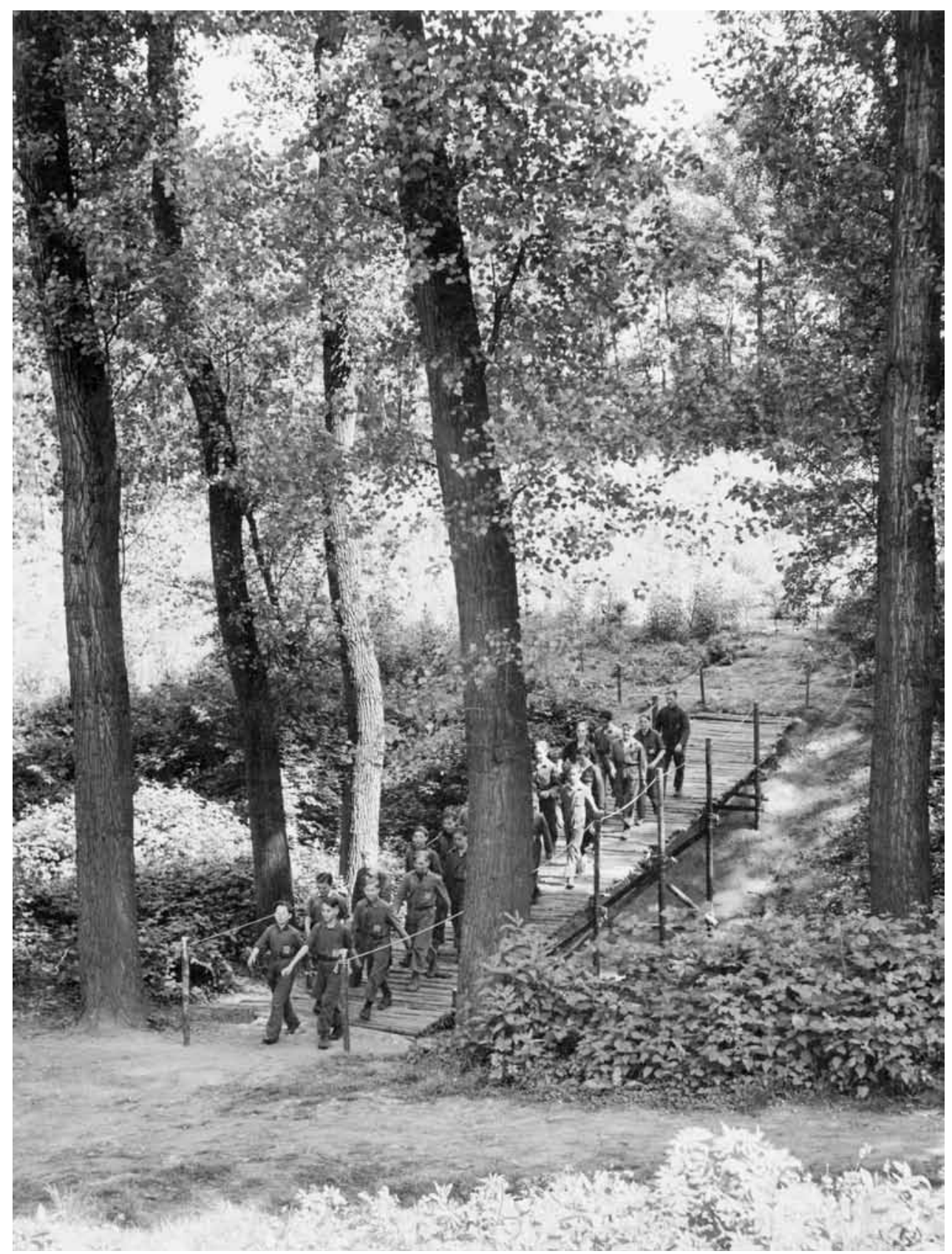

Scholieren van de Ondergrondse Vakschool van de Domaniale Mijn pionieren in het Beerenbosch. 1952. Bron: Fotocollectie Continium Kerkrade, F421. 
grondse vakscholen van de Staatsmijnen Maurits en Emma. Deze mijnzetels, gelegen aan de periferie van de mijnstreek, hadden hun OVS-leerlingen voornamelijk in Midden-Limburg geworven. Door de grote afstand die de scholieren dagelijks naar hun werk moesten afleggen en het ontbreken van een mijnwerkerstraditie in de plaats waar ze woonden, kwamen ze er makkelijker toe een ander beroep te kiezen, zodra de verbetering van de conjunctuur daartoe de mogelijkheden bood. ${ }^{179}$ De creatie van een mijnwerkersstand in de 'nieuwste mijnstreek' kwam daarmee in gevaar. In 1954 bedroeg het verloop bij de gezamenlijke OVS-opleidingen bijna het dubbele van twee jaar eerder (bijlage 20).

In dezelfde periode werd bij de mijnwerkersgezinnen meer en meer een tendens merkbaar om voor hun kinderen een andere carrière dan die als mijnwerker te ambiëren. Ouders zagen voor hun kinderen andere beroepsperspectieven, naarmate de mogelijkheden om te studeren groter werden. De vanzelfsprekendheid dat zonen van handarbeiders zelf ook handarbeider werden, verdween. Scholing en het behalen van diploma's werd het ideaal. ${ }^{180}$ Dat uitte zich in een andere keuze van vervolgonderwijs dan de OVS. In april 1957 merkte directeur G. Zeegers van het Kaski op: ${ }^{\mathrm{I}}$ ' $V a n$ de jongens uit de gezinnen der ondergrondse mijnarbeiders, die na het verlaten van de lagere school nog dagonderwijs genieten, bezoekt slechts $25 \%$ de Ondergrondse Vakschool. Voor de overeenkomstige kinderen uit de gezinnen der bovengrondse arbeiders bedraagt de deelneming I $8 \%$. Er bestaat derhalve zowel bij de onder- als bij de bovengrondse arbeiders een sterke neiging hun zoons een opleiding te geven die niet rechtstreeks op de mijnarbeid is gericht' ${ }^{182}$ Bovendien daalde de vooropleiding van de OVS-ers in de loop van de jaren vijftig. Kwam het begin jaren I950 nog geregeld voor dat OVS-ers enkele jaren vervolgonderwijs hadden genoten voordat ze aan de opleiding begonnen, omstreeks I96o hadden OVS-ers doorgaans alleen lagere school als vooropleiding. Volgens Rob Wolf is deze tendens te verklaren uit de afnemende populariteit van het beroep van mijnwerker. Wanneer de mogelijkheid bestond om na de lagere school een vervolgopleiding te doen, was die gericht op een baan buiten de mijn. Slechts degenen die na de lagere school niet de mogelijkheid hadden van een vervolgopleiding, gingen nog naar de OVS. ${ }^{183}$

Het gevolg van die ontwikkelingen was dat de bezetting van de OVS snel daalde tot minder dan de gewenste 3.600 leerlingen. Slechts tijdens de korte conjuncturele inzinking van I957-I958 was de OVS-opleiding tijdelijk weer een alternatief. Maar ook in deze jaren bleef de bezetting ver achter bij het gewenste niveau. Wel daalde hetverloop in 1958 scherp, een indicatie voor mindere perspectieven voor jeugdigen op de arbeidsmarkt buiten de mijnen. ${ }^{184}$

In de eerste helft van de jaren zestig ging het verder bergafwaarts met de wervingskracht van de Ondergrondse Vakschool. Ondanks een reorganisatie van het curriculum in ig6o, die de OVS technisch bij de tijd bracht, daalde het aantal aanmeldingen van jaar tot jaar en steeg tegelijkertijd het verloop tot een niet eerder bereikt niveau.

Niettemin hebben via de OVS duizenden Limburgse jongens hun weg naar het ondergrondse bedrijf gevonden. Tussen 1945 en 1965 stroomden bij de gezamenlijke mijnen in totaal Io.8oo OVS-ers door naar het ondergrondse bedrijf; 732 anderen kregen een functie

179 Roemen e.a., Verkenning, 78.

I80 Jos Perry, 'Van vader op zoon', 95.

I8I Katholiek Sociaal Kerkelijk Instituut, een religieus-sociologisch onderzoeksinstituut, opgericht in I946.

182 Geciteerd bij: Bardoul, Personeelsverloop, Io.

I83 Wolf, Mijnbouw, II 96.

I84 Segers, Personeelsuerloop, 8I. 


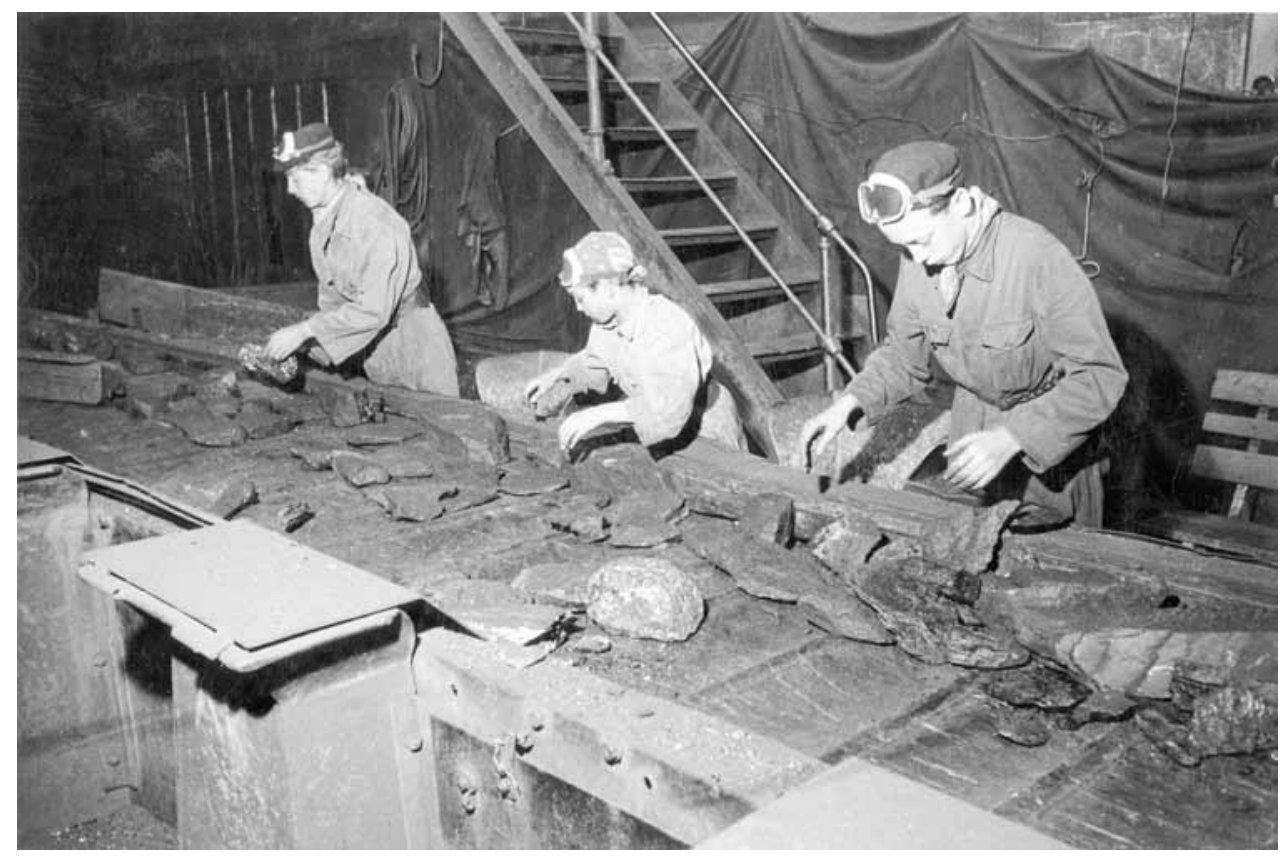

Tweedejaars OVS-leerlingen bovengronds aan het werk in de zeverij. 1957. Bron: Fotocollectie Continium Kerkrade, F4418.

bovengronds.$^{185}$ Inderdaad bleek de OVS, net als eerder de leesjongensopleiding, een positieve invloed te hebben op de binding aan het bedrijf (zie ook tabel 6.9). Degenen die na een mijnbouwopleiding ondergronds gingen, waren minder geneigd tot vertrek dan hun collega's die geen specifieke vooropleiding hadden genoten ${ }^{186}$ De snelle afname van de belangstelling voor de OVS was daarom een teken aan de wand. De poging van de mijnen om via de OVS een mijnbouwtraditie te creëren, bleek minder dan een decennium na het jubeljaar van Staatsmijnen tot mislukken gedoemd.

\section{BESLUIT}

Wat kwam er terecht van het vaste-stamideaal van de Nederlandse mijnen, dat zou moeten worden bereikt door de binding aan het mijnbedrijf te bevorderen? En hoe verhielden zich die bindingsstrategieën van de mijnondernemers tot de autonomiestrategieën van de mijnwerkers?

Aan de vooravond van de economische depressie van de jaren dertig leek de vaste-stampolitiek van de mijnen op een mislukking te zijn uitgelopen. De grote vraag naar arbeidskrachten in de fase van opbouw van de mijnen bracht de mijnwerkers in een gunstige ar- 
beidsmarktpositie en bood hen de mogelijkheid een autonomiestrategie na te streven. Mijnwerkers hadden in het algemeen wat te kiezen op de arbeidsmarkt. In absolute zin was daardoor het jaarlijkse vertrek van arbeidskrachten uit de mijnen aanzienlijk. Ook de toename van het aantal buitenlandse mijnwerkers, een veelal in mijnbouw geschoolde groep die zich, mede door hun vakbekwaamheid, kenmerkte door een grote mobiliteit, was niet bevorderlijk voor het welslagen van de bindingsstrategieën van de mijndirecties.

Maar er waren zeker ook positieve ontwikkelingen voor de mijnondernemingen. Mogelijk kunnen die voor een deel worden toegeschreven aan de maatregelen die de mijnen in drie decennia tijd hadden genomen om de binding van het personeel te bevorderen. Het verloop was sinds de Eerste Wereldoorlog in relatieve zin afgenomen. Hierbij moet worden bedacht dat in bedrijven of bedrijfstakken in opbouw het verloop doorgaans hoog is. Wanneer we de cijfers bij de gezamenlijke mijnen uit grafiek 6.2 bijvoorbeeld vergelijken met Philips, een bedrijf dat zich in de jaren twintig eveneens in de opbouwfase bevond, lijkt het verloop niet bijzonder hoog te zijn geweest. Tussen 1925 tot 1928 vertrok jaarlijks bij Philips 20 procent van de personeelsbezetting, in 192927 procent en in 1930 zelfs 33 procent. ${ }^{187}$ Dat waren hogere percentages dan de mijnen lieten optekenen.

In de jaren twintig nam ook het percentage ongehuwden af (zie tabel 6.5). Meer mijnwerkers met een gezin was voor de mijnen de basis voor de opbouw van een mijnwerkerstraditie, waarbij het de bedoeling was dat de zoon in de voetsporen van zijn vader zou treden en ook mijnwerker zou worden. Het besluit van Staatsmijnen om in 1928 te beginnen met een interne bedrijfsopleiding, aansluitend op de lagere school, was mede op de opbouw van die traditie gericht.

De jaren dertig vormden in economische zin een moeilijke periode voor de mijnen. Maar de ontwikkeling van de arbeidsmarkt in die jaren was voor de vaste-stampolitiek gunstig. In plaats van de mijnwerkers hadden nu de mijnen wat te kiezen. Over het algemeen ging het personeelsbeleid van de mijnen ten koste van de meest mobiele groepen. Voor een deel werden ze vervangen door arbeidskrachten waarvan met reden werd verondersteld dat ze meer binding aan het bedrijf zouden vertonen: jonge arbeiders, geworteld in de Limburgse regio. Door gebrek aan alternatieven waren jonge mensen meer dan voorheen gevoelig voor de werkzekerheid die de mijnen boden. Om dezelfde reden waren ook de zittende mijnwerkers veel minder geneigd hun baan in de mijn op te geven. Ondanks de vele gedwongen ontslagen werd daardoor het verloop in de loop van de jaren dertig lager dan ooit tevoren.

Het arbeidsmarktgedrag van de nieuw aangetrokken Limburgse mijnwerkers bleek inderdaad relatief stabiel. In de jaren vijftig vormde deze groep een hechte kern van arbeiders die redelijk intact bleef en aanvankelijk kon worden aangevuld met leerlingen van de OVS, de opvolger van de leesjongensopleiding. Segers constateerde dat eind jaren vijftig bij ongeveer twee derde deel van het personeel vrijwel geen mobiliteit plaatsvond. ${ }^{188}$ Vergeleken met andere sectoren had de Nederlandse mijnbouwsector omstreeks I960 daardoor geen buitensporig hoog verloop (tabel 6.17).

Vanaf 1953 ontstonden er opnieuw problemen met de arbeidsvoorziening omdat het steeds moeilijker bleek voldoende jongens voor de OVS te rekruteren. Door de hoogcon-

Ad Teulings, Philips. Geschiedenis en praktijk van een wereldconcern (Amsterdam 1977) 79-80.

Segers, Personeelsverloop, ror. 
TABel 6.I7 Het personeelsverloop in de Nederlandse STEENKOLEnMijNEN EN ENIGE ANDERE SECTOREN, I957-I964 (IN PERCENTAGES VAN DE GEMIDDELDE PERSONEELSBEZETTING IN HET BETREFFENDE JAAR)

\begin{tabular}{|c|c|c|c|c|c|c|c|c|}
\hline & 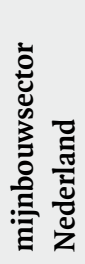 & 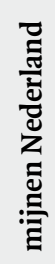 & : & 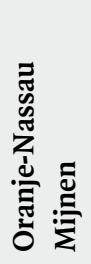 & 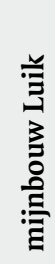 & $\begin{array}{l}n \\
0 \\
0 \\
0 \\
0 \\
0 \\
0 \\
0\end{array}$ & 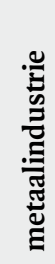 & 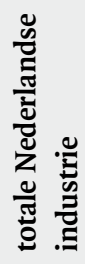 \\
\hline I957 & I3 & 17 & I7 & I5 & 44 & IO & 26 & 30 \\
\hline 1958 & IO & $\mathrm{I} 3$ & I4 & I2 & 35 & 6 & 22 & 23 \\
\hline I959 & 9 & I2 & I3 & IO & 44 & 7 & 23 & 24 \\
\hline I96o & 9 & $\mathrm{I} 2$ & I2 & I2 & 49 & 8 & 26 & 27 \\
\hline I96I & IO & II & IO & I2 & $4 \mathrm{I}$ & 9 & 27 & 29 \\
\hline I962 & II & I2 & II & II & 45 & 9 & 27 & 28 \\
\hline I963 & I3 & I5 & 15 & I5 & 44 & I0 & 26 & 29 \\
\hline I964 & I3 & I4 & I4 & I5 & 38 & 8 & 29 & 30 \\
\hline
\end{tabular}

NB: kolom 'mijnbouwsector Nederland': exclusief mobiliteit tussen de Nederlandse mijnen; kolom 'mijnen Nederland': inclusief mobiliteit tussen de Nederlandse mijnen.

Bron: Verslagen GSL aan MIR; Roels, Arbeidsverloop, 70; Van Elteren, Staal en arbeid, 595; Tabellen en grafieken MIR.

junctuur gingen autonomiestrategieën van arbeidskrachten weer de boventoon voeren. 'Als een bedrijf de kenmerken van de potentiële blijvers kent, dan zal het in perioden van een zeer krappe arbeidsmarkt toch meestal onmogelijk zijn een voldoende groot aantal van deze preferente groep aan te trekken. De werving zal dan moeten worden uitgebreid tot groepen met een grotere geneigdheid tot vertrek', concludeerde Segers. ${ }^{189}$ Het gevolg van deze ontwikkeling was dat de stabiele personeelskern die zich had gevormd, niet langer in voldoende mate van onderop werd aangevuld en verouderde. Ook de tijdelijke opleving van de belangstelling voor de OVS ten gevolge van de korte conjuncturele neergang in de jaren 1957-1958 kon de eenmaal ingezette ontwikkeling niet keren.

Bovendien uitten zich de toenemende keuzemogelijkheden voor mijnwerkers in een stijging van het verloop uit de Limburgse mijnbouw naar andere sectoren of naar de Belgische en Duitse arbeidsmarkt, waar het loonpeil hoger lag. Het komen en gaan in de mijnstreek nam in de jaren 1955-I957 en na 1961 verder toe door het aantrekken van tijdelijke groepen arbeidskrachten uit het buitenland. Dat leidde tot gevoelens van onvrede bij de 'vaste stam', die voortdurend werd geconfronteerd met de komst van onervaren arbeidskrachten van buiten de eigen omgeving. De neiging tot vertrek werd er ook bij deze meest preferente groep door bevorderd, zeker toen de vraagtekens bij de toekomst van de steenkolenwinning begin jaren zestig steeds groter werden. 


\section{Hoofdstuk 7 \\ Samenvatting en conclusies}

\section{DE ARBEIDSMARKT VOOR MIJNWERKERS IN LIMBURG}

In dit boek wordt een langetermijnanalyse gepresenteerd van de arbeidsmarkt voor mijnwerkers in Nederlands-Limburg. Het begrip arbeidsmarkt wordt opgevat als sociologisch verschijnsel, waarbij strategisch gedrag van de arbeidsmarktpartijen centraal staat. Die strategieën resulteren in sociale processen van transformatie, mobiliteit, mobilisering, segmentering en regulering. Een scala aan sociale, economische, culturele, geografische, demografische en juridische factoren vormen samen de context, waarin het arbeidsmarktgedrag van vragers en aanbieders vorm krijgt. Dat gegeven maakt de arbeidsmarkt een geschikt uitgangspunt om deze factoren integraal, dat wil zeggen in onderlinge samenhang te bestuderen.

Het beginpunt van het onderzoek ligt omstreeks I9oo toen de Limburgse mijnbouw begon aan een snelle expansie. De aankondiging van de mijnsluitingen door de Nederlandse overheid in december 1965 markeert het eindpunt. Deze periode van ruim zes decennia werd onderverdeeld in drie tijdvakken. De eerste is de periode I900-I930. In deze jaren was de Limburgse mijnbouw volop in opbouw. Elf nieuwe mijnzetels kwamen in exploitatie. In vergelijking met de mijnen in veel andere Europese bekkens waren de Nederlandse mijnondernemingen modern uitgerust en groot van opzet. De uitbreiding had tot gevolg dat de werkgelegenheid in de Nederlandse mijnbouwsector toenam van 600 man in I 898 tot bijna 38.000 in I930. De vraag naar mijnwerkers was echter nog veel groter dan deze toch al indrukwekkende toename van de arbeidersbezetting suggereert. Het personeelsverloop was in deze eerste drie decennia enorm. Gemiddeld moesten de gezamenlijke mijnen jaarlijks ruim 40 procent van de personeelsbezetting vervangen, met vooral vóór de Eerste Wereldoorlog uitschieters tot bijna go procent.

De regionale, provinciale en nationale arbeidsmarkten schoten in zowel kwalitatief als kwantitatief opzicht tekort om aan deze vraag te voldoen. Daarom moesten de mijnondernemingen in toenemende mate een beroep doen op arbeidskrachten uit het buitenland. Aan het eind van 1920 was ruim 20 procent van de mijnwerkers buitenlander. Tien jaar later was een derde van de arbeidersbezetting van de gezamenlijke mijnen van buitenlandse origine. Ondergronds, waar de personeelsvoorziening het meest problematisch was, bedroeg het percentage buitenlandse mijnwerkers zelfs 40 . Meer dan de helft van de buitenlanders had de Duitse nationaliteit, maar vooral in de tweede helft van de jaren twintig waren ook groepen arbeidskrachten geworven in Centraal- en Oost-Europese landen.

De tweede periode wordt gevormd door de jaren van crisis en oorlog (I93I-I944). De economische neergang in de eerste helft van de jaren dertig had tot gevolg dat de arbeidsmarkt 
omsloeg in het voordeel van de mijnondernemingen. Van arbeidstekorten was geen sprake meer. Voor het eerst konden de mijnen het zich permitteren om kieskeurig te zijn. Nu er door de slechte conjunctuur weinig alternatieven voor mijnarbeid waren, nam het personeelsverloop drastisch af. Ondanks de ontslaggolven van de eerste helft van de jaren dertig die ruim 9.000 banen kostten, was het verloop in deze jaren lager dan ooit tevoren. De mijndirecties kozen in deze omstandigheden voor de in hun ogen meest preferente groep: jonge in de Limburgse regio gewortelde arbeidskrachten. In het algemeen had deze groep de grootste kans gedwongen ontslag te ontlopen. Ook nieuwe arbeidskrachten kwamen in deze periode hoofdzakelijk uit deze groep. Buitenlandse arbeidskrachten, en onder hen vooral degenen die aan het eind van de jaren twintig waren aangenomen, betaalden het gelag van de crisis: $\mathrm{zij}$ werden massaal ontslagen. Aan het eind van 1938 was daardoor de personeelsbezetting aanzienlijk Nederlandser geworden. Nog slechts 12 procent had een buitenlandse nationaliteit.

Tijdens de oorlogsjaren konden de mijndirecties het personeelsbeleid uit de jaren dertig voortzetten. Onder Duitse druk de kolenproductie op te voeren, nam de vraag naar mijnwerkers toe. De nieuwelingen waren voornamelijk Limburgers, maar ook voor arbeidskrachten uit de rest van Nederland werd mijnarbeid een interessante optie toen bleek dat werk in de mijn gedwongen Arbeitseinsatz in Duitsland kon voorkomen. In tegenstelling tot in naburige Belgische en Duitse mijnbouwstreken wisten de Nederlandse mijndirecties met succes de inzet van dwangarbeiders uit Oost-Europa tegen te houden.

De bevrijding van de mijnstreek in september en oktober I944 had onmiddellijk een grote uittocht van mijnwerkers tot gevolg. Onder hen bevonden zich arbeidskrachten die tijdens de oorlog werk in de mijnen als bescherming tegen dwangarbeid in Duitsland hadden beschouwd, jonge mannen die kozen voor militaire dienst en een groep die vanwege een (vermeend) verdacht oorlogsverleden de toegang tot de mijnen werd ontzegd. Hieronder bevonden zich vrijwel alle Duitse mijnwerkers. De sterke afname van de personeelsomvang kwam op het moment dat de Limburgse mijnen de rol van energieleverancier voor de wederopbouw van de Nederlandse economie moesten spelen. In die situatie werd de arbeidsvoorziening opnieuw precair. Door wervingsacties in Limburg en de rest van Nederland, en op gezette tijden ook in het buitenland, wisten de mijnondernemingen de personeelsbezetting tot 1958 op te voeren. In grotere mate dan in de jaren tot I930 konden de mijnen echter putten uit de Nederlandse en vooral Limburgse arbeidsmarkt. Voor veel jongens uit mijnstreekgemeenten, maar ook wel daarbuiten, werd na de lagere school de interne opleiding tot mijnwerker die de ondernemingen na de oorlog hadden uitgebouwd, de instap tot een carrière in de kolenwinning. Dat relatieve succes kon echter niet verhullen dat de mijnen sinds het midden van de jaren vijftig doorgaans werden geconfronteerd met ernstige krapte op de arbeidsmarkt die de personeelsvoorziening problematisch maakte.

Het jaar 1958 markeert het begin van het einde van de Limburgse steenkolenmijnbouw. Afzetmoeilijkheden maakten duidelijk dat de rol van Nederlandse kolen op de energiemarkt uitgespeeld raakte. Aardolie en aardgas hadden de toekomst. Met de afnemende betekenis van steenkool verdween ook het vertrouwen in de toekomst van de werkgelegenheid in de Limburgse mijnen. Structurele personeelsproblemen waren een belangrijke overweging van de Nederlandse regering om in december $1_{96} 65$ de gefaseerde sluiting van de mijnen aan te kondigen. Negen jaar later kwam met de sluiting van de Oranje-Nassau I in Heerlen een einde aan de winning van steenkool in Limburg. 


\section{DE ARBEIDSVOORZIENING: PROBLEMEN EN MOGELIJKHEDEN}

De arbeidsvoorziening van de Limburgse mijnbedrijven werd in het algemeen gekenmerkt door het problematische karakter ervan. Dat probleem was niet typisch voor de Limburgse mijnen, maar was een verschijnsel dat zich overal in mijndistricten voordeed. De problemen waren velerlei. Op de eerste plaats was er de aard van de mijnarbeid, die een lastige concurrentiepositie voor de mijnbedrijven op de arbeidsmarkt opleverde. Arbeidskrachten namen mijnarbeid vaak pas in overweging als alternatieve werkgelegenheid ontbrak of wegviel. In dergelijke omstandigheden, die zich onder meer voordeden tijdens de Eerste Wereldoorlog en de crisisjaren tussen 193 I en 1936 , constateerden de mijnen dat de belangstelling van arbeidskrachten toenam en zagen ze dat het personeelsverloop daalde. Omgekeerd hadden de mijndirecties in tijden van een goede conjunctuur en veel alternatieven, zoals in de tweede helft van de jaren twintig en in het algemeen in de periode na de Tweede Wereldoorlog, moeite om het benodigde personeel op de arbeidsmarkt te vinden. Ook werden ze op die momenten geconfronteerd met een toename van het personeelsverloop. De relatief goede arbeidsvoorwaarden bij de mijnen wogen in die situatie voor menigeen niet op tegen de zwaarte van het mijnwerkersberoep. De mijnen grepen op die momenten vaak terug op de rekrutering van arbeidskrachten in het buitenland.

In dat kader speelde ook de ligging van de Limburgse mijnstreek te midden van buitenlandse kolenbekkens een rol. De naburige grensregio's in Duitsland (Rijnland en Westfalen) en België (Luik en de Kempen) hadden gelijkaardige arbeidsmarkten, waar mijnbouw een belangrijke plaats innam. Op exceptionele momenten rondom de beide wereldoorlogen na, waren er in het Nederlands-Duits-Belgische grensgebied voor pendelaars nauwelijks juridische belemmeringen om voor hun werk de grens te overschrijden. In principe konden ze gebruik maken van betere arbeidsvoorwaarden in het buitenland en/of gunstige valutaverhoudingen. Deze situatie, die is omschreven als de paradox van de grens, deed zich voor in de decennia vóór de Eerste Wereldoorlog, toen het voor Limburgse arbeidskrachten aantrekkelijk was zich aan te bieden op de Duitse arbeidsmarkt, waar hogere lonen werden betaald en in de mijnbouwsector de sociale voorzieningen beter geregeld waren. $\mathrm{Na}$ de Tweede Wereldoorlog was het aanvankelijk de Belgische arbeidsmarkt die Limburgers aantrok. Na het midden van de jaren vijftig was het opnieuw de werkgelegenheid in Duitsland die een pull-factor vormde. De uitstroom uit de Limburgse arbeidsmarkt vormde voor de mijndirecties een bron van zorg. Hun pogingen om Limburgse arbeidskrachten te overtuigen niet als grensarbeider aan de slag te gaan, leidden er toe dat er in ieder geval voor de naoorlogse pendel naar België en Duitsland aanwijzingen zijn dat die in beide gevallen in omvang niet buitenproportioneel hoog was.

Omgekeerd kwam de situatie ook voor dat Nederlandse mijnen aantrekkelijk waren voor buitenlandse grensarbeiders. Het meest sprekende voorbeeld daarvan was de periode tussen 1919 en 1923. De Limburgse mijnondernemingen zagen de grensarbeiders uit het buitenland echter niet als een structurele oplossing voor het personeelsprobleem. Vandaar dat een aantal Limburgse mijndirecties gevoelig was voor de protesten van hun Akense collega's tegen de rekrutering van Duitse grensarbeiders. De Limburgse mijnen streefden naar een stabiele kern van mijnwerkers en realiseerden zich dat grensarbeiders door hun pragmatische keuze geen blijvertjes zouden zijn en waarschijnlijk zouden vertrekken als de 
voordelen wegvielen. Dat gebeurde inderdaad toen eind I923 de valutaverhoudingen stabiliseerden.

Een laatste regelmatig terugkerend probleem bij de arbeidsvoorziening was de woningnood. Goede huisvestingsmogelijkheden waren een onmisbaar middel bij het aantrekken van nieuwe arbeidskrachten, die voor een groot deel van buiten de onmiddellijke omgeving van de mijnen moesten komen. In de periode van opbouw was de huisvestingsproblematiek des te nijpender omdat ook de verkeersmogelijkheden gebrekkig waren. Pendel van wat verder gelegen gebieden naar de mijnen was vaak tijdrovend of simpelweg onmogelijk. Door de aanleg van spoor- en tramverbindingen en vooral door de komst van de autobus in de jaren twintig verbeterden de vervoersmogelijkheden langzamerhand.

Het gebrek aan gezinswoningen in de omgeving speelde de mijnen ook in de jaren na de Tweede Wereldoorlog parten, al waren de vervoersmogelijkheden voor mijnwerkers inmiddels sterk toegenomen. Hierdoor konden mijnwerkers meer dan vóór de oorlog opteren voor pendel in plaats van verhuizen naar de nabijheid van de mijnbedrijven. Wie echter aan reis- en werktijd samen meer dan I 2 à I 3 uren per dag kwijt was, moest verhuizen. Rekruteringsacties buiten die I2- of I3-urengrens moesten zich echter beperken tot arbeidskrachten die ongehuwd waren of bereid waren een tijdlang gescheiden van hun gezin in gezellenhuizen in de mijnstreek te verblijven. Dat deed de concurrentiekracht van de mijnen op de arbeidsmarkt geen goed. De mijnen merkten dat bijvoorbeeld bij de rekrutering van displaced persons vlak na de oorlog en na I955 bij de werving van gastarbeiders in mediterrane landen, omdat ze moesten concurreren met buitenlandse mijnondernemingen die geen eisen aan de burgerlijke staat van de sollicitanten stelden.

Toch was het voor de mijnen niet alleen kommer en kwel met de arbeidsvoorziening. Ten opzichte van andere mijnstreken verkeerden de Limburgse mijnen in een voordelige situatie. Allereerst hadden de Limburgse mijnen te maken met een gunstige demografische ontwikkeling. De bevolking in de mijnstreek en de rest van Limburg groeide snel. Tot I930 werd een belangrijk deel van de groei veroorzaakt door migratie, maar in de jaren dertig sloeg dat om naar voornamelijk natuurlijke groei. Het hoge geboortesaldo zorgde voor een verjonging van de bevolking, waardoor een natuurlijke aanvulling van de potentiële beroepsbevolking plaatsvond. In theorie stonden voortdurend drie à vier jongeren klaar om een opengevallen arbeidsplaats in te nemen. De mijndirecties hebben van die mogelijkheden gebruik gemaakt. Al tijdens de crisis van de jaren dertig kon daardoor een gedeelte van het ontslagen buitenlandse personeel vervangen worden door jonge autochtone Limburgers. Toen de conjunctuur na 1935 weer aantrok, gingen de mijnen op die ingeslagen weg verder.

Het tweede voordeel voor de Limburgse mijnen was de monocultuur die in de loop van de tijd ontstond. De mijnstreekgemeenten werden gekenmerkt door zeer hoge percentages mijnwerkers in de mannelijke beroepsbevolking. Op lokaal niveau waren er weinig alternatieven. In tegenstelling tot elders ontstond er in de Limburgse mijnstreek in het kielzog van de mijnondernemingen geen concurrerende andere grootindustrie. Behalve op sommige momenten de industriële werkgelegenheid over de landsgrenzen, vormde alleen de industrie in Maastricht een concurrent. De agglomeratie Maastricht en het westelijke heuvelland leverden daardoor aanzienlijk minder arbeidskrachten voor de mijnen dan op basis van de omvang van de beroepsbevolking mocht worden verwacht. Ook wervingsacties voor de interne bedrijfsopleidingen van de mijnen hadden in deze regio weinig succes. 


\section{EEN DUBBELE ARBEIDSMARKT}

In het eerste hoofdstuk werd erop gewezen dat 'de arbeidsmarkt' eigenlijk niet bestaat, maar er sprake is van een aantal segmenten of deelmarkten, die niet of nauwelijks met elkaar concurreren. Een van de indelingen in deelmarkten gaat uit van het bestaan van een dubbele arbeidsmarkt. Die bestaat enerzijds uit een intern - primair - segment met vaste werkgelegenheid en stabiele arbeidsverhoudingen en anderzijds een extern - secundair - segment met tijdelijke arbeidscontracten. Het externe segment heeft vaak een bufferfunctie waarmee werkgevers conjuncturele fluctuaties in vooral de kwantitatieve vraag naar arbeidskrachten kunnen opvangen. Herkomst blijkt een van de factoren die bepalen tot welk segment een werknemer behoort. Buitenlandse arbeidsmigranten belanden vaak in het secundaire segment.

In de Nederlandse mijnen was steeds een contingent buitenlandse arbeidskrachten aanwezig. Toch gaat de theorie die deze categorie verbindt aan de dubbele arbeidsmarkt niet zonder meer voor de hele periode op. In de tweede helft van de jaren twintig was een omslag te constateren van een vooral kwalitatief naar een voornamelijk kwantitatief bepaalde vraag naar buitenlandse arbeidskrachten. In de periode van opbouw moesten geschoolde mijnwerkers meestal uit het buitenland gehaald worden. Deze arbeidskrachten speelden een belangrijke rol bij de opleiding aan het kolenfront van Nederlandse arbeidskrachten tot volleerd mijnwerker. Op die manier slaagden de mijnen erin langzamerhand een kern van Nederlandse mijnwerkers op te bouwen. De geschoolde buitenlandse krachten van het eerste uur gingen soms ook zelf behoren tot die kern en daarmee tot het primaire segmentvan de arbeidsmarkt.

Door de toenemende aanwezigheid van volleerde Nederlandse mijnwerkers en veranderingen in de techniek en organisatie van de kolenwinning, die de traditionele transfer van deskundigheid op de werkplek onmogelijk maakte, werd de Nederlandse mijnbouw vanaf de tweede helft van de jaren twintig minder afhankelijk van de vakman uit het buitenland. $\mathrm{Na}$ I925 waren de tekorten aan personeel voornamelijk van kwantitatieve aard. Buitenlandse arbeidskrachten die werden aangetrokken om die tekorten op te vullen, belandden doorgaans wel in het secundaire segment van de arbeidsmarkt. De mijndirecties gingen er bij de werving vanuit dat de aanwezigheid van deze nieuwkomers van tijdelijke aard zou zijn. Ze kregen een arbeidscontract voor bepaalde tijd.

Dat er binnen de groep buitenlandse arbeidsmigranten in de Nederlandse mijnbouw sprake was van twee categorieën bleek duidelijk tijdens de conjuncturele neergang van de jaren dertig. Voornamelijk de buitenlandse arbeidskrachten die in de tweede helft van de jaren twintig waren gerekruteerd, werden ontslagen. Deze groep vormde inderdaad de buffer waarmee de werkgelegenheid van een vaste kern van mijnwerkers werd beschermd. Tot deze laatste kern behoorden vooral Nederlanders, maar ook buitenlandse arbeidskrachten die door hun ervaring niet gemist konden worden. Het was niet uitzonderlijk dat gekwalificeerde mijnwerkers van buitenlandse herkomst een lange carrière in de Nederlandse mijnbouw volbrachten.

In de jaren vijftig kwam het verband tussen het aanwerven van buitenlandse arbeidsmigranten en de dubbele arbeidsmarkt voor mijnwerkers duidelijker aan het licht. Sedert de crisis van de jaren dertig waren de mijndirecties erin geslaagd via interne bedrijfsopleidingen, onmiddellijk aansluitend op de lagere school, jonge Limburgers te interesseren voor mijnarbeid. Deze categorie moest zorgen voor een geregelde instroom van jonge arbeidskrachten in het ondergrondse bedrijf, waarmee de vaste kern van mijnwerkers werd verste- 


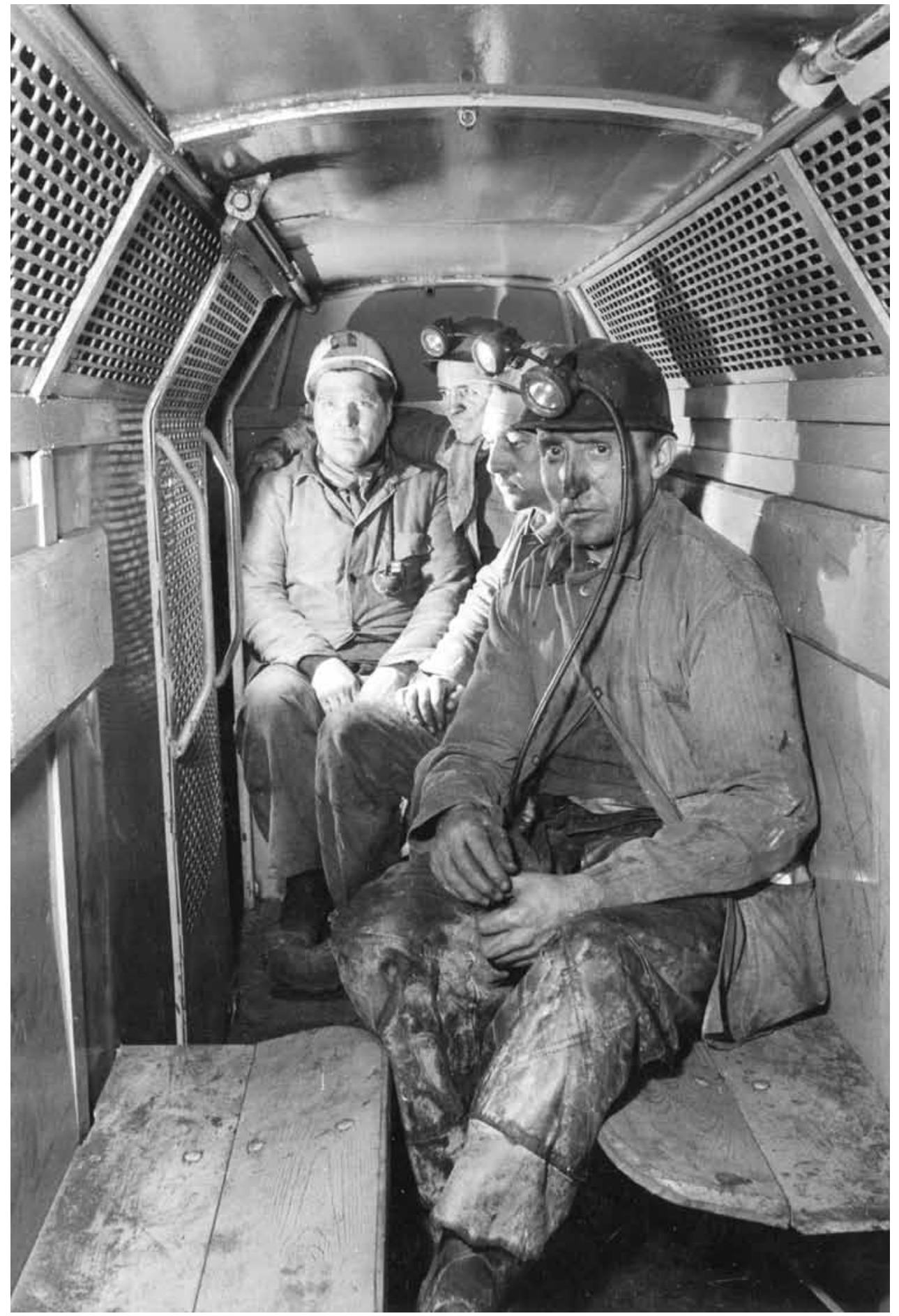

Van de schacht naar de ondergrondse werkplek moesten de mijnwerkers soms nog vele kilometers afleggen. In de steengangen gebeurde dat vervoer per trein. 1962. Bron: Fotocollectie Continium Kerkrade, F3903. 
vigd. De rekrutering van buitenlandse arbeidskrachten vond alleen nog plaats als er tijdelijke tekorten ontstonden. Dat gebeurde in de jaren 1948-195I met de werving van een eerste groep Italiaanse arbeidskrachten en in de jaren tussen 1955 en 1957 toen Oostenrijkers en opnieuw Italianen werden geworven. Op voorhand zagen de mijnen deze groepen als tijdelijk, als gastarbeiders. Door de demografische ontwikkeling in de mijnstreek en de uitbreiding van de woningvoorraad achtten de mijnen de rekruteringsmogelijkheden op de arbeidsmarkt in Limburg en de rest van Nederland op termijn niet zorgwekkend. De conjuncturele neergang en de kolencrisis van de jaren 1958-1960 maakte de plaats van de gastarbeiders op de arbeidsmarkt duidelijk: door de tijdelijke arbeidscontracten van de recent aangeworven Oostenrijkers en Italianen niet te verlengen, voorkwamen de mijndirecties dat de werkgelegenheid van de vaste kern van mijnwerkers in gevaar kwam.

Na 1960, toen het afnemende vertrouwen in de toekomst van de mijnbouw leidde tot teleurstellende wervingsresultaten op de Nederlandse arbeidsmarkt, moesten de mijndirecties zich opnieuw gaan richten op buitenlandse arbeidsmarkten. Meer dan in de jaren vijftig bestond er na 196o behoefte aan geschoolde mijnwerkers uit het buitenland die meteen aan het kolenfront konden worden ingezet. Ervaren mijnwerkers uit Joegoslavië en Marokko voldeden aan die eis. Dat deze noodzakelijke rekrutering van geschoolde buitenlandse mijnwerkers op den duur geleid zou hebben tot een meer structurele aanwezigheid van arbeidskrachten uit het buitenland, een ontwikkeling zoals zich na de Tweede Wereldoorlog in de Luikse mijnen voordeed, is niet onwaarschijnlijk.

Door de aankondiging van de mijnsluitingen in december 1965 was er daarna geen sprake meer van een normaal functionerende arbeidsmarkt voor mijnwerkers. Duidelijk is wel dat buitenlandse mijnwerkers een belangrijke rol in de sluitingsoperatie hebben gespeeld. Mede door hun aanwezigheid kon de sluitingsoperatie gefaseerd verlopen, waardoor het voor veel oudere (Nederlandse) mijnwerkers mogelijk was hun overbruggings- of pensioengerechtigde leeftijd als mijnwerker te halen.

\section{BINDING VERSUS AUTONOMIE}

Het arbeidsmarktbeleid van de mijndirecties werd gedurende de hele onderzochte periode gekenmerkt door het in acht nemen van een soort van hiërarchie van preferente groepen. Mijnstrekers, overige Limburgers, overige Nederlanders en buitenlanders, dat was in het algemeen de volgorde die bij het aantrekken van personeel in acht werd genomen. Bij gedwongen ontslagen was de volgorde omgekeerd. Het beleid ten aanzien van de preferente groepen werd zowel onderschreven door het Staatsmijnbedrijf, dat bij oprichting zelfs het principe had gehuldigd uitsluitend Nederlanders in dienst te nemen, als door de particuliere mijnen, hoewel die veelal in buitenlandse handen waren.

Niet alleen strategieën inzake werving en selectie speelden in dit beleid een rol, ook het vasthouden van eenmaal aangetrokken personeel was cruciaal. Bindingsstrategieën waren erop gericht een vaste kern van mijnwerkers op te bouwen, zodat de mijnen hun afhankelijkheid van de arbeidsmarkt verkleinden. Minder personeelsverloop betekende minder kosten en moeite die aan werving moesten worden besteed.

Tussen werving en selectie enerzijds en binding anderzijds bestond een hechte relatie. 
De mijndirecties hebben dat goed ingezien. De verwachting was steeds dat mijnwerkers die in de streek geworteld waren, de meeste bereidheid zouden vertonen zich aan het bedrijf te binden. De praktijk gaf de mijnondernemers gelijk: in het algemeen correspondeerde de preferentievolgorde met de mate van binding aan het mijnbedrijf. Gedurende de onderzochte periode waren Limburgers het meest bereid zich aan de mijnen te binden met lange dienstverbanden.

Het streven van de mijndirecties om de selectie van personeel in eigen hand te houden, loopt als een rode draad door de geschiedenis van de Limburgse mijnbouw in de twintigste eeuw. De specifieke aard van de mijnarbeid stelde bijzondere eisen aan de selectie en de mijnen zelf konden het best inschatten of iemand geschikt was om mijnwerker te worden. De wervingsagenten die de mijnen uit stuurden om arbeidskrachten te rekruteren beschikten zelf over een vaak lange ervaring in de mijnbouwsector. In de jaren twintig was de oprichting van de Geneeskundige Dienst der Nederlandse Steenkolenmijnen een instrument om de selectie op medisch gebied te verbeteren.

Van inmenging van buitenaf in de selectie van personeel moesten de mijnen niets hebben. Hun huiver om in de periode van opbouw met de geïnstitutionaliseerde arbeidsbemiddeling in zee te gaan, is op dat standpunt terug te voeren. Ook tijdens de periode van crisis en oorlog werd het personeelsbeleid van de mijnen gekenmerkt door hun pogingen controle te houden over de arbeidsvoorziening. Zo verleenden de mijnen in het begin van de jaren dertig weliswaar hun medewerking aan het verzoek van de Rijksoverheid om in Duitsland ontslagen mijnwerkers in dienst te nemen, maar verbonden daaraan wel de voorwaarde dat ze zelf de selectie zouden doen. In de tweede helft van de jaren dertig weigerden de mijnen toe te geven aan de druk van de regering en de arbeidsbeurzen om arbeidskrachten die eerder tijdens de crisis waren ontslagen opnieuw in dienst te nemen. Zelfs tijdens de bezettingsjaren hielden de mijnen voet bij stuk. Niet iedereen die door het gaan verrichten van mijnarbeid gedwongen tewerkstelling in Duitsland wilde voorkomen, kon in die jaren bij de mijnen aan de slag, omdat het selectiebeleid streng bleef. Ook de weigering in die periode om mijnwerkers uit Aken over te nemen en Russische dwangarbeiders te accepteren, zijn voorbeelden van het belang dat de mijnbedrijven hechtten aan een eigen selectie van arbeidskrachten. In de jaren vijftig en zestig tenslotte was in de onderhandelingen met buitenlandse instanties over wervingsovereenkomsten een harde eis van de Limburgse mijnondernemers dat zijzelf het laatste woord hadden bij de selectie van de arbeidsmigranten.

Werving, selectie en binding werden al in de periode van opbouw ondersteund door een resem aan instrumenten waarmee de mijndirecties werk in de mijn wilden stimuleren. Omdat huisvesting bij de werving en binding van personeel essentieel was, bouwden de mijnbouwondernemingen, in samenwerking met vooral katholieke woningcorporaties en gebruikmakend van subsidiemogelijkheden bij de Rijksoverheid, woningen voor het personeel. Ook goede arbeidsvoorwaarden waren van grote importantie. De zware arbeidsomstandigheden in vooral het ondergrondse bedrijf moesten worden gecompenseerd door aangepaste werktijden en een goede salariëring in vergelijking met andere industriële sectoren. De arbeidsvoorwaarden voor de gezamenlijke Nederlandse mijnen werden geüniformeerd in collectieve arbeidsovereenkomsten, waarvan de eerste in I920 werd afgesloten. Daarnaast introduceerden de gezamenlijke mijnen na de Eerste Wereldoorlog een stelsel van sociale verzekeringen tegen ziekte, invaliditeit, ouderdom en overlijden in de vorm van 
het Algemeen Mijnwerkersfonds, richtten ze de al gememoreerde Geneeskundige Dienst op die de medische behandeling van bedrijfsongevallen professionaliseerde en zorgden ze voor sociale voorzieningen, zoals een verenigingsleven op bedrijfsniveau. Doordat de mijnondernemingen bij dergelijke initiatieven doorgaans in gezamenlijkheid optraden, werd het personeelsverloop tussen de mijnen na de Eerste Wereldoorlog teruggedrongen.

Een cruciale strategie waarmee binding aan het bedrijf werd bevorderd, was de instelling van een interne bedrijfsopleiding, waar jongens na de lagere school werden opgeleid voor een functie in het ondergronds bedrijf. Voor deze leesjongensopleiding, die onmiddellijk na de Tweede Wereldoorlog werd omgevormd tot Ondergrondse Vakschool, konden tot het midden van de jaren vijftig met redelijk succes jongens uit de mijnstreek en daarbuiten worden geworven. De OVS-scholieren waren in de ogen van de mijndirecties de dragers van een mijnbouwtraditie. Zij zouden in de toekomst de kern van een op Limburgse leest geschoeide personeelsbezetting gaan vormen. De voortekenen daarvan waren niet ongunstig, toen al snel bleek dat de binding aan het bedrijf bij de ex-leesjongens en ex-OVS'ers aanmerkelijk groter was dan bij hun collega's die die vooropleiding niet hadden genoten.

Het proces van binding aan het bedrijf werd echter niet alleen bepaald door het strategisch beleid van de mijnondernemingen. Exogene omstandigheden speelden een voorname rol in de mate van succes van de bindingsstrategieën. Vooral was de stand van de arbeidsmarkt van belang. De mate waarin alternatieve werkgelegenheid beschikbaar was, bepaalde de mogelijkheden die mijnwerkers hadden om zich te onttrekken aan de werkgelegenheid in het mijnbedrijf en daarmee hun eigen autonomiestrategieën te verwezenlijken. In tijden dat de arbeidsmarkt krap was, stonden de bindingsstrategieën van de mijndirecties en de autonomiestrategieën van de mijnwerkers op gespannen voet. Een paar voorbeelden kunnen dat illustreren. In de periode van opbouw van de Limburgse mijnbouw was vooral de schaarste aan ervaren mijnwerkers verantwoordelijk voor de gespannen verhouding tussen binding en autonomie. Ervaren mijnwerkers hadden een ijzersterke arbeidsmarktpositie en dat gaf hen de mogelijkheid tot Freizügigkeit. Ze bonden zich vaak niet aan één bedrijf, maar vertoonden in het algemeen een zeer mobiel arbeidsmarktgedrag dat hen van mijn naar mijn en zelfs van mijnbekken naar mijnbekken voerde. Veel van de ervaren buitenlandse mijnwerkers die tijdens de opbouwfase in de Limburgse mijnen terechtkwamen, hadden al een migratietraject langs verschillende West-Europese mijnbouwregio's achter de rug. Voortdurend maakten ze van de schaarste aan ervaren mijnwerkers gebruik door zich daar aan te bieden waar de arbeidsvoorwaarden voor hun het meest voordelig waren. De zeer hoge verloopcijfers van vóór de Eerste Wereldoorlog zijn voor een belangrijk deel toe te schrijven aan de mogelijkheden die deze categorie van mijnwerkers had om autonomiestrategieën in praktijk te brengen.

Ook na de Tweede Wereldoorlog waren er momenten van spanning tussen binding en autonomie. Tussen 1953 en 1957 was de arbeidsmarkt zeer krap. Na een korte conjuncturele neergang in de jaren tussen 1958 en 1960 keerde de krapte in de jaren zestig terug. Voor mijnwerkers bood de aanwezigheid van werkgelegenheid elders de mogelijkheid tot een meer mobiel arbeidsmarktgedrag. Men kon er voor kiezen als grenspendelaar de carrière in de Belgische of Duitse kolenwinning voort te zetten, of het mijnbedrijf te verlaten en een baan te nemen in een andere sector. De convergerende tendens van de lonen in de mijn- 
bouw ten opzichte van die in andere sectoren stimuleerde het vertrek uit de mijn. De verloopcijfers in de Limburgse mijnbouwsector namen in die tijd weer toe.

De toename van alternatieven op de arbeidsmarkt (en in het vervolgonderwijs) had ook consequenties voor de OVS. Na I953 nam het aantal aanmeldingen af. Van de leerlingen die nog aan de opleiding begonnen, stroomden er steeds minder door naar het ondergrondse bedrijf. Met dat gedrag toonde de voor de mijnbedrijven meest preferente groep, minder dan ooit tevoren bereid te zijn zich aan het mijnbedrijf te binden. Alleen de jaren tussen I958 en I960 vertoonden een breuk in dat proces van afnemende aanmeldingen en toenemend vertrek. Door de conjuncturele neergang namen alternatieve mogelijkheden op de arbeidsmarkt tijdelijk af. In die situatie liepen de strategieën van mijnbedrijven en mijnwerkers weer meer in de pas.

De jaren tussen I958 en I96o toonden op kleinere schaal hetzelfde proces als tijdens de economische crisis van de jaren dertig: in tijden van economische neergang sloeg de balans om in het nadeel van de autonomiestrategieën van de mijnwerkers. Ook in de jaren dertig uitte zich dat in een daling van het personeelsverloop. Ondanks de gedwongen ontslagen door de mijnbedrijven verlieten aanzienlijk minder arbeidskrachten de mijnbedrijven dan in de periode van opbouw, toen de mijnarbeidsmarkt krap was. De mijndirecties ontsloegen bij voorkeur de groepen die bovengemiddelde arbeidsmobiliteit hadden vertoond: buitenlandse arbeidskrachten en grensarbeiders. Ze werden nog tijdens de crisis, maar zeker daarna vervangen door mijnwerkers waarvan men met goede reden meer binding aan het bedrijf kon verwachten: jonge geboren en getogen Limburgers.

\section{DE REGIONALISERING VAN DE MIJNARBEIDSMARKT}

Van begin af aan was het de opzet van de mijndirecties om de personeelsbezetting op te bouwen uit in de streek gewortelde arbeidskrachten. Dat streven werd door de overheid en de vakbonden onderschreven. Uit cijfers over de hele onderzochte periode bleek dat dit beleid succesvol was. Tussen I9oo en I965 was gemiddeld genomen meer dan de helft van de in dienst genomen mijnwerkers Limburger van geboorte; 70 procent was Nederlander. In december I $_{9} 65$ was 87 procent van de mijnwerkers Nederlander, waarvan de overgrote meerderheid in Limburg was geboren.

De 'verlimburgsing' van de mijnwerkerspopulatie kreeg in de loop van de eeuw steeds meer vorm. De vraag is of dat werd bereikt door weldoordachte en bewuste strategieën van de mijndirecties of doordat de omstandigheden waaronder dat beleid vorm kreeg, meezaten. In de fase van opbouw was de vorming van een Limburgse mijnwerkerspopulatie een moeilijk proces, ondanks strategieën van de mijndirecties om mensen de mijn in te krijgen. De mijnwerkers die van oudsher in Kerkrade aanwezig waren, waren te gering in aantal om de kern te vormen van de veel grotere behoefte aan mijnwerkers na I9oo. Door de crisis en de Tweede Wereldoorlog stopte de expansie van de steenkolenmijnbouw in Limburg. De pas op de plaats die noodgedwongen door de omstandigheden moest worden gemaakt, schiep voor de mijndirecties de mogelijkheden om de samenstelling van het personeelsbestand in de door hen gewenste richting bij te sturen. Vooral de jaren dertig waren het omslagpunt. Door de gedwongen ontslagen in die tijd konden de mijnen schoon schip maken 
en zich ontdoen van de minst welgevallige arbeidskrachten. Toen de conjunctuur weer aantrok bood de gunstige demografische ontwikkeling de mogelijkheid op de arbeidsmarkt te putten uit jonge Limburgse arbeidskrachten, die werden beschouwd als de dragers van een op te bouwen mijnwerkerstraditie. In de jaren I93I-I944 was bijna 8o procent van de nieuwe mijnwerkers Limburger. Tussen IgIg en 1930 was dat nog geen kwart geweest. De vorming van een interne bedrijfsopleiding (de leesjongensopleiding en later de OVS) was in het proces van regionalisering van grote betekenis. Door al in de hoogste klas van de lagere school jongens voor mijnarbeid te ronselen, waren de mijnen eventuele concurrentie een slag voor. Bovendien kregen de jongens als scholier al een salaris en genoten ze vrijstelling van militaire dienst. Tot het midden van de jaren vijftig was dat beleid succesvol. De mijnen konden vertrouwen op voldoende doorstroom van de OVS naar het ondergrondse bedrijf. De omstandigheid dat de mijnstreek het karakter had van een monocultuur zonder alternatieve werkgelegenheid in grootindustriële bedrijven bevorderde de aantrekkingskracht van de OVS. De praktijk leerde dat de mijnwerkers die via de OVS in het ondergrondse bedrijf waren ingestroomd, de meeste binding aan het bedrijf vertoonden. De OVS was daarmee de sleutel tot het succes van de regionalisering van de mijnarbeidsmarkt.

In het midden van de jaren vijftig keerden de kansen door verkrapping van de arbeidsmarkt en toename van de onderwijsmogelijkheden voor arbeiderskinderen. De belangstelling voor de OVS nam zienderogen af en daarmee droogde de jonge aanwas voor het ondergrondse bedrijf op. Het waren de eerste tekenen van wat omschreven kan worden als 'de desertie van de zonen', een proces dat zich in de Waalse mijnen al aan het eind van de negentiende eeuw

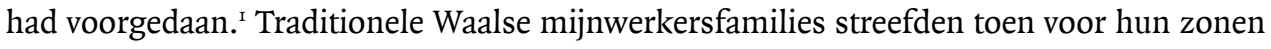
meer en meer een beroepscarrière buiten de mijnbouw na, waardoor ze meer sociaal prestige zouden verwerven. $\mathrm{Zij}$ verbonden deze strategie met een verandering in hun demografisch gedrag: mijnwerkers begonnen het aantal kinderen te beperken. Voor de Waalse mijnen betekende dat op den duur minder beschikbare arbeidskrachten op de regionale arbeidsmarkt.

In Limburg was er omstreeks 1955 echter geen sprake van demografische krimp. De toekomstige instroom van jonge arbeidskrachten op de arbeidsmarkt was niet in gevaar. De mijnen beschouwden de dalende belangstelling voor de OVS daarom aanvankelijk niet als zorgwekkend. In het midden van de jaren vijftig ging men er nog vanuit dat de Staatsmijn Beatrix in productie zou komen, en er in de verdere toekomst ruimte zou zijn - ook op de regionale arbeidsmarkt - voor enkele nieuwe ontginningszetels in de Peelvelden. De tussen I955 en 1957 gerekruteerde arbeidskrachten in Oostenrijk en Italië werden dan ook nadrukkelijk beschouwd als tijdelijke arbeidskrachten.

Nog één keer werden de omstandigheden voor de mijnen gunstiger, toen in de jaren 1958-196o een korte conjuncturele inzinking de alternatieven deed verminderen en de keuze voor de zekerheid van vast werk in de mijnen prevaleerde. Anderzijds gaf de kolencrisis ook de doodklap aan het vertrouwen in de werkgelegenheid in de mijn. Na Ig6o was het met de aantrekkingskracht van de OVS voorgoed gedaan. Daarmee was de 'desertie van de zonen' een onomkeerbaar proces geworden. Door omstandigheden die de mijnondernemingen niet in de hand hadden, moesten hun strategieën het afleggen tegen die van de mijnwerkers.

I Frank Caestecker, 'Arbeidsmarktstrategieën in de Belgische mijnindustrie tot I940', TSEG V nummer 3 (2008) 30-52, aldaar $44-48$. 


\section{Bijlagen}

Bijlage I De personeelsbezetting bij de Nederlandse mijnbedrijven, I895-I972

\begin{tabular}{|c|c|c|c|c|c|c|c|}
\hline & \multicolumn{2}{|c|}{ Staatsmijnen } & \multicolumn{2}{|c|}{ Oranje-Nassau Mijnen } & \multicolumn{2}{|c|}{ Laura \& Vereeniging } & \\
\hline & arbeiders & beambten & arbeiders & beambten & arbeiders & beambten & \\
\hline I895 & & & - & • & - & - & \\
\hline I896 & & & - & - & - & - & \\
\hline I897 & & & - & - & - & - & \\
\hline I898 & & & - & - & - & - & \\
\hline I899 & & & 406 & - & - & - & \\
\hline I900 & & & 805 & - & - & - & \\
\hline IgOI & & & 453 & - & $\cdot$ & $\cdot$ & \\
\hline I9O2 & - & 9 & 653 & - & - & - & \\
\hline I903 & 77 & I5 & 845 & - & - & - & \\
\hline I904 & $\mathrm{I} 26$ & I7 & 855 & • & • & • & \\
\hline I905 & 185 & 28 & 950 & - & 136 & - & \\
\hline I906 & $32 \mathrm{I}$ & 35 & I. 256 & • & I77 & - & \\
\hline I907 & 505 & 52 & I. 368 & • & 496 & • & \\
\hline I908 & 889 & 66 & I. 734 & - & 808 & - & \\
\hline I909 & I.I83 & 84 & I. 878 & - & 948 & • & \\
\hline I9IO & I. 386 & 93 & 2.127 & • & $\mathrm{I} .230$ & • & \\
\hline I9II & 1.620 & I07 & 2.133 & • & 1.303 & • & \\
\hline I9I2 & 2.253 & I27 & 2.289 & • & $\mathrm{I} .4 \mathrm{II}$ & - & \\
\hline I9I3 & $3.05 \mathrm{I}$ & I42 & 2.407 & • & I. 529 & • & \\
\hline I9I4 & 4.332 & I67 & 2.098 & • & I. 545 & - & \\
\hline I9I5 & $5 \cdot 5^{\mathrm{I} 6}$ & 204 & $2.38 \mathrm{I}$ & • & I. 622 & - & \\
\hline I9I6 & 6.732 & 255 & 2.979 & - & I. 872 & - & \\
\hline I9I7 & 8.807 & 346 & $3 \cdot 372$ & - & 2.055 & • & \\
\hline I9I8 & I0.673 & 474 & 3.433 & - & 2.324 & $\cdot$ & \\
\hline I9I9 & II. 748 & 526 & $4.33^{6}$ & - & 2.460 & • & \\
\hline I920 & I4.044 & 599 & $5.15 \mathrm{I}$ & - & 2.690 & • & \\
\hline
\end{tabular}




\begin{tabular}{|c|c|c|c|c|c|c|}
\hline & \multicolumn{2}{|c|}{ Domaniale Mijn } & \multicolumn{2}{|c|}{ Willem-Sophia } & \multicolumn{2}{|c|}{ Neuprick } \\
\hline & arbeiders & beambten & arbeiders & beambten & arbeiders & beambten \\
\hline I895 & 275 & • & • & - & I49 & • \\
\hline I896 & 317 & - & • & - & 148 & - \\
\hline I897 & 326 & . & . & . & I57 & . \\
\hline I898 & 329 & - & - & - & I6o & - \\
\hline I899 & $38 \mathrm{I}$ & • & • & • & 152 & . \\
\hline I900 & 425 & - & • & • & I6o & - \\
\hline I9OI & 487 & • & • & • & 158 & • \\
\hline 1902 & 576 & • & 288 & • & I67 & . \\
\hline 1903 & 654 & • & 267 & • & I66 & • \\
\hline 1904 & 689 & • & 222 & • & 163 & • \\
\hline 1905 & 805 & • & $3 \mathrm{I} 6$ & • & & \\
\hline I906 & 826 & • & $35 \mathrm{I}$ & • & & \\
\hline 1907 & I.098 & • & 426 & • & & \\
\hline 1908 & I.I25 & • & 519 & $\cdot$ & & \\
\hline 1909 & $\mathrm{I} .207$ & - & $55^{8}$ & $\cdot$ & & \\
\hline I9Io & I. 230 & $\cdot$ & 549 & $\cdot$ & & \\
\hline IgII & I. 440 & $\cdot$ & 573 & $\cdot$ & & \\
\hline I9I2 & I. 658 & - & 667 & - & & \\
\hline I9I3 & I. 747 & . & 689 & . & & \\
\hline I9I4 & I. 784 & - & 6ro & - & & \\
\hline I9I5 & I. 595 & • & 801 & • & & \\
\hline I9I6 & I. 646 & • & 889 & • & & \\
\hline I9I7 & $2.0 \mathrm{II}$ & • & 928 & • & & \\
\hline I9I8 & 2.435 & • & I.016 & • & & \\
\hline I9I9 & 2.699 & . & I.020 & . & & \\
\hline I920 & 3.080 & • & I.I94 & • & & \\
\hline
\end{tabular}




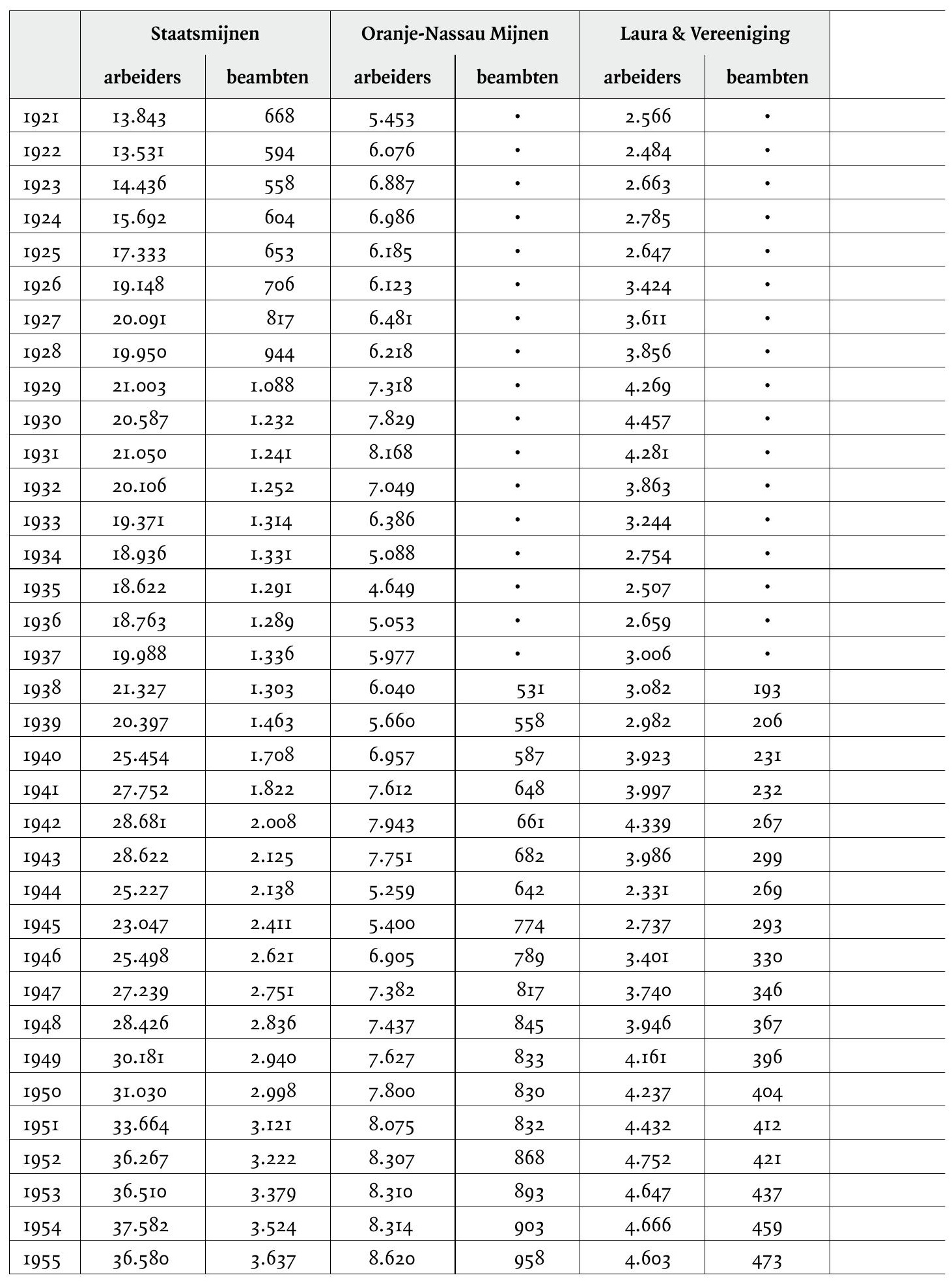




\begin{tabular}{|c|c|c|c|c|c|c|}
\hline & \multicolumn{2}{|c|}{ Domaniale Mijn } & \multicolumn{2}{|c|}{ Willem-Sophia } & \multicolumn{2}{|c|}{ Neuprick } \\
\hline & arbeiders & beambten & arbeiders & beambten & arbeiders & beambten \\
\hline I92I & 3.240 & • & I.290 & • & & \\
\hline 1922 & $3 \cdot 35^{I}$ & • & I. 422 & • & & \\
\hline 1923 & 3.538 & - & I. 523 & - & & \\
\hline I924 & 3.308 & - & I. 548 & - & & \\
\hline 1925 & 3.265 & - & I. 593 & • & & \\
\hline 1926 & 2.924 & • & I.716 & • & & \\
\hline 1927 & 2.938 & • & I. $73^{8}$ & • & & \\
\hline 1928 & 2.939 & • & I.699 & $\cdot$ & & \\
\hline I929 & 3.266 & • & I.705 & • & & \\
\hline 1930 & $3.25 \mathrm{I}$ & • & I. 688 & • & & \\
\hline I93I & 3.117 & • & I. 627 & $\cdot$ & & \\
\hline 1932 & 2.888 & • & I. 534 & • & & \\
\hline 1933 & 2.569 & • & I. 458 & $\cdot$ & & \\
\hline I934 & 2.083 & - & I. 344 & $\cdot$ & & \\
\hline 1935 & I.969 & • & I.369 & $\cdot$ & & \\
\hline 1936 & 2.017 & - & $\mathrm{I} .35 \mathrm{I}$ & $\cdot$ & & \\
\hline I937 & 2.015 & • & I. 385 & • & & \\
\hline 1938 & 2.119 & I3I & I.404 & 73 & & \\
\hline 1939 & I. 887 & I33 & I. 352 & 78 & & \\
\hline I940 & 2.078 & I35 & I. 553 & 86 & & \\
\hline I94I & 2.075 & 140 & I. 557 & 92 & & \\
\hline I942 & 2.076 & $\mathrm{I} 43$ & $\mathrm{I} .758$ & $9 \mathrm{I}$ & & \\
\hline I943 & 2.105 & I49 & I. 536 & 96 & & \\
\hline I944 & $\mathrm{I} .718$ & I33 & I.II7 & 93 & & \\
\hline I945 & I. 769 & I35 & I. 455 & I06 & & \\
\hline I946 & 2.245 & $16_{3}$ & I. 676 & $\mathrm{I} 24$ & & \\
\hline I947 & 2.342 & 176 & I.707 & I3I & & \\
\hline I948 & 2.173 & 180 & I. 628 & I35 & & \\
\hline I949 & 2.283 & I96 & I.7II & 138 & & \\
\hline 1950 & 2.408 & I94 & I. 754 & 137 & & \\
\hline I95I & 2.547 & I92 & I. 787 & I39 & & \\
\hline 1952 & 2.729 & I96 & I. 808 & I47 & & \\
\hline 1953 & $2.82 \mathrm{I}$ & 209 & I.804 & I54 & & \\
\hline I954 & 2.904 & 205 & I. $84 \mathrm{I}$ & 158 & & \\
\hline I955 & 2.867 & 207 & I. 794 & I64 & & \\
\hline
\end{tabular}




\begin{tabular}{|c|c|c|c|c|c|c|}
\hline & \multicolumn{2}{|c|}{ Staatsmijnen } & \multicolumn{2}{|c|}{ Oranje-Nassau Mijnen } & \multicolumn{2}{|c|}{ Laura \& Vereeniging } \\
\hline & arbeiders & beambten & arbeiders & beambten & arbeiders & beambten \\
\hline 1956 & 36.924 & 3.756 & 8.642 & 968 & 4.695 & 482 \\
\hline I957 & 38.152 & 3.884 & 8.544 & I.006 & 4.637 & 550 \\
\hline 1958 & 38.147 & 4.066 & 8.707 & I.043 & 4.734 & 564 \\
\hline I959 & 35.975 & 4.117 & 8.520 & I.057 & $4.63 \mathrm{I}$ & 564 \\
\hline I96o & 33.763 & $4 \cdot 335$ & $8.25 \mathrm{I}$ & I.070 & 4.485 & 558 \\
\hline I96I & 32.529 & $4 \cdot 523$ & $7.95 \mathrm{I}$ & $\mathrm{I} .083$ & 4.319 & 560 \\
\hline 1962 & $32.53 \mathrm{I}$ & 4.742 & 8.168 & I.IO3 & $4 \cdot 347$ & 564 \\
\hline I963 & 31.688 & $4.69 \mathrm{I}$ & 8.402 & I.097 & $4.4 \mathrm{II}$ & 564 \\
\hline 1964 & 3I.154 & 4.732 & 8.606 & 1.085 & $4.46 \mathrm{I}$ & 560 \\
\hline I965 & 29.609 & 4.808 & $8.35 \mathrm{I}$ & I.088 & 4.428 & 566 \\
\hline Ig66 & 24.692 & 4.940 & 7.880 & I.060 & 4.020 & $55^{8}$ \\
\hline I967 & I9.042 & 4.668 & 6.714 & 983 & 3.494 & 519 \\
\hline I968 & 15.792 & 4.457 & $5 \cdot 94 \mathrm{I}$ & 895 & 3.083 & 467 \\
\hline I969 & I3.584 & 4.274 & 5.255 & 845 & 2.679 & 442 \\
\hline I970 & I2.987 & 4.305 & 4.807 & 787 & 2.274 & 410 \\
\hline I97I & II. 675 & 4.007 & 3.720 & 669 & I.960 & 392 \\
\hline I972 & 10.552 & • & 2.940 & 577 & I. 657 & 356 \\
\hline
\end{tabular}

Bron: SHCL, Archief Gezamenlijke Steenkolenmijnen in Limburg, Statistiek.

Bijlage 2 De nettoproductie van steenkolen bij de particuliere mijnen, 1895-1973 (in rooo ton)

\begin{tabular}{|c|c|c|c|c|c|c|c|}
\hline & ON I & ON II & ON III & ON IV & $\begin{array}{c}\text { Oranje } \\
\text { Nassau }\end{array}$ & Laura & Julia \\
\hline I895 & & & & & & & \\
\hline I896 & & & & & & & \\
\hline I897 & & & & & & & \\
\hline I898 & & & & & & & \\
\hline I899 & 44 & & & & 44 & & \\
\hline I900 & I43 & & & & I43 & & \\
\hline IgOI & II9 & & & & II9 & & \\
\hline I902 & $\mathrm{I} 42$ & & & & $\mathrm{I} 42$ & & \\
\hline 1903 & I75 & & & & I75 & & \\
\hline I904 & 173 & 4 & & & I77 & & \\
\hline 1905 & I76 & IO & & & I86 & 8 & \\
\hline
\end{tabular}




\begin{tabular}{|c|c|c|c|c|l|l|} 
& \multicolumn{2}{|c|}{ Domaniale Mijn } & \multicolumn{2}{c|}{ Willem-Sophia } & \multicolumn{2}{c|}{ Neuprick } \\
& arbeiders & beambten & arbeiders & beambten & arbeiders & beambten \\
\hline I956 & 2.830 & 209 & I.760 & I35 & & \\
\hline I957 & 2.776 & 227 & I.806 & I77 & & \\
\hline I958 & 2.834 & 236 & I.819 & I8I & & \\
\hline I959 & 2.888 & 230 & I.828 & I79 & & \\
\hline I960 & 2.838 & 236 & I.728 & I83 & & \\
\hline I961 & 2.762 & 238 & I.667 & I78 & & \\
\hline I962 & 2.654 & 229 & I.646 & I80 & & \\
\hline I963 & 2.595 & 225 & I.6II & I78 & & \\
\hline I964 & 2.582 & 228 & I.552 & I79 & & \\
\hline I965 & 2.535 & 229 & I.513 & I78 & & \\
\hline I966 & 2.197 & 218 & I.459 & I70 & & \\
\hline I967 & I.935 & I87 & I.372 & I64 & & \\
\hline I968 & I.318 & I63 & I.288 & I65 & & \\
\hline I969 & 263 & I03 & I.133 & I43 & & \\
\hline I970 & 67 & 37 & I08 & 67 & & \\
\hline I97I & 4 & 5 & & 20 & & \\
\hline I972 & & & & & & \\
\hline
\end{tabular}

\begin{tabular}{|l|c|c|c|c|c|c|}
\hline L\&V & Domaniale & $\begin{array}{c}\text { Willem } \\
\text { Sophia }\end{array}$ & Neuprick & $\begin{array}{c}\text { particuliere } \\
\text { mijnen }\end{array}$ & $\begin{array}{c}\text { pm in \% } \\
\text { gezamenlijke } \\
\text { mijnen }\end{array}$ \\
\hline I895 & & 80 & & 47 & I27 & 100 \\
\hline I896 & & 92 & & 46 & I38 & I00 \\
\hline I897 & & I04 & & 46 & I50 & 100 \\
\hline I898 & & I06 & & 44 & I50 & I00 \\
\hline I899 & & I23 & & 46 & 213 & 100 \\
\hline I900 & & I25 & & 52 & 320 & I00 \\
\hline I901 & & I30 & & 62 & 311 & 100 \\
\hline I902 & & I65 & 24 & 60 & 391 & I00 \\
\hline I903 & & I80 & $4 \mathrm{I}$ & 62 & 458 & 100 \\
\hline I904 & & 200 & 35 & 35 & 447 & I00 \\
\hline I905 & 8 & 208 & 84 & & 486 & 100 \\
\hline
\end{tabular}




\begin{tabular}{|c|c|c|c|c|c|c|c|}
\hline & ON I & ON II & ON III & ON IV & $\begin{array}{l}\text { Oranje } \\
\text { Nassau }\end{array}$ & Laura & Julia \\
\hline I906 & I84 & 46 & & & 230 & I3 & \\
\hline I907 & I90 & 87 & & & 277 & 79 & \\
\hline I908 & 201 & 140 & & & $34 \mathrm{I}$ & 156 & \\
\hline I909 & 219 & I68 & & & 387 & 240 & \\
\hline I9IO & 240 & $\mathrm{I} 73$ & & & $4 \mathrm{I} 3$ & $29 \mathrm{I}$ & \\
\hline I9II & $27 \mathrm{I}$ & I97 & & & 468 & 304 & \\
\hline I9I2 & 297 & 247 & & & 544 & 323 & \\
\hline I9I3 & 297 & 238 & & & 535 & 332 & \\
\hline I9I4 & 224 & 243 & 49 & & $5^{1} 6$ & 304 & \\
\hline I9I5 & I86 & 278 & 60 & & 524 & 350 & \\
\hline I9I6 & 259 & 317 & 73 & & 649 & 418 & \\
\hline I9I7 & 305 & 373 & 70 & & 748 & 462 & \\
\hline I9I8 & 316 & 373 & I3I & & 820 & 475 & \\
\hline I9I9 & $28 \mathrm{I}$ & 324 & I34 & & 739 & 519 & \\
\hline I920 & 275 & 378 & I75 & & 828 & $55^{6}$ & \\
\hline I92I & 310 & 395 & 204 & & 909 & 498 & \\
\hline I922 & 363 & 440 & 323 & & I.I26 & 520 & \\
\hline I923 & 367 & 494 & 393 & & I. 254 & 600 & \\
\hline I924 & 382 & $52 \mathrm{I}$ & 422 & & I. 325 & 593 & \\
\hline I925 & 385 & 546 & 455 & & I.386 & 630 & \\
\hline 1926 & 370 & 6oI & 560 & & I.53I & 755 & 42 \\
\hline I927 & 354 & 625 & 570 & $3 I$ & I. 580 & 685 & 89 \\
\hline I928 & $3^{6} 5$ & 605 & 566 & I55 & I.69I & 726 & I9I \\
\hline I929 & 470 & 643 & 682 & 235 & 2.030 & 800 & 476 \\
\hline I930 & $5 \mathrm{I} 2$ & 687 & 754 & 320 & 2.273 & $77 \mathrm{I}$ & 701 \\
\hline I93I & 579 & 738 & 857 & $45^{6}$ & 2.630 & 787 & 727 \\
\hline I932 & 492 & 736 & 782 & 486 & 2.496 & 675 & 649 \\
\hline I933 & 510 & 646 & 709 & $46 \mathrm{I}$ & 2.326 & 650 & 614 \\
\hline I934 & 444 & 582 & $74 \mathrm{I}$ & 393 & 2.160 & 557 & 559 \\
\hline I935 & 345 & 520 & 801 & 337 & 2.003 & $55 \mathrm{I}$ & 555 \\
\hline 1936 & 393 & 608 & 917 & 359 & 2.277 & 667 & 578 \\
\hline I937 & $62 \mathrm{I}$ & 782 & I.022 & 505 & 2.930 & $79 \mathrm{I}$ & 758 \\
\hline 1938 & 488 & 709 & 844 & 444 & 2.485 & $77 \mathrm{I}$ & 714 \\
\hline I939 & 529 & 637 & 775 & 398 & 2.339 & 742 & 669 \\
\hline I940 & 546 & 647 & 738 & 385 & 2.316 & 632 & 668 \\
\hline
\end{tabular}




\begin{tabular}{|c|c|c|c|c|c|c|}
\hline & L\&V & Domaniale & $\begin{array}{l}\text { Willem } \\
\text { Sophia }\end{array}$ & Neuprick & $\begin{array}{l}\text { particuliere } \\
\text { mijnen }\end{array}$ & $\begin{array}{c}\mathrm{pm} \text { in } \% \\
\text { gezamenlijke } \\
\text { mijnen }\end{array}$ \\
\hline I906 & I3 & $2 \mathrm{I} 4$ & 89 & & 546 & 99 \\
\hline 1907 & 79 & $23 \mathrm{I}$ & I04 & & $69 \mathrm{I}$ & 96 \\
\hline 1908 & 156 & 234 & 98 & & 829 & $9 \mathrm{I}$ \\
\hline I909 & 240 & 243 & 109 & & 979 & 87 \\
\hline I910 & $29 \mathrm{I}$ & 267 & $\mathrm{I} 29$ & & I.IOO & 85 \\
\hline I9II & 304 & 320 & 138 & & I. 230 & 83 \\
\hline 1912 & 323 & 389 & I44 & & $\mathrm{I} .400$ & $8 \mathrm{I}$ \\
\hline 1913 & 332 & 445 & I43 & & I. 455 & 78 \\
\hline I9I4 & 304 & $4 \mathrm{I} 2$ & 158 & & I. 390 & 72 \\
\hline I9I5 & 350 & 393 & 209 & & I. 476 & 65 \\
\hline I9I6 & $4 I 8$ & 389 & 230 & & I. 686 & 65 \\
\hline I9I7 & 462 & 468 & 247 & & I. 925 & 64 \\
\hline I9I8 & 475 & 484 & 233 & & 2.012 & 59 \\
\hline I9I9 & 519 & 510 & $\mathrm{I} 76$ & & I. 944 & 57 \\
\hline 1920 & 556 & 563 & 242 & & 2.189 & 55 \\
\hline I92I & 498 & $4 \mathrm{II}$ & 268 & & 2.086 & 53 \\
\hline 1922 & 520 & $55^{\circ}$ & 320 & & 2.516 & 55 \\
\hline 1923 & 600 & 637 & 364 & & 2.855 & 54 \\
\hline I924 & 593 & 666 & 379 & & 2.963 & 50 \\
\hline 1925 & 630 & 678 & 393 & & 3.087 & 45 \\
\hline I926 & 797 & 758 & 420 & & 3.506 & 40 \\
\hline I927 & 774 & 761 & 428 & & 3.543 & 38 \\
\hline 1928 & 917 & 803 & 433 & & 3.844 & 36 \\
\hline I929 & I.276 & 947 & $47 \mathrm{I}$ & & 4.724 & $4 \mathrm{I}$ \\
\hline 1930 & I. 472 & 995 & 483 & & 5.223 & 43 \\
\hline I93I & I. 514 & I.029 & 480 & & 5.653 & 44 \\
\hline 1932 & I. 324 & I.010 & 425 & & 5.255 & $4 \mathrm{I}$ \\
\hline I933 & I. 264 & I.037 & 407 & & 5.034 & 40 \\
\hline I934 & I.II6 & 847 & 4IO & & 4.533 & 37 \\
\hline I935 & I.106 & 777 & $40 \mathrm{I}$ & & 4.287 & 36 \\
\hline 1936 & $\mathrm{I} .245$ & 843 & 434 & & 4.799 & 38 \\
\hline I937 & I. 549 & 901 & 503 & & 5.883 & $4 \mathrm{I}$ \\
\hline 1938 & I. 485 & 820 & 500 & & 5.290 & 39 \\
\hline I939 & $\mathrm{I} .4 \mathrm{II}$ & 786 & $47 \mathrm{I}$ & & 5.007 & 39 \\
\hline I940 & I. 300 & 764 & 469 & & 4.849 & 40 \\
\hline
\end{tabular}




\begin{tabular}{|c|c|c|c|c|c|c|c|}
\hline & ON I & ON II & ON III & ON IV & $\begin{array}{l}\text { Oranje } \\
\text { Nassau }\end{array}$ & Laura & Julia \\
\hline I94I & 648 & 764 & 904 & 430 & 2.746 & 705 & 685 \\
\hline I942 & 604 & $69 \mathrm{I}$ & 958 & 449 & 2.702 & 669 & 680 \\
\hline I943 & 579 & 718 & 871 & 430 & 2.598 & 637 & 654 \\
\hline I944 & $35 \mathrm{I}$ & 488 & 515 & 264 & I.6I8 & 397 & 392 \\
\hline I945 & I99 & 287 & 239 & 138 & 863 & 217 & 216 \\
\hline I946 & 390 & 514 & 493 & 243 & I. 640 & 353 & 355 \\
\hline I947 & 499 & 636 & 654 & 275 & 2.064 & 443 & 588 \\
\hline I948 & 510 & 659 & 727 & 327 & 2.223 & 526 & 662 \\
\hline I949 & 533 & 662 & 719 & $3 \mathrm{I} 6$ & 2.230 & 554 & 706 \\
\hline I950 & 584 & 686 & 755 & 355 & 2.380 & 560 & 747 \\
\hline I95I & 559 & 686 & 8I9 & 369 & 2.433 & 573 & 767 \\
\hline I952 & 602 & 710 & 952 & 390 & 2.654 & 609 & 837 \\
\hline I953 & $55 \mathrm{I}$ & 628 & 902 & 405 & 2.486 & 595 & 772 \\
\hline I954 & 534 & 6r9 & 796 & 364 & 2.313 & 553 & $73^{6}$ \\
\hline I955 & 537 & 598 & 794 & 322 & $2.25 \mathrm{I}$ & 527 & $75 \mathrm{I}$ \\
\hline 1956 & 497 & 592 & $78 \mathrm{I}$ & 330 & 2.200 & 500 & 750 \\
\hline I957 & 510 & $5 \mathrm{II}$ & 777 & 324 & 2.122 & 472 & 713 \\
\hline 1958 & 494 & 510 & 914 & 312 & 2.230 & 485 & 733 \\
\hline I959 & 537 & $5 \mathrm{II}$ & 967 & 296 & $2.3 \mathrm{II}$ & 529 & 747 \\
\hline I96o & $55^{2}$ & 577 & 922 & 345 & 2.396 & 569 & 807 \\
\hline I96I & 555 & 645 & 962 & 372 & 2.534 & 502 & $82 I$ \\
\hline I962 & 509 & 6ro & 878 & 347 & 2.344 & 453 & $8 \mathrm{I} 6$ \\
\hline I963 & 586 & 630 & 81o & 329 & 2.355 & 440 & 785 \\
\hline I964 & 633 & 615 & 787 & 398 & 2.433 & $45^{2}$ & 780 \\
\hline I965 & 691 & 670 & 834 & 347 & 2.542 & 490 & 716 \\
\hline I966 & $67 \mathrm{I}$ & 623 & 764 & $3^{12}$ & 2.370 & $45^{\circ}$ & 789 \\
\hline I967 & 617 & 594 & 942 & & 2.153 & 394 & 716 \\
\hline I968 & 595 & 638 & $73 \mathrm{I}$ & & I.964 & & I.045 \\
\hline I969 & 670 & 569 & 599 & & I. 838 & & I.017 \\
\hline I970 & $58 \mathrm{I}$ & 510 & 608 & & г.696 & & 875 \\
\hline I97I & 604 & I55 & 496 & & I. 257 & & 780 \\
\hline I972 & 569 & & 456 & & I.025 & & 688 \\
\hline I973 & 549 & & 132 & & $68 \mathrm{I}$ & & 580 \\
\hline
\end{tabular}

Bron: SHCL, Archief Gezamenlijke Steenkolenmijnen in Limburg, Statistiek. 


\begin{tabular}{|c|c|c|c|c|c|c|}
\hline & L\&V & Domaniale & $\begin{array}{l}\text { Willem } \\
\text { Sophia }\end{array}$ & Neuprick & $\begin{array}{l}\text { particuliere } \\
\text { mijnen }\end{array}$ & $\begin{array}{c}\mathrm{pm} \text { in } \% \\
\text { gezamenlijke } \\
\text { mijnen }\end{array}$ \\
\hline I94I & I. 390 & 772 & 495 & & 5.403 & $4 \mathrm{I}$ \\
\hline I942 & I. 349 & 715 & 473 & & 5.239 & 42 \\
\hline I943 & $\mathrm{I} .29 \mathrm{I}$ & 676 & 488 & & 5.053 & 40 \\
\hline I944 & 789 & 429 & 316 & & 3.152 & 38 \\
\hline I945 & 433 & 318 & 185 & & I.799 & 35 \\
\hline I946 & 708 & 493 & 348 & & 3.189 & 38 \\
\hline I947 & I.03I & 544 & 383 & & 4.022 & 40 \\
\hline 1948 & I.I88 & 492 & 348 & & $4.25 \mathrm{I}$ & 38 \\
\hline I949 & $\mathrm{I} .260$ & 479 & 389 & & 4.358 & 37 \\
\hline 1950 & $\mathrm{I} .307$ & 493 & 367 & & 4.547 & 37 \\
\hline I95I & I. 340 & 496 & 354 & & 4.623 & 37 \\
\hline 1952 & I. 446 & 504 & 406 & & 5.010 & 40 \\
\hline I953 & I. 367 & 516 & $40 \mathrm{I}$ & & 4.770 & 39 \\
\hline I954 & I. 289 & 499 & 377 & & 4.478 & 37 \\
\hline I955 & $\mathrm{I} .278$ & 513 & 376 & & $4.4 \mathrm{I} 8$ & 37 \\
\hline 1956 & $\mathrm{I} .250$ & 509 & 382 & & $4 \cdot 34 \mathrm{I}$ & 37 \\
\hline I957 & I.I85 & $45^{6}$ & $38 \mathrm{I}$ & & 4.I44 & 36 \\
\hline 1958 & I. 218 & 499 & 382 & & 4.329 & 36 \\
\hline I959 & I. 276 & 498 & 387 & & 4.472 & 37 \\
\hline 1960 & I. 376 & 543 & 423 & & 4.738 & 38 \\
\hline I96I & I. 323 & 578 & $4 \mathrm{I} 7$ & & 4.852 & 38 \\
\hline 1962 & I.269 & 536 & 426 & & 4.575 & 40 \\
\hline 1963 & $\mathrm{I} .225$ & 573 & 432 & & 4.585 & 40 \\
\hline 1964 & $\mathrm{I} .232$ & $58 \mathrm{I}$ & 433 & & 4.679 & $4 \mathrm{I}$ \\
\hline I965 & I. 206 & 537 & 433 & & 4.718 & $4 \mathrm{I}$ \\
\hline I966 & I. 239 & 515 & 448 & & 4.572 & 45 \\
\hline I967 & I.IIO & 567 & 435 & & $4.26_{5}$ & 53 \\
\hline I968 & I.045 & 433 & 433 & & 3.875 & 58 \\
\hline I969 & I.017 & I3I & 390 & & 3.376 & 60 \\
\hline I970 & 875 & & 79 & & 2.650 & $6 \mathrm{I}$ \\
\hline I97I & 780 & & & & 2.037 & 56 \\
\hline I972 & 688 & & & & $\mathrm{I} .7 \mathrm{I} 3$ & $6 \mathrm{I}$ \\
\hline I973 & 580 & & & & I. 26I & 73 \\
\hline
\end{tabular}


Bijlage 3 De nettoproductie van steenkolen bij Staatsmijnen, I906-I973 (in Iooo ton)

\begin{tabular}{|c|c|c|c|c|c|c|}
\hline & Wilhelmina & Emma & Hendrik & Maurits & $\begin{array}{l}\text { Staats- } \\
\text { mijnen }\end{array}$ & $\begin{array}{c}\text { SM in \% } \\
\text { gezamenlijke } \\
\text { mijnen }\end{array}$ \\
\hline I906 & 3 & & & & 3 & I \\
\hline 1907 & 32 & & & & 32 & 4 \\
\hline I908 & 79 & & & & 79 & 9 \\
\hline I909 & 142 & & & & $\mathrm{I} 42$ & $\mathrm{I} 3$ \\
\hline I9IO & 192 & & & & 192 & $\mathrm{I} 5$ \\
\hline IgII & 246 & I & & & 247 & 17 \\
\hline I9I2 & 316 & 9 & & & 325 & 19 \\
\hline I913 & 358 & 60 & & & $4 \mathrm{I} 8$ & 22 \\
\hline I9I4 & 383 & I64 & & & 547 & 28 \\
\hline I9I5 & 450 & 333 & I & & 784 & 35 \\
\hline I9I6 & 438 & 455 & 7 & & 900 & 35 \\
\hline I9I7 & 489 & 557 & 46 & & I.092 & 36 \\
\hline I9I8 & 562 & $66 \mathrm{I}$ & I79 & & I. 402 & $4 \mathrm{I}$ \\
\hline I9I9 & 549 & 626 & 302 & & I. 477 & 43 \\
\hline 1920 & 547 & 804 & $42 \mathrm{I}$ & & I. 772 & 45 \\
\hline I92I & 523 & 854 & 478 & & I. 855 & 47 \\
\hline I922 & 617 & 896 & 573 & & 2.086 & 45 \\
\hline I923 & 632 & I.OIO & 828 & 2 & 2.472 & 46 \\
\hline I924 & 689 & I.I86 & I.068 & I8 & $2.96 \mathrm{I}$ & 50 \\
\hline 1925 & 845 & I. 355 & $\mathrm{I} .28 \mathrm{I}$ & 324 & 3.805 & 55 \\
\hline I926 & I.087 & I.74I & I. 703 & $66_{5}$ & $5 \cdot 196$ & 60 \\
\hline I927 & I.I2I & 1.809 & I. 730 & I.I7I & $5.83 \mathrm{I}$ & 62 \\
\hline I928 & $\mathrm{I} .24 \mathrm{I}$ & I. 952 & I. 775 & I.937 & 6.905 & 64 \\
\hline 1929 & I. $35 \mathrm{I}$ & I.932 & I. 630 & I.944 & 6.857 & 59 \\
\hline 1930 & I. 328 & I.996 & I. 673 & I.99I & 6.988 & 57 \\
\hline I93I & I. 364 & 2.019 & I. 752 & 2.113 & 7.248 & 56 \\
\hline 1932 & I. 430 & $2.09 \mathrm{I}$ & I. 833 & 2.147 & $7 \cdot 501$ & 59 \\
\hline I933 & I. 337 & 2.170 & $\mathrm{I} .75 \mathrm{I}$ & 2.282 & $7 \cdot 540$ & 60 \\
\hline I934 & I. 278 & $2.33 \mathrm{I}$ & I. 723 & 2.476 & 7.808 & 63 \\
\hline I935 & I. 258 & 2.269 & I. 565 & 2.499 & $7 \cdot 59 \mathrm{I}$ & 64 \\
\hline 1936 & I. $3 \mathrm{I} 4$ & 2.472 & I. 624 & 2.594 & 8.004 & 62 \\
\hline I937 & I. 438 & 2.527 & I. 670 & 2.803 & $8.43^{8}$ & 59 \\
\hline 1938 & I. 430 & 2.468 & I. 642 & 2.658 & 8.198 & 6I \\
\hline I939 & I. 387 & 2.270 & I. $55 \mathrm{I}$ & 2.646 & 7.854 & 6I \\
\hline
\end{tabular}




\begin{tabular}{|c|c|c|c|c|c|c|}
\hline & Wilhelmina & Emma & Hendrik & Maurits & $\begin{array}{l}\text { Staats- } \\
\text { mijnen }\end{array}$ & $\begin{array}{c}\mathrm{SM} \text { in } \% \\
\text { gezamenlijke } \\
\text { mijnen }\end{array}$ \\
\hline 1940 & I. 252 & 2.054 & I.46I & 2.529 & 7.296 & 60 \\
\hline I94I & I. $48 \mathrm{I}$ & 2.225 & I. 630 & 2.617 & 7.953 & 59 \\
\hline 1942 & I.4IO & I.970 & I. 485 & 2.226 & 7.091 & 58 \\
\hline I943 & I. 390 & I. 886 & $\mathrm{I} .4 \mathrm{I} 3$ & 2.755 & 7.444 & 60 \\
\hline I944 & 998 & I. 250 & 957 & I. 956 & $5 \cdot \mathrm{I} 6 \mathrm{I}$ & 62 \\
\hline I945 & 762 & 706 & 537 & $\mathrm{I} .293$ & 3.298 & 65 \\
\hline 1946 & I.048 & I.099 & 937 & $2.04 \mathrm{I}$ & 5.125 & 62 \\
\hline I947 & I. 296 & 1.303 & I.090 & 2.393 & 6.082 & 60 \\
\hline I948 & I.4IO & I. 507 & I.192 & 2.672 & $6.78 \mathrm{I}$ & 62 \\
\hline I949 & I. $35^{2}$ & I. 876 & I. 337 & 2.782 & $7 \cdot 347$ & 63 \\
\hline 1950 & I. 325 & 2.056 & I. 475 & 2.844 & 7.700 & 63 \\
\hline I95I & I.307 & 2.144 & I. 559 & $2.79 \mathrm{I}$ & 7.801 & 63 \\
\hline 1952 & I. 257 & 2.120 & I.497 & 2.648 & $7 \cdot 522$ & 60 \\
\hline I953 & I. 176 & 2.255 & I.499 & 2.597 & $7 \cdot 527$ & $6 \mathrm{I}$ \\
\hline I954 & I.I28 & 2.363 & I. 524 & 2.578 & 7.593 & 63 \\
\hline I955 & I.082 & 2.355 & I. 459 & $2.58 \mathrm{I}$ & $7 \cdot 477$ & 63 \\
\hline 1956 & I.0I7 & $2.43 \mathrm{I}$ & I. 470 & 2.577 & 7.495 & 63 \\
\hline I957 & 987 & 2.328 & I.4I7 & 2.500 & 7.232 & 64 \\
\hline 1958 & I.042 & 2.515 & I. 464 & 2.530 & $7.55 \mathrm{I}$ & 64 \\
\hline I959 & I.007 & 2.480 & I. 423 & 2.596 & 7.506 & 63 \\
\hline I96o & $\mathrm{I} .026$ & 2.565 & I. 475 & 2.694 & 7.760 & 62 \\
\hline I96I & I.03I & $2.60 \mathrm{I}$ & I. 398 & 2.739 & 7.769 & 62 \\
\hline I962 & I.02I & 2.375 & I. 377 & 2.225 & 6.998 & 60 \\
\hline 1963 & I.054 & $2.4 \mathrm{I} 5$ & I. $32 \mathrm{I}$ & 2.134 & 6.924 & 60 \\
\hline I964 & I.053 & 3.367 & & $2.38 \mathrm{I}$ & $6.8 \mathrm{oI}$ & 59 \\
\hline 1965 & $\mathrm{I} .050$ & $3 \cdot 327$ & & $2.35 \mathrm{I}$ & 6.728 & 59 \\
\hline I966 & I.016 & 2.864 & & I.600 & 5.480 & 55 \\
\hline 1967 & 942 & 2.544 & & 314 & 3.800 & 47 \\
\hline I968 & 577 & $2.2 \mathrm{II}$ & & & 2.788 & 42 \\
\hline I969 & 182 & 2.006 & & & 2.188 & 40 \\
\hline I970 & & I. 684 & & & I. 684 & 39 \\
\hline I97I & & I. 572 & & & I. 572 & 44 \\
\hline I972 & & I.099 & & & I.099 & 39 \\
\hline I973 & & $46 \mathrm{I}$ & & & $46 \mathrm{I}$ & 27 \\
\hline
\end{tabular}

Bron: SHCL, Archief Gezamenlijke Steenkolenmijnen in Limburg, Statistiek. 
Bijlage 4 De steenkolenbalans van Nederland, I895-I970 (in Iooo ton)

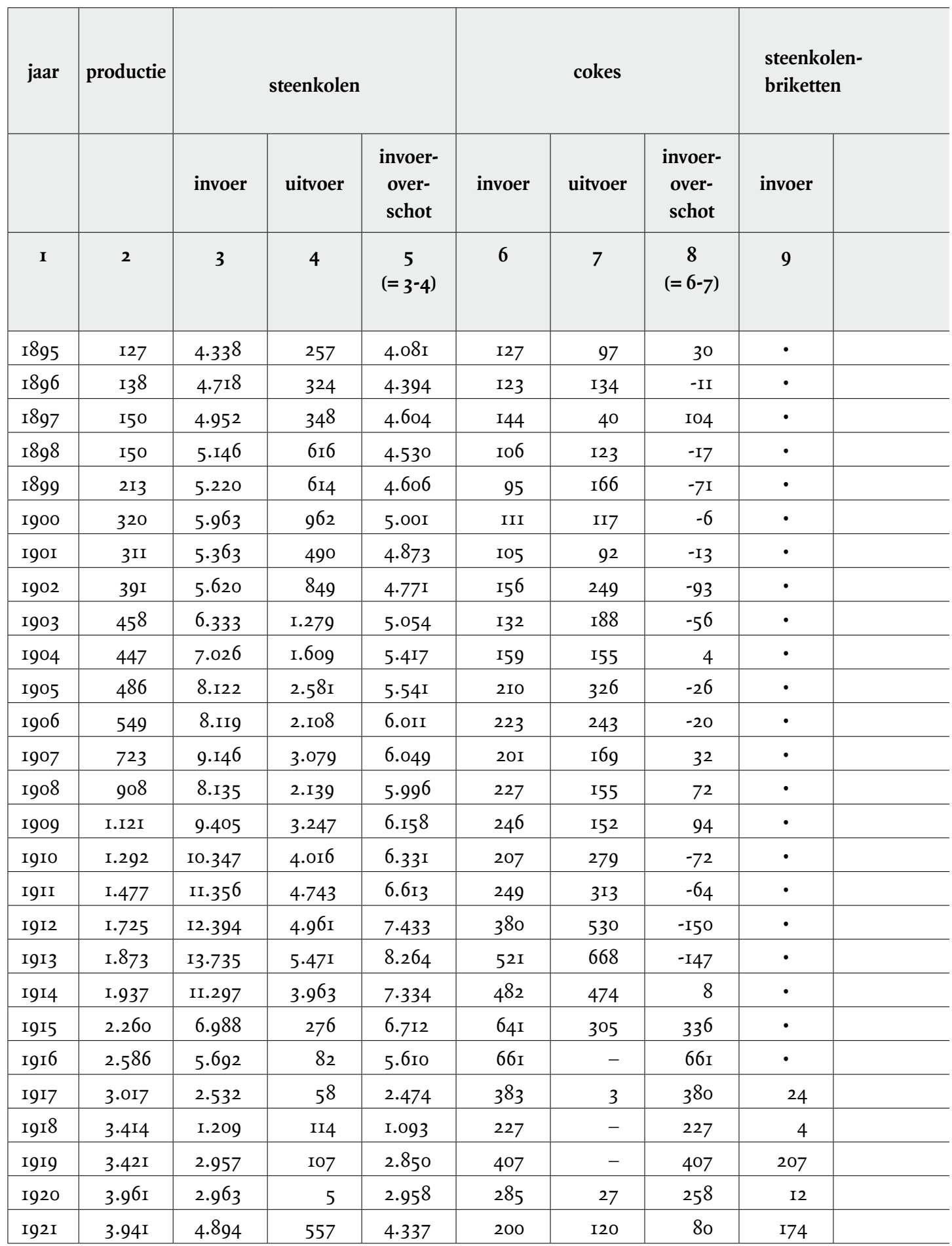




\begin{tabular}{|c|c|c|c|c|c|c|c|c|}
\hline \multicolumn{3}{|c|}{$\begin{array}{c}\text { steenkolen- } \\
\text { briketten }\end{array}$} & \multirow{2}{*}{$\begin{array}{c}\text { bunker- } \\
\text { kolen }\end{array}$} & \multicolumn{3}{|c|}{ totaal } & \multirow[t]{2}{*}{$\begin{array}{c}\text { beschik- } \\
\text { baar voor } \\
\text { gebruik }\end{array}$} & \multirow{2}{*}{$\begin{array}{c}\text { productie } \\
\text { in \% van } \\
\text { het ver- } \\
\text { bruik }\end{array}$} \\
\hline & uitvoer & $\begin{array}{c}\text { invoer- } \\
\text { over- } \\
\text { schot }\end{array}$ & & invoer & uitvoer & $\begin{array}{c}\text { invoer- } \\
\text { over- } \\
\text { schot }\end{array}$ & & \\
\hline & I0 & $\begin{array}{c}\text { II } \\
(=9-\text {-IO) }\end{array}$ & 12 & $\begin{array}{c}13 \\
(=3+6+9)\end{array}$ & $\begin{array}{c}14 \\
(=4+7+ \\
10+12)\end{array}$ & $\begin{array}{c}15 \\
(=13-14)\end{array}$ & $\begin{array}{c}16 \\
(=2+15)\end{array}$ & 17 \\
\hline 1895 & - & • & • & 4.465 & 354 & 4.III & 4.238 & 3 \\
\hline I896 & - & $\cdot$ & $\cdot$ & $4.84 \mathrm{I}$ & $45^{8}$ & 4.383 & $4.52 \mathrm{I}$ & 3 \\
\hline I897 & - & - & $\cdot$ & 5.096 & 388 & 4.708 & 4.858 & 3 \\
\hline I898 & - & $\cdot$ & $\cdot$ & 5.252 & 739 & 4.513 & 4.663 & 3 \\
\hline I899 & - & $\cdot$ & $\cdot$ & $5 \cdot 315$ & 780 & 4.535 & 4.748 & 4 \\
\hline I900 & - & - & $\cdot$ & 6.074 & I.079 & 4.995 & $5 \cdot 315$ & 6 \\
\hline IgOI & $\cdot$ & $\cdot$ & $\cdot$ & $5 \cdot 468$ & 582 & 4.886 & 5.197 & 6 \\
\hline 1902 & - & $\cdot$ & $\cdot$ & $5 \cdot 776$ & I.098 & 4.678 & 5.069 & 8 \\
\hline 1903 & - & $\cdot$ & $\cdot$ & 6.465 & I. 467 & 4.998 & $5.45^{6}$ & 8 \\
\hline 1904 & - & - & • & 7.185 & I. 764 & $5.42 \mathrm{I}$ & 5.868 & 8 \\
\hline 1905 & $\cdot$ & $\cdot$ & $\cdot$ & 8.332 & 2.817 & $5 \cdot 515$ & 6.001 & 8 \\
\hline I906 & - & $\cdot$ & $\cdot$ & 8.342 & $2.35 \mathrm{I}$ & $5.99 \mathrm{I}$ & 6.540 & 8 \\
\hline 1907 & - & $\cdot$ & $\cdot$ & $9 \cdot 347$ & 3.266 & $6.08 \mathrm{I}$ & 6.804 & II \\
\hline I908 & • & $\cdot$ & • & 8.362 & 2.294 & 6.068 & 6.976 & $\mathrm{I} 3$ \\
\hline 1909 & $\cdot$ & $\cdot$ & $\cdot$ & $9.6_{51}$ & $3 \cdot 399$ & 6.252 & $7 \cdot 373$ & I5 \\
\hline I910 & - & $\cdot$ & $\cdot$ & I0.554 & 4.295 & 6.259 & $7 \cdot 55^{\mathrm{I}}$ & I7 \\
\hline IgII & - & $\cdot$ & $\cdot$ & II. 605 & 5.056 & 6.549 & 8.026 & I8 \\
\hline I9I2 & $\cdot$ & $\cdot$ & $\cdot$ & $\mathrm{I} 2.774$ & $5.49 \mathrm{I}$ & 7.283 & 9.008 & 19 \\
\hline 1913 & • & • & • & $\mathrm{I} 4.256$ & 6.139 & 8.II7 & 9.990 & 19 \\
\hline I9I4 & - & • & $\cdot$ & II. 779 & 4.437 & $7 \cdot 342$ & 9.279 & $2 \mathrm{I}$ \\
\hline 1915 & • & • & $\cdot$ & 7.629 & $58 \mathrm{I}$ & 7.048 & $9 \cdot 308$ & 24 \\
\hline I9I6 & $\cdot$ & $\cdot$ & • & 6.353 & 82 & $6.27 \mathrm{I}$ & 8.857 & 29 \\
\hline 1917 & $\cdot$ & 24 & $\cdot$ & 2.939 & 6I & 2.878 & 5.895 & $5 \mathrm{I}$ \\
\hline I9I8 & • & 4 & $\cdot$ & I. 436 & II4 & I. 326 & 4.740 & 72 \\
\hline I9I9 & I & 206 & $\cdot$ & $3.57 \mathrm{I}$ & 108 & 3.463 & 6.884 & 50 \\
\hline 1920 & 9 & 3 & 636 & 3.260 & 677 & 2.583 & 6.544 & 6I \\
\hline I92I & 32 & I42 & 1376 & 5.269 & 2.086 & 3.182 & 7.123 & 55 \\
\hline
\end{tabular}




\begin{tabular}{|c|c|c|c|c|c|c|c|c|c|}
\hline \multirow[t]{2}{*}{ jaar } & \multirow[t]{2}{*}{ productie } & \multicolumn{3}{|c|}{ steenkolen } & \multicolumn{3}{|c|}{ cokes } & \multicolumn{2}{|c|}{$\begin{array}{l}\text { steenkolen- } \\
\text { briketten }\end{array}$} \\
\hline & & invoer & uitvoer & $\begin{array}{l}\text { invoer- } \\
\text { over- } \\
\text { schot }\end{array}$ & invoer & uitvoer & $\begin{array}{c}\text { invoer- } \\
\text { over- } \\
\text { schot }\end{array}$ & invoer & \\
\hline $\mathbf{I}$ & 2 & 3 & 4 & $\begin{array}{c}5 \\
(=3-4)\end{array}$ & 6 & 7 & $\begin{array}{c}8 \\
(=6-7)\end{array}$ & 9 & \\
\hline 1922 & 4.601 & 6.216 & I. 243 & 4.973 & 235 & 350 & $-\mathrm{II}_{5}$ & I97 & \\
\hline 1923 & $5 \cdot 327$ & 6.387 & 2.035 & $4 \cdot 35^{2}$ & I76 & 562 & -386 & II 8 & \\
\hline 1924 & $5 \cdot 924$ & 7.182 & I. 718 & 5.464 & 229 & 703 & -474 & $26 \mathrm{I}$ & \\
\hline 1925 & 6.892 & 8.246 & 2.224 & 6.022 & 206 & 912 & -706 & 449 & \\
\hline 1926 & 8.702 & I0.06I & $3 \cdot 376$ & 6.685 & 282 & 960 & -678 & 394 & \\
\hline 1927 & $9 \cdot 374$ & 8.822 & 2.958 & 5.864 & 278 & I.I45 & -867 & 370 & \\
\hline 1928 & 10.749 & 8.760 & 3.924 & 4.836 & 301 & I.I33 & -832 & 334 & \\
\hline I929 & II. $58 \mathrm{I}$ & 9.618 & $3.62 \mathrm{I}$ & 5.997 & 371 & I.940 & $-\mathrm{I} .569$ & 327 & \\
\hline 1930 & $\mathrm{I} 2.2 \mathrm{II}$ & 9.113 & 3.900 & 5.213 & 289 & 2.080 & $-\mathrm{I} .79 \mathrm{I}$ & $33 \mathrm{I}$ & \\
\hline I93I & I2.90I & 8.501 & 4.093 & 4.408 & 316 & 2.217 & -I.90I & 399 & \\
\hline 1932 & 12.756 & 6.513 & 3.427 & 3.086 & 316 & I.932 & -I.616 & 354 & \\
\hline 1933 & $\mathrm{I} 2.574$ & $5 \cdot 372$ & 3.238 & 2.134 & 332 & I.987 & -I.655 & 373 & \\
\hline 1934 & $\mathrm{I} 2.34 \mathrm{I}$ & $5 \cdot 713$ & 3.160 & 2.553 & 358 & 2.075 & $-\mathrm{I} .717$ & 360 & \\
\hline 1935 & II. 878 & $5.06 \mathrm{I}$ & 2.939 & 2.122 & $3 \mathrm{II}$ & 2.139 & $-\mathrm{I} .828$ & 353 & \\
\hline 1936 & 12.803 & 4.870 & 3.164 & I.706 & 374 & 2.305 & -I.93I & 335 & \\
\hline 1937 & $\mathrm{I} 4 \cdot 32 \mathrm{I}$ & $5.4 \mathrm{IO}$ & 3.963 & $\mathrm{I} .447$ & 426 & 2.438 & -2.012 & 326 & \\
\hline 1938 & I3.488 & 4.915 & 3.417 & I. 498 & $33 \mathrm{I}$ & 2.170 & -I.839 & 319 & \\
\hline 1939 & $\mathrm{I} 2.86 \mathrm{I}$ & $5.88 \mathrm{I}$ & 2.738 & 3.143 & 370 & 2.300 & $-\mathrm{I} .930$ & 353 & \\
\hline I940 & I2.I45 & 2.219 & I. 266 & 953 & I49 & I.I48 & -999 & $\mathrm{I} 32$ & \\
\hline I94I & 13.356 & I. 449 & I. 373 & 76 & I8 & 973 & -955 & 9 & \\
\hline 1942 & 12.330 & I.079 & 812 & 267 & I & 695 & -694 & I & \\
\hline I943 & I2.497 & I.098 & 584 & 514 & I & I.09I & -I.090 & I & \\
\hline I944 & 8.313 & 833 & 428 & 405 & - & 758 & -758 & - & \\
\hline I945 & 5.097 & I.004 & I2I & 883 & 17 & 267 & -250 & - & \\
\hline 1946 & 8.314 & 2.764 & - & 2.764 & 9 & 443 & -434 & I7 & \\
\hline I947 & I0.104 & $3 \cdot 542$ & - & 3.542 & $\mathrm{I}$ & 533 & -532 & Io & \\
\hline I948 & II.032 & 3.379 & 36 & 3.343 & - & 896 & -896 & 39 & \\
\hline 1949 & II. 705 & 3.980 & I8 & 3.962 & 7 & 957 & -950 & 25 & \\
\hline
\end{tabular}




\begin{tabular}{|c|c|c|c|c|c|c|c|c|}
\hline \multicolumn{3}{|c|}{$\begin{array}{c}\text { steenkolen- } \\
\text { briketten }\end{array}$} & \multirow{2}{*}{$\begin{array}{c}\text { bunker- } \\
\text { kolen }\end{array}$} & \multicolumn{3}{|c|}{ totaal } & \multirow[t]{2}{*}{$\begin{array}{l}\text { beschik- } \\
\text { baar voor } \\
\text { gebruik }\end{array}$} & \multirow{2}{*}{$\begin{array}{c}\text { productie } \\
\text { in \% van } \\
\text { het ver- } \\
\text { bruik }\end{array}$} \\
\hline & uitvoer & $\begin{array}{l}\text { invoer- } \\
\text { over- } \\
\text { schot }\end{array}$ & & invoer & uitvoer & $\begin{array}{c}\text { invoer- } \\
\text { over- } \\
\text { schot }\end{array}$ & & \\
\hline & I0 & $\begin{array}{c}\text { II } \\
(=9-10)\end{array}$ & 12 & $\begin{array}{c}13 \\
(=3+6+9)\end{array}$ & $\begin{array}{c}14 \\
(=4+7+ \\
10+12)\end{array}$ & $\begin{array}{c}15 \\
(=13-14)\end{array}$ & $\begin{array}{c}16 \\
(=2+15)\end{array}$ & 17 \\
\hline 1922 & 74 & 123 & 1.013 & 6.648 & 2.680 & 3.968 & 8.569 & 54 \\
\hline 1923 & 49 & 69 & $8 \mathrm{I} 6$ & $6.68 \mathrm{I}$ & $3 \cdot 462$ & 3.219 & 8.546 & 62 \\
\hline I924 & 42 & 219 & $\mathrm{I} .53 \mathrm{I}$ & 7.672 & 3.994 & 3.678 & 9.602 & 62 \\
\hline 1925 & 67 & 382 & 2.513 & 8.902 & $5 \cdot 7 \mathrm{I} 6$ & 3.185 & 10.077 & 68 \\
\hline 1926 & 152 & 242 & 4.748 & 10.738 & 9.237 & I.5OI & I0.203 & 85 \\
\hline I927 & 84 & 286 & 3.449 & 9.469 & 7.636 & I. 834 & II. 208 & 84 \\
\hline 1928 & 77 & 257 & 3.333 & $9 \cdot 395$ & 8.467 & 928 & II. 677 & 92 \\
\hline 1929 & 105 & 222 & 3.066 & 10.317 & 8.732 & I. 585 & I3.166 & 88 \\
\hline 1930 & 194 & $\mathrm{I} 37$ & 2.824 & 9.733 & 8.997 & 736 & I2.947 & 94 \\
\hline I93I & 464 & -65 & 2.500 & 9.215 & 9.274 & -59 & $\mathrm{I} 2.842$ & 100 \\
\hline 1932 & 328 & 26 & I. 498 & 7.184 & 7.185 & -2 & I2. 755 & 100 \\
\hline I933 & 315 & 58 & 379 & 6.078 & 5.919 & I59 & I2.733 & 99 \\
\hline 1934 & 326 & 34 & 368 & $6.43 \mathrm{I}$ & 5.929 & 502 & I 2.842 & 96 \\
\hline 1935 & 305 & 48 & 229 & 5.724 & 5.612 & 113 & II.99I & 99 \\
\hline 1936 & 338 & -3 & 375 & $5 \cdot 580$ & 6.182 & -602 & I2.20I & 105 \\
\hline 1937 & 427 & -IOI & 299 & 6.163 & 7.127 & -964 & I3.357 & 107 \\
\hline $193^{8}$ & $4 \mathrm{I} 3$ & -94 & 243 & $5 \cdot 566$ & 6.243 & -678 & I2.810 & 105 \\
\hline I939 & 313 & 40 & 212 & 6.605 & 5.563 & I.042 & 13.903 & 93 \\
\hline I940 & 107 & 25 & 39 & 2.500 & 2.560 & $-6 o$ & 12.085 & 100 \\
\hline I94I & 62 & -53 & $2 \mathrm{I}$ & I. 476 & 2.429 & -953 & I2.403 & I08 \\
\hline 1942 & - & I & 23 & I.08I & I. 530 & -449 & II. $88 \mathrm{I}$ & 104 \\
\hline I943 & - & I & 25 & I.100 & I. 700 & -600 & II.897 & 105 \\
\hline I944 & - & - & IO & 833 & I.196 & -363 & 7950 & 105 \\
\hline I945 & - & - & 2 & I.02I & 390 & 631 & 5728 & 89 \\
\hline 1946 & - & 17 & 3 & 2.790 & 446 & 2.344 & 10.658 & 79 \\
\hline I947 & - & IO & I5 & 3.553 & 548 & 3.005 & I3.109 & 78 \\
\hline I948 & - & 39 & I8 & 3.418 & 950 & 2.468 & 13.500 & 82 \\
\hline I949 & - & 25 & 30 & 4.012 & I.005 & 3.007 & $\mathrm{I} 4.7 \mathrm{I} 2$ & 80 \\
\hline
\end{tabular}




\begin{tabular}{|c|c|c|c|c|c|c|c|c|c|}
\hline \multirow[t]{2}{*}{ jaar } & \multirow[t]{2}{*}{ productie } & \multicolumn{3}{|c|}{ steenkolen } & \multicolumn{3}{|c|}{ cokes } & \multicolumn{2}{|c|}{$\begin{array}{l}\text { steenkolen- } \\
\text { briketten }\end{array}$} \\
\hline & & invoer & uitvoer & $\begin{array}{l}\text { invoer- } \\
\text { over- } \\
\text { schot }\end{array}$ & invoer & uitvoer & $\begin{array}{c}\text { invoer- } \\
\text { over- } \\
\text { schot }\end{array}$ & invoer & \\
\hline $\mathbf{I}$ & 2 & 3 & 4 & $\begin{array}{c}5 \\
(=3-4)\end{array}$ & 6 & 7 & $\begin{array}{c}8 \\
(=6-7)\end{array}$ & 9 & \\
\hline I950 & I2.247 & 4.437 & 23 & $4.4 \mathrm{I} 4$ & I64 & I.III & -947 & I3I & \\
\hline I95I & $\mathrm{I} 2.424$ & 5.072 & $\mathrm{I} 2$ & 5.060 & 185 & I.I96 & -I.OII & 223 & \\
\hline 1952 & I 2.532 & 5.239 & I6 & 5.223 & I93 & I.399 & -I.206 & 293 & \\
\hline I953 & I2.297 & 5.133 & 296 & 4.837 & 310 & $\mathrm{I} .28 \mathrm{I}$ & $-97 I$ & 260 & \\
\hline I954 & I2.07I & 7.014 & $\mathrm{I} .05 \mathrm{I}$ & 5.963 & 360 & I. 538 & -I.I78 & 288 & \\
\hline I955 & II. 895 & 7.604 & 917 & 6.687 & 432 & I.932 & $-I .500$ & 492 & \\
\hline 1956 & II. 836 & 8.516 & 954 & $7 \cdot 562$ & 432 & 2.049 & -I.6I7 & 456 & \\
\hline I957 & II. 376 & 8.687 & 988 & 7.699 & 504 & 2.049 & $-\mathrm{I} .545$ & 324 & \\
\hline 1958 & II. 880 & 7.095 & I. 317 & 5.778 & 288 & I. 685 & $-\mathrm{I} .397$ & 180 & \\
\hline I959 & II. 978 & 6.507 & I. 805 & 4.702 & 408 & 2.057 & - I. 649 & 132 & \\
\hline I96o & I2.498 & 7.099 & 2.165 & 4.934 & 372 & 2.306 & -I.934 & I44 & \\
\hline I96I & I2.62I & 7.159 & 2.356 & 4.803 & 312 & 2.477 & -2.165 & $\mathrm{I} 20$ & \\
\hline I962 & II. 573 & 8.923 & 2.330 & 6.593 & 360 & 2.223 & $-I .863$ & $\mathrm{I} 32$ & \\
\hline I963 & II. 509 & 9.949 & $2.57 \mathrm{I}$ & $7 \cdot 378$ & 528 & 2.118 & -I.590 & 204 & \\
\hline I964 & II. 480 & 9.299 & 2.158 & $7.14 \mathrm{I}$ & 312 & 2.327 & -2.015 & 96 & \\
\hline 1965 & II. 446 & 7.107 & 2.092 & 5.015 & 276 & 2.404 & -2.128 & 60 & \\
\hline I966 & 10.052 & 6.679 & I. 850 & 4.829 & 204 & I. 903 & -I.699 & 48 & \\
\hline I967 & 8.065 & 7.039 & I.935 & 5.104 & 156 & I.998 & -I.842 & 24 & \\
\hline I968 & 6.663 & 7.412 & I.975 & 5.437 & 396 & I. 497 & -I.IOI & 24 & \\
\hline I969 & $5 \cdot 564$ & 5.930 & I. 792 & 4.138 & I.008 & 789 & 219 & $\mathrm{I} 2$ & \\
\hline I970 & 4.334 & 4.773 & I. 647 & 3.126 & $9 \mathrm{I} 2$ & $69 \mathrm{I}$ & $22 \mathrm{I}$ & - & \\
\hline
\end{tabular}

NB I Bunkerkolen tot en met 1932 inclusief bunkerkolen op doorvoerdocument, daarna exclusief. Vanaf I 958 gegevens niet meer verstrekt.

NB 2 Productie is: nettoproductie $x$ Iooo ton.

Bronnen: I895 tot en met 1947: Rapport van de Staatscommissie ingesteld bij Koninklijk Besluit van 26 november 1946 no 1 ('s-Gravenhage 1948) tabel I, I64-I65; 1948 tot en met I970: SHCL, Archief Gezamenlijke Steenkolenmijnen in Limburg, Statistiek; Tabellen en grafieken Mijnindustrieraad/Bedriifschap voor de Steenkolenmijnindustrie, 1949-1970. 


\begin{tabular}{|c|c|c|c|c|c|c|c|c|}
\hline \multicolumn{3}{|c|}{$\begin{array}{l}\text { steenkolen- } \\
\text { briketten }\end{array}$} & \multirow{2}{*}{$\begin{array}{c}\text { bunker- } \\
\text { kolen }\end{array}$} & \multicolumn{3}{|c|}{ totaal } & \multirow[t]{2}{*}{$\begin{array}{l}\text { beschik- } \\
\text { baar voor } \\
\text { gebruik }\end{array}$} & \multirow{2}{*}{$\begin{array}{c}\text { productie } \\
\text { in \% van } \\
\text { het ver- } \\
\text { bruik }\end{array}$} \\
\hline & uitvoer & $\begin{array}{c}\text { invoer- } \\
\text { over- } \\
\text { schot }\end{array}$ & & invoer & uitvoer & $\begin{array}{c}\text { invoer- } \\
\text { over- } \\
\text { schot }\end{array}$ & & \\
\hline & I0 & $\begin{array}{c}\text { II } \\
(=9-\text { IO })\end{array}$ & 12 & $\begin{array}{c}13 \\
(=3+6+9)\end{array}$ & $\begin{array}{c}14 \\
(=4+7+ \\
10+12)\end{array}$ & $\begin{array}{c}15 \\
(=13-14)\end{array}$ & $\begin{array}{c}16 \\
(=2+15)\end{array}$ & 17 \\
\hline I950 & - & I3I & 34 & 4.732 & I.I68 & 3.564 & I5.8II & 77 \\
\hline I95I & - & 223 & IO & $5 \cdot 480$ & I. 218 & 4.262 & I6.686 & 74 \\
\hline 1952 & - & 293 & I6 & 5.725 & I. $43 \mathrm{I}$ & 4.294 & I6.826 & 74 \\
\hline I953 & I8 & 242 & I5 & 5.703 & I.6Io & 4.093 & I6.390 & 75 \\
\hline I954 & 109 & 179 & 8 & 7.663 & 2.706 & 4.957 & 17.028 & $7 \mathrm{I}$ \\
\hline I955 & 183 & 309 & I3 & 8.529 & 3.045 & $5 \cdot 484$ & 17.379 & 68 \\
\hline 1956 & 207 & 249 & 20 & 9.410 & 3.230 & 6.180 & I8.oI6 & 66 \\
\hline I957 & 310 & I4 & 17 & 9.510 & 3.364 & 6.146 & 17.522 & 65 \\
\hline 1958 & 297 & -117 & - & $7 \cdot 569$ & 3.299 & 4.270 & I6.I50 & 74 \\
\hline I959 & 399 & -267 & - & 7.054 & $4.26 \mathrm{I}$ & 2.793 & I $4.77 \mathrm{I}$ & $8 \mathrm{I}$ \\
\hline I96o & 506 & -362 & • & 7.616 & 4.977 & 2.639 & I5.137 & 83 \\
\hline I96I & 572 & -452 & • & $7 \cdot 589$ & $5 \cdot 405$ & 2.184 & 14.805 & 85 \\
\hline 1962 & 620 & -488 & • & $9 \cdot 418$ & 5.173 & 4.245 & I5.8I8 & 73 \\
\hline 1963 & 769 & -565 & • & 10.672 & 5.458 & 5.214 & I6.723 & 69 \\
\hline I964 & 776 & -680 & • & $9 \cdot 702$ & $5.26 \mathrm{I}$ & $4.44 \mathrm{I}$ & I5.92I & 72 \\
\hline 1965 & 835 & -775 & $\cdot$ & 7.442 & 5.331 & $2 . I I I$ & 13.557 & 84 \\
\hline 1966 & 825 & -777 & • & 6.932 & 4.578 & 2.354 & I2.406 & $8 \mathrm{I}$ \\
\hline 1967 & 742 & -718 & - & 7.252 & 4.675 & 2.577 & 10.642 & 76 \\
\hline I968 & 801 & -777 & $\cdot$ & 7.828 & 4.273 & 3.555 & I0.218 & 65 \\
\hline I969 & 836 & -824 & • & 6.945 & 3.417 & 3.528 & 9.092 & $6 \mathrm{I}$ \\
\hline I970 & 689 & -689 & • & $5.69 \mathrm{I}$ & 3.027 & 2.664 & 6.998 & 62 \\
\hline
\end{tabular}


Bijlage 5 De West-Europese steenkolenmijnbouw: productie en personeel, 1900-1965 (productie in miljoenen ton; personeel in duizendtallen)

\begin{tabular}{|c|c|c|c|c|c|c|c|c|c|c|}
\hline & \multicolumn{2}{|c|}{$\begin{array}{l}\text { Groot- } \\
\text { Brittannië }\end{array}$} & \multicolumn{2}{|c|}{ Frankrijk } & \multicolumn{2}{|c|}{ België } & \multicolumn{2}{|c|}{ Duitsland } & \multicolumn{2}{|c|}{ Nederland } \\
\hline & 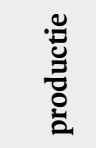 & 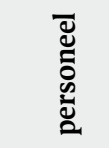 & 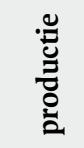 & 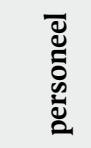 & 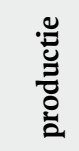 & 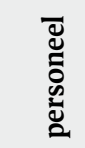 & 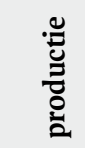 & 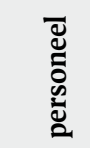 & 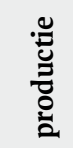 & 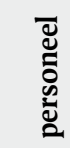 \\
\hline 1900 & 229,0 & $75 \mathrm{I}, 2$ & 33,4 & $\mathrm{I} 62,0$ & 23,5 & I32,7 & 109,3 & 414,0 & 0,3 & $\mathrm{I}, \mathrm{I}$ \\
\hline I9OI & 223,0 & 778,7 & 32,3 & $\mathrm{I} 6_{3}, \mathrm{O}$ & 22,2 & $\mathrm{I} 34, \mathrm{I}$ & 108,5 & 448,0 & 0,3 & $\mathrm{I}, 2$ \\
\hline I9O2 & 231,0 & 796,3 & 29,9 & $\mathrm{I} 64,0$ & 22,9 & I34,9 & 107,5 & $45 \mathrm{I}, \mathrm{O}$ & 0,4 & $\mathrm{I}, 5$ \\
\hline 1903 & 234,0 & $8 \mathrm{I}_{3}, 8$ & 34,9 & $\mathrm{I} 67,0$ & 23,8 & I39,6 & II 6,6 & 470,0 & 0,5 & I,9 \\
\hline I9O4 & 236,0 & $8 \mathrm{I} 8,8$ & $34, \mathrm{I}$ & I7I, 0 & 22,8 & I 38,6 & I2O, 8 & $49 \mathrm{I}, 0$ & 0,4 & $\mathrm{I}, 9$ \\
\hline 1905 & 240,0 & 829,2 & 35,9 & $\mathrm{I} 75, \mathrm{O}$ & $2 \mathrm{I}, 8$ & I34,7 & $\mathrm{I} 2 \mathrm{I}, 3$ & 493,0 & 0,5 & 2,6 \\
\hline I906 & 255,0 & 852,2 & $34, \mathrm{I}$ & $\mathrm{I} 78, \mathrm{O}$ & 23,6 & I 39,4 & $\mathrm{I} 37, \mathrm{I}$ & $5 \mathrm{II}, \mathrm{O}$ & 0,6 & 3,0 \\
\hline 1907 & 272,0 & 909,2 & 36,7 & 183,0 & 23,7 & $\mathrm{I} 42,7$ & $\mathrm{I} 43,2$ & 545,0 & 0,7 & 4,7 \\
\hline 1908 & 266,0 & 957,7 & 37,3 & I95,0 & 23,6 & $\mathrm{I} 45,3$ & $\mathrm{I} 46, \mathrm{I}$ & $59 \mathrm{I}, 0$ & 0,9 & 5,4 \\
\hline 1909 & 268,0 & $983, \mathrm{I}$ & 37,8 & I90,0 & 23,5 & $\mathrm{I} 43, \mathrm{O}$ & $\mathrm{I} 47, \mathrm{O}$ & 613,0 & $\mathrm{I}, \mathrm{I}$ & 6,4 \\
\hline I9Io & 269,0 & IOI8,2 & 38,3 & I96,0 & 23,9 & I 43,7 & I5I,I & 621,0 & $\mathrm{I}, 3$ & 7,2 \\
\hline IgII & 276,0 & 1035,5 & 39,2 & 200,0 & $23, \mathrm{I}$ & $\mathrm{I} 44, \mathrm{I}$ & 158,6 & 628,0 & $\mathrm{I}, 5$ & 8,0 \\
\hline I9I2 & 265,0 & 1057,8 & $4 \mathrm{I}, \mathrm{I}$ & 202,0 & 23,0 & $\mathrm{I} 45,7$ & 174,9 & 640,0 & $\mathrm{I}, 7$ & 9,2 \\
\hline 1913 & 292,0 & 1095,2 & 40,8 & 203,0 & 22,8 & $\mathrm{I} 45,3$ & I90, I & 654,0 & I,9 & I0,7 \\
\hline I9I4 & 270,0 & II 33,0 & 27,5 & $\cdot$ & I6,7 & 92,2 & I6I, 4 & • & I,9 & Io, 4 \\
\hline 1915 & 257,0 & 953,6 & I9,5 & • & $\mathrm{I} 4,2$ & $86, \mathrm{I}$ & 146,9 & • & 2,3 & $\mathrm{II}, 7$ \\
\hline I9I6 & 260,0 & $998, \mathrm{I}$ & $2 \mathrm{I}, 3$ & • & I6,9 & $88, \mathrm{I}$ & 159,2 & • & 2,6 & $\mathrm{I} 4,3$ \\
\hline I9I7 & 253,0 & IO2I, 3 & 28,9 & • & 14,9 & 75,6 & $\mathrm{I} 67,7$ & • & 3,0 & 17,7 \\
\hline I9I8 & $25 \mathrm{I}, 0$ & 1008,9 & 26,2 & $\cdot$ & $\mathrm{I} 3,8$ & 75,5 & I6o, 8 & • & 3,4 & 20,2 \\
\hline I9I9 & • & • & • & • & • & • & • & • & 3,4 & 23,0 \\
\hline I920 & 233,0 & $\mathrm{I} 248,2$ & 25,2 & 207,0 & 22,4 & I59,9 & $\mathrm{II}_{4}, 8$ & - & 4,0 & $27, \mathrm{I}$ \\
\hline I92I & I66,0 & II 44,3 & 28,9 & 219,0 & $2 \mathrm{I}, 8$ & I6I,I & $\mathrm{I} 45,8$ & • & 3,9 & 26,6 \\
\hline 1922 & $\mathrm{I} 54,0$ & II62,8 & $3 \mathrm{I}, 9$ & 229,0 & $2 \mathrm{I}, 2$ & $\mathrm{I} 52,8$ & $\mathrm{I} 4 \mathrm{I}, 2$ & • & 4,6 & 27,5 \\
\hline I923 & $28 \mathrm{I}, \mathrm{O}$ & $\mathrm{I} 220,4$ & 38,5 & 264,0 & 22,9 & $\mathrm{I} 6 \mathrm{o}, \mathrm{o}$ & $7 \mathrm{I}, 5$ & • & 5,3 & 29,5 \\
\hline I924 & 296,0 & I230, 2 & 44,9 & 285,0 & 23,4 & 172,3 & 132,8 & 559,0 & 5,9 & 30,5 \\
\hline 1925 & 247,0 & $\mathrm{III}_{7}, 8$ & 48,0 & 298,0 & $23, \mathrm{I}$ & I6o, 4 & I 45,6 & 557,0 & 6,9 & $3 \mathrm{I}, 3$ \\
\hline 1926 & $\mathrm{I} 28, \mathrm{O}$ & II 28,2 & 52,4 & 307,0 & 25,2 & I6o, 2 & 159,0 & 515,0 & 8,7 & 33,4 \\
\hline I927 & 255,0 & 1005,0 & 52,8 & 313,0 & 27,6 & $\mathrm{I} 74,5$ & $\mathrm{I} 67,2$ & 562,0 & 9,4 & 34,8 \\
\hline I928 & $24 \mathrm{I}, 0$ & $92 \mathrm{I}, 3$ & 52,4 & 292,0 & 27,6 & $\mathrm{I} 6_{3,2}$ & $\mathrm{I} 64,0$ & 518,0 & I0,7 & 34,7 \\
\hline I929 & 262,0 & 939,4 & 54,9 & 287,0 & 26,9 & $15 \mathrm{I}, 3$ & 177,0 & 517,0 & II, 6 & 37,6 \\
\hline
\end{tabular}




\begin{tabular}{|c|c|c|c|c|c|c|c|c|c|c|}
\hline & \multicolumn{2}{|c|}{$\begin{array}{c}\text { Groot- } \\
\text { Brittannië }\end{array}$} & \multicolumn{2}{|c|}{ Frankrijk } & \multicolumn{2}{|c|}{ België } & \multicolumn{2}{|c|}{ Duitsland } & \multicolumn{2}{|c|}{ Nederland } \\
\hline & 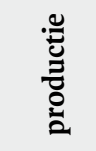 & 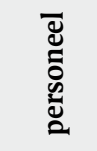 & 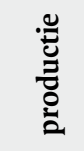 & 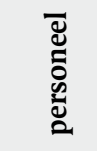 & 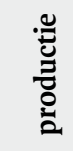 & 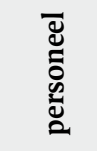 & 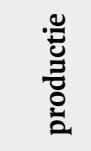 & 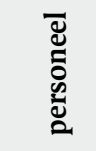 & 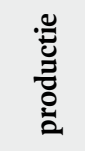 & 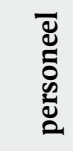 \\
\hline I930 & 248,0 & 914,3 & 55,0 & 292,0 & 27,4 & I55, I & I55,9 & 469,0 & $\mathrm{I} 2,2$ & 37,5 \\
\hline I93I & 223,0 & $85 \mathrm{I}, 6$ & $5 \mathrm{I}, 0$ & 253,0 & 27,0 & $\mathrm{I} 52, \mathrm{I}$ & 130,0 & 372,0 & $\mathrm{I} 2,9$ & 37,9 \\
\hline 1932 & 212,0 & $80_{3}, 6$ & 47,2 & 242,0 & $2 \mathrm{I}, 4$ & I3O,I & $\mathrm{II}_{5}, 2$ & 309,0 & $\mathrm{I} 2,8$ & 35,2 \\
\hline I933 & $2 \mathrm{II}, \mathrm{O}$ & 773,6 & 47,9 & 230,0 & 25,3 & 134,5 & $\mathrm{I} 2 \mathrm{O}, 5$ & 310,0 & $\mathrm{I} 2,6$ & 32,8 \\
\hline 1934 & 224,0 & 772,8 & 48,6 & 230,0 & 26,4 & $\mathrm{I} 25, \mathrm{I}$ & 136,2 & $33 \mathrm{I}, \mathrm{O}$ & $\mathrm{I} 2,3$ & 29,9 \\
\hline 1935 & 226,0 & 754,3 & $47, \mathrm{I}$ & 219,0 & 25,5 & $\mathrm{I} 2 \mathrm{O}, 2$ & $\mathrm{I} 44,7$ & 387,0 & II, 9 & 28,7 \\
\hline 1936 & 232,0 & $75 \mathrm{I}, 7$ & $46, \mathrm{I}$ & 215,0 & 27,9 & $\mathrm{I} 2 \mathrm{O}, 5$ & 158,3 & 394,0 & $\mathrm{I} 2,8$ & 29,3 \\
\hline I937 & 244,0 & $776, \mathrm{I}$ & 45,3 & 220,0 & 29,9 & $\mathrm{I} 24,9$ & $\mathrm{I} 84,5$ & 450,0 & $\mathrm{I} 4,3$ & 32,0 \\
\hline 1938 & 231,0 & $78 \mathrm{I}, 7$ & 47,5 & 232,0 & 29,6 & 130,3 & $\mathrm{I} 5 \mathrm{I}, 3$ & 418,9 & 13,5 & $32, \mathrm{I}$ \\
\hline I939 & 235,0 & 766,3 & 50,2 & • & 29,8 & $\mathrm{I} 28,7$ & 152,9 & $4 \mathrm{I} 4,4$ & $\mathrm{I} 2,9$ & $34, \mathrm{I}$ \\
\hline I940 & 228,0 & 749,2 & 40,9 & • & 25,5 & II7,2 & I49,7 & $4 \mathrm{I} 8,9$ & $\mathrm{I} 2, \mathrm{I}$ & $37, \mathrm{I}$ \\
\hline I94I & 210,0 & 697,6 & 43,8 & $\cdot$ & 26,7 & $\mathrm{I} 25,4$ & $\mathrm{I} 53,8$ & $432, \mathrm{I}$ & $\mathrm{I} 3,4$ & 40,6 \\
\hline I942 & 208,0 & 709,3 & 43,8 & • & $25, \mathrm{I}$ & $\mathrm{I} 2 \mathrm{I}, 7$ & $\mathrm{I} 53,2$ & 454,8 & $\mathrm{I} 2,3$ & 42,3 \\
\hline I943 & 202,0 & 707,8 & 42,4 & $\cdot$ & 23,7 & $\mathrm{I} 22,3$ & $\mathrm{I} 53,4$ & $508, \mathrm{I}$ & $\mathrm{I} 2,5$ & 42,0 \\
\hline 1944 & I96,o & 710,2 & 26,5 & - & $\mathrm{I} 3,5$ & 97,5 & 130,3 & $499, \mathrm{I}$ & 8,3 & 37,0 \\
\hline 1945 & $\mathrm{I} 86, \mathrm{o}$ & 708,9 & 35,0 & $\cdot$ & $\mathrm{I} 5,8$ & 89,0 & 38,9 & 317,4 & $5, \mathrm{I}$ & $33, \mathrm{I}$ \\
\hline 1946 & 193,0 & 696,7 & 49,2 & 330,0 & 22,9 & 96,4 & $6 \mathrm{I}, 8$ & 365,2 & 8,3 & $36, \mathrm{I}$ \\
\hline I947 & 200,0 & 703,9 & 47,3 & 330,0 & 24,4 & $\mathrm{II} 8,4$ & $8 \mathrm{I}, 6$ & 446,0 & $\mathrm{IO}, \mathrm{I}$ & 38,8 \\
\hline 1948 & $2 \mathrm{II}, 5$ & 716,5 & $45, \mathrm{I}$ & 291,0 & 26,7 & $\mathrm{I} 44,2$ & 99,5 & 499,7 & $\mathrm{II}, \mathrm{O}$ & 40,9 \\
\hline I949 & 218,2 & 712,5 & 53,4 & 284,0 & 27,9 & $\mathrm{I} 46,3$ & II7,4 & 522,8 & II, 7 & 43,6 \\
\hline 1950 & 219,6 & 690,8 & 52,5 & 258,0 & 27,3 & $\mathrm{I} 35,8$ & $\mathrm{I} 25,7$ & $53^{6,8}$ & $\mathrm{I} 2,2$ & 45,4 \\
\hline I95I & 225,6 & 692,6 & 54,9 & 255,0 & 30,0 & 134,3 & $\mathrm{I} 35, \mathrm{O}$ & 548,8 & $\mathrm{I} 2,4$ & 48,8 \\
\hline 1952 & 228,4 & 709,7 & 57,3 & 248,0 & 30,4 & I36,I & I 39,4 & 569,6 & $\mathrm{I} 2,5$ & 52,2 \\
\hline I953 & $227, \mathrm{I}$ & $7 \mathrm{II}, 5$ & 54,3 & 235,0 & $30, \mathrm{I}$ & $\mathrm{I} 32, \mathrm{I}$ & I40,7 & 588,9 & $\mathrm{I} 2,3$ & $55, \mathrm{I}$ \\
\hline I954 & 227,2 & 701,8 & 56,3 & 227,0 & 29,2 & $\mathrm{I} 20, \mathrm{I}$ & $\mathrm{I} 44,7$ & $588, \mathrm{I}$ & $\mathrm{I} 2, \mathrm{I}$ & 56,5 \\
\hline I955 & 225,2 & 698,7 & 57,3 & 218,0 & 29,9 & II6,6 & I47,9 & 586,9 & II, 9 & $56, \mathrm{I}$ \\
\hline 1956 & 225,6 & 697,4 & 57,3 & 215,0 & 29,5 & II 2,9 & $\mathrm{I} 5 \mathrm{I}, 4$ & 592,9 & $\mathrm{II}, 8$ & $5^{6,5}$ \\
\hline I957 & 227,2 & 703,8 & 59,0 & 216,0 & 29,0 & $\mathrm{II} 2,3$ & I 49,4 & 604,0 & $\mathrm{II}, 4$ & 57,6 \\
\hline 1958 & 219,3 & 692,7 & 60,0 & 213,0 & $27, \mathrm{I}$ & I04,7 & $\mathrm{I} 48, \mathrm{O}$ & $599, \mathrm{I}$ & II, 9 & 58,2 \\
\hline I959 & 209,4 & 658,2 & 57,7 & 205,0 & 22,8 & $8 \mathrm{I}, 7$ & I4I,7 & 557,5 & $\mathrm{I} 2, \mathrm{O}$ & 55,4 \\
\hline
\end{tabular}




\begin{tabular}{|c|c|c|c|c|c|c|c|c|c|c|}
\hline & \multicolumn{2}{|c|}{$\begin{array}{l}\text { Groot- } \\
\text { Brittannië }\end{array}$} & \multicolumn{2}{|c|}{ Frankrijk } & \multicolumn{2}{|c|}{ België } & \multicolumn{2}{|c|}{ Duitsland } & \multicolumn{2}{|c|}{ Nederland } \\
\hline & 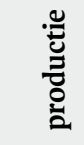 & 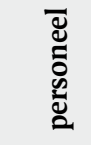 & 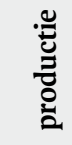 & 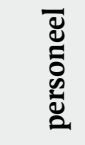 & 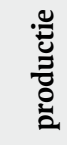 & 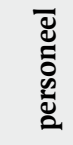 & 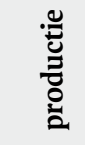 & 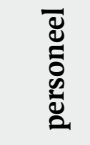 & 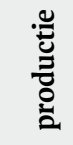 & 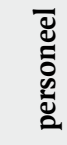 \\
\hline I96o & 196,7 & $602, \mathrm{I}$ & 58,2 & I9I,O & 22,5 & 71,5 & $\mathrm{I} 42,3$ & 505,0 & $\mathrm{I} 2,5$ & 52,8 \\
\hline I96I & 193,6 & 570,5 & 55,2 & $\mathrm{I} 82, \mathrm{O}$ & $2 \mathrm{I}, 5$ & 64,0 & $\mathrm{I} 42,7$ & 476,6 & $\mathrm{I} 2,6$ & 49,6 \\
\hline 1962 & 200,6 & 550,9 & 55,2 & $\mathrm{I} 78, \mathrm{O}$ & $2 \mathrm{I}, 2$ & 59,0 & I4I,I & 446,4 & II, 6 & 49,4 \\
\hline I963 & $25 \mathrm{I}, 5$ & 517,0 & 50,2 & 172,0 & $2 \mathrm{I}, 4$ & 58,6 & $\mathrm{I} 42, \mathrm{I}$ & $42 \mathrm{I}, 3$ & II, 5 & 47,7 \\
\hline I964 & 195,6 & $49 \mathrm{I}, 0$ & $5^{6,2}$ & 167,0 & $2 \mathrm{I}, 3$ & 58,5 & $\mathrm{I} 42,2$ & 405,7 & II, 5 & 47,2 \\
\hline 1965 & I85,7 & 455,7 & 54,0 & I6I, & I9,8 & 52,0 & I35, I & 387,7 & $\mathrm{II}, 4$ & 45,3 \\
\hline
\end{tabular}

Bron: Feldman en Tenfelde, Workers, owners and politics appendix I, 396-400; Nederland: SHCL, ArchiefGSL, Statistiek.

\section{Bijlage 6 Economisch-geografische gebieden in Limburg ${ }^{1}$}

Noord- en Midden-Limburg: is gebied I $t / m 5$

Economisch-geografisch gebied I (Mook-Arcen en Velden)

Omvat de gemeenten: Arcen en Velden, Bergen, Gennep, Mook en Middelaar, Ottersum

Economisch-geografisch gebied 2 (Venray-Grubbenvorst)

Omvat de gemeenten: Horst, Sevenum,Venray, Broekhuizen, Grubbenvorst, Meerlo, Wanssum (Wanssum, per I-7-1969 samengevoegd met Meerlo: Meerlo-Wanssum)

Economisch-geografisch gebied 3 (Maasbree-Weert-Thorn)

Omvat de gemeenten: Baexem, Grathem, Helden, Heythuysen, Hunsel, Maasbree, Meijel, Nederweert, Roggel, Stramproy, Weert (Ittervoort, per I-7-I942 bij Hunsel; Neeritter, per I-7-I942 bij Hunsel), Beegden, Haelen, Heel en Panheel, Horn, Kessel, Neer, Thorn, Wessem (Buggenum, per I-IoI942 bij Haelen; Nunhem, per I-IO-I942 bij Haelen)

Economisch-geografisch gebied 4 (Venlo-Beesel)

Omvat de gemeenten: Beesel, Belfeld, Tegelen, Venlo

Economisch-geografisch gebied 5 (Swalmen-Roermond-Echt)

Omvat de gemeenten: Echt, Herten, Linne, Maasbracht, Maasniel, Melick en Herkenbosch, Montfort, Ohé en Laak, Posterholt, Roermond, Sint Odiliënberg, Stevensweert, Swalmen, Vlodrop

Zuid-Limburg: is gebied $6 \mathrm{at} / \mathrm{m} 8$

Economisch-geografisch gebied 6a (westelijke mijnstreek)

Omvat de gemeenten: Beek, Born, Elsloo, Geleen, Geulle, Grevenbicht, Limbricht, Munstergeleen,

I Fusies van gemeenten tot 1974 . 
Nieuwstadt, Obbicht en Papenhoven, Roosteren, Schimmert, Schinnen, Sittard, Spaubeek, Stein, Susteren, Ulestraten, Urmond (Broeksittard, per I-Io-I942 bij Sittard)

Economisch-geografisch gebied 6b (oostelijke mijnstreek)

Omvat de gemeenten: Amstenrade, Bingelrade, Bocholtz, Brunssum, Eygelshoven, Heerlen, Hoensbroek, Hulsberg, Jabeek, Kerkrade, Klimmen, Merkelbeek, Nieuwenhagen, Nuth, Oirsbeek, Schaesberg, Schinveld, Simpelveld, Ubach over Worms, Voerendaal, Wijnandsrade (Rimburg, per I-I-I887 bij Ubach over Worms)

Economisch-geografisch gebied 7 (Maastricht en omstreken)

Omvat de gemeenten: Bunde, Maastricht, Meerssen, (Oud-Vroenhoven, per I-I-I920 bij Maastricht; Sint Pieter, per I-I-I920 bij Maastricht; Amby, per I-7-I970 bij Maastricht; Borgharen, per I-7-I970 bij Maastricht; Heer, per I-7-I970 bij Maastricht; Itteren, per I-7-I970 bij Maastricht)

Economisch-geografisch gebied 8 (heuvelland)

Omvat de gemeenten: Bemelen, Berg en Terblijt, Cadier en Keer, Eijsden, Gronsveld, Gulpen, Margraten, Mheer, Noorbeek, Sint Geertruid, Slenaken, Vaals, Valkenburg, Wijlre, Wittem (Houthem, per I-IO-I940 bij Valkenburg; Oud-Valkenburg, per I-IO-I940 bij Valkenburg; Schin op Geul, per I-IOI940 bij Valkenburg; Mesch, per I-I-I943 bij Eijsden; Rijckholt, per I-I-I943 bij Gronsveld)

De gebieden staan ingetekend op de kaart op p. 289.

\section{Bijlage 7 Verantwoording van het kaartmateriaal (metadata) ${ }^{2}$}

De reeksen kaartmateriaal kwamen tot stand door een Geografisch Informatiesysteem (GIS). Hierbij worden geografische gegevens (in digitale vorm) in relatie gebracht met zogenaamde attribuutgegevens. Dit zijn hoofdzakelijk kwantitatieve data, die in dit geval inzicht verschaffen in de historische ontwikkeling van de arbeidsmarkt van mijnwerkers in Nederland. De bestanden met geografische data, waaronder shapefiles, zijn afkomstig van DANS (Data Archiving and Networked Services) en bevatten gemeentelijke en provinciale indelingen voor de jaren I830-I997. ${ }^{3}$ Ze zijn gemaakt met het doel een Nederlands historisch GIS te ontwikkelen en worden ter beschikking gesteld voor historisch onderzoek op basis van geografische en kwantitatieve analyses. Het door DANS opengestelde materiaal werd bewerkt en toegesneden op de Limburgse situatie. Het is de ambitie van het Sociaal Historisch Centrum voor Limburg in Maastricht om een eigen historisch GIS tot stand te brengen met als referentiekader de Euregio Maas-Rijn en met betrekking tot onderzoek naar de steenkolenindustrie.

Voor de samenstelling van de kaarten werd gebruik gemaakt van attribuutgegevens (kwantitatieve data) op basis van de beroepstellingen van I909, I930, I947 en I96o als onderdeel van de respectievelijke volkstellingen. De cijferreeksen zijn afkomstig van het Centraal Bureau voor Statistiek (CBS). Om het aantal mannelijke mijnwerkers te becijferen en in kaart te brengen werd geput uit: 1909, aantal mijnwerkers C,D; 1930, Bedrijfsgroep no. 2 (steenkolenmijnen); 1947, Bedrijfsklasse ı0; 1960, Kolenmijnbouw, mijnwerkers. De CBS-data betreffende de beroepsbevolking in de mijnbouwsector zijn niet onproblematisch. ${ }^{4}$ In de jaren dat de Limburgse steenkolenmijnen uitbreidden met verschillende nevenactiviteiten was niet altijd meer duidelijk welke bedrijfsonderdelen door het CBS nog tot

2 Met dank aan dr Erwin Steegen, Regionaal Historisch Centrum voor Limburg in Maastricht.

3 De gebruikte en bewerkte DANS shapefiles en bijbehorende bestanden werden gecreëerd door O. Boonstra, 2007, nl_1909, nl_1930'nl_1947 en nl_1960 (.shp, .shx, .dbf).

4 Zie voor een kritische beschouwing over het gebruik van CBS-gegevens: C.A. Oomens en G.P. den Bakker, 'De beroepsbevolking in Nederland I849-1990', Supplement bij de sociaal-economische maandstatistiek (I994-2) 3-42. 
de steenkolenmijnbouw werden gerekend. Vooral gold dat voor de cokes- en gasfabrieken en de chemische tak van Staatsmijnen in de periode na de Tweede Wereldoorlog. ${ }^{5}$ Mogelijk dat deze onduidelijkheid met name in de gemeenten in de westelijke mijnstreek, waar de chemische activiteiten waren geconcentreerd, enige vertekening tot gevolg heeft. Daarentegen zijn de CBS-gegevens over de beroepsbevolking vanaf Igog ook op gemeenteniveau beschikbaar en dat maakt het mogelijk ook op dat niveau kwantitatieve aspecten van de arbeidsmarkt voor mijnwerkers te onderzoeken.

De kaarten vormen chronologische reeksen die relatieve waarden of procentuele verhoudingen weergeven. Ten gevolge van het chronologisch verloop werd er voor gekozen de categorieën en de bijhorende kleurenweergave voor alle steekjaren gelijk te laten lopen. Dit komt de onderlinge vergelijkbaarheid ten goede, maar heeft als nadeel dat de ontwikkeling per afzonderlijk steekjaar niet altijd op de meest geprononceerde wijze wordt gepresenteerd. De categorieën percentages lopen per tien omhoog, met uitzondering van de eerste categorie die het aandeel van o,or tot I procent bevat. De bedoeling hiervan is om gemeenten met een marginale werkgelegenheid in de mijnbouw te abstraheren. Gemeenten zonder mijnwerkers zijn wit gekleurd en niet gerepresenteerd in de legenda. Ten behoeve van de presentatie is er voor gekozen de gemeente Bergen deels en de uiterst noordelijke gemeenten Gennep, Ottersum en Mook en Middelaar niet weer te geven. Voor de laatste drie gemeenten geldt bovendien dat er voor de onderzochte jaren geen mijnwerkers hebben gewoond. Gemeentenamen op de kaarten zijn vermeld als het inwoneraantal van de betreffende gemeente 7.500 in 1909 , 10.000 in 1930 en 15.000 inwoners in 1947-1960 overstijgt, of als het gemeenten betreft waarvan de becijferde waarde van het aandeel mijnwerkers meer dan 50 procent bedraagt in I909-I930 en 40 procent in I947-I960. ${ }^{6}$ De mijnzetels op de kaarten tenslotte zijn bij benadering gelokaliseerd.

5 Messing, Geschiedenis van de mijnsluiting, 558-56o.

6 Voor de kaarten uit de B-reeks werden dezelfde beginselen gehanteerd. De categorie-indeling werd in de mate van het mogelijke gelijkblijvend gehouden. Gemeentenamen op de kaart betreffen de centra Maastricht, Venlo en Roermond, of gemeenten met een mijnzetel. 
Bijlage 6 Economisch-geografische gebieden in Limburg (vervolg van p. 287)

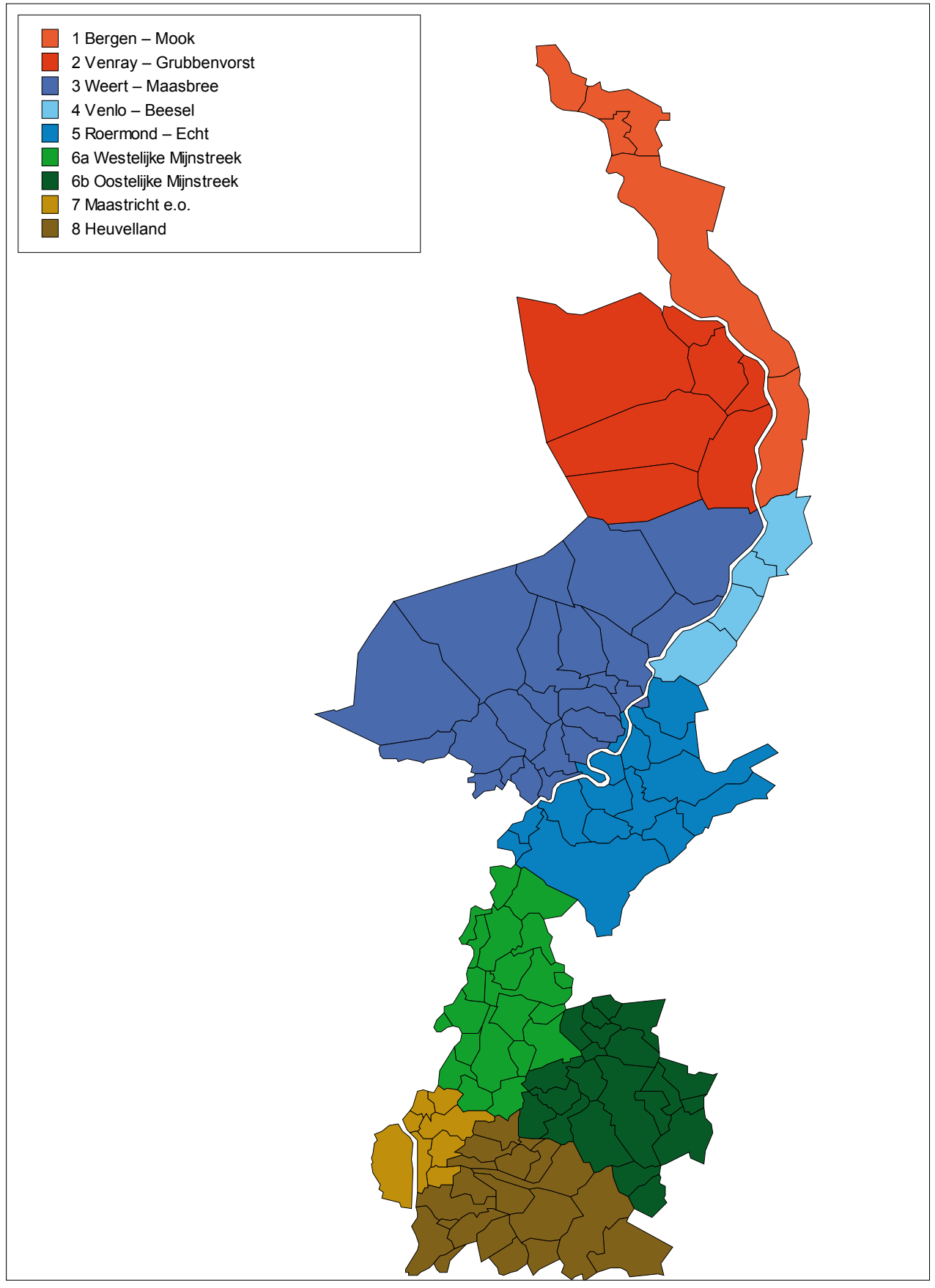


Bijlage 7a Aandeel mijnwerkers in de mannelijke beroepsbevolking 1909

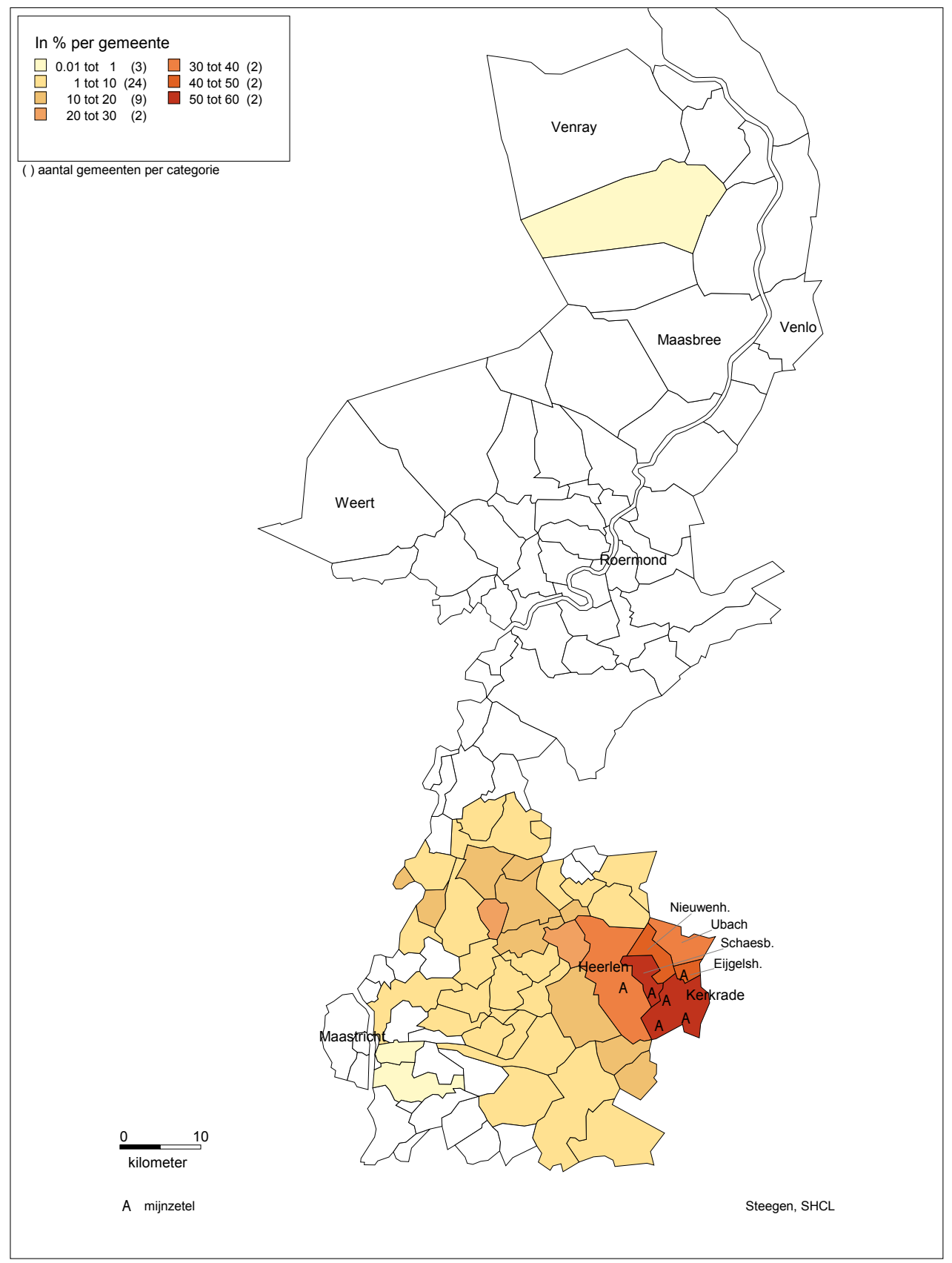


Bijlage 7a Aandeel mijnwerkers in de mannelijke beroepsbevolking 1930

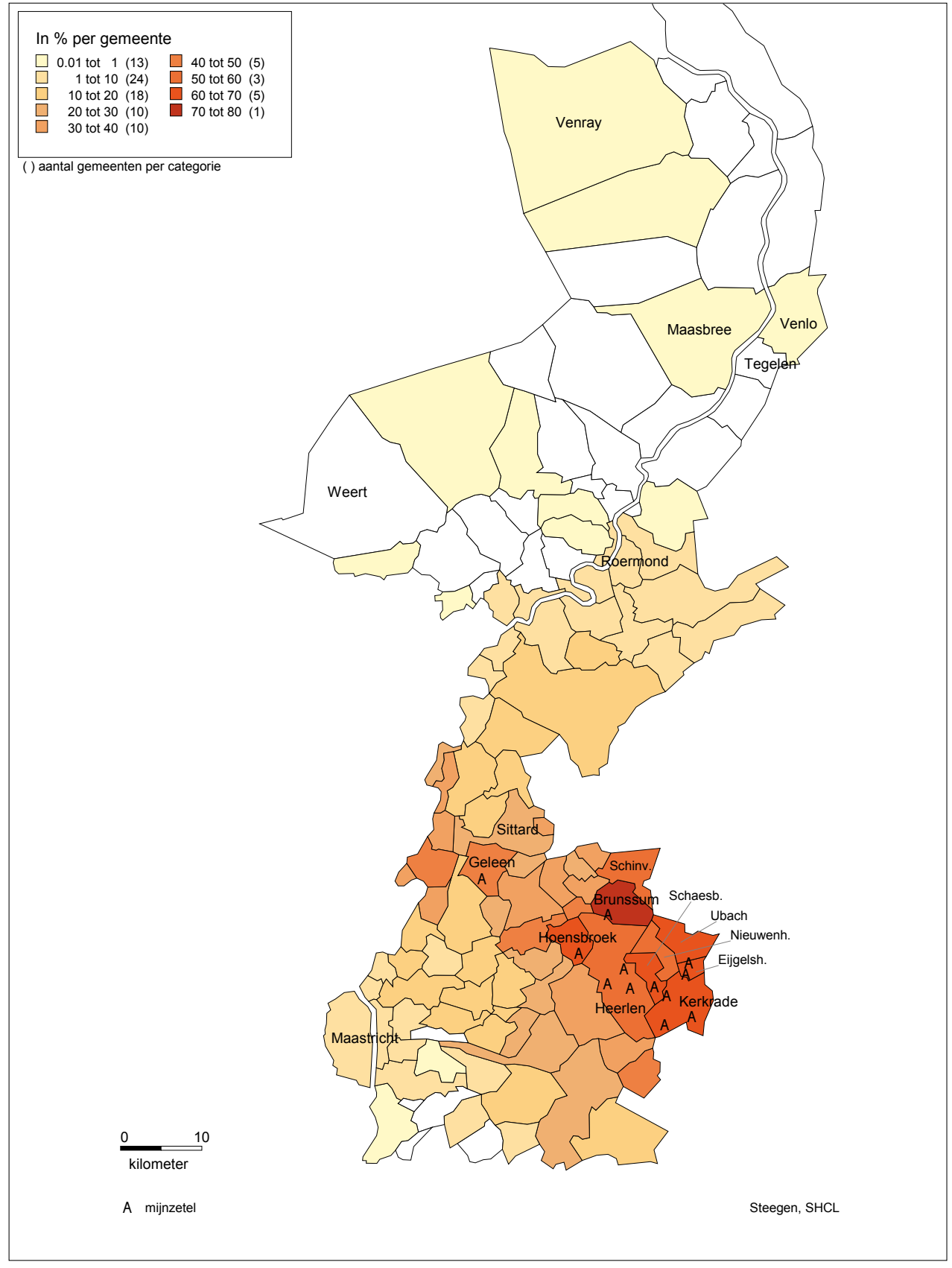


Bijlage 7a Aandeel mijnwerkers in de mannelijke beroepsbevolking 1947

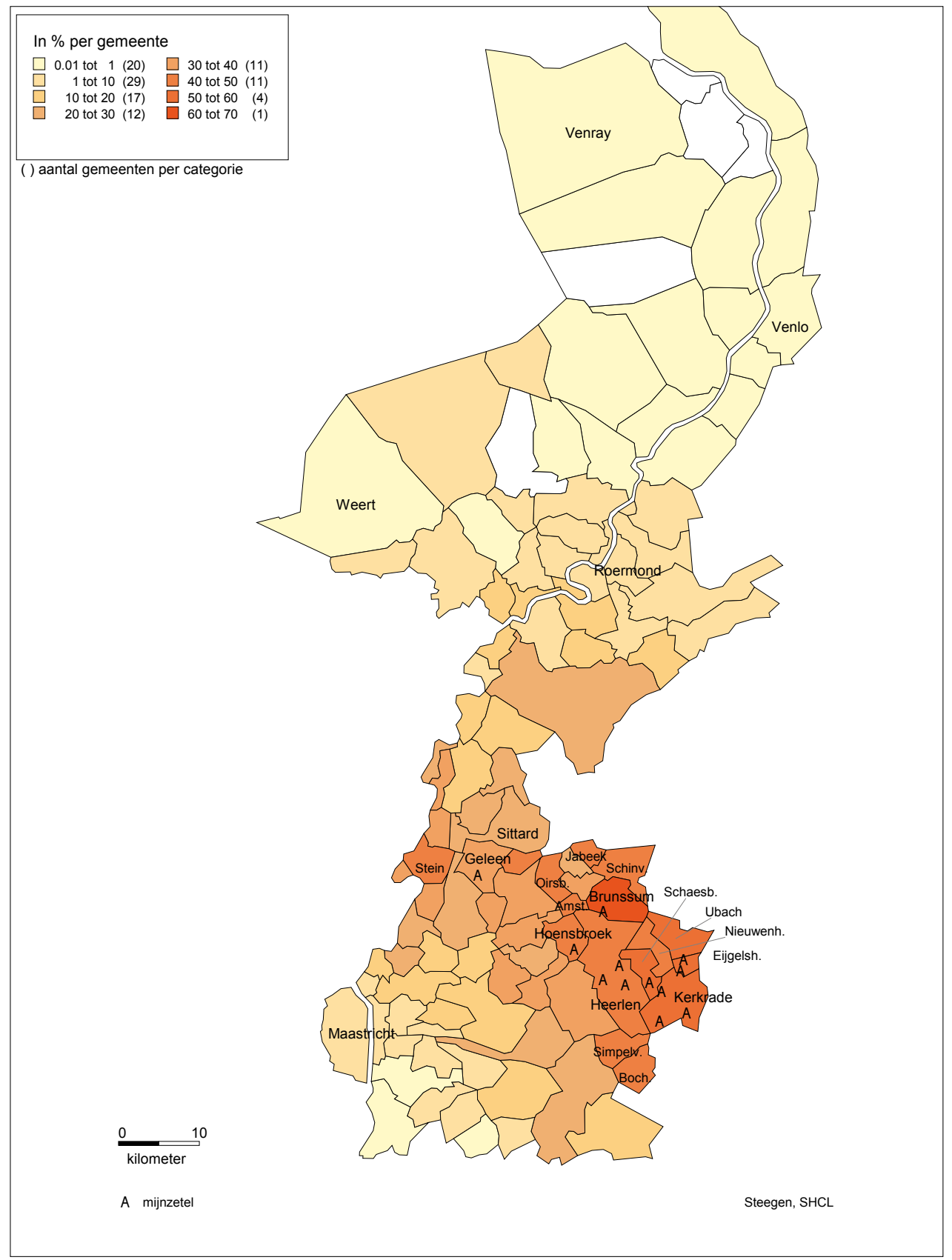


Bijlage 7a Aandeel mijnwerkers in de mannelijke beroepsbevolking I96o

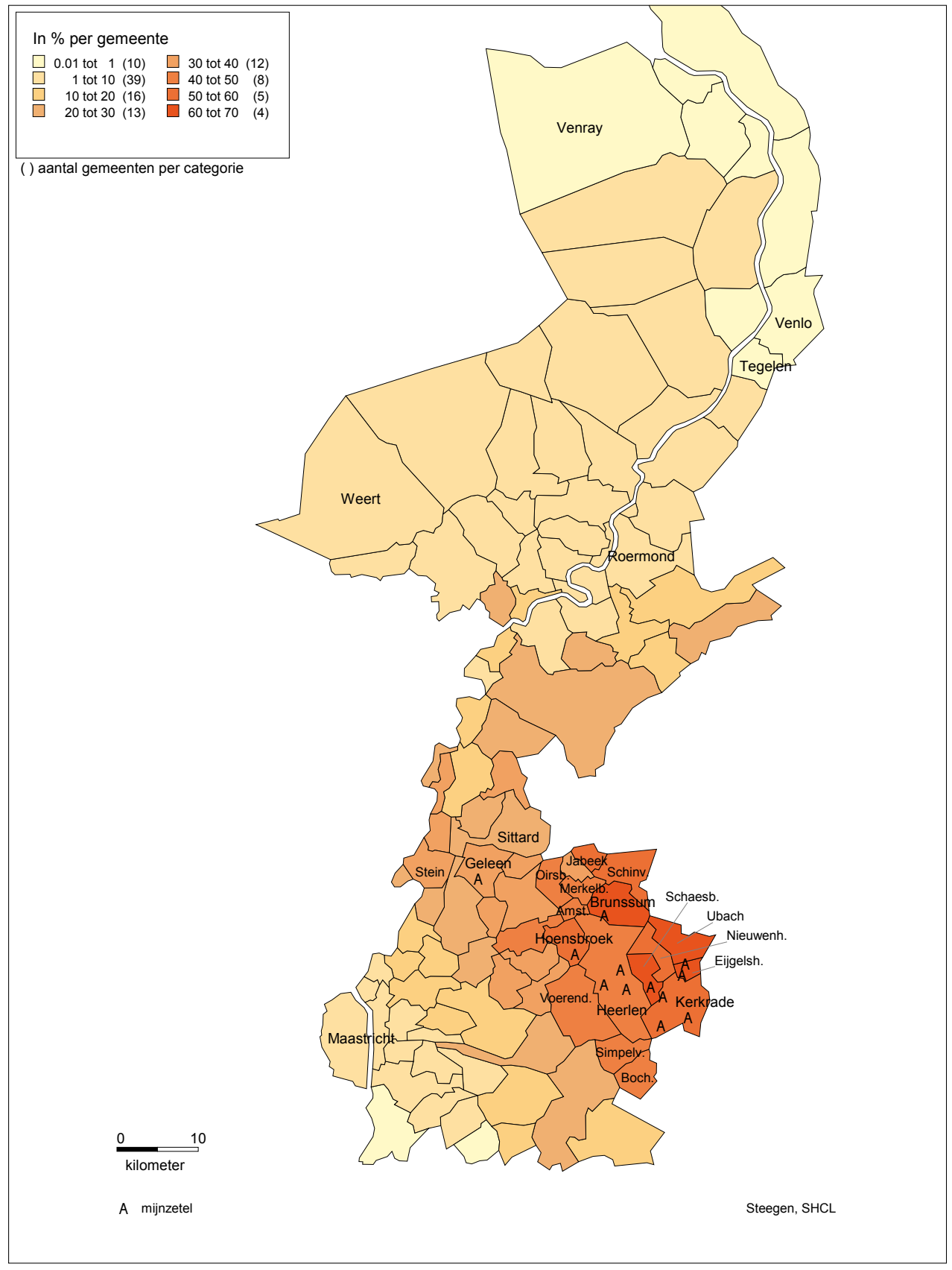


Bijlage 7b Gemeentelijk aandeel mijnwerkers in het totaal van de provincie 1909

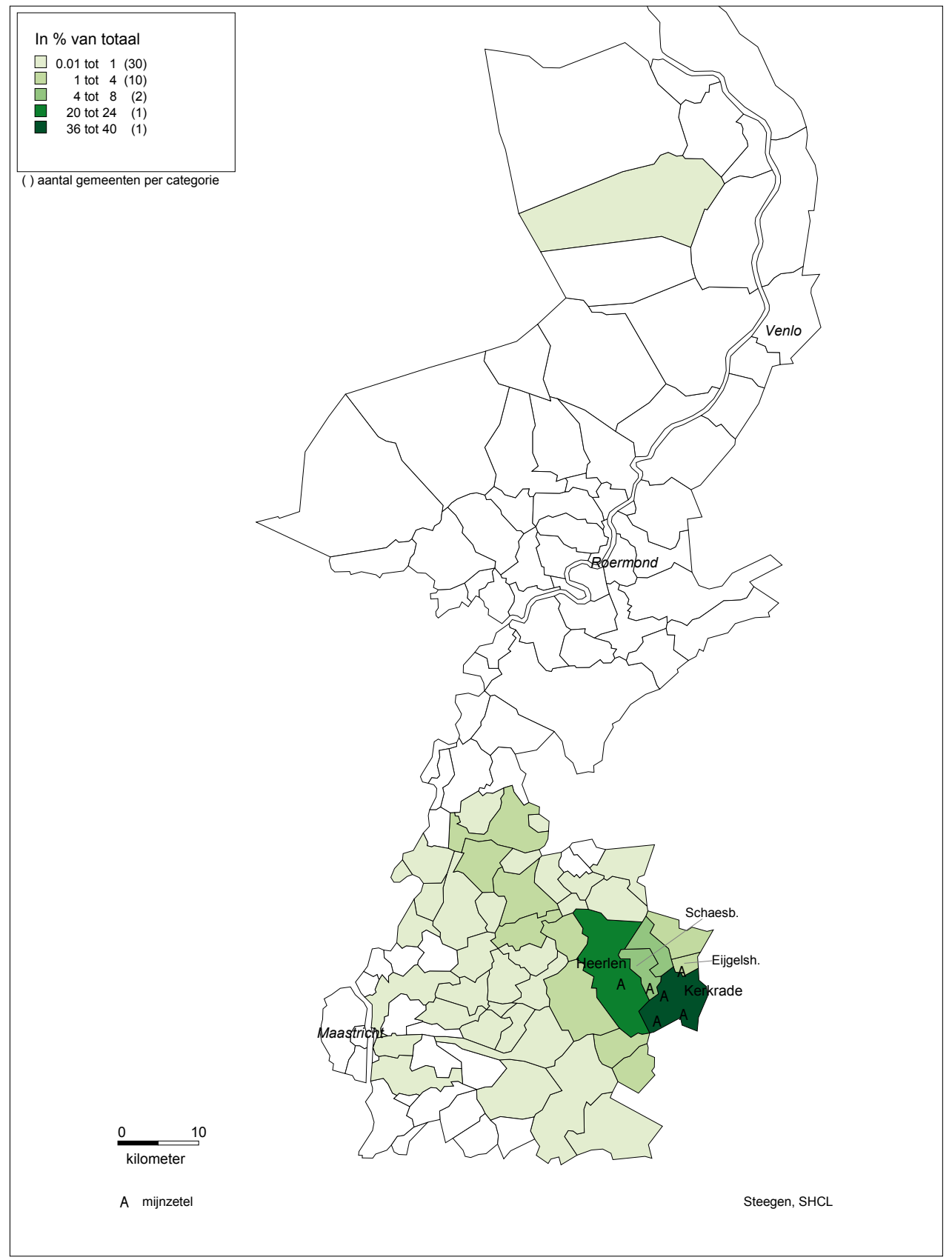


Bijlage 7b Gemeentelijk aandeel mijnwerkers in het totaal van de provincie 1930

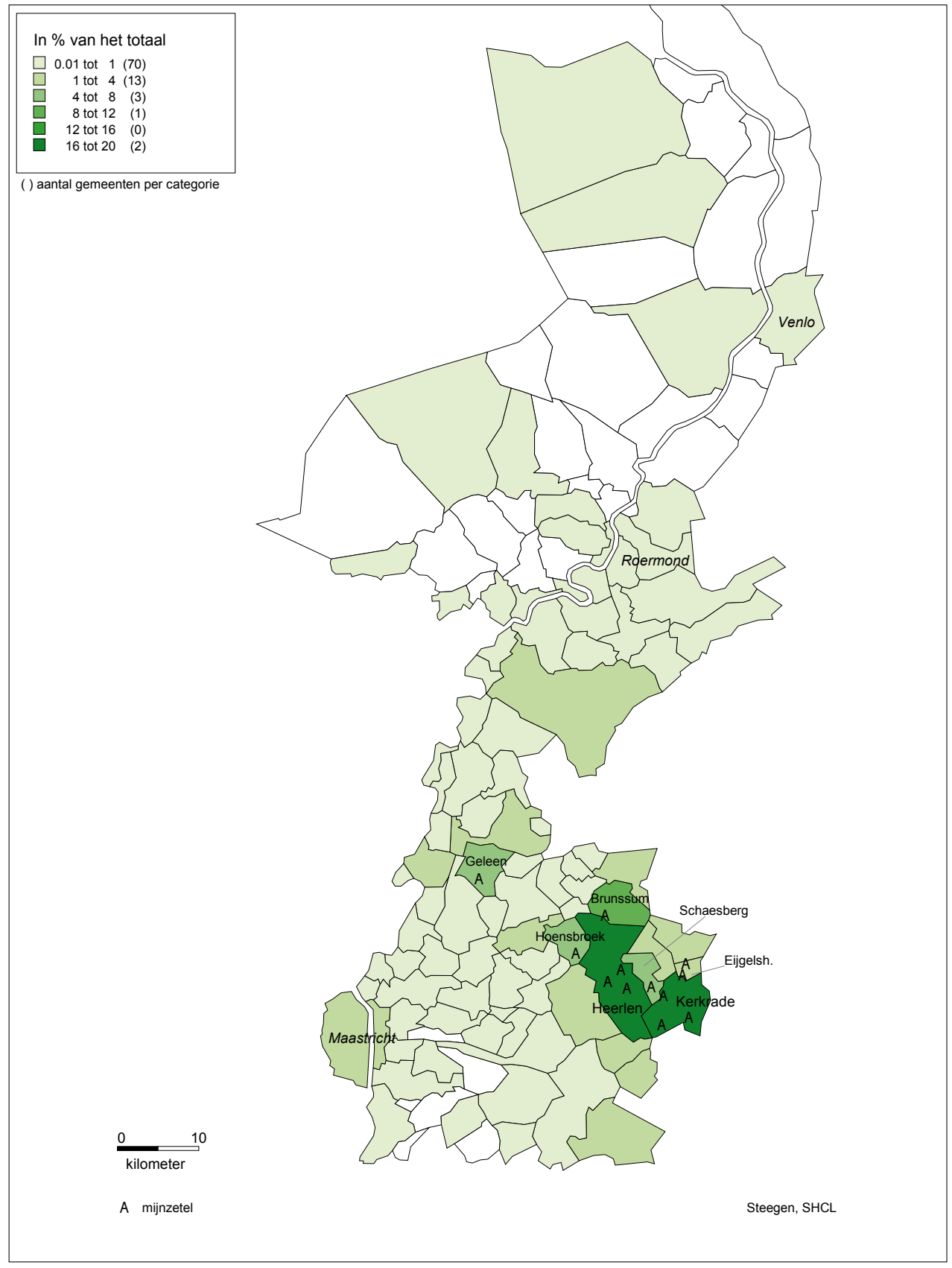


Bijlage 7b Gemeentelijk aandeel mijnwerkers in het totaal van de provincie 1947

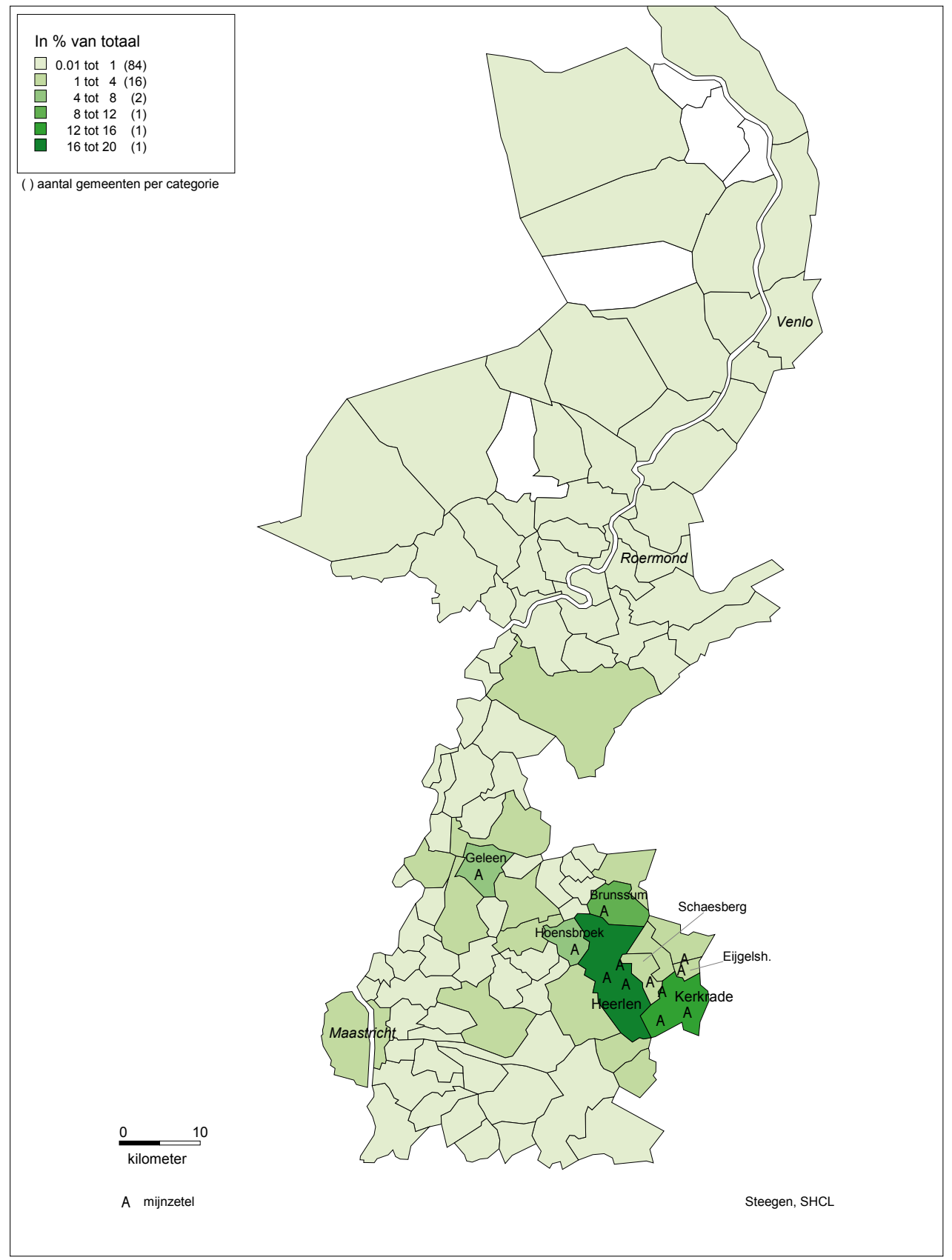


Bijlage 7b Gemeentelijk aandeel mijnwerkers in het totaal van de provincie 1960

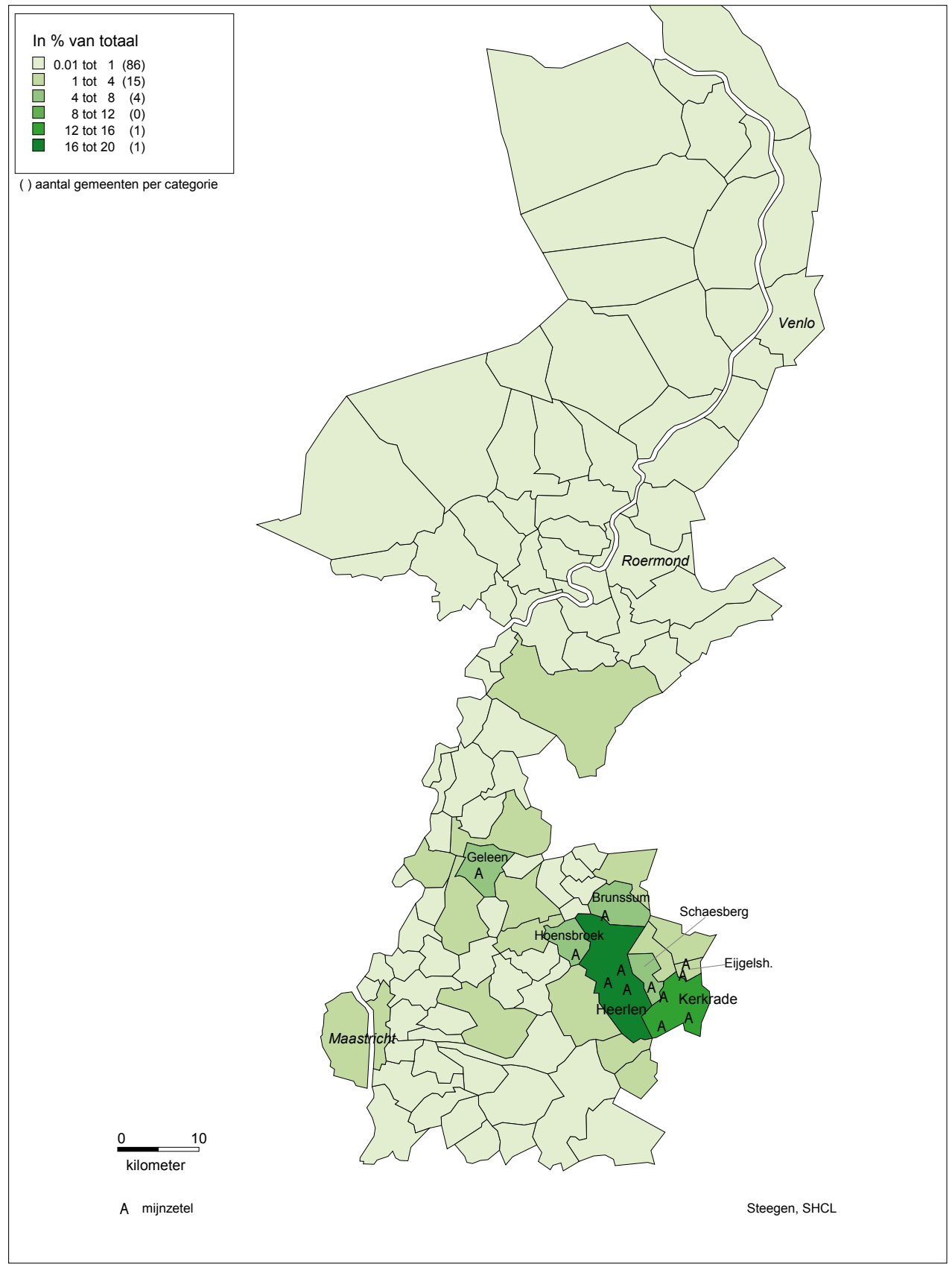


Bijlage 7c Het aandeel van mijnwerkers in de mannelijke beroepsbevolking Locatiequotiënten Limburgse gemeenten (provincie Limburg = I)

\begin{tabular}{|c|c|c|c|c|}
\hline gemeente & 1909 & 1930 & 1947 & 1960 \\
\hline Kerkrade & 8,76 & 2,77 & 2,59 & $2,6 \mathrm{I}$ \\
\hline Schaesberg & 7,76 & 2,95 & 2,89 & $2,8 \mathrm{I}$ \\
\hline Nieuwenhagen & 6,50 & $2,6 \mathrm{I}$ & 2,45 & 2,56 \\
\hline Eygelshoven & 6,47 & 2,98 & 2,95 & 3,04 \\
\hline Heerlen & 5,75 & 2,24 & 2,04 & 2,07 \\
\hline Ubach over Worms & $4,6 \mathrm{I}$ & 2,83 & 2,72 & 2,77 \\
\hline Hoensbroek & 3,95 & 2,77 & $2,4 \mathrm{I}$ & $2,5 \mathrm{I}$ \\
\hline Spaubeek & 2,95 & $\mathrm{I}, \mathrm{IO}$ & $\mathrm{I}, 82$ & $\mathrm{I}, 53$ \\
\hline Bocholtz & $2,6 \mathrm{I}$ & 2,03 & 2,17 & 2,17 \\
\hline Schinnen & 2,44 & $\mathrm{I}, 36$ & $\mathrm{I}, 73$ & $\mathrm{I}, 68$ \\
\hline Nuth & 2,39 & $\mathrm{I}, 95$ & $2, \mathrm{OI}$ & $\mathrm{I}, 97$ \\
\hline Munstergeleen & 2,38 & $\mathrm{I}, 3 \mathrm{I}$ & 2,02 & $\mathrm{I}, 83$ \\
\hline Voerendaal & $2,3 \mathrm{I}$ & $\mathrm{I}, 64$ & $\mathrm{I}, 84$ & $\mathrm{I}, 97$ \\
\hline Amstenrade & 2,26 & 2,07 & 2,22 & 2,19 \\
\hline Simpelveld & 2,08 & $\mathrm{I}, 57$ & 2,04 & 2,15 \\
\hline Geleen & $\mathrm{I}, 99$ & $\mathrm{I}, 93$ & $\mathrm{I}, 88$ & $\mathrm{I}, 42$ \\
\hline Elsloo & $\mathrm{I}, 80$ & $\mathrm{I}, 37$ & $\mathrm{I}, 8 \mathrm{O}$ & I,29 \\
\hline Klimmen & $\mathrm{I}, 46$ & $\mathrm{I}, 27$ & $\mathrm{I}, 69$ & $\mathrm{I}, 82$ \\
\hline Sittard & $\mathrm{I}, 40$ & 0,94 & $\mathrm{I}, 24$ & I,06 \\
\hline Broeksittard & $\mathrm{I}, 23$ & $\mathrm{I}, 49$ & & \\
\hline Wijnandsrade & $\mathrm{I}, \mathrm{I} 4$ & $\mathrm{I}, 06$ & $\mathrm{I}, 5 \mathrm{I}$ & $\mathrm{I}, 45$ \\
\hline Merkelbeek & $\mathrm{I}, \mathrm{II}$ & $\mathrm{I}, 34$ & $\mathrm{I}, 87$ & 2,17 \\
\hline Brunssum & $\mathrm{I}, 07$ & 3,17 & 3,04 & 2,82 \\
\hline Oirsbeek & $\mathrm{I}, 03$ & $\mathrm{I}, 39$ & 2,08 & 2,02 \\
\hline Hulsberg & 0,87 & 0,69 & 1,56 & $\mathrm{I}, 47$ \\
\hline Geulle & 0,77 & 0,52 & $\mathrm{I}, 09$ & 0,77 \\
\hline Beek & $0,7 \mathrm{I}$ & 0,84 & $\mathrm{I}, 26$ & 0,95 \\
\hline Houthem & 0,70 & 0,75 & & \\
\hline Schin op Geul & 0,66 & $\mathrm{I}, 03$ & & \\
\hline Valkenburg & 0,63 & 0,49 & 0,99 & 0,80 \\
\hline Stein & 0,40 & $\mathrm{I}, 92$ & 2,04 & $\mathrm{I}, 72$ \\
\hline Wittem & 0,39 & 0,92 & $\mathrm{I}, \mathrm{II}$ & $\mathrm{I}, 24$ \\
\hline Wijlre & 0,37 & 0,96 & $\mathrm{I}, 02$ & $\mathrm{I}, \mathrm{OO}$ \\
\hline Berg en Terblijt & 0,37 & 0,60 & 0,84 & 0,63 \\
\hline Gulpen & 0,36 & 0,49 & 0,52 & 0,65 \\
\hline
\end{tabular}




\begin{tabular}{|c|c|c|c|c|}
\hline gemeente & 1909 & 1930 & 1947 & 1960 \\
\hline Meerssen & 0,35 & 0,70 & 0,83 & 0,52 \\
\hline Oud-Valkenburg & 0,34 & 0,59 & & \\
\hline Schinveld & 0,29 & 2,37 & 2,33 & 2,43 \\
\hline Vaals & 0,25 & 0,85 & 0,66 & 0,82 \\
\hline Schimmert & 0,23 & 0,70 & 0,92 & $\mathrm{I}, \mathrm{OO}$ \\
\hline Limbricht & $0,2 \mathrm{I}$ & o,6r & $\mathrm{I}, 40$ & $\mathrm{I}, \mathrm{O} 4$ \\
\hline Heer & $0, \mathrm{II}$ & 0,24 & 0,40 & 0,24 \\
\hline Gronsveld & 0,08 & 0,04 & 0,05 & 0,09 \\
\hline Horst & 0,07 & 0,00 & 0,04 & 0,05 \\
\hline Amby & 0,00 & $0,3 \mathrm{I}$ & 0,37 & 0,35 \\
\hline Arcen en Velden & 0,00 & 0,00 & 0,01 & 0,03 \\
\hline Baexem & 0,00 & 0,00 & 0,06 & 0,16 \\
\hline Beegden & 0,00 & 0,00 & 0,12 & $0,3 \mathrm{I}$ \\
\hline Beesel & 0,00 & 0,00 & 0,04 & 0,17 \\
\hline Belfeld & 0,00 & 0,00 & $0, \mathrm{OI}$ & 0,06 \\
\hline Bemelen & 0,00 & 0,00 & 0,10 & 0,14 \\
\hline Bergen & 0,00 & 0,00 & 0,00 & 0,00 \\
\hline Bingelrade & 0,00 & $\mathrm{I}, 06$ & $\mathrm{I}, 32$ & $\mathrm{I}, 77$ \\
\hline Borgharen & 0,00 & 0,13 & 0,35 & 0,22 \\
\hline Born & 0,00 & 0,50 & 0,95 & 0,85 \\
\hline Broekhuizen & 0,00 & 0,00 & 0,00 & 0,00 \\
\hline Buggenum & 0,00 & 0,00 & & \\
\hline Bunde & 0,00 & 0,80 & $\mathrm{I}, 05$ & 0,78 \\
\hline Cadier en Keer & 0,00 & 0,02 & $0,3 \mathrm{I}$ & 0,07 \\
\hline Echt & 0,00 & 0,67 & $\mathrm{I}, 09$ & $\mathrm{I}, 07$ \\
\hline Eijsden & 0,00 & o,oI & 0,03 & 0,03 \\
\hline Gennep & 0,00 & 0,00 & 0,00 & 0,00 \\
\hline Grathem & 0,00 & 0,00 & 0,04 & 0,18 \\
\hline Grevenbicht & 0,00 & $\mathrm{I}, 23$ & $\mathrm{I}, \mathrm{I} 8$ & 0,94 \\
\hline Grubbenvorst & 0,00 & 0,00 & 0,03 & 0,05 \\
\hline Haelen & 0,00 & 0,04 & 0,05 & 0,21 \\
\hline Heel en Panheel & 0,00 & 0,00 & 0,16 & 0,20 \\
\hline Helden & 0,00 & 0,00 & 0,02 & 0,22 \\
\hline Herten & 0,00 & $0, \mathrm{II}$ & $0,3 \mathrm{I}$ & 0,25 \\
\hline Heythuysen & 0,00 & 0,01 & 0,00 & 0,17 \\
\hline Horn & 0,00 & 0,04 & 0,06 & 0,18 \\
\hline
\end{tabular}




\begin{tabular}{|c|c|c|c|c|}
\hline gemeente & 1909 & 1930 & 1947 & 1960 \\
\hline Hunsel & 0,00 & 0,00 & 0,10 & 0,31 \\
\hline Itteren & 0,00 & 0,32 & 0,56 & 0,27 \\
\hline Ittervoort & 0,00 & 0,00 & & \\
\hline Jabeek & 0,00 & $\mathrm{I}, 55$ & 2,12 & 2,31 \\
\hline Kessel & 0,00 & 0,00 & 0,03 & 0,34 \\
\hline Linne & 0,00 & 0,42 & 0,84 & 0,34 \\
\hline Maasbracht & 0,00 & 0,38 & 0,43 & 0,30 \\
\hline Maasbree & 0,00 & 0,00 & 0,01 & 0,10 \\
\hline Maasniel & 0,00 & $0, \mathrm{II}$ & 0,15 & 0,00 \\
\hline Maastricht & 0,00 & 0,13 & 0,15 & 0,14 \\
\hline Margraten & 0,00 & 0,08 & 0,29 & 0,32 \\
\hline Meerlo & 0,00 & 0,00 & 0,00 & 0,03 \\
\hline Meijel & 0,00 & 0,00 & 0,10 & 0,29 \\
\hline Melick en Herkenbosch & 0,00 & 0,10 & 0,19 & 0,56 \\
\hline Mesch & 0,00 & 0,00 & & \\
\hline Mheer & 0,00 & 0,06 & 0,17 & 0,18 \\
\hline Montfort & 0,00 & 0,55 & 0,77 & $\mathrm{I}, 09$ \\
\hline Mook en Middelaar & 0,00 & 0,00 & 0,05 & 0,00 \\
\hline Nederweert & 0,00 & 0,00 & 0,10 & 0,12 \\
\hline Neer & 0,00 & 0,00 & 0,02 & O,II \\
\hline Neeritter & 0,00 & 0,02 & & \\
\hline Nieuwstadt & 0,00 & 0,72 & $\mathrm{I}, 39$ & $\mathrm{I}, 40$ \\
\hline Noorbeek & 0,00 & 0,00 & 0,03 & 0,02 \\
\hline Nunhem & 0,00 & 0,00 & & \\
\hline Obbicht en Papenhoven & 0,00 & $\mathrm{I}, 39$ & $\mathrm{I}, 87$ & $\mathrm{I}, 4 \mathrm{I}$ \\
\hline Ohe en Laak & 0,00 & 0,07 & 0,43 & 0,35 \\
\hline Ottersum & 0,00 & 0,00 & $0,0 \mathrm{I}$ & 0,00 \\
\hline Oud-Vroenhoven & 0,00 & 0,00 & & \\
\hline Posterholt & 0,00 & $0,3 \mathrm{I}$ & 0,54 & 0,79 \\
\hline Rijckholt & 0,00 & 0,00 & & \\
\hline Roermond & 0,00 & 0,09 & 0,12 & 0,18 \\
\hline Roggel & 0,00 & 0,00 & o,oI & 0,31 \\
\hline Roosteren & 0,00 & 0,25 & 0,63 & 0,64 \\
\hline Sevenum & 0,00 & 0,00 & 0,00 & 0,10 \\
\hline Sint Geertruid & 0,00 & 0,00 & 0,17 & 0,10 \\
\hline Sint Odiliënberg & 0,00 & 0,23 & 0,33 & 0,64 \\
\hline
\end{tabular}




\begin{tabular}{|l|c|c|c|c|}
\hline gemeente & $\mathbf{1 9 0 9}$ & $\mathbf{1 9 3 0}$ & $\mathbf{1 9 4 7}$ & 1960 \\
\hline Sint Pieter & 0,00 & 0,00 & & \\
\hline Slenaken & 0,00 & 0,12 & 0,30 & 0,51 \\
\hline Stevensweert & 0,00 & 0,16 & 0,65 & 0,55 \\
\hline Stramproy & 0,00 & 0,02 & 0,05 & $0,2 \mathrm{I}$ \\
\hline Susteren & 0,00 & 0,53 & 0,95 & 0,99 \\
\hline Swalmen & 0,00 & 0,02 & 0,08 & 0,37 \\
\hline Tegelen & 0,00 & 0,00 & 0,01 & 0,04 \\
\hline Thorn & 0,00 & 0,24 & 0,97 & 1,22 \\
\hline Ulestraten & 0,00 & 0,43 & 0,83 & 0,60 \\
\hline Urmond & 0,00 & $\mathrm{I}, 42$ & $\mathrm{I}, 72$ & $\mathrm{I}, 38$ \\
\hline Venlo & 0,00 & 0,00 & 0,01 & 0,03 \\
\hline Venray & 0,00 & 0,00 & 0,00 & 0,02 \\
\hline Vlodrop & 0,00 & 0,08 & 0,26 & 0,98 \\
\hline Wanssum & 0,00 & 0,00 & 0,00 & 0,01 \\
\hline Weert & 0,00 & 0,00 & 0,01 & 0,10 \\
\hline Wessem & 0,00 & 0,09 & 0,53 & 0,50 \\
\hline
\end{tabular}

Bron: Eigen berekening op basis van de CBS-volks- en beroepstellingen van 1909, I930, 1947 en 1960.

\section{Toelichting}

Per gemeente werd de verhouding van het aantal mijnwerkers tot de totale mannelijke beroepsbevolking (als promillage) berekend. Dezelfde berekening werd ook gemaakt voor de provincie Limburg als geheel, die als referentiegebied geldt. Vervolgens werd voor elke gemeente het quotiënt berekend van het eigen promillage en dat van het referentiegebied. De waarde waarmee de uitkomst groter of kleiner is dan $\mathrm{I}$ is een maatstaf voor de mate van over- of ondervertegenwoordiging.

\section{Bijlage 8 Steekproef uit de kaartadministratie van het Algemeen Mijnwerkersfonds}

Op I augustus IgIg trad het Algemeen Mijnwerkersfonds van de Steenkolenmijnen in Limburg (AMF) in werking. Het AMF werd opgericht door de vijf Nederlandse mijnondernemingen, de Nederlandse Mijnwerkersbond en de Algemene Bond van Christelijke Mijnwerkers in Nederland. ${ }^{7}$ Het AMF verving de uiteenlopende regelingen betreffende sociale ondersteuning van mijnarbeiders die bij de $\mathrm{Ne}$ derlandse steenkolenmijnen bestonden. In het AMF waren alle mijnarbeiders die in de Nederlandse steenkolenmijnen werkten, op een uniforme wijze verzekerd. Het AMF kende daartoe drie kassen: het ziekenfonds verstrekte geneeskundige behandeling en geneesmiddelen voor de mijnarbeider en zijn gezinsleden, de ziekenkassen keerden ziektegeld uit aan mijnarbeiders die door ziekte niet in staat waren hun werkzaamheden te verrichten en de pensioenkas gaf recht op een uitkering bij ouderdom of invaliditeit. ${ }^{8}$

8 Rapport Staatscommissie 1946, II2-II8. 
Alleen mijnarbeiders traden toe tot het AMF. Voor beambten golden per mijnonderneming afzonderlijke regelingen. Pas in 1953 zou ook een algemeen Beambtenfonds voor het Mijnbedrijf (BFM) tot stand komen.

Het AMF hield van elke mijnwerker een administratie bij met ondermeer een kaartsysteem. Bij intreding in het AMF werd voor elke mijnwerker een zogenaamde A-kaart aangemaakt, met daarop zijn persoonlijke gegevens: naam, geboorteplaats, geboortedatum en nationaliteit. Gedurende zijn hele carrière als arbeider in een Nederlandse steenkolenmijn werd op de A-kaart de afdracht van premies genoteerd. Ook werd op de kaart bijgehouden bij welke mijnzetel de mijnwerker in dienst was en welke mutaties van mijnwerkgever in de loop van de tijd plaatsvonden. Door middel van toevoeging van de letter 'o' of ' $b$ ' werd daarbij tevens aangegeven of de mijnwerker ondergronds dan wel bovengronds was tewerkgesteld. Bij uittreding uit het mijnbedrijf werd daarvan op de kaart aantekening gemaakt. De A-kaart bleef ook na uittreding uit het AMF in de administratie bewaard, omdat de gegevens over premieafdracht en diensttijd van belang waren bij de berekening van de rechten waarop de mijnwerker uiteindelijk aanspraak kon maken. Op de A-kaart is dus de hele carrière van een mijnarbeider in de Limburgse steenkolenmijnbouw te volgen.

De administratie van het Algemeen Mijnwerkersfonds is momenteel ondergebracht bij het AZL in Heerlen. Daar worden ook de meer dan 200.000 A-kaarten bewaard. In de loop van de tijd zijn de fysieke A-kaarten gescand en digitaal opgeslagen in het programma Canonfile. Canonfile heeft een zoekfunctie, waarmee gezocht kan worden op familienaam en op registratienummer van het AMF. De registratienummering correspondeert grotendeels met de chronologische volgorde van aanmelding bij het AMF. Hoewel het AMF pas op I augustus IgIg van start ging, bevat de administratie ook A-kaarten van mijnarbeiders die vóór die tijd bij een Nederlandse steenkolenmijn in dienst zijn getreden, en bij de start van het AMF nog bij een van de mijnbedrijven werkzaam waren. Het kaartsysteem is bijgehouden tot augustus I970.

Voor het trekken van een steekproef uit de A-kaarten, werd het totale bestand eerst opgedeeld in vijf periodes (tabel 8.I)

TABel 8.I Globale Chronologische verdeling Registratienummers A-KaARTen AMF

\begin{tabular}{|c|c|}
\hline periode aanmaak & registratienummers \\
\hline vóór I-8-I9I9 & $\approx$ I-20.000 \\
\hline I-8-I9I9 t/m 3I-I2-I930 & $\approx 20.000-80.000$ \\
\hline I-I-I93 t/m 3I-I2-I944 & $\approx 80.000-115.000$ \\
\hline I-I-I945 t/m 3I-I2-I965 & $\approx$ II5.000-200.000 \\
\hline na 3I-I2-I965 & $\approx 200.000-207.000$ \\
\hline
\end{tabular}

Uit elk van de vijf tijdvakken werd, uitgaande van een maximale foutenmarge van 5 procent, een betrouwbaarheid van 95 procent en een spreiding van 50 procent, een steekproef getrokken van ongeveer 400 kaarten. Dat gebeurde at random met behulp van een tabel met toevalscijfers. ${ }^{9}$ Op deze manier ontstonden vijf intredecohorten.

De gegevens uit de aldus geselecteerde A-kaarten werden ingevoerd in een database. Hiervoor werd het programma Microsoft Access gebruikt. 


\section{Bijlage 9 Nationaliteitsbewijzen}

Nationaliteitsbewijzen waren bewijzen van Nederlanderschap. Nederlanders die in Duitsland werk zochten en daar ook (tijdelijk) wilden verblijven, hadden sinds 1875 in principe een nationaliteitsbewijs nodig. De Duitse overheid eiste dat, voor het geval de arbeider een beroep zou moeten doen op de armenzorg. Wanneer duidelijk was waar de betreffende persoon vandaan kwam, kon hij immers teruggestuurd worden. ${ }^{10}$ Het nationaliteitsbewijs vermeldde dan ook expliciet dat de houder in het land van herkomst zou worden toegelaten, wanneer hij ten laste van de buitenlandse staat zou komen.

Het nationaliteitsbewijs moest door de betrokkenen worden aangevraagd bij de burgemeester van de Nederlandse gemeente waar hij in het bevolkingsregister stond ingescheven. De gemeente stuurde de aanvraag vervolgens door naar het provinciaal bestuur. Daar werd de aanvraag beoordeeld. Wanneer er geen bezwaren tegen afgifte bestonden, werd het nationaliteitsbewijs opgesteld en via de gemeente aan de aanvrager verstrekt.

Het Centraal Bureau voor de Statistiek (CBS) hield sedert Igoo aantekening van het aantal door de Commissarissen van de Koningin uitgereikte nationaliteitsbewijzen. Vanaf 1903 werden die overzichten, met terugwerkende kracht tot Igoo, jaarlijks gepubliceerd. ${ }^{11}$

De CBS-overzichten geven alleen de aantallen per provincie. De formulieren, die de aanvrager moest invullen om voor een nationaliteitsbewijs in aanwerking te komen, geven veel meer informatie. Ze vermelden een schat aan persoonlijke gegevens van de betrokkene: behalve de naam, de geboorteplaats en -datum, de burgerlijke staat (met personalia van echtgenote en eventuele kinderen) zijn ook het beroep, de woonplaats en de plaats van bestemming vermeld. Dat maakt deze reeks van aanvragen tot een belangrijke seriële bron voor migratieonderzoek.

Bij het Historisch Centrum Limburg in Maastricht worden in het Provinciaal Archief (EAN 04.or, inventarisnummers 6895-7263) circa 70.000 aanvraagformulieren voor nationaliteitsbewijzen bewaard. In de zomer van $200 \mathrm{I}$ werd, in samenwerking tussen het Rijksarchief in Limburg en het Sociaal Historisch Centrum voor Limburg (SHCL) begonnen met digitalisering van gegevens uit dit enorme bestand. Het project behelst de invoer van de basisgegevens uit de formulieren in een database, waarvoor het programma Microsoft Access wordt gebruikt. ${ }^{12}$ Medio april $201 \mathrm{z}$ zijn de gegevens van circa 60.000 aanvraagformulieren ingevoerd.

Voor het onderzoek naar de arbeidsmarkt voor mijnwerkers in Limburg maakte ik gebruik van de database, zoals die in november 2007 beschikbaar was. De database bestond op dat moment uit de gegevens uit 34.I59 aanvraagformulieren, ongeveer de helft dus van het totale bestand. Omdat bij de invoer van de gegevens de ordening van de formulieren in het archief (op familienaam) is aangehouden, bezit dit deelbestand een aanvaardbare regionale representativiteit. Concreet omvat de gebruikte database de familienamen Aacken $\mathrm{t} / \mathrm{m}$ Kurtjens.

Om de ingevoerde gegevens geschikt te maken voor analyse, was het noodzakelijk gegevens te standaardiseren. Dit gold vooral de schrijfwijze van plaatsnamen en de aanduiding van beroepen. Aan de beroepen werd bovendien toegevoegd de CBS-beroepsclassificatie van de beroepstellingen van 1889 en 1909 . Voorts werden de Limburgse gemeenten van aanvraag samengebracht in econo-

Io Lucassen, 'Many-headed monster', I25-253. Zie ook: Van Eijl, Al te goed is buurmans gek, 77 e.v.

II Het eerst gebeurde dat in: Tijdschrift van het Centraal Bureau voor de Statistiek nummer 2 (Ig03) 266. Vanaf Igo8 werden maandelijkse overzichten gepubliceerd in het Maandschrift van het Centraal Bureau voor de Statistiek.

12 Serge Langeweg, 'Aanvragen voor nationaliteitsbewijzen als bron voor migratieonderzoek', Nieuwsbrief Rijksarchief in Limburg VI nummer I (2002) 4 . 
misch-geografische gebieden ${ }^{13}$ en werden de Duitse bestemmingen geplaatst in de Kreis waartoe ze behoorden. ${ }^{14}$

Bijlage ro De geboorteplaats in de mijnstreek van nieuwe AMF-leden

\begin{tabular}{|c|c|c|c|c|c|}
\hline & 1900-1965 & $\begin{array}{c}\text { vóór I aug } \\
\text { I9I9 }\end{array}$ & I919-1930 & I93I-I944 & $1945-1965$ \\
\hline Amstenrade & 5 & 2 & I & I & I \\
\hline Beek & II & - & 2 & 7 & 2 \\
\hline Bingelrade & 4 & I & 2 & I & - \\
\hline Bocholtz & II & 5 & I & 3 & 2 \\
\hline Born & 4 & - & 2 & 2 & - \\
\hline Broeksittard & 4 & I & 2 & I & - \\
\hline Brunssum & 20 & 4 & - & I3 & 3 \\
\hline Eijgelshoven & 7 & 4 & - & 2 & I \\
\hline Elsloo & $\mathrm{I} 2$ & I & 4 & 6 & I \\
\hline Geleen & 24 & 4 & 2 & 6 & $\mathrm{I} 2$ \\
\hline Geulle & 2 & I & - & I & - \\
\hline Grevenbicht & 4 & - & 3 & - & I \\
\hline Heerlen & 97 & I3 & 5 & 39 & 40 \\
\hline Hoensbroek & 32 & 4 & - & I9 & 9 \\
\hline Hulsberg & II & 3 & I & 4 & 3 \\
\hline Jabeek & 3 & - & - & I & 2 \\
\hline Kerkrade & 123 & 40 & 17 & 36 & 30 \\
\hline Klimmen & 4 & 2 & - & 2 & - \\
\hline Limbricht & 6 & I & - & 3 & 2 \\
\hline Merkelbeek & 4 & 2 & - & I & I \\
\hline Munstergeleen & 3 & I & - & I & I \\
\hline Nieuwenhagen & I2 & 4 & 3 & 5 & - \\
\hline Nieuwstadt & 4 & I & - & I & 2 \\
\hline Nuth & II & - & 3 & 5 & 3 \\
\hline Obbicht & I & - & - & I & - \\
\hline Oirsbeek & 3 & 2 & I & - & - \\
\hline Roosteren & 2 & I & - & I & - \\
\hline Schaesberg & 22 & 5 & 2 & 7 & 8 \\
\hline Schimmert & 6 & I & - & 5 & - \\
\hline Schinnen & 15 & I & I & 9 & 4 \\
\hline
\end{tabular}

I3 Zie voor de indeling het hoofdstuk over de woonplaatsen van de mijnwerkers.

I4 Friedrich Müller (ed.), Grosses Deutsches Ortsbuch (Barmen 19274). 


\begin{tabular}{|l|r|r|r|r|r|}
\hline Schinveld & I2 & 5 & - & 7 & - \\
\hline Simpelveld & I5 & 2 & - & 9 & 4 \\
\hline Sittard & I9 & 2 & 3 & 8 & 6 \\
\hline Spaubeek & 7 & I & - & 5 & I \\
\hline Stein & I5 & 5 & 3 & 3 & 4 \\
\hline Ubach over Worms & 24 & 9 & I & 9 & 5 \\
\hline Ulestraten & 3 & - & - & 2 & I \\
\hline Urmond & 5 & - & I & I & 3 \\
\hline Voerendaal & I0 & 2 & - & 5 & 3 \\
\hline Mijnstreek & 577 & I30 & 60 & 232 & I55 \\
\hline Limburg & 854 & 2 II & I04 & 3 I2 & 227 \\
\hline & & & & & 68,3 \\
\hline $\begin{array}{l}\text { Mijnstreek \% van } \\
\text { Limburg }\end{array}$ & 67,6 & 61,6 & 57,8 & 74,4 & \\
\hline
\end{tabular}

Bron: Eigen berekening op basis van steekproef AMF-leden.

\section{Bijlage II Onderzoek naar de mijnwormziekte}

Tussen 1905 en 1925 werden alle arbeidskrachten die zich voor ondergrondse arbeid bij een van de Nederlandse mijnen aanboden, onderzocht op de aanwezigheid van de mijnwormziekte (ankylostomiasis). De mijnworm is een parasiet die zich via de huid nestelde in de dunne darm en bloedarmoede, diarree of darmkrampen veroorzaakte. De worm gedijde prima in de vochtige en warme atmosfeer van het ondergrondse bedrijf. De mijnworminfectie was zeer besmettelijk en tot in de jaren twintig een veelvoorkomende beroepsziekte onder mijnwerkers. Bij KB van 24 augustus I925 (Staatsblad no. 362) werden de bepalingen uit het Mijnreglement I 906 betreffende het mijnwormonderzoek ingetrokken. ${ }^{15}$

De geaggregeerde resultaten van de keuringen werden elk jaar in het jaarverslag van de Hoofdingenieur der Mijnen gepubliceerd. Nauwgezet werd per mijnzetel vermeld hoeveel arbeidskrachten dat jaar waren onderzocht, of de nieuwkomers eerdere mijnervaring hadden - en zo ja, waar - of dat ze 'particulieren' waren, dat wil zeggen nog niet eerder in een mijn werkzaam waren geweest. De jaarlijkse overzichten zijn een waardevolle bron voor de herkomst en mobiliteit van de arbeidskrachten in de Nederlandse mijnen.

15 Jaarverslag van den Hoofd-Ingenieur der Mijnen over 1925, Io. 
Bijlage 12 De herkomst van nieuwe ondergronders in de Nederlandse steenkolenmijnen, 1905-1925

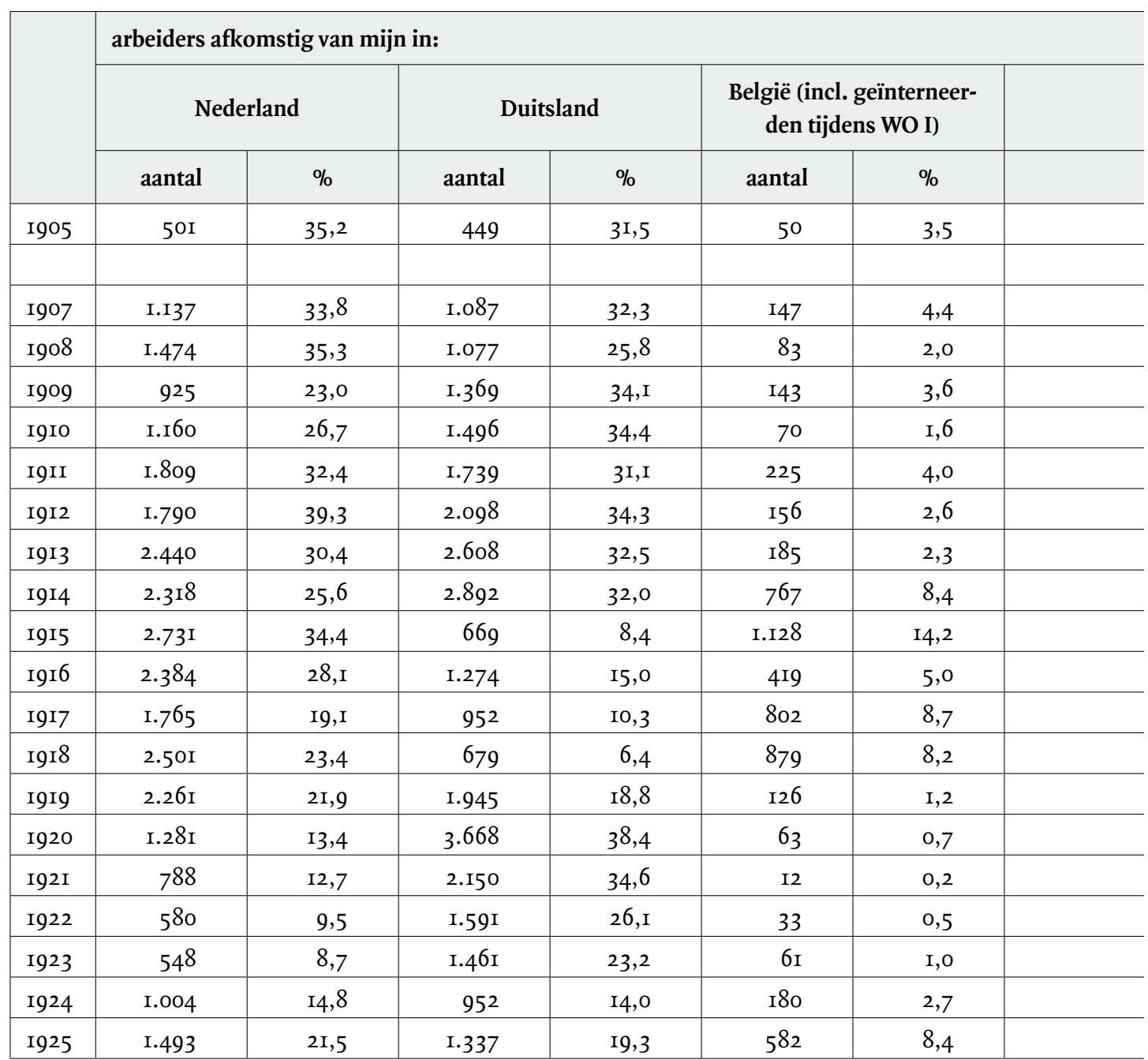

Bron: Onderzoek naar de mijnwormziekte, Jaarverslagen van de Hoofd-Ingenieur der Mijnen, I905-I925. 


\begin{tabular}{|c|c|c|c|c|c|c|}
\hline & \multicolumn{2}{|c|}{ overig buitenland } & \multicolumn{2}{|c|}{ totaal buitenland } & \multicolumn{2}{|c|}{ totaal mijnen } \\
\hline & aantal & $\%$ & aantal & $\%$ & aantal & $\%$ \\
\hline 1905 & 9 & o,6 & 508 & 35,7 & I.009 & 70,8 \\
\hline 1907 & 28 & 0,9 & I.262 & 37,5 & 2.399 & $7 \mathrm{I}, 2$ \\
\hline I908 & I6 & 0,4 & I.I76 & 28,2 & 2.650 & 63,5 \\
\hline 1909 & 25 & o,6 & I.537 & 38,2 & 2.462 & $6 \mathrm{I}, 3$ \\
\hline I9IO & 39 & 0,9 & I.605 & 36,9 & 2.765 & 63,5 \\
\hline I9II & 72 & $\mathrm{I}, 3$ & 2.036 & $3^{6,4}$ & 3.845 & 68,8 \\
\hline 1912 & 85 & $\mathrm{I}, 4$ & 2.339 & 38,3 & 4.129 & 67,6 \\
\hline I913 & I09 & $\mathrm{I}, 4$ & 2.902 & $3^{6,2}$ & $5 \cdot 34^{2}$ & 66,6 \\
\hline I9I4 & $\mathrm{I} 22$ & $\mathrm{I}, 4$ & $3.78 \mathrm{I}$ & $4 \mathrm{I}, 7$ & 6.099 & 67,5 \\
\hline I9I5 & II & $0, \mathrm{I}$ & I.808 & 22,8 & 4.539 & $57, \mathrm{I}$ \\
\hline I9I6 & 6 & $0, \mathrm{I}$ & I.699 & 20,1 & 4.083 & 48,2 \\
\hline 1917 & 6 & $\mathrm{O}, \mathrm{I}$ & I. 760 & I9,0 & 3.525 & 38,1 \\
\hline I9I8 & I & 0,0 & I. 559 & $\mathrm{I} 4,6$ & 4.060 & 38,0 \\
\hline I9I9 & 6 & $0, \mathrm{I}$ & 2.077 & $20, \mathrm{I}$ & 4.338 & 42,0 \\
\hline 1920 & 2 & 0,0 & 3.733 & $39, \mathrm{I}$ & 5.014 & 52,5 \\
\hline I92I & 8 & $0, \mathrm{I}$ & 2.170 & $35, \mathrm{I}$ & $2.95^{8}$ & 47,8 \\
\hline 1922 & 5 & $\mathrm{O}, \mathrm{I}$ & I.629 & 26,7 & 2.309 & $3^{6,3}$ \\
\hline 1923 & I6 & 0,3 & I. 538 & 24,4 & 2.086 & $33, I$ \\
\hline I924 & 22 & 0,3 & I.I54 & $\mathrm{I7}, \mathrm{O}$ & 2.158 & $3 \mathrm{I}, 7$ \\
\hline 1925 & 212 & $3, \mathrm{I}$ & $2.13 \mathrm{I}$ & 30,7 & 3.624 & 52,2 \\
\hline
\end{tabular}




\section{Bijlage 12 (Vervolg)}

\begin{tabular}{|c|c|c|c|c|c|c|c|}
\hline & \multicolumn{6}{|c|}{ arbeiders zonder mijnervaring, uit: } & \multirow{3}{*}{$\begin{array}{l}\text { totaal- } \\
\text { generaal }\end{array}$} \\
\hline & \multicolumn{2}{|c|}{ Nederland } & \multicolumn{2}{|c|}{ buitenland } & \multicolumn{2}{|c|}{ totaal } & \\
\hline & aantal & $\%$ & aantal & $\%$ & aantal & $\%$ & \\
\hline 1905 & 294 & 20,6 & 102 & 7,2 & 396 & 27,8 & $\mathrm{I} .425$ \\
\hline 1907 & 658 & 19,5 & $3 \mathrm{II}$ & 9,2 & 969 & 28,8 & $3 \cdot 368$ \\
\hline I908 & $\mathrm{I} .052$ & 25,2 & 472 & $\mathrm{II}, 3$ & $\mathrm{I} .524$ & 36,5 & 4.174 \\
\hline I909 & I.099 & 27,3 & 459 & $\mathrm{II}, 4$ & $\mathrm{I} .55^{8}$ & 38,8 & 4.020 \\
\hline I9IO & I.I44 & 26,3 & 444 & Io, 2 & I. 588 & $3^{6,5}$ & $4 \cdot 353$ \\
\hline I9II & I.299 & 23,2 & 445 & 8,0 & I.744 & $3 \mathrm{I}, 2$ & $5 \cdot 589$ \\
\hline I9I2 & I.454 & 23,8 & 528 & 8,6 & I. 982 & 32,4 & 6.III \\
\hline I9I3 & 2.017 & 25,2 & 667 & 8,3 & 2.684 & 33,4 & 8.026 \\
\hline I9I4 & 2.214 & 24,5 & 729 & $8, \mathrm{I}$ & 2.943 & 32,6 & 9.042 \\
\hline I9I5 & 2.716 & 34,2 & $69 \mathrm{I}$ & 8,7 & 3.407 & 42,9 & 7.946 \\
\hline I9I6 & 3.486 & $4 \mathrm{I}, 2$ & 901 & Iо, 6 & 4.387 & $5 \mathrm{I}, 8$ & 8.470 \\
\hline I9I7 & $5 \cdot 198$ & $5^{6,2}$ & 529 & 5,7 & $5 \cdot 722$ & 61,9 & 9.247 \\
\hline I9I8 & 6.143 & 57,6 & $47 \mathrm{I}$ & 4,4 & 6.614 & 62,0 & Iо. 674 \\
\hline I9I9 & $5 \cdot 4 \mathrm{I} 4$ & 52,4 & 579 & 5,6 & 5.998 & 50,0 & I0.33I \\
\hline 1920 & 3.740 & $39, \mathrm{I}$ & 805 & 8,4 & $4 \cdot 545$ & 47,6 & 9.559 \\
\hline I92I & $2.92 \mathrm{I}$ & 47,2 & 809 & 5,0 & 3.230 & 52,2 & 6.188 \\
\hline I922 & 3.299 & 54,2 & 584 & 9,6 & 3.883 & 63,7 & 6.092 \\
\hline I923 & 3.705 & 58,8 & 508 & $8, \mathrm{I}$ & 4.218 & 66,9 & 6.299 \\
\hline I924 & 4.294 & $63, \mathrm{I}$ & 350 & $5, \mathrm{I}$ & 4.644 & 68,3 & 6.802 \\
\hline I925 & 2.916 & 42,0 & 403 & 5,8 & 3.319 & 47,8 & 6.943 \\
\hline
\end{tabular}


Bijlage 13 De herkomst van nieuwe ondergronders bij

Staatsmijnen en de particuliere mijnen, 1905, 1913-1925

\begin{tabular}{|c|c|c|c|c|c|c|c|c|c|c|}
\hline \multicolumn{11}{|c|}{ Staatsmijnen } \\
\hline & \multicolumn{4}{|c|}{ mijnervaring } & \multicolumn{4}{|c|}{ onervaren } & \multirow{2}{*}{ 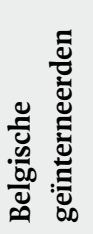 } & \multirow[b]{2}{*}{ totaal } \\
\hline & 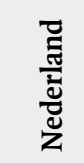 & $\%$ & 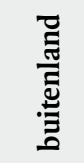 & $\%$ & 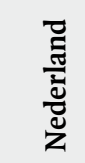 & $\%$ & 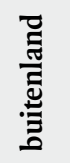 & $\%$ & & \\
\hline I905 & 39 & 78,0 & 8 & I6,o & 3 & 6,0 & - & 0,0 & & 50 \\
\hline I9I3 & 767 & 36,4 & 235 & $\mathrm{II}, 2$ & 963 & 45,7 & I4I & 6,7 & & 2.106 \\
\hline I9I4 & $97 \mathrm{I}$ & 32,3 & 736 & 24,5 & I.053 & 35,0 & 247 & 8,2 & & 3.007 \\
\hline I9I5 & 1.050 & 37,7 & 331 & II, 9 & I.I53 & $4 \mathrm{I}, 4$ & 252 & 9,0 & & 2.786 \\
\hline I9I6 & 920 & $25, \mathrm{I}$ & $5^{62}$ & 15,3 & $\mathrm{I} .788$ & 48,8 & 388 & Iо, 6 & 7 & $3.66_{5}$ \\
\hline I9I7 & 675 & $\mathrm{I} 4,5$ & 371 & 8,0 & 2.710 & $58, \mathrm{I}$ & 248 & 5,3 & 660 & 4.664 \\
\hline I9I8 & I.06o & $2 \mathrm{I}, 6$ & 183 & 3,7 & 2.980 & 60,7 & I5I & $3, \mathrm{I}$ & 532 & 4.906 \\
\hline I9I9 & $\mathrm{I} .282$ & 23,3 & 745 & 13,5 & 3.206 & 58,2 & 279 & $5, \mathrm{I}$ & & $5 \cdot 512$ \\
\hline 1920 & 667 & $\mathrm{I} 2,7$ & I. $98 \mathrm{I}$ & 37,7 & 2.294 & 43,6 & 407 & 7,7 & & 5.259 \\
\hline I92I & 470 & $\mathrm{I} 3,4$ & $87 I$ & 24,7 & 2.004 & 56,9 & $\mathrm{I} 75$ & 5,0 & & 3.520 \\
\hline I922 & I57 & 5,5 & 440 & 15,5 & I. 970 & 69,5 & 266 & 9,4 & & 2.833 \\
\hline I923 & 233 & 7,7 & 394 & 13,0 & 2.122 & 69,9 & 286 & 9,4 & & 3.035 \\
\hline I924 & 570 & I6,2 & 183 & 5,2 & 2.596 & 73,7 & 183 & 5,2 & & 3.522 \\
\hline I925 & 940 & $2 \mathrm{I}, \mathrm{I}$ & I. $3 \mathrm{I} 5$ & 29,5 & 2.013 & $45, \mathrm{I}$ & 192 & 4,3 & & 4.460 \\
\hline $\begin{array}{l}\text { gem } \\
\text { pj }\end{array}$ & & 24,9 & & I6,9 & & $5 \mathrm{I}, 3$ & & 6,9 & & \\
\hline
\end{tabular}


Bijlage 13 (Vervolg)

\begin{tabular}{|c|c|c|c|c|c|c|c|c|c|c|}
\hline \multicolumn{11}{|c|}{ particuliere mijnen } \\
\hline & \multicolumn{4}{|c|}{ mijnervaring } & \multicolumn{4}{|c|}{ onervaren } & \multirow{2}{*}{ 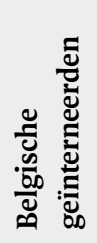 } & \multirow[b]{2}{*}{ totaal } \\
\hline & 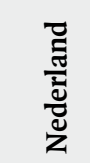 & $\%$ & 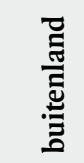 & $\%$ & 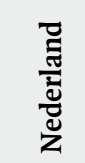 & $\%$ & 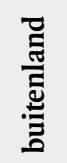 & $\%$ & & \\
\hline 1905 & 482 & $35, \mathrm{I}$ & 500 & $3^{6,4}$ & $29 \mathrm{I}$ & $2 \mathrm{I}, 2$ & 102 & 7,4 & & $\mathrm{I} .375$ \\
\hline 1913 & I.673 & 28,3 & 2.667 & $45, \mathrm{I}$ & I.054 & 17,8 & 526 & 8,9 & & 5.920 \\
\hline I9I4 & I. 347 & 22,3 & 3.045 & 50,5 & I.I6I & 19,2 & 482 & 8,0 & & 6.035 \\
\hline I9I5 & 2.310 & 44,8 & 848 & I6,4 & I. 563 & 30,3 & 439 & 8,5 & & 5.160 \\
\hline I9I6 & 2.464 & $5 \mathrm{I}, 3$ & 767 & I6,o & 698 & $\mathrm{I} 4,5$ & 513 & I0,7 & 363 & 4.805 \\
\hline I9I7 & I.090 & 23,8 & 630 & 13,7 & 2.483 & 54,2 & $28 \mathrm{I}$ & $6, \mathrm{I}$ & 99 & 4.583 \\
\hline I9I8 & I.44I & 25,0 & 530 & 9,2 & 3.163 & 54,8 & 320 & 5,5 & 314 & 5.768 \\
\hline I9I9 & 979 & 20,3 & I. 332 & 27,6 & 2.208 & 45,8 & 300 & 6,2 & & 4.819 \\
\hline 1920 & $6 \mathrm{I} 4$ & $\mathrm{I} 4,3$ & I. 842 & 42,8 & I. 446 & 33,6 & 398 & 9,3 & & $4 \cdot 300$ \\
\hline I92I & 318 & II, 9 & I.299 & 48,7 & 917 & 34,4 & I34 & 5,0 & & 2.668 \\
\hline I922 & 423 & 13,0 & I.I89 & $3^{6,5}$ & I. 329 & 40,8 & 318 & 9,8 & & 3.259 \\
\hline I923 & 315 & 9,7 & I.I44 & 35,0 & I. 583 & 48,5 & 222 & 6,8 & & 3.264 \\
\hline I924 & 434 & 13,3 & $97 \mathrm{I}$ & 29,7 & I.698 & $5 \mathrm{I}, 9$ & I67 & $5, \mathrm{I}$ & & 3.270 \\
\hline I925 & 553 & 22,3 & $8 \mathrm{I} 6$ & 32,9 & 903 & 36,4 & $2 \mathrm{II}$ & 8,5 & & 2.483 \\
\hline $\begin{array}{l}\text { gem } \\
\text { pj }\end{array}$ & & 24,0 & & $3 \mathrm{I}, 7$ & & 36,2 & & $8, \mathrm{I}$ & & \\
\hline
\end{tabular}

Bron: Onderzoek naar de mijnwormziekte. Jaarverslagen (Hoofd-) Ingenieur der Mijnen, 1905; Igo6-I925. 
Bijlage I4 Het aandeel per provincie in de Nederlandse bevolking en het aandeel per provincie in de inschrijvingen van nieuwe AMF-leden

\begin{tabular}{|c|c|c|c|c|c|c|c|c|c|c|}
\hline & \multicolumn{2}{|c|}{ I900-1965 } & \multicolumn{2}{|c|}{ vóór I-8-1919 } & \multicolumn{2}{|c|}{ 1919-1930 } & \multicolumn{2}{|c|}{ I93I-I944 } & \multicolumn{2}{|c|}{$1945-1965$} \\
\hline & 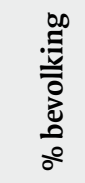 & $\sum_{0}^{\infty}$ & 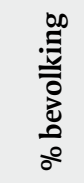 & $\begin{array}{l}\sum_{<}^{L} \\
0\end{array}$ & 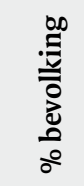 & $\sum_{0}^{\infty}$ & 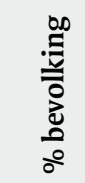 & $\begin{array}{l}\sum_{i}^{\infty} \\
0\end{array}$ & 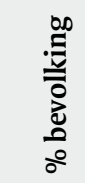 & $\sum_{\substack{0 \\
0}}^{\infty}$ \\
\hline Groningen & 4,6 & 0,9 & 5,5 & 0,7 & $5, \mathrm{I}$ & o,6 & 4,9 & 0,3 & 4,4 & $\mathrm{I}, 9$ \\
\hline Friesland & 4,8 & $2, \mathrm{I}$ & $6, \mathrm{I}$ & 3,7 & 5,3 & 4,0 & 5,0 & 0,0 & 4,4 & I,9 \\
\hline Drenthe & 2,8 & 2,5 & 3,0 & 3,0 & 2,9 & 6,3 & 2,9 & $\mathrm{I}, 4$ & 2,8 & $\mathrm{I}, 3$ \\
\hline Overijssel & 6,9 & $2, \mathrm{I}$ & 6,4 & 3,0 & 6,5 & 3,4 & 6,7 & $\mathrm{I}, 4$ & 6,9 & $\mathrm{I}, 3$ \\
\hline Gelderland & $\mathrm{II}, 3$ & $4, \mathrm{I}$ & Io,9 & 6,4 & Iо, 6 & 8,6 & 10,8 & 0,5 & $\mathrm{II}, 3$ & 3,5 \\
\hline Utrecht & 5,7 & 0,9 & 4,9 & $\mathrm{I}, \mathrm{O}$ & 5,0 & $\mathrm{I}, \mathrm{I}$ & 5,4 & 0,5 & 5,9 & 0,9 \\
\hline $\begin{array}{l}\text { Noord- } \\
\text { Holland }\end{array}$ & 18,0 & 2,9 & 18,9 & 2,7 & I8,9 & 3,4 & I8,6 & $\mathrm{I}, 6$ & 17,9 & $4, \mathrm{I}$ \\
\hline $\begin{array}{l}\text { Zuid- } \\
\text { Holland }\end{array}$ & 23,0 & 3,2 & 23,5 & 2,0 & 24,5 & 2,9 & 23,9 & 2,5 & 23,2 & 5,4 \\
\hline Zeeland & 2,9 & 0,3 & 3,9 & $\mathrm{I}, \mathrm{O}$ & 3,4 & 0,0 & 2,8 & 0,0 & 2,4 & 0,3 \\
\hline $\begin{array}{l}\text { Noord- } \\
\text { Brabant }\end{array}$ & $\mathrm{I} 2,7$ & $7, \mathrm{I}$ & Io, 7 & 5,7 & $\mathrm{II}, \mathrm{O}$ & Io, 3 & $\mathrm{II}, 9$ & 6,3 & $\mathrm{I} 3, \mathrm{I}$ & 7,6 \\
\hline Limburg & 7,2 & 74,0 & $6, \mathrm{I}$ & 70,8 & 6,8 & 59,4 & $7, \mathrm{I}$ & 85,5 & 7,6 & $7 \mathrm{I}, 8$ \\
\hline Nederland & 100,0 & 100,0 & 100,0 & 100,0 & 100,0 & 100,0 & 100,0 & 100,0 & 100,0 & I00,0 \\
\hline
\end{tabular}

Bron: Eigen berekening op basis van steekproef AMF-leden; Centraal Bureau voor de Statistiek, Statistiek van den loop der bevolking van Nederland over het jaar [1899, 1919, 1931]; Centraal Bureau voor de Statistiek, Gegevens per gemeente betreffende de loop der bevolking in het jaar [1944 en 1965]. 
Bijlage 15 Buitenlandse nationaliteiten in de Nederlandse steenkolenmijnen

(totale arbeidersbestand), 1905-1973

\begin{tabular}{|c|c|c|c|c|c|c|c|c|}
\hline & Duitsers & Polen & $\begin{array}{l}\text { Joego- } \\
\text { slaven }\end{array}$ & $\begin{array}{c}\text { Oosten- } \\
\text { rijkers }\end{array}$ & Belgen & Tsjechen & Italianen & Hongaren \\
\hline 1905 & 378 & & & 9 & 39 & & I & \\
\hline I906 & $4 \mathrm{I} 6$ & & & - & 52 & & - & \\
\hline I907 & 770 & & & 57 & 83 & & . & \\
\hline I908 & 814 & & & II7 & 130 & & - & \\
\hline I9O9 & I.072 & & & I79 & I37 & & - & \\
\hline I9Io & $\mathrm{I} .286$ & & & 236 & II5 & & - & \\
\hline I9II & I. 397 & & & 244 & 200 & & - & \\
\hline I9I2 & I.53I & & & 298 & $\mathrm{I} 72$ & & - & \\
\hline I9I3 & เ. 876 & & & 435 & 210 & & - & \\
\hline I9I4 & I.098 & & & I99 & 660 & & . & \\
\hline I9I5 & 873 & & & I43 & I. 529 & & - & \\
\hline I9I6 & $\mathrm{I} .226$ & & & 332 & I. 648 & & - & \\
\hline I9I7 & $\mathrm{I} .533$ & & & 304 & 2.107 & & $\bullet$ & \\
\hline I9I8 & I. 670 & & & 306 & 903 & & $\bullet$ & \\
\hline I9I9 & 2.626 & 105 & 4 & 344 & 532 & - & 39 & II \\
\hline I920 & 5.144 & I47 & 5 & $4 \mathrm{I} 4$ & $47 \mathrm{I}$ & 2 & $4 \mathrm{I}$ & 2 \\
\hline I92I & 4.937 & I53 & $\mathrm{I} 2$ & 426 & 402 & IO & 43 & IO \\
\hline I922 & 5.247 & I64 & IO & 392 & 375 & 32 & 59 & I8 \\
\hline I923 & $5 \cdot 342$ & I35 & I8 & 375 & $35^{I}$ & 35 & 74 & 22 \\
\hline I924 & $4.4 \mathrm{I} 9$ & 132 & 32 & $3^{66}$ & 368 & 40 & 83 & $2 \mathrm{I}$ \\
\hline I925 & 4.808 & 301 & 78 & $42 \mathrm{I}$ & 425 & I67 & I40 & 36 \\
\hline I926 & $5 \cdot 504$ & 555 & 290 & 497 & 552 & I46 & I68 & 105 \\
\hline I927 & 5.846 & 957 & 508 & 482 & 676 & 229 & 210 & III \\
\hline I928 & 5.823 & I.OI7 & 735 & 510 & 601 & 240 & 207 & IIO \\
\hline I929 & 7.189 & I. $30 \mathrm{I}$ & I.I84 & 688 & 505 & 292 & 227 & I87 \\
\hline I930 & $7 \cdot 563$ & I. 257 & I.I55 & 688 & 467 & 266 & $2 \mathrm{I} 6$ & 204 \\
\hline I93I & $7 \cdot 359$ & I.I97 & I.087 & 632 & $4 \mathrm{I} 5$ & 246 & 259 & I94 \\
\hline I932 & $6.03 \mathrm{I}$ & I.0I8 & 770 & 504 & 373 & 213 & 216 & I53 \\
\hline I933 & 4.867 & 796 & 533 & 388 & 285 & I65 & I80 & I $2 \mathrm{I}$ \\
\hline I934 & $3 \cdot 39 \mathrm{I}$ & 690 & 4IO & 285 & 294 & I57 & I5I & 88 \\
\hline I935 & 2.534 & $58 \mathrm{I}$ & 349 & 228 & 288 & $\mathrm{I} 22$ & 136 & $8 \mathrm{I}$ \\
\hline 1936 & $2.09 \mathrm{I}$ & 478 & 301 & I84 & 289 & IOg & II5 & 72 \\
\hline
\end{tabular}




\begin{tabular}{|c|c|c|c|c|c|c|c|}
\hline & Russen & $\begin{array}{l}\text { Span- } \\
\text { jaarden }\end{array}$ & Grieken & $\begin{array}{l}\text { Marok- } \\
\text { kanen }\end{array}$ & $\begin{array}{l}\text { Overigel } \\
\text { statelozen }\end{array}$ & $\begin{array}{l}\text { totaal } \\
\text { buiten- } \\
\text { landers }\end{array}$ & $\begin{array}{l}\text { percentage van } \\
\text { totale bezetting }\end{array}$ \\
\hline 1905 & • & • & • & - & 2 & 429 & I7 \\
\hline 1906 & - & - & - & - & 25 & 493 & I6 \\
\hline 1907 & . & • & • & • & I2 & 922 & 20 \\
\hline 1908 & - & - & - & - & $\mathrm{I} 3$ & I.074 & 20 \\
\hline 1909 & $\cdot$ & - & • & • & 20 & I. 408 & 22 \\
\hline I9I0 & - & - & - & • & 27 & I. 664 & 23 \\
\hline IgII & • & • & • & • & 38 & I. 879 & 24 \\
\hline I9I2 & $\cdot$ & - & - & - & 35 & 2.036 & 22 \\
\hline 1913 & • & • & • & • & 46 & 2.567 & 24 \\
\hline I9I4 & • & • & • & • & 40 & I.997 & I9 \\
\hline 1915 & • & • & • & • & 53 & 2.598 & 22 \\
\hline I9I6 & $\cdot$ & • & - & • & II5 & $3 \cdot 32 \mathrm{I}$ & 23 \\
\hline I9I7 & • & - & • & • & 234 & 4.178 & 24 \\
\hline 1918 & • & - & - & • & 317 & $3 \cdot 196$ & I6 \\
\hline I919 & 56 & I & - & - & 48 & $3.76_{5}$ & I6 \\
\hline 1920 & 43 & I & • & • & 55 & 6.324 & 23 \\
\hline I92I & 28 & - & $\cdot$ & • & 27 & 6.050 & 23 \\
\hline 1922 & 33 & • & • & • & 76 & 6.406 & 23 \\
\hline 1923 & 29 & - & - & • & 66 & 6.447 & 22 \\
\hline 1924 & 25 & - & - & - & 73 & $5 \cdot 559$ & I8 \\
\hline 1925 & 29 & • & - & - & 90 & 6.495 & $2 \mathrm{I}$ \\
\hline 1926 & 27 & • & - & • & 100 & 7.944 & 24 \\
\hline I927 & 29 & • & - & • & 103 & $9.15 \mathrm{I}$ & 26 \\
\hline 1928 & 25 & 2 & $\cdot$ & • & 98 & $9 \cdot 366$ & 27 \\
\hline 1929 & 32 & • & • & • & 100 & 11.705 & $3 I$ \\
\hline 1930 & 23 & - & • & • & 130 & II.969 & 32 \\
\hline I93I & $2 \mathrm{I}$ & • & - & • & I23 & II. 863 & $3 \mathrm{I}$ \\
\hline 1932 & I6 & • & • & • & $\mathrm{II}_{3}$ & 9.708 & 28 \\
\hline 1933 & I8 & • & • & • & 105 & 7.743 & 24 \\
\hline I934 & 8 & • & • & - & 227 & 5.693 & I9 \\
\hline 1935 & 8 & - & - & • & 237 & 4.564 & I6 \\
\hline 1936 & 7 & • & • & • & $34 \mathrm{I}$ & 3.987 & I4 \\
\hline
\end{tabular}




\begin{tabular}{|c|c|c|c|c|c|c|c|c|}
\hline & Duitsers & Polen & $\begin{array}{l}\text { Joego- } \\
\text { slaven }\end{array}$ & $\begin{array}{l}\text { Oosten- } \\
\text { rijkers }\end{array}$ & Belgen & Tsjechen & Italianen & Hongaren \\
\hline I937 & 2.153 & 484 & 304 & I8I & 300 & $\mathrm{I} 27$ & II9 & 78 \\
\hline 1938 & I. 834 & 457 & 290 & 135 & 290 & $\mathrm{I} 26$ & $\mathrm{I} 20$ & 74 \\
\hline 1939 & I. 770 & 432 & 284 & & 267 & 105 & $\mathrm{II} 3$ & 65 \\
\hline I940 & I. 715 & 407 & 283 & & $29 \mathrm{I}$ & 99 & II9 & 60 \\
\hline I94I & I. 700 & 468 & 299 & & 350 & 102 & II4 & 54 \\
\hline I942 & I. 698 & 496 & 300 & & 370 & 97 & $\mathrm{II}_{3}$ & 46 \\
\hline I943 & I.706 & 490 & 286 & & 368 & 92 & I06 & 36 \\
\hline I944 & 4 & 426 & $2 \mathrm{I} 4$ & & 345 & 65 & 86 & 29 \\
\hline I945 & 8 & 394 & 183 & 4 & $3 \mathrm{I} 3$ & 56 & 73 & 25 \\
\hline I946 & 357 & 407 & I98 & I5 & 337 & 47 & 86 & 25 \\
\hline I947 & 384 & I.6I2 & I8o & I8 & $33 \mathrm{I}$ & 47 & 89 & 39 \\
\hline I948 & 480 & I. 512 & I88 & 27 & 350 & I 37 & 92 & 40 \\
\hline I949 & 900 & I.269 & $2 \mathrm{I} 4$ & 35 & 388 & $8 \mathrm{I}$ & 522 & 37 \\
\hline 1950 & I.008 & I.I8I & 216 & $3 \mathrm{I}$ & 380 & 69 & 303 & 35 \\
\hline I95I & I.020 & I.023 & 218 & 33 & $36 \mathrm{I}$ & 63 & I68 & $3 \mathrm{I}$ \\
\hline 1952 & I.042 & 967 & 202 & 35 & 382 & $5 \mathrm{I}$ & 138 & $3 \mathrm{I}$ \\
\hline I953 & 946 & 954 & I8I & 35 & 368 & 60 & I3I & 30 \\
\hline I954 & 984 & 909 & I7I & 35 & 356 & 55 & II9 & 26 \\
\hline I955 & 922 & 839 & I59 & 230 & $43^{6}$ & 52 & $2 I I$ & 22 \\
\hline I956 & 996 & 772 & I4I & 256 & 605 & 48 & 886 & 312 \\
\hline I957 & 938 & 694 & I 26 & 293 & 798 & 42 & I.966 & 237 \\
\hline 1958 & 871 & 666 & II9 & 192 & 800 & 36 & I.269 & I75 \\
\hline I959 & 804 & 614 & 108 & I4I & 721 & $3^{8}$ & 467 & 125 \\
\hline I96o & 738 & 577 & 92 & 109 & 696 & 29 & 510 & 102 \\
\hline I96I & 665 & 528 & 75 & 9I & $7 \mathrm{II}$ & 27 & $5^{12}$ & 70 \\
\hline I962 & 588 & 447 & 257 & 282 & 710 & 26 & 692 & 84 \\
\hline I963 & 548 & 423 & 504 & 72 & 673 & 25 & $58 \mathrm{I}$ & 67 \\
\hline I964 & 547 & 407 & 550 & 73 & 625 & 22 & 535 & 76 \\
\hline I965 & 510 & 372 & 692 & 67 & 602 & $2 \mathrm{I}$ & 490 & 69 \\
\hline I966 & 455 & 303 & 547 & 55 & 56I & 20 & 394 & 50 \\
\hline I967 & $4 \mathrm{OI}$ & 256 & 293 & 50 & 483 & I6 & 329 & $4 \mathrm{I}$ \\
\hline I968 & 320 & 216 & 230 & 43 & $43^{6}$ & 13 & 268 & 30 \\
\hline I969 & 265 & I69 & 178 & 35 & 378 & 9 & 243 & I6 \\
\hline I970 & 207 & 150 & 133 & 23 & 327 & 9 & 205 & 9 \\
\hline
\end{tabular}




\begin{tabular}{|c|c|c|c|c|c|c|c|}
\hline & Russen & $\begin{array}{l}\text { Span- } \\
\text { jaarden }\end{array}$ & Grieken & $\begin{array}{l}\text { Marok- } \\
\text { kanen }\end{array}$ & $\begin{array}{c}\text { Overigel } \\
\text { statelozen }\end{array}$ & $\begin{array}{l}\text { totaal } \\
\text { buiten- } \\
\text { landers }\end{array}$ & $\begin{array}{l}\text { percentage van } \\
\text { totale bezetting }\end{array}$ \\
\hline I937 & 6 & • & • & • & $4 \mathrm{I} 7$ & 4.I69 & I3 \\
\hline 1938 & 6 & • & $\cdot$ & • & 434 & 3.766 & $\mathrm{I} 2$ \\
\hline 1939 & 6 & $\cdot$ & • & - & 434 & 3.476 & IO \\
\hline 1940 & 7 & - & • & - & 462 & 3.443 & 9 \\
\hline I94I & 5 & $\cdot$ & $\cdot$ & $\cdot$ & 500 & $3 \cdot 59 \mathrm{I}$ & 9 \\
\hline 1942 & 5 & $\cdot$ & • & • & 520 & 3.645 & 9 \\
\hline I943 & 4 & - & - & - & 499 & 3.587 & 8 \\
\hline I944 & 4 & $\cdot$ & $\cdot$ & $\cdot$ & 426 & I.599 & 4 \\
\hline I945 & 6 & $\cdot$ & $\cdot$ & • & 385 & I. 447 & 4 \\
\hline I946 & 6 & • & • & • & 479 & I.957 & 5 \\
\hline I947 & 37 & $\cdot$ & $\cdot$ & $\cdot$ & 596 & 3.333 & 9 \\
\hline I948 & $\mathrm{I} 2$ & $\cdot$ & • & • & 916 & 3.754 & 9 \\
\hline I949 & I4 & $\cdot$ & $\cdot$ & $\cdot$ & I.059 & 4.519 & I0 \\
\hline 1950 & 9 & • & • & • & I.053 & 4.285 & IO \\
\hline I95I & 8 & $\cdot$ & • & • & I.045 & 3.970 & 8 \\
\hline 1952 & 7 & $\cdot$ & $\cdot$ & $\cdot$ & I.033 & 3.888 & 8 \\
\hline I953 & 7 & • & • & • & I.008 & 3.680 & 7 \\
\hline 1954 & 6 & $\cdot$ & • & • & 949 & 3.610 & 7 \\
\hline 1955 & 6 & $\cdot$ & • & • & 904 & $3.78 \mathrm{I}$ & 7 \\
\hline 1956 & 6 & • & • & • & 833 & 4.855 & 9 \\
\hline I957 & 4 & . & . & . & 785 & 5.883 & II \\
\hline 1958 & 4 & $\cdot$ & • & • & 736 & 4.868 & 9 \\
\hline I959 & 5 & • & • & • & 708 & $3.73 \mathrm{I}$ & 7 \\
\hline 196o & 5 & $\cdot$ & $\cdot$ & $\cdot$ & 655 & 3.513 & 7 \\
\hline I96I & $\cdot$ & $\cdot$ & • & • & 660 & 3.339 & 7 \\
\hline I962 & $\cdot$ & 474 & $\cdot$ & $\cdot$ & 744 & 4.104 & 8 \\
\hline 1963 & • & 469 & • & • & I.I33 & 4.495 & 9 \\
\hline 1964 & • & $55 \mathrm{I}$ & 172 & I. 358 & 738 & 5.654 & $\mathrm{I} 2$ \\
\hline 1965 & • & 532 & 146 & I.607 & 710 & 5.818 & I3 \\
\hline I966 & • & 344 & 88 & I.425 & 654 & 4.896 & $\mathrm{I} 2$ \\
\hline 1967 & • & 176 & 59 & 933 & 545 & 3.582 & II \\
\hline I968 & • & I34 & 50 & 764 & 443 & 2.947 & II \\
\hline I969 & • & II 2 & 35 & 736 & 363 & 2.539 & II \\
\hline I970 & • & 105 & 29 & I. 275 & 304 & 2.776 & I4 \\
\hline
\end{tabular}




\begin{tabular}{|l|r|r|r|r|r|r|r|r|r}
\hline & Duitsers & Polen & $\begin{array}{c}\text { Joego- } \\
\text { slaven }\end{array}$ & $\begin{array}{c}\text { Oosten- } \\
\text { rijkers }\end{array}$ & Belgen & Tsjechen & Italianen & Hongaren & \\
\hline I97I & I67 & I27 & I07 & 20 & 30 I & 7 & I67 & 7 & \\
\hline I972 & I50 & III & 78 & I6 & 275 & 2 I & I28 & 5 & \\
\hline I973 & I26 & 66 & 67 & I0 & 253 & 4 & 76 & 4 & \\
\hline
\end{tabular}

Bron: Jaarverslagen van de (Hoofd-) Ingenieur/Inspecteur-Generaal der Mijnen [1905-1973].

Bijlage I6 Buitenlandse nationaliteiten in het arbeidersbestand ondergronds van de Nederlandse steenkolenmijnen, 1913-1973

\begin{tabular}{|c|c|c|c|c|c|c|c|c|}
\hline & Duitsers & Polen & $\begin{array}{l}\text { Joego- } \\
\text { slaven }\end{array}$ & $\begin{array}{c}\text { Oosten- } \\
\text { rijkers }\end{array}$ & Belgen & Tsjechen & Italianen & Hongaren \\
\hline I9I3 & I. 579 & & & 4I9 & I90 & & - & \\
\hline I9I4 & 860 & & & I89 & 593 & & • & \\
\hline I9I5 & • & & & - & $\bullet$ & & $\cdot$ & \\
\hline I9I6 & - & & & • & - & & - & \\
\hline I9I7 & $\cdot$ & & & $\cdot$ & - & & $\bullet$ & \\
\hline I9I8 & - & & & - & - & & - & \\
\hline I9I9 & 2.209 & 98 & 4 & 319 & 4I9 & • & 38 & II \\
\hline I920 & $4 \cdot 346$ & 138 & 5 & 383 & 355 & 2 & 37 & 2 \\
\hline I92I & 4.176 & 146 & $\mathrm{I} 2$ & 392 & 299 & 9 & 40 & 9 \\
\hline I922 & 4.503 & I58 & 9 & 360 & 280 & 30 & 58 & I5 \\
\hline I923 & 4.670 & $\mathrm{I} 23$ & I8 & $35^{8}$ & 258 & 34 & 69 & I9 \\
\hline I924 & 3.795 & $\mathrm{I} 23$ & $3 I$ & 344 & 273 & 39 & 78 & I9 \\
\hline I925 & 4.154 & 289 & 76 & 396 & 325 & I62 & I34 & 32 \\
\hline I926 & 4.855 & 547 & 289 & 467 & 454 & I43 & $\mathrm{I} 62$ & IOO \\
\hline I927 & $5 \cdot 154$ & 935 & 504 & 455 & 567 & 225 & 203 & I06 \\
\hline I928 & 5.072 & 990 & 725 & 479 & 493 & 237 & 204 & 105 \\
\hline I929 & 6.253 & I. 258 & I. 146 & 649 & 393 & 282 & 222 & I79 \\
\hline I930 & 6.548 & $\mathrm{I} .2 \mathrm{I} 2$ & I.I 25 & 656 & 364 & 254 & 209 & I96 \\
\hline I93I & 6.394 & I.I53 & I.055 & 601 & 329 & 228 & 253 & I86 \\
\hline I932 & 5.229 & $98 \mathrm{I}$ & 745 & 477 & 288 & 203 & 209 & 146 \\
\hline I933 & 4.154 & 764 & $5 \mathrm{I} 4$ & 370 & 207 & I6I & $\mathrm{I} 73$ & IIO \\
\hline I934 & 2.850 & $66 \mathrm{I}$ & 400 & 257 & 209 & I53 & 146 & 76 \\
\hline I935 & 2.123 & 553 & 339 & 206 & 209 & II 4 & I29 & 69 \\
\hline I936 & I. 750 & 466 & 292 & I64 & $2 \mathrm{I} 3$ & 105 & II 2 & 66 \\
\hline
\end{tabular}




\begin{tabular}{|l|c|c|c|c|c|c|c|}
\hline & Russen & $\begin{array}{c}\text { Span- } \\
\text { jaarden }\end{array}$ & Grieken & $\begin{array}{c}\text { Marok- } \\
\text { kanen }\end{array}$ & $\begin{array}{c}\text { Overigel } \\
\text { statelozen }\end{array}$ & $\begin{array}{c}\text { totaal } \\
\text { buiten- } \\
\text { landers }\end{array}$ & $\begin{array}{c}\text { percentage van } \\
\text { totale bezetting }\end{array}$ \\
\hline I97I & $\cdot$ & 83 & 23 & I.I95 & 260 & 2.464 & I5 \\
\hline I972 & $\cdot$ & 64 & $2 \mathrm{I}$ & 885 & $22 \mathrm{I}$ & $\mathrm{I} .975$ & $\mathrm{I} 3$ \\
\hline $\mathrm{I} 973$ & $\cdot$ & 44 & 20 & 486 & I5I & I.307 & II \\
\hline
\end{tabular}

\begin{tabular}{|c|c|c|c|c|c|c|c|}
\hline & Russen & $\begin{array}{c}\text { Span- } \\
\text { jaarden }\end{array}$ & Grieken & $\begin{array}{l}\text { Marok- } \\
\text { kanen }\end{array}$ & $\begin{array}{l}\text { Overigel } \\
\text { statelozen }\end{array}$ & $\begin{array}{l}\text { totaal } \\
\text { buiten- } \\
\text { landers }\end{array}$ & $\begin{array}{l}\text { percentage van } \\
\text { totale bezetting }\end{array}$ \\
\hline I9I3 & • & • & . & • & $4 \mathrm{I}$ & 2.229 & 28 \\
\hline I9I4 & . & . & . & . & 36 & I. 678 & 22 \\
\hline 1915 & • & • & - & • & • & • & • \\
\hline I9I6 & • & • & . & • & . & . & • \\
\hline 1917 & $\cdot$ & . & $\cdot$ & $\cdot$ & $\cdot$ & . & . \\
\hline I9I8 & . & . & . & • & . & . & . \\
\hline I9I9 & 54 & I & • & • & $4 \mathrm{I}$ & 3.193 & 20 \\
\hline 1920 & 38 & I & . & . & 43 & 5.349 & 28 \\
\hline I92I & 25 & • & • & • & I8 & $5 \cdot 126$ & 27 \\
\hline 1922 & 32 & • & • & • & 58 & 5.503 & 28 \\
\hline 1923 & 28 & . & . & • & 52 & 5.629 & 26 \\
\hline 1924 & 24 & • & . & • & $6 \mathrm{I}$ & 4.787 & 22 \\
\hline 1925 & 28 & • & • & • & $7 \mathrm{I}$ & 5.667 & 25 \\
\hline 1926 & 25 & • & . & . & 83 & 7.125 & 29 \\
\hline 1927 & 27 & • & - & • & 86 & 8.262 & 33 \\
\hline 1928 & 24 & 2 & . & • & 72 & 8.401 & 34 \\
\hline 1929 & 29 & - & - & • & 79 & I0.490 & 39 \\
\hline 1930 & $2 \mathrm{I}$ & • & • & • & IOI & 10.686 & 40 \\
\hline I93I & $2 \mathrm{I}$ & $\cdot$ & • & $\cdot$ & 93 & I0.528 & 39 \\
\hline 1932 & I6 & • & • & • & 89 & 8.584 & 35 \\
\hline 1933 & I8 & . & . & . & $8 \mathrm{I}$ & 6.738 & 30 \\
\hline I934 & 8 & $\cdot$ & • & • & I89 & $4.94 \mathrm{I}$ & 25 \\
\hline 1935 & 8 & • & • & • & I9I & $3.94 \mathrm{I}$ & $2 \mathrm{I}$ \\
\hline 1936 & 7 & . & . & . & $28 \mathrm{I}$ & 3.456 & I8 \\
\hline
\end{tabular}




\begin{tabular}{|c|c|c|c|c|c|c|c|c|}
\hline & Duitsers & Polen & $\begin{array}{l}\text { Joego- } \\
\text { slaven }\end{array}$ & $\begin{array}{l}\text { Oosten- } \\
\text { rijkers }\end{array}$ & Belgen & Tsjechen & Italianen & Hongaren \\
\hline I937 & I. 803 & 467 & 293 & 165 & 224 & II8 & II 2 & 69 \\
\hline 1938 & I. 515 & 437 & 276 & $\mathrm{I} 24$ & 216 & II5 & II4 & 66 \\
\hline I939 & I. 473 & $4 \mathrm{I} 3$ & 273 & & I98 & 95 & 108 & 59 \\
\hline I940 & I. 434 & 390 & 274 & & $2 \mathrm{I} 6$ & 94 & II 3 & 58 \\
\hline I94I & $\mathrm{I} .4 \mathrm{I} 7$ & 429 & 275 & & 266 & 94 & 107 & 49 \\
\hline I942 & I. 403 & 447 & 277 & & 280 & 93 & Io6 & 44 \\
\hline I943 & $\mathrm{I} .43 \mathrm{I}$ & 449 & 263 & & 279 & 85 & IOI & 34 \\
\hline I944 & 2 & $38 \mathrm{I}$ & I93 & & 254 & 57 & $8 \mathrm{I}$ & 27 \\
\hline I945 & 3 & 357 & I66 & 4 & 218 & 48 & 65 & 22 \\
\hline I946 & 336 & 357 & I68 & $\mathrm{I} 4$ & 220 & 42 & 77 & 23 \\
\hline I947 & 349 & $\mathrm{I} .55 \mathrm{I}$ & I49 & I6 & 208 & 38 & 79 & 34 \\
\hline I948 & 396 & I.434 & 146 & 23 & 213 & $\mathrm{I} 28$ & $8 \mathrm{I}$ & 34 \\
\hline I949 & 720 & I.I57 & I55 & 27 & 218 & 66 & 501 & $3 \mathrm{I}$ \\
\hline 1950 & 783 & I.072 & I5I & 24 & 215 & 54 & $28 \mathrm{I}$ & 28 \\
\hline I95I & $75 \mathrm{I}$ & 913 & I53 & 25 & 202 & 46 & I50 & 27 \\
\hline 1952 & 760 & 852 & I44 & 30 & 203 & 34 & II5 & 25 \\
\hline I953 & 672 & 828 & I24 & $3 \mathrm{I}$ & I99 & 34 & 103 & 26 \\
\hline I954 & 725 & 793 & II7 & 32 & I75 & 33 & 93 & 22 \\
\hline I955 & 644 & 732 & I08 & 227 & I66 & 33 & I35 & I8 \\
\hline I956 & 6ro & 678 & 97 & 250 & I57 & 34 & $86 \mathrm{I}$ & 280 \\
\hline I957 & 555 & 609 & 89 & 288 & $\mathrm{I} 42$ & 32 & I. 938 & 218 \\
\hline 1958 & 530 & 585 & 85 & I86 & I4I & 25 & I. 245 & I53 \\
\hline I959 & 489 & 542 & 75 & 136 & I29 & 26 & 433 & III \\
\hline I96o & 449 & 504 & 65 & I02 & II 8 & 23 & $45^{6}$ & 90 \\
\hline I96I & $4 \mathrm{I} 2$ & $45^{8}$ & 52 & 86 & II4 & 22 & 446 & 59 \\
\hline 1962 & $3^{6 I}$ & 383 & 217 & 79 & 99 & 20 & 594 & 6I \\
\hline 1963 & 329 & 363 & 444 & 68 & 93 & 20 & 462 & 48 \\
\hline I964 & 324 & 348 & 486 & 68 & 89 & 18 & 417 & 54 \\
\hline I965 & 294 & 320 & 633 & 62 & 83 & I6 & 371 & 50 \\
\hline I966 & $25 \mathrm{I}$ & 258 & 493 & $5 \mathrm{I}$ & 64 & I6 & $29 \mathrm{I}$ & 33 \\
\hline I967 & 220 & 217 & 260 & 46 & 46 & I3 & 238 & 25 \\
\hline 1968 & 173 & 184 & 202 & 39 & 39 & I6 & 194 & 17 \\
\hline I969 & 130 & I35 & I57 & 32 & 28 & 6 & 170 & 9 \\
\hline I970 & 88 & II5 & II7 & I9 & $\mathrm{I} 5$ & 5 & 137 & 2 \\
\hline I97I & 64 & 94 & 96 & I6 & 9 & 4 & 107 & 2 \\
\hline
\end{tabular}




\begin{tabular}{|c|c|c|c|c|c|c|c|}
\hline & Russen & $\begin{array}{l}\text { Span- } \\
\text { jaarden }\end{array}$ & Grieken & $\begin{array}{l}\text { Marok- } \\
\text { kanen }\end{array}$ & $\begin{array}{c}\text { Overigel } \\
\text { statelozen }\end{array}$ & $\begin{array}{l}\text { totaal } \\
\text { buiten- } \\
\text { landers }\end{array}$ & $\begin{array}{l}\text { percentage van } \\
\text { totale bezetting }\end{array}$ \\
\hline I937 & 6 & • & • & • & 339 & $3 \cdot 596$ & I7 \\
\hline 1938 & 6 & • & - & - & 353 & 3.222 & I6 \\
\hline I939 & 6 & • & • & • & 354 & 2.979 & I4 \\
\hline I940 & 7 & • & • & • & 382 & 2.968 & $\mathrm{I} 2$ \\
\hline I94I & 5 & • & • & - & 403 & 3.045 & $\mathrm{I} 2$ \\
\hline 1942 & 5 & • & • & • & 425 & 3.080 & II \\
\hline I943 & 4 & - & - & • & 410 & 3.056 & II \\
\hline I944 & 3 & • & • & • & 344 & I. 342 & 6 \\
\hline I945 & 5 & • & - & • & 313 & $\mathrm{I} .20 \mathrm{I}$ & 6 \\
\hline I946 & 5 & • & • & • & 392 & I.634 & 8 \\
\hline I947 & $3^{6}$ & • & - & - & 482 & 2.942 & I3 \\
\hline I948 & Io & • & • & • & 794 & 3.259 & I3 \\
\hline I949 & I3 & $\cdot$ & • & • & 913 & 3.801 & I5 \\
\hline 1950 & 8 & • & • & • & 888 & $3 \cdot 504$ & I3 \\
\hline I95I & 7 & • & • & • & 895 & 3.169 & II \\
\hline 1952 & 5 & • & • & • & 888 & 3.056 & IO \\
\hline I953 & 5 & • & • & • & 838 & 2.867 & 9 \\
\hline $\mathrm{I} 954$ & 4 & $\cdot$ & - & - & 795 & 2.789 & 9 \\
\hline 1955 & 4 & $\cdot$ & • & • & 742 & 2.859 & 9 \\
\hline 1956 & 4 & • & • & • & 679 & 3.650 & $\mathrm{I} 2$ \\
\hline I957 & 2 & • & • & • & 6ra & 4.492 & I4 \\
\hline 1958 & 2 & • & • & • & 682 & 3.534 & II \\
\hline I959 & 2 & • & • & • & 557 & 2.500 & 8 \\
\hline I96o & 2 & • & • & • & 510 & 2.319 & 8 \\
\hline I96I & • & • & - & • & 485 & 2.134 & 8 \\
\hline 1962 & • & 436 & • & • & 528 & 2.778 & IO \\
\hline 1963 & • & 375 & • & • & 762 & 2.964 & II \\
\hline I964 & • & 359 & 4 & I. 244 & 485 & 3.896 & I5 \\
\hline 1965 & • & 286 & • & I. 368 & 445 & 3.928 & I6 \\
\hline I966 & • & I92 & I & I. 207 & 405 & 3.262 & I6 \\
\hline 1967 & • & 103 & • & 803 & 336 & 2.307 & 15 \\
\hline I968 & $\cdot$ & 75 & I & 672 & 268 & $\mathrm{I} .874$ & 15 \\
\hline I969 & • & 66 & I & 656 & 218 & I.6o6 & 17 \\
\hline I970 & • & 57 & I & I.086 & 172 & $\mathrm{I} .8 \mathrm{I} 4$ & 25 \\
\hline I97I & • & 46 & I & I. 063 & I47 & I.649 & 28 \\
\hline
\end{tabular}




\begin{tabular}{|l|c|c|c|c|c|c|c|c|c}
\hline & Duitsers & Polen & $\begin{array}{c}\text { Joego- } \\
\text { slaven }\end{array}$ & $\begin{array}{c}\text { Oosten- } \\
\text { rijkers }\end{array}$ & Belgen & Tsjechen & Italianen & Hongaren & \\
\hline I972 & 52 & $8 \mathrm{I}$ & $6 \mathrm{I}$ & $\mathrm{I} 2$ & 7 & $\mathrm{I} 8$ & 70 & 2 & \\
\hline $\mathrm{I} 973$ & 33 & 39 & 39 & 6 & 4 & 2 & 24 & $\bullet$ & \\
\hline
\end{tabular}

Bron: Jaarverslagen van de (Hoofd-) Ingenieur/Inspecteur-Generaal der Mijnen [1913-1973].

Bijlage 17 Buitenlandse nationaliteiten in het arbeidersbestand bovengronds van de Nederlandse steenkolenmijnen, 1913-1973

\begin{tabular}{|c|c|c|c|c|c|c|c|c|}
\hline & Duitsers & Polen & $\begin{array}{l}\text { Joego- } \\
\text { slaven }\end{array}$ & $\begin{array}{c}\text { Oosten- } \\
\text { rijkers }\end{array}$ & Belgen & Tsjechen & Italianen & Hongaren \\
\hline I9I3 & 297 & & & I6 & 20 & & - & \\
\hline I9I4 & 238 & & & IO & 67 & & $\bullet$ & \\
\hline I9I5 & $\bullet$ & & & - & $\bullet$ & & • & \\
\hline I9I6 & - & & & - & - & & - & \\
\hline I9I7 & - & & & • & • & & • & \\
\hline I9I8 & $\cdot$ & & & $\bullet$ & $\bullet$ & & $\bullet$ & \\
\hline I9I9 & 417 & 7 & • & 25 & II 3 & • & I & • \\
\hline I920 & 798 & 9 & $\bullet$ & $3 \mathrm{I}$ & II6 & • & 4 & - \\
\hline I92I & $76 \mathrm{I}$ & 7 & $\bullet$ & 34 & 103 & I & 3 & I \\
\hline I922 & 744 & 6 & I & 32 & 95 & 2 & I & 3 \\
\hline I923 & 672 & $\mathrm{I} 2$ & $\bullet$ & I7 & 93 & I & 5 & 3 \\
\hline I924 & 624 & 9 & I & 22 & 95 & I & 5 & 2 \\
\hline I925 & 654 & $\mathrm{I} 2$ & 2 & 25 & IOO & 5 & 6 & 4 \\
\hline I926 & 649 & 8 & I & 30 & 98 & 3 & 6 & 5 \\
\hline I927 & 692 & 22 & 4 & 27 & I09 & 4 & 7 & 5 \\
\hline I928 & $75^{I}$ & 27 & IO & $3 I$ & I08 & 3 & 3 & 5 \\
\hline I929 & 936 & 43 & 38 & 39 & II 2 & IO & 5 & 8 \\
\hline I930 & I.OI5 & 45 & 30 & 32 & 103 & $\mathrm{I} 2$ & 7 & 8 \\
\hline I93I & 965 & 44 & 32 & $3 I$ & 86 & I8 & 6 & 8 \\
\hline I932 & 802 & 37 & 25 & 27 & 85 & IO & 7 & 7 \\
\hline I933 & 713 & 32 & I9 & I8 & 78 & 4 & 7 & II \\
\hline I934 & $54 \mathrm{I}$ & 29 & IO & 28 & 85 & 4 & 5 & $\mathrm{I} 2$ \\
\hline I935 & 4II & 28 & IO & 22 & 79 & 8 & 7 & $\mathrm{I} 2$ \\
\hline 1936 & $34 \mathrm{I}$ & $\mathrm{I} 2$ & 9 & 20 & 76 & 4 & 3 & 6 \\
\hline I937 & 350 & I7 & II & I6 & 76 & 9 & 7 & 9 \\
\hline 1938 & 319 & 20 & I4 & II & 74 & II & 6 & 8 \\
\hline
\end{tabular}




\begin{tabular}{|l|c|c|c|c|c|c|c|} 
& Russen & $\begin{array}{c}\text { Span- } \\
\text { jaarden }\end{array}$ & Grieken & $\begin{array}{c}\text { Marok- } \\
\text { kanen }\end{array}$ & $\begin{array}{c}\text { Overigel } \\
\text { statelozen }\end{array}$ & $\begin{array}{c}\text { totaal } \\
\text { buiten- } \\
\text { landers }\end{array}$ & $\begin{array}{c}\text { percentage van } \\
\text { totale bezetting }\end{array}$ \\
\hline $\mathrm{I} 972$ & $\cdot$ & 36 & $\mathrm{I}$ & 762 & $\mathrm{II} 9$ & $\mathrm{I} .22 \mathrm{I}$ & 27 \\
\hline $\mathrm{I} 973$ & $\cdot$ & 22 & $\mathrm{I}$ & 374 & 62 & 606 & 26 \\
\hline
\end{tabular}

\begin{tabular}{|c|c|c|c|c|c|c|c|}
\hline & Russen & $\begin{array}{c}\text { Span- } \\
\text { jaarden }\end{array}$ & Grieken & $\begin{array}{l}\text { Marok- } \\
\text { kanen }\end{array}$ & $\begin{array}{l}\text { Overigel } \\
\text { statelozen }\end{array}$ & $\begin{array}{l}\text { totaal } \\
\text { buiten- } \\
\text { landers }\end{array}$ & $\begin{array}{l}\text { percentage van } \\
\text { totale bezetting }\end{array}$ \\
\hline I9I3 & . & . & . & . & 5 & 338 & $\mathrm{I} 2$ \\
\hline I9I4 & . & - & • & - & 4 & 319 & $\mathrm{I} 2$ \\
\hline 1915 & . & . & . & . & . & . & \\
\hline I9I6 & . & . & . & . & . & . & \\
\hline 1917 & . & . & . & . & . & . & \\
\hline I9I8 & . & . & . & . & . & . & \\
\hline I9I9 & 2 & . & - & • & 7 & 572 & 8 \\
\hline 1920 & 5 & • & - & • & $\mathrm{I2}$ & 975 & $\mathrm{I} 2$ \\
\hline I92I & 3 & . & . & . & 9 & 924 & $\mathrm{I} 2$ \\
\hline I922 & I & • & - & • & I8 & 903 & I2 \\
\hline 1923 & I & . & . & • & I4 & 818 & IO \\
\hline 1924 & I & . & . & . & $\mathrm{I} 2$ & 772 & 9 \\
\hline 1925 & I & • & . & . & I9 & 828 & IO \\
\hline 1926 & 2 & . & . & . & 17 & 8I9 & 9 \\
\hline 1927 & 2 & • & . & • & I7 & 889 & 9 \\
\hline 1928 & $\mathrm{I}$ & . & . & • & 26 & 965 & I0 \\
\hline 1929 & 3 & - & - & • & $2 \mathrm{I}$ & $\mathrm{I} .2 \mathrm{I} 5$ & II \\
\hline 1930 & . & • & • & • & 29 & $\mathrm{I} .283$ & $\mathrm{I} 2$ \\
\hline I93I & $\cdot$ & . & • & • & 30 & I.335 & 12 \\
\hline 1932 & . & . & . & . & 24 & I.I24 & IO \\
\hline 1933 & • & • & • & • & 24 & I.005 & IO \\
\hline 1934 & • & • & • & • & 38 & 752 & 7 \\
\hline I935 & . & . & . & . & 46 & 623 & 6 \\
\hline 1936 & • & • & • & • & 60 & $53 \mathrm{I}$ & 5 \\
\hline 1937 & . & . & • & • & 78 & 573 & 5 \\
\hline 1938 & • & • & • & • & $8 \mathrm{I}$ & 544 & 5 \\
\hline
\end{tabular}




\begin{tabular}{|c|c|c|c|c|c|c|c|c|}
\hline & Duitsers & Polen & $\begin{array}{l}\text { Joego- } \\
\text { slaven }\end{array}$ & $\begin{array}{l}\text { Oosten- } \\
\text { rijkers }\end{array}$ & Belgen & Tsjechen & Italianen & Hongaren \\
\hline I939 & 297 & 19 & II & & 69 & IO & 5 & 6 \\
\hline I940 & $28 \mathrm{I}$ & I7 & 9 & & 75 & 5 & 6 & 2 \\
\hline I94I & 283 & 39 & 24 & & 84 & 8 & 7 & 5 \\
\hline I942 & 295 & 49 & 23 & & 90 & 4 & 7 & 2 \\
\hline I943 & 275 & $4 \mathrm{I}$ & 23 & & 89 & 7 & 5 & 2 \\
\hline I944 & 2 & 45 & $2 \mathrm{I}$ & & 9I & 8 & 5 & 2 \\
\hline I945 & 5 & 37 & I7 & - & 95 & 8 & 8 & 3 \\
\hline I946 & $2 \mathrm{I}$ & 50 & 30 & I & II7 & 5 & 9 & 2 \\
\hline I947 & 35 & 6I & $3 \mathrm{I}$ & 2 & $\mathrm{I} 23$ & 9 & IO & 5 \\
\hline 1948 & 84 & 78 & 42 & 4 & I37 & 9 & II & 6 \\
\hline I949 & I8o & II 2 & 59 & 8 & 170 & I5 & $2 \mathrm{I}$ & 6 \\
\hline 1950 & 225 & 109 & 65 & 7 & I65 & I5 & 22 & 7 \\
\hline I95I & 209 & IIO & 65 & 8 & I59 & 17 & 18 & 4 \\
\hline 1952 & 282 & II5 & 58 & 5 & 179 & I7 & 23 & 6 \\
\hline 1953 & 207 & II6 & 57 & 4 & I69 & I6 & 28 & 4 \\
\hline I954 & 259 & II6 & 54 & 3 & I8I & 22 & 26 & 4 \\
\hline I955 & 278 & I07 & $5 \mathrm{I}$ & 3 & 270 & I9 & 26 & 4 \\
\hline 1956 & 386 & 94 & 44 & 6 & 448 & I4 & 25 & 32 \\
\hline I957 & 383 & 85 & 37 & 5 & 656 & IO & 28 & I9 \\
\hline 1958 & $34 \mathrm{I}$ & $8 \mathrm{I}$ & 34 & 6 & 659 & II & 24 & 22 \\
\hline I959 & 315 & 72 & 33 & 5 & 592 & I2 & 34 & I4 \\
\hline 1960 & 289 & 73 & 27 & 7 & 578 & 6 & 54 & $\mathrm{I} 2$ \\
\hline I96I & 253 & 70 & 23 & 5 & 597 & 5 & 66 & II \\
\hline 1962 & 227 & 64 & 40 & 3 & $6 \mathrm{II}$ & 6 & 98 & 23 \\
\hline 1963 & 219 & 60 & 60 & 4 & 580 & 5 & II & I9 \\
\hline I964 & 223 & 59 & 64 & 5 & $53^{6}$ & 4 & II 8 & 22 \\
\hline 1965 & 216 & 52 & 59 & 5 & 519 & 5 & II9 & I9 \\
\hline I966 & 204 & 45 & 54 & 4 & 497 & 4 & 103 & I7 \\
\hline 1967 & I8I & 39 & 33 & 4 & 437 & 3 & $9 \mathrm{I}$ & I6 \\
\hline I968 & I47 & 32 & 28 & 4 & 397 & 3 & 74 & I3 \\
\hline I969 & I35 & 34 & $2 \mathrm{I}$ & 3 & 350 & 3 & 73 & 7 \\
\hline I970 & II9 & 35 & I6 & 4 & 312 & 4 & 68 & 7 \\
\hline I97I & 103 & 33 & II & 4 & 292 & 3 & 60 & 5 \\
\hline I972 & 98 & 30 & I7 & 4 & 268 & 3 & 58 & 3 \\
\hline I973 & 93 & 27 & 28 & 4 & 249 & 2 & 52 & 4 \\
\hline
\end{tabular}

Bron: Jaarverslagen van de (Hoofd-) Ingenieur/Inspecteur-Generaal der Mijnen [1913-1973]. 


\begin{tabular}{|c|c|c|c|c|c|c|c|}
\hline & Russen & $\begin{array}{l}\text { Span- } \\
\text { jaarden }\end{array}$ & Grieken & $\begin{array}{l}\text { Marok- } \\
\text { kanen }\end{array}$ & $\begin{array}{l}\text { Overigel } \\
\text { statelozen }\end{array}$ & $\begin{array}{l}\text { totaal } \\
\text { buiten- } \\
\text { landers }\end{array}$ & $\begin{array}{l}\text { percentage van } \\
\text { totale bezetting }\end{array}$ \\
\hline 1939 & - & - & • & • & 80 & 497 & 4 \\
\hline 1940 & - & - & - & • & 80 & 475 & 4 \\
\hline I94I & - & - & $\cdot$ & • & 97 & 546 & 4 \\
\hline 1942 & • & • & • & & 95 & $5^{6} 5$ & 4 \\
\hline 1943 & - & $\cdot$ & • & • & 89 & 531 & 4 \\
\hline I944 & I & • & • & • & 82 & 257 & 2 \\
\hline 1945 & I & • & • & • & 72 & 246 & 2 \\
\hline 1946 & I & $\cdot$ & $\cdot$ & • & 87 & 323 & 2 \\
\hline I947 & I & • & $\cdot$ & $\cdot$ & II 2 & $39 \mathrm{I}$ & 2 \\
\hline 1948 & 2 & • & - & - & II9 & 495 & 3 \\
\hline I949 & I & $\cdot$ & $\cdot$ & • & $\mathrm{I} 46$ & 718 & 4 \\
\hline 1950 & I & - & - & • & I65 & $78 \mathrm{I}$ & 4 \\
\hline I95I & I & • & $\cdot$ & • & 150 & 801 & 4 \\
\hline 1952 & 2 & $\cdot$ & $\cdot$ & • & 145 & 832 & 4 \\
\hline 1953 & 2 & - & - & • & 170 & 833 & 4 \\
\hline 1954 & 2 & - & $\cdot$ & • & I54 & 821 & 3 \\
\hline 1955 & 2 & $\cdot$ & $\cdot$ & • & 162 & 922 & 4 \\
\hline 1956 & 2 & • & - & • & I54 & I.205 & 5 \\
\hline I957 & 2 & • & $\cdot$ & - & I66 & I.39I & 6 \\
\hline 1958 & 2 & • & • & • & I54 & I. 334 & 5 \\
\hline I959 & 3 & - & • & • & I5I & $\mathrm{I} .23 \mathrm{I}$ & 5 \\
\hline 1960 & 3 & • & • & • & I45 & I.192 & 5 \\
\hline I961 & • & • & • & • & I75 & I. 205 & 6 \\
\hline 1962 & • & 38 & • & • & 216 & I. 326 & 6 \\
\hline 1963 & • & 94 & $\cdot$ & • & $37 \mathrm{I}$ & $\mathrm{I} .53 \mathrm{I}$ & 7 \\
\hline I964 & • & 192 & II 4 & II 4 & 254 & I. 758 & 8 \\
\hline 1965 & • & 246 & 146 & 239 & 265 & I. 890 & 9 \\
\hline I966 & • & 152 & 87 & 218 & 250 & I. 634 & 8 \\
\hline 1967 & • & 73 & 59 & 130 & 209 & I. 275 & 8 \\
\hline I968 & • & 59 & 49 & 92 & $\mathrm{I} 75$ & I.073 & 8 \\
\hline I969 & • & 46 & 34 & 80 & I47 & 933 & 7 \\
\hline I970 & • & 48 & 28 & I89 & 132 & 962 & 8 \\
\hline I97I & • & 37 & 22 & 132 & $\mathrm{II}_{3}$ & $8 \mathrm{I} 5$ & 8 \\
\hline 1972 & - & 28 & 20 & $\mathrm{I} 23$ & 102 & 754 & 7 \\
\hline 1973 & . & 22 & I9 & II 2 & 89 & 701 & 8 \\
\hline
\end{tabular}


Bijlage 18 Het overlevingspercentage van intreders in het Algemeen Mijnwerkersfonds, 1919-1960

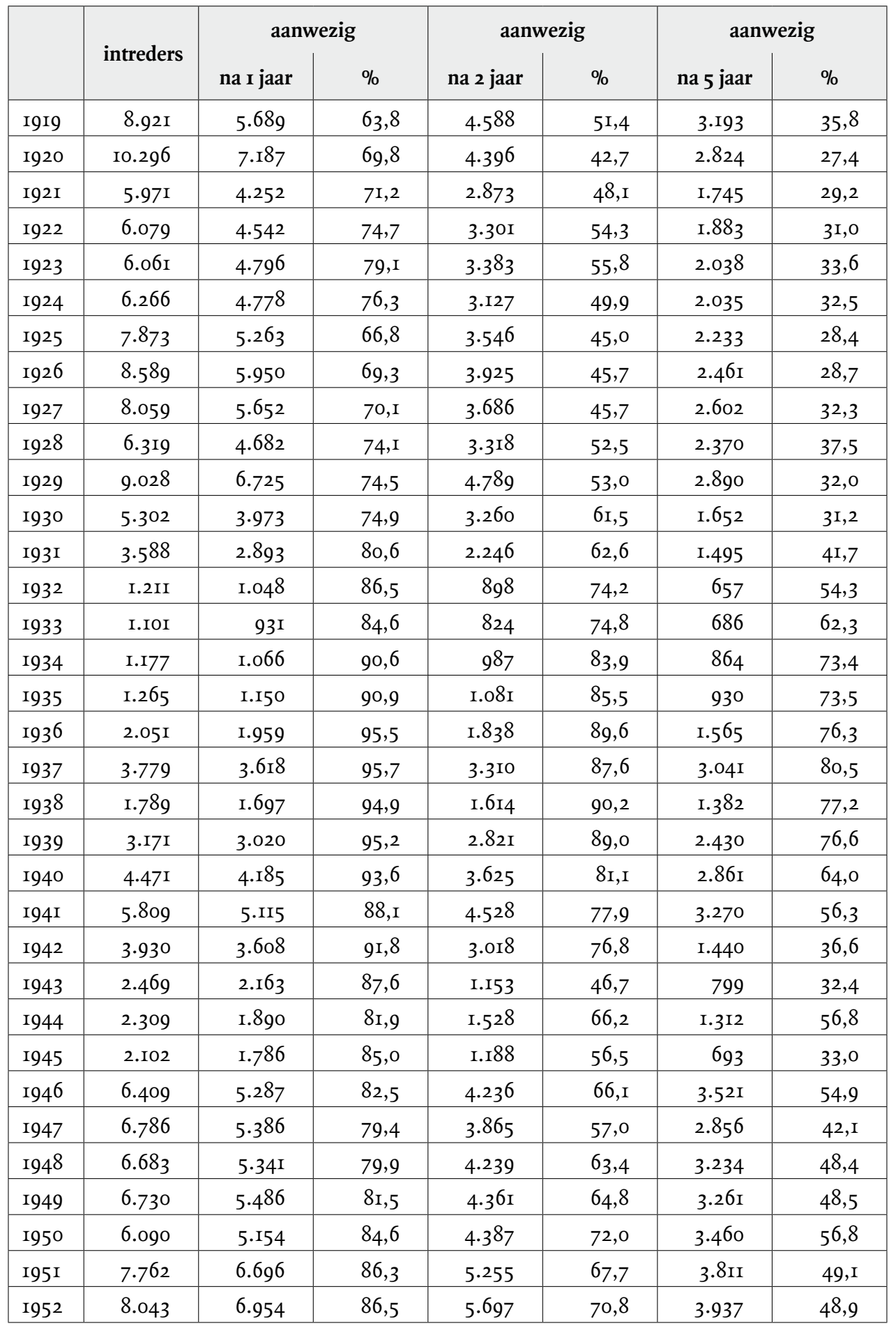




\begin{tabular}{|l|c|c|c|c|c|c|c|}
\hline & \multirow{2}{*}{ intreders } & \multicolumn{2}{|c|}{ aanwezig } & \multicolumn{2}{c|}{ aanwezig } & \multicolumn{2}{c|}{ aanwezig } \\
& & na I jaar & $\%$ & na 2 jaar & $\%$ & na 5 jaar & \% \\
\hline I953 & 5.380 & 4.753 & 88,3 & 3.996 & 74,3 & 2.679 & 49,8 \\
\hline I954 & 6.443 & 5.208 & 80,8 & 4.308 & 66,9 & 3.082 & 47,8 \\
\hline I955 & 5.242 & 4.350 & 83,0 & 3.553 & 67,8 & $2.57 \mathrm{I}$ & 49,0 \\
\hline I956 & 6.160 & 4.984 & 80,9 & 3.863 & 62,7 & 2.382 & 38,7 \\
\hline I957 & 7.842 & 6.584 & 84,0 & 5.350 & 68,2 & & \\
\hline I958 & 5.772 & 4.925 & 85,3 & 4.238 & 73,4 & & \\
\hline I959 & 2.156 & 2.065 & 95,8 & I.749 & $8 \mathrm{I}, \mathrm{I}$ & & \\
\hline I960 & 2.206 & 2.110 & 95,6 & & & & \\
\hline
\end{tabular}

Bron: Eigen omrekening naar overlevingspercentages op basis van gegevens uit Jaarverslagen AMF (1919-1960).

Bijlage I9 Het verloop van het ledental van de pensioenkas van het Algemeen Mijnwerkersfonds, I920-1960

\begin{tabular}{|c|c|c|c|c|c|c|}
\hline & $\begin{array}{c}\text { aantal } \\
\text { leden op } \\
3^{I-I 2}\end{array}$ & toegetreden & uitgetreden & toename & $\begin{array}{l}\text { gemiddeld } \\
\text { aantal leden }\end{array}$ & $\begin{array}{l}\text { aantal } \\
\text { uittreders als } \\
\text { percentage } \\
\text { van } \\
\text { gemiddeld } \\
\text { aantal leden }\end{array}$ \\
\hline I920 & 25.852 & I0.296 & 7.178 & 3.118 & 24.293 & 29,5 \\
\hline I92I & $25 \cdot 309$ & 5.97I & $6.5 \mathrm{I} 4$ & -543 & $25 \cdot 58 \mathrm{I}$ & 25,5 \\
\hline 1922 & 26.301 & 6.079 & 5.087 & 992 & 25.805 & I9,7 \\
\hline I923 & 28.260 & $6.06 \mathrm{I}$ & 4.102 & I.959 & $27.28 \mathrm{I}$ & I5, O \\
\hline I924 & 29.260 & 6.266 & 5.266 & I. 000 & 28.760 & $\mathrm{I} 8,3$ \\
\hline 1925 & 30.165 & 7.873 & 6.968 & 905 & 29.713 & 23,5 \\
\hline I926 & 32.186 & 8.589 & 6.568 & $2.02 \mathrm{I}$ & 31.176 & $2 \mathrm{I}, \mathrm{I}$ \\
\hline I927 & 33.649 & 8.059 & 6.596 & I. 463 & 32.918 & 20,0 \\
\hline I928 & 33.695 & 6.319 & 6.273 & 46 & 33.672 & I8,6 \\
\hline 1929 & 36.567 & 9.028 & 6.156 & 2.872 & 35.131 & 17,5 \\
\hline 1930 & 36.624 & $5 \cdot 302$ & 5.245 & 57 & 36.596 & $\mathrm{I} 4,3$ \\
\hline I93I & 37.103 & $3 \cdot 588$ & 3.109 & 479 & 36.864 & 8,4 \\
\hline 1932 & 34.383 & $\mathrm{I} .2 \mathrm{II}$ & $3.93 \mathrm{I}$ & -2.720 & $35 \cdot 743$ & $\mathrm{II}, \mathrm{O}$ \\
\hline I933 & 32.092 & I.IOI & $3 \cdot 392$ & $-2.29 \mathrm{I}$ & 33.238 & I0, 2 \\
\hline I934 & $29 \cdot 388$ & I.I77 & $3.88 \mathrm{I}$ & -2.704 & 30.740 & I2,6 \\
\hline I935 & 28.292 & I. 265 & $2.36 \mathrm{I}$ & $-\mathrm{I} .096$ & 28.840 & 8,2 \\
\hline 1936 & $28.89 \mathrm{I}$ & $2.05 \mathrm{I}$ & I. 252 & 599 & 28.592 & 4,4 \\
\hline
\end{tabular}


Bijlage 19 (Vervolg)

\begin{tabular}{|c|c|c|c|c|c|c|}
\hline & $\begin{array}{c}\text { aantal } \\
\text { leden op } \\
3^{\mathbf{I}-\mathbf{I} 2}\end{array}$ & toegetreden & uitgetreden & toename & $\begin{array}{l}\text { gemiddeld } \\
\text { aantal leden }\end{array}$ & $\begin{array}{l}\text { aantal } \\
\text { uittreders als } \\
\text { percentage } \\
\text { van } \\
\text { gemiddeld } \\
\text { aantal leden }\end{array}$ \\
\hline 1937 & $3 \mathrm{I} .6 \mathrm{I} 8$ & 3.779 & 1.052 & 2.727 & 30.255 & 3,5 \\
\hline 1938 & 31.837 & I. 789 & I. 570 & 219 & 31.728 & 4,9 \\
\hline 1939 & $33.84 \mathrm{I}$ & $3 \cdot 17 I$ & I.I94 & I.977 & 32.839 & 3,6 \\
\hline 1940 & 36.923 & $4.47 \mathrm{I}$ & I. 389 & 3.082 & $35 \cdot 382$ & 3,9 \\
\hline I94I & 40.362 & 5.809 & 2.370 & 3.439 & 38.643 & $6, \mathrm{I}$ \\
\hline 1942 & 42.156 & 3.930 & 2.136 & I.794 & 4I.259 & 5,2 \\
\hline I943 & 42.003 & 2.469 & 2.622 & $-\mathrm{I} 53$ & 42.080 & 6,2 \\
\hline I944 & 36.798 & 2.309 & $7 \cdot 514$ & -5.205 & $39.40 \mathrm{I}$ & $\mathrm{I} 9, \mathrm{I}$ \\
\hline I945 & 32.852 & 2.102 & 6.048 & -3.946 & 34.825 & 17,4 \\
\hline 1946 & $35 \cdot 310$ & 6.409 & $3.95 \mathrm{I}$ & $2.45^{8}$ & $34.08 \mathrm{I}$ & $\mathrm{II}, 6$ \\
\hline I947 & 37.874 & 6.786 & 4.222 & 2.564 & 36.592 & $\mathrm{II}, 5$ \\
\hline I948 & 40.082 & 6.683 & 4.475 & 2.208 & 38.978 & $\mathrm{II}, 5$ \\
\hline I949 & 42.979 & 6.730 & 3.833 & 2.897 & $4 \mathrm{I} .53 \mathrm{I}$ & 9,2 \\
\hline 1950 & $42.8 \mathrm{I} 4$ & 6.090 & 4.I64 & & 43.777 & 9,5 \\
\hline I95I & 44.740 & $7 \cdot 762$ & 4.383 & $3 \cdot 379$ & 46.430 & 9,4 \\
\hline 1952 & 48.1I9 & 8.043 & 4.769 & 3.274 & $49 \cdot 757$ & 9,6 \\
\hline I953 & 51.393 & 5.380 & $4.63 \mathrm{I}$ & 749 & $5 \mathrm{I} .768$ & 8,9 \\
\hline I954 & 52.142 & 6.443 & 4.863 & I. 580 & 52.932 & 9,2 \\
\hline I955 & 53.722 & 5.242 & 5.876 & -634 & 53.405 & $\mathrm{II}, \mathrm{O}$ \\
\hline 1956 & 53.088 & 6.160 & 5.827 & 333 & 53.255 & Io,9 \\
\hline I957 & $53.42 \mathrm{I}$ & 7.842 & 6.695 & I.I47 & 53.995 & $\mathrm{I} 2,4$ \\
\hline 1958 & 54.568 & 5.772 & 5.073 & 699 & 54.918 & 9,2 \\
\hline 1959 & 55.267 & 2.156 & 4.688 & -2.532 & 54.001 & 8,7 \\
\hline 196o & 52.735 & 2.206 & $4.52 \mathrm{I}$ & -2.315 & $5 \mathrm{I} .505$ & 8,8 \\
\hline
\end{tabular}

Bron: Jaarverslagen AMF, 1920-1960. 
Bijlage 20 Het verloop van de OVS-ers bij de gezamenlijke Nederlandse steenkolenmijnen, $1945-1965$

\begin{tabular}{|c|c|c|c|c|c|c|c|c|c|}
\hline & 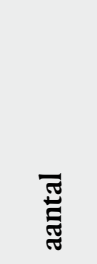 & 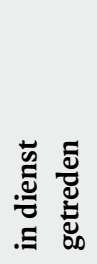 & 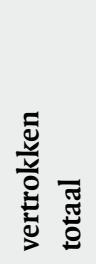 & 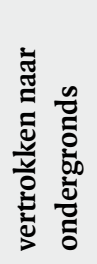 & 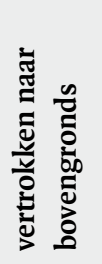 & 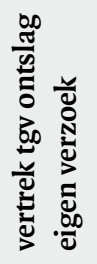 & 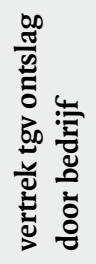 & 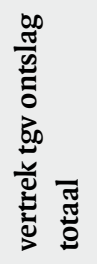 & $\frac{0}{\frac{0}{7}}$ \\
\hline I945 & 557 & 616 & 59 & 23 & 4 & • & • & 32 & 557 \\
\hline I946 & I.229 & 844 & I72 & 43 & 24 & • & • & 105 & 672 \\
\hline I947 & I. 270 & 575 & 534 & 295 & 20 & • & • & 219 & $4 \mathrm{I}$ \\
\hline I948 & I. 487 & $7 \mathrm{I} 4$ & 497 & 326 & 26 & • & • & $\mathrm{I} 45$ & 217 \\
\hline I949 & I.986 & I.I44 & 645 & $45^{8}$ & 29 & • & • & 158 & 499 \\
\hline 1950 & 2.572 & I. 369 & 783 & 533 & 12 & • & • & 238 & 586 \\
\hline I95I & 3.007 & I. $4 \mathrm{I} 8$ & 983 & 662 & 34 & 182 & 105 & 287 & 435 \\
\hline 1952 & 3.812 & I.903 & I.098 & $77 \mathrm{I}$ & 38 & $\mathrm{I} 74$ & II5 & 289 & 805 \\
\hline 1953 & 3.438 & 956 & $\mathrm{I} .330$ & 850 & 53 & 320 & 107 & 427 & -374 \\
\hline I954 & 3.186 & I.239 & I.49I & 905 & 63 & 449 & 74 & 523 & -252 \\
\hline 1955 & 2.695 & I.0IO & I. 501 & 976 & 38 & 429 & 58 & 487 & $-49 \mathrm{I}$ \\
\hline 1956 & 2.476 & I.039 & I. 258 & 824 & 25 & $3^{61}$ & 48 & 409 & -219 \\
\hline I957 & 2.569 & I.195 & I.IO2 & 679 & 56 & 325 & 42 & 367 & 93 \\
\hline 1958 & 2.869 & I. 390 & I.090 & 677 & 39 & I94 & 64 & 258 & 300 \\
\hline 1959 & 2.662 & 913 & I.I2O & 635 & I2I & 282 & 82 & 364 & -207 \\
\hline 1960 & I. 848 & 486 & I. 300 & 609 & 33 & 533 & 57 & 590 & $-8 \mathrm{I} 4$ \\
\hline I96I & I. 424 & $6 \mathrm{I}_{4}$ & I.038 & 489 & 39 & 406 & 26 & 432 & -424 \\
\hline I962 & I.I62 & 557 & 819 & 382 & 26 & 263 & 25 & 288 & -262 \\
\hline 1963 & I.I32 & $66 \mathrm{I}$ & 691 & 256 & 22 & 308 & 26 & 334 & -30 \\
\hline 1964 & I.009 & 593 & 716 & 237 & I8 & 298 & $3 \mathrm{I}$ & 329 & $-\mathrm{I} 23$ \\
\hline 1965 & 895 & 435 & 549 & 170 & $\mathrm{I} 2$ & 299 & II & 310 & -II4 \\
\hline
\end{tabular}

Bron: SHCL, ArchiefGSL, Statistiek. 


\title{
Geraadpleegde bronnen
}

\section{Archieven en documentatie}

\author{
AZL, Heerlen \\ Archief Algemeen Mijnwerkersfonds van de Steenkolenmijnen in Limburg \\ Discovery Center Continium, Kerkrade \\ Documentatie Steenkolenmijnbouw \\ Gemeentearchief, Kerkrade \\ Archief Gemeentesecretarie 1795-1945 \\ Oranje-Nassau Groep, Amsterdam \\ Archief Oranje-Nassau Mijnen \\ Regionaal Historisch Centrum Limburg, Maastricht \\ Archief Oranje-Nassau Mijnen \\ Bisschoppelijk Archief Roermond na I840 \\ Centraal Archief DSM \\ Provinciaal Archief \\ Staatstoezicht op de Mijnen \\ Sociaal Historisch Centrum voor Limburg, Maastricht \\ Archief Gezamenlijke Steenkolenmijnen in Limburg \\ Archief Laura \& Vereeniging \\ Archief Nederlandse Katholieke Mijnwerkersbond \\ Archief Willem-Sophia
}

\section{Gepubliceerde bronnen en literatuur}

70 jaar FSI, Fonds voor Sociale Instellingen (http://www.stichtingfsi.nl).

Akkermans, Math, De publiekrechtelijke bedrijfsorganisatie in de Nederlandse steenkolenmijnindustrie (doctoraalscriptie, Amsterdam I986).

Albert de la Bruhèze, A.A. en F.C.A. Veraart, Fietsverkeer in praktijk en beleid in de twintigste eeuw. Overeenkomsten en verschillen in fietsgebruik in Amsterdam, Eindhoven, Zuidoost-Limburg, Antwerpen, Manchester, Kopenhagen, Hannover en Basel (Den Haag 1999).

'Annalen van de Willem-Sophia', Steenkool (maart 1948) ro8-rog.

Arbeidsmarktbeschrijuing van de Provincie Limburg (Districtsbureau voor de Arbeidsvoorziening Limburg, I95I-I965). 
Arnold, Paul, 'Laura en Julia. Een kleine geschiedenis van de Naamloze Vennootschap Laura \& Vereeniging', Studies over de sociaal-economische geschiedenis van Limburg L (2005) 139-172.

Arnold, Paul, Jac van den Boogard en Willibrord Rutten, Historisch vademecum Limburg 1900-2000 (Maastricht 1999).

Bade, Klaus J. (ed.), 'Arbeiterstatistik zur Ausländerkontrolle: die 'Nachweisungen' der preußischen Landräte über den 'Zugang, Abgang und Bestand der ausländische Arbeiter im preußischen Staate' I906-I9I4', Archiv für Sozialgeschichte XXIV (1984) I63-285.

Bade, Klaus J., 'Billig und willig - die ausländischen Wanderarbeiter im kaiserlichen Deutschland', in: Klaus J. Bade (ed.), Deutsche im Ausland-Fremde in Deutschland. Migration in Geschichte und Gegenwart (München 1993) 3II-324.

Bade, Klaus J. (ed.), Deutsche im Ausland-Fremde in Deutschland. Migration in Geschichte und Gegenwart (München 1993).

Bade, Klaus J., Europa in Bewegung. Migration vom späten 18. Jahrhundert bis zur Gegenwart (München 2000).

Bade, Klaus J., 'Preußengänger' und 'Abwehrpolitik'; Ausländerbeschäftigung, Ausländerpolitik und Ausländerkontrolle auf dem Arbeitsmarkt in Preußen vor dem Ersten Weltkrieg', Archiv für Sozialgeschichte XXIV (I984) 9I-I62.

Bade, Klaus J., Pieter C. Emmer, Leo Lucassen en Jochen Oltmer (ed.), Enzyklopädie Migration in Europa. Vom 17. Jahrhundert bis zur Gegenwart (Paderborn, München, Wenen, Zürich 2007).

Baines, Dudley, 'Labour markets, emigration and internal migration in Europe I850-1913', in: Jeffrey G. Williamson en Timothy J. Hatton (eds.), International labour market integration and the impact of migration on national labour markets since 1870 (Milaan 1994) 5I-6I.

Bardoul, H.J., Personeelsverloop in het ondergrondse bedrijf der mijn Julia in een tijd van hoogconjunctuur (scriptie, z.p. mei 1958).

Baud, Michiel, 'Familienetwerken, redistributie van inkomen en migratie', in: Michiel Baud en Theo Engelen (red.), Samen wonen, samen werken? Vijfessays over de geschiedenis van arbeid en gezin (Hilversum I994) I23-I47.

Baud, Michiel en Theo Engelen, Samen wonen, samen werken? Vijfessays over de geschiedenis van arbeid en gezin (Hilversum 1994).

Baudhuin, Fernand, Histoire economique de la Belgique 1914-1939. Tome premier: Grandeurs et misères d'un quart de siècle (Brussel 1944).

Bedrijfschap voor de Steenkolenmijnindustrie. Verslag over ... [1955-1965].

Belinfante, A.D., In plaats van bijltjesdag. De geschiedenis van de Bijzondere Rechtspleging na de Tweede Wereldoorlog (Assen I978).

Berger, Stefan, 'Introduction', in: Stefan Berger, Andy Croll en Norman LaPorte, Towards a comparative history of coalfield societies (Aldershot/Burlington 2005) I-II.

Berger, Stefan, Andy Croll en Norman LaPorte, Towards a comparative history of coalfield societies (Aldershot/Burlington 2005).

Berghuis, C.K., Geheel ontdaan van onbaatzuchtigheid. Het Nederlandse toelatingsbeleid voor vluchtelingen en displaced persons van 1945 tot 1956 (Amsterdam 1999).

Berufsausbildung im Steinkohlenbergbau der Länder der Gemeinschaft, Die. Europäische Gemeinschaft für Kohle und Stahl. Hohe Behörde, Teil VI Niederlande (Luxemburg 1956) 44I-507.

Bieleman, Jan, Geschiedenis van de landbouw in Nederland 1500-1950. Veranderingen en verscheidenheid (Meppel 1992).

Blaich, Fritz, Der Schwarze Freitag. Inflation und Wirtschaftskrise (München $1990^{2}$ ).

Blink, H., Duitschland in zijn opkomst en beteekenis als economisch-geographisch gebied (Amsterdam 1927).

Blok, Johan, Cor Campagne en SjefJanssen, Trams in Midden- en Zuid-Limburg 1888-1950 (Heerlen I998).

Boeri, Tito en Jan van Ours, The economics of imperfect labor markets (Princeton and Oxford 2008). 
Boogard, Jac van den e.a. (ed.), Onder de rook van de mijn. Het leven van de mijnwerker in Zuid-Limburg (Zwolle 20II).

Bossenbroek, M. en J.B.C. Kruishoop, Vluchten voor de Groote Oorlog. Belgen in Nederland 1914-1918 (Amsterdam I988).

Bosworth, Derek, Peter Dawkins en Thorsten Stromback, The economics of the labour market (Harlow I996).

Bouwen in Limburg. Woningbouw door de Vereniging Ons Limburg sinds haar oprichting (Heerlen z.j.).

Bouwens, Sophie, 'Mijnwerkersgemeenschap Lauradorp: Lokale gevolgen van industrialisering en deïndustrialisering', Studies over de sociaal- economische geschiedenis van Limburg XLVII (2002) I07-I36.

Bouwens, Sophie, Over de streep. Grensarbeid vanuit Zuid-Limburg naar Duitsland, 1958-2001 (Hilversum 2008).

Bouwens, Sophie, 'Werk in de marge? Grensarbeid vanuit het Nederlandse naar het Duitse deel van de Euregio Maas-Rijn, I960-200o', Studies over de sociaal-economische geschiedenis van Limburg L (2005) I97-2i6.

Brassé, Paul en Willem van Schelven, Assimilatie van vooroorlogse immigranten. Drie generaties Polen, Slovenen en Italianen in Heerlen ('s-Gravenhage I980).

Brepohl, Wilhelm, Der Aufbau des Ruhrvolkes im Zuge der Ost-West-Wanderung. Beiträge zur deutschen Sozialgeschichte des 19. und 20. Jahrhunderts (Recklinghausen 1948).

Brouns, G., Uit de geschiedenis van Laura \& Vereeniging (Eygelshoven 1975).

Brüggemeier, Franz-Josef, Leben vor Ort. Ruhrbergleute und Ruhrbergbau 1889-1919 (München I983).

Buren, Frank van, 'Kolenwinning onder Duitse druk: productie- en arbeidsverhoudingen in de Limburgse mijnen tijdens de bezetting I940-I944', Studies over de sociaal-economische geschiedenis van Limburg XLIX (2004) I35-I64.

Caestecker, Frank, 'Arbeidsmarktstrategieën in de Belgische mijnindustrie tot I940', Tijdschrift voor Sociale en Economische Geschiedenis V nummer 3 (2008) 30-52.

Caestecker, Frank, 'Vervanging of verdringing van de buitenlandse mijnwerkers in Limburg. De emancipatie van de Limburgse mijnwerkers. Migratie naar het Limburgse mijnbekken. Een vergelijking met de migratie naar de Waalse mijnen (I920-I940)', Limburg-Het Oude Land van Loon 77 (I998) 309-325.

Cammaert, A.P.M., Het verborgen front. Een geschiedenis van de georganiseerde illegaliteit in de provincie Limburg tijdens de Tweede Wereldoorlog (Leeuwarden/Mechelen I994).

Cammaert, Fred, 'Tijdens de oorlogen', Weet je nog, koempel? De mijnen in Limburg deel I4 (Zwolle 2004) 32I-344.

Cammaert, Fred, 'De Tweede Wereldoorlog', Het Land van Herle LVII aflevering 2 (2008) 5I-66.

Campbell, Alan, The Scottish miners, 1874-1939 (Aldershot/Burlington/Singapore/Sidney 2000).

Centraal Bureau voor de Statistiek, Vijfennegentig jaar statistiek in tijdreeksen 1899-1994 ('s-Gravenhage 1994).

Charpentier, P.H.M., De verkeersontwikkeling op de wegen in Zuid-Limburg in de periode 1927-1941 en het beleid, dat nodig was bij de aanpak van het wegenverkeersuraagstuk (doctoraalscriptie KU, Nijmegen 1989).

Cillekens, Caspar, Arbeidsmarkt, werklozenzorg en werkloosheidsbestrijding te Maastricht 1914-1939 (doctoraalscriptie, Nijmegen 1980 ).

Colsen, J., Poels (Roermond/Maaseik 1955).

Corpeleijn, A.W.F., 'Arbeidsmobiliteit en werkgelegenheidsstructuur. Oorzaken van sectorale verschillen in personeelsverloop', Economisch Statistische Berichten LXV nummer 3239 (I980) 88-92.

Cottaar, Annemarie en Nadia Bouras (m.m.v. Fatiha Lasuikili), Marokkanen in Nederland. De pioniers vertellen (Amsterdam 2009).

Cranssen, Tanja, 'Marokkaanse mijnwerkers in Limburg, 1963-1975', Studies over de sociaal-economische geschiedenis van Limburg XLVIII (2003) I2I-I48. 
Cranssen, Tanja, "Sjöppe, sjöppe". Marokkaanse mijnwerkers in de Nederlandse steenkolenmijnen 1963-1975 (doctoraalscriptie Leiden z.j).

'Dat was de Neuprick', Steenkool (1949).

Dehing, P.W.N.M., '... Eene soort van dynastie van spoorwegbeambten'. Arbeidsmarkt en spoorwegen in Nederland, 1875-1914 (Hilversum 1989).

Delbroek, Bart, 'Op zoek naar koolputters. Buitenlandse mijnwerkers in Belgisch-Limburg in de twintigste eeuw', Tijdschrift voor Sociale en Economische Geschiedenis V nummer 3 (2008) 80-103.

Dennis, Norman, Fernando Henriques en Clifford Slaughter, Coal is our life. An analysis of a Yorkshire mining community (Londen 1974) Eerste druk: 1956.

De Rijck, Tine en Griet van Meulder, De ereburgers. Een sociale geschiedenis van de Limburgse mijnwerkers (Berchem 2000).

Derks, Wim, 'De arbeidsmarkt in Limburg 1960-2005: is de sluiting van de mijnen verwerkt?', Studies over de sociaal-economische geschiedenis van Limburg L (2005) I73-I96.

Dieteren, Frans, Brood op de plank. 'Brikkebekkers’, arme Limburgse gastarbeiders in Duitsland (Heythuysen 1985).

Dieteren, Remigius, Grondbeleid en volkshuisvesting in de Mijnstreek. N.V. Bouwgrondmaatschappij Tijdig 1913-1963 (Assen 1964).

Dieteren, Remigius, Mens en mijn. Een halve eeuw strijd, groei en bloei van de Nederlandse Katholieke Mijnwerkersbond (Heerlen 1953).

Dieteren, Remigius, De migratie in de Mijnstreek 1900-1935. Een sociaal-historische studie (Maastricht 1959).

Dieteren, Remigius, 'De moeizame weg naar een stabiele mijnwerkersbevolking', Oranje-Nassau Post. Sluitingsnummer mijnzetel Oranje-Nassau I (Heerlen z.p.) I9-34.

Dieteren, Remigius, Veertig jaar arbeiderswoningen in Limburg: "Ons Limburg", 1911-1951 (Heerlen I95I).

Dieteren, Remigius en J.F.R. Philips, Stein. Een achterland werd bruggehoofd. Historisch overzicht van gemeente en bevolking (Stein 1962).

Dijk, Jouke van, Migratie en arbeidsmarkt (Assen/Maastricht 1986).

Dohmen, Antoine, Mijnkolonies in Zuid-Limburg. Stedebouw met een missie (scriptie Technische Universiteit, Eindhoven 1995).

Donnan, Hastings en Thomas M. Wilson, Borders. Frontiers of identity, nation and state (Oxford/New York 200I).

Doorn, J.A.A. van, Arbeidsmarkt en arbeidsbestel. Brugpijlers tussen sociologie en economie. Rede uitgesproken bij de aanvaarding van het ambt van gewoon hoogleraar in de sociologie van de Nederlandsche Economische Hoogeschool te Rotterdam op 26 januari 1961 (Assen 196r).

Drukker, J.W., De elektronische steentijd. Vijftig jaar techniek en samenleving (Den Haag 1996).

Eijl, Corrie van, Al te goed is buurmans gek. Het Nederlandse vreemdelingenbeleid 1840-1940 (Amsterdam 2005).

Eijl, Corrie van en Leo Lucassen, 'Holland beyond the borders. Emigration and the Dutch state, $1850-$ I940' (Paper for the workshop 'Citizenship and those who leave: the politics of emigration and expatriation', École des Hautes Études en Sciences Sociales, Parijs 6-8 december 200I).

Eiynck, A. e.a. (ed.), Wanderarbeit jenseits der Grenze. 350 Jahre auf der Suche nach Arbeit in der Fremde (Assen etc I993) I3I-I39.

Elteren, M.C.M. van, Staal en arbeid. Een sociaal-historische studie naar industriële accommodatieprocessen onder arbeiders en het desbetreffend bedrijfsbeleid bij Hoogovens IJmuiden, 1924-1966 (Leiden 1986).

Engelen, Th.L.M., Fertiliteit, arbeid, mentaliteit. De uruchtbaarheidsdaling in Nederlands-Limburg, 1850-1960 (Assen/Maastricht I987).

Engelen, Th.L.M., 'Van I.300 zielen naar 50.000 inwoners. Een eerste aanzet tot de demografische analyse van Kerkrade in de periode I600-1975', Studies over de sociaal-economische geschiedenis van Limburg XXXV (I990) I-29. 
Eussen, Ron, Akkomodatie en verzet bij de Nederlandse steenkolenmijnen tijdens de Duitse bezetting, mei 1940-september 1944 (doctoraalscriptie VU, Amsterdam I984).

Feldman, Gerald D. en Klaus Tenfelde (ed.), Workers, owners and politics in coal mining. An international comparison of industrial relations (New York/Oxford/München I990).

Galan, C. de en A.J.M. van Miltenburg, Economie van de arbeid (Alphen aan den Rijn 199133).

Gales, Ben, 'Houwen en stof bijten? Maakbaarheid in een mijnstreek', Studies over de sociaal-economische geschiedenis van Limburg XLV (2000) 27-64.

Gales, Ben, 'Mijnarbeiders tussen agrarische en urbane arbeidsmarkten', in: Geurt Collenteur e.a. (ed.), Stad en regio. Opstellen aangeboden aan prof. dr. Pim Kooij bij zijn afscheid als hoogleraar economische en sociale geschiedenis aan de Rijksuniversiteit Groningen (Assen 2010) I7I-I84.

Gales, Ben, 'De techniek ondergronds', Weet je nog, koempel? De mijnen in Limburg deel 7 (Zwolle 2004) $153-176$.

Gales, B.P.A., Delven en slepen. Steenkolenmijnbouw in Limburg: techniek, winning en markt gedurende de achttiende en negentiende eeuw (Hilversum 2004).

Gales, B.P.A., 'Himmel, Hergot, Sakremint! Nomdedju! Kool in de roetsj! Het begin van wetenschappelijk bedrijfsbeheer in de Limurgse mijnbouw in de jaren twintig', Jaarboek voor de Geschiedenis van Bedriifen Techniek X (1993) I6I-2I5.

Gales, B.P.A., 'Mijnbouw', Geschiedenis van de techniek in Nederland in de negentiende eeuw. De wording van een moderne samenleving IV (Zutphen I993) I3-35.

Gales, B.P.A., H. van den Hoogen, G. Legebeke en J. de Roos, Bedriffsvoering, arbeidsverhoudingen in de Limburgse mijnen, 1920-1940 (doctoraalscripties Katholieke Universiteit, Nijmegen z.j.)

Gales, B.P.A. en E.J.G. van Royen, 'De fabrikanten van de geschiedenis. Sociaal-economische geschiedschrijving en Limburg', Publications de la Sociéte Historique et Archéologique dans le Limbourg CXXV (I989) I26-I83.

Gales, B.P.A. en J.P. Smits, 'Een Nederlands scheppingsverhaal', Techniek in Nederland in de twintigste eeuw. II: Delfstoffen, Energie, Chemie (Zutphen 2000) 29-43.

Gales, B.P.A., J.P. Smits en R. Bisscheroux, 'Steenkolen', Techniek in Nederland in de twintigste eeuw. II: Delfstoffen, Energie, Chemie (Zutphen 2000) 45-65.

Gargas, Sigismund, 'Die niederländische Auswanderung', Economisch-Historisch Jaarboek XIV (I928) I79-28I.

Garibaldi, Pietro, Personnel economics in imperfect labour markets (Oxford 2006).

Gemmeke, Ch., Maastricht. Een bijdrage aan de demografisch-historische studie in het byzonder over de periode 1830-1930 (Leuven 196r).

Gielen, Bart, In belang van het mijnbedrijf? Een onderzoek naar het functioneren van de Geneeskundige Dienst der Nederlandse Steenkolenmijnen en de rol van hoofdmijnarts A.H. Vossenaar, 1918-1939 (doctoraalscriptie, Amsterdam 2003).

Gielen, Bart, “ "Sjtub”. Hoofdmijnarts Vossenaar en stoflongen als beroepsziekte', Skript historisch tijdschrift XXV nummer 3 (2003) 5-I9.

Gillissen, J.M.A.G., De invloed van de Staatsmijnen in Limburg op de ontwikkeling van het locale personenvervoer en op de woningbouw in de mijnstreek tot negentien honderd en veertig (kandidaatsscriptie, z.p. z.j.).

Goddeeris, Idesbald, De Poolse migratie in België 1945-1950. Politieke mobilisatie en sociale differentiatie (Amsterdam 2005).

Goedings, Simone, 'Echtgenotes, mijnarbeiders, au-pairs en soldaten. De pionnen op het Europese schaakbord. Gender en de Europese migratieonderhandelingen, I950-I968', Tijdschrift voor Sociale en Economische Geschiedenis V nummer I (2008) 49-74.

Goedings, Simone, Labor migration in an integrating Europe: national migration policies and the free movement of workers, 1950-1968 (Den Haag 2006). 
Green, Nancy L., 'The comparative method and poststructural structuralism: new perspectives for migration studies', in: Jan Lucassen en Leo Lucassen (ed.), Migration, migration history, history. Old paradigms and new perspectives (Bern etc 1999) 57-72.

Grond, A., 'Onze kolen, waar ze liggen en hoe ze ontstonden', Steenkool (1947) 5I-53.

Grond, A., 'Over kolenvoorraad, gemiddelde laagdikte en nog wat', Steenkool (I946) I52-I53.

Haegendoorn, Mieke van en Bart Pluymers, 'Belgisch-Limburgse mijnwerkers in de jaren twintig. Willige slachtoffers van het kapitaal of een blauwe-maandag compagnie?', Tijdschrift voor Sociale Geschiedenis XXIV (1998) 3I-55.

Hamaker, H.G., Arbeidsmarkt en personeelvoorziening (Alphen aan den Rijn/Brussel $1978^{2}$ ).

Hatton, Timothy J. en Jeffrey G. Williamson, 'International migration and labor market organisation in the nineteenth and twentieth centuries', in: Jeffrey G. Williamson en Timothy J. Hatton (ed.), International labour market integration and the impact of migration on national labour markets since 1870 (Milaan 1994) 7-I6.

Helfer, Malte, 'Meilensteine technischer Innovationen und ihre räumlichen Auswirkungen im Steinkohlenbergbau der Nachkriegszeit. Eine vergleichende Betrachtung der Reviere Saar, Lothringen, Aachen, Wallonien und Campine', in: Hans-Walter Herrmann en Paul Wynants (ed.), Acht Jahrhunderte Steinkohlenbergbau / Huit siècles du Charbonnage (Namen 2002) 403-425.

Herbert, Ulrich, Geschichte der Ausländerpolitik in Deutschland. Saisonarbeiter, Zwangsarbeiter, Gastarbeiter, Flüchtlinge (München 200I).

Heringa, J., D.P. Blok, M.G. Buist en H.T. Waterbolk (ed.), Geschiedenis van Drenthe (Meppel/Amsterdam I985).

Hermens, Piet, Buitenlandse arbeiders in het Zuid-Limburgse kolendistrikt, in het bijzonder de rol van de Duitse arbeiders in de mijnen 1900-1930 (scriptie, z.p. 1983).

Herpers, R.J. e.a., Kerkrade, van dorp naar stad 1816-1998 (Kerkrade I998).

Hoerder, Dirk, 'Segmented macrosystems and networking individuals: the balancing functions of migration processes', in: Jan Lucassen en Leo Lucassen (ed.), Migration, migration history, history. Old paradigms and new perspectives (Bern etc 1999) 73-84.

Hoffius, Rob en Babette Vriend, De geschiedenis van de openbare arbeidsbemiddeling in Nederland (afstudeerscriptie Sociale en Organisatiepsychologie, Leiden 1987 ).

Hofstee, E.W., Korte demografische geschiedenis van Nederland van 1800 tot heden (Haarlem I98I).

Homburg, Ernst, Groeien door kunstmest. DSM Agro 1929-2004 (Hilversum 2004).

Hoof, Jacques van, De arbeidsmarkt als arena. Arbeidsmarktproblemen in sociologisch perspectief (Amsterdam I987).

Iterson, F.K.Th. van, 'Woningbouw in verband met steenkolenontginning bij de Staatsmijnen te Heerlen', De Ingenieur XXXIV nummer 2 (I9I9) I7-I9.

Jaarverslag Algemeen Mijnwerkersfonds van de Steenkolenmijnen in Limburg over [1919-1965].

Jaarverslagen Arbeidsbeurs voor de Limburgsche Mijnstreek (1913-1931). Gemeentelijke Arbeidsbeurs Heerlen (1932-

1941) en Gewestelijk Arbeidsbureau Heerlen (1941-1953).

Jaarverslagen van de Districtsarbeidsbeurs Sittard (1928-1939).

Jaarverslagen van de Limburgse RK Werkliedenbond (1910-1931).

Jaarverslagen van den Ingenieur / Hoofd-Ingenieur / Inspecteur-Generaal der Mijnen (1898-1974).

Jaarverslagen van het bedrijf der Staatsmijnen in Limburg [1902-1965].

Jackson, James H., Migration and urbanization in the Ruhr Valley, 1821-1914 (Boston 1997).

Jacobs, Jac., Het gouden boek der K.A.B. Limburg 1900-1950. Vijftig jaren arbeidersbeweging in Limburg (Heerlen 195 I).

Jacobson, Joyce P. en Gilbert L. Skillman, Labor markets and employment relationships. A comprehensive approach (Malden/Oxford/Carlton 2004). 
Jansen, J.C.G.M., 'De armoedigste provincie des rijks (I820-I940)', Maaslandse Mélange. Opstellen over Limburgs verleden, Dr. P.J.H. Ubachs aangeboden bij gelegenheid van zijn vijfenzestigste verjaardag (Maastricht I990) I49-I60.

Jansen, J.C.G.M., 'Economische geschiedenis van Limburg, I800-1990', Studies over de sociaal-economische geschiedenis van Limburg XLII (1997) I5-89.

Jansen, J.C.G.M., 'Industrie en mijnbouw in de beide Limburgen van I839-1989', Eenheid en scheiding van de beide Limburgen. Verslagbundel van het op 26 mei 1989 te Alden Biesen gehouden congres bij gelegenheid van de herdenking 150 jaar beide Limburgen (Leeuwarden/Maastricht 1989) I3-67.

Jansen, J.C.G.M., 'Specifieke kenmerken van de Limburgse economie', Studies over de sociaal-economische geschiedenis van Limburg XXX (1985) 56-89.

Jansen, J.C.G.M., 'Wisselende perspectieven van grensligging in de geschiedenis van de Euregio Maas-Rijn', Studies over de sociaal-economische geschiedenis van Limburg XLII (1997) I-I4.

Jansen, J.C.G.M. en W.J.M.J. Rutten, Geschiedenis van de landbouw in Limburg in de twintigste eeuw (Leeuwarden/Mechelen I992).

Janssen, J.H.M., 'Van lokale markt tot internationale handel. De commercialisatie van de landbouw in Heythuysen, I850-I9I4', Studies over de sociaal-economische geschiedenis van Limburg XXXIII (1988) 6299.

Jenniskens, A.H., Het spoor. Honderdvijftig jaar spoorweggeschiedenis Maastricht (Maastricht 1985).

Jubileumboek uitgegeven ter gelegenheid van het 25-jarig bestaan der RK Werkliedenvereeniging in Heerlen 19051930 (z.p. z.j.).

Kemp, M. (ed.), Mijn en spoor in goud (Maastricht 1952).

Kistermann, A.H.M., 'Het Miljoenenlijntje', Historische en Heemkundige Studies in en rond het Geuldal. Jaarboek 1994 (Valkenburg aan de Geul I994) I80-I97.

Klank, Kristin, 'Secondary labour force or permanent staff?', Tijdschrift voor Sociale en Economische Geschiedenis V nummer 3 (2008) I26-I54.

Klemann, Hein A.M., Nederland 1938-1948. Economie en samenleving in jaren van oorlog en bezetting (Amsterdam 2002).

Knotter, Ad, Economische transformatie en stedelijke arbeidsmarkt. Amsterdam in de tweede helft van de negentiende eeuw (Zwolle/Amsterdam 199I).

Knotter, Ad, 'Grenzen aan de loonpolitiek. De langzaam-aan-actie van de Nederlandse Katholieke Mijnwerkers Bond (1957) tussen nationale integratie, grensligging en katholiek regionalisme', Studies over de sociaal-economische geschiedenis van Limburg LIII (2008) II7-I57.

Knotter, Ad, 'Inleiding. Arbeidsmigranten en grensarbeiders. Vergelijkende perspectieven op de mijnarbeidsmarkten in het Belgisch-Duits-Nederlandse grensgebied in de twintigste eeuw', Tijdschrift voor Sociale en Economische Geschiedenis V nummer 3 (2008) 2-29.

Knotter, Ad, 'Paradoxen van de grens. Ongelijke ontwikkeling, grensoverschrijdende mobiliteit en de vergelijkende geschiedenis van de Euregio Maas-Rijn', Studies over de sociaal-economische geschiedenis van Limburg XLVI (200I) I59-I74.

Kösters-Kraft, Michael, Großbaustelle und Arbeitswanderung. Niederländer beim Bau des Dortmund-Ems-Kanals 1892-1900 (Osnabrück 2000).

Kok, Jan, Ad Knotter, Richard Paping en Eric Vanhaute, Levensloop en levenslot. Arbeidsstrategieën van gezinnen in de negentiende en twintigste eeuw (Groningen/Wageningen 1999).

Korres, Achim, 'Arbeitsmigration in der Euregio Maas - Rhein im I9. und 20. Jahrhundert. Problemstellungen und Ergebnisse eines Forschungsprojektes', Interregiones Io (200I) I5-6I.

Korres, Achim, 'Historische interacties in de Euregio Maas-Rijn: migratiestromen in een grensgebied', Studies over de sociaal-economische geschiedenis van Limburg XLVI (2002) 7-26.

Korres, Achim, 'Paspoortregime en migratie in het Duits-Nederlandse grensgebied in de negentien- 
de en twintigste eeuw tot ca 1940', Studies over de sociaal-economische geschiedenis van Limburg LI (2006) I07-I34.

Korsten, J., Standhouden door veranderingen. De Limburgse Land-en Tuinbouwbond als behartiger van agrarische belangen, 1896-1996 (Nijmegen 1996).

Kreukels, L.H.M., Mijnarbeid: volgzaamheid en strijdbaarheid. Geschiedenis van de arbeidsverhoudingen in de Nederlandse steenkolenmijnen (Assen/Maastricht I986).

Kreukels, Loek, Kolen en kompels. De geschiedenis van de Nederlandse mijnwerkers (Amsterdam/Brussel I986).

Kreukels, Loek, 'De mijnkolonie', Weet je nog koempel? De mijnen in Limburg deel I3 (Zwolle 2004) 297320.

Kreukels, Loek, 'Vreemd gespuis. Buitenlanders in de Limburgse mijnen', in: Anne Frank Stichting (ed.), Vreemd gespuis (Amsterdam I987) 66-76.

Krutzen, Marcel, 'Over strafkampen voor "foute Nederlanders" en het mijnkamp Julia te Eygelshoven [1947-I957]', Het Land van Herle LX nummer 4 (2010) I47-I62.

Kusters, Johan, De tocht der duizenden; Maaslandse brikkenbakkers naar Duitsland 1840-1914 (Eisden I998). Kusters, Wiel en Jos Perry, Versteende wouden. Mijnen en mijnwerkers in woord en beeld (Amsterdam 1999).

Lange, Tesseltje de, Staat, markt en migrant. De regulering van arbeidsmigratie naar Nederland 1945-2006 (z.p. 2007).

Langeweg, Serge, 'I mei I902: Het begin van Staatsmijnen', De kleine geschiedenis van Limburg in 25 dagen, dag 16 (Zwolle 2009) 4-13.

Langeweg, Serge, 'Aanvragen voor nationaliteitsbewijzen als bron voor migratieonderzoek', Nieuwsbrief Rijksarchief in Limburg VI nummer I (2002) 4.

Langeweg, Serge, 'Begin en einde van beleid: de staatsmijnen in Limburg', Openbaar Bestuur, Tijdschrift voor beleid, organisatie en politiek XIV nummer Io (2004) II-I4.

Langeweg, Serge, 'Bekende buren en verre vreemden. Buitenlandse arbeiders in de Nederlandse steenkolenmijnen, Igoo-I974', Tijdschrift voor Sociale en Economische Geschiedenis V nummer 3 (2008) 53-79.

Langeweg, Serge, 'Immigranten', Weet je nog koempel? De mijnen in Limburg deel 9 (Zwolle 2004) 20I224.

Langeweg, Serge, 'Integratie en identiteit van de Polen in de Limburgse mijngebieden: een vergelijking', Brunssumse Geschiedenissen III (Brunssum 2007) 57-72.

Langeweg, Serge, 'Mijnen, mijnwerkers en migranten. Buitenlandse arbeiders in de Nederlandse steenkolenmijnen', Het Land van Herle LIX aflevering 3-4 (2009) 97-III.

Langeweg, Serge, 'Trekarbeiders en pendelaars. Grensarbeid in oostelijk Zuid-Limburg, I875-19I4', Zestig jaar vorsen in de geschiedenis. Jubileumboek Het Land van Herle 1945-2005 (Heerlen 2006) 295-308.

Langeweg, Serge, Van Adreskantoor tot Arbeidsvoorziening; Arbeidsbemiddeling en arbeidsmarkt in Zuid-Limburg, 1904-1994 (Leeuwarden/Mechelen 1994).

Langeweg, Serge, 'Werken over de grens: Limburgers naar Duitsland, I870-I9I4', Studies over de sociaaleconomische geschiedenis van Limburg XLVII (2002), 27-48.

Langeweg, Serge, 'Ziel Deutschland: Grenzarbeit und Arbeitsmigration aus dem Niederländischen Limburg nach Deutschland I870-I9I4', Interregiones io (2001) 63-79.

Langeweg, Serge en Erwin Steegen, 'Het bereik van de mijn. Ruimtelijke aspecten van de arbeidsmarkt voor mijnwerkers in Limburg, I900-I960', Publications de la Société Historique et Archéologique dans le Limbourg, Jaarboek 2008 (z.p. 2009) 159-200.

Langeweg, Serge en Leen Roels, 'Buitenlandse arbeiders in de steenkolenmijnen van Luik en Nederlands-Limburg in de twintigste eeuw: een vergelijking', Studies over de sociaal-economische geschiedenis van Limburg LIII (2008) 88-II5.

Langeweg, Serge, Leen Roels en Ad Knotter, 'Regional labour markets and international labour migration in twentieth-century Europe: the cases of coal mining in Liège (B) and Limburg (NL) com- 
pared', Mitteilungsblatt des Instituts für soziale Bewegungen. Forschungen und Forschungsberichte 40 (2008) IOI-I2O.

Laugs, J., De tewerkstelling van geïnterneerde Belgische militairen in de Limburgse Mijnstreek 1915-1918 (doctoraal scriptie Katholieke Universiteit, Nijmegen 1988).

Leboutte, René, 'Coal mining, foreign workers and mine safety: steps towards European integration, I946-85', in: Stefan Berger, Andy Croll en Norman Laporte (ed.), Towards a comparative history of coalfield societies (Aldershot/Burlington 2005) 219-237.

Leideritz, W.J.M., Trams en tramlijnen. De stoomtram van Noord-Brabant en Limburg (Rotterdam 1972).

Leiner, Stefan, 'Wanderungsbewegungen im Saarländisch-Lothringisch-Luxemburgischen Grenzraum I856-I9I4', in: René Leboutte en Jean-Paul Lehners (ed.), Passé et avenir des bassins industriels en Europe (Luxemburg z.j.) I2I-I38.

Linde, Wim van der, 'Migratie van Nederlanders via het Ruhrgebied naar Zuid-Limburg', Tijdschrift Heemkundevereniging Geleen 3 (2007) 35-60.

Linde, Wim van der, 'De naoorlogse zuiveringen in het mijnbedrijf als reactie op sociale en religieuze tegenstellingen', Studies over de sociaal- economische geschiedenis van Limburg XLIX (2004) I9I-2I3.

Lucassen, Jan en Leo Lucassen, 'Migration, Migration History, History: Old paradigms and new perspectives', in: Jan Lucassen en Leo Lucassen (ed.), Migration, Migration History, History: Old paradigms and new perspectives (Bern etc. 1999) 9-38.

Lucassen, Jan en Rinus Penninx, Nieuwkomers, nakomelingen, Nederlanders. Immigranten in Nederland 15501993 (Amsterdam $1999^{3}$ ).

Lucassen, Leo, 'Agent of koopman? Theorie en praktijk van de controle op arbeidsmigratie in Nederland, I918-1980', in: Marjolein 't Hart, Jan Lucassen en Henk Schmal (ed.), Nieuwe Nederlanders. Vestiging van migranten door de eeuwen heen (Amsterdam 1996) I5I-I68.

Lucassen, Leo, 'A many-headed monster: The evolution of the passport system in the Netherlands and Germany in the long nineteenth century', in: John Torpey en Jane Caplan (ed.), Documenting individual identity: the development of state practices in the modern world (Princeton en Oxford 200I) 125-253.

Lucassen, Leo en Jan Lucassen, Winnaars en verliezers; Een nuchtere balans van vijfhonderd jaar immigratie (Amsterdam 20II).

Lucassen, Leo en Floris Vermeulen, Immigranten en lokale arbeidsmarkt. Vreemdelingen in Den Haag, Leiden, Deventer en Alkmaar (1920-1940) (Amsterdam 1999).

Mallmann, Klaus-Michael, Lohn der Mühen. Geschichte der Bergarbeiter an der Saar (München 1989).

Manning, Patrick, Migration in world history (New York en London 2005).

Mensink, J., De kolenvoorziening van Nederland tijdens den tweeden wereldoorlog (Amsterdam I946).

Messing, F.A.M., Geschiedenis van de mijnsluiting in Limburg. Noodzaak en lotgevallen van een regionale herstructurering, 1955-1975 (Leiden 1988).

Minten, Luc e.a., Een eeuw steenkool in Limburg (Tielt 1992).

Moch, Leslie Page, Moving Europeans. Migration in western Europe since 1650 (Bloomington/Indianapolis 1992 ).

Moonen, W., Brunssum de eeuwen door (z.p. 1952).

Moritz, H., Marokkaanse gastarbeiders bij mijnen Laura en Julia (scriptie Sociale Akademie, Sittard z.j.)

Müller, Friedrich (ed.), Grosses Deutsches Ortsbuch (Barmen $1927^{4}$ ).

Müller, Thomas, 'Dwangarbeid aan de grens. Regionale aspecten van de dwangarbeid in het grensgebied bij Aken in de nazi-tijd', Studies over de sociaal-economische geschiedenis van Limburg XLVII (2002) 49-6o.

Mulders, Milena, Met de buik het brood achterna. Mijn Sloveense geschiedenis (Amsterdam 2009).

Mulders, Milena, 'Sloveense migranten in de Limburgse mijnstreek: verenigingsleven en internationale politiek', Studies over de sociaal-economische geschiedenis van Limburg LIV (2009) 7I-Ioo. 
Muntjewerff, H., 'Waterinfusie in de Nederlandse steenkolenmijnen (1945-I974)', Erfgoed van Industrie en Techniek V, nummer 2 (1996) 56-64.

Nederlander in Duitschland, De (I909-1912).

Nijhof, Erik, 'Bespreking van L. Kreukels, Mijnarbeid en strijdbaarheid. Geschiedenis van de arbeidsverhoudingen in de Nederlandse steenkolenmijnen, I900-I940 (Assen/Maastricht I986)', Tijdschrift voor Sociale Geschiedenis XVI (I990) 94-96.

Nijhof, Erik, Jan Boersma en Gertjan de Groot, 'Regions in transition. An interregional comparison of industrialization, labour market and labour movement in the Netherlands', Tijdschrift voor Sociale Geschiedenis XVIII nummer 2/3 (I992) 294-3II.

Noordegraaf, Leo, 'Arbeid en arbeidsmarkt. Recent onderzoek in historiografisch perspectief', Tijdschrift voor Sociale Geschiedenis XIII (november 1987) 357-372.

Obdeijn, Herman en Marlou Schrover, Komen en gaan. Immigratie en emigratie in Nederland vanaf 1550 (Amsterdam 2008).

Offermans, Joep, De abdij Kloosterrade - Rolduc (1104-1830) (Rotterdam 2003).

Ontstaan en huidige functie van de Geneeskundige Dienst der Nederlandse Steenkolenmijnen (z.p. z.j.).

Oomens, C.A. en G.P. den Bakker, 'De beroepsbevolking in Nederland I849-I99o', Supplement bij de sociaal-economische maandstatistiek (1994-2) 3-42.

Oranje-Nassau Groep. Jubileumuitgave 1893-1993 (Amsterdam z.j.).

Oranje-Nassau Post. Sluitingsnummer: Mijnzetel Oranje-Nassau I en centrale bovengrondse bedrijuen van de Oranje-Nassau mijnen (I974).

Os, Geertje van, Ik kwam met een koffer van karton. Spanjaarden in Zuidoost-Brabant 1961-2006 (Alphen aan de Maas 2006).

Overhage, P. Paul, Heerlen. Der städtische Mittelpunkt des südlimburgischen Bergbaugebietes. Landschaft-, Wirtschafts-, Bevölkerungs- und Siedlungsbild (Hamburg 1939).

Panhuysen, M.P.G., 'Vruchtbaarheid en mijnarbeid. Een gezinsreconstructie te Heerlen I87I-I9I6', Studies over de sociaal-economische geschiedenis van Limburg XXVII (I992) 7I-I27.

Pater, Ben de, 'Nederlanders naar en in het Ruhrgebied', in: Kinie Hoogers, Jaap Hoogeveen en Roel Visser (ed.), 100 Jaar Nederlandse Kerk in Duitsland (Duisburg-Ruhrort 2002) 17-28.

Peet, Jan en Willibrord Rutten, Oranje-Nassau Mijnen. Een pionier in de Nederlandse steenkolenmijnbouw 1893-1974 (Zwolle 2009).

Perry, Jos, 'Jubeljaren. Staatsmijnen weerspiegeld in vier jubilea', Publications de la Société Historique et Archéologique dans le Limbourg CXXXIV-CXXXV (I998-I999) 7-84.

Perry, Jos, 'Limburg en de mijn: een bekering', Het Land van Herle LIX aflevering 3-4 (2009) I25-I34.

Perry, Jos, 'Limburg kolenland. Een collage van oud en nieuw', Studies over de sociaal-economische geschiedenis van Limburg XLV (2000) 65-78.

Perry, Jos, 'Van vader op zoon', in: Wiel Kusters en Jos Perry, Versteende wouden. Mijnen en mijnwerkers in woord en beeld (Amsterdam I999) 83-96.

Philips, J.F.R., J.C.G.M. Jansen en Th.J.A.H. Claessens, Geschiedenis van de landbouw in Limburg 17501914 (Assen 1965).

Pierenkemper, Toni, 'Historische Arbeitsmarktforschung. Vorüberlegungen zu einem Forschungsprogramm', in: Toni Pierenkemper en Richard Tilly, Historische Arbeitsmarktforschung. Entstehung, Entwicklung und Probleme der Vermarktung von Arbeitskraft (Göttingen I982) 9-36.

Pieters, J.M.G., Lonen en bedrijfsresultaten bij de Nederlandse steenkolenmijnondernemingen in de Gemeenschappelijke Steenkolenmarkt van de EGKS (proefschrift, Rotterdam I98I).

Pluymers, Bart, De Limburgse mijnwerkers (1917-1939). Ontstaan en consolidatie van de arbeidsmarkt voor mijnarbeid (Diepenbeek z.j.).

Poels, H.A., 'Tijdig', Een zestal redevoeringen (z.p. z.j.) 23-69. 
Raedts, C.E.P.M., 'De eerste zestig jaren van het bestaan der Oranje Nassau Mijnen', Mijnennummer 1954 (z.p. z.j.) 3-23.

Raedts, C.E.P.M., De opkomst, de ontwikkeling en de neergang van de steenkolenmijnbouw in Limburg (Assen 1974).

Raedts, C.E.P.M., 'Het mijnwerkersverzet tijdens de Tweede Wereldoorlog', Studies over de sociaal-economische geschiedenis van Limburg XXIV (I979) I-23.

Raedts, C.E.P.M., 'Van een moeilijk begin naar volle ontplooiing', Oranje-Nassau Post. Sluitingsnummer mijnzetel Oranje-Nassau I (Heerlen 1974) 7-I8.

Rapport van de Commissie Verhoging Kolenproductie (z.p. z.j).

Rapport van de Commissie voor de Mijnen, ingesteld bij Koninklijk Besluit van 17 April 1899, no. 50 (z.p. augustus 1900).

Rapport van de Staatscommissie ingesteld bij Koninklijk Besluit van 26 november 1946 no 1. Deel I en II ('s-Gravenhage 1948).

Rapport van een onderzoek naar de aanpassing van immigranten (z.p. 1956).

Rapporten en voorstellen betreffende den oeconomischen toestand der landarbeiders in Nederland ('s-Gravenhage I908).

Rass, Christoph, Institutionalisierungsprozesse auf einem internationalen Arbeitsmarkt: Bilaterale Wanderungsverträge in Europa zwischen 1919 und 1974 (Paderborn/München/Wenen/Zürich 2010).

Reumkens, P.J.M., Een onderzoek naar het verloop van mijnwerkers werkzaam bij de Oranje-Nassau mijnen (z.p. I958).

Ritt, A.J., Statistische gegevens opleiding leesjongens (z.p. I962).

Roels, Leen, Arbeidsverloop en geografische mobiliteit (manuscript, z.p. 2010).

Roels, Leen, 'Buitenlandse arbeiders in de Luikse steenkolenmijnen, I900-I974', Tijdschrift voor Sociale en Economische Geschiedenis V nummer 3 (2008) I04-I25.

Roels, Leen, Où sont les mineurs belges? Het probleem van het arbeidstekort in de Luikse mijnen tijdens en na de Tweede Wereldoorlog (manuscript, z.p. 2009).

Roemen, H.C.W. e.a., Verkenning omtrent het huidige en toekomstige personeelsuraagstuk van de mijnbouw in Nederlands Limburg (Luxemburg 1957).

Römkens, H., Problemen bij tewerkstelling van buitenlandse arbeiders (scriptie Sociale Academie, Sittard I965).

Roodt, Evelyn de, Oorlogsgasten. Vluchtelingen en krijgsgevangenen in Nederland tijdens de Eerste Wereldoorlog (Zaltbommel 2000).

Rooij, Arjan van, Building plants: markets for technology and internal capabilities in DSM's fertiliser business, 1925-1970 (Amsterdam 2004).

Royen, E.J.G. van, 'Beheersaspecten in het huisvestingsbeleid van mijnondernemingen en roomska-

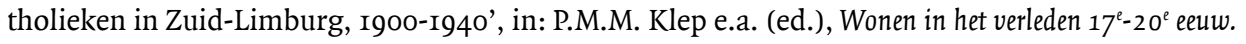
Economie, politiek, volkshuisvesting, cultuur en bibliografie (Amsterdam I987) 8I-94.

Rutten, Willibrord, 'Alsof de taalgrens niet bestond. Limburgse kompels in de Luikse kolenmijnen na de Tweede Wereldoorlog', Het Land van Herle LIX aflevering 3-4 (2009) II4-I24.

Rutten, Willibrord, 'Bevolking, gezondheid en levensstandaard in Limburg in de negentiende eeuw: een overzicht', Studies over de sociaal-economische geschiedenis van Limburg XLIII (I998) I-36.

Rutten, Willibrord, 'Buitenbeentjes. Nederlandse kompels in de Luikse kolenmijnen na de Tweede Wereldoorlog'. Concept (2010). Te verschijnen in Studies over de sociaal-economische geschiedenis van Limburg LVI (20II).

Rutten, Willibrord, 'Russen niet gewenst: de mislukte inzet van Russische dwangarbeiders in de Nederlandse steenkoolmijnen in de Tweede Wereldoorlog', Studies over de sociaal-economische geschiedenis van Limburg XLIX (2004) I65-Igo. 
Rutten, Willibrord, 'Werken over de grens', Weet je nog, koempel? De mijnen in Limburg deel i9 (Zwolle 2005) 44I-464.

Scherdin, Georg, Die Verbreitung der hochdeutschen Schriftsprache in Süd-Limburg. Beiträge zur kulturellen Entwicklungsgeschichte einer deutsch-niederländischen Grenzlandschaft (Berlijn I937).

Schrover, Marlou, Judith ten Broeke en Ronald Rommes, Migranten bij de Demka-staalfabrieken in Utrecht (1915-1983) (Utrecht 2008).

Schunder, Friedrich, Geschichte des Aachener Steinkohlenbergbaus (Essen I968).

Segers, J.H.G., Het personeelsverloop in het ondergronds mijnbedrij: methoden en resultaten (Tilburg 1968).

Sijes, B.A., De Arbeidsinzet. De gedwongen arbeid van Nederlanders in Duitsland, 1940-1945 ('s-Gravenhage $\left(1990^{2}\right)$.

Sillekens, J.Th., De Limburgse arbeidsmarkt na de tweede wereldoorlog (doctoraalscriptie, Nijmegen 1974).

Sintermaartensdijk, Jan en Yfke Nijland, Operatie Black Tulip. De uitzetting van Duitse burgers na de oorlog (Amsterdam 2009).

Sipman, W., 'Agrarische problemen in de gemeente Stein', Tijdschrift voor Economische Geographie XXXIV nummer II (I943) I62-I65.

Slangen, L.J., 'Van pijlerbouw tot wandelpijler', Oranje-Nassau Post. Sluitingsnummer mijnzetel Oranje-Nassau I (Heerlen i974) 57-88.

Solow, Robert M., The labor market as a social institution (Cambridge Massachusetts I990).

Staatscommissie over de Werkloosheid Deel IX Eindverslag ('s-Gravenhage 19I4).

Staatsmijnen in Limburg: Gedenkboek bij gelegenheid van het vijftigjarig bestaan (Heerlen I952).

Steenkool: bedrijfstijdschrift van de Nederlandse steenkolenmijnen (I946-I955).

Stokvis, P.R.D., 'Nederland en de internationale migratie, I8I5-I960', in: F.L. van Holthoon (ed.), De Nederlandse samenleving sinds 1815. Wording en samenhang (Assen/Maastricht I985) 7I-92.

Strijkers, Harry, Van sociaal pionier tot cultuursponsor. Kroniek Fonds voor Sociale Instellingen 1918-2008 (Geleen 2009).

Tabellen en grafieken Mijnindustrieraad / Bedrijfschap voor de Steenkolenmijnindustrie (1949-1965).

Taylor, Andrew, 'So many cases but so little comparison: problems of comparing mineworkers', in: Stefan Berger, Andy Croll, Norman Laporte (ed.), Towards a comparative history of coalfield societies (Aldershot/Burlington 2005) I2-28.

Tenfelde, Klaus, Sozialgeschichte der Bergarbeiterschaft an der Ruhr im 19. Jahrhundert (Bonn/Bad Godesberg 1977).

Tenfelde, Klaus (ed.), Towards a social history of mining in the 19th and 2oth centuries / Sozialgeschichte des Bergbaus im 19. und 20 Jahrhundert. Papers presented to the International History Congress Bochum, Federal Republic of Germany September $3^{\text {rd }}-7^{\text {th }}, 1989$ / Beiträge des Internationalen Kongresses zur Bergbaugeschichte Bochum, Bundesrepublik Deutschland, 3.-7. September 1989 (München 1992).

Teulings, Ad, Philips. Geschiedenis en praktijk van een wereldconcern (Amsterdam 1977).

Tilly, Louise A., 'Coping with company paternalism. Family strategies of coal miners in nineteenthcentury France', Theory and Society vol. I4, no. 4 (july i985) 403-4I7.

Tilly, Richard H., 'Märkte-Mächte-Arbeit; Beiträge zur Arbeitsmarktforschung', in: Toni Pierenkemper en Richard Tilly (ed.), Historische Arbeitsmarktforschng; Entstehung, Entwicklung und Probleme der Vermarktung von Arbeitskraft (Göttingen I982) 277-288.

Tinnemans, Will, Een gouden armband: Een geschiedenis van mediterrane immigranten in Nederland (19451994) (Utrecht 1994).

Uitkomsten van het onderzoek naar den toestand van den landbouw in Nederland, ingesteld door de Landbouwcommissie, benoemd bij Koninklijk Besluit van 18 September 1886, no. 28 ('s-Gravenhage I89o).

Van 1810 Administration des Mines tot 1960 Staatstoezicht op de Mijnen. Bijlage bij het Verslag van de InspecteurGeneraal der Mijnen over het jaar 1959. 
Vergaderingen Contact-Commissie 1917-1941 (z.p. z.j.).

Vermeeren, Linda, Vuur joonge noa Oche. Aken als aantrekkingsgebied voor Vaalser arbeidsmigranten, 18701914 (eindscriptie FdCW UM, Maastricht 2002).

'Verordening betreffende de werving en tewerkstelling van mijnpersoneel', Verordeningenblad Bedrijfsorganisatie 10/1963.

Verslag betreffende den toestand der landarbeiders in Limburg ('s-Gravenhage I9o8).

Verslag van de Commissie, ingesteld bij beschikking van den minister van landbouw, nijverheid en handel van 4 april 1916 no 2751, afdeeling nijverheid, tot het uitbrengen van advies over de wijze, waarop een algemeen mijnwerkersfonds zal kunnen worden tot stand gebracht ('s-Gravenhage I9I8).

Verslag van de Commissie, inzake den aanleg en de exploitatie van tramwegen, in verband met de ontwikkeling van de mijnexploitatie in Zuid-Limburg (Heerlen z.j.).

Verslag van de Gezamenlijke Steenkolenmijnen in Limburg aan de Mijnindustrieraad betreffende de economische gang van zaken in het jaar [1954-1965].

Versteegh, A.P., De onvermijdelijke afkomst? De opname van Polen in het Duits, Belgisch en Nederlands mijnbedrijf in de periode 1920-1930 (Hilversum I994).

Vianen, Theod. C., Bevolkingstoestanden in het Zuid-Limburgsche Kolenrevier (Nieuwe Limburger Koerier, Heerlen igo8).

Vogel, Jaap, Nabije vreemden. Een eeuw wonen en samenleven (Den Haag 2005).

Vrancken, P.C.M., De pendel naar Duitsland vanuit de Oostelijke Mijnstreek tegen de achtergrond van de werkgelegenheid 1958-1968 (kandidaatsscriptie, Nijmegen z.j.).

Vries, Hille de, 'Enkele aspecten van de agrarische arbeidsmarkt in Nederland, I850-I900', Economisch-en Sociaal-Historisch Jaarboek 47 (I984) I05-I2I.

Vromen, G.C.M., De Limburgse mijnen en hun mijnwerkers 1900-1939. De opbouw van een stabiel arbeidersbestand (doctoraalscriptie, Leiden I986).

Vromen, G.C.M., 'Personeelsbeleid bij de Nederlandse mijnen tijdens de jaren dertig', Studies over de sociaal-economische geschiedenis van Limburg XXXII (I987) 27-79.

Wachelder, J., 'Het geboorte-overschot in Limburg in de laatste eeuw', Jaarboek Sociaal Historisch Centrum voor Limburg II (Maastricht 1956) 65-97.

Wachelder, J., 'De migratie in Limburg in de laatste eeuw', Jaarboek Sociaal Historisch Centrum voor Limburg III (Maastricht I957) 98-2I2.

Wachelder, J., 'Enige aspecten van de historisch-demografische ontwikkeling van Limburg', Studies over de sociaal-economische geschiedenis van Limburg V (1960) 45-I35.

Wachelder, J., 'Het geboorteniveau in Limburg', Studies over de sociaal-economische geschiedenis van Limburg VI (I962) 2I-IO2.

Wachelder, J., 'De gemiddelde grootte van het gezin en het huishouden in Limburg vanaf 1829 tot I96o en de indeling der bevolking naar de wijze van samenwoning van I879 tot I960', Studies over de sociaal-economische geschiedenis van Limburg IX (I964) I43-I80.

Waterschoot van der Gracht, [W.A.J.M. van], 'De Limburgsche steenkolenmijnindustrie gedurende de laatste 40 jaar', Veertig jaren spoor en mijnen in Zuid-Limburg, 1896-1936 (Heerlen 1936) 76-88.

Wehler, Hans-Ulrich, 'Die Polen im Ruhrgebiet bis I9ı'', in: Hans-Ulrich Wehler (ed.), Moderne deutsche Sozialgeschichte (Keulen/Berlijn I966) 437-455.

Wennemann, Adolf, Arbeit im Norden; Italiener im Rheinland und Westfalen des späten 19. und frühen 20. Jahrhunderts (Osnabrück 1997).

Wereld van groei. Ontstaan en uitbreiding van het Staatsmijnbedrijf in zijn verschillende geledingen (z.p. 1962).

Williams, Chris, Capitalism, community and conflict. The South Wales coalfield, 1898-1947 (Cardiff 1998).

Williamson, Jeffrey G. en Timothy J. Hatton (ed.), International labour market integration and the impact of migration on national labour markets since 1870 (Milaan 1994). 
Wojciechowski, Franciszek, 'Zij kwamen van ver. Towarzystwo Sw. Wojciecha w Heerlen I9Io-2oro. De geschiedenis van de oudste Poolse vereniging in Nederland', Het Land van Herle LX aflevering 3 (2010).

Wojciechowski, Frans, 'Het Poolse Huis in Brunssum I937-2002. 65 jaar brandpunt van Pools Verenigingsleven in Zuid-Limburg', Brunssumse geschiedenissen (Brunssum 2002) 9-52.

Wojciechowski, Frans, Voor brood en vrijheid. Honderd jaar Polen in Zuid-Limburg 1900-2000 (Heerlen 2000).

Wojtkowiak, Stephan, Je moet weten hoe haas hupt. Herinneringen aan een microkosmos in Limburg (Schinveld 2000).

Wolf, Rob, Mijn ziekenhuis. 100 Jaar ziekenhuiszorg in Parkstad Limburg (Heerlen 2004).

Wolf, Rob, Mijnbouw, techniek en onderwijs: De ondergrondse vakscholen van de Staatsmijnen (doctoraalscriptie, Nijmegen I978).

Wolf, Rob, 'Tussen Delft en Nijmegen. De Ondergrondse Vakscholen van de Staatsmijnen', Het Land van Herle LIX aflevering 3-4 (2009) I35-I46.

Wrigley, E.A., Industrial growth and population change. A regional study of the coalfield areas of north-west Europe in the later nineteenth century (Cambridge 1962).

Zanden, Jan Luiten van, Een klein land in de $20^{\circ}$ eeuw. Economische geschiedenis van Nederland 1914-1995 (Utrecht I997).

Zanden, J.L. van, De economische ontwikkeling van de Nederlandse landbouw in de negentiende eeuw, 1800-1914 (Utrecht I985). 


\section{Summary}

Mining and labour market in the Dutch Province of Limburg. Origin, recruitment, mobility and commitment of miners between 1900 and 1965

\section{A LABOUR MARKET FOR MINERS IN LIMBURG}

This book offers a long term analysis of the labour market for mine workers in the Dutch Province of Limburg. The labour market concept is conceived as sociological phenomenon, with specific attention drawn to strategic behaviour of labour market parties. These strategies result in social processes of transformation, mobility, mobilization, segmentation and regulation. A range of social, economic, cultural, geographic, demographic and judicial factors forms the context in which labour market behaviour of suppliers and demanders takes shape. It is this central idea that makes the labour market a suitable starting point for an integral study of these factors - i.e. in mutual context.

The study's starting point lies around I900, at the time when mining in Limburg rapidly expanded. The Dutch government's announcement of pit closures in December of ${ }^{9} 65$ marks its final point. This era comprises well over six decades and is divided into three periods. The first period runs from I900 to 1930 . During these years mining in Limburg was building up in full force. The exploitation of eleven new mining sites was taken control of. Compared to mines in several other European mining basins the Dutch mining companies were run with sophisticated equipment and operated on a large scale. The expansion led to an increase of employment in the Dutch mining sector, from 6oo men in 1898 to 38,000 in 1930. Mine workers were in even far greater demand than these already impressive figures suggest. Labour turnover during the first three decades was enormous. In general the joint mining companies had to replace more than $40 \%$ of the total number of employees, and particularly before World War I up to almost 90\%.

The regional, provincial and national labour markets failed to meet this demand, qualitatively as well as quantitatively. This forced the mining companies to call upon colliers from abroad in increasing degree. At the end of the year 1920 more than $20 \%$ of the coal miners came from abroad. Ten years later a third of the labour force of the joint mining companies came from a foreign country. Underground in the pits it was most problematic to recruit personnel and $40 \%$ of the miners had foreign nationalities. More than half of these foreigners had the German nationality, but especially in the latter part of the Nineteen Twenties groups of labourers were recruited in Central and Eastern European countries.

The second period is formed by the years of War and Depression, from I93 I to I944. The 
economic decline in the early Thirties caused the labour market to change to the advantage of the mining companies. There was no question of labour shortages anymore. For the first time mining companies could afford to pick and choose colliers. Because of the declining economy there were few alternative jobs for working in the mines and labour turnover dropped drastically. Notwithstanding the massive redundancies in the early Thirties that caused the loss of 9,000 jobs, the labour turnover at the time was at its lowest level. Under the circumstances mining management picked the group most preferred: young labourers with regional Limburg roots. In general this group had the best chance to escape forced redundancy. New labourers were primarily recruited from this group. Through massive redundancies foreign labourers and especially those who were taken on in the late Twenties, footed the bill for the Depression. At the end of 1938 the work force had become considerably more Dutch: a mere $12 \%$ was of foreign nationality.

During World War II mining management was able to continue its personnel policy from the Thirties. German pressure to raise coal productions increased the demand for miners. These new labourers mainly came from Limburg, but working in the coal mines turned out to be an option for labourers from the rest of the Netherlands as well, when working in the Dutch mines could prevent them from being forced into German Arbeitseinsatz. Unlike mining companies in neighbouring Belgium and Germany the boards of directors of the Dutch mines were successful in preventing forced labourers from Eastern Europe being brought into service as mine workers.

The liberation of the mining area in September and October of 1944 immediately led to a vast exodus of miners. Among them labourers who considered working in the mines protected them against forced labour in Germany, young men who preferred to join the army and some who were barred from the mines because of an (alleged) suspicious war record. The last group comprised almost all German coal miners. The steep decline in the number of workers took place when the mines in Limburg were called upon to play the role of energy supplier for the reconstruction of the Dutch economy. This caused employment supply again to operate in a precarious situation. Mining companies were able to enhance the number of personnel by means of recruitment campaigns in Limburg and other parts of the Netherlands, and at times across the border as well, up to 1958. To a larger extent than in the period before 1930 the mines were able to draw from the Dutch and specifically the Limburg labour market. On leaving primary school many boys from mining communities and from other areas as well took the on-the-job collier training the mining companies had expanded after the war, as a first step on the road to a career in coalmining. This relative success could not conceal that from the mid Fifties on the mining industry was regularly faced with severe labour shortages that caused problems in supplying personnel.

The year 1958 marks the beginning of the final years of coal mining in Limburg. The loss of potential markets clearly indicated that Dutch coal had played its part on the energy markets. Petroleum and natural gas had the best possibilities for the future. The declining significance of coal caused a loss of faith in future employment in the mines in Limburg. Structural personnel problems were an important consideration for the Dutch government to announce the closure in stages of the mines in December 1965 . With the closure of the Oranje Nassau I mine nine years later coal mining in Limburg came to an end. 


\section{THE LABOUR SUPPLY: PROBLEMS AND POSSIBILITIES}

Labour supply for mining companies in Limburg was generally defined by its problematic character. The problem was not typical for Limburg mining, being a phenomenon that occurred in mining districts anywhere. The problems were manifold. In the first place there was the nature of mining itself, causing a difficult competitiveness for mining companies on the labour market. Labourers often only considered coal mining jobs when all other employment was lacking or no longer available. Such circumstances were more frequent during World War I and the Depression between I93 I and 1936 and mines subsequently noticed an increase in job interests and declining labour turnover. Conversely mining management had to go to great lengths during times of rising economy and other employment in the latter part of the Twenties and the post War years, in order to find employees on the labour market. Those were the times they were met with an increase in labour turnover. In that situation the comparatively good conditions of employment in the mines were not considered to offer enough compensation for the hard labour of the coal mining profession. In these times the mines had to resort to recruiting foreign labourers.

The geographical position of the Limburg mining region amidst coal basins across the border plays a part in this. The neighbouring border regions in Germany (Rhineland and Westphalia) and Belgium (Liege and the Campine region) had similar labour markets, in which mining played an important role. Except for extraordinary moments before and after both World Wars there were hardly any judicial impediments for commuters to cross the border and they could thus profit from better conditions of employment abroad and/or favourable rates of exchange. This situation, described as the border paradox, took place during the decades before World War I, when labourers from Limburg presented themselves on the German labour market where higher wages were being paid and social provisions in the mining industry were better organised. After World War II it was initially the Belgian labour market that was able to attract labourers from Limburg. In the late Fifties it was again ample employment in Germany that formed a pull-factor. The flow from the Limburg labour market was a cause of concern for the mining directors. They tried to keep the workers in Limburg from taking jobs as cross-border workers and there are indications that their efforts did cause commuting to Belgium as well as to Germany after the war not to rise to disproportionally high levels.

The Dutch mines, however, could also be attractive work places for foreign cross-border workers. The most telling examples of this occurred in the period between 1919 and 1923. The Limburg mining companies did not consider cross-border workers to be a structural solution for their personnel shortage. It was for this reason that a number of boards of directors of Limburg mines took the protests of their fellow directors in Aix-la-Chapelle against the recruitment of German labourers to heart. The mines in Limburg aimed for a stable core group of miners and realised that cross-border workers because of pragmatic reasons would never be there to stay. They would probably leave as soon as their advantages would cease. This did happen when the exchange rates stabilised at the end of 1923.

A final and recurring problem of labour supply was the housing shortage. Suitable housing was an indispensable means to attract new labourers mainly from areas outside of the immediate surroundings of the mines. In the buildup period before 1930 housing problems 
were all the more pressing because means of transport were still quite inadequate. Commuting from areas somewhat further away to the mines was often time consuming or simply impossible. The means of transport gradually changed for the better by the construction of railway and tramway connections and especially by the arrival of the bus in the Twenties.

The lack of family housing in the vicinity kept causing problems for the mines in the post war years, even if the means of transportation for miners had greatly improved. This enabled more miners than before World War II to opt for commuting instead of moving to the mining district. Those who spent more than $\mathrm{I}_{2}$ to $\mathrm{I} 3 \mathrm{~h}$ hours a day travelling and working were made to leave home and move. Recruiting campaigns across the line of 12 or I 3 hours were to be restricted to unmarried labourers or workers willing to be separated from their families and put up in workman's lodgings in the mining area. This caused some harmful consequences for the competitiveness of the mines on the labour market. The mines discovered this when recruiting displaced persons right after the war and immigrant workers after I955 from Mediterranean countries. It made them compete with foreign mining companies that required no specific civil status of the applicants.

It was, however, not all sorrow and misery for the mines regarding the labour supply. Compared to other mining areas the Limburg mines were in a favourable position. First of all the mines in Limburg met with favourable demographic developments. The population of the mining district and the rest of Limburg grew rapidly. Up to I930 a large part of this population growth was caused by migration, but in the Nineteen Thirties this turned into a largely natural rise in population. Because of the high birth rate the population rejuvenated and caused a subsequent natural addition to the potential working population. In theory there were 3 to 4 young men ready to fill any one job that had fallen vacant. Management of the mines took advantage of this situation. Already during the Depression part of the foreign workers made redundant could be replaced by young native Limburg labourers. When the economy improved from 1935 onwards the mines continued this policy.

The mines' second advantage was the gradual rise of a monoculture in Limburg. The mining towns were characterised by very high percentages of miners among the male professional workforce. Locally there were few non mining jobs. Contrary to other regions no competitive large industry developed in Limburg in the wake of the mining industry. It was just the industry in Maastricht that formed any competition, apart from some industrial employment across the border at certain times. The agglomeration Maastricht and Western South Limburg therefore supplied far less mine workers than was to be expected on the basis of the size of the professional labour force. Recruiting campaigns for intern on-the-job training in this area were not very successful either .

\section{A DUAL LABOUR MARKET}

In the first chapter it is indicated that there is no 'labour market' as such, but it is a question of several market shares or segments which are barely in competition with each other, or even not at all. There is a market segment classification based on the existence of a dual labour market. On the one hand a primary internal segment of permanent employment and secure labour relations and on the other hand a secondary external segment of temporary 
employment contracts. The external segment often acts as a buffer with which employers are able to meet economic fluctuations in especially quantity demands for labourers. It is origin that seems to decide in which segment labourers belong. Migrant workers often end up in the secondary segment.

There was a constant contingent of foreign workers in the Dutch mines. The theory, however, that ties this category to the dual labour market, is not valid all the time. In the latter part of the Twenties a change can be seen from a demand for foreign labourers based on quality to one based on quantity. In this period of building up Dutch mining skilled workers had to be recruited abroad. These labourers played an important role in training Dutch labourers to become skilled mine workers. This enabled the mines to gradually build up the backbone of Dutch mine workers. The skilled foreign workers from the very beginning sometimes were part of this core group of miners and subsequently of the primary segment of the labour market.

The ever growing presence of fully-qualified Dutch miners, the changing techniques and organisation of coal mining which shut the door to the traditional transfer of expertise, made mining in the Netherlands from the latter part of the Twenties on less dependent on foreign professionals. As from 1925 on personnel shortages were mainly of a quantitative nature. Foreign labourers taken on to make good these shortages usually ended up in the secondary segment of the labour market. Mining management assumed the presence of these beginners to be temporary. They received employment contracts for limited periods.

The economic decline in the Thirties made it quite obvious that there were two categories within the group of foreign labour migrants in the Dutch mining industry. Especially the foreign coalmine workers taken on during the latter part of the Twenties were made redundant. This group indeed acted as a buffer which safeguarded the employment of the backbone of coal miners. This core group comprised mainly Dutchmen but also foreign labourers who because of their skills could not be missed. Qualified coal miners of foreign origin fulfilling a long career in Dutch mining were no exception.

In the Fifties the correlation between recruiting labour migrants from abroad and the dual labour market for miners came to light more clearly. Since the Depression of the Thirties mining directors had by means of internal on-the-job training straight after primary school succeeded in attracting young men in Limburg to apply for mining jobs. These miners were meant to provide a steady inflow of young labourers in working underground which strengthened the core group of coal miners. Recruiting labourers abroad now only occurred during temporary shortages, e.g. from 1948 to 195 I when a first group of Italian labourers were recruited and between 1955 and 1957 when workers were recruited in Austria and again Italy. From the beginning the Dutch mines considered them temporary immigrant workers (guest workers/gastarbeiders). Because of the demographic development in the mining district and the expansion of council housing, the recruitment possibilities on the Dutch labour market in Limburg and the Netherlands in the long run were no cause for alarm for the Dutch mines. The economic decline and the Coal Crisis between 1958 and I96o clearly set out the place of immigrant workers on the labour market: recently recruited Austrian and Italian workers did not have their contracts renewed and thus the mining management prevented the employment of the core group of mine workers running a risk.

From 1960 on the diminishing belief in the future of mining industry led to disappoint- 
ing recruiting results on the Dutch labour markets and forced management to turn to foreign labour markets. After 1960 the demand for skilled coal miners from abroad who could be set to work underground immediately was greater than in the Fifties. Experienced coal miners from Yugoslavia and Morocco were able to meet this demand. Whether this indispensible recruitment of skilled foreign miners would in the long run have led to a more permanent presence of labourers from abroad, a development which occurred after World War II in the Liege mining district is not unlikely. After announcing the closure of the mines in December 1965 the labour market for coal mining workers could never function on a normal level again. It is however obvious foreign coal miners played an important role in the closing operation. Partly due to their presence the closing operation could be executed in phases, which enabled quite a few (Dutch) miners to reach retirement age or their agreed transitional payment schemes.

\section{COMMITMENT VERSUS AUTONOMY}

During all of the period researched the labour market policy of the mining boards was characterised by taking heed of a sort of hierarchy of preferred groups. In general the order of recruitment of personnel considered was: mining district residents; inhabitants of Limburg; fellow countrymen; foreigners. In case of compulsory redundancy the order was inverse. The State Mining Company, which at its foundation had even declared on principle to employ only Dutchmen, endorsed the policy regarding preferred groups and so did all privately owned mines, even though the latter were largely in foreign hands.

Not just strategies regarding recruitment and selection played a part, but retaining personnel once hired was crucial to this policy as well. Commitment strategies were aimed at forming core groups of miners, in order to minimize the dependency of the mines on the labour market. Less labour turnover meant less cost and effort to be spent on recruiting.

Recruitment and selection on the one hand and commitment on the other hand were firmly connected. The boards of directors of mining companies had a sound perception of this. It was to be expected that miners rooted in the region were foremost in committing themselves to the company. Actual practice proved the mining employers right in this: generally speaking the preferred order matched the extent of commitment to the company. During the period researched inhabitants of Limburg were most willing to commit themselves to the mines.

The mining boards' aspiration to keep recruiting personnel in their own hands is a connecting theme in the history of mining in Limburg during all of the Twentieth century. The specific character of mining made particular requirements upon selection and the mines themselves were the best equipped to assess the qualities of becoming a miner. Recruitment agents sent out by the mines to recruit labourers often had long experiences themselves in mining. In the Twenties the founding of the Medical Office of the Dutch Mines (Geneeskundige Dienst der Nederlandse Steenkolenmijnen) proved to be an instrument in improving the selection on medical grounds.

The mines wanted nothing to do with outside interference in the selection of personnel. Their hesitation to work with institutionalised employment finding during the buildup pe- 
riod is based on that policy. During the Depression and the War the personnel policy of the mines is characterised by the efforts to control labour supply. In the early Thirties the mines did comply with a request of the national government to hire coal miners made redundant in Germany, but attached the condition that they themselves would select the workers. In the latter part of the Thirties the mines refused to yield to the pressure of the government and the labour exchanges to rehire the workers which were made redundant during the Depression. Even during the German occupation the mines stood firm. The mines did not hire everyone trying to escape being sent to Germany to do hard labour, because of the strict selection policy. Refusing to take on miners from Aix-la-Chapelle and forced labourers from Russia during that time are two examples of the great interest the mines attached to selecting their own personnel. Finally in the Fifties and Sixties during negotiations with foreign authorities about recruitment agreements it was a strict requirement of the Limburg mining employers that they themselves had the final say in selecting migrant workers.

Already in the buildup period selection and recruitment and commitment were supported by a series of instruments with which the mining management wanted to stimulate working in the mines. Because housing played an essential role in selection and commitment, the mining companies built houses for their personnel, in cooperation with mainly Roman Catholic housing corporations and making use of national government subsidy schemes. Good terms of employment were of great importance. The hard working conditions, especially underground, had to be compensated by adjusting working hours and good payment in comparison to other sectors of industry. Working conditions for the joint Dutch mines were made uniform in collective wage agreements, the first of which was concluded in I920. In addition to this the joint mines after World War I introduced a system of social securities against sickness, invalidity, old age and death in the form of the General Miners Fund (Algemeen Mijnwerkersfonds). They founded the Medical Office mentioned earlier, which professionalised medical treatment of industrial accidents and they provided social facilities, like a club life on a company level. Because the mining companies acted collectively in these initiatives, labour turnover between the mines was reduced after World War I.

A crucial strategy to encourage commitment to the mining company was establishing an internal on-the-job training programme, where boys were trained for functions underground. For this training course (the so-called Leesjongensopleiding), which after World War II was transformed into the Underground Industrial School (Ondergrondse Vakschool, OVS) boys from the mining district and outside of it could rather successfully be recruited until the mid-Fifties. In the eyes of the mining boards' of directors OVS pupils carried on a mining tradition. In the future they would form the backbone of a workforce following Limburg based patterns. Signs for this were not unfavourable when commitment to the mining company turned out to be considerably stronger with former pupils of the leesjongensopleiding and the OVS than with their fellow miners who had not received these training courses.

The process of company commitment was not just determined by the strategic policy of the mining companies. Exogenous circumstances played a major role in the degree of success of the commitment strategies. The state of the labour market was particularly important. The degree in which alternative employment was available determined the possibili- 
ties miners had to get away from employment in the mines and realise their own strategies for autonomy. In times of labour market shortages the commitment strategies of mining directors and autonomy strategies of the miners were at loggerheads with one another. A few examples may illustrate this. In the period in which mining in Limburg was being built up, it was mainly the shortage of experienced miners that caused the strained relations between commitment and autonomy. Experienced miners occupied an incontestable position on the labour market giving them the possibility to Freizügigkeit. Often they did not commit themselves to one mining company but represented the pinnacle of worker mobility by moving from one mine to the next and even from mining basin to mining basin. Many of the experienced miners from abroad who turned up in the Limburg mines during the building up period had followed a road of migration along several Western European mining areas. They continually used the shortage of experienced coal miners by presenting themselves at those places where working conditions were most advantageous. The high numbers of labour turnover before World War I can be mainly attributed to the possibilities this category of miners used to put their strategies for autonomy in practice.

But after World War II there was tension between commitment and autonomy as well. From I953 to I957 the labour market was very tight. After a brief economic decline between I958 and I960 the labour shortage returned during the Sixties. For miners employment elsewhere offered the possibility of more worker mobility. One could continue one's career in Belgian or German coal mining through commuting, or leave mining altogether and take up a job in a different sector. The converging tendency of payments in mining compared to those in other sectors stimulated them to leave their mining jobs. Labour turnover figures in Limburg mines rose again during this period.

The increase of alternative employment on the labour market and in secondary education also raised consequences for the OVS From 1953 on the number of applications declined. Of the pupils who enrolled in the training courses, fewer and fewer moved on to underground jobs. This behaviour of the most preferred group in mining showed them to be less willing than ever before to commit themselves to a mining company. Only the period between I958 and I960 was uncharacteristic in this process of declining applications and increasing departures. The economic decline caused alternative possibilities on the labour market to temporarily decrease. This situation forced strategies of mining companies and mine workers once more to stay in line with one another.

The period between 1958 and 1960 showed the same process on a smaller scale as during the Depression in the Thirties: in times of economic decline the scale tipped to the disadvantage of the miners' autonomy strategies. In the Thirties this also led to a declining labour turnover. In spite of compulsory redundancies by mining companies considerably less numbers of labourers left the mines than in the build up years, when the mining labour market was tight. Mining management preferred to fire the groups that had shown more than average worker mobility: foreign labourers and cross-border workers. During the Depression and certainly in the years to follow they were replaced by miners who could be expected to show more commitment to the mining companies: young men born and bred in Limburg. 


\section{THE REGIONALIZATION OF THE MINING LABOUR MARKET}

From the start the mining directors planned to build up their workforce with labourers with regional roots. This aim was supported by the authorities and the trade unions. Figures from all of the period researched show that this turned out to be a successful policy. In general more than half of the miners hired between 1900 and 1965 were born in Limburg and $70 \%$ was Dutch. In December $196587 \%$ of the miners was Dutch, a vast majority of which was born in Limburg.

In the course of the century the 'limburgisation' of the mining population was taking on a more and more definite shape. Whether this was achieved by well-thought-out and consciously considered strategies of mining boards' of directors or by favourable circumstances in which this policy took shape, remains the question. In the initial phase creating a Limburg mining population was a difficult process, in spite of the mining directors' strategies to get people to work in the mines. The coal miners of old in Kerkrade were too few in numbers to form the backbone of the much larger demand for coalminers after 1900. The Depression and World War II put an end to the expansion of coal mining in Limburg. The circumstances helped the directors to mark time in this and create possibilities to steer the assembling of their workforce towards a direction they preferred. Especially the Thirties marked a turning point in this. In those days forced redundancies enabled the mines to make a clean sweep and dispose of the least acceptable labourers. As soon as the economy improved the favourable demographic development offered a possibility on the labour market to draw from the number of young labourers from Limburg who were considered the bearers of a miner's tradition to be newly formed. Between I93I and 1944 almost $80 \%$ of the new miners came from Limburg. Between I9I9 and 1930 this had been less than a quarter. It had been the founding of internal industrial schools (leesjongens training and subsequently the OVS) that was of great importance in the regionalization process. Recruiting boys for mining labour in the final form of primary schools caused mines to be one step ahead of any competitors. As a pupil the boys were already paid a salary and were exempted from military service. This policy proved successful until the mid-Fifties. The mines could depend on a sufficient flow from the OVS to underground jobs. The mining district being a monoculture without alternative employment in large-scale industrial companies enhanced the OVS' attraction. In practice it turned out that miners who came to underground mining jobs by way of the OVS showed the closest commitment to the mining company. This made the OVS the key to the success of regionalizing the mining trade market.

In the mid-Fifties the tide turned by a tightening of the labour market and the growing possibilities of education for working class children. The interest in the OVS noticeably declined and the flow of young men to underground labour subsequently dried up. These were the first signs of what can be described as 'desertion of the sons' a process that had already taken place in Walloon mines at the end of the nineteenth century. ${ }^{1}$ More and more traditional Walloon families of coal miners wished a professional career for their sons outside the mining industry, which would gain them more social status. They coupled this strategy with a change in demographic behaviour: miners began to limit their number of children.

I Frank Caestecker, 'Arbeidsmarktstrategieën in de Belgische mijnindustrie tot I940' TSEG V nr. 3 (2008) 30-52 q.v. 44-48. 
For the Walloon mines this meant in the long run a decrease in available work force on the regional labour market.

Around 1955 there was no sign of any demographic decrease in Limburg. The future influx of young labourers on the labour market was not to be endangered. At first the mines were therefore not concerned about the declining interest in the OVS. In the mid-Fifties the taking in production of the State Mine Beatrix was still thought to be feasible. In the not too near future there would even be room for several new exploitation sites in the Peel fields. The labourers recruited in Austria and Italy between I955 and I957 were emphatically considered to be temporary workers.

Only one more time the circumstances for the mines took a turn for the better, when a brief economic decline in the years between 1958 and 1960 decreased the possibilities for alternative employment and the securities of permanent jobs in the mines prevailed. On the other hand it was the Coal Crisis that dealt faith in employment in the mines the final blow. From I 960 on the attraction of the OVS was done with once and for all. The 'desertion of the sons' had now become an irreversible process. Circumstances beyond the control of the mining companies caused their strategies to be defeated by those of the miners. 


\section{Register}

Aalberse, P.J.M. $\quad$ I37

Abruzzen I92

Acker, Achille van 236

Aken I5, 27, 32, 35-36, 59, 64, 75, 89-90, 108, IIO, I2I, I29-I3O, I39, I57, 238, 262

Aken-Maastrichtse Spoorwegmaatschappij

(AMSM) 27, 35

Algemeen Mijnwerkersfonds van de Steenko-

lenmijnen in Limburg (AMF) I3, 23, 25, 72,

77-78, 84, 93, I04, I06-I07, II2, I38, I4I, I82, 204-209, 2I2, 2I4, 2I7-2I8, 220, 226-229,

$247,263,301-302,304-305,311,324-326$

Algemene Bond van Christelijke Mijnwer-

kers $85,137,218,301$

Algemene Nederlandse Mijnwerkersbond I37, 218, 301

Alsdorf 89-90, I39

Amby 287, 299

Amstenrade 287, 298, 304

Amsterdamse Bank 32

Anders, Wladyslaw $\quad$ I78-I79

Anna, mijn 89-90

Antwerpen I33

Arbeidsbeurs voor de Limburgse Mijn-

streek I00-I02, 132, I35, I4I

Arcen en Velden 69, 286, 299

Auswanderungs Emissariat des Königreiches der

Serben, Kroaten und Slovenen $\quad$ I45

Baexem 286, 299

Bakker, J. 226

Bamberg I8I

Banque d'Outremer 32

Bardenberg I39

Bardoul, H.J. 234, 24I

Beambtenfonds voor het Mijnbedrijf

(BFM) 218, 302

Beegden 286, 299

Beek 72, 286, 298, 304
Beersdal I34

Beesel 69, 247, 286, 299

Bekman, Bernard 243

Belfeld 286, 299

België (Belgen) 4I, I08, I29-I30, I32, I34-I35, I38-I39, I43, I48, I50, I54-I55, I6o, I84, I90, I98, 236-239, 257, 284-286, 306, 3I2, 3I4, 3I6, 318, 320, 322

Belgrado 196

Bemelen 7I, 287, 299

Berg en Terblijt 287, 298

Bergen 286, 288, 299

Berghuis, C.K. 179

Bergwerkvereeniging voor Nederland $3 \mathrm{I}$

Bilt, C. van der 137

Bingelrade 73, 287, 299, 304

Blegny-Trembleur 237

Bleijerheide 36

Bocholtz 72-73, 287, 298, 304

Bochum 86, I48

Borgharen 287, 299

Born 286, 299, 304

Bottrop 86

Bouwens, Sophie 239

Brassé, Paul I40, I8I

Broekhuizen II4, 286, 299

Broeksittard 287, 298, 304

Bruch, Hermann Wilhelm Iog-II3

Brunssum 38, 59-63, 66-67, 70-73, II8, I44, I62, I94, 287, 298, 304

Brussel 32

Buggenum 286, 299

Bunde 70, 287, 299

Bundesministerium für Soziale Verwaltung $\quad$ I87

Cadier en Keer 7I, 287, 299

Cals, J. 49

Carl, concessie 30

Centraal Arbeidsbureau Zagreb $\quad$ I97 
Centraal Bureau voor de Statistiek (CBS) 59, 287-288, 303

Centre $3 \mathrm{I}, \mathrm{I} 83$

Cheratte 237

Commissie inzake toelating van Displaced Persons $179-180$

Commissie Oriëntatie Tewerkstelling Italiaanse Arbeidskrachten I84

Commissie voor de Mijnen $\quad 37,88$

Congo 32

Contact-Commissie voor het Mijnbedrijf 2I4$2 \mathrm{I} 6$

Cranssen, Tanja 199

Crespin-Nord 30

Daelen, Karl Ignatz 89

De Egge 194

De Wendel (zie Les Petits-Fils de François de Wendel \& Cie)

Den Haag 65

Deurne 59

Dieteren, Remigius 20, 9I, 2I4-2I5

Directoraat-Generaal Bijzondere Rechtspleging II6

Directoraat-Generaal voor de Arbeidsvoorziening I84, I86, I89-I9o

Districtsarbeidsbeurs Heerlen Ioo, I40

Districtsarbeidsbeurs Sittard I08, I00

Districtsbureau voor de Arbeidsvoorziening (DBA) 46, 242, 247

Domaniale Mijn $\quad 27,35-36,49,64,69,83$, 91, I08-I09, I27, I30, I42, I8I, 217, 250, 267, 269, 27I, 273, 275

Donaumonarchie 87

Dortmund $86-87$

Drenthe $78,85-86,3$ II

Drnis 195

DSM 39

Duisburg 86-87

Duitsland (Duitsers) 25, 36, 42, 44, 80-8I, 85, 87-90, 92-95, 99, I04-I05, I08-II3, II5, I27I32, I35-I39, I4I, I45, I48, I52-I6o, I7I, I77I83, 2I7, 225, 230, 236, 238-240, 256-257, 262, 284-286, 303, 306, 3I2, 3I4, 3I6, 3I 8 , 320,322

Echt 69-70, 72, 245, 247, 286, 299

Ede 85

Eendracht $\quad 33-34$

Eijsden $\quad 69,7 \mathrm{I}, 287,299$
Eindhoven $85,187,218$

Eisden 139

Elsloo 72, 286, 298, 304

Elteren, M.C.M. van 202

Emigratie Commissie Warschau I45

Emmen 84

Emscher 86-87

Engeland (Engelsen) 4I, I78-I79, I82

Enka 85

Eschweiler Bergwerksverein (EBV) 32, 36, I37

Essen 30, 86

Euregio Maas-Rijn $\quad$ 2I, 9I, 287

Europese Economische Gemeenschap

(EEG) 48, 76, I84, I92-I93

Europese Gemeenschap voor Kolen en Staal (EGKS) 46-48, II8, I84, I87-I88

Eygelshoven $\quad 32-33,51,60-63,66-73,89$, I34, I94, 287, 298, 304

Feldbiss 33

Fonds voor Sociale Instellingen (FSI) 222

Frankrijk (Fransen) 42, I08, I43, I48, I78, I98, 284-286

Friesland 78, 3II

Frische, Paul 243

Frowein, W.F.J. I08, I37-I38, 225

Gaasterland I33

Gales, Ben 2I

Gelderland $77-78,85,31 \mathrm{II}$

Geleen I5, 38-39, 54-55, 60-63, 66-68, 70-74, I40, 286, 298, 304

Gelsenkirchen 86

Gemmenich 139

Geneeskundige Dienst der Nederlandse Steenkolenmijnen I02, 2I4, 218-220, 262-263, 347

Gennep 59, 286, 288, 299

Geulle 286, 298, 304

Gewestelijk Arbeidsbureau Heerlen II4-II5

Gezamenlijke Steenkolenmijnen in Limburg

(GSL) 23, 26, I88, I93-194, I96-197, 205, 23I

Grathem 286, 299

Graz I87

Grevenbicht 286, 299, 304

Griekenland (Grieken) 160, 186, 313, 315, 317, 319, 321, 323

Groningen $78,3 \mathrm{II}$

Gronsveld 7I, 287, 299 
Groot-Brittannië (Britten) 42, I78-I79, 284286

Groothoff, C.Th. $\quad$ II3, II6, I78, I85

Grootjans, Nic. I35, I40

Grubbenvorst 69, 247, 286, 299

Gulpen 287,298

Haelen 286, 299

Haex, A. 99-100, I38

Ham 3I

Hamm 30, 86

Harderwijk 133

Hasselt 35

Hayange 30

Heel en Panheel 286, 299

Heer 287, 299

Heerlen I3, I5, 29-30, 53, 55, 60-68, 70-74, 8082, 93-94, 98, I00, I02, II3-II7, I35, I37, I39I4I, I44-I45, I65, I87, 2I8-2I9, 24I, 256, 287, 298, 302, 304

Heerlerheide 30

Heksenberg 30

Helden 70, II4, 286, 299

Hellweg 86-87

Hermans, Henri $\quad$ I37

Herten 286, 299

Herzogenrath 29-30, 32, 35, 64, 89-90, I39

Heythuysen 79, 286, 299

Historisch Centrum Limburg (HCL) I3, 23, 303

Hoensbroek $38,60-63,65-67,70-73,8 \mathrm{I}, \mathrm{I} 49$, $287,298,304$

Höngen 90

Honigmann, Carl 29

Honigmann, Friedrich 29-30

Hoof, Jacques van 202

Hopel 62

Horn 286, 299

Horst II4, 286, 299

Houthem 287, 298

Hulsberg 287, 298, 304

Hunsel 286, 300

Indonesië II6

Intergovernmental Committee on Refugees (IGCR) I80, I82

International Refugee Organization (IRO) $\quad$ I82 Italië (Italianen) 87, 136, I40, I44, I53-156, I6o, I77-I78, I84-I9I, I92-I95, I98, 225, 24I242, 26I, 265, 3I2, 3I4, 3I $6,3 \mathrm{I} 8,320,322$
Iterson, F.K.Th. van 108

Itteren 287, 300

Ittervoort 286, 300

Jabeek $73,287,300,304$

Joegoslavië (Joegoslaven) I35-I36, I40, I44I46, I48, I53-156, I6o, I77, I86, I9I-198, 225, 240, 312, 314, 316, 318, 320, 322

Joeuf 30

Johow, Oberbergrath 108-109

Julia I9, 33-34, 5I, 69, 7I, 73, IOI, II9-I20, I22, I44, I89, I94-I95, 2I9, 22I, 234-235, 24I, 246, 270, 272, 274

Kärnten I88

Kempen I5, 59, IIO, II5, I2I, I5O, I57-I59, I83, 236, 238, 257

Kerkrade I3-I5, I9, 27, 3I, 38, 49, 53, 55, 60, 62-75, 80-82, 89-93, 98, 130, 175, 247, 264, $287,298,304,350$

Kersten, vader en zonen $\quad 244$

Kessel 286, 300

Keulen 32, 35

Kirpenstein, familie 244

Klagenfurth $\quad$ I87

Klimmen 73, 287, 298, 304

Kloosterrade 27

Kohlscheid 32, 36, I39

Kolenbureau 4I

Königliche Eisenbahn Direktion Köln 35

Kreukels, Loek 20, 82, 203, 205-206, 224

Kroatië (Kroaten) I45, I95

Kroon, F.G. van der I45-I46

La Calamine 139

La Courtine $\quad$ I79

Landelijke Organisatie voor de Hulp aan Onderduikers (LO) II3

Landesarbeitsamt Wenen I88

Laura $32-34,51,65,69,73$, I20, I27, I30, I34, I94-I95, I97, 246, 270, 272, 274

Laura \& Vereeniging $32,34,83,108,143-145$, I47-I48, I87-I88, I9I, I97-I99, 2I6, 266, 268, 270

Leijenbroek 194

Lely, Cornelis $\quad 37,96$

Lemmens, firma iI8

Les Petits-Fils de François de Wendel \& Cie 303I, 222

Limbricht 286, 299, 304

Limburg (Belgisch) I39, I57 
Limburg (Nederlands) I5-16, 20-22, 25, 27-29, 3I, 37, 4I, 50, 52-6o, 63-65, 67-69, 73-86, 8994, 96-97, I05, I07-IIO, II4, II8-II9, I2I-I22, I27, I29-I30, I35, I42, I44, I48, I5I, I58-I59, I8I, I86, I97-I98, 208-210, 226, 230, 237-239, 24I-242, 244-245, 255-256, 258, 26I, 264265, 286, 298, 301, 303, 305, 3II

Limburgsche Tramweg Maatschappij (LTM) 66-67, 93

Limburgse Rooms-Katholieke Werkliedenbond 98, 223

Linne 286,300

Linz $\quad$ I87

Lippe 86

Lotbroek 62

Luik 2I, 59, 78, IIO, II5, I2I, I33, I39, I5O, I57-I58, I77, I83, 236-239, 254, 257, 26I

Lutterade 38

Lutz, B. 203

Maasbracht 286, 300

Maasbree 69-70, 247, 286, 300

Maaseik 139

Maasmechelen I39

Maasniel 286, 300

Maastricht $23,35,64-66,68-70,72,74,79,8 \mathrm{I}$, 84, I32, I89, 237, 24I, 247, 258, 287, 300, 303 Maczek, Stanislaw 177

Margraten 7I, 287, 300

Mariëndorf 90

Marl 86

Marokko (Marokkanen) I60, I77, I86, I9I-ı92, I98-199, 26I, 313, 315, 317, 319, 321, 323

Meerlo II4, 286, 300

Meerssen 70, 287, 299

Meiderich 87

Meijel II4, 286, 300

Melick en Herkenbosch $\quad$ 286, 300

Meppen I80

Merkelbeek 73, 287, 298, 304

Merkstein 90, 139

Mesch 287, 300

Mheer 7I, 287, 300

Mijnindustrieraad (MIR) 23, 75, I2I, I84, I98, 235

Moers 86

Mons $\quad \mathrm{I} 83$

Montfort 286, 300

Mook en Middelaar 59, 69, 286, 288, 300
Moritz, H. I98-I99

Munstergeleen 286, 298, 304

Nederlandsche Zuider Spoorwegmaatschappij 29

Nederlandse Arbeidsbeurs Oberhausen 94, I04, I29, I43

Nederlandse Katholieke Mijnwerkersbond

(NKMB) 26, I44, I70

Nederlandse Selectie Commissie Milaan $\quad 192$

Nederweert II4, 286, 300

Neer 286, 300

Neeritter 286, 300

Neuprick 27, 36, 217, 267, 269, 27I, 273, 275

Neu-Voccart, mijn 36

Niederländisches Arbeitsamt Bochum $\quad$ I43

Nieder-Österreich $\quad$ I88

Nieuwenhagen $72,73,81,90,287,298,304$

Nieuwstadt 287, 300, 304

Noorbeek 7I, 287, 300

Noord-Brabant $55,77-78,83,85$, I07, 3II, 318

Noord-Holland 78,3 II

Nord 30, 42, I43, I9I

Nordstern, mijn 90

Nunhem 286, 300

Nuth $65,72,287,298,304$

Obbicht en Papenhoven 287, 300, 304

Oberhausen $86-87$, 94, I04-I05, I29, I43

Ober-Österreich $\mathrm{I} 88$

Ohé en Laak 286, 300

Oirsbeek 287, 298, 304

Oldenbroek 133

Ondergrondse Vakscholen (OVS) I2I, I67-I69, 22I, 229-230, 245-254, 263-265, 327, 348-35I

Ondersteuningsfonds van de Staatsmijnen in Limburg $2 \mathrm{I} 8$

Ons Limburg 6o-6r, 74

Oostelijke Mijnstreek $\quad 52-58,62,68,70-73,80$, 90-9I, I39, 287

Oostenrijk (Oostenrijkers) 87, I29-I32, I35I36, I44-I45, I53-156, I6o, I77, I87-I9I, 225, 261, 265, 312, 314, 316, 318, 320, 322

Oppenheim 32

Oranje-Nassau I $\quad 3 \mathrm{I}, 64, \mathrm{I} 34,256$, 270, 272, 274

Oranje-Nassau II $30-31,134,181,270,272,274$

Oranje-Nassau III 30-3I, I44, I8I, I87, 270, 272, 274

Oranje-Nassau IV 30-3I, I57, 24I, 270, 272, 274 
Oranje-Nassau Mijnen 2I, 29-3I, 5I, 83, 85, 99, I08, I18, I27, I29, I38, I42-I45, I47, I5I, I58, I86-188, 198, 208, 217, 219, 222, 224, 23I, 234, 236, 240, 243, 254, 266, 268, 270

Oranje-Nassau Sportvereniging (ONS) 222

Osterfeld 87

Ottersum 59, 286, 288, 300

Oud-Valkenburg $\quad 287,299$

Oud-Vroenhoven 287,300

Overhage, Paul 6o, 68

Overijssel 78, 3 II

Pannesheider Bergwerksverein 28, 36

Pas-de-Calais 42, I43, I9I

Paulen, A. $\quad$ I78-I79

Peel 45, 49, 59, 246, 265, 35I

Peet, Jan 2I

Perry, Jos 244

Philips 85, II3, I8I, 218, 253

Poels, H.A. $\quad 60,85,98-99$

Polen 42, 87, I29-I30, I35-I36, I40, I42, I44I46, I48, I53-156, I60, I77-179, I8I-182, 225, 242, 312, 314, 316, 318, 320, 322

Portugal (Portugezen) $\quad 186$

Posterholt 70, 286, 300

Prickkoul 27

Pruisen 27, 36, 99

Queue-du-Bois 237

Raedts, C.E.P.M. 2I, IIO, I42, 224, 243

Ravensbosch 24I

Recklinghausen 86

Reumkens, P.J.M. $\quad 236,240$

Rheinisch-Westfälisches Kohlensyndikat (RWKS) 30, 37, 4I

Richterich 139

Rijckholt 287,300

Rijksarbeidsbureau I79-I8I, I84-I87, I96

Rijksarchief in Limburg (RAL) 303

Rijksdienst der Werkloosheidsverzekering en Arbeidsbemiddeling $\mathrm{I33}, \mathrm{I} 46, \mathrm{I} 53$

Rijkskolendistributie (RKD) $\quad 4 \mathrm{I}-42$

Rijksverzekeringsbank 219

Rijksvreemdelingendienst I8I, I87, I96

Rijnland 80, 257

Rimburg 287

Roermond 69-70, 79, 245, 247, 286, 300

Roggel 243, 286, 300

Rolduc 27, 64

Roosteren 287, 300
Ruhrgebied 28, 4I, 80, 86-88, 90-9I, 94-96, I27-I30, I43-I 45

Rumpen $38, \mathrm{I} 34, \mathrm{I} 62$

Rusland (Russen) 87, I13, I36, I54, I56-I58, I6o, I8I, 313, 315, 317, 319, 32I, 323

Rutten, Th. 249

Rutten, Willibrord $\quad$ 2I, I57-I58, 238

Ruys de Beerenbrouck, Gustave 89

Saarland 96, 102, I43

Salzburg I88

Sardinië (Sardijnen) I89, I92

Sarolea, Henri 29

Schaesberg 30, 60-63, 65-67, 70-73, 8I, 93, I34, I73, 287, 298, 304

Scheepvaart- en Steenkolenmaatschappij 35

Schelven, Willem van 20, I40, I8I

Schimmert 287, 299, 304

Schinnen 72, 287, 298, 304

Schin op Geul $\quad 65,287,298$

Schinveld $72-73,75,287,299,305$

Schümmer, G.A. $\quad 32$

Segers, J.H.G $\quad 203,232,234,240,253-254$

Sevenum II4, 286, 300

Silezië ro8

Simpelveld $\quad 64-65,72-73,287,298,305$

Sint Geertruid $\quad 74,287,300$

Sint Odiliënberg 286,300

Sint Pieter 287,301

Sint-Jozefcomité 99

Sittard $62,64,69,72,79,81,98$, I00, I02, I07I08, I94, 247, 287, 298, 305

Slenaken 7I, 287, 301

Slovenië (Slovenen) I29-I30, I45, I48, I57-I58

Sociaal Historisch Centrum voor Limburg

(SHCL) 287, 303

Société Tchèque de Colonisation Praag I45

Sophia, concessie 3 I

Spanje (Spanjaarden) I60, I77, I9I-I95, I98, 313, 315, 317, 319, 321, 323

Spaubeek 287, 298, 305

Spekholzerheide 3I, I34, 244

Staatsmijn Beatrix 40,45 , II4, II9, 242, 246, $265,35 \mathrm{I}$

Staatsmijn Emma $38-40,62,65$, I03, I27, I34, I53, I79, I8I, 25I, 276-277

Staatsmijn Hendrik $38,40,62,65$, I03, I34, I79, I8I, 229-230, 24I, 244, 276-277

Staatsmijn Maurits $38-40,42,55,68,70-7 \mathrm{I}$, 
73, IOO, I03, I40, I8I, 2I7, 243-244, 25I, 276277

Staatsmijn Wilhelmina $38-40,65,7$ I, I03, I34, 229-230, 248, 276-277

Staatsmijnen $\quad 24-25,33,36-37,39-40,42-43$, 47-49, 65, 72, 83-85, 95-98, I03, Io8-I09, II4, II8, I2I, I27, I34, I37, I42-I43, I45, I47, I50I52, I65, I78, I80, I84, I86, I88, I9I, I93-I94, 205, 2II-2I3, 2I5-2I9, 222, 224, 226, 228, 234, 24I, 244, 248-249, 25I-254, 266, 268, 270, 276-277, 288, 309

Staatstoezicht op de Mijnen $\quad 23,64,75-76$, I45 Steenkolen-Handelsvereeniging (SHV) 37, 4I Steiermark I88

Stein 72, 287, 298, 305

Stevensweert 286, $30 \mathrm{I}$

Stikstofbindingsbedrijf (SBB) 39

Stins, H.J. I37, 2 I8

Stokkem I39

Stramproy 286, 30I

Susteren $69,287,301$

Swalmen $69-70,247,286,301$

Tegelen 286, 30I

Tenfelde, Klaus 20

Terwinselen 37

Thijs, Albert 32

Thorn 69-70, 247, 286, 3 OI

Thuis Best 6I

Treebeek $\quad 38-39,62$, I36, I44, I46, I54, I56, I6o, 3I2, 3I4, 3I6, 3I8, 320, 322

Tsjecho-Slowakije (Tsjechen) Io8, I40, I45

Tunesië (Tunesiërs) I86

Turkije (Turken) I86

Ubach over Worms 73, 8I, 90, 287, 298, 305

Ulestraten 287, 30I, 305

Urmond 72, 287, 301, 305

Utrecht 78,3 II

Uyl, J.M. den 22, 27, 49, I2I

Vaals 66, 69, 7I, I08, I39, 287, 299

Valkenburg 7I, 24I, 287.298

Varazdin I95

Venlo 69, 247, 286, 30 I

Vereeniging tot Behartiging van de Belangen der Limburgsche Mijnindustrie 205

Vereeniging, concessie 32-33

Vereinigungsgesellschaft für Steinkohlenbergbau im Wurmrevier 32

Verenigde Staten 47
Verheyen, gebroeders $\quad 243-244$

Versteegh, A.P. I40

Vianen, Theodoor 90, I27, 212

Vlaanderen (Vlamingen) $\quad$ I33

Voccart, mijn $89-90$

Voerendaal 72-73, 8I, 287, 298, 305

Vorm, Willem van der 35

Vossenaar, A.H. $\quad$ 219-220

Vromen, G.C.M. 226

Wackers, A.H. 32

Walkowiak, F. I5I

Wallonië (Walen) I I3, I45, 236, 265

Wanderungsamt Wenen I45

Wanssum 286, $30 \mathrm{I}$

Waubach 90

Weert 69-70, II4, 247, 286, 30I

Weltz, F. 203

Wenen I45, I87, I88

Werkverschaffing aan Invalide Mijnwerkers der Staatsmijnen (WIM) 222

Wessem 70, 286, 30I

Westelijke Mijnstreek 57-58, 62, 68, 72-74, I0o, 245, 286, 288

Westende, mijn 87

Westfalen 30, 87-89, 94, 96, 257

West-Yorkshire I6

Wijlre $66,7 \mathrm{I}, 287,298$

Wijnandsrade $73,287,298$

Willem, concessie $3 \mathrm{I}$

Willem-Sophia $\quad 3 \mathrm{I}-32,36,69$, I08, II7, I27,

I34, I75, I8I, I88, I98, 244, 267, 269, 27 I

Wittem 7I-72, 287, 298

Wolf, Rob $\quad 25 \mathrm{I}$

Worm 27, 35-36

Würselen $\quad$ I39

Zagreb I95, I97

Zeegers, G. 25I

Zeeland $78, \mathrm{II} 6$, 3II

Zeist I33, I35

Zuid-Holland 78, 3II

Zwolle 2 I9 


\section{Maaslandse Monografieën}

Dr. M.G. Spiertz, Maastricht in het vierde kwart van de achttiende eeuw $w^{\star}$

Drs. J.F.R. Philips, Drs. J.C.G.M. Jansen, Drs. Th.J.A.H. Claessens, Geschiedenis van de landbouw in Limburg I750-1914*

Dr. P.Th. van Beuningen, Wilhelmus Lindanus als inquisiteur en bisschop*

Dr. E. Roebroeck, Het land van Montfort`

J. Koreman, De stadsrekening van Maastricht over het jaar 1399-1400*

Dr. J.M. Gijsen, Joannes Augustinus Paredis (1795-1886), bisschop van Roermond en het Limburg van zijn tijd

Dr. Jean Baerten, Het graafschap Loon (11e-14e eeuw)

Io A.H. Paape, Donkere jaren $\star$

Dr. Mr. H.H.E. Wouters, Grensland en bruggehoofd ${ }^{\star}$

Dr. J. Grauwels, Dagboek van gebeurtenissen opgetekend door Christiaan Munters (I529-I545) ${ }^{\star}$

Dr. P.L. Nève, Het rijkskamergerecht en de Nederlanden

Prof. Dr. W. Jappe Alberts, Geschiedenis van de beide Limburgen, deel I

Dr. L. Peters, Geschichte des Geschlechtes von Schaesberg*

Prof. Dr. W. Jappe Alberts, Geschiedenis van de beide Limburgen, deel II

Ir. C.E.P.M. Raedts m.i., De opkomst, de ontwikkeling en de neergang van de steenkolenmijnbouw in Limburg*

Dr. S.Y.A. Vellenga, Katholiek Zuid-Limburg en het fascisme

Dr. W. Krings, Wertung und Umwertung von Allmenden im Rhein-Maas-Gebiet vom Spätmittelalter bis zur Mitte des 19. Jahrhunderts

Dr. P.J.H. Ubachs, Twee heren, twee confessies. De verhouding van Staat en Kerk te Maastricht, $1632-1673^{\star}$

Jaak Brepoels, Het Lager Onderwijs in de provincie Limburg (1815-1830)

Harry Schillings, Toneel en Theater in Limburg in de 1ge en zoe eeuw

Prof. Dr. W. Jappe Alberts, Van heerlijkheid tot landsheerlijkheid*

Ph. Vander Maelen, Dictionnaire géografique du Limbourg

Dr. J.P. Gribling, Willem Hubert Nolens 1860-1931

Dr. J.A.K. Haas, De Verdeling van de Landen van Overmaas 1644-1662

Prof. Dr. W. Jappe Alberts, Overzicht van de geschiedenis van de Nederrijnse Territoria tussen Maas en Rijn, \pm 8001288

Henry Baillien, Tongeren van Romeinse Civitas tot Middeleeuwse Stad*

Dr. J.C.G.M. Jansen, Landbouw en economische golfbeweging in Zuid-Limburg 1250-1800

M.P. Gutmann, War and rural life in the early modern Low Countries

Dr. Rudolf Philips, Gezondheidszorg in Limburg

Dr. A.Fl. Gehlen, Het notariaat in het tweeherig Maastricht

P.J.H. Baghus, De slag om de Roerdriehoek ${ }^{\star}$

Dr. Ton Meijknecht, Bartholomeus van Maastricht († 1446), Monnik en Conciliarist

Prof. Dr. W. Jappe Alberts, Overzicht van de geschiedenis van de Nederrijnse Territoria tussen Maas en Rijn, Deel II, 1288$\pm 1500$

François Vanduffel, Industrialisatie en verandering: Lommel tussen 1890 en 1914

Drs. A.P.M. Cammaert, Tussen twee vuren 
39 Drs. J.M.B. Tagage, De Ordinarius van de collegiale Onze Lieve Vrouwekerk te Maastricht

40 Dr. G.H.A. Venner, De Meinweg

$4 \mathrm{I}$ Dr. C.A.A. Linssen, Historische opstellen over Lotharingen en Maastricht in de Middeleeuwen

42 Dr. L.H.M. Kreukels, Mijnarbeid: volgzaamheid en strijdbaarheid

43 Dr. E. Lavigne, Kroniek van de abdij van Sint-Truiden, deel 1: 628-1138

44 Dr. J.L.H. Hartmann, De reconstructie van een middeleeuws landschap*

45 Dr. Th.L.M. Engelen, Fertiliteit, Arbeid, Mentaliteit

46 Dr. E. Lavigne, Kroniek van de abdij van Sint-Truiden, deel 2: 1138-1558

Eenheid en Scheiding van de beide Limburgen. Verslagbundel van het op 26 mei I 989 te Alden Biesen gehouden congres bij gelegenheid van de herdenking 150 jaar beide Limburgen ${ }^{\star}$

48 Dr. J.G.C. Venner, Beeldenstorm in Hasselt, $1567^{\star}$

49 Mark Hanson, Van Frans naar Nederlands

50 Dr. Hans van Dijk, Panorama van drie eeuwen muziek in Limburg

5 I Dr. P.J.M. Teeuwen, Uit aarde geschapen ${ }^{\star}$

52 Prof. Dr. J.C.G.M. Jansen en Drs. W.J.M.J. Rutten, Geschiedenis van de landbouw in Limburg in de twintigste eeuw

53 Dr. E. Lavigne, Kroniek van de abdij van Sint-Truiden, deel 3:1558-1679*

54 Drs. J.M.B. Tagage, De Ordinarius Chori van de collegiale Sint-Servaaskerk te Maastricht

55 Dr. A.P.M. Cammaert, Het verborgen front, deel I

56 Dr. A.P.M. Cammaert, Het verborgen front, deel II

57 Dr. E.M.F. Koch, De kloosterpoort als sluitpost? Adellijke vrouwen langs Maas en Rijn tussen huwelijk en convent, 1200$1600^{*}$

58 Economische betrekkingen in grensregio's in een industrieel tijdperk, 1750-1965. Verslagbundel van het op I4 en I5 september 1995 te Maastricht gehouden congres van de Verenigingen voor economische geschiedenis in België, Duitsland en Nederland

59 Robert Nouwen, Tongeren en het Land van de Tungri (31 v.Chr.-284 n.Chr.)*

6o Dr. P.Th.R. Mestrom, Uurwerken en uurwerkmakers in Limburg, 1367-1850*

6I W.A.J. Munier, Het simultaneum in de landen van Overmaas. Een uniek instituut in de Nederlandse kerkgeschiedenis $(1632-1878)$

62 Arnout Mertens, Loons, Diets en Luiks. Hasselt en de volksvertegenwoordiging in het land van Loon en het prinsbisdom Luik $(1477-1538)^{\star}$

63 Dr. P.J.H. Ubachs, Handboek voor de geschiedenis van Limburg ${ }^{\star}$

64 Dr. Hans van Dijk, Henri Hermans (I883-I947). De grondlegger van het Limburgs muziekleven

65 Dr. M.C.A. Kessels-van der Heijde, Maastricht, Maestricht, Mestreech. De taalverhoudingen tussen Nederlands, Frans en Maastrichts in de negentiende eeuw

66 Dr. J.H. Verhage, Katholieken, Kerk en Wereld. Roermond en Helmond in de lange negentiende eeuw*

67 Dr. B.P.A. Gales, Delven en slepen. Steenkolenmijnbouw in Limburg: techniek, winning en markt gedurende de achttiende en negentiende eeuw

68 Jos Wassink, Van stad en buitenie. Een institutionele studie van rechtspraak en bestuur in Weert 1568-1795

69 Erwin Steegen, Kleinhandel en stedelijke ontwikkeling. Het kramersambacht te Maastricht in de vroegmoderne tijd

70 Thunnis van Oort, Film en het moderne leven in Limburg. Het bioscoopwezen tussen commercie en katholieke cultuur politiek (1909-1929)

7I Sophie Bouwens, Over de streep. Grensarbeid vanuit Zuid-Limburg naar Duitsland, 1958-2001

72 Lou Spronck, Theodoor Weustenraad (1805-1849) en de 'Percessie van Scherpenheuvel'

73 Paul Bronzwaer, Maastricht en Luik bezet. Een comparatief onderzoek naar vijf aspecten van de Duitse bezetting van Maastricht en Luik tijdens de Tweede Wereldoorlog

74 Hans van Hall, Eijsden, een vrijheid met Luikse stadsrechten. Een rechtshistorische schets van de ontwikkeling van een Minderstadt tussen Maas en Rijn (ca. 1300-ca. 1550)

75 Serge Langeweg, Mijnbouw en arbeidsmarkt in Nederlands-Limburg. Herkomst, werving, mobiliteit en binding van mijnwerkers tussen 1900 en 1965

\section{$\star$ DEZE TITELS ZIJN UITVERKOCHT}




\section{Curriculum Vitae}

Serge Langeweg (1958) volgde de opleiding tot onderwijzer aan de Katholieke Pedagogische Academie te Maastricht, behaalde de akte Geschiedenis MO en studeerde sociale en economische geschiedenis aan de Universiteit Utrecht. Na onder meer een tiental jaren werkzaam te zijn geweest in het middelbaar onderwijs, is hij sinds 1994 als wetenschappelijk medewerker/medewerker collectie verbonden aan het Discovery Center Continium (voorheen Industrion) in Kerkrade. In het kader van dit promotieonderzoek was hij van 2005 tot 2009 bovendien als promovendus in dienst bij de Universiteit Maastricht. 